




\section{DICTIONARY}

OF

NATIONAL BIOGRAPHY

\section{ERRATA}

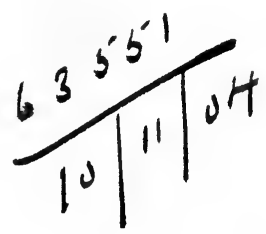

LONDON

SMITH, ELDER, \& CO., I5 WATERLOO PLACE 1904 


$$
\begin{aligned}
& D A \\
& 28 \\
& D 4 \\
& 1885 \\
& \text { Errata }
\end{aligned}
$$




\section{PREFACE}

THIs collection of 'Errata' has been prepared for presentation to subscribers to the 'Dictionary of National Biography,' in conformity with that desire for ac curacy and completeness which actuated the projector and proprietor in all his relations with the undertaking. The work has been carried out by the Editor at the instance of Mrs. George M. Smith.

With its Supplement the 'Dictionary' supplies some two million facts and dates, which have been recorded by nearly seven hundred writers. The sixty-three volumes of the substantive work were issued at quarterly intervals between 1 Jan. 1885 and 1 July 1900, and the three volumes of the Supplement followed in the early autumn of 1901. No care could exclude a certain percentage of errors from a work of such character and dimensions. The aim of this collection of 'Errata' is to correct the inevitable misprints and misstatements. In some instances it has been found necessary to justify the correction by adding to the information that is already given in the published article some reference to new researches. But the main endeavour is to remove, as briefly as is consistent with clearness, typographical mistakes or undoubted errors of statement which are liable, if unnoticed, to puzzle or mislead.

The volume containing the 'Index and Epitome' of the 'Dictionary' supplies a full and revised list of cross references. It has, therefore, been unnecessary to deal with cross references here.

Various volumes of the 'Dictionary' have been reprinted from the stereotyped plates in the course of the past few years, and before the reprinting was begun in each case several corrections were incorporated in the plates. Recent purchasers of the 'Dictionary' will consequently find their sets to include some reprinted volumes in which many of the corrections that are noted here have been made already.

Most of the 'Errata' which are recorded in the following pages have been forwarded to the Editor by several hundred correspondents during the progress of the publication of the 'Dictionary,' or since its completion. To the 
following correspondents who have devoted themselves to the correction of the 'Dictionary' more or less systematically the thanks of the Editor are especially due, viz. the Rev. A. B. Beaven, the Rev. H. E. D. Blakiston, Fellow and Tutor of Trinity College, Oxford, the Ven. Archdeacon Cheetham, Mr. Frank Cundall, F.S.A., Secretary and Librarian of the Institute of Jamaica, Mr. C. L. Kingsford, Mr. H. Elliot Madge, Librarian of the Imperial Library of Calcutta, and Dr. John Peile, Master of Christ's College, Cambridge.

It ought also to be stated that full use has been made of the long list of corrections which the Rev. W. C. Boulter contributed to 'Notes and Queries' on the publication of each volume of the 'Dictionary,' and that Dr. Edward. Scott, formerly keeper of manuscripts of the British Museum, has kindly put at the disposal of the Editor the manuscript notes which have been entered in the copy of the 'Dictionary' belonging to his department

31 July 1904.

SIDNEY LEE. 


\title{
Dictionary OF NATIONAL BIOGRAPHY
}

\author{
ERRATA IN VOLUME I
}

\author{
ABBADIE-ANNE
}

Page Col. Line

11 i 5 f.e. 4-3 f.e.

3 f.e.

21 ii 20

23 ii 12

13

29

$30 \quad$ i $\quad 37$

ii $\quad 37$

Abbot, George (1562-1633): for Early in 1614 read In March 1611-12 for Burton-upon-Trent read Lichfield

Abbot, George (1603-1648) : for 1648 read 1649 after training insert He was M.P. for Tamworth from 1645 till his death for 2 Feb. 1648 read 2 Feb. 1648-9

Abbot, Sir Maurice: for on his return read in his absence in July 1615 for 10 Jan. 1641-2 read late in 1642 after buried insert on 7 Dec. 1642 for in the Long Parliament read in both the Short and the Long Parliaments Abbott, Edwin: for 12 May 1882 read 27 May 1882, and was buried at Kensal Green Abbott, Thomas Eastoe : add to list of works 'Resignation, a poem on the death of Princess Charlotte,' Hull, 1817

35 ii 11 f.e. Abell, William : for 1637 read 1636

36 i $31-34$ for Ten years later .... alderman read In the same year he resigned his office of alderman. Ten years later Abell was again imprisoned

38 ii $\quad 29$ 5 f.e.

39 i 15 f.e.

40 ii 30

34

41 i 3-4

15-17

27

37-38

Abercromby, Alexander (1745-1795) : after ALEXANDER insert LoRD ABERCRombY omit courtesy

Abercromby, Alexander (1784-1853) : before in 1817 insert in the whig interest

Abercromby, David : omit Curiously enough and for so read So for by him read in which his name occurs

Abercromby, James, 1st Baron Dunfermline: for On the accession . . . 1827 read On the accession of Canning to power in 1827 .

for he was put forward . . . Manners Sutton read his claims for the speakership were considered by his party in 1833, but Edward John Littleton, afterwards Baron Hatherton [q. v.], was chosen to oppose Charles Manners-Sutton [q. v.], who was eleoted. for 310 read 306

omit received a pension of 4,000l. a year, and

12 i 16 f.e. Abercromby, Sir John: for 1814 read 1815

43 i 23 f.e. Abercromby, Patrick: for 1716 read 1715

44 i 23-25 Abercromby, Sir Ralph: for The war with France .... no hesitation read The war with France recalled him to military life. He had been made majorgeneral in $\mathbf{1 7 8 7}$, and in $\mathbf{1 7 9 3}$ he had no hesitation

28 omit promoted major-general and

45 i 35

after Scotland add $\mathrm{He}$ held the governorship of Forts Augustus and George from 1798 till his death

46 ii $\mathbf{3 - 2 f . e . ~ A b e r c r o m b y , ~ R o b e r t ~ ( 1 5 3 4 - 1 6 1 3 ) : ~ f o r ~ a n d ~ t o ~ d i e . . . . ~ f a i t h ~ r e a d ~ b u t ~ s h e ~ d i e d ~}$ (1619) without professing the catholic faith 
Page Col. Line

17 i 25 f.e. Abercromby, Sir Robert: for in 1781 read in April 1782

16 f.e. $\quad$ after Mysore add He was promoted major-general in the same year

48 i 29-30 Abernethy, John (1680-1740): for Coleraine . . . Ulster read Brigh, Co. Tyrone

55 i 22 f.e. Abney, Sir Thomas (1640-1722): for that office on read that office. On

21 f.e. for Louis XIV. read Louis XIV,

13 f.e. after London add $\mathrm{He}$ was a whig and an unsuccessful candidate for London in 1702

ii 12f.e. Abney, Sir Thomas $(d .1750)$ : after became insert K.C. and attorney-general for the duchy of Lancaster in 1733, steward of the Marshalsea Court in 1736

Acland, Sir John : for (d. 1613) read (d. 1620)

15 f.e.

$$
\text { for in } 1613 \text { read } 14 \text { Feb. 1619-20. (Will dated } 9 \text { Feb. 1619-20, proved }
$$
4 July 1620)

61 ii 6
f.e.

13 f.e.

17 f.e.

Acland, John D. : for minority read ministry for 31 Oct. 1778 read 2 Nov. 1778

Acland, Sir Thomas D.: for Grillon's Club read Grillion's Club

Acland, Sir Wroth P.: for in 1816 read on 8 March 1816

Acworth, George : after year add he was M.P. for Hindon in 1563

Adair, James : for From 1780 . . Ferrars read From 1775 to 1780 he was whig M.P. for Cockermouth, and from 1793 until his death for Higham Ferrers. for As king's serjeant he read He became king's serjeant in 1782, and omit prime for Ferrars read Ferrers

Adair, Patrick : for 1563 read 1663 for 4 th ser. read 1 st ser.

Adair, Sir Robert : after 1845 insert In 1828 he was made a privy councillor. omit For his services . . o order for His successful mission . . . and the grant read He was appointed G.C.B. (civil) in 1831, and the success of his mission was further rewarded by the grant

Adam, Sir Charles : for January read August after M.P. insert for Kinross in 1831-2 and before from insert in Nov.-Dec. 1834

Adam, Sir Frederick : omit and . . K.C.M.G.

for in 1824 read in 1821

Adam, Robert: The journal referred to was by James Adam [q. v.], not by Robert Adam, and relates to a tour in Italy during 1760-1 (cf. Library of Fine Arts, vol. ii. No. 9, Oct. 1831)

Adam, William: for the general election read a bye-election after the general election

for (who was now attorney-general ... Cornwall) read (who had become solicitor-general to the Prince of Wales in 1802, attorney-general in 1805, and keeper of the great seal of the duchy of . . . Cornwall in 1806)

for for the county of Kinross read for both the counties of Kinross and Kincardine, but he sat for the latter

96 ii 16 f.e. Adams, George : after and insert was transferred to that

13 f.e. omit resigned ... a and

98 ii 1 Adams, John (1662-1720): after never printed insert He was vice-ohancellor of Cambridge University 1712-3

101 i 31 Adams, Sarah F.: for 1827 read 1829

102 ii 17 f.e. Adams, Sir Thomas : for 1667 read 1668

103 i 4

after offices insert He was M.P. for London in 1654 and 1656 for $1667 \mathrm{read} 1667-8$

106 ii 31 Adams, William (1706-1789): before In 1755 insert $\mathrm{He}$ was made prebendary of Lichfield in 1747, prebendary of Llandaff in 1749, and also precentor in the latter cathedral in 1750 omit afterwards

37 after Llandaff insert in $\mathbf{1 7 7 7}$

for the prebendal house read his prebendal house 
Page Col. Line

108. i 9-11 Adams, William (1814-1848): omit There is . . . century

7-6f.e. Adams, William (1772-1851) : for a descendant read of the family

111 ii 22 Adamson, John : for Quillanan read Quillinan

115 i 39 Adamson, Patrick : for Anglicanæread Scoticanæe

116 i 13 Addington, Anthony: for commoner read scholar

14

117 i 8 f.e. ufter school add 1758

119 ii 23 f.e.

120 ii 7 j.e.

121 i 6

122 i 27

124 ii 28

32

34

125 ii 45

132 i 5 f.e.

135 ii 15

136 ii 34

137 ii 9 f.e.

138 i 8-7f.e.

140 ii 20 f.e.
142 i $4-3$ f.e.

142 i 4-3f.e.

$2 f . e$.

155 i 4 f.e.

164 i 12 f.e. ii $13 s q q$.
f.e. boroughs and after third election insert for Wigtonshire
Agutter, William: after Agutter insert who had leanings towards

Addison, John : for 1753 read 1793

Addison, Joseph : after friends insert From 1704 to 1708 he was a commissioner of appeals and for 1706 read 1705

for 1707 read 1706

for Elector of Hanover read Electoral Prince, afterwards George II after speaking insert He was M.P. for Cavan borough in the Irish parliament 1709-1713

Addison, Lancelot: for afterwards read in 1678

Adela : for Poitou read Ponthieux

Adelaide, Queen Dowager : for Lord Melbourne's read Lord Grey's

Adeliza of Louvain : omit ? after 1151

for 23 March .... and read 24 March 1151 (Ann. of Margam) and

Adolphus Frederick, Duke of Cambridge: for 1842 read 1825

Adolphus, John I. : for received .... attorney-general read became solicitorgeneral

after Durham insert 1855

Elfred, King: for 871 read 878

Elfric, called Bata : omit (or the bat)

Elfric, Grammaticus: The suggested identification of Elfric the grammarian with Ælfric, archbishop of York, is confuted in Dr. E. Dietrich's elaborate account of the former in Niedner's 'Zeitschrift fuir Historische Theologie,' 1855, xxv., pp. 487-594, and 1856, xxvi., pp. 163-256. Cf. AElfric's 'Lives of Saints,' ed. by Prof. Skeat, Early Engl. Text Soc., 1881-1900 for St. George read St. Gregory

Elfric (d. 1051): For the use of puttock in the sense of kite cf. Shakespeare's ' 2 Hen. VI,' Act iii. Scene 2, lines 191-3

Affleck, Sir Edmund : after blue insert He was M.P. for Colchester from 1782 till his death, and was a supporter of Pitt.

Aglionby, Edward : after 1544 insert He was M.P. for Carlisle 1552-3

Agnew, Sir Andrew (1793-1849): for Kinsale read Kingsale

after former' insert In 1837 he was conservative M.P. for the Wigton

184 ii 17 Aikin, Arthur : omit at his brother's house

188 i 14 Ainger, Thomas : for 1861 read on 19 Feb. 1859 omit honorary

10 f.e.

l.l.

189 i 24

190 , i 15 f.e.

14 f.e.

Ainslie, George Robert: for general read lieutenant-general for in 1813 read in June of the same year after promoted insert in 1813 after employment insert $\mathrm{He}$ became lieutenant-general in 1825

Ainslie, Sir Robert : for 1804 read 1812

Ainslie, Robert : after Dunse insert Berwickshire after father insert Robert Ainslie (1734-1795) and after Douglas insert Sir Whitelaw Ainslie [q. v.] was his brother after 1838 insert $\mathrm{He}$ and his brother Whitelaw married sisters, the daughters of Col. James Cuninghame, of Balbougie, Fifeshire. 
Page Col. Line

190 ii $24-5$ 26

6 f.e.

Ainslie, Whitelaw : for Whitelaw ( $f$. 1788-1835) read Sir Whitelaw (1767-1837) before was insert was brother of Robert Ainslie [1766-1838, q. v.]. Born on 17 Feb. 1767 at Dunse, Berwickshire, he

after wife insert $\mathrm{He}$ was knighted 10 June 1835, and died 29 April 1837. He married a daughter of Col. James Cuninghame, of Balbougie, Fife shire. His widow died 17 March 1840, leaving an only child, Jane Catherine, who married James C. Grant-Duff. Ainslie Douglas Grant-Duff, the second son of this marriage, assumed, in 1866, the surname of Ainslie

191 i 26-46 Ainsworth, Henry: for was according to the Lancashire historians ..... graduate read was son of Thomas Ainsworth, yeoman of Swanton Morley, Norfolk, where he was baptised. He was admitted to Caius College, Cambridge, 15 Dec. 1587, and resided there as a scholar for four years (Cains College Register). Roger Williains writes with small justification :

196 ii 28

42

199 i 23

200 ii 19

202 i 9 f.e.

7 f.e.

4 f.e.

l.l.

ii $33-34$

35

203 i 3 f.e.

ii 4

6

206 ii $l . l$.

210 i 33

ii $32-33$

ว8

212 1i 21-2 22-3

214 i 15 f.e. 7 f.e.

215 i l.l.

216 i 26

29

235 ii 11 f.e.

236 i 26

15 f.e.

237 ii 22

$2 \% 8$ i 20

for (d.1459 ?) read (d. 1458)

4 f.e. Alcock, Thomas : for (d. 1563) read (d. 1564)

-41 ii 21 f.e. Alder, Joshua : for Easter-Eve real 7 Apr. 'listory' of Ingulf, abbot of Croyland in 1609 4 June 1811

for in the same year read in 1812

omit was promoted . . 1821

for in 1833 read on 15 Feb. 1833 general from 1847 to 1851

after headquarters insert 1851-3 for commission read committee omit' An Epistle . 1744.

Alabaster, William : omit was made . . Cathedral, for Tharfield read Therfield

Alan of Lynn : for ( fl. 1424 ?) read (d. 1421) ad.d Blomfield, Norfolk, viii. 525-6 pp. xl-lviii. after her death insert on $29 \mathrm{Jan} .1824$

Albert, Prince : for (16 Feb.) read (10 Feb.)

$$
\text { for } 19 \text { April read } 10 \text { April }
$$

for (14 Dec.) read (14 Sept.)

Alchin, William T. : after London insert in 1845

Alcock, John : for 1462 read 1471

for 1474 read 1475

Alcock, Nathan : for Wirrel read Wirral

for the Rev. B. W. B. Beatson read the Rev. B. W. Beatson

Aio (d. 974): Note The only authority for the existence of Aio is the spurious

Airay, Henry : after twin brothers insert Airay became prebendary of Canterbury

Airey, Richard, Lord Airey : for deputy adjutant-general read assistant adjutant

before 7 th regiment insert 17 th regiment from 1860 to 1868 and of the for commission appointed in 1879 read committee appointed in 1879 by the commander-in-chief with the approval of the secretary of state for war

Aitkin, John : add He died at Edinburgh on 22 Sept. 1790 (Gent. Mag. 1790, ii. 866)

Akenside, Mark : after. Christ's Hospital insert and to St. Thomas's Hospital

after 1766 add 'An epistle to the Rev. Mr. Warburton occasioned by his treatment of the Author of the "Pleasures of Imagination," 1744, sometimes assigned to Akenside, is by his friend Jeremiah Dyson [q. v.]

Alan of Tewkesbury: add Epistols Cantuarienses, ed. Stubbs, Rolls Series;

Aland, Sir John F. : after 1716 insert He became K.C. in 1714

after the king insert $\mathrm{He}$ was whig M.P. for Midhurst from 1715 until he
became a judge

Albany, Countess of: for Louisa read Louisa Maximiniana Carolisa Emanule

Albini, William de : for the preceding read William de Albini (Brito) d. 1155-6
[q.v.] 
Page Col. Line

243 i 17 f.e. Alderson, Sir James: for Dr. Lee, a dissenting minister read the Rev. George Lee, Unitarian minister.

15f.e. for clerk to a wine merchant real clerk in the army commissariat

ii 5 f.e. Alderson, John: for 1758 reall 1757

$3 f . e . \quad$ afiter boin insert 4 June 1757

244 i $13-12$ omit and several .... Exercises'

f.e.

251 i $17 f . e$. Aldrich, Henry : after college insert He was vice-chancellor of Oxford in 1692

252 ii 18 Aldrich, Robert: for 1536 read 1534

253 i 35 Aldridge, William: for Treveca real Treveca

256 i 17 Alesius, Alexander : ajter a book add viz. the 'Loci Theologici'

19-23 omit (The book .... a year later)

$2 t 4$ ii 1

265 i $10-11$

Alezander III : for 1285 read 1286

266 i 36

ii $23 f . e$.

$15 f . e$.

271 i 9 f.e.

ii 18

282 i 41

41

omit who .... household

for Lewis read Lewes

for 1284-5 read 1284

fơr 16 Mar. 1285 read 16 Mar. 1285-6

Alexander of Hales: for an archdeaconry read the archdeaconry of Coventry for in 1245 iead on 21 Aug. 1245 (LE NEVE)

Alford, Henry : for in 1871 real 7 Jan. 1871

289 ii 28

Alison, Archibald: for (Mrs. Gerald) read the wife of Col. John Gerard, son of Gilbert Gerard [q. v.] and adjutant-general to Lord Lake in India

32

Alison; Sir Archibald : for Cutlar Ferguson read Cutlar Fergusson for 1851 read 1850

294 i

5 f.e.

300 ii 19f.e. Alleine, Joseph: for Charles Sanford read Charles Stanford

303 i 13 Allen, Bennet : for Calvert, George read Calvert, Frederick

305 ii $1-5$ Allen, John $(1476-1534)$ : for even .... till 1515 read at least as early as $150 \$$, when he became prebendary of Lincoln, till 1515

308 i 28 Allen, John (1660?-1741): after patented inse't in 1729

310 i 44 Allen, John (1771-1843): after his death insert He was auditor of the duchy of Lancaster from 1841 till his death

311 ii 16 f.e. Allen, Ralph : for Coventry, Lichfield reacl Coventry and Lichfield

313 i 30 Allen, Thomas (1542-1632): for Peleusiensis read Pelusiensis

326 i 23-2 Alley, William : for with the prebend of St. Pancras in that church read and to f.e. the prebend of St. Pancras in that church in 1559-60

329 i 33 Alleyn, Edward : for 1622 read 1623

330 i 19 Allibond, John : for St. Mary-le-Crypt read St. Mary-de-Crypt

38 after. 'Clerk's Register' insert in Bloxam's Register of Magdalen College, Oxford

332 ii 20 f.e. Allin, Sir Thomas : for November 1670 read 15 Apr. 1671

6 f.e. $\quad$ for 1785 real 1685

358 ii 5-4f.e. Amherst, Jeffrey, Baron Amherst: for and made governor of Virginia read He was made governor of Virginia in Sept. 1768

359 i $20-22$ for in 1780 colonel .... the 2nd Life Guards read in April 1779 colonel of the 2nd Horse.Grenadiers, transferring him to the colonelcy of the 2nd Horse Guards in 1782

361 ij 7 Amherst, William P., Earl Amherst : add He was gazetted governor-general of Canada on 1 Apr. 1835, on the nomination of Peel, but a change of ministry followed immediately, and he did not take up the appointment

366 ii l.l. Amos, Andrew: after Brompton insert serving from 1847 to 1852 and for 1848 read in May 1849

367 ii 15 f.e. after politics insert He died $18 \mathrm{Apr} .1860$

369 i 9-10 Amyot, Thomas: jor having become treasurer . . 1829 real as treasurer of the latter society from 1823 to 1847

384 i 19 Anderson, John ( $f$. 1799) : for T. Bursley read T. Bensley

26-30 for His treatment of foliage ... may be attributed read His treatment of foliage is seen to admirable advantage in the cuts in Bloomfield's 'Farmer's Boy.' The first edition of this work (1800) states that the 'ornaments' were engraved by Anderson. Nevertheless its euts have long been erroneously ascribed to Bewick 


\section{ERRATA-Volume I}

Page Col. Line

401. ii 6 f.e.

402 i 7

ii 13

405 ii 22

421 ii 35

423 i 13

425 i $12-11$

$$
\text { f.e. }
$$

8-7 f.e.

ii $\quad 1-9$

Andrewes, Lancelot: before His insert From 1589 to 1609 he was prebendary of Soutliwell

after stall insert (1597-8)

after Essex insert He died 26 Sept. 1626

Andrewes, Eusebius: for Holton read Hopton

Anne of Bohemia : for duke of Bedford read earl of Bedford

Anne, Queen of Richard III : for seven years old read five years old

Anne (Boleyn) (1507-1536) : omit (though . . . descended)

for was afterwards made duke of Norfolk read had his father's dukedoin restored to him

for It was Mary Boleyn ... and being made, read Both sisters spent some of their early years in France. It would seem that Anne, then seven years old, accompanied her elder sister Mary, when she went thither in the suite of Henry VIII's sister Mary, who was married to Louis XII in 1514. Mary Boleyn was in England again in 1520, when she married William Carey; while Anne, who became

11 for she remained there read she remained in France

23-4 for Sir William Cary read. William Carey

9-8f.e. for Sir Piers Butler, son of the Earl of Ornond read the son of Sir Piers Butler, Earl of Ormond

432 ii 11 f.e. Anne of Denmark : for Upslo read Opsloe

448 ii 31 Anne, Queen : after letter insert (the original is at Longleat)

450 i $\quad 35-6$

455 i 14 f.e.

458 ii 17 f.e

466 ii $35-6$ omit [for further details ... GLovCESTER]

for flattered read fluttered

for Trimmel read Trimnel

for Dr. Smallridge read. Dr. Smalridge 


\title{
Dictionary OF NATIONAL BIOGRAPHY
}

\author{
ERRATA IN VOLUME II
}

\author{
ANNESLEY_BAIRD \\ N.B.-f.e. stands for from end and 1.7. for last line \\ Page Col. Line \\ 3 i 10 Annesley, Arthur, 1st Earl of Anglesey : for 1672 read 1673 \\ 10 f.e. $\{$ for Strafford read Stafford \\ 4 i 16 Annesley, Francis, Viscount Valencia : for 1613 read 1614 \\ 27 before In 1622 insert In 1625 he became M.P. for the county of Carmar- \\ then in the English parliament \\ 8 ii 35 Annesley, Samuel : for the meeting-house read at the meeting-house \\ 33 i 15 Anson, George, Lord Anson : after administration insert He was M.P. for Hedon \\ from 1745 to 1747 \\ 36 ii 13 f.e. Anspach, Elizabeth, Margravine of : for 1780 read 1783 \\ 37 i 34, 35 for Nevertheless . . . . separation read Three years later they separated \\ 39 ii 30 Anstey, Christopher: after other pieces insert 'A Serious Alarm to the People \\ of Bath' [1772]; 'The Priest Dissected,' an exceptionally virulent satire \\ 34 for was a contribution read and 'Priest Dissected' were contributed \\ 40 i 16 Anstey, Thomas C. : omit at Wellington College and \\ l.l. omit the government of \\ ii 30,31 for he retired from parliamentary life read he failed in his candidature for \\ Bedford, and his parliamentary life ended \\ 43 , i 24 \\ Anstis, John, the elder: for 1745 read 1744 \\ 31-35 for Although a strong tory he voted ... among the 'tackers' read As \\ a strong tory he voted for the bill for the prevention of occasional con- \\ formity, and his name appeared among the 'tackers' \\ ii 37-8 for 1744-45 read 1743-44 \\ 44 i 20 f.e. for folio read quarto
}

45 i 10 Anstis, John, the younger: for Coliton read Colyton

11 f.e. Anstruther, Sir John : after 1790-96 insert and for Crail and Anstruther district of Burghs 1796-7. He was solicitor-general to the Prince of Wales 1793-5

4 f.e. for and created a baronet read and in 1798 was created a baronet

46 i 6 f.e. Anstruther, Robert: for June read January 1809

50 i 38 Appleyard, Sir Mathew : for 1669 read 1670

ii 15 f.e. for Headon read Hedon from 1661 till his death

12 f.e. after State, insert was M.P. for Charlemont in the Irish House of Commons 1665-6,

12-11f.e. $\quad$ for in 1669 read on 20 Feb. $1669-70$

8 f.e. $\quad$ for vii. read ii.

54 i 1 Aram, Eugene: for Netherdale read Nidderdale

30 for a private school at Lynn Regis read the corporation school of Lynn Regis

61 ii 6 Arbuthnot, Charles : after. St. Ires insert and in 1830-1 the constituency of Ashburton 
Page Col, Line

67 i 14 f.e. Arbuthnot, Sir Thomas: for queen read prince-regent

9 f.e. $\quad$ after rank of insert major-general in 1825, and of

5 f.e. $\quad$ for in 1849 read on $26 \mathrm{Jan} .1849$

ii 29 Archdall, Mervyn : after cathedral insert this he resigned in $\mathbf{1 7 7 2}$

71 i 26 Archer, John (1598-1682): for Hide read Hyde

44 for 1661 read 1672

75 i 23 f.e. Arden, Richard P., Baron Alvanley : for In 1782 he became M.P. for Newton read In 1783 he became M.P. for Newtown (I. of W.)

22 f.e. $\quad$ for a year later read two years later

78 i 24 Ardmillan, Lord : for Crawford read Craufund

83 i 17 Arkwright, Sir Richard : for Reed real Need

i 8 f.e.

85 i $20-26$

28

36

37

$42-46$

61

87

94 i 16-14

t.e.

l.l.

$2 f . e \cdot$

99 ii 11

100 i 12-11

f.e

ii 35

103 i, 14 f.e.

9 f.e.

7 f.e.

105

25 f.e.

24 f.e.

$22 f . e$.

ii $25 f . e$.

113 ii 24

30

117 i 22-23

118 ii 36

119 ii 29

35

for That Arkwright was not over-scrupulous . . . . the character of a barber read It has been argued in error that Arkwright misdescribed his occupation in his first patent, but as a matter of fact he merely described himself there as 'of the town of Nottingham in the county of Nottingham,' nor was any trade mentioned in his second patent

omit moreover

for inventions of Paul .... patents read invention of Lewis Paul [q. v.]. who had obtained a patent

omit and 1758

for Not only did Paul .... adopted reaul Another of Paul's machines patented in 1758 did not include spinning by rollers

for it is now known that read according to the somewhat disputable evidence of Baines

Armine, or Armyne, Lady Mary : for LADY MARY read MARY, LADY

f.e. Armstrong, John (1673-1742): for 1673 read 1674

after 1742) insert ' Chief Engineer of England, born at Ballyard, King's Co., 31 March 1674, was eldest son of Robert Armstrong, who married Lydia, daughter of Michael Howard of Ballyard. He saw much active service under the Duke of Marlborough and Prince Eugene. He

for He appears . . . England, read He was quartermaster-general from Jan. 1712-3 and 'Chief Engineer of England' from Nov. 1714 till his death on $25 \mathrm{Apr}$. 1742. In 1716, while Armstrong was surveyor-general of the ordnance, Woolwich Arsenal was founded, but though the development of the scheme owed much to his co-operation it is doubtful if it was initiated by him [see Schalch, Andrew]. He

after the 'Report' insert He married on 20 Sept. 1714 Anne Priscilla, daughter of Major Burroughs, and left five daughters, of whom the second, Anne, became second wife of Benjamin Hoadly (1706-1757) [q. v.]

for Badesdale read Badeslade

Armstrong, John (1813-1856): after truer insert popularity

Armstrong, Sir Thomas : omit joined Ormond ..... and

after Stafford insert in the two parliaments of 1679 and in the one of 1681

Arnald, Richard : after was insert senior wrangler in 1766

for preceptor read sub-preceptor

after canon of Windsor insert in $\mathbf{1 7 7 9}$

Arne, Thomas A.: for In the same year real On 12 Jan. 1734

omit (19 Dec.)

for Early in the following year read Shortly afterwards

for 30 March read 20 March

Arnold, Thomas (1795-1842) : after his father insert William Arnold

after the heart insert on 3 March 1801. (There is a tablet to his memory in Whippingham church.)

for other sermons . . . lifetime read 'Christian Life' (1841) and two posthumously published volumes of sermons (edited by Mrs. Arnold in 1842 and 1845)

Arnold, Thomas J. : for Stephen read Samnel

omit This was .... appeared

Arnot, Hngo: for 1777 read 1776

for 1817 read 1816 


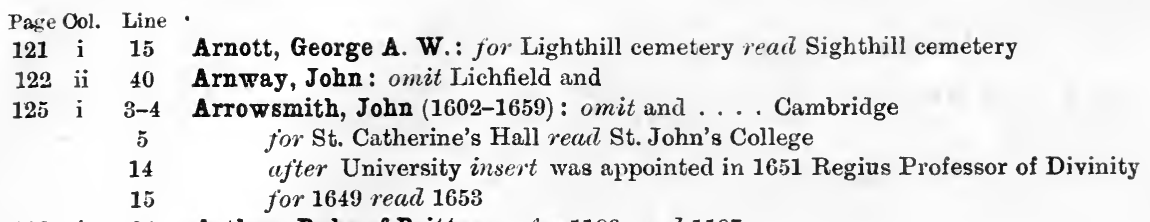

129 i 31 Arthur, Duke of Brittany : for 1189 read 1187

131 i 32 Arthur, son of Henry VII : after the Bath insert and in 1491 knight of the Garter

132 ii 4 f.e. Arthur, Sir George: for 1823 read 1824

135 ii 9-10 for in $1853, \ldots$... year read was promoted major-general in 1846 and lieutenant-general in 1854. He died on 19 Sept. 1854

141 ii 3 Arundell, of Cornwall: for Perranzabula read Perranzabuloe

143 i 10 Arundell, Lady Blanche: for Lady Blanche read Blanche, Lady

145 i 3 Arundell, Henry : for 26 Dec. read 29 Dec.

146 i 4 f.e. Arundell, John $(d .1477)$ : for the deanery read a canonry
ii 26 Arnndell, John $(d .1504)$ : after living insert He became treasurer of Hereford in 1464 and prebendary in 1476

147 i 14 f.e. Arundell, Sir John (1576-1656?): for 1623 read 1643

11-9 for He was at different times . . . Michell read he was M.P. in 1597 for f.e. Michell

6 f.e.

148 i 22

29

30

153 i 32 ii 24 f.e.

159 ii 35

160 i 3

2 f.e.

ii $\mathbf{2 - 3}$

162 i 24 f.e.

163 ii 12 f.e.

164 i 13

165 ii 6 f.e.

166 ii 27

170 i 32

ii 4

25

$172 \quad$ i 37

$173 \mathrm{i} \quad 41$

ii 13

177 ii 3 f.e.

178 i 19 f.e

ii 4-5

23

187 i 26

190 i 8

after Edward I insert In 1601 and 1621 he was M.P. for Cormwall, in 1624 for St. Mawes, and in 1628 and the Short Parliament of 1640 for Tregony

Arundell, Richard: for 1639 read the Short and Long Parliaments of 1640

before and insert He was elected M.P. for Beeralston in 1660, and again in 1662

for 1664 read $1664-5$

Ascham, Roger: for John Tindal read William Tyndale for of whom read and

Asgill, Sir Charles: for the colonelcy of the 85th Foot in Oct. 1806 read the colonelcy of the 3rd West India Regiment in 1806, that of the 85th foot in Oct. of the same year

Asgill, John : after Bramber insert and was first elected for the place in 1699, retiring at the dissolution of 1700 for On the dissolution of 1707 read After the prorogation in 1707 omit being returned to the next parliament

Ashburnham, John : after the duke insert In 1628 he was elected M.P. for Hastings for 1643 read 1643-4

after any other insert He was M.P. for Sussex from 1661 till his expulsion in 1667 for taking a bribe of $500 l$. from French merchants

Ashburnham, William: after the household insert and was elected M.P. for Ludgers Hall in 1661, sitting till the dissolution of 1678

Ashby, George (1724-1808) : for 926, 1006, 136 read $92 b-100 b, 109,111,112$

Ashby, Sir John: after he died insert He was comptroller of the store-keeper's accounts in the navy from 1690 till his death

Ashby, Sir Anthony : for 1627 read 1628

after Eliz.) insert He was M.P. for Tavistock in 1588 and for Old Sarum in 1593 for 1627 read $1627-8$

Ashley, Robert : before His mind insert He was M.P. for Dorchester in 1597

Ashmole, Elias : for Martin read WiLliaM omit commissioner

Ashton, John (d. 1691): before was clerk insert of the family of Ashton of Penketh

after 1690-1 insert being buried at St. Faith's under St. Paul's on the same day

for Ashton's widow .... Rigby read Ashton married in 1685 Mary, daughter of Edward Rigby of Covent Garden. She

Ashton, Peter : for ( $f l .1546)$ read (d. 1548), translator, was prebendary of Lincoln in 1542, and died in 1548. (Le Neve's Fasti.) He

Ashworth, Sir Charles: for 1825 read 1830

Aske, Robert : for On a tower read On the tower 
Page Col. Line

192 i 7 f.e.

ii 33

202 ii $11-10$

f.e.

Askew, Anthony : for 1772 read 1774

ii 8 f.e.

7 f.e.

4 f.e.

3 f.e.

Astell, William: for in the same year .... the House read after an unsuccess-

ful contest in 1806 was in 1807 returned to the House

for six successive read seven successive

$203 \quad 29$

after subsequently insert from 1841

after filled insert each of

after London insert He died 7 March 1847

205 ii 15 f.e. Astley, Sir Jacob: for Manchester. During read Manchester during

14 f.e. after (27 Oct.; insert a full stop

206 i 9 for Stow-in-the-Wold read Stow-on-the-Wold

ii 30 Astley, John (d. 1595): before Maidstone insert Lyme Regis in the parliament of 1750 and

31-32 omit having before .... Commons

212 i 44 Aston, Sir Richard : for the Rockingham read Lord North's

ii 4 f.e. Aston, sir Thomas: after part insert $\mathrm{He}$ was M.P. for Cheshire in the Short Parliament of 1640

219 i 2 Atherton, Sir William: for 1852 read 1851

ii 28 f.e. Atkins, Henry : for He read Matriculating at Trinity College, Oxford, in 1574, he

221 i 24 f.e. Atkins, William : for 1679 read 1681

222 ii 6 f.e. Atkinson, James (1759-1839): after grave' insert In addition to his other acquirements, Atkinson had a remarkable talent for portraiture, and no less than eight portraits by him, variously in oils, water colours, and pen and ink, are in the National Portrait Gallery

5 f.e. $\quad$ for $\mathrm{His}$ works are : 1 read His only work is

4 f.e. $\quad$ for 2 read The

223 i 3 after 8vo. insert usually ascribed to our James Atkinson, was by James Atkinson, 1780-1852 [q. v.]

226 ii 14 f.e. Atkinson, William : for within the bounds .... of York read in the ainsty of York

227 i 19 Atkyns, Sir Edward : for Hensington read Bensington

229 i 19 f.e. Atkyns, Richard : for Newnham-by-Gloucester read Newnham-on-Severn

232 i 8 f.e.

ii 14 f.e. Atkyns, Sir Robert: for Saperton read Sapperton

5 f.e.

234 i 20-23 Atterbury, Francis : for been thrust . . . . the Reformation read been elected to the mastership of University College in 1676, had printed an attack upon the Reformation from the pen of Abraham Woodhead

24 f.e. $\quad$ after in reality insert in great part

235 i $26 \quad$ for 1711-12 read Ang. 1711

ii 16 for bishop of Rochester read dean of Westminster

16 f.e. $\quad$ after $\mathrm{He}$ was arrested insert in 1722

237 ii 7 f.e. for in 1732 read on 22 Feb. 1731-2

238 i 21 f.e. Atterbury, Lewis (d. 1693) : after in town insert From 1690 till his death he was prebendary of Lincoln

241 i 5 Attwood, Thomas: after wrote insert other anthems

242 i 4 Attwell, Hugh : for Duborne read Daborne

245 ii 9 f.e. Aubrey, William: before He died insert He was M.P. for Carmarthen Borough in 1554, Brecon in 1558, Hindon in 1559, Arundel in 1562, and Taunton in 1592

247 i 20 Auchmuty, Sir Samuel : for made a knight of the Bath read knighted

22-3 omit and .... 103rd regiment

27-32 for 1806 had been nothing .... Buenos Ayres, which read 1806 had been suggested to Sir Home Riggs Popham [q. v.] when at the Cape by the report of an American merchantman to the effect that the inhabitants of Monte Video and Buenos Ayres were discontented with their Spanish government, and Sir Home Popham recognised that the seizure of a rich city like Buenos Ayres

ii 16 before and in 1810 insert and made colonel of the 103rd regiment

18 f.e. after parliament insert became knight of the Bath

13 f.e. after active service insert In that year he became G.C.B. 
Page Col. Line

248 ii 10

20

249 i 5 f.e.

ii $\quad 27$

$350 \quad$ i $\quad 29$

ii 34

251 i 10-11

4 f.e.

Audley, Edmund : for Hereford read Lichfield for Gevendale read Givendale

Audley, Hugh : after money-lender insert admitted student of Inner Temple Nov. 1603, and called to the bar 1611

after of Literature' insert Audley Street in west London, which runs through lands owned by him, was named after him.

Audley, James : for 1369 read 1386

$$
\text { for } 1362 \text { read } 1367
$$

Audley, Thomas, Baron Audley : for Magdalen College, Cambridge .... He then came read Cambridge, apparently studying for a time at Buckingham College, which was founded in 1519. In 1542, two years before his deatl, he reconstituted the foundation at his own cost, and obtained a royal license to change its name to 'the College of the St. Mary Magdalene.' Audley was thus founder of Magdalene College, Cambridge after More insert In 1529 Audley was elected M.P. for Essex

Aufrere, Anthony : for in the preface . . . . in the reformation read (The "Tribute" was really by Herder, and appeared under the title of 'Denkmal Ulrichs von Hutten' in the 'Teutscher Merkur' for July 1776, being reprinted in a spurious edition of Goethe's works in 1779; see Herder's 'Werke,' ed. Hempl, xv. 355.)

Augustus Frederick, Duke of Sussex : after 1773 insert He was made K.G.in 1786 for 1839 read 1838

Austen, Jane : for July read January

Austin, John (1613-1669) : for Hicks read Hickes

Austin, John (1790-1859): after Timon insert [Cormenin]

Awdelay, John : for 1575 read 1567

Aylmer, John : after persuasion insert He resumed the Stow archdeaconry in 1559 before For the next insert and received three prebends in Lincoln Cathedral

Aylmer, Matthew : before After the peace insert and was also appointed a lord of the Admiralty after peerage insert of Ireland

after Balrath insert $\mathrm{He}$ had been elected whig M.P. for Portsmouth in 1695 and for Dover in 1697, 1713, and 1715

Ayloffe, John : after (iii. 186) insert together with another poem 'On the Cambridge Commencement, by Captain Ayloffe' (iii. 188-9)

Ayloffe, Sir Joseph : for Cowdry read Cowdray

Aymer de Valence $(d .1200)$ : for 1352 read 1252

Ayreminne, Richard de : after Norwich insert $\mathrm{He}$ became prebendary of York in 1316

Ayreminne, William de : after Salisbury insert Hereford 1320 for he is said .... received read while living in France, he received for and to have... pope's nomination read The pope was then at Avignon, and Ayreminne immediately obtained his nomination

Ayscough, Francis : for 1766 read 1763. for Bristol .... Magazine' read Bristol in 1761. He died 16 Aug. 1763 Ayscough, Samuel: for John Wane read Hans Sloane

Baber, Sir John : for March 1660 read March 1660-1

Babington, Francis : for Keymes read Keynes

Babington, Gervaise : for prebendary read prebend

Backwell, Edward: for Lisscosis's read Lrpscome's for the same year read 1673 for 1680 read 1681 for 1657 and .... and the city read 31 Jan. 1659-60, and was discharged from that office on payment of $700 l$. on 13 June 1661 for Libscomb's read Lipscomb's

Bacon, Ann: for LADY ANx read ANn, LADY

for John Cawnton of London read Sir William Fitzwilliam of Gains Park, Essex

13-12 Bacon, Francis : for in June 1575 read on 27 June 1576

f.e. 


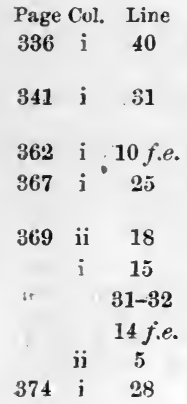

39

32-5

385 i 7 f.e.

388 i 8

389 i $12-13$

15

17-19

394 i 6 f.e.

399 i 13

5

Bacon, Francis : after seat in it insert (he had been returned both for Ipswich and St. Albans and sat for the former)

after resources insert Bacon had been elected for Ipswich, St. Albans, and Cambridge University, and sat for the last

Bacon, John (1740-1799): for Whitfield's read Whitefield's

Bacon, Sir Nicholas: after Cambridgeshire insert and next year was elected M.P. for Dartmouth for it. read Hist. Comm. MSS. Rpt.

after 1562 insert in which year he had been elected M.P. for Beverley for son of the lord keeper's fourth son read fourth son of the lord keeper's son after 1604 insert was M.P. for Norfolk in the same year omit for Suffolk (1592-3)

Bacon, Robert: after Edmund Rich insert which has been identified with the MS. C 12, 9 at St. John's College, Cambridge. A fragment, or a fragment of an abridgment of it, is at the end of Lambeth MS. 135 (cf. Wilfrid Wallace, St. Edmund, 189:, pp. 5-6). for this read the life omit but as a separate work . . . a authority

Badew, Richard : after 1326 insert and again in 1338

Badiley, Richard : jor ( $f i .1649-1656)$ read (d. 1657) for In the summer of 1656 read On $14 \mathrm{Feb}$. $1655-6$ after the Downs insert (Public Intelligencer, 11-18 Feb. 1655-6)

for he probably died ..... whilst read he died in August 1657, according to the announcement in 'Mercurius Politicus,' 11 Aug. 1657

Bagehot, Walter: after of thought insert $\mathrm{He}$ was the unsuccessful liberal candidate for Bridgewater against George Patton [q. v.] in 1866

Bagot, Lewis: omit was

for his deanery read the deanery of Christchurch

Bagot, Richard: for Blithfield ..... Worcester read Blithfield. In 1812 he became prebendary of Lichfield; in 1817 canon of Worcester, and in 1822 canon of Windsor; he was appointed dean of Canterbury 2 Sept. 1827

ajter D.D. insert he held the deanery of Canterbury in commendam

Bagot, Sir William : after (Claus. 1 H. IV) insert He was M.P. for Warwickshire in eleven parliaments, from Feb. 1387-8 till his death

Bagshaw, Christopher: before About 1579 insert In 1578 he was made prebendary of Lichfield

10 f.e. Bagshaw, Henry: before and insert in 1668

8 f.e. for Barnaby read Barmby

2f.e. for 1681 read 1680

6 Bagshaw, William: for Chalmarton read Chelmorton

28 f.e. Bailey, Thomas: jor Gillingham read Gilling

16 f.e. Baillie, Charles (1542-1625): for Rudolfi read Ridolfi for L.H.S. read I.H.S.

Baillie, Charles, Lord Jerviswoode (1804-1879) : for 1683 read 1684

Baillie, John (1772-1833) : for from 1830 to 1832 read in 1830 and from 1832 till his death next year

before $\mathrm{He}$ was elected insert $\mathrm{He}$ was a moderate whig supporting Catholic

8 before He was elected insert He was a mode

22-3 Baillie, Matthew : for Duntisbourne read Duntisburne Abbots Baillie, Robert (1599-1662): for James Charles Stuart read Prince Charles Edward
Stuart

27 Baily, Edward H. : for British read Bristol

Bainbridge, Christopher : for 1511 read 1511-2

Bainbrigge, Sir Philip : for on 31 March 1854 read in May 1860

Baine, James: omit a tradition runs that after Lord's Supper there insert in accordance with the principle of his denomination ' to hold communion with all visible saints , for Whitfield read Whitefield

Baines, Matthew T.: for Lord Russell's read Lord John Russell's

Baines, Thomas (1822-1875): for 1876 read 1875

Baird, Sir David : for a filibustering read the 


\title{
DiCTIONARY OF NATIONAL BIOGRAPHY
}

\author{
ERRATA IN VOLUME III
}

\author{
BAKER-BEADON
}

\section{Page Ool. Line \\ vi ii 4 \\ 3 ii $36-7$ \\ 12 i 21}

23

24,25

27

19 f.e.

List of Writers : insert E. S. . . . Edward Smith

N.B.-f.e. stauds for from end and 7.7 . for last line

Baker, David: for hitherto unpublished read published in Ellis's 'Original Letters,' 2nd ser. iii. 256

Baker, Sir John (d.1558): after law insert on 12 May 1520 he was made undersheriff and judge of the Sheriff's Court of London (Letter Book N, fo. $136 \mathrm{~b})$. That post he held until he was appointed recorder of London in Nov. 1526 (ib. O, fo. 168 b).

after Denmark insert In 1529 he was elected to parliament for both Bedford and City of London and sat for the latter constituency till 1536.

He was subsequently M.P. for Guildford 1542-4, Lancaster 1545-7, Huntingdonshire 1547-52, Bramber 1553, and Kent from 1554 till his death. for Not long afterwards read In July 1585, when he resigned the recordership omit elected speaker.... subsequently

after exchequer insert Two years later, 1547, he was elected Speaker.

after office insert of chancellor of the exchequer

13 i 6 Baker, John (1661-1716): after 1716 insert He was whig M.P. for Weymouth in 1713, was unseated on petition next year, was re-elected in 1715 .

after death insert was whig M.P. for Hythe in four. parliaments from 1722 till his death

14 i 35

38

Baker, Philip : after He insert was proctor at Cambridge in 1549 and after appointments ; insert he was a prebendary at Hereford 1560-9.

ii 15 f.e. Baker, Sir Richard : after Baker insert was M.P. successively for Horsham, Lancaster, Romney, and Shoreham in the parliaments between 1554 and 1558. $\mathrm{He}$

15 i 5

before In 1603 insert In 1593 he was elected M.P. for Arundel and in 1597 for East Grinstead

25 ii 11 f.e. Balcanquhall, Walter, D.D.: for 1624 read 1624-5

28 ii 3 f.e. Baldock, Robert de : after pluralities insert He held prebends in the cathedrals of Lichfield and Lincoln

35 ii 16 Baldwin, George : for 1818 read 1826

17-19 for was born .... uncertain read son of William Baldwin, hop merchant in the Borough, was born about 1743.

29, 30 for from Cyprus .... death read of the death of his brother, consul at Cyprus.

$\begin{array}{llll}36 & \mathrm{i} & 13 & \text { for } 1778 \mathrm{read} \\ 1798\end{array}$

11 f.e. $\quad$ after Baldwin insert died 19 Feb. 1826, aged 83 (Gent.Mag.1826, i. 283). He

8 f.e. $\quad$ after her insert Dean Burgon wrote a memoir of Mrs. Baldwin, his great aunt, who died in 1839 (Gent. Mag. 1839, ii. 656-8).

38 i 19 f.e. Baldwin, Sir Timothy : after 1660) insert holding the office till 1663. 


\section{ERRATA-VOLUME III}

Page Col. Line

42 i 13

57 ii 13

14

15

61 i 1

19

20 f.e.

18 f.e.

17 f.e.

76 ii 31

24 f.e.

21 f.e.

Bale, John : for 1559 read 1558

Balfour, Nesbit : after Burghs insert from 1790 to 1796

after Arundel insert from $\mathbf{1 7 9 7}$

after made insert colonel of the 93rd regiment in 1793 and

Balguy, John : for 1727 read $1727-8$

Balgny, Thomas : for 1785 read 1795

after shire insert $\mathrm{He}$ was a prebendary in Lincoln cathedral from 1748 till his death.

for Salisbury read Winchester omit the line

Ball, John (1585-1640): for Treatise read Catechisme for a William Seaman in $\mathbf{1 6 6 6}$ read William Seaman [q. v.] in $\mathbf{1 6 6 0}$

Ball, Nicholas : after Inn insert and one of the king's Irish serjeants. for 1835 read 1836 after Ireland insert in July 1838

89 ii 6-5 f.e. Balmford, James: for Andrew Barnes read Aubrose Barnes

103 i 8 Bampfield, Thomas : for $(f l .1658)$ read (d. 1693)

ii $17 f . e$. Bampfylde, John C. : for vii. 309 read iv. 301

104 i 3 f.e. Bampton, John : for in 1751 read 2 June 1751, aged 61

The articles on John van der Banck and Peter van der Banck are re-written under the headings Vanderbank, John, and Vanderbank, Peter. (See volume lviii. pp. 100-101.)

24 f.e. Bancroft, Edward : after Priestley insert was born at Westfield, Massachusetts, 9 Jan. 1744. He received only a rudimentary education, and after a few years' apprenticeship to some trade ran away to sea. In 1763 he settled in Guiana, where he practised medicine. He afterwards removed to England, where he was elected F.R.S. 20 May 1773. Meanwhile he after them insert Bancroft died at Margate on 8 Sept. 1821. Edward Nathaniel Bancroft [q. $\mathrm{v}$ ] was his son.

107 ii 30, 31 Bancroft, John: for the resignation of Dr. Samuel Harsnett read the promotion of Dr. Samuel Harsnett to the see of Chichester.

109 ii 7 Bancroft, Richard: for In April 1585 read On 10 Feb. 1585-6

4 f.e. $\quad$ after \&c. insert He was a prebendary of Canterbury from 1595-7. omit the cross reference BANGoR, HUGH

115 i 28

120 i 9

s f.e. et seq.

Banister, Richard : for 1624 ? read 1626

for was living . . . . about 1624 read was buried at St. Mary's, Stamford, Lincolnshire, 7 April 1626. His wife Anne was buried there on 16 April 1624.

ii 4 Banister, Sir William : for ( $f$ l. 1713) read (d. 1721)

27 after 787) insert He died at Turk Dean on 21 Jan. 1720-1, and was buried in the church there (Hist. Reg. 1721, Chron. Diary, p. 6).

Bankes, Henry : after year insert and was returned without opposition in 1830

2 f.e. $\quad$ for 1830 read 1831

ii 10 for Woodward read Woodley

19 f.e. Bankes, Sir John : after parliament insert in 1624 for Wootton Bassett and

123 i 16 Bankes, Lady Mary : $f c r$ Lady Mary read Mary, Lady

124 i 12 f.e. Bankes, William John: after 1811 insert $\mathrm{He}$ was a tory like the rest of his family

11 f.e. $\quad$ for 1821 read 1822

9 f.e. $\quad$ for 1825 read 1826

8 f.e for 31 read 32

5 f.e for lost this seat read voluntarily retired

128 ii 14-18 Banks, John : for Mention is made . . . . British Museum read On the title-page of an edition of his poems in two volumes (London, 1738) his name is spelt Bancks

129 ii 28, 29 Banks, Sir Joseph : omit after taking . . . degree

131 i 23 f.e. after Deal insert On 21 Nov. Banks was created Hon. D.C.L. at Oxford

136 ii 13 Bankwell, John de: after 1308 read He had been alderman successively of Cripplegate (1286-9) and Dowgate (1291-8) wards, and was the first 'clerk' or Town Clerk of London on record. (Cf. Letter Book A, fo. 74 b, under date Nov. 1284.) He lost his life by being trampled on at court at Edward II's coronation, 25 Feb. 1308 
Page Col. Line

139 i 29

ii 1,2

Bannerman, Anne: for ( $f$. 1816) read (d. 1829)

for We have not ... . career read She died at Portobello near Edinburgh on 29 Sept. 1829.

18 f.e. Bannerman, James, D.D. : for Ormond's read Omond in

i 6 f.e. Barclay, Alexander : for Much Badew read Great Baddow

167 ii $35 \quad$ Barclay, Joseph : for 1881 read 1879

175 ii 19 f.e. Bardelby, Robert de : after 1321 insert $\mathrm{He}$ was a prebendary of York in 1305

176 ii 33 Bardolf, William: for on read after and for 5 read 13

182 ii 16 f.e. Barford, William : after 1771 insert He was proctor in 1761

14 f.e. $\quad$ for 1761 read 1762

191 ii 13 Baring, Charles Thomas : omit Thomas

17 f.e. for 1841 read 1861

17, 18 Baring, Sir Francis : for

19,20 omit at the ... Baring

28 after represented insert as a whig

11 f.e. $\quad$ for 1790 read 1772

Baring,

7 f.e. Baring, Thomas : for two . . . 1838 read three subsequent occasions, 1837, 1838

3 f.e. $\quad$ for 156 read 165

ii 12 after Baring insert He was chairman of the committee of Lloyds and, like Sir Francis Baring [q. v.], president of the London Institution

27 Baring, William B., 2nd Baron Ashburton : for After the Reform Bill he read He sat for Winchester from 1832 to 1837 ; up to that date he was a moderate whig, but it was as a Conservative that he

7 f.e. $\quad$ for She read Lady Ashburton

194 i 5

for no surviving issue read one daughter, Mary Florence, who married, 30 April 1884, Lord William Compton, afterwards fifth Marquis of Northampton

195 i 25 f.e. Barker, Sir Christopher : for Risebane read Rysbank

201 ii 16-14 Barker, Hugh : omit and for several years . . . . in London

f.e.

Barker, Sir Robert : after Wallingford insert in 1774

213 ii 10

216 ii 17

217 i 4

Barker, William: after 1571 insert and was
Barkstead, John : for John read Sir John after Middlesex insert having been elected for Reading as well after 1659) insert He was elected alderman of Cripplegate Ward 22 Feb. 1657-8 (Repertory 66, fo. 51), and held the office till discharged on the score of 'infirmity,' 31 Jan. 1659-60 (ib. 67, fo. $36 \mathrm{~b}$ ).

Barlow, Sir George H. : for 1847 read 1846

ii 18 f.e. after Bath insert in Oct. 1806

221 i 24 f.e. after a year insert He was made G.C.B. in 1815

22 f.e. $\quad$ for Eebruary 1847 read 18 Dec. 1846

222 ii 8 f.e. Barlow, Peter : for 1827 read 1862

225 ii 3 f.e. Barlow, Thomas: for 1657 read 1657-8

229 ii 18f.e. Barlow, William (d.1568): for (d. 1568) read (d. 1569?)

231 i 2 f.e. $\quad$ for August 1568 read probably 10 Dec. 1569

ii 13 for Wykeham read Wykeham, or more correctly Wickham

233 i 12 f.e. Barlow, William (d. 1613): for 1600 read 1608

ii 24 for Mayer read Mayor

234 i 4 Barlow, William (d. 1625): after James I insert was made prebendary of Southwell in 1614 and of York in 1617

235 ii 8-9 Barnard, Sir Andrew F. : for Mary .... Bovagh read his second wife, Sarah (Robertson), of Bannbrook, co. Londonderry

54-55 omit In July . . . Bath

l.l. after clasps insert He was made K.C.B. in January 1815

236 i 17

22 f.e. for grand cross read knight

21 f.e. $\quad$ for 1834 read 1819 and a grand cross in 1833 
Page Col. Line

237 ii 18

19

21

240
Barnard, Edward : for 1761 read 1760

for 1764 read 1765

for 1801 read 1781

Barnard, John (d. 1683) : for Asgarty read Asgardby

4 Barnard, John ( $f$. 1685-93) : for 1688 read 1688-9

15 f.e. Barnard, Sir John : for 1750 read 1758

14-13

f.e.

13 f.e.

omit from $1750 \ldots$. . Bridge Without

after which insert ultimately

ii 21-20 Barnard, Sir John : for About 1758 ..... and, after he had been dead read He f.e.

8-7f.e.

243 ii 23

244 i 15-16 ii 32

245 ii 4 f.e. 246 ii 36

4 f.e.

247 i $5-6$

248 i 17 ii 6

21 f.e. 20 f.e.

263 i 18 f.e. was president of Christ's Hospital from 1740 till his retirement
corporation and from public life in 1758 . He, having been dead

for Jane ..... Palmerston read Jane married the Hon. Henry Temple (d. 1740) and was mother of Henry Temple, second Viscount Palmerston [q. v.]

Barnardiston, Sir Nathaniel : for Worthinesse read Worthlesnesse for Sir Nathaniel's only daughter read one of Sir Nathaniel's two daughters

Barnardiston, Sir Samuel : for In 1668 read As early as 1661 he was a member of the committee of the East India Company. From 1668 to 1670 for Skipton read Skippon

Barnardiston, Sir Thomas : for resigning through ill health read disabled as a royalist

after supported insert He was elected M.P. for Sudbury in 1661 on a double return, but was unseated

for frequently .... Suffolk read twice returned to parliament for Great Grimsby, 1685 and 1689 , and thrice for Sudbury, Suffolk, 1690, 1695, and 1698

Barnes, Barnabe : for i. read ii.

for Wonders read Wordes

for Cambridge read Oxford

Barnes, Sir Edward: after 1813 insert He was lieut.-governor of Dominica 1808-12 and was gazetted lieut.-governor of Antigua Dec. 1813, though he did not take up the appointment

after He insert was colonel of the 4th garrison battalion 1815-16 and

after 1819 insert $\mathrm{He}$ was colonel 1st battalion rifle regiment 1820-2

for M. A. Taylor, Esq. read the Right Hon. Michael Angelo Taylor [q. v.]

before the borough insert in the conservative interest

Barnes, Robert: for mid-Lent Sunday read the third Sunday in Lent

Barnes, Thomas (1785-1841) : for he criticised read he suffered Dean Blakesley to criticise

ii 18 f.e. Barnham, Benedict: after sheriff insert He was M.P. for Yarmouth, Isle of Wight, in the parliament of 1597

3 f.e. $\quad$ for Alice read Dorothy

264 ii l.l. Barnston, John: for 1600 read $1600-1$

275 ii 21 f.e. Barré, Isaac: before Through insert He was lieut.-colonel-commandant of 106th foot from 1761 until he was deprived in 1763

282 ii 4 f.e. Barrett, John (1753-1821): for J. R. Abbott read the Rev. T. K. Abbott

285 ii 13 f.e. Barrett, William: for 15 Sept. read 13 Oct.

290 ii 10 f.e Barrington, John S., 1st Viscount Barrington : for Sheriff of Bristol read a local whig leader of Bristol, where he was sheriff, mayor, and M.P.

291 i 9 f.e. Barrington, Sir Jonah: for 1792 read 1790

7 f.e. $\quad$ for $1798 \mathrm{read} 1797$

6 f.e. $\quad$ for 1799 read 1798, and for Bannagher read Clogher

5-4 f.e. for the dissolution ..... in 1800 read January 1800 . He contested Dublin City unsuccessfully in 1802. He was knighted in May 1807.

293 ii 28 Barrington, Samuel : after his flag insert He had been colonel of marines 1770-8 (when he was promoted to flag rank), was lieut.-general of marines 1786-99, and general of marines in succession to Lord Howe from 1799 till his death

295 ii 9 Barrington, William W., 2nd Visconnt Barrington: for Lord Shelburne's read Lord Rockingham's 
Page Col. Line

299 i 16 f.e.

ii 26 f.e. Barrow, Isaac (1630-1677): for Spivey read Spiney

301 ii 26 f.e.

302 i 13

20

i 17 f.e.

9 f.e.

8 f.e.

314 ii 16

319 i $8-7$ f.e.

320 ii 2

321 i 15

327 ii 9

329 ii 12 f.e.

342 i 24

ii 22

350 ii 18 f.e.

17 f.e.

351 ii 23 f.e.

353 i 4

23

358 ii 30

369 i 10 f.e.

375 ii $\quad 27-28$

376 ii 3 f.e.

377 i 8

ii 25

385 ii 9 f.e.

387 ii $35-36$

37-38

388 ii $\quad 22$

$398 \mathrm{i}-7$

8

24

402 i 6 f.e.

406 ii 23 f.e.

407 ii 12

21

408 i 17 f.e

16 f.e.

15 f.e.

14-10

f.e.

10 f.e.

9 f.e.

4 f.e.

ii 32

l.l. Bathurst, Henry : after government add He died on 5 April 1837

for 1672 read $1672-3$

after rest insert He was vice-chancellor of Cambridge in 1675 after died insert on 4 May 1677

Barrow, Sir John : for near Ulverston read in the parish of Ulverston for thyme read gorse and bracken omit the Hill of

Barry, Sir Edward: for 1745 read $1743-4$

Barry, George : omit and the occurrence . . . ' mort-cloth'

Barry, James, Lord Santry : for 1672 read 1673 for 1672 read 1672-3

Barry, Sir Redmond : after 1877 insert when he was made a K.C.M.G.

Barthélemon, F. H. : after 1808 insert He was a follower of Swedenborg

Barton, Bernard : for Major E. Moor Wood' read Major E. Moor,' Woodbridge

Sander's's 'Voyage in Tripoli' in ARBER's Garner, ii 24 seq.) He appears

Barwell, Richard : for 1784 read 1781 and for as read as a tory after for insert Helston, in 1784 for

Barwick, John : after Cathedral insert in 1641 Oxgate

after London insert on 22 Oct. 1664

Basire, Isaac : for 1809 read 1869 in parliament of 1592

'Historical Account of New South Wales,' 1799, by David Collins [q. v.]

Basset of Cornwall : for [See also De DunstanviLle] read Family of

Basset, Sir Francis : for and M.P. for read of 1640

Basset, Francis, Baron Dunstanville : after parliament insert from 1780 to 1796

Basset, Richard : for 1154 ? read 1144 ? and Devonshire omit as a member .... party

Baston, Philip : for monk read friar 1772-6, and of Greenwich Hospital from 1775 till his death for this read his post-office for Soon after this read In 1785

Bathe, Henry de : for duke of Cornwall read earl of Cornwall

Bathurst, Allen, 1st Earl Bathurst : for 1784 read 1684

Bathurst, Henry, 2nd Earl Bathurst : after 1736 add $\mathrm{He}$ became K.C. in 1745 omit (1745), and after to the prince insert (in 1746 and 1747 respectively) Treasury 1789-91, and commissioner of the board of control 1793-1802 for his read Mr. Pitt's omit This . . . in 1809

for subsequently read subsequently he also foreign secretary

after council insert He was made K.G. in 1817

after parties add He died on 27 July 1834

Barton, Edward for and appears read and was at Constantinople in 1584 (cf.

after emolument insert with which was combined the prebendal stall of

Baskerville, Sir Thomas : after 1589 insert He was M.P. for Carmarthen borough

after Tehidy insert He was M.P. for St. Michael's in the short parliament of

Bastard, John P. : for Devonshire in parliament read Truro in parliament in 1783-4

Bates, Joah : after a year insert He was a commissioner of the Sixpenny Office

Bathurst, Henry, 3rd Earl Bathurst: after 1794 insert He was M.P. for Cirencester 1783-94. From 1790 till his death he was a teller of the exchequer after Mr. Pitt, insert served as lord of the Admiralty 1783-9, lord of the

after duke of Portland insert 1807-9, and under Perceval 1809-12, holding concurrently the mastership of the Mint from Oct. to Dec. 1809; he was 
Page Col. Line

410 i 5 f.e.

ii 24

416 ii $\quad 22$

417 i $10-7$

f.e.

ii 3

418 i 7

421 i 23-22 f.e.

435

44

ii 8 f.e.

f.e.

445 ii 21

34

35

446 i 5

449 i 6

ii $11 f$ Bathurst, Ralph : before and in 1691 insert From 1673 to 1676 he was vice-
chancellor of Oxford

Batteley, John: for 1647 read 1646

Batteley, Nicholas : for 1650 read 1648

for Newton read Nowton

Battell, Ralph : for 1685 read 1680

Battine, William: for Throughout the reign of George IV read From 1812 to 1827

Baxter, Richard : after wife insert Margaret Charlton, and after married insert on 10 Sept. 1662

Bayley, Sir Edward C. : for $\mathrm{He}$ was . . 1877 read He was made C.S.I. in 1875 and K.C.S.I. in 1878

Bayley, Walter : for 1592 read 1593

after 1581 insert $\mathrm{He}$ was in the service of the Earl of Leicester (cf. Leicester's Commonwealth)

for 1592 read $1592-3$

after authorities add Bayley also wrote 'A Brief Discourse of Certaine Bathes or Mineral Waters in the Co. of Warwick,' London, 1582

Bayly, Lewis : before On his patron's death insert He was treasurer of St. Paul's 1611, prebendary of Lichfield 1613-14, and archdeacon of St. Albans 1616

453 ii 14 Baynard, Fulk : for (d. 1306) read (fl. 1226)

454 ii 21 Baynes, Adam: for 1631 read 1622

22-23 for was born in 1631 read son of Robert Baynes, was baptised at Leeds parish church on 22 Dec. 1622

455 i $3-4$

for Northamptonshire read near Leeds in Yorkshire

456 ii 2 Baynes, Ralph : for France read Paris

458 ii 13 f.e. Beach, Thomas : after 1783 insert He was president of the Society of Artists in 1783

459 ii 7 f.e. Beadon, Sir Cecil: before and finally insert 1860-2

6 f.e. $\quad$ after Bengal add 1862-6

461 ii 8 Beadon, Frederick : after 1875 insert He held the prebend of Compton Bishop from 26 May 1809 till his death 70 years later. He was also chancellor of Wells Cathedral from 1825 till his death

462 i 16 Beadon, Richard : after Denmark insert He held the prebendal stall of Reculverland in St. Paul's Cathedral 1771-5

after London insert with the prebend of Mapesbury in St. Paul's Cathedral, which he held till 1802 


\title{
DicTiONARY OF NATIONAL BIOGRAPHY
}

\author{
ERRATA IN VOLUME IV
}

BEAL_BIBER

Page Col. Line

$1 \quad$ i 3 f.e. Beale, Francis: for He read Beale

N.B.-f.e. stands for from end and l.l. for last line

$\mathrm{i} \quad 5 \quad$ after xx. $\mathbf{1 5 2}$ add Beale lived in Westminster and had a son of his own names (cf. Mayor, Adm., St. John's Coll. Cambridge, i. 54, 61)

3 ii 2 Beale, Robert: for is said to have been read born in the City of London, was

13 f.e. $\quad$ for The same year read In 1574

$6 \quad$ i 15 f.e. for 25 read 27

14-13 for He appears ... daughters read Beale had issue two sons, Francis and

f.e. Robert, and nine daughters

4 f.e. $\quad$ for The other read Another

2 f.e. $\quad$ for Easington read Eastington

7 ii $4 \quad$ after 218 insert Bigland's 'Gloucestershire,' i. 540

18 f.e. Beale, William : for Dr. Herne read Dr. Sterne

9 i 23 Beales, Edmond : for James read John

11 i 23 f.e. Beamish, North L.: after bodies insert He was one of the few British subjects who received the Guelphic order from King Ernest of Hanover after the separation of Hanover and England

12 i 15 f.e. Bearblock, John : for 1579 read 1569

13 i' 26-25 Beard, John: for 'Atalanta' read'Athalia'

f.e.

14 ii 9 Beard, John R. : for many minor theological read other

27 f.e. Beard, Thomas : after century insert Beard was prebendary in Lincoln cathedral from 1612 till his death

19 ii 6 Beaton, James: before archbishop insert the last Roman catholic and before second insert was

7 for Balfour read Auchmuty

8-10 for was the last... in 1552 read and of John Beaton of Balfour

14 after the cardinal insert in $\mathbf{1 5 4 6}$

23 before It insert He was consecrated at Rome archbishop of Glasgow in 1552

31 ii 12 f.e. Beauchamp, Richard de : for 16 Oct. read (according to Le Neve) 4 Nov.

10 f.e. $\quad$ after will insert dated 16 Oct. 1481

32 i 22 Beauchamp, Thomas de, Earl of Warwick : before In the insert He was subsequently made K.G.

34 ii l.l. Beauclerk, Charles, 1st Duke of St. Albans : for can scarcely read may

35 i 3-4 for before the end ... birth read on 27 Dec. 1676, six years after his birth

26-27 before regiment of horse insert Princess Anne's or the 8th

ii 21 after George I insert was from 1714 till his death lord-lieutenant of Berkshire

38 i 13 f.e. Beaufort, Daniel A.: omit and archdeacon 
Page Col. Line

39 i 1

2

Beaufort, Edmund, 2nd Duke of Somerset: before Somerset insert the earldom of and omit titles . . . earldom for and . . 1448) read (He was created a duke anew in 1448)

41 i 28 f.e. Beaufort, Henry : after Lincoln $a d d$ and of Riccall in York cathedral in 1390

23 f.e. $\quad$ for The next year read The previous year

48 i 31 Beaufort, John, 1st Duke of Somerset : after made insert K.G. about 1440

19 f.e. Beaufort, Margaret: for 1441 read 1443

14 f.e. for only three read less than two

ii $i \quad$ after year insert (3 Nov.)

1-2 for leaving ... son read A son, afterwards Henry VII, was born posthumously, 28 Jan. 1456-7

Beaufort, Sir Thomas, Duke of Exeter : after made insert K.G. about 1400

25-23

f.e.

21-19

f.e.

for and after . . . his garrison and read He remained in charge of Harfleur and during the winter

for Armagnac .... a fleet under read In March 1416 he was defeated by Armagnac at Balmont and was closely besieged in Harfleur till relieved in August by

18 f.e.

17 f.e.

13 f.e.

11 f.e.

omit Plantagenet

omit the line

omit and also received the garter

after and insert subsequently and after Raid insert (Oct. 1417)

for 21 Sept. read 31 Aug.

Beaufoy, Henry : for 1780 read 1783

for He read Although a dissenter he was a supporter of Pitt's ministry and from 1791-3

Beaumont, Francis (1584-1616): after studies insert (See Sloane MS. 1709 ff. 1322)

for afterwards read before

Beaumont, Sir John : for 1547 read 1597

Beaumont, John T. B.: for 1824 read 1823

Beaumont, Joseph : for seems to read cannot

for $\mathrm{He}$ was appointed ... wife read $\mathrm{He}$ is said by church historians to have succeeded to a vacant prebend in Ely cathedral in 1651 , but he was not installed till 1660. And under the Commonwealth he necessarily vacated, except in name, all his preferments. He married in 1650 Miss Brownrigg, a niece of Matthew Wren [q. v.] the ejected bishop of Ely. Beaumont had been Wren's domestic chaplain. With his wife he

i 8-7f.e. Beaumont, Thomas W.: for After representing read A few. months later, in Dec. 1826, he was returned for

7-6 f.e. $\quad$ for for a short . . 1830 read and sat till 1830, when he was

ii 11 for 10 read 20

70 ii 1 Beaver, John : omit this cross reference

75 i 17-19 Becher, Eliza, Lady : for By the death . . . baronet read He was created a baronet on William IV's coronation in 1831

ii 15 f.e. Becher, John T.: for 1801 read 1802

8 f.e.

79 ii $\quad 6$

for dean read provost 3 Beckford, William (1709-70): after parliament insert as member for Shaftesbury after spring insert (1754)

for On 29 Sept. 1769 . . . the third 676 read On 29 Sept. 1769, three instead of the customary two names were presented to the livery, viz. those of Aldermen Beckford, Trevithick, and Sir Henry Bankes; the first two were both of the party opposed to the court, and Bankes was alone a court candidate. The livery had to return no more than two names to the court of aldermen, with whom the final choice of lord mayor lay, and the preliminary submission to the livery of three instead of the customary two names gave it the opportunity of which it availed itself, of excluding any court candidate even from nomination. The names of Alderman Beckford and of his friend Trevithick were, after a poll on 6 Oct., alone returned by the livery to the aldermen. 


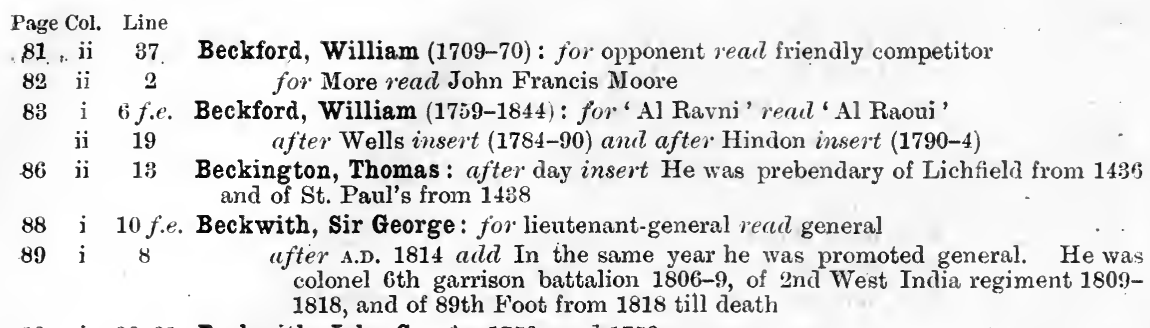

90 i 20-21 Beckwith, John C. : for 1750 read 1759

91 ii 27 Beckwith, Sir Thomas S.: for Sir W. Erskine read Sir William Erskine, 17691813 [q. v.]

15 f.e. before made insert in 1815 was

$8 f . e$. $\quad$ for in January read on $15 \mathrm{Jan}$.

93. i 21 f.e. Becon, Thomas : for 1541 read 1543

14-13 for $\mathrm{He}$ was again . . . in 1543. He read After the recantation Becon

f.e.

104 ii 13 Bede: for A. Whelo read Abraham Wheloc or Wheelocke [q. v.]

105 i 33-34 for F. Stevens read John Stevens

106 i 10 f.e. Bedell, William : for Du Plessis, Mornay read Du Plessis-Mornay

109 ii 4 Bedford, Arthur : for Tiddenham real Tidenham

15 for in 1692 ... and was real (according to the minutes of the corporation) in April 1693. He held the benefice till 1713, though he seems to have been non-resident from 1701 , when he was

113 ii 8 f.e. Bedingfield, Sir Henry (1509 ?-1583) : for 1509 ? read 1511

6 f.e. $\quad$ for about 1509 read in Sept. 1511

114 i 6 after 1553 insert and was M.P. for Suffolk in the first parliament of that year

115. i 15 Bedingfield, Sir Henry (1633-1687): after He insert was admitted to Caius College, Cambridge, in 1650 and

21 after Yarmouth insert and in 1685 became M.P. for Aldeburgh

118 i 18-19 Bedloe, William : for changeable read chargeable

120 i 17 Bedwell, William: for 1732 read 1632

121 i 1 Bedyll, Thomas : for Searle read Scarle

122 i 12 f.e. Beechey, Frederick W.: for From this time read From 1850 till his death he was superintendent of the marine department of the Board of Trade. He was naval A.D.C. to Queen Victoria from 1851 to 1854 , when he was promoted to flag rank. After 1847

123

28-29 Beechey, Sir William: for Stowe, in Gloncestershire read Stow-on-the-Wold, Gloucestershire

7 f.e. $\quad$ for 1793 read 1798

124 ii 8 Beeke, Henry : for 1814 read 1813

18 f.e. for Sir Lewis Palk real Sir Lawrence Palk

130 i 9 f.e. Behn, Aphra : for Poets' Corner read the Cloisters (cf. Athenaum, 21 Sept. 1895)

134 i 20 Bek, Antony I.: after Edward I insert He held the prebends of St. Pancras in St. Paul's cathedral in 1278 and of Strensall at York in 1279

140 i 2-1f.e. Beke, Charles T. : for but the subsequent conduct of the king read but his mission appears to have been of questionable prudence, and to have irritated the king, whose subsequent conduct

142 i 18 f.e. Belasyse, John, Baron Belasyse : before On the breaking out insert He represented Thirsk in both the Short and Long parliaments, but was 'disabled' as a royalist to sit, on 6 Sept. 1642

3 f.e. $\quad$ omit made

2 f.e. after Riding insert (1661-73) and after Hull insert From 1664 to 1666 he was governor of Tangier

l.l. after pensioners insert 1667-72

ii 2-5 omit he was then ... post also

13 f.e. Belasyse, Thomas, Earl Fauconberg : for 1667 read 1657

9 f.e. $\quad$ after Italy insert He was lord-lieutenant of the North Riding (1660-1692)

148 ii 13 Bell, Alexander $\mathbf{M}$. : for 1809 read 1808

155 i 35 Bell, sir Charles : for Majendie read Magendie 
Page Col. Line

160 i 6

165 ii 31-2

166 i 4

29

13 f.e.

171 i 2 f.e.

172 i 29

176 i 6-7

8

187 i $5-6$

189 ii 21 f.e. Bellenden, Willam, Lord Bellenden: after the Restoration insert (see

189 ii 21 f.e.

190 i 9

193 ii 9

Bellers, Fettiplace : for Sept. read Aug.

Bell, Henry : for made by Bell read (constructed by John Robertson of Glasgow and now preserved in the Victoria and Albert museum)

Bell, John (d. 1556) : for Sub-Edge read Weston-sub-Edge

for 1632 read 1532

for Sir Joln More read Sir Thomas More

after Aug. insert 1539

Bell, Lady Maria : for Lady Maria read Bell, Maria, LadY

Bell, Robert : for Robert read Srr RoberT

Bell, William (1625-1683) : for Three years later read In March 1665-6 for Reculversland read Reculverland

Bellenden, John : for the first version read one of the earliest versions

Bellenden, William, Lord Bellenden : after the Resto
of State Papers and Nicholas Papers, Camden Soc.)

Bellingham, Sir Edward : after ${ }^{-H e}$ insert represented Gatton in parliament in 1544 and

12-10 for No distinct mention .... State Papers read (see BAGwelL's Ireland under f.e. the Tudors, i. 339)

198 i 12-11 Belmeis, John : for Nasburgh read Newburgh

f.e.

200 i 31 Belmeis, Richard de (d. 1128) : for 1127 read 1127-8

201 ii 9-8f.e. Beloe, William : for and in 1803 became read from 1800 till his death he was prebendary of Lincoln and from 1804 till his death he was also prebendary at St. Paul's in succession to Paley. In 1803 he had become

203 i 26 f.e. Belsham, Thomas : for 1755 read 1775

213 i 14 f.e. Bendlowes, William: for Penrhyn read West Looe

216 i 9 f.e. Benedict of Norwich : for monk read friar

217 i $32 \quad$ Benedict, Sir Julius : for 1873 read 1882

ii 29-30 Benefield, Sebastian : for By the latter date . . . quaint words read In 1626

221 i 29 Benfield, Paul : after 1782 insert Benfield sat for Malmesbury 1790-2 and for Shaftesbury 1793-1802

222 ii 23 f.e. Benjamin, Judah P.: for 1811 read 1807

39-42 omit New Orleans . . . the ship put into

17 f.e. $\quad$ after Great Britain insert but subsequently ceded to Denmark

16 f.e. $\quad$ for 1815 read 1818

11 f.e. for In 1815 his parents settled in read In 1818 his parents removed from St. Croix to

9 f.e. $\quad$ for He read After attending a good school at Fayetteville, he

223 i 5 f.e.

225 i 26

ii 2

230 ii $22-23$

231 i 7 f.e.

233 i 26

234 ii 15

27

236 ii 14

242 i $\quad 21$ f.e. Bennett, George John for Cairns read Selborne

for 8 May read 6 May Bennet, Henry, Earl of Arlington : for born at . . . Middlesex read baptised at
Little Saxham, Suffolk after parliament insert for Callington

after 1685 insert $\mathrm{He}$ had been lord-lieutenant of Suffolk since 1681

Bennet, Sir John : for this year read 1617 for of the same year read 1616 Bennet, Robert $(d .1617)$ : after appointed insert prebendary of Winchester, and on
23 March 1595-6 for year read month

Bennett, George John : after Birmingham insert In earlier life he published an interesting rolume called 'A Pedestrian Tour through North Wales' with 20 etchings by A. Clint, London, 1838 ii 23 Bennett, James: after he resigned add $\mathrm{He}$ was chairman of the Congregational

245 i 3 f.e. Bennett, John $\mathbf{H}$. : for the Institute read the Institutes

ii 32 for at the Institute read of the Institutes

246 i 13 f.e. $\}$ Bennett, John J. : for 1875 read 1876

255 i 15 f.e. Benson, Christopher : for several years read from 1827 to 1845 
Page Col. Line

257 ii 23 f.e. Benson, Joseph : for Treveca read Trevecca

258 i 15 f.e. after methodism insert He was president of the Wesleyan conference in 1798 and 1810

14 f.e. $\quad$ for 1821 read 1791 ii 11 Benson, Martin: after his return insert He was prebendary of Salisbury (1720-7)

259 i 9 Benson, Robert, Lord Bingley : for daughter read sister

261 i 30 Benson, William : after steps insert Sir Jacob Bankes was M.P. for Mineheud from 1695 to 1714 and in 1713 Benson unsuccessfully contested the constituency against him

$\begin{array}{ccc} & \text { ii } & 37 \\ 271 & \text { ii } & 12 \\ 277 & \text { i } & 11 \\ 278 & \text { ii } & 3 \\ 279 & \text { i } & 21 \\ & \text { ii } & 17 \\ & & 30\end{array}$

for Herenhausen read Herrenhausen

Bentham, Jeremy : for test read rest

for nine read eleven

for genus read genius

for 1730 read 1780

for. Wolesely read Wolsely

for Gout read Government

284 i 25 f.e. Bentham, Thomas : for 1578 read 1579

for 1578 read $1578-9$

Bentinck, Lord William C. : after Netherlands insert He was M.P. for Camelford March to May 1796, for Nottinghamshire 1796-1803, 1812-4, and 1816-26, and for Lynn 1826-7

after unemployed insert He had been made a knight of the Bath in 1813, G.C.B. in 1815 , and G.C.H. in 1817. He was colonel of the 20th Light Dragoons 1810-3, and of the 11th Light Dragoons from 1813 till his death

21

296 ii 9 f.e.

297 ii 22

after 1828 insert $\mathrm{He}$ was sworn of the privy council on 17 Aug. 1827

after interest insert in February 1836 and was re-elected

to his brother, Lord William (appointed governor-general of India)

302 i 12 f.e. Bentinck, William H.C., 3rd Duke of Portland : for 1760 read 1761

303 i 16 f.e. for northern department . . . secretary read home department

304 ii 13 for Nov, read Oct.

305 i 3 Bentinck-Scott, William J. C., 5th Duke of Portland : for his brother Lord George Bentinck [q. v.] read his uncle Lord William Bentinck [q. v.] omit Lord

311 ii 3 Bentley, Richard (1662-1742): after master add He was elected vice-chancellor of the university in the same year. From 1701 till his death he was archdeacon of Ely, and from 1717 regius professor of divinity

326 ii $\begin{gathered}14 \\ 1-28\end{gathered}$ Berengaria : for Espan read Espau

327 ii 4 Beresford, John : omit of

329 i 28 Beresford, Sir John P. : for 1768 ? read 1766

330 i 16 f.e. $\quad$ for 19 July 1821 read 27 May 1825

13 f.e. for 1812 to 1823 read 1809 to 1812 and from 1814 to 1823 in the tory interest

12 f.e. $\quad$ for in 1823 read from 1823 to 1826

11 f.e. for in 1832 for Northallerton read from 1826 to 1832 for Northallerton, but being re-elected for Coleraine in 1832 was unseated on petition next year

334 ii 1-2 Beresford, William C., Viscount Beresford : for and made governor of Jersey in 1814 read was governor of Cork from 1811 to 1820 and of Jersey from 1820 till his death

after 1807 insert From 1819 to 1823 he was colonel of the 69th regiment

before colonel insert was from 1823 till death

after rifles insert (from 1852 in succession to Prince Albert)

335 i 9 f.e. Berewyk, John de: after king insert He was prebendary both of St. Paul's and Lichfield

340 i 1-2 Berkeley, Family of : for probably ... Berkeley; for read a small castle built at Berkeley by William FitzOsbern (Domesday 163) had probably given place to one of greater size, when

343 i 10-11 orit and at that time ... Gloucester

17 before applied insert who was then M.P. for the county of Gloucester 
Page Col. Line

345 ii 3 f.e.

346 i 14-15

347 i 6

19

6 f.e.

348 i 28

30

950 i 20

358 ii 23

27

28

859 i 21-22

23

26

27

361 ii 21 f.e.

362 ii $17-18$

363 i 28

365 ii 24 f.e. Berkeley, Maurice, Lord Fitzhardinge : after 1857 insert (from 1833-4 under Grey and Melbourne; 1837-9 under Melbourne; 1846-52 under Russell; 1852-7 under Aberdeen and Palmerston)

12-10 for With few intermissions ... Gloucester read $\mathrm{He}$ four times contested

f.e.

$10 f . e$.

$9-8$ f.e.

366 i 27 f.e.

Robert $(d, 1219)$ : for Came read Cam represented it

for 1857 read 1833

for though in $1833 \ldots$... candidate read from 1835 to 1837 and from 1841 to 1857

Berkeley, Sir Robert : after county insert and in 1620 and 1624 he was elected M.P. for Worcester

369 i 17-18 Berkeley, Sir William: for In $1676 \ldots$ and returned read $\mathrm{He}$ was still in Virginia in April 1677, keeping on his government in defiance of Herrbert Jeffreys, who had arrived to supersede him (Longleat Papers, $50 \mathrm{~B}$ ). In the early summer of 1677 he returned

872 ii 27

873 i 17

Bermingham, William : for 1311 read 1312 for 1311 read 1311-2

37 Bernal, Ralph: after a seat insert as a liberal

15 f.e. for retired from political life read was rejected

12 f.e. for about 1830 to 1850 read 1833 to 1841 and from 1847 to 1852

ii 12 f.e. Bernal Osborne, Ralph : for Lord Carington read Lord Carrington

886 i 20 Bernard, Richard : for 1567 ? read 1568

23-28 for This gives us . . . Lincolnshire read He was born at Epworth in Lincoln shire in 1568, as the parish register shows; in a preliminary page of his translation of 'Terence,' he described himself as of that place ('Epwortheatis') and says that the work was done in the island of Axholme

30

8 f.e.

7 f.e.

397 i for that county read Lincolnshire

for is found parson read stayed with relatives

after 'Terence' insert in Latin with an English trauslation

12 f.e. Berry, James: before Cromwell insert He was elected M.P. in 1656 by three constituencies, Herefordshire, Monmouthshire, and Worcestershire, and sat for the
last

399 i 6

15

$26-8$

Berry, Sir John: after the navy insert He held the post for 'general business' from 1686 to July 1688

for in which he read From October 1688 to 1689 he acted among the commissioners of the navy as comptroller of victualling accounts. In that post he for but it appears . . . already dead read but the true date is 14 Feb. 1689-90 


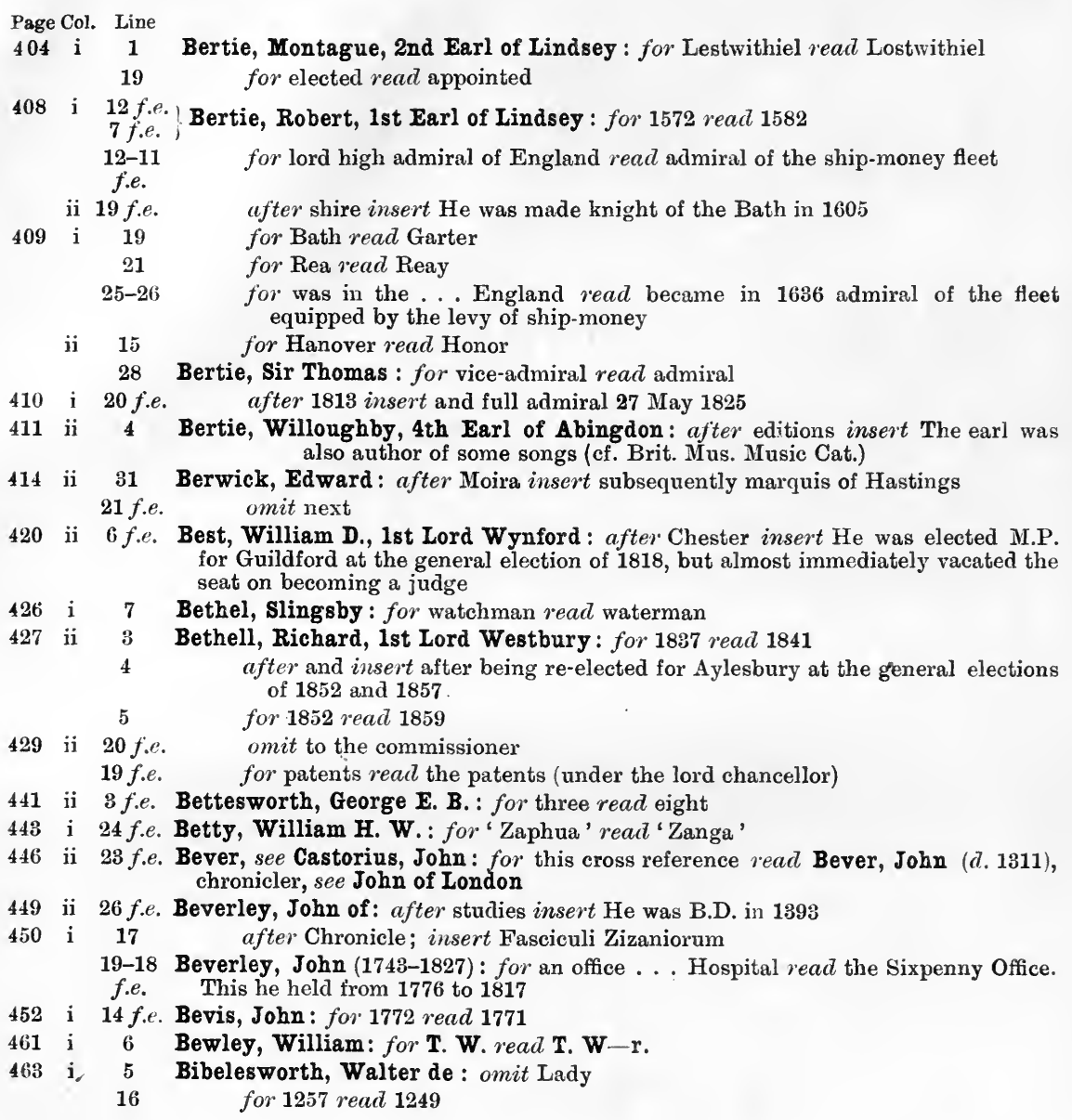





\title{
Dictionary OF NATIONAL BIOGRAPHY
}

\author{
ERRATA IN VOLUME V
}

\author{
BICHENO—BOTTISHAM
}

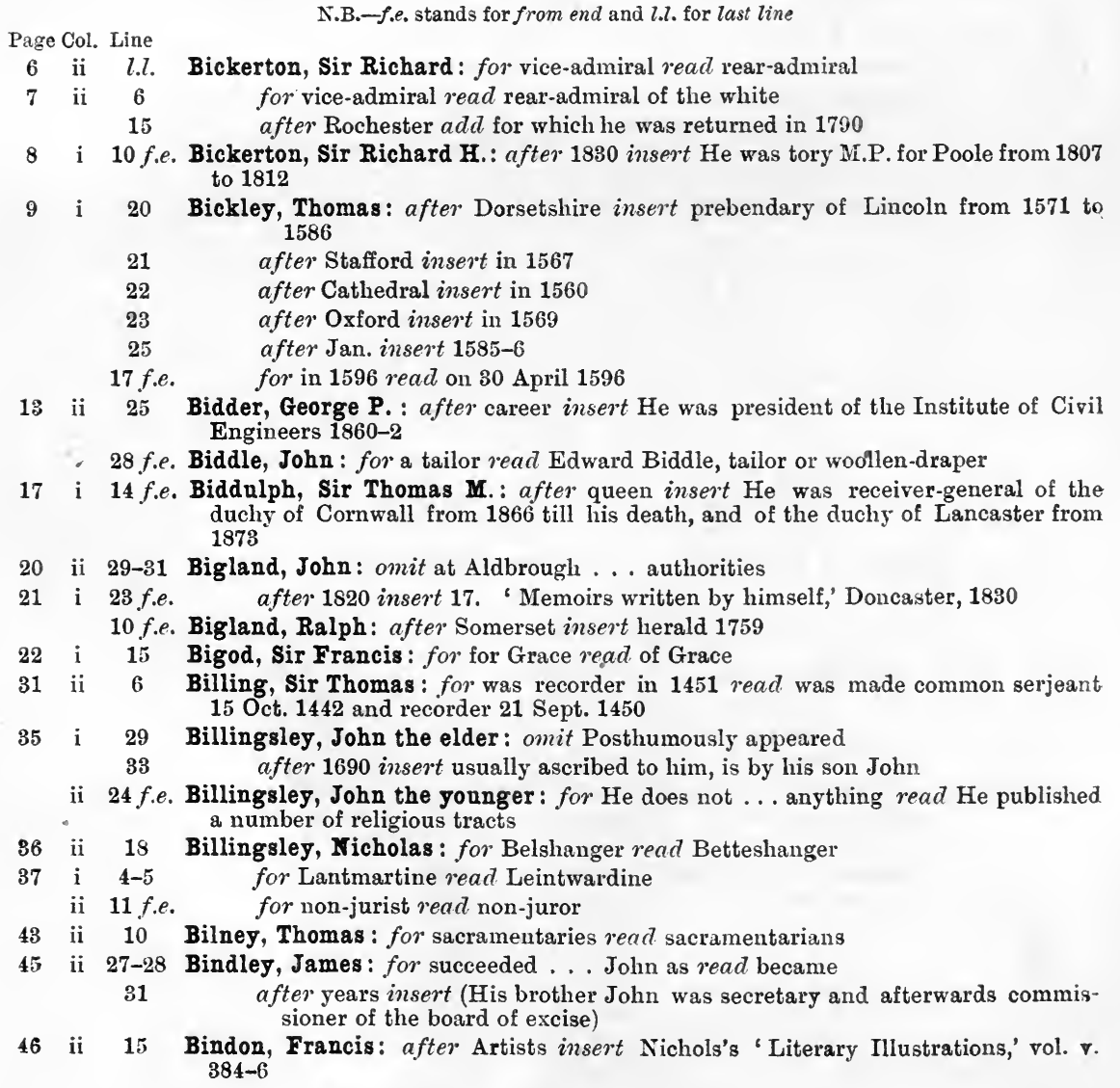




\section{ERRATA-VOLUme V}

Page Col. Line

$47 \quad$ ii $\quad 39$

Bingham, Sir George R. : after esteem insert $\mathrm{He}$ became major-general in August 1819 and colonel 2nd battalion rifle brigade in June 1831

48 ii 11

49 i 12

63 ii 13 f.e.

Bingham, Joseph : for 1768 read 1668

for Elmore read Colmer

64 i $8 f . e$.

Birch, John (1616-1691): after Leominster insert (1646). He was excluded by Pride's Purge in 1648 and was re-elected in 1654-6 and 1658-9

$7 f^{\prime} . e$.

for 1671 read 1661

for Penrhyn read Penryn and after and insert in 1678-9, 1680-1, 1688-9, and 1689-90

68 i 20 Birch, Samuel : for 1840 read December 1839

70 i 26 f.e. Birch, William : for (d. 1794 ?) read (1755-1834)

24 f.e. . . : for about 1760 read 9 April 1755

4-3 f.e. $\quad$ for the date ... uncertain read He died at Philadelphia 7 Aug. 1834. His MS. journal is in the possession of Mr. Charles H. Hart of Philadelphia

71 ii , 18 Birckbek, Simon : for 1634 read 1635

72 i 29 Bird, Charles $\mathbf{s}$ : for Bell read Bird

10 f.e. $\quad$ after 67 insert on 9 Nov. 1862

82 ii 19 Birkenhead, Sir John : omit and probably his knighthood

29 after requests insert He was knighted 14 Nov. 1662

88 i 17 Birnston, for Birsston read Birnstan, and for Byrnston read Byrnstan

89 ii 10 Biscoe, Richard: after George II insert $\mathrm{He}$ was prebendary of Ealdstreet in St. Paul's from 1736 till his death

98 ii 20 f.e. Bisse, Thomas : for John read Joseph

103 i 34 Bisset, William : for 5 June read 25 June

105 i 14-13 Blacader, Robert: for Sir Robert Blacader of Tulliallan by Elizabeth read Sir f.e. $\quad$ Robert Blacader of Blackader, co. Berwick. His brother, Sir Patrick Blacader or Blackader of Tulliallan, married Elizabeth

12 f.e. for He read Robert

116 ii 22 j.e. Blackader, Cuthbert: for CuTHBERT read CuthBert or more correctly RoBERT

21-19 for received ... his success read belonged to the family of Blackader f.e. which owned the barony of that name in co. Berwick, as vassals of the Earls of March through the 14th century. Charters of full ownership were granted to Robert Blackader of Blackader on 20 Jan. 1426, and again on 4 July 1452 by James I and James II of Scotland respectively (Scottish Register of Great Seal). Robert Blackader, the grantee of 1452, seems to have been carelessly misnamed 'Cuthbert' in Crichton's 'Memoirs of John Blackadder the elder.' He achieved his success

$12 f . e . \quad$ for the kingdom read Scotland

6 f.e. for Cuthbert read Blackader

122 ii 17 f.e. Blackburn, Francis: for 1834 read April 1835

123 i 24 for Lord Greene read Baron Greene

125 ii 16-15 Blacker, Valentine : for 1780 ?-1826 read 1778-182:

f.e.

14 f.e. $\quad$ before obtained insert born on 19 Oct. 1778

126 i $19 \quad$ for 1826 read 1823

128 ii 25 f.e. Blacklock, Thomas : omit to Burns

24 f.e. for the poems read Burns's poems to George Lawrie, who sent it to Gavin Hamilton, who sent it to the poet.

130 ii 15 f.e. Blackmore, Sir Richard: for fol. read 8vo.

.134 ii 11.f.e. Blackstone, Sir William: after 1761 insert In the same year he became K.C.

150 ii 11-12 Blackwood, Henry : for descended from a . . . was a brother read son of William Blackwood and brother.

152 ii 5 Blackwood, Sir Henry: for on 19 July 1821 read in May 1825

154 ii 18-17 Bladen, Martin : omit with the great Duke of Marlborough

f.e.

13 f.e. after lient.-colonel insert He was colonel of the 40th foot 1709-10

4f.e. after Portsmouth insert From 1715 to 1727 he was M.P. for Bandon in the Irish house of commons

155 i $8 f . e$. for 2nd series read 3rd series

156 ii 20 f.e. Blagge, Robert: for Gaze's read Gage's 
Page Col. Line

156 ii 8 f.e.

7 f.e.

157 i 14-15

159 ii 30 Blague, Thomas : for 1591 read 1591-2

162 i 14 f.e. Blair, Sir James H. : after the city insert He was made a baronet in 1786

165 ii 28 Blair, Robert (1699-1746): for keep read bear

166 ii 22-23

Blair, Robert (174

169

171

175

183

186

187

ii 27

$194 \quad$ i 22

14 f.e.

197 i 4

5

8

17

5 f.e.

Blake, Charles : for 1716 read April 1715

15-16 Blake, Robert : omit on the expulsion of Colonel Windham

for De With read De Witt

17 f.e. Blake, William (1757-1827) : for 1813 read 1818

5 Blakeney, Sir Edward : for 1776-83 read 1781-3 and 1790-1800

13 f.e. for 1838 read 1836 and for 1 read 21

Blakeney, William, Lord Blakeney: after him insert major-general 1745 and after Abbey add $\mathrm{He}$ was M.P. for Kilmallock 1725-57 and colonel of the 27 th foot 1737 till death. He was lieut.-governor of Plymouth 1746-8

Blanchard, Samuel L. : for 1840 read 1804 for M.P. read afterwards (from 1832) M.P.

Bland, Humphrey : after foot insert in 1737

after dragoons insert in $\mathbf{1 7 4 1}$

after dragoons insert in $\mathbf{1 7 4 3}$

before In 1749 insert $\mathrm{He}$ was governor of Fort William 1743-52

after Lord Stair insert was really sister of John Dalrymple, 5th Earl of Stair. Bland married her at Edinburgh 12 Jan. 1755. She

199 i 3 f.e. Bland, Miles : for 1868 read 1867

ii 11-12 for in 1868 read 27 Dec. 1867

205 ii 22 f.e. Blaquiere, John, Baron de Blaquiere : for until 1783 read 1773-83

20 f.e. for Newtown read Newtownards

206 i 12 f.e. Blathwayt, William : for council in ordinary read privy council

11-10 for and clerk of the privy council read $\mathrm{He}$ was re-gazetted to the post at the f.e.

ii 3 f.e. Blayney, Andrew T., Lord Blayney: after of the insert 91st regiment from opening of the next reign

208 i 2

16 f.e. Blayney, Benjamin : after He was insert in 1787 1761 to 1763 , when it was disbanded, and colonel from 1766 of the

15 f.e.

14 f.e.

210 ii 18 f.e. Blencowe, Sir John : for king's bench read common pleas

17-16 omit and transferred from the common pleas

f.e.

6 f.e.

212 ii 14 Blenkiron, William : for Beverlace read Beverlac

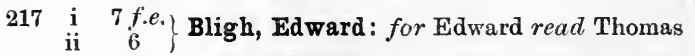

8 for 1715 insert holding the seat till his death sixty years later

218 i 31 Bligh, Richard: for son of read son by his wife Lucy Shuter of John Bligh, the cousin of 20 f.e. after years insert He married a daughter of his cousin, Admiral William

219 i 3-4 Bligh, Sir Richard R. : omit and a modified ministry

15-17 Bligh, William: for was born ... the year 1753 read baptised at St. Andrew's church, Plymouth, on 4 Oct. 1754, was son of Francis and Jane Bligh. He was born

20-25 omit the son of Charles ... Trigg Minor)

ii 17-19 for obtained a schooner ... survivors, he read took passage in the Vlydte packet and after 1790 insert Twelve of his companions, the survivors, followed in the Dutch fleet 
Page Col. Line

220 i 21

24-25

221 i 14

224 ii 8

9

228 ii 23 f.e.

232 ii

235 ii

10-11

18

239

17-19 Blore, Thomas : omit The latter borough . . . interest

242 i 19 Blount, Charles, Earl of Devonshire : for 1604 read 1603

245 i 8 f.e. Blount, Sir Christopher : for On read In 1592 and on

249 ii 2 Blount, Mountjoy, Earl of Newport : for 1665 read 1666

23 f.e. omit Don

252 i 18 f.e. Blonnt, Richard : for studied at Oxford, but read matriculated at Balliol College, Oxford, and became in 1583 a fellow of Trinity on the nomination of his aunt, Lady Paulet. He only held the fellowship three weeks and

256 ii 9

Blount, Sir Thomas P. : for 1679 read $1679-80$

10 for two read three

258 ii $6-7$

23 April 1472 (Nicolas)

14 f.e. $\quad$ omit the governor, the Earl of Oxford

264 ii 16 Bloxham, John (d. 1387): after 1375 insert He was archdeacon of Winchester from 1382 till death

275 ii 5 f.e. Blunt, John J.: for 18 read 17

276 i 14-16 Blyke, Richard : omit In $1764 \ldots$ the journals

277 i 15 f.e. Blythe, Geoffrey $(d .1530)$ : for May following read March 1496-7

278 i 33 Blythe, John: for 1478 read 1477

34

for Huntingdon read Stow, in 1478 archdeacon of Huntingdon, from 1482 to 1485 prebendary of Lincoln

294 i 18 f.e. Bodley, Lanrence : for He was a read He was made prebendary of Wells in 1580, and a

295 i 25 f.e. Bodley, Sir Thomas: for In April of the next year however read He was elected M.P. for Portsmouth in the same year and for St. German's in 1586. In April 1585

296 i $11-13$

for Sir Thomas... accession read Bodley, who had been knighted on 18 April 1604 (Dugdale MS. R. f. 201, Bodl. Libr.) for 1603 read 1602

303 i 8 f.e. Bogne, David : for the Rev. Dr. Grasomer read Benjamin Grosvenor, D.D. [q. v.]

306 ii 15 f.e. Bohun, Edmand : for 1784 read 1684

309 ii 20 Bohnn, Humphrey VIII de : for 1291 read 1301

310 ii 12 f.e. Bohun, William de : after Gascony insert He was K.G.

315 i 19 Bokenham, Osbern: after place insert Horstmann has shown Bokenham to be author of 'Mappula Mundi,' a translation of Higden's 'Polychronicon' (cf. Englische Studien, 1886)

322 ii 5 Boleyn, Sir Thomas: before On 1 Sept. insert In May 1523 he was made K.G.

323 ii 8 f.e. Bolland, Sir William: for soon became read was from 1804 till his elevation to the bench in 1829

324 i 11 f.e. Bollard, Nicholas : for two copies read at least five copies

10 f.e. before Cotton MS. insert Sloane MSS. 7 f. 92,122 f. $83 b, 686$ f. 41

327 ii 11-12 Bolton, Edmund : for and he is probably the 'E. B.' read Edward Blount [q. v.] and not Bolton was the 'E. B.'

331 i 33 Bolton, Robert : for 1668 read 1668-9

335 ii 15 f.e. Bonar, James

336 ii 30 Bonar, John the younger f after excise insert in Scotland

338 ii 19 f.e. Bond, George : after 1786 insert and a king's serjeant in 1795 


\section{ERRATA-VOLUME V}

Page Col. Line

338 ii 10 f.e. Bond, Henry J. H. : for Hales read Hayles

339 i $20 \quad$ for 1 read 3

341 i 11 f.e. Bond, Nicholas: for 1590 read 1589 and for 1591 read 1590

357 ii 17 f.e. Bonner, Edmund: before In the spring insert From 1537 to 1539 he was prebendary of St. Paul's (Chiswick stall)

363 i 9 Bonnycastle, Sir Richard H.: for 1848 read 1847

19 f.e. $\quad$ for in 1848 read on 3 Nov. 1847 at Kingston, Canada

364 ii 4 f.e. Bonville, Anthony: for Ternill read TeriLl

368 i 25 f.e. Booker, John : after value insert Booker's quaintly rhymed 'Dutch Fortune Teller' firstappeared in 1650 ; the first edition is excessively rare

7-6fe. $\quad$ omit The 'Dutch Fortune Teller' and

$4 f . e$. for are read is

371 i 27 f.e. Boorde, Andrew : for Parforatus read Perforatus

380 i 2 f.e. Booth, Henry, 1st Earl of Warrington : after Cheshire insert 1678-81

384 ii 10 Booth, James (1806-1878): for 1843 read the institution closed its doors at Christmas 1841. He was ordained at Bristol and acted there as curate till he removed to Liverpool in 1843

14-15 omit these lines

389 i 1 Booth, Peniston: before On 9 May 1722 insert He was prebendary of Lincoln 17191746

23 Booth, Robert: after 1657 add He married Anne, daughter of Oswald Mosley of Ancoats, Manchester; she afterwards married Thomas Case [q. v.]

390 i 29 Booth, Thomas ( $f$. 1611): after 1609 insert He was prebendary of Lichfield 1615-7

391 i 1 Booth, Sir William : for ( $f$. 1673-1689) read (d. 1703)

34 before In 1683 insert On 12 Nov. 1682 he was knighted (Le Neve's Knights)

ib. after the Grafton : insert in February 1687-8 was made commissioner of the navy 'for general business.'

36-39 for February ... the navy read October he was appointed comptroller of the store keeper's accounts at the navy

40

42

$5-4$ f.e. for his read any and after allegiance insert that he made to William III after March insert 1688-9

394 i $\quad 34$ for No account . . . death read He died in February 1702-3

Boreman, Robert : for in the winter of read on 15 Nov.

395 ii 2 f.e. Borgard, Albert: after 1839 insert Biographical Notes by Major Hime, reprinted from Proc. Royal Artillery Institute, No. 4, Volume xiii (with portrait)

397 i 27 f.e. Borlase, Edmund : for ( $f$. 1662) read (d. 1682)

ii 13-12 for The date... mentioned read He was dead before 18 Feb. 1681-2

f.e. $\quad$ (Sloane $M S .1008$, f. 49)

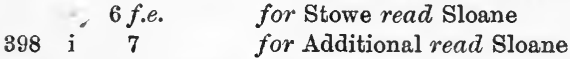

8 f.e. Borlase, Sir John : for $(d .1649)$ read (1576-1648)

ii 29-31 for in the spring of $1649 \ldots$ lately deceased read in the spring of 1648 . He died in London 15 March 1647-8, and was buried in the church of Great St. Bartholomew

401 i 20 f.e. Borough, Sir John : after Clarenceux insert He was M.P. for Horsham in three parliaments, $1624,1625,1626$

407 i 1-2 Borrow, George: for philologist read author

409 ii 26 Borthwick, Peter: for He sat for Evesham read He lost his seat for Evesham on petition in 1838, but was re-elected in 1841, and sat

Bosanquet, Charles : after the city insert He was sub-governor of the South Sea Company 1808-38 and governor 1838-50. From 1823 to 1836 he was chairman of the exchequer bill office

for Meyers's read L. C. Meyer's

413 i 14 Bosanquet, Sir John B. : for 1814 read 1847

21 f.e. after Company insert in $\mathbf{1 8 1 4}$

20 f.e. after England insert in 1819

417 i 11 Boscawen, Edward: for 1741 read 1742

419 ii 23 f.e. Boscawen, Edward, 1st Earl of Falmouth : after and insert was M.P. for Truro from 1807 until he

420 i 19 f.e. Boscawen, Hugh, 1st Viscount Falmouth: after death insert He was governor of St. Mawes from 1696 to 1710 and from 1714 till death 


\section{ERRATA-VOLUME V}

Page Ool. Line

428 i 16 Boswell, Alexander, Lord Auchinleck : for 29 Dec. 1729 read 22 July 1727 for 31 read 25

429 ii 28 Boswell, sir Alexander : for 1818 read 1816

432 i 19 f.e. Boswell, James the elder: for 1765 read 1763

439 ii $\quad$\begin{tabular}{c|c} 
B & Boswell, John : for 1756 read 1757
\end{tabular}

440 i 23 f.e. Boswell, Sir William : after 1606 insert He was M.P. for Boston in 1624 and 22 f.e. 16 for subsequently read had already and after service insert He was secretary to Lord Herbert of Cherbury, while ambassador in Paris, in 1620 21 f.e. after and was insert subsequently

441 ii 17 Bosworth, Joseph : omit College

446 ii 5 f.e. Bott, Thomas : for Long read Longe

447 ii 18: for 23 Sept. read 19 Sept. 


\title{
DiCTIONARY OF NATIONAL BIOGRAPHY
}

\author{
ERRATA IN VOLUME VI
}

\author{
BOTTOMLEY-BROWELL
}

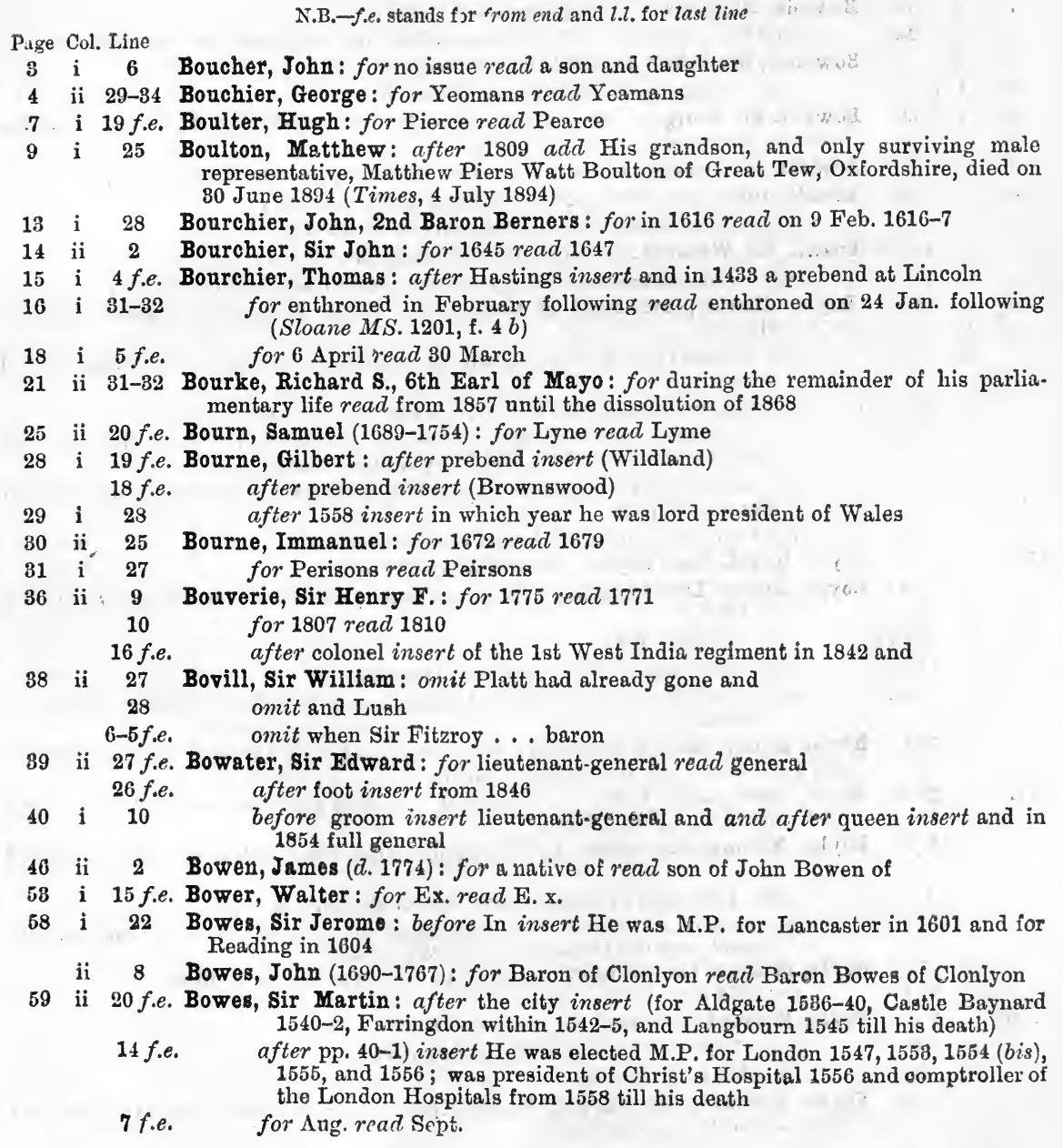


Page Col. Line

60 ii 21

62 i 24

ii 7

8

63 ii $\quad 38-39$

64 i. $18 j$

68 i 16

10 f.e.

6 f.e.

69 i $\quad 2-3$

4

ii 21 f.e. Bowles, William I. : for of which in read and in 1805 prebendary of Major Pars Altaris, which he held till his death. In

70 ii $\quad 35$

73 ii 22

$75 \quad$ i 13

15

77 ii 8

78 i $5-4$ f.e.

81 i 36

82 i 26

86 i 26

27

\section{3 f.e.}

i 23

ii 13

i 5 f.e.

$$
4 \text { f.e. }
$$$$
\text { ii } 4
$$

Bowes, Mary E., Countess of Strathmore : for Trowbridge read Troubridge

Bowes, Sir Robert : after accord insert He had been M.P. for Yorkshire in 15.12, for Newcastle-on-Tyne in 1545, and for Middlesex in 1547 and 1553

Bowes, Robert: for In 1571 read $\mathrm{He}$ had been M.P. for Knaresborough 1562-7. In 1572

for Carlisle read Appleby and he was M.P. for Cumberland 1581-5, 1586-7, and 1588-9

Bowet, Henry : omit at this time the and after Richmond insert in 1418 after London insert (1399) and another at York (1400)

Bowles, Sir George: after West India Regiment insert (1855) after 1846 insert lieutenant-general 1854 and general 1862 after London insert He became G.C.B. in 1873

Bowles, Phineas : for in 1749 read on 12 Dec. 1746 ; before member insert whig for in February 1734-5 read 1735-41 after Salisbury insert on 7 April 1850

Bowman, Walter: for $\mathrm{f} .324$ read $\mathrm{f} .334$

Bownde, Nicholas : for daughter read sister for his widow married read his mother married as her second husband

Bowring, Sir John : for twelve read thirteen omit subsequently held the appointment of

Bowyer, Sir George (1740 ?-1800) : after the year insert From 1787 to 1793 he was colonel of marines

Bowyer, Sir George (1811-83) : for Earl of Stanhope read Earl Stanhope

Boxall, John : for dean read archdeacon and prebendary after Winchester insert prebendary of St. Paul's

Boxall, Sir William: for In 1867 read On 24 March 1871

after knighthood insert and became a retired academician in 1877

Boyle, Charles, 4th Earl of Orrery: for Baron Marston read Baron Boyle of Marston

for elected read M.P. for Charleville in the Irish house of commons 1695-9 and

for but his return read 1701-5; his return for Huntingdon

after general insert $\mathrm{He}$ was colonel of $22 \mathrm{nd}$ foot 1704-7, of the 5 th foot 1707-10, and of the 21st foot from 1710 till death

for but resigned this post read and lord-lieutenant of Somerset, but resigned the former post

for his military command read the latter office

3 Boyle, David, Lord Boyle: for 30 Jan. read 4 Feb.

15-14 Boyle, Henry, Lord Carleton : for in the latter year he became the read from 1701 f.e. to 1708

18 f.e. $\quad$ for 1710 read 1715

11 f.e. $\quad$ after state insert of the Northern Department.

6 f.e. $\quad$ before Boyle insert $\mathrm{He}$ was lord-lieutenant of the West Riding of Yorkshire 1702-15

ii 19 f.e. Boyle, Henry, Earl of Shannon : after neglected insert He was M.P. for Middleton 1707-13 and for Kilmallock 1713-5

29-30 Boyle, John (1563 ?-1620): for is stated . . 1610 read was collated prebendary of Lichfield on 5 Feb. 1610-1

6 f.e. Boyle, Michael the elder: before obtained insert was archdeacon of Cork 1613-4 and

4 f.e. $\quad$ after 1619 insert resigning the Lismore deanery in 1621

4-3f.e. for several ... church read till death the chancellorship of Lismore and Cashel, and the treasurership of Waterford

ii 16 Boyle, Michael the younger: after dean of Clord

13 f.e. for 1675 read 1678 for : after dean of Cloyne insert in 1640

116 i 2 f.e. Boyle, Richard (d. 1644): for 1644 read 1645

ii 6 after 1603 insert dean of Tuam May 1604

18 for 1644 read 1644-5

86 Boyle, Richard, 1st Earl of Burlington: afte designs insert He was lord treasurer of Ireland 1660 -95 
Page Col. Line 117 i 2-1f.e. Boyle, Richard, 3rd Earl of Burlington: for In May 1715 . . and in read From from June 1715 to 1733 of the West Riding

1-2

2-3

125 i 39

126 ii 6 f.e.

130 i 27

ii $\quad 81$

149 ii 7

153 i 11

154 ii 10

161 ii 24

26

174

3-2f.e.

l.l.

211 i 1

ii 15 f.e. Brancker, Thomas : for Rhenanus read Rhonius

9 f.e.
omit June following . . . West Ridings

for of the same year read 1715

Boyle, Roger, Baron Broghill : after parliament insert and also in the parlia. ment of 1661 which lasted till 1679

Boyle, Roger (1617 ?-1687) : after Cork insert in Oct. 1662

Boyse, Samuel : for 4033 B read 4038, ff. 340, 342 ; cf. Stowe MS. 709, ff. 113, 114 for 1729 read 1789

Bradburn, Samuel: after merit insert He was president of the Wesleyan Conference in 1799

Braddock, Edward : for 1720 read 1725 for United States army read president of the United States

Bradford, Sir Thomas : after four years insert He was colonel of the 94th regiment from 1823 to 1829

for the 38th regiment read the 30th regiment, which he held till 1846

Bradock, Thomas : after 1584 insert $\mathrm{He}$ was proctor in the same year

Bradshaw, Henry : for College read Hall

Bradshaw, John (1602-1659): for apparently read subsequently for till 1649 when read till his death, although in 1649

for Edward Prideaux read Edmund Prideaux

omit permanent

after elected insert for Stafford

Bradwardine, Thomas : for soon afterwards read had already in 1333

before Archbishop insert In 1347 Bradwardine became archdeacon of Norwich

Brady, Sir Maziere : for Nicholas Ball read Stephen Woulfe for 1847 read 1846

Braham, John : for Brompton read Kensal Green

Bramhall, John: for Elvington read South Kilvington

Bramston, Sir John the younger: before In accordance insert $\mathrm{He}$ was elected for Bodmin to the long parliament

for To the first parliament of James II read To the parliaments of 1679 and 1685 (under James II)

omit the line

for Peel read Pell

Dacre

214 ii 20 f.e. Brand, John (d. 1808): for Oxford read Cambridge

217 ii 30 Brande, William T. : for in 1866 read 11 Feb. 1860

224 i 8 f.e. Brandon, Sir Thomas: for 1509 read 1510

ii 16 f.e. for in 1509 read on $29 \mathrm{Jan} .1509-10$

226 i 31 Brandreth, Thomas S.: for in 1873 read 27 May 1873

229 ii 24 f.e. Braose, William de : for (alias Colwyn) read (or Pains Castle)

19 f.e. $\quad$ after Castle Maud insert (or Pains Castle)

18 f.e. $\quad$ omit fell back ... where he

232 i 23 Brassey, Thomas: for Duke read Marquis

233 ii 35 Brathwaite, Richard : for In May read On 4 May

234 ii 28-32 for It is very doubtful ... 'A Happy Husband' 1619 resed Brathwaite's 'Good Wife ; or, a Rare One amongst Women, by.'Musophilus,' was published in 1618 ; a unique copy which once belonged to Sir Edward Dering was sold by Messrs. Sotheby in November 1897. A second elition appeared in 1619

237 i 23 f.e. Bray, John: for 232,32 read 282

241 ii 12 f.e. Bray, William : for Having licensed read After he had licensed

243 i 23 Braybroc, Henry de: for 1334 read 1234

$25 j$ ii 7-9 Brembre, Sir Nicholas : for He first appears ... 1376 real He was elected an alderman on 21 Sept. 1372 (Letter Book G. f. 298Z) 
Page Col. Line

258 i 3

263 i 15

ii 5 f.e.

266 i 14 f.e. Brenton, Sir Jahleel : after Sheerness insert He

Bremner, Robert : for 1763 read 1762

Brent, Sir Nathaniel : for 1639 read 1630

for Latin read Italian

ii 23 f.e. Brereton, Owen S.: after Lloyd insert He was M.P. for Liverpool from 1724 till his death in 1756, changing his name to Salusbury some years before

269 i 18 f.e. $\quad$ omit about the year 1756

270 i 3 f.e. Brereton, Thomas : for Queen's square read Queen square

271 i 12 f.e. Brereton, Sir William (1604-61): for 1639-40 read to the short and to the long parliaments in 1640

273 i 4 Brereton, Sir William (1789-1864): after constabulary insert and in April 1864 was made colonel commandant of the royal artillery

274 i 15 f.e. Brerewood, sir Robert : after law insert He was M.P. in the same year for Chester in the short parliament

282 i 32 Brett, Henry: for was for a short time member read was in three parliamentsfrom 1701-8-the tory member

283 ii 1-2 Brett, John W. : for but he did not live to see it accomplished read and an electric telegraph cable across the Atlantio was completed in 1858 , though it failed to work after the transmission of a few messages

4 for Trim read Trym

284 i 9 f.e.

Brett, Sir Peircy : for He became a vice-admiral read $\mathrm{He}$ was colonel of marines 1760-2 and M.P. for Queenborough 1754-74. He became a vice-admiral of the blue on 18 Oct. and of the white

285

286

299

300 i

301 ii 17 f.e. $\quad$ for In 1838 read On 7 Dec. 1837

7 f.e. Brett, Thomas : for 1743 read 1744
$21 \quad$ for 1743 read $1743-4$

14 f.e. Brewster, Abraham : for home secretary read first lord of the admiralty

11 f.e. $\quad$ after $\mathrm{St}$. Andrews insert $\mathrm{He}$ held the post till 1859. From that year till his death he was principal of Edinburgh University

302 i $\quad 38$

303 i 14 for Professor Blackie read Professor Blaikie for Montrose read Melrose

29

17 f.e.

Brewster, Sir Francis : for ( $f$. 1674-1702) read (d. 1704)

after 1674 insert He was M.P. in the Irish house of commons for Tuam 1692-1703, and for Doneraile 1703 4

304 ii 2-1f.e. Brewster, William: for but he mentions ... nor read He matriculated from Peterhouse in 1580 , but apparently failed to graduate

305 i 1 omit the line

314 ii 14 Brideoake, Ralph : omit his deanery of Salisbury

8 f.e. Bridge, Bewick : after 1811 insert He was proctor in 1800

318 i 3-2f.e. Bridgeman, Sir Orlando: for the long parliament read both the short and the long parliaments

$l . l$. for in the read on 27 Nov. 1648 omit same year

320 ii 83

321 ii 25

325 ii 6

327 ii 15

16

17-18

11 f.e.

7 f.e.

328 ii 22

Bridges, John $(d .1618)$ : after Thent insert From 1560 to 1610 he was prebendary of Winchester

Bridges, John (1626-1724) : for 1711 read 1711-2

Bridport, Giles of : for Buckinghamshire read Berlishire

Briggs, Henry P. : for 1793 read 1791 ? after painter insert son of John Hobart Briggs

for in 1793; he was . . . Opie the artist read about 1791; he was descended from Vincent Perronet [q. v.] whose daughter Elizabeth married William Briggs of the Customs House, secretary to the Wesleys after 1844 insert He married Eliza Alderson, by whom he had one son who died young, and a daughter who married John Carr, rector of Adisham, for Redgraves' read Redgrave's

Briggs, John (1785-1875): after major-general insert of lieutr.-general 1851 and 
Page Col. Line

333 i 6 f.e. Bright, Sir John : after Hull insert He was M.P. for the East Riding in 1654

ii 28 Bright, John (1783-1870): after Hospital insert From 1828 to 1845 he was a commissioner in lunacy

341 i 6 Brigit, Saint : for Dal, Conchobar read Dal Conchobar

342 ii 3 f.e. Brihtnoth : for sister read sister-in-law

348 ii 19 Brinsley, John : for 1663 read 1633

356 i $33 \quad$ Brisbane, Sir Thomas M. : for 1829 read 1825

7 f.e. Bristol, Ralph de: for Cashel read Kildare

7-6f.e. $\quad$ omit by William of Malmesbury

357 ii $\left.\begin{array}{c}23 \text { f.e. } \\ 3 \text { f.e. }\end{array}\right\}$ Bristowe, Edmund : for Bristowe read Bristow

865 i l.l. Brocas, Sir Bernard : after 1395 insert In 1391 he was M.P. for Wilts

379 ii 14 f.e. Brodie, Sir Benjamin C.: after examinations insert $\mathrm{He}$ was elected first president of the General Medical Council 23 Nov. 1858

383 ii 22-21 Brodrick, Alan, Iord Midleton : for king's-serjeant read second serjeant

f.e.

8 f.e. $\quad$ for Earl Pembroke read Earl of Pembroke

385 i 13 f.e. Brograve, Sir John : after years insert He was M.P. for Preston in 1586, 1597, and 1601, and for Boroughbridge in 1592

ii 28 f.e. Broke, Arthur: for Boaistuan read Boaistuau

388 ii 22 f.e. Broke, Sir Richard : for In the spring of 1511 (2 Hen. VIII) read On 19 July 1510

389 i 27-25 Broke, Sir Robert : for and recorder of London ... several parliaments read f.e. (1536-45) and recorder of London 1545-54 and represented the city in the parliaments of 1547,1553 , and 1554

$\left.\begin{array}{l}399 \text { ii } 23 \text { f.e. } \\ 400 \text { i } 18\end{array}\right\}$ Bromley, Sir Richard $\mathbf{M}$. : for 1866 read 1865

27 f.e. Bromley, Sir Thomas (d. 1555 ?) : for king's bench read common pleas

401 i 1 Bromley, Sir Thomas (1530-1587): after Bacon insert He was M.P. for Bridgnorth 1558, for Wigan 1559, and for Guildford 1562

403 ii 11 Bromley, Valentine W.: for congestion of the lungs read smallpox

15-11 Bromley, William (1664-1732): for Having in 1689 ... recognise William III f.e.

10 f.e. read $\mathrm{He}$ was elected in February 1689-90 M.P. for Warwickshire

404 ii 30 Bromley, William (1699?-1737): for of Warwick read of Fowey in 1725 and of Warwick

405 ii " 9 Brompton, Richard: after 1782 insert He was president of the Society of Artists till 1779

9 f.e. Bromyarde, John de : after Cambridge insert He was chancellor of the university in 1383

406 i 22 f.e. Brontë, Charlotte: for a curacy in Essex and read a curacy at Wethersfield in Essex and left in January 1809 to become curate at Wellington, whence he came to Dewsbury. Leaving this place at the end of the year he was presented

ii 31-32 for Heckmondwike read Liversedge

408 i 11 f.e. for in a lower situation read on a table-land

412 i 11f.e. for June read January

414 ii 3 f.e. Brook, David : after governors insert He was recorder of Bristol 1541-9 and M.P. for the city 1542-4

415 i 28 for earl of Guilford read Baron Guilford

416 .ii 13-12 Brooke, Sir Arthur : for and was rewarded read In 1822 he was rewarded

f.e.

10 f.e. $\quad$ for 1817 read 1819

9 f.e. $\quad$ after regiment insert in 1837

419 i 13 f.e. Broke, Christopher: after Essex insert He was M.P. for York in six parliaments, $1604,1614,1620,1624,1625,1626$, and was also elected for Newport (I. of W.) in 1624

423 i 27 Brooke, Henry, 8th Lord Cobham: after Henry insert who was M.P. for Kent in 1588-9 and for Hedon 1592-3

429 ii 12 f.e. Brooke, Sir James : after K.C.B. insert in 1848

433 ii 18-17 Brooke, Samuel: omit He was elected proctor at Cambridge in 1613 and f.e. 


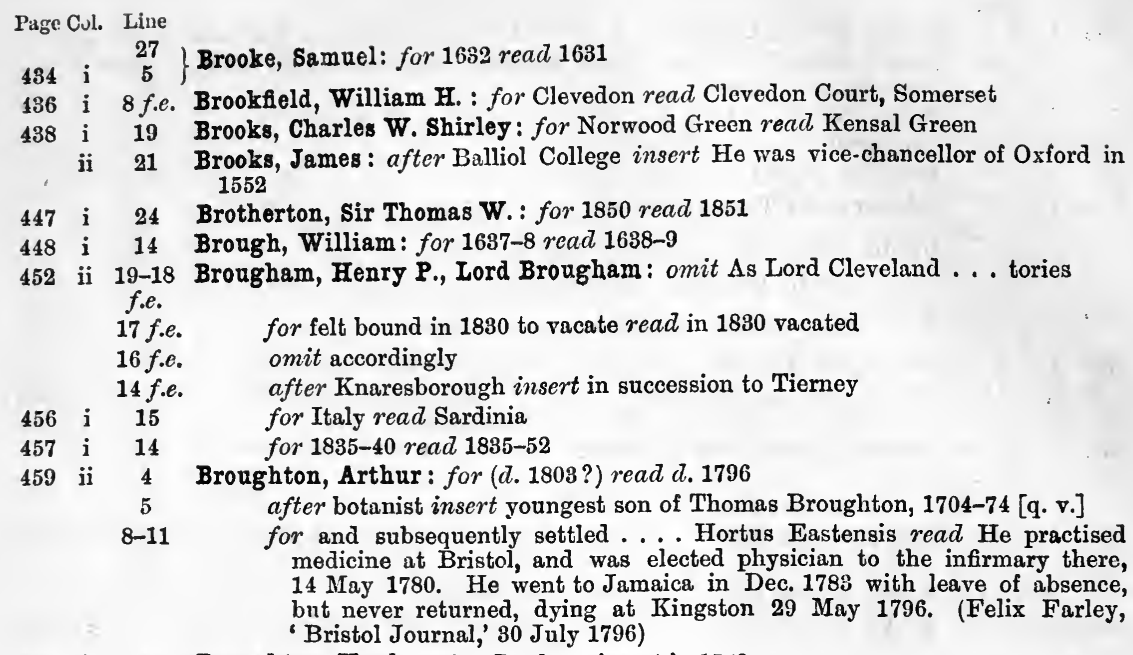

460 i 9 Broughton, Hugh: after Durham insert in 1578

464 i 34 Broughton, Thomas (1704-1774): before the vicarage insert a prebend in Salisbury Cathedral, to which belonged

37-8 omit To the same influence he owed ... . Salisbury Cathedral

38-9 for and on receiving this read On this

467 i 27 Broughton, William R.: after 1821 insert He was colonel of marinos from 1819 till his death

469 ii 20 f.e. Brouncker, William, 2nd Viscount: for 1642 read 1646

470 i $9 \quad$ after nation insert He was M.P. for Westbury in the convention parliament of 1660

$\begin{array}{cl}17 \text { f.e. } & \text { for Mr. Pitt read Mr. Pett } \\ \text { ii } 2 & \text { before Pepys insert He was a commissioner of the navy for general business } \\ & 1664-8 \text { and comptroller of the treasurer's accounts } 1668-79\end{array}$

3 for in this office read at the admiralty

32 after 1648 insert was M.P. for Romney from 1665 till he was expelled the house in 1669 


\title{
Dictionary OF NATIONAL BIOGRAPHY
}

\author{
ERRATA IN VOLUME VII \\ BROWN-BURTHOGGE \\ X.B.-f.e. stands for from end and l.l. for last line
}

Page Col. Line

1 i 11 f.e. Brown, Charles: for 1742 read 1741

ii 8 Brown, Charles A. : for 1787 ? read 1786

$9 \quad$ after Keats insert born in June 1786

2 i 24 for 1835 read 1837

3 ii 27 f.e. Brown, David (1763-1812): for a grammar school read tho grammar school

5 i 11 f.e. Brown, Sir George: before $\mathrm{He}$ was made insert $\mathrm{He}$ was colonel of the 77 th foot 1851-4 and of the 7th foot 1854-5

8 f.e. $\quad$ after brigade insert in Jan. 1855

7 ii 2 f.e. Brown, James B. the younger : omit Dr.

21 ii 1 Brown, John C.: for Charles read Crawrord

22 i 9-8f.e. Brown, Lancelot: for M.P. for Huntingdonshire read M.P. for Totnes 1780-4, for Huntingdon 1784-90, and for Huntingdonshire 1792-4

6 f.e. for London read Loudon

25 i 14 f.e. Brown, Sir Robert: for 1743 read July 1742

28 i 28 Brown, Samuel (1817-1856): omit Dr.

35 i 13 f.e. Brown, Ulysses $M$. von: for Charles V read Charles VI

38 ii 16 f.e. Browne, Sir Anthony : after Browne insert He was M.P. for Surrey in 1542 and 1547

39 i 11 f.e. Browne, Anthony (1510?-1567): after Cromwell insert He was M.P. for Lostwithiel in 1545, for Preston in 1553, and for Maldon in 1554

40 i 20 f.e. Browne, Anthony, 1st Viscount Montague (1526-1592): after Elizabeth insert $\mathrm{He}$ was M.P. for Guildford 1542 and 1547, for Peterstield 1553, and for Surrey 1554 10-9 for Gylesland read Gilsland

f.e.

43 ii 23 f.e. Browne, George (d. 1556) : after 1534 insert He was consecrated at Lambeth by the archbishop of Canterbury on 19 March 1534-5

47 i 7 Browne, Hablot K.: for Fairleigh read Fairlegh

54 ii l.l. Browne, Sir Richard : after recruiters insert in October 1645

55 i 1 for 1647 . . London read 1648 was also chosen alderman of Langbourn ward and sheriff of London

ii 4 after baronet insert $\mathrm{He}$ was commissioner of appeals in the excise from 1661 till death, and also president of Bethlehem and Bridewell hospitals 1660-8

60 ii 19 f.e. Browne, Robert: for Allen read Alden

7-6f.e. for and his last descendant... Pomfret read A son Edward was one of twenty gentlemen who under the leadership of Cecilius Calvert, 2nd Lord Baltimore, founded the colony of Maryland in 1634. He settled permanently in the colony, and by his wife, Mary, daughter of Morgan Williams, was father of Morgan and Edward Browne, whose descendants are still numerous in the United States of America 
Page Col. Line

61 ii $82-33$

34

62 i $\quad 32-38$

64

$\left.\begin{array}{ccc}65 & \text { i } & 30 \\ 72 & \text { i } & \begin{array}{c}32 \\ l, l\end{array} \\ 78 & \text { i } & \begin{array}{c}4 \\ 5\end{array} \\ & & \\ & & 4\end{array}\right\}$

10 f.e.

7 f.e.

ii 9 f.e.

79 i 20

81 ii 24

83 ii 19 29-30

85

$$
\text { 21-22 }
$$

92 i $\quad 37-38$

97 i 10

104 i 32

105 ii 16

$107 \cdot \mathrm{i} \quad \mathbf{3 6}$

Browne, Samuel $(d .1668)$ : for Two years previously read In October 1641 for boroughs read parishes for After this ... when he read He was elected M.P. for Bedford in 1659, and for Bedfordshire in 1660 . At the restoration he

Browne, Thomas : for in 1673 read 6 Dec. 1673 not by the subject of this article

Browne, Sir Thomas: for twelve read ten for three read two

Browne, Thomas (1708?-1780): after 1761 insert Clarenceux in 1778

Browning, Elizabeth Barrett : for 1809 read 1806

for Burn Hall read Coxhoe Hall in the parish of Kelloe for about eleven or twelve read thirteen after printed insert in 1819; it was issued in 1820 for seventeen years of age read twenty years of age (1826) after drowned insert in Babbicombe Bay after 1861 insert Another mural tablet is in Kelloe church

Brownrig, Ralph : after Cambridge insert in 1681 for in the same year read in 1642

Brownrigg, 8ir Robert: for K.C.B. read G.C.B. for was made G.C.B. in 1822 read was governor of Landguard Fort from 1823 till his death for April read May

Bruce, David II: for Oldham read Odiham

Bruce, Edward, Lord Kinloss : for Aylesbury read Ailesbury.

Bruce, James, 8th Earl of Elgin: after government insert His election for Southampton was, however, declared void on petition after Elgin insert who was made G.C.B. the year before

Bruce, Sir James I. Knight- : for In August 1837 read In 1835 and again in 1837

Bruce, John (1745-1826): before and historiographer insert to the privy council

Bruce, Sir John H.: for lieutenant-general read major-general 1754 and lieutenant-general 1758 after Bermudas insert (1721-7) after Parliament insert (1727-34 and 1741-7) after eighty-two insert on 6 June 1766

15 f.e. Bruce, Robert de, VI: $\}$ for Guisburn reall Gisburn

12 f.e. for Hemingford read Hemingburgh

119 i 12 f.e. Bruce, Robert de, VII : for Jan. read July.

130 i 32 Bruce, Thomas, 2nd Earl of Allesbury: before When the insert He was lordlieutenant of Bedfordshire and Huntingdonshire 1685-9

ii 35 Bruce, Thomas, 7th Earl of Elgin: after major-general insert in 1809, lieutenantgeneral in 1814, and general in 1837

181 ii 20 for from 1790 to 1840 read from 1790 to 1807 and from 1820 to 1840

136 i 23-24 Brudenell, James T., 7th Earl of Cardigan: for Hambledon in Hampshiro read Hambleden in Buckinghamshire

137 i 16-7 for what was known as the 'Black. Bottle' riot read a very serious episode

40 for James read Garner Phipps

15 f.e. $\quad$ for in 1847 read on 20 June 1854

139 i 9 , Brudenell, Robert: after 1790 insert [see Montagu, George Brudenell]

141 i 34 Brühl, John M., Count of: for Miss Cherone read Maria, daughter of Gene. al Christopher Chowne, who died in 1835

142 ii 18 f.e. Brundish, John J.: for three read two

15-14 omit and Smith ... 1836

f.e.

151 ii 24 Bryan, Sir Francis : after occasion insert He was M.P. for Buckinghamshire in 1542 and 1544 


\section{ERRATA-VOLUME VII}

Page Col. Line

154 ii 14 f.e. Bryan, Matthew: for Mews read Mew

155 i 15 for Waller read Walker

157 ii 11 f.e. Bryce, Sir Alezander : for and in 1829 was appointed read colonel commandant royal engineers in 1829 and in 1830

158 ii 18 f.e. Bryce, James, the elder: omit Scottish and after Church insert at Wick in Caithness

160 i 4 f.e. Brydges, Grey, 5th Lord Chandos: before His insert Grey Brydges was M.P. for Cricklade in 1597

162 ii 24 f.e. Brydges, James, 1st Duke of Chandos : for Chandos read Canons

3 f.e. after George II insert He resigned the lord-lieutenancy of Hertfordshire in 1742

166 ii 17 f.e. Brydone, Patrick: for 1741 ? read 1736

16-15 for was borm ... 1741 read was son of Robert Brydone (1687 ?-1761),

f.e. minister of Coldingham in Berwickshire, by his wife Elizabeth (d. 1764), daughter of John Dysart, his predecessor in the benefice. Patrick was born, probably at Coldingham, on 5 Jan. 1736

167 i 29 . after office insert from 1779 till death

33 after p. 643 insert Hew Scott, Fasti, ii. 431

168 i 1 Bryne, Albertus : for 1669 ? read 1677

33 after name insert He was organist and fourth fellow of Dulwich College from 1671 to 1677 and organist of All Hallows Barking in 1676

171 i 34 Buc, Sir George : after (Cottonian MSS.) insert He was M.P. for Gatton in 1592 and 1597

186 ii 32-33 Buchanan, Francis H. : for do not appear . . except read appeared in

36 after death insert and in 'Eastern India' by Robert Montgomery Martin [q. v.] 1838 (3 vols.)

11 f.e. $\quad$ after year insert He was married and left a son

189 i 24 Buchanan, George (1506-1582): for (10 Feb.) read (10 Feb. 1567)

38 for 16 Sept. read 16 Sept. 1568

190 ii $10 \quad$ for 1569 read 1570

191 i 3 f.e. 'for death read retirement

193 i 6 f.e. for 'Irones'read'Icones

199 ii 16 f.e. Buckenham, Robert: after 1531 insert In the latter year he became archdeacon of Lewes

200 ii 33 Buckeridge, John : for Colwell read Colwall

210 i 17 f.e. Buckle, Henry T.: for Lord Coleridge read John Duke (afterwards Lord) Coleridge

215 i 21 f.e. Buckley, William (d. 1570 ?): for Ufton read Ufton Decani

224 i-3-2f.e. Budgell, Eustace : for a member of the Irish House of Commons read M.P. for Mullingar in the Irish House of Commons 1715-27

226 ii 13 Budworth, William: for Shareshull read Shareshill

231 i 6 f.e. Bulkeley, Arthur : for 4 March read 14 March

ii 19 Bulkeley, Launcelot: for Some years later read In 1613

23 after kingdom insert From 1634 till death he was treasurer of Cashel

232 i 4 Bulkeley, Sir Richard (1583-1621): for parliaments . . 1570 read parliaments of 1562 and 1571

$9 \quad$ for 1576 read 1576-7

ii 16 f.e. after Notes and Queries inser't 1st Series

238 i 5 f.e. Bulkeley, Sir Richard (1644-1710): after 1672 insert He was M.P. for Fechard (Wexford) in the Irish House of Commons from 1692 till death

242 ii 20 f.e. Bull, John ( $f l .1636)$ : for ( $f$. 1636) read (d. 1642)

2 f.e. $\quad$ for Throskites read Thraskites

after p. 571) insert Bull died in January 1641-2

243 i 6

250 i 12 f.e. Buller, Sir George : after 1862 insert $\mathrm{He}$ was appointed colonel of the 88th foot in August 1860, but was transferred next month to the Highland Brigade

251 i 5-6 Bullingham, John : for the recently created bishopric of Bristol read the bishopric of Bristol (created in 1542)

252 ii 17 f.e. Bullingham, Nicholas : for 24 April read 18 April

257 ii 23-22 Bullokar, William : for Sir Ad. Toinings at Newhaven read Sir Adrian Poinings f.e. at Havre 
Page Col. Line

259 i 24 f.e. Bulstrode, Edward : for Hedgeley read Hedgerley

9f.e.

after Astley insert He was chief justice of the Anglesea circuit the same year

260 ii 15 Bulstrode, Whitelocke : after excise insert 1710-5 ?

261 ii 13-12 Bulteel, John: for To a certain John Bulteel who read One John Bulteel was f.e. $\quad$ secretary to Edward earl of Clarendon, was created M.A. of Oxford 9 Sept. 1661, was elected M.P. for Lostwithiel in 1661 and

11 f.e. $\quad$ for has read To him has

7 f.e. $\quad$ for John Bulteel read another John Bulteel

4-1 f.e. $\quad$ omit these lines

264 i 10 f.e. Bulwer, W. Henry Lytton E., Baron Dalling : after Bulwer insert who contested Hertford in 1826

2-1f.e. for for four sessions during which he read till the dissolution of 1837 and

266 i 14 Bunbury, Sir Henry E.: for 1815 read 1814

16 f.e. for 1820 read 1821

ii 6 after followed insert He withdrew from the army in 1832

268 i 7 f.e. Bundy, Richard: for a month later read on 24 Ang.

271 i 7 Bunny, Edmund : for 1619 read 1618

14 f.e. $\quad$ after 1585 insert resigned 1603

7 f.e. for $1618-9$ read $1617-8$

272 i 26 Bunny, Francis : after Calvinist insert At the time of his death he was prebendary of Carlisle

285 ii 13 f.e. Burbage, Richard: after stage insert and seems to have joined the Earl of Leicester's company of players which was long in high repute, and was afterwards known successively as the Earl of Derby's company, as the Lord Chamberlain's company, and after the accession of James $I$ as the king's company

11 f.e. for his father read Burbage's father

286 i 8-23 for Except for the mention . . . the day in a warrant read At Christmas 1594 he was summoned with two other members of his company (then known as the Lord Chamberlain's company), William Kempe [q. v.] and William Shakespeare, to act before the queen at Greenwich palace; they played in two several interludes on 27 and $28 \mathrm{Dec}$. and received $20 l$. for their services. A warrant

24 for authorising read constituted

25-26 for - the company in highest repute at the time-read the king's company and authorised them

31-36 omit from Burbage's position . . . from 1593

ii 35

288 i $\quad 27-28$

$39-40$

289 ii $7-8$

291 ii $28-29$

for 1594 read 1589

for very suspicious read quite authentic

for Chamberlain's 'Letter Writer' real Chamberlain, the letter writer

Burch, Edward : for On the death of Richard Wilson read In 1794

Burchett, Josiah : for On his return to England he real He

for (1695) read (February 1698-4)

after Sandwich insert as a whig

for 1721 read 1722

for $\mathrm{He}$ married Thomasine ... vi. 463) read Burchett married on $22 \mathrm{July}$

1721 the widow of Captain Robert Aris, commissioner of the navy at Plymouth (Hist. Reg. 1721, p. 31). His only daughter Elizabeth married Sir Charles Hardy the elder [q. v.]

295 ii 19 Burder, Henry F.: after 1830 insert He was chairman of the Congregational Union in 1844

297 ii 18-15 Burdett, Sir Francis: for In $1806 \ldots$ for Westminster read At the general election of 1806

16 for Paull, who read Paull for Westminster. Paull

298 ii 14-15 for In $1820 \ldots$... and shared read In 1819 George Lamb took Romilly's seat and in 1820 it was filled by Hobhouse, who slared

305 i 24 Burges, Sir James B.: for commissioner of excise, and died read a commissioner of the Scottish excise 1761-8, and afterwards comptroller-general of the Scottish customs from 1768 till his death on 16 March 1786

306 ii 21 for General Alexander Fordyce read Alexander Fordyce [q. v.]

307 i 11 f.e. Burges, Mary A.: for He real She

7 for 188 - read 1885 
Page Col. Line

311 ii 14 Burgess, John: for Hamsacre read Hunsacre

5-1f.e. for Dr. Munk ... certainly mistaken read He also had a son, Dr. John Burgess of Sutton Coldfield, whose 'Medical Commonplaces' are preserved in Sloane MS. 250

313 ii 6 Burgess, Thomas : after Salisbury insert He was prebendary of Salisbury 17871803

19-20 for In 1794 read In September 1791

315 ii 19 Burgh, Benedict: after Estsex' insert Burgh also edited and completed Lydgate's 'Secretes of Philosophers' (see Robert Steele's edition of the 'Secreta' for the Early English Text Society, 1893)

319 i 37 Burgh, Hubert de : for 1330 read 1230

.823 i $\quad$ l.l. Burgh, Richard de: for FitzAldelm read Fitzaldhelm

327 ii 7 Burgh, Sir Ulysses B.: for Lord Downes read 2nd Baron Downes [q. v.]

4f.e. before $\mathrm{He}$ became insert $\mathrm{He}$ was M.P. for Carlow Co. 1818-26 and for Queenborough 1826-30

328 i $3-1$ for the following year read 1833

5-7 for during the Duke ... ordnance read remained surveyor-general of the ordnance during the Duke of Wellington's ministry till 1830

before He died insert $\mathrm{He}$ was colonel of the 54th foot 1845-50

Burgh, Walter de : for Walter de Laci's wife read Walter de Burgh's wife

332 ii 12 f.e. Burghall, Edward : for RaIne read RaInes

333 ii 4 Burghers, Michael : for (d. 1727) read (1653 ?-1727)

5-6 for came to England ... Oxford read born at Amsterdam about 1658, and settled at Oxford in $\mathbf{1 6 7 3}$

9

after 1720 insert $\mathrm{He}$ succeeded David Loggan [q. v.] as 'sculptor' to the university in 1692

14 for John Barefoot, letter-doctor read Richard Barefoot, letter-carrier

339 13 f.e.

341 i 5

343 ii 27

4 f.e.

345 i 28

32

Burgoyne, Sir John (1739-85) : for 1783 read 1782

Burgoyne, John (1722-1792): for 1768 read 1769

Burgoyne, Sir John F. : for 1850 read 1851

after engineers insert (November 1854)

Burhill, Robert : for Beconum read Becanum for Beconi read Becani

372 ii 19 f.e. Burley, John : for 1647 read 1648

373 i 4

377 ii 28 for 1647 read 1647-8

378 ii 36

21 f.e.

Burn, Richard: for 1733 read 1734

Burn, William : omit Dalkeith Palace and

for Sandown read Sandon

380 ii 8 f.e. Burnaby, Frederick G. : for 1874 read 1875

386 ii 14 f.e. Burnell, Robert: after obtained insert He was presented to prebends in St. Paul's and Hereford cathedrals

397 ii 1

398 i 36

399 i 42

402 ii 39

404 ii 34

405 i 1

407

408 i

410 i

ii $\quad 20-19$

f.e.

415 i 8 f.e.

416 i 6 f.e.

417 ii 9-8f.e.

Burnet, Gilbert : for 1672 read 1671

for Grimstone read Grimston

for the Earl of Stafford read Viscount Stafford

for 1699 read 1698

for 7 read 17

after controversy insert He was prebendary of Salisbury from 1715 urtil his death, 17 June 1726

Burnet, Margaret: omit 1670 or

Burnet, Thomas (1635?-1715) : for 1661 read 1667

Burnet, Thomas (d. 1750): after and insert was prebendary of Salisbury from 1711 till his death, 28 May 1750. He Burnet, Sir Thomas : for was at length called to the bar reacl at length bcrall
practice at the bar

Burnett, Sir William : after K.C.B. insert in 1850

Burney, Charles : for 'The Coming Man' read 'The Cunning Man '

for Reynolds, now .... Oxford read Reynolds for Mrs. Thrale, at whose sale it was bought by Charles Burney (1757-1817) [q. v.]; it now belongs to Archdeacon Burney; a replica is in tho Music School, Oxford omit Busby's Anecdotes, ii. 52 


\section{ERRA'TA-VOLUME VII}

Page Col. Line

418 ii 14 f.e. Burney, Charles (1757-1817) : for afterwards . . . Burney read successively archdeacon of St. Albans and Colchester, the friend of Bishop Blomfield, and a man of considerable social gifts. Burney himself

419 i 16-15 Burney, James: for captain in the royal navy read rear-admiral f.e.

ii 35

after apoplexy insert a rear-admiral on the retired list

428 ii 20 f.e. Burns, Robert (1759-1796) : for East Indian read West Indian

430 ii 12 f.e. for 18 read 16

440 i 23 f.e. Burrard, Sir Harry : for from 1706 to 1736 read from 1705 to 1727 and for Yarmouth (I. of W.) from 1727 till his death, 30 May 1735

21 f.e. $\quad$ for 1784 read 1778

11 f.e. after Sir Harry insert He was M.P. for Lymington 1780-8, 1790-1, and 1802 ii, 8 for and also made read He had already, in 1787 , been made

442. i 25 Burrell, Lady Sophia : for Burkell, Lady Sophia read Burreli, Sophua Lady

ii 26 Burrell, sir William : after Rochester insert continuing in both posts till death. 28 for 1771 read 1774, being re-elected for Haslemere in that year

443 i $3 \quad$ Burrough, Edward: for 1662 read 1663

444 i $20^{\circ}$ for towards the end of 1662 read on 14 Feb. 1662-3 (Ellwood's Autobiography)

445 i 5 Burrough, Sir James: after 1727 insert resigning the post in 1749

9 after 1764 insert $\mathrm{He}$ was vice-chancellor of Cambridge in $\mathbf{1 7 5 9}$

ii 4 for by way of consolation read in November 1759

448 i 7 . Burrow, Sir James : for At the early age of twenty-three read In 1733, at the age of thirty-two

450. ii 1, 2 Burrowes, Peter: for In 1821 he was appointed judge read From 1821 to 1835 he was commissioner 


\title{
DiCTIONARY OF NATIONAL BIOGRAPHY
}

\author{
ERRATA IN VOLUME VIII
}

\author{
BURTON-CANTWELL
}

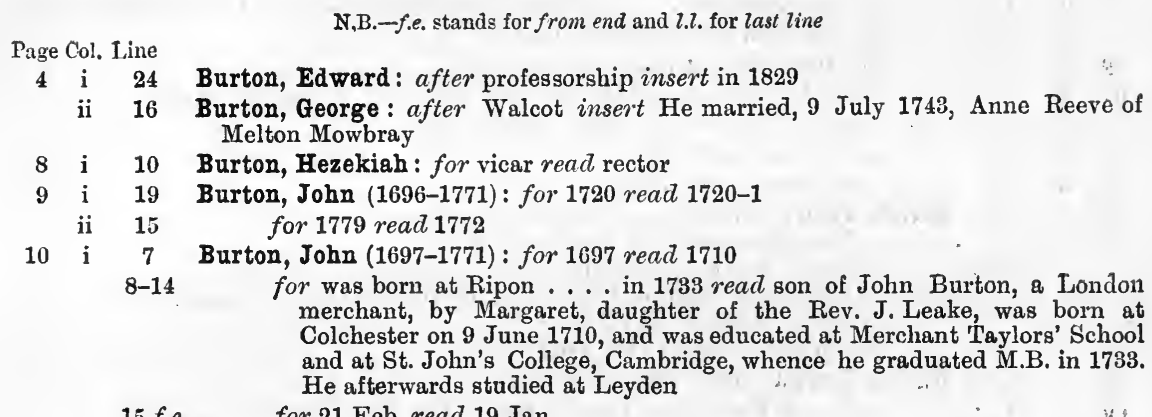

15 f.e. $\quad$ for 21 Feb. read 19 Jan.

14 f.e. $\quad$ after Burton insert Burton married, on 2 Jan. 1734-5, in York Minster, Mary Henson. She survived him a few months and was buried by his side in Holy Trinity Church, Micklegate

11 i 10 f.e. Burton, John $\mathbf{H}$. : for 1862 read 1864

17 i 12-16 Burton, Thomas: for The Westmoreland returns . . . . re-elected to it read Burton was re-elected for Westmoreland to Richard Cromwell's parliament (27 Jan. 1658-9 to 22 April 1659)

18 ii 17 f.e. Burton, William (1575-1645) : for 1662 read 1622

21 ii 27 f.e. Bury, Arthur: for 1714 ? read 1713

11 f.e. $\quad$ before and was offered insert was made prebendary of Exeter

22 i 4 f.e. for evidently the composition of Bury read by James Parkinson [q. v.] 1658-1722

2 f.e. $\quad$ for his read Bury's and for he read Bury

ii 12-14 for The date of his death .... about 1714 read $\mathrm{He}$ died, according to Rawlinson MSS. in Bodleian Library, in Sept. 1713

Bury, Lady Charlotte S. M. : for died quite forgotten .... and her read was described in the

83-84 for curiously says read as

12 f.e. for Disinterested read Disinherited

28 ii 21 Bury, Thomas : for 1667 read 1667-8

32 ii 39 Bush, Paul : for about 1517 read in June 1518

36-39 for the 'Bonhommes'.... Black Prince), whose house read the Austin Friars), whose house

Bushe, Charles $\mathrm{K}$. : for 1797 read 1796
after Callan insert He sat for that place till 1799, when he was returned for Donegal borough
12-11 for On the dissolution ..... in 1803 read Bushe was made third serjeant in
f.e. July 1805. On the promotion of the solicitor-general Plunket to the attormey-generalship in the following October

35 i 11 Bushell, Brown : for April read March 
Page Col. Line

35 i 35

39 i 10 f.e.

8 f.e.

1

Bushell, Seth : for and M.A. read He proceeded M.A. 1655

Busk, Hans (1772-1862): for Wordsworth read Wadsworth

Butcher, Edmund: after Edmund insert a churchman and a tory, and alderman of Bristol from 1838 to 1850

45 ii 19 f.e. Butler, Charles (1750-1832): for 1832 read 1831

50

17 f.e. Butler, Sir Edward G. for the latter year read 1815

ii 9 Butler, James, 2nd Earl of Ormonde : for 1377 read 1337-8

i Tf.e. Butler, James ( $f$ l. 1631-4): for 1642 read 1643

4-3f.e. $\quad$ for earl (afterwards .... of Ormonde read twelfth earl (afterwa:ds murquis and duke) of Ormonde

53 i 10 Butler, James, 1st Duke of Ormonde : for In 1631 he read He then

57 i 4-3f.e. for from February to April read till April

ii 23 after Somerset insert (resigned in 1672)

60 i 87-89 for an English dukedom .... Lauderdale read one English dukedom having lapsed with the death of Lauderdale, another

61 i 12 f.e. Butler, James, 2nd Duke of Ormonde: for Ormonde read In Sept. 1688 James II made Ormonde K.G., but the duke

ii 11

62 ii 8 f.e.

64 i 17

23-24

25

ii 12

$67 \quad$ i 18

20-23

ii 6 for was gratified . . . . the read was installed K.G. and was gratified by the for life-guards read horse-guards

for the following year read April 1707

after 529-530) insert He was lord-lieutenant of Norfolk 1713-14

omit and confirmed in the lord-lieutenancy

omit from both offices

after June insert 1716

Butler, John (1717-1802) . for was born at Hamburg read son of James Butler of Hamburg, was born there in 1717

for He was not a member . . . . Cambridge read He matriculated from

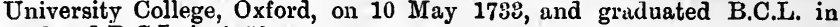
1746 and D.C.L. in 1752

for in 1802 read 10 Dec. 1802

69 i 19 f.e. after St. Paul's insert with a prebend and a residentiary canonry.

18 f.e. $\quad$ after installed inscrt as dean

18-17 for his other preferments read his preferments at Rochester and Stanhope

f.p.

ii 10 f.e.

78 ii $23-24$

for 1741 read 1750

ii 29

3 f.e.

77 i 8

79 ii 8

38

81 i 33

$38-41$

41

16 f.e.

ii 5-1 f.e. Butler, Thomas, Earl of Ossory : for in the Irish House of Commons read M.P. for Dublin University in the Irish House of Commons 1661-2 for in June read on 11 Aug.

86 ii 10

92 i 17

93 i 34

20 f.e.

19 f.e.

2 f.e.

\section{and Aughrim}

Butler, Samuel (1774-1839) : for 1822 read 1821

after 1797 insert and of 'Sidneiana' for the Roxburghe Club in 1837

after 311 insert A full life was published by Samuel Butler, his grandson, in 1896

Butler, Thomas, 10th Earl of Ormonde: after time insert holding that office till death

omit with his views

after Armada insert and was made K.G.

omit Early in 1599 ... Ireland but

for with read With

after loyalty insert (cf. Letters and Despatches relative to the Taking of the Earl of Ormonde by O'More A.D. 1600, edited by J. Graves, 1863.

Butler, Walter, 11th Earl of Ormonde : for Poyntz read Preston

Butler, William A. : for Thomson read Thompson

Butt, Isaac : after 1852 insert (having contested Mayo Co. as a conservative in 1850) for Sir J. M'Kenna read the Hon. J. W. Fortescue after 1865 insert when he was defeated by Sir J. M'Kenna after 1871 insert having been defeated for Monaghan Co. the previous July

\section{ii 24 Butter, Nathaniel : for Giffard read Gifford}


Page Col. Line

98 ii $10-11$

4-3f.e. Button, Ralph : for Dr. Henry Hammond read Edward Corbet, the successor of Dr. Henry Hammond

99 i $28 \quad$ for Wood's read Ward's

101 i 20 Button, William : omit and afterwards dean

13 f.e. $\quad$ for 1248 read 1247

ii 11 Button, Sir William : for 1654 read 1655

16 f.e. for 1654 read $1654-5$

102 ii 5 Butts, Robert: for four read five

105 ii 10 Buxton, Charles : for M.A. in 1843 read B.A. in 1845 and M.A. in 1850

110 i 20 Byam, Henry : for 1637 read 1627.

21 for the vicarage read afterwards became vicar

113 ii 15 f.e. Byles, John B.: for JoHn read Sin JoHN

114 i 12,13 omit and he was the last survivor of the order

21 for June read January

115 i 13 Byng, Andrew : for 1651 read 1652

for 1651 read March 1651-2

after business insert He was sub-dean of York for forty-six years, from 1600 till his death

118 i 30 Byng, George, Viscount Torrington, after Torrington insert He had been M.P. for Plymouth since 1705

120 i 12 f.e. Byng, John (1704-1757) : after 1757 insert He was M.P. for Rochester from 1751 till his death

122 i 11, 12 Byng, Sir John, Earl of Strafford : omit and governor . . . Culmore

21 before in 1822 insert the colonelcy of the York Infantry Volunteers (1815-6), the colonelcy of the 4th West India regiment (1816-9),

27

for but resigned his command read In 1832 he was made governor of Londonderry and Culmore, but he resigned his Irish command

ii 9 Byng, Thomas : for 1572 read 1572 and 1578

l.l. Bynneman, Henry : for Ball read Bell

123 i 21 f.e. Byrd, William: for 1538 ? read 1540

ii 24-26 for It was .... he married read On 14 Sept. 1568 he married at St. Mar. garet's in the Close, Lincoln

124 i 22 f.e.

ii $17-7$

f.e.

for is read in

for Somewhere about this time . . . the crown read In April 1592 Byrd was still living at Harlington, but about 1593 he became possessed of the remainder of a lease of Stondon Place, Essex, an estate belonging to William Shelley, who was shortly afterwards convicted of high treason. The property was sequestrated and on $15 \mathrm{July} 1595$ Byrd obtained a crown lease of it for the lives of his eldest son, Christopher, and his daughters Elizabeth and Rachel

for 1698 read 1608

for What the end of the dispute .... much longer read Mrs. Shelley died in 1609, and the long dispute was settled by Byrd's purchase of Stondon Place in the name of John and Thomas Petre, charging part of the property with a payment to himself of $20 l$. for his life with remainder to his second son, Thomas - an arrangement which gave rise to further litigation after his death

for Sir Thomas Leighton's read Sir William Leighton's

for but the copies of the two .... Antiquarian Society in 1841 read with. out title-pages probably in 1588 , and have been published in modern editions

after Gresham College insert and was alive in 1651

after married insert (1)-Hook, by whom she had two children, William and Katherine, wife of Michael Walton, and (2)

for Thomas Falconbridge read (1) Henry Hawksworth, by whom slie had four sons, and (2) Thomas Faulconbridge; and 6. Anne, who died young

Byrne, William: after success insert His second daughter, Mary, married James Green, 1771-1834 [q. v.]

8 f.e. Byron, George, 6th Lord: for 245 read 45

ii 12 for John read John Thomas

i 18 f.e. for Cappetread Coppet 
Page Col. Line

153 , ii ... 13

165 ii 8 f.e.

175

175 i 11 Cade, Salusbury: after 1660

184 i $9-11$ 85-38 ii 16

24-26 32

3-1 f.e. 185 i 17 f.e. 2-1 f.e. 186 i 12 f.e.

7 f.e.

6 f.e.

3 f.e.

Byron, George, 6th Lord: for Tinton read Turton omit Cadogan was lieutenant . . . of London A pp.) omit lieutenant . . . until 1718 Isle of Wight omit In September .... Wight for 1709 read 1719 after Charles Cadogan insert (1691-1776)

for several read two and after Reading insert 1716-22

after Wight insert 1722-6

Cadogan, William, 1st Earl : omit The lieutenancy .... same year

before Before the death insert The lieutenancy of the Tower of London was conferred on him in December 1706, and he held it till January 1713

after Holland insert On 31 Aug. 1715 Cadogan was appointed governor of the for the posts of commander-in-chief of the arny and read post of

after dragoons insert $\mathrm{He}$ was governor of Sheerness 1749-52 and of Graves. end and Tilbury 1752 till death.

202 ii 16 f.e. Cæsar, Sir Charles : for Bletchingley, Surrey read Weymouth

204 i 11 Cæsar, Henry : for 7 Oct. read 27 June

3-1 f.e. Cæsar, sir Julius : omit Many of his prescriptions . . . manuscripts

ii 1

206 ii 7

207 ii 22 omit by Sir Hans Sloane for Essex read Suffolk

Cæsar, Julius : after (1720) insert Many of his prescriptions are preserved in Sloane MS. 2815, having been copied from original manuscript by Sir Hans Sloane

40

42

215 i $\quad 89$

216 ii $5-6$

218 i $7-6 f . e$.

Cøsar, Sir Thomas : after undistinguished insert He was M.P. for Appleby in 1601 omit puisne or

Cairnoross, Alexander: for in 1701 read 14 May 1701

Cairnes, David : for till the close of his life read till 1703

Cairns, Hugh M., 18t Earl Cairns : for the conduct . . Of this read the Oude despatch of Lord Ellenborough, who was president of the board of control, and this speech was subsequently published. In the following session he introduced two bills, one to simplify titles to real estate and another to establish a land registry, and his speeches introducing them produced a very favourable impression. Of his subsequent speech on the Reform Bill, 22 Márch 1859 ,

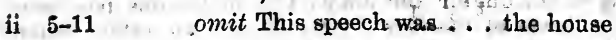

12

219 i $\quad 26-28$

39-40 for 'Cagliari' read 'Charles and Georges' is: is

for Caims to some extent.... the bench read Subsequently in 1877 Cairns as a sort of reparation appointed Lord Chelmsford's son, Alfred Henry Thesiger [q. v.], a lord justice of the appeal cuurt

for On 21 July, when the bill read On 20 July 1869, when Gladstone's Irish Church bill

220 ii $\cdots 11$

14

for him read new buildings

omit the line

221 i 15 f.e. Caius, John : after Althorp insert which is now at the John Rylands library at Manchester

235 ii 26 Calcott, Wollins: for Cheshire read Shropshire

237 i 20 Calcraft, John (1726-1772): after treasury insert He was M.P. for Calne 1766-8 for the same constituency read Rochester

240 ii 33 Caldecott, Thomas : for 1743 read 1744 before New College insert Winchester ard

241 ii 5 f.e. Calder, Robert: for Neuthorn read Nenthorn

243 ii 36 Calder, Sir Robert : after 1810 insert He was made K.C.B. Jan. 1815

24 ii 4 f.e. Calderwood, David: for Grubb's read Grub's

247 i 19 Caldwell, sir Alexander : for 1765 read 1763

19-23 for Captain Alexander Caldwell .... in 1765 read William Caldwell by his third wife, Isabella, daughter of Alexander Clark of Inverness. He was a grandson of Sir John Caldwell, 2nd baronet, of Castle Caldwell, Co. Fermanagh 
247 ii 11 f.e. Caldwell, Sir Alexander : after 1839 insert Sir Alexander was twice married, first to Ann Miller, who died 22 Oct. 1836, and secondly to Elizabeth Shepheard. The second Lady Caldwell afterwards married Colonel Le Blanc and died in 1891

248 i 9 f.e. Caldwell, Sir Benjamin : after 1783 insert He was M.P. for Knocktopher in the Irish House of Commons 1776-83 and for Harristown 1783-90

249 i 35 Calendar, Earl of : omit this cross reference

254 i 8 f.e. Call, Sir John : for Lord Oxford read Lord Orford

261 i 12 f.e. Calthorpe, Sir Henry: for Foster's read Forster's

4-8f.e. Calthorpe, Sir Charles: for 1583, in succession to Thomas Snagge read 1584

265 ii 7-11 Calverley, Walter: for But more interesting .... was first published read Calverley's story was twice dramatised - first by George Wilkins [q. v.] in 'Miseries of Enforced Marriage' (1607) and secondly in 'The Yorkshire 'Tragedy,' which was first published for the play read 'The Yorkshire Tragedy'

266 i 36 Calvert, Caroline Louisa W.: for Dr. Woold read Dr. Woolls

268 ii 9 f.e. Calvert, Frederick, 7th Lord Baltimore: for seventh read sixth

7 f.e. $\quad$ for sixth read fifth

12-16 note that Carlyle refers not to the subject of this article, but to his father, under date 1739

270. ii 4 f.e. Calvert, George, 1st Lord Baltimore: before In the insert On 8 Jan. 1623-4 he was elected M.P. for Oxford University

for Anne, daughter of George Wynne read in 1604-5 Anne(d.1622), daughter of a Roman catholic, George Mynne

12 after Hertfordshire insert By her he had six sons and five daughters. There is some evidence of a second marriage

18 f.e. $\quad a d d$ A portrait by Mytens has been often engraved

273 i 19-20 Calvert, Sir Harry: for G.C.B. . . . adjutant-general read G.C.B. in 1815 and G.C.H. in 1817, received next year

26-27 for about the time of his marriage read in January 1799, five months before his marriage

274 i 16 Calvert, Leonard : for Port Comfort, Virginia, on 24 Feb. read Point Comfort, Virginia, on 27 Feb.

18 after Indian village insert in Maryland

26 f.e. after Virginia insert In April 1637 Calvert was constituted lieutenantgeneral, admiral, commander, chancellor, and chief justice of Maryland. He stood by the authority of the king during the Civil War, and was viewed with hostility by the parliamentary party.

21-20 for and finally drove Calvert to Virginia read Richard Ingle, who held a f.e. commission from the parliament against malignants in Chesapeake Bay, finally drove Calvert to Virginia

11 f.e. for Frank White read Father Andrew White, S.J.

275 i 28 Calvert, Thomas : for about 1819 read in 1817

30 for 1814 read 1815

ii 27 Cambell, Sir James : for 1613 read 1614

28, 29 for Broad Street read Bread Street

31 before and twice insert governor of the East India Company 1602-3

40 for Lion Street read Lime Street

280 i 15 f.e. Camden, William: for a music lecture read the professorship of music

281 ii 17 f.e. for 1515 read 1615

286 ii 23 Cameron, Sir Alexander : for Inverallort read Inverailort

30,31 for the 95th regiment read the corps of riflemen and afterwards as the 95th regiment

288 ii 26 Cameron, Charles D.: for Cobourg read Coburg for 1866 read 1865

289 ii 43 Cameron, Donald: before was proclaimed insert his father

295 i 6-7 Cameron, John (1579 ?-1625): omit of respectable parents

10 before After completing insert His father is identified with John Cameron, rector of Dunoon, and the family claim connexion with that of Lochiel

299 ii 18 Cameron, Sir John : before On 10 Jan. 1837 insert He had been colonel 93rd foot 1832-3 and was lieutenant-governor of Plymouth 1823.435 
Page Col. Line

308 ii $34-38$

$\begin{array}{ccc}312 & \text { i } & 44 \\ & & \\ 314 & \text { i } & 6 \\ & & 9 \\ 318 & \text { i } & 2 f . e . \\ & \text { ii } & 34 \\ 319 & \text { ii } & 29 \\ & & \\ 320 & \text { i } & 23 \\ & \text { ii } & 26 \\ & & 13 f . e . \\ 324 & \text { i } & 16 f . e . \\ & & 10 f . e . \\ 328 & \text { ii } & 39 \\ & & l . l . \\ 329 & \text { i } & 1,2 \\ & & 29 \\ & & 29 \\ 332 & \text { ii } & 22 \\ 339 & \text { ii } & 9 \\ 341 & \text { i } & 41 \\ & & \\ & \text { ii } & 8 \\ & & 27 \\ & & 31 \\ 342 & \text { i } & 19 \\ & & 4,3 f . e . \\ & & \end{array}$

313 i 14 Campbell, sir Archibald (1739-1791): for and in the following month read In the

Campbell, Alexander, 2nd Earl of Marchmont : for Hugh, on whose death . . . . in existence read Hugh [see Hume, Hugr, 3rd and last EarL of MaRchmonT], through whose daughter Lady Diana the barony of Polwarth descended to her

son Hugh Scott of Harden
Campbell, Anna M., Countess of Balcarres : for eighth earl of Argyll read ninth earl of Argyll

Campbell, Archibald, 4th Earl of Argyll : for 1447-8 vead 1547-8

9 for Henry VIII read the English

Campbell, Archibald, 5th Earl of Argyll : for death read divorce

Campbell, Archibald, 7th Earl of Argyll : for the nearest heir read near heir for one son and one daughter read five daughters and three sons, including James, colonel of the Scots Guard in France, created earl of Irvine in 1642, who died in $\mathbf{1 6 4 5}$

Campbell, Archibald, Marquis of Argyll : for 1660 read 1661

for tutor read guardian

for 69 read 70

for 20,000l. read 20,000l. (Scots)

for depositions read dispositions

for did not disprove .... only his read disproved cowardice but showed

for St. Margaret's Chapel read St. Magdalene Chapel

for whence after .... removed read thence to Newbattle Abbey, and after a few weeks

for three read four

Campbell, Archibald, 9th Earl of Argyll : for Maydock read Mugdock

Campbell, Archibald, 1st Duke of Argyll : for 1690 read 1696

Campbell, Archibald, 3rd Duke of Argyll : for the 30th regiment of foot read the 36th regiment of foot 1709-10

for 1725 read 1721

for the university of Aberdeen read: Marischal College, Aberdeen for 1784 read 1733

Campbell, Archibald ( $f .1767)$ : for ( $f$. 1767) read (1726 ?-1780)

for After this .... this author read Campbell died at Kingston, Jamaica, on 10 Dec. 1780 , in his fifty-fourth year, and was buried in Kingston parish churchyard previous July he was

345 i 16 f.e. Campbell, Sir Archibald (1769-1843): after. lieutenant-general insert was colonel of the 95th regiment $1829-34$ and of the 77 th regiment $1834-40$

350 i 20 f.e. Campbell, Colin (1754-1814): before Campbell was pramoted insert He was colonel of the 5th garrison battalion 1808-12 and of the 55th foot 1812 till death

351 i 29 Campbell, Sir Colin (1776-1847): after some years insert He was lieutenantgovernor of Tobago in 1828 and of Portsmouth 1828-35

31 for In 1839 read In November 1840

17 f.e. $\quad$ after Piccadilly insert $\mathrm{He}$ had been colonel of 99th foot 1834-6 and of 72nd foot from 1836 till his death

7 f.e. Campbell, sir Colin, Lord Clyde: for Colin read John

353 i 39,40 for he it was .... victory read he rendered the highest services at the battle 20 f.e. $\quad$ for Crown Prince of Germany read the Prince of Prussia

354 i 10 f.e. for 1858 read 1861

355 ii 1,2 Campbell, Daniel (1671?-1753): for Catherine Denham read Catherine, daughter of Henry, third Lord Cardross, and relict of Sir William Denham, bart., of West Shields

3 ;6 ii 15 f.e. Campbell, Duncan : for Hayward read Haywood

357 i 5 f.e. Campbell, Lord Frederick : after 1765 insert was secretary to the lord-licutenant of Ireland 1767-8

3 f.e. $\quad$ for 1771 read 1777

2 f.e. $\quad$ for 1784 read 1787

i.l. omit the line

ii 1 omit tenant and for 1786 read 1790

2 after India insert He was a member of the committee of council for trade 1784-1801

15 f.e. Campbell, Frederick W. : for Sir Edward Warrington read Sir Edward Winnington, bart. 
Page Col. Line

357 ii 14 f.e.

359 i 26 Campbell, sir Guy : for commanded it read was attached to the staff

28 for 1828 read 1830

ii 11 f.e. Campbell, Hugh, 3rd Earl of Loudoun : for in the following year read of the same year

361 ii 36 Campbell, Sir Jamos (1667-1745): after colonel of the insert 9th foot in 1715 and of the

37-39 omit and was returned ... 1727

41, 42 omit promoting Campbell to be major-general and

42 for him read Campbell

18 f.e. after Castle insert He was M.P. for Ayrshire 1727-1741. He was promoted brigadier-general in 1735 and major-general in 1739

362 i 14 Campbell, Sir James (1763-1819): for general read lieutenant-general

ii 15

363 ii 4 f.e. Campbell, Sir James (1773 ?-1835): after major-general insert from 1825 to 1833 was governor of Grenada for 1830 read 1831

3 f.e. $\quad$ for 74 th read 94 th and for 94 th read 74 th

364 i 18,21 , Campbell, Sir John (d. 1563): for Sir Jolin Lundy read Campbell of Lundy

368 i 29 Campbell, John, 1st Earl of Breadalbane : before On the insert He was a representative peer in parliament in $\mathbf{1 7 1 3}$

369 i 33 Campbell, John, 2nd Duke of Argyll : after Keyserswaert insert He was colonel 10th foot 1702-3, 4 th horse-guards 1703-15, 5th foot 1706-7, 1st horse-guards 1715-17 and 1733-40, and 3rd horse-guards 1726-33

370 i 20 f.e.

372 i 41

ii 8 f.e.

373 i 25

31

ii 24

$\mathbf{3 0}$

375 ii 27

33-34

38

40

376 i 18

17 f.e.

ii $\quad 6-7$

12

878 ii 17 f.e.

12 f.e. 386 i 37 Campbell, John, 2nd Marquis of Breadalbane: for In 1843 he was chosen read

ii 9 f.e. Campbell, sir John (1780-1863): for K.C.T.S. read K.T.S.

387 ii 16 Campbell, sir John (1802-1877): for 1877 read 1878

388 i $26-27$

31

389 ii 31

390 i 9 f.e.

892 i

$898 \quad i$

402 i

17

8

22

28

ii 26

403 i 22

after castle insert $\mathrm{He}$ was also governor of Minorca (1712-4 and 1714-6)

after offices add (He had been lord-lieutenant of Surrey 1715-6)

after Jacobites insert From 1725 to $\mathbf{1 7 3 0}$ he was master-general of the ordnance, and from 1730 to 1737 was governor of Portsmouth. He was made field marshal Jan. 1735-6

omit field marshal and

for Oxford read Orford

Campbell, John (1708-1775): omit about the age of eighteen

for 1721 read 1736-7

Campbell, John, 3rd Earl of Breadalbane : for Oxford read Orford

for In January 1746 read In 1745

after Scotland insert and sat till 1768 and again from 1774 to 1780

for 1761 read 1756

Campbell, John, 4th Earl of Loudoun : after highlanders insert (the 54th)

after Skye insert From 1749, when his old regiment, the 54th, was disbanded, he held until 1770 the colonelcy. of the 30 th foot. From 1755 to 1757 he was also colonel-in-chief of the 60th foot (rifles)

for King George read Saint George

before He died insert He was colonel of the 3rd foot guards from 1770 till death, and governor of Stirling Castle till 1763, when he was transferred to Edinburgh Castle, the governorship of which he held at death

Campbell, Sir John (1816-1855) : for 1816 read 1807

for on the enlargement read in 1869 after the enlargement

for in December 1877 read on 21 April 1878

Campbell, Neil (d. 1627) : for 1514 read 1574

Campbell, Sir Neil : before He accompanied insert He was made C.B. in 1815

Campbell, Robert C. : for Dodswell read Dodwell

Campbell, Willielma, Viscountess Glenorchy : for Staffordshire read Shropshire

Campion, Edmund : for five read six

for 14 read. 12

after away insert Two of the prisoners, Bosgrave and Orton, were not executed

Campion, Thomas : for (d.1619) read (d.1620 
Page Col. Line

403 i 23

26-27

19 f.e.

11 f.e.

6-4 f.e

ii $15-16$

24-25

26

27

18-17

f.e.

$12-11$

f.e.

404 i 15

for was probably the read has been wrongly stated to be

for and was born .... Elizabeth read This couple only married in 1597 when the poet was about 30 . Campion's connexion with the Witham family is not clear

for at home read at Cambridge (cf. Cherke's Polimanteia, 1595)

for He appealed read He was entered at Gray's Inn in 1586 but before 1595 withdrew from the society. He was writing verse in 1593 , but

for The book is one . . . . early bibliographers read No copy seems now accessible

for we lose sight ... when he read In January 1606-7 Campion published 'A Booke of Ayres.' There followed without date, probably in 1613, 'Two Bookes of Ayres.'

for in 1612 read about 1617

for Next year read In 1612

for of the same year read 1613

for During the same year read About 1617

for Campion's publications ... collected read Campion's works (save the treatise on counterpoint) were collected by Mr. A. H. Bullen in 1889, and his lyric gift is now generally acknowledged to give him a very high place among the song-writers of his age.

before Brit. Mus. Cat. insert Mr. Bullen's Introduction to the Works of Dr. Thomas Campion, 1889.

412 i 4 Canne, John : for 1649 read 1649-50

30 after Overton insert [q. v.], who must be distinguished from the pamphleteer Richard Overton [q. v.]

31 for he read Canne

414 i 8 f.e. Canning, Charles J., Earl Canning : for the spring of 1851 real February 1852

417 ii 2 f.e. after death insert He had been make K.S.I. on the institution of the order in 1861

421 i 10 f.e. Canning, George : for Newport read Newtown

ii 4-7 for In 1796 ... Wendover read In 1796, when he exchanged Newtown for Wendover, Canning was made under-secretary of state for foreign affairs. He held that post till 1799, when he became a commissioner of the board of control and (1800-1) was paymaster-general. He was M.P. for Tralee (1802-6), for Newtown again (1806-7), and for Hastings (1807-12)

8-9 for From 1799 to 1801 . . . Ellis read From September 1797 to July 1798 he contributed to the 'Anti-Jacobin or Weekly Examiner' with Ellis

omit contributed

omit such was

for that we only wonder .... in the following July read was great. The 'Anti-Jacobin or Weekly Examiner' was continued after July 1798 as the 'Anti-Jacobin Review,' a monthly magazine, which lasted till 1821

35-36 for and sister to the Duchess of Portland read (Her sister married in 1795 William Henry Cavendish Scott Bentinck, Marquis of Titchfield, who became Duke of Portland in 1809)

for at war read for war and the colonies

41 for the fall read the course

425 i $\quad 41-42$

ii 9

for his only son in the previous April read his eldest son in the previous March

after Harwich insert In 1826-7 he was M.P. for Newport, and in 1827 for Seaford

11-12 for fifteen read thirteen

427 i 18 f.e.

428 ii 30

omit his relative

for 27 Jan. read 5 Jan. 1827

$\begin{array}{cccc}430 & \text { ii } & 8 & \text { for marquis Clanricarde read marquis of Clanricarde } \\ 443 & \text { ii } & 7-9 & \text { Canning, Stratford, Viscount Stratford de Redeliffe : }\end{array}$ occasion .... the Bath

Cannon, Robert: for 1707 read 1707-8

$\begin{array}{ccc}452 & \text { i } & 8 \\ 457 & 38\end{array}$

Cantelupe, Thomas de: omit He was the last canonised Inglishman Canton, John: after Electricity; insert the Crmton papers, 'A thenæum,' 1849 , pp. E,
162, 375; 


\title{
DiCTIONARY OF NATIONAL BIOGRAPHY
}

\author{
ERRATA IN VOLUME IX
}

\author{
CANUTE-CHALONER
}

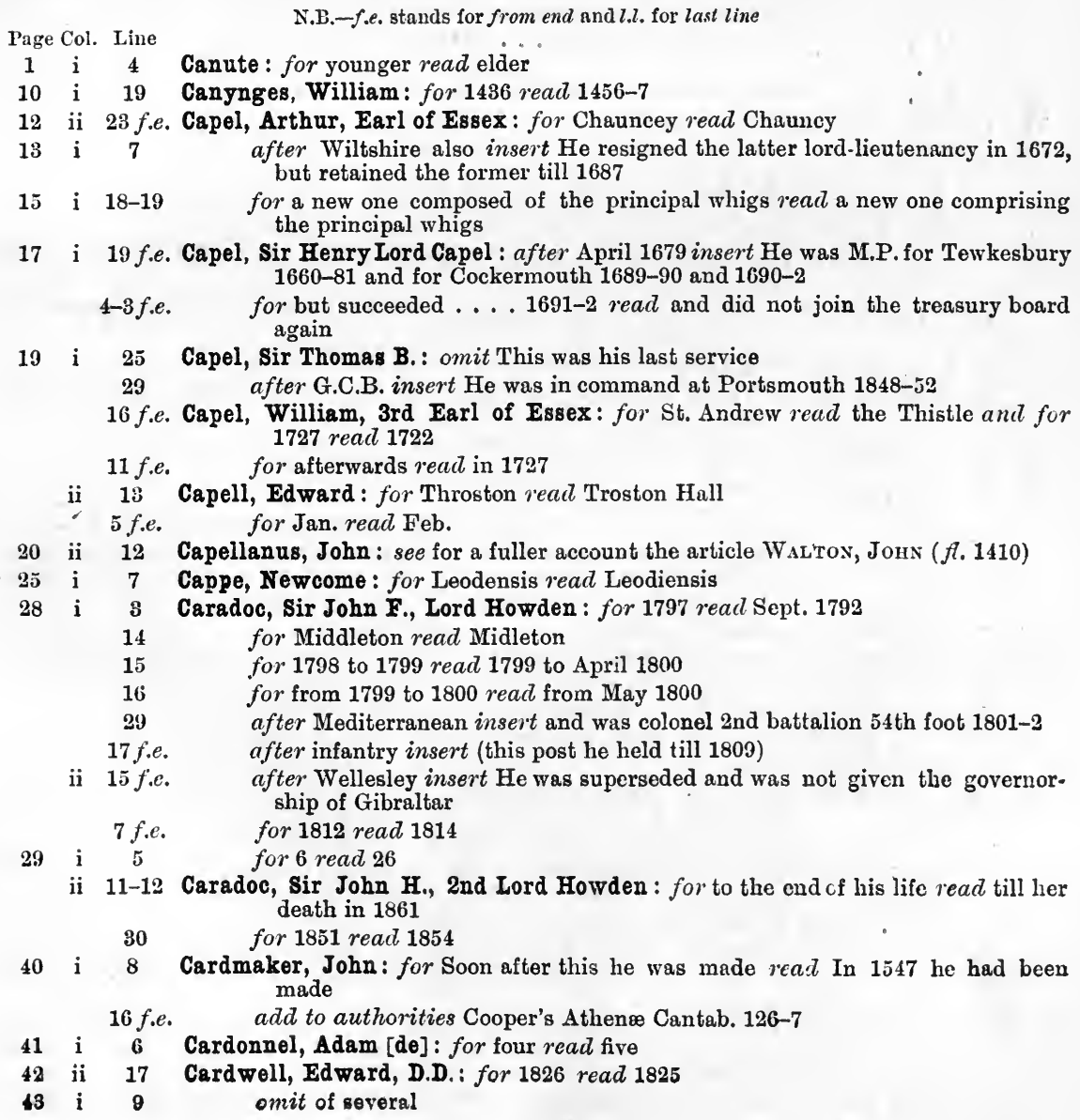


Page Col. Line

43 ii 4

26

44 i $18-19$

$46 \begin{array}{ccc} & \text { ii } & 21 \\ 4 & \text { i } & 6-9\end{array}$

f.e.

16 f.e.

$\left.\begin{array}{ccc} & & \\ & & 11-6 \\ & & \text { f.e. } \\ & & 5 \text { f.e. } \\ 52 & \text { i } & 25 \\ 53 & \text { i } & 10 f . e . \\ & \text { ii } & 35 \\ & & 47 \\ 54 & \text { i } & 24\end{array}\right\}$

13-12 f.e.

Cardwell, Edward, Viscount Cardwell : after Commons insert on petition after 1852 insert when he also contested Ayrshire unsuccessfully for but shortly afterwards regained it on petition read But the successful candidate, Charles Neate, was unseated on petition and Cardwell was returned at the new election, defeating his opponent, W. M. Thackeray, by 58 votes

Cardwell, Edward, Viscount Cardwell : for ingratitude read decrepitude

Care, Henry : for a German translation ..... F. E. Rambach' 1766 read Rambach's 'Unpartheiische Historie des Papstthums' (Magdeburg, 1751-80, 10 vols.), although often described as a translation of Care's book, is really a translation of Archibald Bower's 'History of the Popes'

Carew, Bampfylde $\mathbf{M}$. : for BAMFYLDE read BAMPFyLdE

\section{7 f.e. for 440 read 401}

Carew, sir Benjamin H. : for June read Jan.

Carew, Sir George : after 1601 insert and 1604

Carew, George, Earl of Totnes : for Bath and Wells read Wells after following year insert when he was M.P. for Queenborough omit 1 March 1598-9 . . . Wallop, and on

after Munster insert (It was not Carew but Sir George Carey of Cockington, co. Devon, who was appointed treasurer at wars in Ireland 22 March 1598-9, and a lord justice in September 1599)

for but on Essex's recall ... . January, when read when

for successor. The read successor, the

for Anne read Joyce

Carew, Sir John: for Macleane read Maclean

83 Carew, John $(d .1660)$ : for at one of the universities read at Gloucester Hall, Oxford

55 ii 9 f.e. Carew, Sir Matthew : for ultimately read in $\mathbf{1 5 8 3}$

59 ii 15 f.e. Carew, Sir Peter: after knighted insert He was M.P. for Tavistock in 1545 and for Devonshire in 1558

62 ii 23 f.e. Carew, Sir Richard : for 1642 read 1641

$\left.\begin{array}{rr}63 & \text { i } \quad 26 \\ & 29\end{array}\right\}$ Carew, Thomas: for 1598 read 1595

30-32 for He entered . . . a degree read Wood's statement that he entered at Corpus Christi College, Oxford, is uncorroborated. He apparently matriculated at Merton College on 10 June 1608, aged 13, and graduated B.A. 31 Jan. 1611

64 i 1-2 Carew or Cawe: omit cross reference under Thomas

65 ii 35 Carey, George, 2nd Lord Hunsdon: after Dumbarton insert He was M.P. for Hertfordshire in 1571 and afterwards for Hampshire $(1584,1586,1588-9,1592)$

67 i 40-41 Carey, George J.: for Whaley Grange read Whalley Runge

69 i 5 Carey, Henry, 1st Lord Hunsdon : for the Earl of Sussex read Lord Howard of Effingham

70 ii $1-3$

Carey, Henry, 2nd Earl of Monmouth : omit and the only one . . . nobleman after England insert He was M.P. for Camelford 1620, Beveriey 1624, Tregony 1625, St. Mawes 1626, and Grampound 1628

73 i 16-15 Carey, John, 3rd Lord Hunsdon: for marshal of Berwick, where read M.P. for f.e. Buckingham 1584, 1588-9, and 1592. As marshal of Berwiok

74 i 19 f.e. Carey, Mathew : for premier read chancellor of the exchequer

75 ii 1 Carey, Robert, 1st Earl of Monmouth : after Morpeth insert being returned in 1592 for the same constituency, but preferring then to sit for Callington, which had also elected him

77 ii $22-33$ Carey, William (1761-1834): for and left three sons, one of whom was Felix Carey [q.v.] read His eldest son, Felix Carey [q.v.], predeceased him. Three sons survived him

3 f.e. Carey, William (1769-1846) : for stall of read stall of Barnby, in York Cathedral, was conferred on him in 1802 , nnd that of 
Page Col. Line

80 i 29-81 Cargill, Donald : insert brackets before The Torwood and after 1741

21 f.e. $\quad$ for Bethan read Bethune

88 i 27-30 Carleton, Sir Dudley, Viscount Dorchester : for daughter of Sir Henry Saville .... Oxford read daughter of George Gerrard of Dorney, Buckingham. shire, by Margaret, whose second husband was Sir Henry Saville

89 ii 28 for 5 read 15

90 i 21-28 omit though there . . . . is inexplicable

19 f.e. Carleton, George (1559-1628): after Llandaff insert where he was already pre. bendary

ii 11-12 omit represented Arundel ..... and afterwards

93 i 24 Carleton, Guy (1598 ?-1685): after Carlisle insert and prebendary of Durham

94 ii 25 Carleton, Guy, 1st Lord Dorchester: for in the same year read next year

11 f.e. after elder sons insert In 1782-8 he was colonel of the 84th foot

95 i 11 f.e. for Morgan read Morgann

ii 13-14 Carleton, Hngh, Viscount Carleton: for lord chief justice in Ireland read chief justice of common pleas in Ireland

18

19

20

$22-23$

25-30

34

96 i 34

$104 \quad$ i $\quad 32$

105 i 11

106 i 29

108 i 1

125 ii $12-13$

126 i 10 f.e.

127 ii $12-13$

130 ii 11 Carmichael, John, 1st Earl of Hyndford : for retained the offices read resigned the office

for privy councillor under read in June 1702 after the accession of

after Queen Anne insert From 1702 to 1705 he was colonel of a regiment of horse

31

133 ii 22

Carmichael, John, 3rd Earl of Hyndford: for 10 Aug. read 16 Aug.

Carnac, Sir James R. : for 4 Jan. read 28 Jan.

134 ii 2-2f.e. Carne, Sir Edward : for San Gregorio in Monte Celio read S. Maria de Populo

139 ii 22 Carnegie, William, Earl of Northesk : for several read four

23

144 ii 21 . Carolinter Scotland insert $(1796,1802,1806,1830)$

Caroline, Queen (1683-1737): after will insert (Brit. Mus. MS. Addit. 35349, $f .1)$.

153 i 35 Caroline Amelia Elizabeth : for 29 July read 19 July

ii 26 Caron, Redmond : for Dr. Neill read O'Neill

154 i 22 f.e. Carpenter, George, Lord Carpenter : for general read lieutenant-general

ii 3 after gallantry insert He was M.P. for Newtownards in the Irish House of Commons

38 for 1714 read January 1714-5

44 for 1729 read 1727

156 ii 5 Carpenter, John (d. 1476): for Westbury read Westbury-on-Trym

13 before was appointed insert was made prebendary of Lincoln in 1426 and for 1430 read 1428

for town read village

157 i 36 Carpenter, Lant: for (1730-1799) [q. v.] read (see under Blalie, WiLLiam, 17731821)

165 i 5 Carpenter, Richard C.: after and insert designed

170 i 8-7 f. . Carr, John (1723-1807): for Beverley read Barnsley 
Page Col. Line

170 ii 13 f.e. Carr, John (1732-1807): before He died insert He was prebendary of Lincoln from 1805 till death

173 i 28 Carr, Robert, Earl of Somerset : after Hay insert In the same year he was made K.G.

176 ii 21 f.e. Carr, Robert J. : after George IV insert He was prebendary of Salisbury 1819-24, of Chichester 1821-4, and of Hereford 1822-4

177 i 7 for in 1841 read on 24 April 1841

179 i 2 f.e. Carrick, Thomas : for Upperley read Upperby

180 i l.l. Carrington, sir Codrington E. : after returned insert in the tory interest

190 ii l.l. Carstares, William : after Edinburgh add Macaulay's History

191 ii 2 Carswell, Sir Robert: after country insert in July 1850

35 Carte, Samuel : after Lichfield insert (from 1682 till death, a period of 58 years)

197 i 6-7 Carter, Ellen : for Maddeson read Maddison

202 ii 14 f.e. Carter, Lawrence : for 1717 read December 1715

206 i 3 Carter, Sir Richard : after 1681 insert He was lieutenant-governor of Southsea Castle from 1682 till his death

44 add to authorities Macaulay's History

207 i 17 Carter, Thomas (1735 ?-1804): for G.C.B. read K.B.

209 ii 19 f.e. Carteret, Sir George : for Tangiers read Tangier

210 i 12 f.e. Carteret, John, Earl Granville : for 26 April 1706 read 12 July 1756

211 ii 22 for Brodericks read Brodricks

23 after whom insert Allan Brodrick [q. v.]

221 i 7

Cartwright, Christopher : for Baylie read Bayly for Coles's read Cole's

Cartwright, Edmund : after Belvoir insert He was prebendary of Lincoln from 1786 till his death

222 ii $\quad 27$

224 i 9 f.e. Cartwright, John (1740-1824): for Northamptonshire read Nottinghamshire

ii 13 f.e. after in vogue insert He unsuccessfully contested Nottinghamshire in 1780 , Boston in 1806 and 1807, and was nominated for Westminster in 1818 and 1819

225 ii 17

after issue insert His wife died on 21 Dec. 1834, and was buried beside her husband in the churchyard of Finchley, Middlesex

229 i 7 f.e. Cartwright, Thomas (1535-1608): for (1588) read (1589-90)

6 f.e. $\quad$ for (1589) read (1588)

230 i 15 for MS. 826 read MS. 271, f. 22 b.

ii 15 f.e. Cartwright, Thomas (1634-1689): for (1675) read (1675-6)

10-9 for very soon after the accession of James read in December 1686

f.e.

231 i 11 f.e. for C. J. Wright read Chief Justice Wright

232 i 41-43 Cartwright, Sir Thomas: for after holding ..... Sweden read entered the diplomatic service. He was secretary of legation at Munich 1821-8 and at The Hague 1828-30. He was minister plenipotentiary at Frankfort 1830-8 and at Stockholm 1838 till death

13 f.e. $\quad$ for knighthood read G.C.H.

234 i 9 f.e. Carus, Thomas: before $\mathrm{He}$ joined insert $\mathrm{He}$ was M.P. for Wigan in 1547 and for Lancaster in 1553 and 1555.

236 i 21 f.e. Carver, John: for 42 persons read 41 persons, including 39 colonists proper 20-18 for 4 spinsters .... 101 persons read 25 children (19 sons and 6 daughters), f.e. one spinster, 12 serving men, 5 serving boys, and 2 maid-servants constituted the colony of 104 persons

16 f.e. for three read two

10-9 omit at the foot of a cliff

f.e.

3 f.e

l.l.

for 31 Dec. read 31 Jan. 1620-1

for the first American independent read in accordance with the resolve made on leaving home that they should form ' an absolute church by themselves,' the American independent omit in accord with .... Holland

8 for on 5 April read in April

8 for the day read after 
Page Col. Line 236 ii $18-22$

25

26

28

30-31

33

39

41

for his daughter ..... At the latter date read Desire Minter, a maid-servant, two men-servants (John Howland and Roger Wilder), and two boys (William Latham and Jasper More). The last died in 1620. In 1627

before The William Carver insert who does not seem to have had any children omit leaving many descendants

omit though probably a relation

for Carver's daughter ..... with his children read Elizabeth Tilley, and although unrelated to Carver shared

for last read last but three and for 1672 read 1673

for a township read the southern portion of the township

for 'Carver's Town' read 'Carver'

238 ii 11 f.e. Carver, Robert : after director insert He was president of the Society of Artists in 1777

259 ii 19-18 Carwell, Thomas: for an ancient Lincolnshire family now extinct read the ancient f.e. Lincolnshire family of Thorold

241 i 4 Cary, Sir Henry, 1st Viscount Falkland : for Henry prince of Wales 1608 reall Charles, prince of Wales in $\mathbf{1 6 1 6}$

11 after 1627 insert He was elected M.P. for Hertfordshire 11 Dec. 1620

244 ii 20 f.e. Cary, John (d. 1720?): after commercial matters insert He was warden of the Merchant Venturers Company at Bristol 1683-4

19 f.e. $\quad$ for In 1687 read In Jan. 1687-8

15 f.e. $\quad$ before At the request insert He was superseded in October 1688. Hc was parliamentary candidate for Bristol in 1698

251 ii 20-19 Cary, Patrick : for After this it does not appear what became of him reacl He is f.e. said to have turned protestant and gone as secretary of Penn's expedition to the

West Indies in 1655, and died there (Egerton MS. 2535, f. 487 b; cf. Athencum, 7 May 1887).

252 ii 19 Cary, Valentine : for 1609 read 1610

34 after Cary insert who was vice-chancellor of the university that year

253 ii 3 for Cooke read Coke

258 i 13 f.e. Casaubon, Isaac : for 1696 read 1596

267 i 19 f.e. Caslon, William, the elder : for Psalmanzar read Psalmanazar

268 ii 15 Cassan, Stephen H. : after 1827 insert in the list of works 'Lives of tho Bishops of Winchester,' London, 1827, 2 vols.

269 i 33 Cassell, John : for Cassell's 'Magazine of Art' reacl 'Cassell's Magazine'

ii 6 omit 'Cassell's Magazine'

381 i 35 Castell, Edmund: omit Tadlow by

ii 3-2f.e. for he was about the same time appointed read he lad been appointed in 1664

$272 \mathrm{i}^{\prime} 19$ f.e. for Beverell read Peverell

273 ii 14 f.e. Castine, Thomas : for Cutler Fergus read Cutlar Fergusson

274 i 21 Castle, Edmund: for the same year read in 1744-5

22 after College insert In $\mathbf{1 7 4 6}$ he was vice-chancellor

23 for the following year read 1748-9

279 i 21-22 Catcott, Alexander : for but styles himself read From July 1766 till his death he was

ii 5 Catcott, Alexander S.: after Oxford insert and was first appointed chaplain to the mayor of Bristol

284 i 31 Catesby, William : for the execution read its fulfilment

285 i 16-15 Cathcart, Charles, 9th Baron Cathcart : for at the time of his death read from f.e. $\quad 1752$ till his death

286 ii 11 Cathcart, David, Lord Alloway : for lord-justiciary read lord of justiciary

33-34 Cathcart, Sir George : transpose and entered Paris . . . 1814 to line 37 after Dresden

287 i 21 for In March 1854 read On 12 Dec. 1853

289 i 20 Cathcart, Sir William S., 1st Earl Cathcart : for In May 1813 read In July 1812 21 f.e. $\quad$ omit and the governorship of Hull

18-16 for until the suicide .... England, read He returned to England in 1820.

f.e. He became governor of Hull in 1830

290 i 9 Catherine of Valois : for at her son's read and to her on's

89-40 for grandson read great-grandson 
Page Col. Line

806 i 5 f.e.

that

322 i 28 Caton, William: for promulgation read proclamation

325 i 34 Catton, Charles, R.A., the elder: for 28 Aug. read 28 Sept.

326 i 11 Caulfeild, James, 1st Earl of Charlemont: after 1728 insert He succeeded to the peerage in 1734, when a child

829 i 14 Caulfeild, William, 2nd Viscount Charlemont : after papists insert From 1701 to 1706 he was colonel of the 36th foot

381 ii 8 f.e. Caunt, Benjamin : for Skipworth read Skipwith

334 i 32 Cautley, Sir Proby T.: for [q. v.] read (see Supplement)

338 i 19 Cavallo, Tiberius: for Watt's 'Bibliotheca Britannica' read 'The Philosophical Transactions'

20 f.e. Cave, Sir Ambrose : for M.P. for Warwickshire read M.P. for Leicestershire 1545 1547 , and 1553 ; M.P. for Warwickshire 1557-8, 1558-9, and 1562-8

l.l. $\} \quad$ for White of Manchester read White of Winchester

340 i 15 Cave, Edward: for Dr. Halde's read Du Halde's

i 6 f.e. for Harl. MS, read Sloane MS.

341 ii 3 Cave, Sir Stephen: for April read March

3 f.e. Cave, William : for 1813 read 1713

344 i 6 Cavendish, Christiana, Countess of Devonshire: for duchess read countess

18 Cavendish, Elizabeth, Duchess of Devonshire : for 1759 read 1758

19-20 for born in 1759 read baptised 13 May 1758

17 f.e. $\quad$ for 1814 read 1811

ii 9 f.e. for 4 th ser. read 5 th ser.

345 i 38 Cavendish, Lord Frederick: after 1763 insert Ho was colonel of the 67th regiment $1759-60$

41 for four years read seven years

ii 16-17 Cavendish, Lord Frederick C. : for until he resigned it in May 1882 read until his death

848 i 15 Cavendish, Georgiana, Duchess of Devonshire : for Lady De Beauclerk read Lady Di Beauclerk

22 f.e. Cavendish, Sir Henry : after 1774 insert In the Irish House of Commons he was M.P. for Lismore 1766-8, 1776-91, 1798-1800, and for Killibegs 1791-7

ii 13 f.e. Cavendish, Hon. Henry : omit HoN.

853 i 1 before Sir Everard insert Cavendish told

354 i 6 Cavendish, Lord John : for 1790 read 1784

19-18 for was defeated .... contest read failed to gain a seat

f.e.

358 ii 20 f.e. Cavendish, Thomas : for 1555 ? read 1560

16 f.e. after Harwich insert and was baptised 19 Sept. 1560 (Addit. MSS. 19122, f. 350, 19087, f. 131)

363 i 22

ii 6

10

$16-17$

25

28

364 i 8

24

27

39

ii 1

2

3

add to authorities Cooper's Athenæ Cantabrigienses, vol. ii. p. 186

Cavendish, Sir William (1505?-1557) : for Anne read Margaret (d. 1540)

for Margaret (d.16 June 1540) read on 3 Nov, 1542 'at the Black Fryars in London' Elizabeth

for 'at the Black Fryars in London' 3 Nov. 1541 read at Bradgate, Leicestershire, on $20 \mathrm{Aug} .1547$

for Cavendish, William, read William Cavendish after 1572 insert 1584, 1586, 1588, 1592, and 1597

Cavendish, William, 1st Earl of Devonshire: after M.P. insert for Liverpool in 1586 and

after title insert He was made lord-lieutenant of Derbyshire 1 Lay 1619

for Kighley read Keighley

for in 1618 read on 3 Nov. 1616

Cavendish, William, 2nd Earl of Devonshire : for for Derby in 1621 read for Bishopscastle in 1610 and for Derbyshire in 1614, 1621

after Derbyshire insert jointly with his father

lafter 1625-6 insert alone after his father's death 
Page Col. Line

365 i 26

366 ii 3

370 i 25

ii 26

871 i 18

374 i 6

83

ii $\quad 6-7$

13 f.e.

875 i 41

ii 24

37

376 i 12

86

11 f.e.

377 ii 5 f.e

378 i 36

15 f.e. Cawley, William: for 1666? read 1667

379 i $\quad 7-8$

14

23

41

ii 40

380 i $\quad 39$

Cawood, John: for Rugge read Jugge

for Whealer read Wheater and for 1812 read 1882

381 ii 11 f.e. Caxton, William : after the Weeld' insert-at Tenterden

382 i 17 f.e.

ii 20 f.e.

386 ii 29

387 ii $8-10$

2 f.e.

388 i 3

4

389 i 11 f.e.

10-9

f.e.

3 f.e. 1660 till death

for SeLbY read Selby Rome 9 Jan. 1659 (Sloane MS. 2142, f. 36) for Edmundsbury read Edmundbury for Mr. Villiers read Mrs. Villiers set and Earls of Jersey, Marlborough and Albemarle

for Broadsworth read Brodsworth

for Bishop read Archbishop borough

for February 1755 read March 1754 lord-lieutenant of Derbyshire from 1811 till his death

for St. Andrew read St. Alexander

Cawdry, Zachary : after degree insert was proctor 1647-8

for Boden read Bowdon Cawley, junior, who

for in 1666 read on 6 Jan. 1666-7

for 1666 read 1666-7 1667-1709 Room at Westminster Abbey

for 5 Jan. 1463 read 9 July 1468

after 1477 ? insert [7]

for 39 read $39^{*}$

after copy insert formerly

after stadt insert was purchased by the British Museum in 1890

for is read up to 1897 was New York then sold at Sotheby's for 2,100l.

Dover in 1624

Cecil, Richard : for third real second Sarisbury and 1st Viscount Cranbonne

for Neyle read Neile 1586

for Essingdon read Essendine, Rutlandshire

lieutenant for Hertfordshire from 1605 till his death

for for some years read from February 1600-1

fur Sir Anthony Bacon read Anthony Bacon

Cavendish, William, Duke of Newcastle: before 'The earl's ámbition insert $\mathrm{He}$ was lord-lieutenant of Derbyshire 1628-38 and of Wiltshire 1626-42 and

Cavendish, William, 1st Duke of Devonshire: after Savoy insert He was at for Lord William Russell read William, afterwards Lord William Russell

before On 12 May insert $\mathrm{He}$ was lord-lieutenant of Nottinghamshire 1692-4

for Lords Somerset, Jersey, Marlborough, and Albemarle read Duke of Somer-

Cavendish, William, 6th Duke of Devonshire: for Lanesborough read Londes-

Cavendish, William G. S., 6th Duke of Devonshire : after day insert He was

for he was one of the few regicides who read it was his son William

after James II insert Another son, John Cawley, was archdeacon of Lincoln

after twenty marks insert A paper copy of Large's will is in the Muniment

for the two last sections .... Worcester read There seems, however, no doubt that the work was undertaken by William of Worcester [q. v.]

for in behalf of a Chicago merchant read in behalf of $\mathrm{Mr}$. Robert Hoe of

after cerned insert On 9 Dec. 1897 a higher price was reached. The finest of seven known copies of Le Fevre's Boke of the Hoole Lyf of Jason, was

Cecil, Sir Edward, Viscount Wimbledon: after 12-22 Aug. insert He was M.P. for Aldborough in 1601, for Stamford in 1609, for Chichester in 1620, and for

Cecil, Robert, Earl of Salisbury: for Earl of Salisecry read 1st Earl of

after four years insert He was elected M.P. for Westminster in 1584 and

for of the same month read May 1606 and after Garter insert He was lord- 
Page Col. Line

404 i 36

ii 9

4-3f.e.

405 i $11-10$

f.e.

9 f.e.

ii 15

407 i 14 f.e. Cecil, William, Lord Burghley : for Pinkney read Pinkey

409 i 13 f.e. after 1563 insert when he sat for Northamptonshire

410 i 2 f.e. for Earl read Marquis

412 i 31 for Mayer read Mayor

421 i 34-35 Centlivre, susannah : for eighteen read nineteen

424 i 35 Cenwulf: for No works .... to him read The works of Kynewulf [q. v.] have at times been assigned to him in error

431 i 16 f.e. Chaderton, Laurence : after puritans insert From 1598 to 1640 he was prebendary of Lincoln

12 f.e. $\quad$ for Millenerary read Millenary

ii 8 f.e. after intercisa' insert and one sermon printed in London in 1580, of which copies are in the libraries of Sion College, London, and Emmanuel College, Cambridge

436 i 14 f.e. Chafy, William: for 13 read 4

437 i 15 Chalkhill, John : for $1678 \mathrm{read} 1600$

448 i 14 f.e. Chalmers, Sir John : for 1814 read April 1815

450 ii 20 Chalmers, Thomas : for 1840 read 1820

455 i 46 Chalmers, Sir William : after 1848 insert was colonel of the 20th foot Feb.-Oct. 1853

456 ii 13 Chaloner, - : for - read Richard

457 i 4 Chaloner, James : for 1645 read 1648

5-6 for the two gentlemen .... royalists read to fill a vacancy created by death

ii 19 Chaloner, Sir Thomas, the elder : after council insert He was M.P. for Wigan in 1545 , Lancashire in 1547, and Knaresborough in 1555

4 f.e. $\quad$ after alliance insert (his safe-conduct is dated 26 Nov. 1558)

458 ii 10 f.e. Chaloner, Sir Thomas, the younger: after the age insert He was M.P. for St. Mawes in 1586 and for Lostwithiel in 1604 


\title{
Dictionary OF NATIONAL Biography
}

\author{
ERRATA IN VOLUME $\mathrm{X}$
}

\author{
CHAMBER—CLARKSON
}

N.B. -f.e. stands for from end and 1.l. for last line

Page Col. Line

5 i $\quad 8$ Chamberlain, Robert $(f l .1640-1660):$ for in read on

6 i 22 f.e. Chamberlain, Thomas: for His jurisdiction was extended read He was trans. ferred

21 f.e. $\quad$ after to insert Chester circuit, which embraced

ii 32 for Nestor read Neston

8 i 31 Chamberlayne, Edward: for Odington read Oddington

ii 21 for sixth read seventh

13 i $8-7$

f.e.

5 f.e.

l.l.

21 ii 7

Chamberlen, Paul : omit His other works were: 1

22 i 23

for 2 read by John Campbell, LL.D., 1708-1775 [q. v.], has been wrongly ascribed to him. Of his

Chambers, Richard: after alderman insert of Walbrook ward

Chambers, Sir Robert: for (January 1762) read (1766)

for Four years later read In 1777

23 i 6-5 f.e. for Bengal $1823 \ldots$... 1827, and read Bombay 1823

f.e.

26 i. $7-6$ f.e.

29 ii $17-18$

Chambers, Sir William: for whose daughter (celebrated for her beauty) reacl Not long afterwards

Chambers, William F.: for His majesty at St. James's Palace read King Ernest of Hanover

Chambre, John : for Codringham read Coringham

after Westminster insert A portrait by Holbein is in the picture gallery at Vienna

Champion, John George : for 1815 ? read 1815

after botanist insert born in Edinburgh, 5 May 1815, was eldest son of Major John Carey Champion by Elizabeth Herries, daughter of William Urquhart of Craigstone Castle, Aberdeenshire. After education at Sandluurst, where he distinguished himself, he for in 1831 read on 2 Aug. 1831

after Hongkong read Champion was an ardent botanist. While in Ceylon and at Hongkong he energetically worked at the science, and was in constant correspondence with Sir William Hooker

after Hongkongensis' insert They were also enumerated in Seemann's 'Botany of the Voyage of H.M.S. Herald' and by Forbes and Hemsley in the 'Journal of Linnean Society' (xxiii., xxvi., and xxxvi.)

after Crimea insert in April 1854

after herbarium insert where his correspondence with Sir W. Hooker and Professor Lindley is now preserved

after He insert took part in the battle of the Alma and before for his insert and C.B 
Pag Col. Line

33 ii $\quad 38-39$

43

44

for only enjoyed .... dying read died

after Championi insert (Cf. 'Bot. Mag.' 1853). Entomology also engaged Champion's attention. He contributed notes on various insects to the 'Entomological Magazine' for 1836 (iii. 176-8, 376-9, 460-5), and on the Coleoptera of Hongkong in the 'Journal of Asiatic Society of Bengal' for 1848 (xvii. pt. ii. 206-9; cf. Westwood in 'Trans. Ent. Soc. Lond.' N.S. ii. 84, 232). Adam White [q. v.] named the red Longicorn beetle Erythrus Championi. Many drawings and written descriptions of plants and insects discovered by Champion are in the possession of his family.

4 Champion, John George : ádd to authorities Kinglake's History of the Crimea,1863; Edinburgh New Philosophical Journal, Dec. 1855, p. 302; A Sketch [by various friends] of the Life of Lieut.-Colonel Champion, 1855 (for private circulation)

\footnotetext{
34 ii 15

Champion, Richard: after city insert He was warden of the Society of Merchant Venturers at Bristol $1772-3$ and treasurer of the Bristol Infirmary 1768-78
$36 \quad$ i $\quad 32$ Baynard ward 1527-38, of Broad Street 1533-4, and of Cordwainer 1534 till death

Champneys, John: for Somersetshire read Somerset, was alderman of Castle

37 i 15 f.e. Chancellor, Richard : for Condia read Candia

39 i 19 Chandler, John : for l read $p$

44 ii 11 Chantrey, Sir Francis L. : for 1842 read 1841

11-10f.e. for near Norton, Derbyshire read at Jordanthorpe, in the parish of Norton Derbyshire, near Sheffield

$\begin{array}{cccl}45 & \text { i } & 22 & \text { for 'Trio' read 'Iris' } \\ 46 & \text { ii } & 2 & \text { for Eardcliffe read Endcliffe } \\ & & 19 \text { f.e. } & \text { for } 1842 \text { read } 1841\end{array}$

53 i 26 Chapman, George: for Joy read Folly

54 i 20 Chapman, Henry S.: for March 1852 read 29 July 1851

35-40 for he was called on .... retained it read he resumed his former place of attorney-general in O'Shanassy's new ministry. He retained office

ii 33 Chapman, John (1704-1784) : omit afterwards

84 after Sudbury insert in 1741 and after Chichester insert in 1750

56 i 16-17 Chapman, John (1801-1854): omit then M.P.

67 ii 14 Chapman, Sir Stephen R.: for his promotion read Dec. 1818. He was promoted 16 for From 1825 read For several years 26 after lieutenant-general insert he was colonel commandant Royal Engineers
}

13 f.e. Chapman, Thomas: for in 1760 read 9 June 1760

61 i 21 Chappelow, Leonard: after Ockley insert combining with this the Lord Almoner's professorship of Arabic from 1729

62 i 1 Chapple, William (1677-1745): for William read Sir William

9 - before made insert in 1727

21 for Grantly read Grantley

64 i 1 Chardin, Sir John: for Nov, read March

ii 24 f.e. Chardon, John : after B.D. insert on 24 Nov. 1581 became rector of Tedburn-St.Mary, Devonshire

97 ii 9 f.e. Charles II. : after state insert and was himself superseded by Henry Coventry

8 f.e. for was Henry Coventry read secretary throughout the period being Lord Arlington

100 i l.l. omit after in

ii 1-4 omit from October.... Meal-tub plot

5 for him read Shaftesbury

116 ii 9 f.e. Charleton, Walter: for twenty-two (1641) read twenty-four (1643)

124 ii 30 Charlton, Edward, 5th Lord Charlton: for Berkley read Berkeley

125 i 11 f.e. Charlton, Sir Job : for chief justice of the common pleas read a puisne judge

5 f.e. after Chester insert from which he retired in 1689

8 f.e. $\quad$ for 29 May read 24 May

128 ii 13 f.e. Charlton, Thomas: after preferments insert He was made archdeacon of Totnes in 1302 and prebendary of Hereford in 1317 132 i $10 \begin{gathered}\text { Charnock, John : for Merton College, Oxford read was commoner of Trinity } \\ \text { College, Oxford, in } 1775\end{gathered}$ 
Page Col. Line

134 i 30-32

185 i 23

24

25

136

188 i

147

154

$156 \mathrm{i}$

170 i

34

171 i 85

173 ii 8 f.e.

174 i 18

22

179 i 29

ii 10

188 ii 8

192 i 25

193 ii 2 f.e.

l.t.

198 i 5

Charnock, Stephen: for In the conflict.... for the control read After the practical extermination of the high church party and the surrender to the puritan party of the control

Charnock, Thomas : for 1524 ? read 1526

for in the Isle of Thanet read at Faversham

for 1524 or 1525 reacl 1526

f.e. Charteris, Francis: for ' Rake's Progress ' read 'Harlot's Progress'

5 for Institution read Museum and Library

for Institution read Museum and Libr

Chauncy, Sir Henry : after Radnor insert but resigned next year (1689)

for Thruston read Thurston

for Chauncey read Chauncy

Cheape, Sir John : for and read He became in Dec. 1853

after K.C.B. insert (1849)

after being made insert colonel commandant Royal Engineers (1862 till death)

Cheke, Sir John : for October 1551 read 1547

for In or about 1544 read In 1542

Chermside, Sir Robert A. : for In 1835 .... Guelphic order read He became K.H. in 1831, a knight-bachelor in 1885, and K.C.H. in 1837

Cheselden, William: after anatomist insert son of George Cheselden by his wife Deborah, daughter of Major William Hubbert of Rearsby, Leicestershire

for 1764 read 1754

after daughter insert Deborah Wilhelmina

Chesney, Francis R.: after year insert major-general 6 Jan. 1855, and full general 1 Jan. 1868

14 f.e. Chesney, Robert de : after Leicester insert and also of Lincoln

200 i 20 Chessar, Jane A. : after a member insert for Marylebone

ii 19 f.e. Chesshyre, Sir John: for Richard read Christopher

201 i 29-31 for From the inscription .... knight in 1733 read He was knighted on 7 June 1733

204 ii 17 Chester, Sir William : for 1553-4 read 1554-5

205 i 21-23 for resigned his office . . . . wife's death real in 1573 was removed from his office of alderman. (In 1556 he had left Farringdon-ward-without for Billingsgate, in 1559 Billingsgate for Bassishaw, and in 1566 Bassishaw for Langbourn.) He was president of Bethlehem and Bridewell Hospitals 1565-8

212 ii 18 Chetwynd, Edward : for Barclay read Berkeley

21 after sermons insert $\mathrm{He}$ died 13 May 1639

213 ii 28 f.e. Chetwynd, William R. C., 3rd Viscount Chetwynd : after 1702 inser M.P. for Tamworth 1698-1700

23 f.e. $\quad$ omit and Lichfield and after to insert 1722 and 1724 to

22 f.e. for 1735 read 1734

214 i 29 Chevalier, John : for ( $f$ l. 1651) read (1589-1675)

30 after war insert son of Clement Chevalier of St. Heliers by his second wife, - Jane, daughter of John Malzard. $\mathrm{He}$

13 f.e. after sovereign insert Chevalier died 30 Nov. 1675, aged 86 . He married Marie, daughter of Edward La Cloche

215 i 32 Chevallier, Anthony R.: for professor read professor or locturer

2 f.c. $\quad$ for Syriac read Aramaic

ii 11-9 Chevallier, Temple : for eldest son ..... Suffolk read youngest son of the Rev. f.e. Temple Chevallier

216 ii 13 f.e. Cheyne, Charles, Visoount Newhaven: after chosen insert tory

12 f.e. $\quad$ for Agmondisham in 1660 read Great Marlow in 1665-6

10 f.e. $\quad$ after 1681 insert He was commissioner of customs 1675-87

8 f.e. $\quad$ after for insert Harwich in 1690 and

$217 \quad 14$

for Buckinghamshire under Queen Anne read Agmondisham 1685-7, 1701-2, and 1705-9, Appleby 1689-95, and Buckinghamshire 1696-1701 and 1702-5 
Page Col. Line 220 i 8-9

ii $\quad 30$ 19 f.e. 12 f.e. 24-25

10 f.e. 2 f.e.

1.1.

224 i 11

22

27

13 f.e.

12 f.e.

7 f.e.

5 f.e.

4 f.e.

ii $\quad 6$

31

19 f.e.

8 f.e.

7 f.e.

6 f.e.

Cheyne, Sir William: for was recorder of London as early as 1378-9, but read is probably distinct from the William Cheyne who was recorder of London from 1377 (see Letter Book H, ff. 49, 75) to 1390 (ibid. ff. 246, 253), as he

Cheynell, Francis : for Allen read Robert Abbot
for ' Chillingworth read ' Chillingworthi

for 1640 read 1632

for Colchester read Chichester

for with assiduous kindness read and his exhortations are said to have shortened Chillingworth's days

after professor insert and in right of the professorship prebendary of Worcester

for 1755 read 1775

for in 1655 read in Sept. 1655

for at read near

for distracted read little better than distracted

for ' Chillingworth read ' Chillingworthi

for 1643 read 1643-4

for Lover read Tower

for Tenets read Tenents

for 1736 read 1738

for Calamy's read Palmer's

for 1755 read 1775

Cheyney, John : for 1694 read 1674

Cheyney, Richard : for 1578 read 1579

for Plainsford read Painswick

for 1568 read 1563

Chichele, Henry : for 1473 read 1373

for 1442 read 1443

for T. Cole read J. Cole

Chicheley, Sir John : after 1690 insert He was tory M.P. for Newton, Lancashire, 1679-81, 1685-7, and 1689 till death

Chicheley, Sir Thomas: for 1694 read 1699 for in 1694 read 1 Feb. 1698-9 for seventy-six read eighty-nine for Chicheleiana read Chicheleana

Chichester, Arthur, Lord Chichester : for Letitia read Lettice for Vaughan Blackham read Walter Vaughan of Golden Grove

Chichester, Arthur, 1st Earl of Donegal : for Rorkholt read Knockholt

Chiffinch, William : after p. 186) insert He was M.P. for Windsor 1685-7

Chifney, Samuel : for Chifney read Chiffney and so through article

Child, Sir Francis (1642-1713): for Evans read Evance

after 1702 insert when he became colonel of the Orange Regiment of the Trained Bands

before The election insert Child entered the House of Commons as tory M.P. for Devizes in 1698, and was re-elected in Dec. 1700 and again in 1701. In 1700 he also stood for London

after April 1705 insert $\mathrm{He}$ was re-elected in May for Devizes and sat till the dissolution in 1708

before $\mathrm{He}$ was insert $\mathrm{He}$ was an original commissioner of Greenwich Hospital

before and in 1705 insert of which he was president 1702-12

Child, Sir Francis (1684 ?-1740) : for in the year of his mayoralty . . . 1732 read in 1718-9, 1721-5, 1726-30, 1731-5

Child, Sir Josiah : after the town insert He was M.P. for Petersfield in 1659, for Dartmouth 1673-8, and for Ludlow 1685-7

after director insert from 1677, deputy governor 1684-6 and 1688-90 for chairman read governor before and for a time insert 1681-3, 1686-8 Chillingworth, William : after 1628 insert He was prebendary of Chester

for 1637 read 1638 
Page Col. Line

258 i 4 f.e. Chinnery, George : for ( $f l .1766-1846)$ read ( $d .1852)$

ii 20 for about 1850 read of apoplexy in 1852

259 ii 20 Chippendale, Thomas : for 1752 reacl 1754

22 for Prince William Henry reacl Hugh, Earl of Northumberland

26 f.e. Chisenhale, Edward : for ( $l .1653$ ?) read (d. 1654)

8 f.e. $\quad$ after 1653 8vo. read He died 5 March 1653-4

261 ii 24 f.e. Chisholm, Walter: for Cockburnshaw read Cockburnspath

263 ii 12 Chishull, Edmund : after queen insert in 1719 prebendary of St. Paul's

266 i 5 Chiswell, Richard (1673-1751): for in 1714 M.P. read in 1715 whig M.P.

19 f.e. Chiswell, Trench : after Yorkshire insert from 1790 till death as a supporter of Pitt

267 ii 16-17 Chitty, Thomas : for Sir Emerson Tennent read Sir James Emerson Tennent

268 ii 2 f.e. Cholmley, Sir Hugh : after Long parliaments insert until he was 'disabled,' 3 April 1643. He was knighted 19 May 1626 and made a baronet Aug. 1641

269 i 6 f.e. for Slingby read Slingsby

270 i 29 Cholmley, Sir Roger : for 1546 read 1545

2f.e. $\quad$ after privy council insert He was M.P. for Middlesex in 1554, 1555, 1558, and 1559

271 i 27 Cholmondeley, George, 2nd Earl of Cholmondeley : after bedchamber insert He was M.P. for Newton $1690-5$ and colonel of the 1st Horse Guards 1693-1715

16 f.e. $\quad$ for 20 March reall 18 Jan.

272 i 15 Cholmondeley, Hugh, 1st Earl of Cholmondeley : after Cheshire insert in 1704

27, 31, Cholmondeley, Mary : for Poever real Peover

ii 7 Cholmondeley, Robert, Earl of Leinster : after baronet insert became M.P. for Cheshire in 1625

279 i 17 Christian, Sir Hugh C. : for in 1851 read 31 Aug. 1849

281 i 15 Christian, William : for 1666 read 1656

289 i 27 Christie, William D.: after parliament insert at Cambridge and Greenock in 1865 and 1868 respectively

297 ii 20 f.e. Chubb, Thomas : for election read nomination

300 ii 5 f.e. Chudleigh, Elizabeth, Countess of Bristol : for 1659 read 1759

301 ii 8 f.e. Chudleigh, Sir George : for 1631 read 1601

7 f.e. $\quad$ for Lostwithiel read East Looe

7-6f.e. for parliaments read parliament

6 f.e. omit respectively

5 f.e. $\quad$ after 1614 and insert for Lostwithiel to that which met on

302 ii 5-4 f.e. Chudleigh, James: for On 30 Sept. 1643 .... General Fairfax read In the autumn of 1643 he was with the army of Prince Maurice in the west of England, and when on 6 Oct. the royalists captured Dartmouth

3-2 f.e. omit a few days afterwards

303 ii 24 Chudleigh, Thomas : before In April 1687 insert He was M.P. for Romney 1685-7

507 i 20 Churchill, Arabella : for 1668 read 1667 for 1670 read 1667 after daughter insert Arabella

308 i 26

ii 13

29

34

9 f.e.

8 f.e.

7 f.e.

4-2 f.e.

309 i 36

311 ii 35

314 ii 22

23

Churchill, Awnsham : after Churchill insert He was M.P. for Ipswich 1707-17

Churchill, Charles (1656-1714) : for October 1705 read 26 May 1702 for 1711 read death after foot guards insert (he was colonel of the 3rd foot March to Dec. 1688) after Churchill insert was colonel of the 1st foot 1709-13, of the 16th dragoons 1713-17, and of the 10th dragoons 1723 till death. $\mathrm{He}$ after and was also governor insert of Chelsea 1720-2 and after Plymouth insert 1722 till death omit with whom .... Sir Robert Walpole

Churchill, Charles (1731-1764) : for fellowship read postmastership for Grey read Gray

Churchill, George : for 1700 read 16S5 to 1687 and 1689 after St. Albans insert voting with the tories 
Page Col. Line

315 i 40

41

317 ii 10 f.e. Charchill, John, 1st Duke of Marlborough : after

Churchill, Sir John : for 1683 read Dec. 1682 for Sir Thomas Atkins read Sir Robert Atkyns for summer vacation read vacation (16 Oct.) removed from the colonelcy of the 3rd horse guard insert Having been April 1689 and Fusiliers)

320 i 25 f.e. $\quad$ for 1798 read 1698

10 f.e. for rural read nine

321 i 9

13

322 ii $\quad 20$

323 ii 2

10

325 ii 22-23

326 i 28

.329 i -38

382 ii 15 f.e.

337 i 7

340 ii 17 f.e.

341 ii 18 f.e. Churchill, John W. S., 7th Duke of Marlborough : for seventh read sixth

16 f.e. for sixth read fifth

342 i 12 after 1868 insert He had been made K.G. 23 May 1868

18 after president insert of the Royal Agricultural Society in 1859 and

ii 25 Churchill, Sir Winston : for Plymouth read Weymouth

26 for 1663 read Jan 1663-4

20 f.e. $\quad$ for Lynn Regis read Lyme Regis

346 i 21 Churton, Edward: for 1810 read 1830

354. i 20 f.e. Cibber, Colley : for 1694 read 1696

355 ii 2 f.e. for Dover read Truro 1713-14

366 ii 12-9 Clagett, Nicholas : for He was doubtless . . . the degree of D.D. read He was f.e. admitted at Trinity College, Cambridge, on 14 April 1702 and graduated B.A. 1705-6, M.A. 1709, and D.D. 1724. He was elected librarian of Trinity 27 Nov. 1706

367 i 12 f.e. Clagett, William : after p. 129) insert He became chaplain in ordinary to the king in 1677

369 ii 28 Clairmont, Clara M. J.: for twenty-two read eighteen

371 i 21 Clapham, David : for Beamesley read Beamsley

372 i 16 Clapham, Henoch : for a year read three years

375 ii 4 f.e. Clare, De, Family of: for 1173 read 1183?

376 ii 29 Clare, Elizabeth de: for was born read who was born

377 i 5 for Armoy read Amory

384 ii 16 f.e. Clare, John (1793-1864) : for 1821 read 1820

386 i 31 for Clare's portrait read A portrait of Clare painted by Grimshaw when the poet was about fifty is now in the Northampton Museum. Another

388 ii 32 Clare, Sir Ralph : before In the cause insert He was M.P. for Droitwich in 1621 and for Bewdley in 1624, 1625, 1626, 1627-8

35

398 i 15-12 Clarges, Sir Thomas: for That he sat.... clear from 'Tharloe read He was M.P. f.e. for Ross and Cromarty in 1656 and for Haddington in 1658-9. Cf. "Thurloe

404 i 27 Clark, Richard (1739-1831): for on 19 May read in May

32-33 for appointed president of Bridewell read was treasurer of Bridewell from 1781 till death. He was colonel of a regiment of City militia 1778-94

410 ii 3 f.e. Clark, William G.: for Gainsford read Gainford

411 i 23 f.e. for Scale read Score

ii 29 for Munro read Munby

412 ii 17 f.e. Clark-Kennedy, John: for commanded the 7 th dragoon guards read was colonel of the 6th dragoon guards from 1860 to 1862

16 f.e. for at the time of read from 1862 till

413 i $34 \quad$ for 1862 read 1860 
Page Col. Line

416 i 9 f.e.

ii $\quad 10-9$

f.e.

8 f.e.

7 f.e.

420 ii $l . l$.

7 f.e.

ii 34

15 f.e.

425 i 12

13

22

18 f.e.

16 f.e.

430 i 23
424 i 8 f.e.

Clarke, Sir Alured: after India insert He was made K.B. in 1797

Clarke, Charles $(d .1750)$ : for In the new parliament of 1741 read In Jan. 1742-3

omit in its second session

before Hilary term insert the following

Clarke, Edward (1730-1786) : after living insert From 1771 till death be was prebendary of Chichester

Clarke, George (1660-1736) : for 1660 read 1661

after virtuoso insert born 7 May 1661

after he insert was M.P. for Winchester 1702-5 and

after but insert was M.P. for Launceston 1711-13

for 1684 read 1681

for from 1692 read in Ireland 1690-2 and in England 1692-3

after held it insert (1710-14)

after group insert by Giovanni da Bologna

after until insert it was sold for old lead

Clarke, Henry : for 30 read 29

Clarke, James S. : for to the king read and royal chaplain from 1816

Clarke, Je remiah : for Chapel read College

Clarke, John (1687-1734): Note that the work numbered 10-' Formulæ oratoriæ,' \&c.-is not by the subject of this article. Through the greater part of the seventeenth century this work was a very popular school book, being originally published before 1632, in which year it reached a fourth edition, and being often reissued (e.g. in London in 1637 and 1670, and at Zürich in 1694). Its author was John Clarke, B.D. (of Fiskerton, Lincolnshire).

ii 7 Clarke, John (1682-1757): omit held a prebend a,t Norwich

435 ii 22 Clarke, Joseph : before 1776 insert 1742, second edition

436 ii 15 f.e. Clarke, Marcus A. H. : for 34 read 35

437 ii 16 Clarke, Mary A. : omit J. Wilson Croker

447 ii 20 Clarke, Sir Thomas : for following read preceding

449 ii 17

Clarke, William (1696-1771) : for Haghmon read Haughmond for 1738 read 1727 and after prebendary and insert in 1738 canon for Chittingley read Chiddingly

453 i 27 Clarkson, David: for Addle read Adel 



\title{
DicTiONARY OF NATIONAL BIOGRAPHY
}

\author{
ERRATA IN VOLUME XI
}

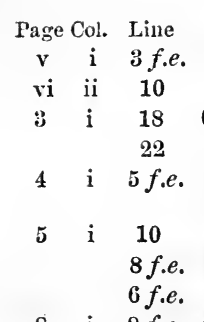

\author{
CLATER_CONDELL \\ N.D.-f.e. stands for from end and l.l. for last line
}

\author{
List of Writers : omit RIGH'T \\ for WeLsh read WeLch \\ Claughton, Piers C. : for in 1870 he was read he was in March 1871 \\ for death read resignation
}

Clavering, Sir John : after Bath insert From 1770 till death he was gorernor of Landguard Fort for Delaware read Delawarr

8 i 8 f.e. Clay, James: after he sat insert till he was unseated on petition in 1853 , and then from 1857

7 f.e. $\quad$ for in 1873 read on 26 Sept. 1873

11 i 2 Clay, William K. : for Wheatley read Wheatly

17 Claymond, John : for 1504 read 1506-7

22 f.e. $\quad$ for 1510 read 1516-7

12 i 39-42 Claypoole, Elizabeth : for exhumed and cast.... Kennet, Register) read allowed to remain in the Abbey (STANLEY's Westminster Abbey, ed. 1868, p. 179)

13 ii 13 Clayton, John (1709-1773): for 1825 read 1725 and for 1829 read 1729

16 ii 4 f.e. Clayton, Richard: after 11 Dec. 1595 insert was transferred in 1606 to the Leicester St. Margaret prebend

17 i 32 Clayton, Sir Richard: for where he died read from 1825 till his death there

22 f.e. for an only daughter read a son, who became second baronet, and a daughter

ii 36 Clayton, Sir Robert : for 1688 read 1683, when he was turned out on the withdrawal of the city's charter. On his reinstatement after the restoration of the charter in October 1688 he immediately resigned, but was re-elected in October 1689 and sat for Cheap Ward till death.

18 ii $39-40$ for a governor of the Irish Society read governor of the Irish Society 16921706

18 f.e. after Hospital. insert $\mathrm{He}$ was colonel of the Orange regiment of the London militia 1680-1, 1689-90, 1694-1702.

Clayton, Robert (1695-1758): for Robert read Joln for St. Michael's read St. Michan's

after Busie. insert His uncle William, a prominent citizen of Liver ool, was M.P. for that city 1698-1702 and 1713-14.

Cleasby, Sir Anthony : for 1867 read Feb. 1868

Cleaver, William: for master read principal for lxxxiii. read lxxxv.

Cleeve, Bourchier: for probably the son read the tenth son after p. 221) insert by his second wife, Anme daugliter of Joln Burchier 
Page Col. Line

23 ii 23-34

9 f.e.

ii 26 f.e.

10 f.e.

25 i 21 f.e.

30

i 18-17

f.e.

32 ii $\quad 34$

39 i 32

44 ii 2

29

Clerk-Maxwell, Sir George : after the customs insert in Scotland from 1763 till death

45 i 18 Clerke, Bartholomew : for professor of read lecturer in

46 i 10 f.e. Clerke, Charles : after circumnavigator insert son of Joseph Clerke of Weatherfield, Essex,

ii 40 after 1779. insert Clerke's sister married Paul Henry Maty [q. v.])

47 i 30-31 Clerke, Gilbert: for Luffingham, Northamptonshire read Luffenham, Rutland

ii 27 Clerke, Henry : omit probationer 48 i 30-31 Clerke, Richard : for one of the six preachers .... Canterbury read sixth pre-

ii 10 Clerke, Thomas H. S.: after 1830 insert and made K.H. 1831

55 ii 32 Cliff, Henry de : after secured. insert In 1319 he became canon of York.

$56 \quad$ i $32 \quad$ Clifford, Anne, Countess of Dorset : for second earl read third earl

58 ii 14 f.e. Clifford, Sir Augustus W. J.: for retired admiral read admiral of the blue

13 f.e. $\quad$ after 1864 insert becoming retired admiral 31 March 1866

61 i 15 f.e. Clifford, George, 3rd Earl of Cumberland : after 1605. insert He was lord-lieutenant of Cumberland from 1595 till death.

63

l.l. Clifford, Henry de, 1st Earl of Cumberland : before He died insert He was made K.G. in 1537.

64 ii 8

Clifford, Henry, 5th Earl of Cumberland : after lasting. insert In 1614 and 1620 he was M.P. for Westmoreland.

66 ii 36 Clifford, Hugh Charles, 7th Lord Clifford of Chudleigh: for Mary read Mary Lucy

$\begin{array}{rrr}67 & \text { ii } \quad 27-31 \\ & 32\end{array}$

33

\section{2 f.e.} after Blore Heath insert took the oath of allegiance to Henry VI for $(i b .84)$ read (ib. 84, where he is confused with John, Lord Clinton, who was attainted; see Rotuli Parl. v. 349)

, Richard: after (9 Aug. 1392) insert in Lincoln Cathedral, and prebendary of Chiswick (18 April 1397)

for and of Norwell read It seems to have been another Richard Clifford who was prebendary of Norwell

Clifford, Robert de, 5th Baron Clifford: omit (? d. 29 Nov. 1301)

Clifford, Rosamond : for president of read resident in omit Before his death .... about 1175

for emphatically stated read adopted

for But the main argument . . . the Cliffords. read It is true that William Longsword first appears in history in 1196, when a son of Henry by Rosamond would come of age. The manor of Appleby in Lincolnshire was granted before 1200 to one William Longsword, but he proves to be the brother and not the son of Henry II.; the manor of Appleby in Westmoreland belonged to the Cliffords of the fourteenth century. A confusion between these two properties may well have led the suitors of 1607 to associate the younger Longsword with the Clifford genealogy and to support his suggested parentage.

11 f.e. Clifford, Thomas de, 8th Baron Clifford : for 1334 read 1434 :

81 ii 32 Clifford, Thomas, 1st Lord Clifford of Chudleigh: for third son, George, read fourth spn, Hugh.

88 ii 22-25 Clifton, Rdbert C.: omit in which college . . . experimental philosophy. 
Page Col. Line

91 ii 35-36

93 i 18,12

f.e.

94 ii 6 f.e. Clinton, Sir Henry (1738 ?-1795): after appointed insert governor of Limerick in 5 f.e. $\quad$ after 1779, insert colonel in chief of the 84th regiment 1778-1802,

96 i 20

11 f.e. Clinton, Henry F., 2nd Duke of Newcastle-under-Lyne : for Lyne read Lyme 8 f.e.

18f.e. after exchequer, insert (appointed 1751)

98 ii 29 Clinton, Henry P. F. P., 4th Duke of Newcastle : after insatiable. insert $\mathrm{He}$ brought Gladstone in as M.P. for Newark in 1832, and turned him out on the Free Trade question in $\mathbf{1 8 4 6 .}$

99 i 16 Clinton, Henry P. F. P., 5th Duke of Newcastle : after majority. insert and then contested North Nottinghamshire with equal want of success,

ii 33 Clinton, Sir William H. : after 1790. insert He was M.P. for East Retford 1794-6. 14 f.e. $\quad$ for Alkmar read Alkmaar

100 i 32-33 omit At the conclusion of the war

33 after was made insert lieutenant-general 1813

34 after regiment, insert 1814 and omit and promoted lieutenant-general

19 f.e. $\quad$ for 1830 read 1829

8 f.e. for 23 Dec. 1846. read 15 Feb. 1846. He was lieutenant-governor of Chelsea from 1842 till death.

i 4-5 Clipstone, John : for professor of sacred literature read doctor of divinity

102 i 21 Clitherow, Sir Christopher : for in 1625 read from 1624 to 1635

2 f.e. $\quad$ for 1625 read $1625-6$

ii 2 for 1627 read $1627-8$

7 f.e. $\quad$ for In 1636-40 read From 1636 till death

107 i 23 f.e. Clive, Catherine : for Boys in Petticoats' read Bayes in Petticoats'

108 i 10 Clive, Edward, Earl of Powis : after 1694. insert He was lord-lieutenant of Shropshire 1775-98 and 1804 till death

118 ii 15 f.e. Clive, Robert, Lord Clive : after year. insert He was lord-lieutenant of Shropshire and Montgomery from 1772 till his death

120 ii 25 Cloëte, Sir Abraham J.: after 1854 insert He became major-general 1855, lieutenant-general 1862, and general 1871.

121 i 3 f.e. Clopton, Sir Hugh : for (d. 1497) read (d. 1496)

ii 11 after He was insert alderman of Dowgate ward from Oct. 1485 and

14 for 1492 read Oct. 1491

$36 \quad$ for 1497 read 1496

123 i 17 f.e. Close, Sir Barry : after Close insert who was promoted major-general in 1810

126 i 13 Clotworthy, Sir John, 1st Lord Massereene : for and read becoming M.P. for Co. Antrim in the Irish parliament of 1634 . He

127 ii 23 Clough, Arthur H.: for at read under

139 i 32 Coates, Charles : after prince regent. insert From 1808 till death he was prebendary of Wells.

140 i 17 Coates, Robert : omit where he soon after married.

27 after Emma Anne insert whom he married at St. George's, Hanover Square,

30 before Gent. Mag. insert Robinson's Life of Robert Coates

37 for Kent's read Dent's

ii 36 Cobb, James : after secretary insert in 1814

144 i 8 f.e. Cobbett, William: for (1821) read (1820)

ii 2 after places. insert In 1832 he unsuccessfully contested Manchester.

10 for in June read on 18 June

148 ii 24 f.e. Cobden, Richard : for Salden read Sabden

149 i 4 f.e. for 418 read 412

ii 7-8 for In the same year read He was one of the first aldermen, and held office till 1844. In 1838, too

152 ii 21 f.e. for 1858 read 1859 
Page Ool. Line

155 i 3 f.e.

ii 4-6

11-17

18-88

20 f.e.

156

i 9 f.e.

8 f.e.

4 f.e.

l.l.

ii 1

4

5

5-6

10

25

26

28

29

24-22

f.e.

159 ii 30

34

85

36

160 i 7 f.e.

166 ii 13 fe. Coch

67 f.e.

36

23 f.e.

7 f.e.

6 f.e.

174 ii 6

Cobham, John de, 3rd Lord Cobham: for (1260-1335) read (d. 25 Aug. 1339)

for His mother's name ... lord Beauchamp read His mother was Joan, daughter of Sir Joln Beauchamp of Stoke-under-Hamden

for As Henry de Cobham . . . his death in 1408 read Dugdale is altogether wrong. According to the extant brasses in the church at Cobham, where almost all the family are buried, Henry de Cobham died in 1339, and John de Cobham the elder, who was already married in 8 Edward III (1314-15), and an admiral of the fleet in 1335, died 25 Feb. 1354-5

for The Cobham records ... died in 1358 or 1359 read The younger John de Cobham succeeded to his father's estates in 1355. He was first summoned to parliament 20 Sept. 1355. He went to France in 1359 and was made a banneret in 1370

after Rome insert to obtain from Urban $\mathrm{V}$ the appointment of William of Wykeham to the see of Winchester

for 1408) he seems to have died read 1407-s) he died

after years old insert and was buried in Cobham Church

after 1331 insert (she died in 1395)

after married insert in $\mathbf{1 3 6 2}$

after de la Pole insert and died about 1388

after widow of insert Her third husband

omit is said to have been and after times insert and died $13 \mathrm{Jan} .1433-4$

for One of her husbands read Her fourth husband

for another husband read her second husband and for Gerard read Reginald

for ten read twenty

for (1370-1) read (1380-1)

for were read on enamelled copper are

omit in Hasted's time

for which have been ... the above article read The Lords of Cobham and their Monuments, by J. G. Waller, in Archœologia Cantiana, vol. xi. 64 et seq.

Cochrane, Sir Alexander F. I.: for Marcotis read Mareotis

omit when

for was read had been after boroughs insert in 1800 and sat till defeated at the general election in
1806

for June reacl Jan. 1806

for 13 March 1805 read June 1806

after the 27th. transfer to this place the paragriph as corrected from page 166, col. ii, lines 13-2 from end.

for by a triumphant majority read unopposed

for at the head of the poll read with

for being his colleague read although with 1,400 fewer votes

after 31 Oct. 1860 insert The reparation was tardily completed on $19 \mathrm{March}$ 1878, when, in accordance with the report of a parliamentary committee, $5,000 l$. was voted to his grandson, Lord Cochrane, 'in respect of the distinguished services of his grandfather, the late earl of Dundonald,' but really as an equivalent for Dundonald's half-pay during the period of his exclusion from the British navy (Parl. Papers, 1877, Nos. 92,;338; Times, 20 March
1878 .)

175 ii 4 f.e. Cochrane, Sir Thomas J.: after same station, inscrt from 1825 to 1834 was governor of Newfoundland,

3 f.e. after rear-admiral. insert He was M.P. for Ipswich 1839-41. 177 ii 10-9 Cockburn, Sir Alexander J. E.: for secretary of state in 1806, read under-

for in 1811 read from 1811 to 1819

ii 16 f.e.

i 14

ii 24 f.e.

for Columbia read Colombia

for Dundee read Dundas

after the Bath insert (1873)

for Hatherly read Hatherley 
Page Col. Line

181 i 7-8 Cockburn, Catharine : for In defence of Locke read 'Defence of Locke's Essay' ii 14 f.e. Cockburn, Sir George (1763-1847): after British army. insert He was G.C.H. in 1831.

185 ii 12 f.e. Cockburn, Sir George (1772-1853) : for (1813) read (1814)

186 i 5 f.e. for 1820 rearl 1828

3 f.e. after admiralty insert (1818-30 and 1834-5)

190 i 22 Cockburn, John: after D.D. insert aithough he was not presented for that degree at Oxford until 27 May 1709 (Hearse's Collections, Oxf. Hist. Soc. ii. 202)

192 ii 21 Cockburn, William (1669-1789): for 1796 read 1696

20 f.e. $\quad$ for when war broke out read but war broke out in 1702

199 i 12 Cockezell, Frederick P.: for Crayley read Crawley

12 f.e. after Hampstead insert (alterations only)

200 i 3 Cockerill, William : for or read and

ii 31 after Brit. Mus. Cat.; insert Emerson Tennent's Belgium, 1841, vol. ii. 161-4, 174-85;

204 i 7 f.e.

205 ii 4

207 ii 15

214 ii 9

219 ii 8

2 f.e.

i.l.

220 i 1

224 i 29

30-81

226 i 10-15

Codrington, Christopher : after gave him insert in May 1699

Codrington, Sir Edward : for on 10 July 1821 read in 1825

after 24 Oct. insert He was made G.C.M.G. in 1832, and was liberal M.P. for Devonport 1832-9.

Coetlogon, Charles E. de: for Martyn read Martin

Cogan, Eliezer : omit if not thrice

omit Mr. Milner

for Gibson read and and omit Lord Overomit stone

Cok, John : for In the Cottonian Collection read Among the Additional Manuscripts for (Plut. clxviii. c.) read (MS. Addit. 10392)

Cokayne, George : for compiled by . . . 470,982). read but this was the work of

Thomas Cokayne [q. v.]: George is merely one of the signatories of a recommen-

datory letter addressed 'to the reader.'

Cokayne, Thomas : after published insert in collaboration with others

omit This statement is accepted

omit in the Cockayne 'Memoranda' . . . . in this work.

after Museum. insert But there is a copy in the Amherst College Library, Massachusetts, from an examination of which it appears that Thomas was the sole author. Henry Jessey prepared the two indexes, and appended is the English-Greek grammar of Joseph Caryl [q. v.]

Cokayne, Sir William: after alderman of insert Farringdon Without (1609-13), of and for soon read (1618-8)

for afterwards read of Lime Street (1618-25) and of Broad Street (1625 till death). He was governor of the Irish Society 1611-14 for Holdemess read Holdernesse

Coke, Daniel P.: for All Souls read Queen's College

before B.A. insert He migrated to All Souls and graduated

for 1775 read 1776

omit tory

for prebends read prebendaries

Coke, Sir Edward : for three read more

Coke, Thomas W., Earl of Leicester: after Edward insert who was returned in his place for Norfolk

Colbatch, John: after 20l. yearly, insert which he held from 1702 to 1720 , after divinity, insert which he held from 1707 till death,

Colborne, Sir John, 1st Baron Seaton : before entered insert was educated at Christ's Hospital and

after Peninsula, insert joining Wellington at Jaraicejo about 11 Aug.

for Venegas, read Cuesta, who was, however, replaced (12 Aug.) by General Eguia before Colborne reached the Spanish headquarters. Eguia was superseded in Oct. by Areizaga

for he witnessed read Colborne witnessed

omit He commanded 
Page Col. Line 253 ii 18

19

21

22

23

29

30

2 f.e.

l.l.

254 i 5

19

20

27

29-30

261 ii $16 f e$

264 ii 24 f.e.

22 f.e.

266 i 21

ii 24 f.e. Cole, Henry : omit Oxford

274 i 26 f.e. Cole, Thomas : (1627?-1697) for and read of

ii 22 Cole, William (d. 1600): for Lincoln read Lincolnshire

18 f.e. $\quad$ for lii read ii

275 i 16-12

f.e.

ii 13

24 f.e.

276 i 13-16

33

ii 7

i 13-14

ii 14 f.e.

Cole, William (1626-1662) : omit became B.D. . . . . New College and

as member for Rye and

298 ii 10 f.e. Coleridge, Derwent : for 2 April read $28 \mathrm{March}$

299 i 13 f.e. Coleridge, Hartley : for (1826) read (1820)

302 i 29 Coleridge, Sir John T. : after schools insert in 1812

33 after College insert in $\mathbf{1 8 1 2}$

19f.e. $\quad$ after Ellison insert (he graduated B.A. 1815 and M.A. 1817)

12 f.e. for 1834 read 1824

ii 41 for Gibb read Gilbert

307 ii 13 f.e. Coleridge, Samuel T. : for Gozlar read Goslar

314 ii $31 \quad$ before Vandyck insert Peter

321 i 12-11 Colet, Sir Henry : for Castle Baynard read Bassishaw

f.e.

10 f.e. for 1 Feb. 1483-4 read 28 Aug. 1478, and retired from the, corporation 15 Feb. 1481-2. He returned as alderman of Castle Baynard 1 Feb.

9 f.e. $\quad$ for 1487-8 read 1486-7

323 ii 22 Colet, John: for extracts read extant

324 ii 6 
Page Col. Line

326 i 28

328 ii 9 f.e.

329 i 12,55

330 i 7 Colfe, Abraham : for brother read uncle

32 Colfe, Isaac: after Canterbury. insert He was prebendary of Canterbury from 1596 till his death.

332 i 9 College, Stephen: for Lord William Stafford read William, Lord Stafford

337 i 19 f.e. Colley, Sir George P.: after C. B. insert (1874) and after C. M. G. insert (1878) 18 f.e. $\quad$ after K.C.S.I. insert (July 1879).

344 ii 23 f.e. Collier, Jeremy : for Nicholson read Nicolson

351 i 18 f.e. Collier, John P.: for C. W. Singer read S. W. Singer

353 i 5 f.e. Collier, Robert P., Lord Monkswell : for 1842 read 1841

l.l. for Kemp read Kempe

354 i 42-43 for protected read protested

365 i 28 Collins, Arthur : for thrust into the fourteenth volume read introduced

373 ii 24 Collins, Mortimer : for 1865 read 1855

375 ii 46-47 Collins, Samuel (1619-1670): omit and was incorporated . . . . 1659

376 ii 29 Collins, Samuel (1618-1710): for in 1652 read on 24 June 1659

378 i 18 f.e. Collins, William (1721-1759): for 408 read 419

381 ii 21 Collins, William L.: for 1835 read 1853

382 i 5 f.e. Collinson, John : for Sept. read Aug. and after thirty-six insert and was buried in the nave of Long Aston church

384 ii 13 Collinson, Septimus : after 1827 insert He left 1,500l. to found a school in the parish of Grat Musgrave, which is still in existence.

29-30 Colles, John D.: for Kennicott, Pusey, and Ellerton read Kennicott, and Pusey and Ellerton

390 ii 24 Colman, George, the elder: for 1755 read 1757

399 i 29 Colonia, Adam de : for Berchem read Berghem

400 i 1

ii 3

14-15

402 ii 29

403 i 12

405

i 1,13

4

406

407

$$
\begin{aligned}
& \text { Colpoys, Sir John : for July read June } \\
& \text { after year insert when he was made K.B } \\
& \text { omit he had also been . . . the Bath, }
\end{aligned}
$$

Colquhoun, John C. (1785-1854) : omit (brother of the third)

Colquhoun, John C. (1803-70): before was born insert eldest son of Archibald Campbell-Colquhoun [q. v.]

Colquhoun, Patrick: for Yates read Yeats for Dr. H. Boase read Henry. Boase

Colson, Lancelot : after stone. insert He also compiled an almanack for 1680.

Colt, Maximilian : after resign. insert He married in the Dutch church in Austin Friars, on 31 Jan. 1604, Susanna Geeraerts van Antwerpen (Register, ed. W. J.C. Moens).

22-23 for the preceding June read June 1606

25 for Anne read Mary

26 for the previous December read 16 Sept. 1607

6 f.e. after or Coult. insert In the marriage register he is described as 'Maximilian Poictrin van Utrecht.'

408 ii $43-44$

409 i 35

417 i 20

Colton, John : for Caius and Gonville College read Gonville Hall

$$
\text { for } 1381 \text { read } 1382
$$

Colvile, Sir James W.: for Wedderburn Colville read Wedderburn, who changed his name to Colvile

32-5 for the influence .... the appointment of read he was appointed

419 ii 35

Colville, Sir Charles: for 1834 read 1832 . He was colonel 5th garrison battalion 1812-5, ;colonel 34th foot 1815-23, 74th foot 1823-34, 14th foot 1834-5, and 5th foot 1835 till death.

422 i 5-4 f.e. Colville, William: for the Tron Church read Trinity College

424 ii 7 f.e. Colyear, Sir David, 1st Earl of Portmore : after Scotland. insert He was colonel Scots Greys (2nd Dragoon Guards) 1714-7.

425 i 11 omit of

428 i 34 Combe, George : for 1830 read 1820

435 ii 3 f.e. Comber, Thomas (1645-1699): for Barkham read Barcombe

439 ii 4 Comgall, Saint : for St. Finian's read St. Finnian's 
Page Col. Line

444 i 30-2 Compton, Henry (1632-1713): for although a beneficed clergyman .... point of view read although once a nonconformist, was now opposed to nonconformity, attacked Compton for his liberality

448 ii 3 f.e. Compton, Sir Herbert A. D. : after cutta. insert $\Lambda$ portrait is in the Oriental Club, Hanover Square.

449 i 23 Compton, Henry, 2nd Earl of Northampton : after (DorLw). insert He was lordlieutenant of Warwickshire from 1630 till death.

450 i 8 Compton, Spencer, Earl of Wilmington : after Campden. insert $\mathrm{He}$ became a commoner of Trinity College, Oxford, in 1690. Five years later he contested East Grinstead unsuccessfully.

9 for July read June

11 for five read six

452 i 35

Compton, Spencer J. A., 2nd Marquis of Northampton : for 1819 read 1848

for Smeedly read Smedley

ii 27 Compton, Thomas : for Winceslaus read. Wenceslaus

453 ii 15 Compton, Sir William (1625-1663): for who gave him command of a read He joined his father's

459 i 17 f.e. Comyn, John, the elder (d. 1300?) : after Margaret insert the Maid of Norway, the child of Princess Margaret and King Eric

463 ii 39 Comyn, Sir Robert B. : for Calcutta reacl Madras

464 ii 32 Comyns, Sir John : omit was educated .... Cambridge

87-9 for in every parliament . . . . 1712 (inclusive) read in 1701-8 and 1710-5

465 ii 2 Conant, John : for 1693 read 1694

466 i 17 f.e. for Woollebius read Wollebius

167 i 24 for 1693 read 1693-4

25 for eighty-six read eighty-five

468 i 33-4 Concanen, Matthew : for but a few weelis afterwards real at the end of 1743 . Hc 85 for 1729 read 1749 


\title{
DiCTIONARY OF NATIONAL Biography
}

\section{ERRATA IN VOLUME XII}

\author{
CONDER_CRAIGIE
}

Page Col. Line

\section{N.B.-f.e. stands for from end and l.l. for last line}

4 i 21 f.e. Conduitt, John: for March read June

20 f.e. for 1715 he was elected member read 1721 he was elected on petition (having been unsuccessful in the contest of the preceding month) whig member

5 ii 2 Condy, Nicholas: for Ann Trevanion Pyll read Ann Trevanion Pyle, daughter of Captain Mark Oates of the marines.

6 i 24 Congallus I : for Ferchand read Ferchard

7 i 39 Congreve, William: for 13 Oct. 1707 read December 1705, when he became com. missioner of wine licenses

$9 \quad$ i 22 Congreve, Sir William : for 1820 real 1818

11 i 21 f.e. Coningsby, Sir Thomas : for Hereford read Herefordshire and after 1593 insert 1597

ii 4 f.e. Coningsby, Thomas, Earl Coningsby : after side. insert $\mathrm{He}$ was commissioner of appeals in the exchequer 1689-90

$12 \quad$ i 17 after Ireland. insert $\mathrm{He}$ was vice-treasurer of Ireland from Jan. 1692-3 until he was deprived of the office in $\mathbf{1 7 1 0 .}$

$25 \quad$ omit again and the vice-treasurer and

ii 2 for 1715 read 1716

11 after 1720. insert He resigned his two lord-lieutenancies in 1721 and was dismissed from the privy council Nov. 1724 .

21 i 19 f.e. Connell, Sir John : for In 1822 read Some time before 1821

18-16 omit on occasion of . . Edinburgh

f.e.

23 ii 11 f.e. Connor, George H. : for Jan. 1883 real Oct. 1882

29 ii 2 Conolly, Thomas : omit first

$3 \quad$ after Ballyshannon insert from 1727 till death

11 for 1760 read 1753

26 for until the union. read until May 1800. He resigned just before the union.

36 for 1784 read 1780

30 i 15 f.e. Conolly, William: after of which he insert was elected member for Donegal borough $1692-3$ and $1695-9$, and for co. Londonderry 1703 till death. He

5 f.e. $\quad$ after revenues insert (1709-10 and 1714 till death)

33 ii 27 Constable, Archibald : after Edinburgh.' insert A son, John Constable (d. 1892), was principal of the Royal Agricultural College, Cirencester, from 1859 to 1880, and afterwards rector of Marston Bigot, near Frome.

34 ii 7 Constable, Henry (1562-1613): after Spain. insert Two letters of the same period from the poet to the Countess of Shrewsbury are printed in Lodge's Illustrations' (ii. 498-500)

35 ii $8-\bar{\tau}$ f.e. Constable, Henry, Visconnt Dunbar : for Yortishire read Eboracum 3 f.e. before On the death read Constable became commoner of Trinity College,
Oxford, in 1596 . 
Page Col. Line

Co nstable, Sir Marmadnke : for Milton read Hilton

23 f.e.

after Yorkshire insert and in that of 1544-5 for Warwickshire

46 ii 37 Constable, Sir William: for Yorkshire read York

47 ii 9 f.e. Constantine II : for Bernacia read Bernicia

48 ii 6 for Borough-on-the-Humber read Brough-on-the-Humber

i 11 f.e. Conway, Anne, Viscountess Conway : for ventured read are said to have ventured

Conway, Edward Viscount Conway : for He was also made lord president read On 14 Dec. 1628 he became lord president

17 f.e. Conway, Francis S., Marquis of Hertford : for Earl of Hertford in 1736 read second Baron Conway in 1732

7f.e. for 1766. read 1765. He was lord chamberlain 1776-82, and again in the coalition ministry, April to December 1783. He was lord-lieutenant of Warwickshire from 1757 till his death.

for Francis read Francis (Ingram) Seymour [q. v.]

ii 1

27

Conway, Henry S. : after Antrim insert which he represented till 1761 for 28 Dec. read 28 Dec. 1741

$\begin{array}{lll}52 & \text { ii } & 16 \\ & & 36 \\ & & 40 \\ 54 & \text { ii } & 19 \\ & & \\ 55 & \text { ii } & 10\end{array}$ for 29 th regiment read 34 th regiment, and held it for two years after 282). insert $\mathrm{He}$ was colonel 8 th horse, now 7th dragoon guards, 1784-9 for March read March 1755

after secretary of state insert for the northern department (in substitution for the southern department, of which he was already secretary)

after iii. 399). insert In Oct. 1770 on Granby's death he received the command of the royal regiment of horse guards

57 ii 7 omit during his absence .... horse guards.

$\begin{array}{cl}\text { 3-1 f.e. } & \text { omit during his absence } \\ 7 & \text { for } 19 \text { Oct. read } 9 \text { July }\end{array}$

11 f.e. Conway, Sir John : after folio). insert In Dec. 1583 he seems to have been imprisoned in connection with the Somerville-Arden case, and it was probably during this imprisonment that he wrote his 'Meditations and Praiers' (see next page)

58 i 4-7 omit During his confinement ... . of leade.' for Ostend read England

59 i 14 Conway, William A. : after actor, insert whose real name was Rugg,

60 ii 11 f.e. Conybeare, John : after Oxford. insert He was proctor in $\mathbf{1 7 2 5}$.

61 i 25 f.e. after that year. insert With the bishopric he held the Christ Church deanery. 23 f.e. for the cathedral read Bristol Cathedral

ii 4 Conybeare, John J. : after 1797 insert and won the University Latin verse prize, 1800

5 for Somersetshire read Somerset. He was prebendary of York from 1803 till his death

7 for 1807 read 1808

63 i 10 f.e. Conyngham, Henry, 1st Marquis Conyngham: for privy chamber read privy council

ii 22 for Conyngham read Conyngham was made general of the army on 22 July 1830, but

32 after 1849 insert [see Denison, AlbenT]

$\begin{array}{llll}66 & \text { ii } & 37 & \text { Cook, James }(d .1611) \text { : for } 1592 \text { read Jan. 1592-3 } \\ 76 & \text { ii } & 19 & \text { Cooke, Sir Anthony: for Shoreham read Lewes }\end{array}$

78 i 15 f.e. Cooke, Benjamin : for 40 read 74

ii 19 Cooke, Edward (1770?-1799): for 1770 ? read 1772

20 after navy, insert born 14 April 1772,

24 for Colonel read Major-General

26 for a sister of Admiral Boyer read Penelope, daughter of Sir William Bowyer and sister of Admiral Sir George Bowyer [q. v.]

79 ii 34 Cooke, Edward (1755-1820): before and in 1790 insert He was M.P. for Lifford $1789-90$,

80 ii $3-6$

30 Cooke, Edward W.: omit (1817)

85 ii 4 f.e. Cooke, George W.: for twice read in 1850 
Page Col. Line

85 ii 3 f.e. Cooke, George W.: for once read in 1861

92 i 30 Cooke, John (1738-1823): after Hospital insert and a commissioner from 1773 till death

93 i 15 f.e. Cooke, Robert: for fl. 1793 read 1768

9 f.e. $\quad$ after minster insert in 1806

ii 27 f.e. Cooke, Roger : for 1523 read 1553

94 i 8 f.e. Cooke, Sir Thomas: for 1454 read 1456 (being transferred to Broad Street in 1458)

ii 3 f.e. after well-reasoned.' insert $\mathrm{He}$ was elected an alderman of Bread Street Oct. 1470, and again deprived next year.

ii 9 f.e. Cooke, Thomas (1703-1756): after ' Germanicus' insert (see 11th Rep. Hist. MSS. Comm. App. pt. vii. p. 42)

ii 20 f.e. Cooke, Thomas (1807-1868): for Bishop's Hill read Bishophill

101 i 27 Cooke, William (1711-1797): for Halifax read Hallifax

18 f.e. $\quad$ for 1793 read 1792

ii 4 for Harward's read Harwood's

104 i 8 Cookes, Sir Thomas : for Worcester read Gloucester for Nashe's read Nash's

105 i 29 Cookson, George : for 1801 read 1809

ii 6-7 Cookson, Henry W.: for Soon afterwards read In due time

9 after Thomson insert (Lord Kelvin). He was proctor in 1842.

$11 \quad$ for 1877 read 1867 13 f.e. $\quad$ for four read five and after 1848 insert 1863

Cooper, Anthony A., 1st Earl of Shaftesbury: for and was never contradicted read but it has been contradicted (cf. Sloane MS. 3371, f. 24)

133 ii 23-22 f.e.

Cooper, Anthony A., 7th Earl of Shaftesbury : for and sat for Dorsetshire from 1833 to 1846. read but was elected at a bye-election for Dorset Co. in Sept. 1881, and sat for that constituency till 1846.

for Mr. W. J. Sadler read Michael Thomas Sadler [q. v.]

after 1885. insert He was lord-lieutenant of Dorset from 1856 till death.

Cooper, Charles P.: for Lady Henley's read Lady Hewley's

Cooper, Edward J. : omit College

before member insert conservative

20 f.e. Cooper, Sir Grey: for 1675 read 1765

3 Cooper, John G.: for Thurgaton read Thurgarton

13 f.e. Cooper, Thomas (1517 ?-1594) : for Languet read Lanquet

7 f.e. for 1566 read 1567

4 f.e. for 1570 read 1570-1

for i. read ii.

ii 29 Cooper, Thomas (1759-1840): for is said to have been sent to read matriculated in Feb. 1779, aged nineteen, from University College.

after services. insert In 1787 he was called to the bar from the Inner Temple.

157 i 29 Coote, Sir Charles, Earl of Mountrath : before On the deposition insert He was

M.P. for cos. Sligo and Mayo 1654, 1656, and 1659.

159 ii 6 f.e. Coote, sir Eyre (1726-1783): after England. insert The year before he was elected M.P. for Maryborough in the Irish House of Commons, but was unseated on petition.

160 i 11 after 1771, insert was M.P. for Poole 1774-80,

13-14 for the Inniskillings on 19 Feb. 1773, read in 1771, being transferred to the 37 th regiment in 1773 ,

161 i 16 f.e. Coote, Sir Ejre (1764-1824?): for 1824 ? read 1823

162 i 26 after Coote. insert $\mathrm{He}$ had already been elected to the Irish House of Commons as member of Ballynakill (1790-7) and Maryborough (17971800).

17 f.e. after 1802 read to that of the 62 nd regiment in 1806 , and

16 f.e. after Barnstaple insert (1812)

ii 7

for is supposed to have died . . . 1824. read died 10 Dec. 1823. He was twice married and left issue by both wives. His first wife, Sarah (d. 1795), daughter of John Robbard, is the subject of a famous painting by Romney. 
Page Col. Line

163 ii 25-26 Coote, Richard, 1st Earl of Bellamont : for Nansan of Bridg-norton reail Nanfan of Birtsmorton

166 i 12 Cope, Sir Anthony : for six parliaments (1586-1604) real seven parliaments (157188, 1586-1604) and Oxfordshire 1606-14

ii 26-27 Cope, Sir John: for Lord Strafford reacl Thomas Wentworth, third earl of Strafford [q. v.]

23 f.e.

$$
177 \text { i } 30
$$

for the 7 th regiment of foot read the 39th regiment of foot (1730-2), the 5th regiment (1732-7), the 9th dragoons (1734-41), and the 7 th dragoons 1741 till death. He was promoted brigadier-general 1735 , major-general 1739, and lieutenant-general 1743

after the Bath. insert He was M.P. for Queenborough 1722-7, for Liskeard 1727-34, and for Orford 1738-41

for unable read impossible

for May read July

Cope, Sir Walter: after Cope [q. v.], insert was elected M.P. for St. Mawes in 1588 , for Weymouth in 1601, for Westminster in 1604, and for Stockbridge in 1614 ,

Copeland, William T.: for in the following year read. during the year (Feb. 1829) for many read seven after Bethlehem insert (1861-8)

after 1833 he insert as a liberal after returned insert as a conservative for in politics read after abandoning the liberal party

Copleston, Edward : for immediate read direct before In 1814 insert He was proctor in 1807, and was prebendary of Hoxton in St. Paul's Cathedral in 1812. for 1828 read 1827

Copley, sir Godfrey : for 1705 read his death

Copley, John S., the elder : for in a year or two read subsequently after Copley insert who was made A.R.A. in 1776 and R.A. in 1779

Copley, John S., Lord Iyndhurst : for dividing the highest honours . . . with read the senior wrangler of the year being for 1829 read 1818

for Cambridge read Cambridge University

Copley, Sir Thomas : for 1514 read 1534

for 1533 read 1554

for nineteen read twenty

omit 1554

Corbet, Sir John : omit sometime . . . Castle

Corbet, Richard : after subsequently insert (1619-20) for 1624 read 1628

207 i 22 f.e. Corbett, Thomas : before secretary insert chief clerk of the admiralty 1725, and in 1728 second

9 f.e. $\quad$ after equal. insert He was M.P. for Saltash from 1734 till death.

211 i 35 Corbould, Henry : for 1707 read 1807

213 ii 18 f.e. Cordell, Sir William : after Suffolk insert and was M.P. for Dunheved 13 f.e. for Wyat read Wyatt

223 ii 18 f.e. Cornelys, Theresa : after 1753. insert She came to England in 1759 (Home Off Papers, 1770-2, p. 139).

226 i 11 f.e. Cornewall, Charles : for the next two years read 1709-10

10 f.e. after member insert for Bewdley, and from 1715 till death as member

2 f.e. $\quad$ for the navy read the storekeeper's accounts at the admiralty

ii 30 for 1717 read 1717-8

20 f.e. for Nov, read Oct.

227 i 21 Cornewall, Folliott, H. W. : for 1792 read Jan. 1793 for Exeter read Hereford

ii 35 Cornewall, James: after seconds insert (11 Feb. 1743-4) 16 f.e. after Abbey, insert He was M.P. for Weobley 1732-4 and 1737-41. 
Page Col. Line

229 ii 11 f.e. Cornioh, Henry : for St. Michael Bassishaw read Vintry from 24 Sept. 1680 till the surrender of the city's charter in Oct. 1683 (Repertory, 85, fo. 225)

230 ii 28 for Hawkes read Hawles

232 ii 21 Cornish, Sir Samuel: after the following year. insert He was whig M.P. for Shoreham from 1765 till his death.

234 i 13 Cornwallis, Sir Charles : after knighted. insert He was M.P. for Norfolk in 1604.

235 i 20 f.e. Cornwallis, Charles, 1st Marquis Cornwallis : after office insert in England 17 f.e. before on which insert for the post of joint vice-treasurer of Ireland

13-11 for The voluntary banishment .... as in read The letter is a genuine f.e.

236 ii $\quad 36-37$

$39-40$

42 work of Junius, though signed 'Domitian.' In

omit and his distrust of the ministry

for and to show his dislike .... power, he read $\mathrm{He}$ for January 1784 read Feb. 1783

241 ii 32 Cornwallis, Frederick : after Paul's insert holding with the deanery the prebend Wildland

242 ii 1 Cornwallis, James, 4th Earl Cornwallis : for Salisbury read Canterbury

19 for fifty-three read forty-three

243 i 15 f.e Cornwallis, Sir Thomas: after 1554 insert during which year he was also elected M.P. for Grampound

244 ii 9 Cornwallis, Sir William (d.1631 ?) : after children. insert He was M.P. for Lostwithiel in 1597 and for Orford in 1604 and 1614.

247 i 38 Cornwallis, Sir William (1744-1819) : after Cross. insert He was M.P. for Eye 1768-74, 1782-4, and 1790-1807, and for Portsmouth 1784-90, and he was colonel of marines 1787-93.

249 i 39-40 Cornysshe, William: for Calendars of State Papers .... Series read Calendar of Letters and Papers, Henry VIII

251 i 32 Corrie, Archibald : for F. F. H. read T. F. H.

252 i 40 Corrie, George E.: before In 1851 insert He was vice-chancellor of the university in 1850.

6 f.e. for Wheatley read Wheatly

254 ii 41 Corry, Henry T. I.: for $1826 \mathrm{read} 1825$

4-3 omit successively .... health and

f.e.

Corry, Isaac : after unknown insert He was defeated at Newry in both 1806 and 1807, but was elected in the former year for Newport (I. of W.)

31-35 Coryate, George : for According to his own showing . . . . taken the degree. read He is registered as having 'supplicated' for the degree of B.D. in July 1592, but New College men were exempt from 'supplication,' and this entry may have been a mistake of the registrar for Coryate's actual graduation.

260 i 20 f.e. Coryate, Thomas: for Kircunerus read Kirchnerus

261 i 25-27 for and that the book .... in our own day. read It was only once reprinted since its publication, viz. in 1776 , when it was issued in three volumes.

263 i 40 Cosby, sir Henry A. M.: for lieutenant-general in due course read majorgeneral in 1793 and lieutenant-general in 1816 (antedated to June 1799)

ii 12 f.e. Cosby, Phillips: after 1790. insert He was colonel of marines 1787-90.

264 ii 6 Cosin, John : for in 1594 read 30 Nov. 1594 (Sloane MS. 1708, f. 109)

271 i 16 f.e. Cosin, Richard : for parliaments read parliament

15 f.e. after 1586 and insert for Downton in that meeting

ii 39 Costa, Emanuel Mendes da : after London insert and died 24 June 1726 (Hist. Reg. 1726, p. 26)

285 i 29 Cotgrave, John : after 14 insert Gent. Mag. 1821, ii. 415-6

290 i 11-10 Cotterell, Sir Charles : for (1615-1687 ?) read (1612?-1702)

f.e.

9 f.e. $\quad$ for in 1615 read about 1612

ii $\quad 20-19$

f.e.

291 i 17 f.e.

for apparently died in the following year reacl died, according to the 'Mercurius Historicus,' on 19 July 1702, at the age of 90

11 f.e. for Cotterell Dormer read Cottrell Dormer

292 ii 10 Cottingham, Lewis N. : for St. Mary's Church read St. James's Church

293 ii 37 Cottington, Francis, Lord Cottington: before When Prince Charles insert He was M.P. for Camelford in 1624, for Bossiuey in 1625, and for Saltash in 1628. 
Page Col. Line 302 i 7

15 12 20 f.e. 14 f.e.

305

i $\quad 8-9$ 21 f.e. 20 f.e. 19 f.e.

308 i 1 8-7 f.e.

ii 6 f.e. 5 f.e.

309

22 f.e.

ii 2

8

3-4

5

ii $\quad 13-12$ f.e.

323 ii 4

13

Cotton, Sir Charles : after 1808 insert in which year he was made full admiral for 1778 read. 1798

Cotton, Henry : after ministry insert (He resigned his deanery in 1849)

for 1833 read 1832

for 1845-78 read 1851-78

for (5 vols. 1845-1860) read (6 vols. 1851-78)

Cotton, Sir John Hynde: for a year read two years

for September 1713 read July 1712

for board read council

Cotton, Richard L. : for 1857 read 1856

Cotton, Sir Robert B. : for Sir Thomas Billing and Thomas Lacy [q. v.] read Sir Thomas Billing [q. v.] and Thomas Lacy

for no part read little part

after affairs insert $\mathrm{He}$ was M.P. for Newtown in 1601

for entered read re-entered

omit Sarmiento's successor.

for second read third

for in 1711 read from Dec. 1710 to Aug. 1713

Cotton, Sir Stapleton, 1st Visconnt Combermere : after 1st life guards insert having already been colonel 20th light dragoons 1813-8 an $\vec{\alpha}$ 3rd light

dragoons 1821-9
after a pleasant picture. insert He was governor of Sheerness from 1821 to 1852.

after the Bath insert (1815, having been K.B. since 1812)

after Guelphic order insert (1817)

omit of the order of the Star of India

after a knight of insert the Star of India 1861

Cotton, Sir Sydney J. : for a daughter of Captain Hallack read Marianne, daughter

Cotton, Sir Willoughby : after 98 th foot. insert In 1838 he was made K.C.B. after 32nd foot insert April 1854

326 i 13 f.e. Coulson, Walter: for who read Hunt

12 f.e. for and adds read Procter says

327 ii 22 f.e. Coulton, David T. : omit dean of Bristol

336 ii $\quad 8$ Courtenay, Henry, Marquis of Exeter : for 1387 read 1357

36 for Jan. read June

339 ii $\quad 33$

34

340 ii 21 f.e.

342 ii 10

13

39

343 i 16

347 ii 21 f.e.

349 ii 13

354 i 4

356 i 16

358 i 5

Courtenay, Peter : for 1477 read 1476-7 before On 5 Sept. insert and in 1477 dean of Exeter.

Courtenay, Richard: before In 1400 insert and also a prebend at Lincoln

Courtenay, Thomas P. : for 1810 read 1811 after 1831. insert $\mathrm{He}$ was deputy paymaster of the forces 1807-11 after died insert being accidentally drowned

Courtenay, William : for 1639 read 1369-70

Courteville, Raphael : for 1838 read 1738

Cousen, John : for Mirashay read Miryshaw

Coutances, Walter de : for 1197 read 1198

Covel, John : before appears insert Covel

Coventry, Henry : after Henry insert who was M.P. for Droitwich 1661-81, for 1679 read 1680

Coventry, Sir John : for The son John read The father John for He served read The son John served

Coventry, Sir Thomas : for Whittington read Robert Wydington (no connection of Richard Whittington)

Coventry, Thomas, Lord Coventry : after supporters. insert He was M.P. for Droitwich in 1620 .

Coventry, Sir William : for 1663 read Feb. 1661-5

6 f.e. $\quad$ for 1668 read 1668-9

375 ii 44-45 Cowell, John : omit in an expurgated edition 
Page Col. Line

375 ii 17 f.e. Cowell, John: after 1637 insert (unohanged)

376 i 12 Cowell, Joseph L.: for Witchett read Whitshed

381 i 6 f.e. Cowley, Abraham: for Suckling's verses read Some verses of the 'Session of the Poets,' in 'State Poems,' 1697

384 ii 16 f.e. Cowper, Sir Charles: for 1850 read 1860

385 i 5 for Some time before his death read In 1871

386 i 19 Cowper, Henry: for For many years he was clerk ... house of peers read From 1785 to 1826 he was deputy clerk of the parliaments and clerk assistant of the house of lords

387 ii 23 f.e. Cowper, Spencer (1669-1727) : for 1727 read 1728

27 for 1711 read 1715 , when he was made K.C.

30-32 for On the accession of George II ... the duchy of Lancaster and read He was appointed

34 for 1727 read 1728

389 ii 2 f.e.

390 i $34-35$

46-47

2 f.e.

393 ii 9

Cowper, William, 1st Earl Cowper : for 1680-90, 1695-9 read 1689-1700

omit king's counsel, and about the same time

omit $\mathrm{He}$ seems to have been . . . in 1694.

before In 1699 insert He was made K.C. 8 March 1698-9.

after the Charterhouse insert He was lord-lieutenant of Hertfordshire 1700-2 and 1714-22.

399 i 13

ii 33

Cowper, William (1731-1800) : for 1785 read 1784

for Mr. Unwin read Mrs. Unwin

404 i 15 f.e. Cox, Daniel : after 1742. insert Cox is said by Munk to have died in January 1750. In that case he cannot have written, as Munk asserts,

9-8f.e. for is attributed, both by Munk and by the compilers read Munk and the compilers

6 f.e. $\quad$ after Society insert erroneously attribute

4-3f.e. $\quad$ omit appears to be ... Medical Compendium '

410 i 13 Cox, Edward W.: after 1870). insert He became serjeant-at-law in 1868

412 i 6 f.e. Cox, Richard : before In 1542 insert He was also made prebendary of Ely in 1541 and dean of Ely 1545.

$414 \quad$ i $\quad 37 \quad$ Cox, Sir Richard : for 1764 read 1674

420 i 12 f.e. Coxe, John : for 1783 read 1583

422 i 6 Coxe, William : for 16 June read 8 June

425 ii 9 f.e. Cozens, John R.: for Mr. Henderson read Mr. Henderson's son

428 i 3 Crabbe, George : for grandfather read father

ii 14 f.e. for August read Sept.

436 i l.l. Cradock, Matthew : after Staffordshire; insert was recorder of Stafford from 30 Nov. 1620 ; was elected M.P. for the city in 1624, 1625, and 1627-8;

ii 10 f.e. for At the close of 1640 read In 1640

9-8f.e. for the Long parliament read the Short and the Long parliaments

438 i 25-26 Cradock, Walter: for Brampton Briars read Brampton Bryan

441 ii 22 Craig, Alexander: for 1640 read 1604

444 i 24-25 Craig, Sir James H. : for lieutenant-governor read deputy-governor

445 i 33

after 1812. insert Hewas colonel of the 46th foot 1795-1804, of the 86th foot 1804-6, of the 22nd foot 1806-9, of the 78th foot from 1809 till death. He was governor of Blackness Castle from 1806 till death.

ii 13-14 Craig, James T. G.: for Kirkpatrick, Sharpe read Kirkpatrick Sharpe

29 omit and a preface by Mr. W. E. Gladstone

448 ii 19 Craig, Sir Lewis, Lord Wrightslands : for Traboun read Trabroun

449 i 37-39 Craig, Sir Thomas : for Helen Hunt . . George Buchanan read Helen, youngest daughter of Robert Heriot of Lumphoy or Lymphoy, an estate in the parish of Currie, Midlothian

450 i 11 f.e. for Louis read Lewis

ii 1 for of Warriston, whose son Sir James read whose son Sir Archibald, of Warriston

451 i l.l. Craig, Sir William G.: after eldest son of insert James Gibson, afterwards

ii 17 for 1842 read 1841

452 ii 36 Craigie, Robert: for 1710 read 1709

37 after 1754. insert He was M.P. for Wick borough 1742-7. 



\title{
DiCTIONARY OF NATIONAL BIOGRAPHY
}

\author{
ERRATA IN VOLUME XIII
}

\author{
CRAIK-DAMER
}

Page Col. Line

N.B.-f.e. stands for from end and l.l. for last line

2 i 26 f.e. Crakanthorpe, Richard: for of Germany read Rudolph II

5 ii 34 Cramer, Wilhelm: for H. V. D'Esterre read John D'Esterre

6 i 2 f.e. Cramp, John M.: for 1862 ' read 1662,' 1862

14 ii 19 Cranfield, Lionel, Earl of Middlesex : after master of requests. insert He was elected M.P. for Hythe in 1614 and for Arundel in 1620.

29-30 for Spanish Marriage, i. 170). read Hist. of England, iii. 200).

43-4 for Spanish Marriage, i. 183). read Hist. of England, iii. 213).

15 i 35-37 for England... . Charles $I$, i. 8). read Hist. of England, v. 178).

45 for i. 63 read $\mathrm{v}, 229$

16 ii 16 Cranford, James : for Under the Commonwealth read From 20 June 1643 to 16 March 1649

17 i 5

after ii. 13; insert Husband's Ordinances, 1646, p. 215 ; Merc. Pol. 27 June 1650 ;

20 Cranke, James: for Leigh read Legh

18 ii 17, 18 Cranmer, George : omit If an unsupported statement . . . believed,

14 f.e. for On the death of Killigrew read Subsequently

33 i 55 Cranwell, John: for Brown's read Browne's

ii 20 f.e. Crashaw, Richard: for Nympha read Lympha

35 i 4

4 for Car read Carre [q. v.]

39 i 40 Craufurd, Sir Charles Gregan-: after Cliff Fort insert holding office from 1796 till his death

42 for 1803 until his election read Dec. 1795 to Dec. 1799. He was elected

42 ii 14 f.e. Craufurd, Robert : for Dudley Costello's read Col. Edward Costello's

43 ii 24 Craven, William, Earl of Craven : after younger insert was commoner of Trinity College, Oxford, from 1623 to 1626 , and gave $100 l$. to the college library in 1636. But he

25-27 for when only seventeen .... Oxford (Doyle) read before he was twenty

46 i 12 f.e. after Southwark insert 1670-89

11 f.e. $\quad$ after guards insert 1670-89

11-10 after lieutenant-general insert 1667

f.e.

9 f.e. after Trinity House insert 1670

8 f.e. $\quad$ after Cambridge insert 1667

7 f.e. for Tangiers read Tangier

48 i 18 after earldom insert became extinct; his barony

ii 13 f.e. Craven, Sir William : for 15 read 18

49 i 15 for In July 1611 read On 14 Jan. 1611-12

ii 20 after Cambridge. insert He was commoner of Trinity College, Oxford, 1626-8.

59 i 11-9 Crawford, William S. : for Crawford's age . . . . autumn of 1852, read Crawford f.e. was defeated when candidate for Down Co. at the general election of 1852 . He did not re-enter parliament, 
Page Col. Line

61 i 8 f.e. Crawfurd, John: after Indo-China. insert He unsuccessfully contested, as an advanced radical, Glasgow in 1832, Paisley in 1834, Stirling in 1835, and Preston in 1837.

62 i 8-9 Crawley, Sir Francis : for There is no trace of him .... . however. read According to the register of Caius College, Cambridge, he was, however, a native of Norton, Leicestershire, and became a scholar of the college on 2 May 1592.

64 ii 12-11 Creech, Thomas : for One of Creech's translations of the idyllium read Creech's f.e. translation of one of the idylls

69 i 28 f.e. Creed, William : after in 1639, insert was proctor in 1644,

14 f.e. for June 1660 read July 1661

ii 31 Creighton, Robert : for 1631 read 1631-2

70 i 13 f.e. for Sgoropulos read Sguropulus

72 ii 15 f.e. Cresswell, Sir Cresswell : after king's counsel. insert From 1834 to 1842 he was also solicitor-general for the county palatine of Durham.

78 ii 4 f.e. Crew, John, 1st Baron Crew : for 1625 read 1624 and 1625

79 ii 6 Crew, Nathaniel, 3rd Baron Crew : for 1722 read 1721

29 for dean read dean and precentor

for 1722 read 1721

80 ii $\quad 34$

81 ii $\quad 37$

Crew, Sir Ranulphe : for Lords read Commons

82 ii 23-21 Crew, Sir Thomas : for Though the official lists.... in 1614, as read He was f.e. M.P. for Beeralston in 1614 and

84 i 33 Crewe, Frances Anne, Lady Crewe: omit [q. v.]

35 for in $1776 \mathrm{read}$ on 4 May 1766

9-8 f.e. omit and in another with Mrs. Bouverel

ii 13-14 Crewe, John, 1st Baron Crewe: for the close of the century read 1802

$21 \quad$ for 1776 read 1766

87 ii 5 f.e. Crichton, James, surnamed The Admirable: for this read all this

91 i $32 \quad$ for 82 read 81

ii 11 f.e. Crichton, Robert, 6th Lord Sanquhar: for Farmer read Fermor

93 ii 36 Crichton, William $(f l .1615)$ : for Zeland read Zeeland

10-7 for A ridiculous story .... they were found read Some papers which he

f.e. tore in pieces were blown on board again, were pieced together by Sir William Waad [q. v.], and were found

4 f.e. $\quad$ after iv. 95). insert This story, though often ridiculed, has been substantiated by Mr. T. G: Law in the 'English Historical Review' (viii. 698)

95 ii 26 Crisp, Sir Nicholas : before He was a widower insert His mother, Hester, sister of John Ireland, first master of the Salters' Company, was afterwards married to Sir Walter Pye, attorney-general of the Court of Wards.

5 f.e. $\quad$ for 1641 read $1639-40$

4 f.e. $\quad$ for the Long parliament read both the Short and the Long parliaments

97 i 15 f.e.

before On 16 April 1665 insert He was M.P. for Winchelsea, his old constituency, from 1661 till his death.

l.l. before The magnificent house insert On 15 June 1898 his body was reinterre $l$ in the churchyard of St.' Paul's, Hammersmith. His widow, possibly his third wife, was Anne, daughter and heiress of Edward Prescott, salter, of London; her will, dated 31 May 1669, was not proved till 6 Oct. 1699.

105 ii 3 Croft, Herbert (1603-1691): for 1616 read 1626

106 ii 2 for 1792 read 1797

110 ii 22 f.e. Croft, Sir James : for (d. 1591) read (d. 1590)

$112 \mathrm{i} 4 \mathrm{for}$ in 1591 read on 4 Sept. 1590

31 after 1571 insert 1584

37 for CRoft the elder, Sir James read CRofT, the elder Sir James

114 ii 37 Crofton, Zachary: for 1646 read 1644

38-39 for His first living was at Wrenbury read He was preaching in Cheshire in 1645 , and was for some time pastor at Newcastle-under.Lyme before he obtained the living of Wrenbury

for 1648 read 1651

18 f.e. $\quad$ for rectory read vicarage

16 f.e. for for nonconformity. read for maintaining that the Solemn League and Covenant was still binding on the nation. 
Page Col. Line

115 ii 3

3-4

27

118 ii $7-6$

f.e.

119 i 18

9 f.e.

4-3

f.e.

ii 12

14

120

124 ii $3-4$

6-7

4 f.e.

$17 f . e$

3

35

Crofton, Zachary : after grocer's shop. insert He probably returned to London before the Great Plague of 1665 , at which date he published a book entitled

'Defence against the Dread of Death.' omit again came to London and

for Nactroff read Noctrof and note that the publication here numbered 8 is a lampoon on Crofton and not a work from his pen

Croke, Sir John : for king's serjeant 29 May 1603 read for the office

after M.P. insert for Oxfordshire in 1614 and

for Sir Unton Croke read Unton Croke (1594 ?-1671)

omit actively aided . . . . Oxford in 1649

for Sir Unton's read his

after 1655. insert He died 28 Jan. 1670-1. His son also, UntoN Croke ( $f$ l. 1658), was a major in the parliamentary army, and afterwards colonel of horse; he was created B.C.L. at Oxford in 1649 , became a barrister of the Inner Temple in 1653, and high sheriff of Oxfordshire in 1658.

Croke, Richard : for Hatton read Hutten

Croker, John Wilson: for Croker made an unsuccessful .... was, however, successful read Croker succeeded in obtaining the seat on petition. He was re-elected

for He now read and retained the seat till 1812, when he was rejected at the general election. He was thereupon returned for Athlone, which he represented till 1818. He unsuccessfully contested Dublin University that year, and next year was returned for Yarmouth (I. of W.) His subsequent constituencies were Bodmin, 1820-6, Aldeburgh, 1826-7, Dublin University, 1827-30, and Aldeburgh again 1830-2. During the parliament of 1807-12 Croker

for 1854 read 1845

come, Edward : for but although his friend .... resigned in 1536. read and was president of Physick Hostel, a dependency of Caius College, from 1509 to 1511.

ii 18 f.e. Cromer, George : for (d. 1542) read (d. 1548)

11 f.e. after attention. insert $\mathrm{He}$ died in March 1542-3.

ii 35 Crompton, Hugh : for Cousin's read Corser's

ii 28 Cromwell, Henry : for lieutenant read deputy

29-30 for his deputy .... to fill read commander-in-chief of the army and a

member of the council.
for the deputy's supporters read the supporters of the petition for lieutenant read deputy

Cromwell, Oliver (1599-1658) : for 1711, p. 198). read 1730, p. 124).

for And made more rich read And the state fixed

8 f.e. Cromwell, Richard : for Cambridge read Cambridge University

i 9 f.e. Cromwell, Thomas, Earl of Essex : for Lord Rochford read Earl of Wiltshire

ii 7 f.e. 31 Cropper, James : for 1841 read 1840

i 16 f.e. Crosby, Brass : for 1,048 read 1,043, and for 1772 read 1782

ii 23 Crosby, sir John: before alderman insert doubtfully said to be after 1468 insert and was transferred to Bishopsgate ward next year for 1475 read 1475-6

Crosdill, John : for a Mr. B. Thompson read Beilby Thompson of Escrick, M.P. for Hedon

35 Cross, Mary Ann (George Eliot) : for Two short read Of two short for appeared in 'Blackwood ' in 1860. read the first appeared in 'Blackwood' in 1859, and the second in 'Cornhill' in 1864.

41 for 'Women read' Woman

42 for Tablé' read Sable'

10 f.e. $\quad$ after four insert excluding 'Silly Novels'

4 f.e. $\quad$ for 1866 read 1868

222 i 3 f.e. Cross, Nathaniel : omit [q. v.]

228 i 13 Crossley, Sir Francis : for 1869 read 1868 
Page Col. Line

229 i 27-28 Crossley, James : for Mr. Gladstone championed the conservative cause. read Mr. Gladstone, without his consent, was put forward as conservative candidate.

236 i 14 f.e. Crow, Mitford: after Baltimore. insert He was M.P. for Southampton 1701-2.

237 i 35 Crowder, Sir Richard B.: for for a long time read from 1849 till 1854

238 ii 5 f.e. Crowe, William (d. 1743) : after Ludgate. insert $\mathrm{He}$ was prebendary of Chiswick in St. Paul's Cathedral 1726-7, and of St. Pancras 1727 till death.

239 ii 37 Crowe, William (1745-1829): for LL.D. read D.C.L.

246 ii l.l. Croxall, Samuel: for his obtaining a victory over the read his victory at Sheriffmuir.

247 i 1 omit rebels.

252 ii 26 Cruikshank, George : for Coombe) read Combe)

256 ii $\left.\begin{array}{c}25-26 \\ 33\end{array}\right\} \quad$ for Fairleigh read Fairlegh

261 i 13f.e. Cruikshank, William C.: for Leigh Thomas read Honoratus Leigh Thomas [q. v.]

267 i 9 Cubbon, sir Mark : for 1856 read Feb, 1856

10 for 1859 read the following May

270 i 2 Cubitt, William : for 1847-9 read 1847-8

3 for Langborn read Langbourn

274 ii 5 f.e. Cuff, Henry : for Daphne read Daphnis

275 ii 18 Cuit, George, the elder : for of the name of Harrison. read Thomas Harrison (1744-1819) [q. v.].

276 i 38 Culbertson, Robert: for orders in the Secession church read license in the Antiburgher Secession church

282 i 17 Cullen, William : after Hamilton insert reprinted in his 'Discussions,' pp. 238-59

283 ii 6 f.e. Cullum, Sir Thomas: after personally. insert He was alderman of Cordwainer ward 1643-52.

284 i 33 for Basire read James Basire (1730-1802)

287 ii 15 f.e. Culpeper, Sir Thomas, the elder: after iii. 568). insert He was M.P. for Tewkes. bury 1628.

291 i 31, 32 Cumberland, Riohard (1792-1811): for election for Northampton read election for Northamptonshire

35 for Thomas Pownall [q. v.] read John Pownall, brother of Thomas Pownall [q. v.]

296 ii 5 f.e. Cumming, James (1777-1861): after 1803. insert He was proctor in the university in 1818 .

813 i 25 Cunningham, James, 14th Earl of Glencairn : omit chosen

26 for in 1780 read the parliament of $1780-4$

18 f.e. $\quad$ for 1839 read 1787

314 ii 16-17 Cunningham, John William: for governor-general .... his death. read lieu. tenant-governor of St. Christopher's (and St. Kitt's) from 1839 till his death in 1847.

19 for Sir Henry Verney read Sir Harry Verney

315 ii 3-4 Cunningham, Joseph D. for or rather Major Broadfoot . . the army read (16 Jan. 1846)

321 i 25 f.e. Cunningham, William (1805-61): for Berwick read in the county of Berwick

324 ii 19 Cunynghame, sir Arthur A. T.: for in March read 1 April

325 i 9 f.e. Cureton, William: for LL.B. read B.C.L.

8 f.e. $\quad$ for LL.D. read D.C.L.

326 i 4 for Wordsworth read Christopher Wordsworth, afterwards bishop of Lincoln [q. v.]

ii 13 f.e. Curling, Henry: for 91 st regiment read 52 nd foot

329 i 10 f.e. Curll, Edmund : for 1733 read 1735

331 i 24 for Wharton read Grafton

335 i 20 f.e. Curran, John P.: for 1756 read 1776

ii 20 for 1785 read 1788

338 i 1 after outlawry. insert Curran was elected to the Irish House of Commons for Banagher in May 1800 for gross brutality to Hevey read and alleged against Sirr gross brutality
towards Hevey 
Page Col. Line

339 i 1-2

\section{1}

340 i 5

341 ii 1-3

9

11

14

348

350 i 18

19

22

Curran, John P.: for a borough of Lord Camelford's read a borough formerly belonging to Lord Camelford for 146 read 346 for wit read wisdom

Currie, Sir Frederick: for he was the last chairman ... 1857. read he was elected chairman of that company in April 1858.

for six read eight

for elected by the expiring company. read nominated by the crown. for his death read 1860

\section{Curtis, Sir Roger : for 1803 read 1804}

Curtis, sir William: for president read colonel after company insert from 1806 to 1817 and president from 1795 till death after 1802 insert He was president of Christ's Hospital from 1813 till death

Cusack, Sir Thomas : for He became lord chancellor .... for his read He was master of the rolls in Ireland from 1542 till 1550 , and acted as lord chancellor in 1551. Next year he received the patent for the latter office. Hugh Curwen [q. v.] succeeded him in 1553. For his

for He was made .... applied read He applied in the course of the negotiations

\section{2-43 Cuthbert, Saint: for Croquet read Coquet}

$$
23 \text { for formally read formerly }
$$

36 Cutler, Sir John : after their relief. insert He was M.P. for Bodmin from 1689 till his death.

Cutts, John, Baron Cutts: for from 1689 ... one occasion read from 1693 to 1701 , and on his first election

after are few insert Cf. 'Military and other Poems . . . .' anon. 1716 (four

relate to Cutts)
Dacre, Leonard : after lord Dacre. insert He was M.P. for Cumberland in 1558, 1559 , and 1562 .

Dacres, Sir Richard J. : for 1867 read 1868

for Field-marshal Sir Charles Yorke read Sir Fenwick Williams

Dacres, Sir Sidney C.: after 1872. insert He was promoted full admiral in 1870.

Daffy, Thomas : for 1760 read 1680

9 D'Aguilar, Sir George C.: for 1821 read 1823

10f.e. for 1849 read 1848

8 f.e. $\quad$ for lieutenant-colonel read lieutenant-general

7 f.e. $\quad$ after K.C.B. insert in 1852

ii f.e. Dalbiac, Sir James C.: for 1848 read 1847

29 for president read prosecutor

30-31 for the British rioters in 1831 read the military officers (Colonel Brereton and Captain Warrington) who were at Bristol during the riots of 1831

43

386 ii 8 f.e.

387 i 11 for 1848 read 1847

Dale, Thomas (1797-1870): for 1840 read 1837

for bookseller read publisher, East India agent

Dale, Valentine : for 1574-5, read 1573-4,

Dalgarno, George : for James Bulwer read John Bulwer [q. v.] after 1835 insert (reprinted in his 'Discussions,' pp. 174 seq.)

Dallas, Robert C.: omit ' Ode to the Duke of Wellington, and other Poems,' 1819

Dallaway, James : after Chichester insert which he resigned in 1826

Dalrymple, Sir David (d. 1721): for Roehead read Rochead for 1721 read 3 Dec. 1721 (Hist. Reg. 1721 p. 44)

$\begin{array}{ccc} & \text { ii } & 17 \\ 405 & \text { ii } & 18 \\ 408 & \text { i } & 19 \\ & \text { ii } & 39\end{array}$

Dalrymple, sir David, Lord Hailes : for nineteen read twelve for Thomas Dalrymple read Alexander Dalrymple

Dalrymple, Sir Hew W.: for Sir John read Sir James after 1818 insert ( $\mathrm{He}$ had been colonel of the 81st foot $1797-8$, of the $97 \mathrm{th}$ foot 1798-1810, and of the 19th foot 1810-1)

$10-9$

f.e. for for many years . . . . borough. read M.P. Weymouth 1817-8, Appleby

8 f.e. 1819-26, Haddington Burghs 1826-30, 1831-2, and Brighton 1837-41. for daughter read sister 
Page Col. Line

421 i 17 Dalrymple, John, 2nd Earl of 8tair: for 1792 read 1692

. ii 14 f.e.

422 i 18

26 for Louis XV read Louis XIV

ii $\mathbf{3 9 - 4 1}$ after more insert 1714

for in regular attendance .... of which read He regularly attended the House of Lords (1707-8 and 1715-34) while

425 i 15 f.e. Dalrymple, John, 6th Earl of Stair : after Berlin insert retiring in 1788

13 f.e. $\quad$ omit several times chosen

12 f.e. after peer insert 1793-1807 and 1820 till his death

ii 12 f.e. Dalrymple, Sir John H. M., 8th Earl of Stair : after Wellington insert He was colonel of the 92nd foot 1831-43 and of the 46th foot 1843 till death

427 ii 20 Dalton, John (1709-1763): omit [q. v.]

428 i 32 Dalton, John (1726-1811): for and grandson read He was great-great-grandson

ii 23-6 omit by whom he had . . . . 4th dragoons

29 after 1811 insert Of his three sons (1) Thomas, captain 11th dragoons, succeeded in 1807 to the Norcliffe estates, and took the name of Norcliffe; (2) John, colonel 4th light dragoons, inherited the Wray estates; and (3) James, rector of Croft, Yorkshire, was an eminent botanist, whose collections are now in the York Museum. Dalton also had three daughters.

33 for accuses read disputes the account given by

36-8 omit of not having done justice . . . . in which he took part

435 i 6 D'Alton, John (1792-1867): for Archbishop read Archbishops

488 i 7 f.e. Daly, Denis : for 1768 read 1767

5 f.e. $\quad$ for county read borough

4f.e. after Galway insert and at the general election of 1768 was returned for the county

442 ii 27 Dalyell, Robert, 2nd Earl of Carnwath : for 1644 read 1645

449 i 15 Dalzell, Robert: for who married Dalzell's sister read whose daughter Dalzell married

after foot insert (the 41st)

for lieutenant-general read major-general

for General Wade read General Hawley

for became general in $\mathbf{1 7 4 5}$ read became lieutenant-general in 1735 and general in $\mathbf{1 7 4 5}$

12 f.e. before Gibson Dalzell insert his son

11 f.e. for Tidcombe read Tidmarsh

8 f.e. $\quad$ omit the late

$3-1$

f.e.

omit and whose daughter... this branch of the family 


\title{
DictionaRY OF NATIONAL BIOGRAPHY
}

\author{
ERRATA IN VOLUME XIV \\ DAMON-D'EYNCOURT
}

Page Col. Line

$\mathrm{v}$ ii 10

20

$1 \quad$ ii 19

21

10 i 24

11 ii 33

13 ii 12 f.e.

14 i 19

30 i 21

38

ii 4 f.e.

i $\quad 39$

33 ii 10

36 ii 3 f.e.

40 ii

43-45

14 f.e.

43 ii 15

48 i 12-13

17

ii 8

53 ii 20

28-33

57 i 22

6-5

f.e.

3 f.e.

61 i 7

8

65 i 18

27

31

List of Writers : insert G. J. G. . . . G. J. GRAY

for R. M. J. J. read R. J. J.

Dampier, Thomas : for Sherborne read Sherburn

after favour. insert $\mathrm{He}$ was prebendary of Durham from 1778 to 1808.

Dance, Charles : for Charles read George

Dance, alias Love, James : for son read brother

Dancer, Thomas : for 1810 read 1811

Daniel, Samuel : for Edmundes's read Edmondes's for Hayward read Hayman

for MS. 3942 read MS. 3943

for 241489 read 24489

Daniell, John F.: after 1842. insert He was foreign secretary of the Royal Society from 1839 till 1845.

Danvers, Sir Charles : after p. 119). insert He was elected M.P. for Cirencester in 1586.

Danvers, Sir John : after Danvers insert sat in the House of Commons as M.P. for Arundel in 1610, for Montgomery in 1614, for the university of Oxford in 1621, and for Newport (I. of W.) in 1624. He was re-elected for Oxford University in 1625, 1626, and 1628 omit and about 1640 ... a political career after parliament insert for a fifth time

Darby, George : after Great Britain. insert $\mathrm{He}$ was M.P. for Plymouth from 1780 to 1784, and an elder brother of Trinity House from 1781 till his death.

D'Arcy, Robert, 4th Earl of Holderness: for one of the principal secretaries of state read secretary of state for the south for and took charge of read but was transferred to for earl of Leeds read duke of Leeds

Darcy, Thomas, Lord Darcy : after was insert Dowsabella, daughter and heiress of Sir Richard Tempest of Ribblesdale. His second wife was omit $\mathrm{He}$ afterwards married . . . x xiii. $127 \mathrm{~b}$ ).

Darling, Sir Charles H. : for 1865 read 1862

for the only daughter read in 1851 Elizabeth Isabella Caroline, only daughter

for survived him read died on 10 Dec. 1900

Darling, Sir Ralph : after 90th insert (1823-37) and after 41st insert (1837-48) after 69 th foot insert (1848 till death)

Darnell, sir Thomas : for 15 Nov, read 22 Nov. for Heveringham read Heveningham for 22 Nov. read 28 Nov.

66 ii 16 f.e. Darracott, Risdon : for Darratt read Darracott 
Page Col. Line

69 ii 19

25

26

27-38

Dartiquenave, Charles : after wy insert from 1706 to 1726 after king's gardens insert giw.ted June 1726, for succeeded read expected to ,ceed for This succession was apparen. disputed ..... into a public road. He read But the latter office was iferred (15 May) on Richard Arundel, M.P. for Knaresborough, who hela po post till his appointment as master of the Mint in 1737, when Thomas nley [q. v.] became surveyor of roads. Dartiquenave lived

84 ii 3 Darwin, Charles Robert: for 1875 read 1864

90 i 13 f.e. Daubeney, Giles, Lord Daubeney : after Bridgrater. insert He was M.P. for Somerset in the parliament of 1477-8.

8

l.l. 14 f.e.

$$
9
$$

l.l.

\section{2 f.e.} i 28 35

ii 10 f.e. 29 13 5

Daubeny, Charles : for Ferrick read Terrick

$$
\text { for Antiquakeristica read Antiquakeriana }
$$

Daunt, Achilles : after him insert in 1875

Davenant, Charles : for (1683-9) read (1678-89)

Davenant, John : for in 1641 read on 20 April 1641

Davenant, William (d. 1681): for La Motte read La Mothe

Davenport, Sir Humphrey : after 1618 'insert He seems to hav been elected M.P. for Brackley on 16 Oct. 1588.

for Elliot read Eliot

Davenport, Richard A. : for June read Jan.

David I : for Cutton Moor read Cowton Moor for L'Esper read L'Espec for Newbury read Newburgh

David, Edward : for R. M. J. J. read R. J. J.

Davidson, Thomas (1838-1870): for Onnam Row read Oxnam Row

Davidson, Thomas (1817-1885): after death insert (16 Dec. 1885)

Davidson, William: for Keates read Keats

Davies, Benjamin: for in 1875 read on 19 July 1875

Davies, Catherine: for Madame Mauprat, the second sister read Madame Murat, the third sister for Italy read Naples for a niece of Byron read absurdly described by Miss Davies as a niece of Byron omit in a very interesting manner

Davies, Cecilia : for Lyson read Lysons

16 Davies, Christian : for 1842 read 1742

39 Davies, James : after Herefordshire insert in 1858

46-48 Davies, Sir John : omit and in the same year . . . . iii. 173)

ii 8-9 for Newcastle-under-Lyne read Newcastle-under-Lyme

i 11 f.e. Davies, John (1627 ?-1693): for on the title-page read in the dedication

ii 47 for 1634 read 1654

50-51 for ' Hierocles, or read ' Hierocles on

i 28 Davies, Jonathan: after Windsor insert (gazetted April 1782)

ii 33 Davies, Robert (1769?-1835): for Nantglas read Nantglyn

i , 15 Davies, Sir Thomas : for 1679) read 1680)

31 after knighted. insert He was alderman of Farringdon Without from 1667 till death.

16 f.e. for a wit read Littleton

10 f.e. for 1679 read March 1679-80

ii 37-38 Davis, J. P.: for J. P. read JонN PhiLip and for (d. 1862) read (1784-1862)

8 for in September read on 28 Sept.

43 Davis, Richard B.: for in March read on 13 March

ii 18 f.e. Davis, William (1627-1690): for Sudbury read Sodbury

ii 27 Davison, Alexander : after in arrear. insert In the 'All the Talents' administration of 1806-7 Davison served as treasurer of the ordnance.

ii 31 Davison, James W. : after Maria Duncan insert [See Davison, Maria Rebecca]

ii 11 f.e. Davison, John: for grammar school read cathedral school

l.l.

for For a few years read From 1824 till death

for in 1826 read on 19 Dec. 1825 
Page Col. Line

178 i $5-6$

8

Davison, John : for in 1834 read on 6 May 1834

after Cathedral. insert On 20 July 1819 he married Mary, daughter of Robert Thorp, elder brother of Charles Thorp [q. v.]; by her he left four sons and six daughters.

180 i 5 f.e.

Davison, William (1541 ?-1608) : after attendance on her. insert He was elected M.P. for Knaresborough in the same year.

184

196

i 19 f.e.

Davy, Charles : for Suffolcienses read Suffolcenses

ii 12-13 Davy, Martin: omit notwithstanding the latter's whig principles

15

17

18

43

211 ii $22-20$

f.e.

7 f.e.

3 f.e.

214

ii 10 f.e.

216

i 22

30

ii $\quad 31$

38

219

ii 38

13 f.e.

220

223

227

228 ii 12 f.e. Dawson, Robert K. : after the civil division insert in Feb. 1836

$$
\text { i } \quad l . l \text {. }
$$

for the whig ministry read the tory ministry

omit a gross political job

after Chichester insert in 1832

for Beechy read Beechey

Dawes, Lancelot : for Shortly after this ... prebendaryship read In 1619 he was preferred to a prebendal stall

for the rebellion read the civil war

for February 1653-4 read (according to Le Neve) 18 May 1655

Dawes, Sophia, Baronne de Feuchères: for Louis XIII read Louis XVIII

Dawes, Sir William : for 1696 read 1697

after regular course. insert $\mathrm{He}$ was vice-chancellor of Cambridge University in 1698.

for 1713 read 1713-4

for in 1724 read on 30 April 1724

Dawson, Abraham: after Thomas insert [q. v.]

for Paul read Paull

Dawson, Benjamin : for nephew read brother

Dawson, Henry : for Water Street read Waterhouse Lane

Dawson, John : for Thomas read Joseph

4 f.e. $\quad$ for Cheetham read Chetham

11 f.e. $\quad$ for 1 April read 28 March

6-4 Dawson, Thomas: for a dissenter .... began life as read and brother of Abraham

f.e. Dawson [q. v.] He entered Kendal Academy in 1746 and Glasgow College in 1749 , and graduated M.D. there on 8 June 1753. In March 1754 he became

l.l.

299 i $1-2$

231 ii 19

$23 j$ ii $9-11$

$243 \quad$ i 22

$244 \quad$ i 2

245 i 34

ii $\mathbf{2}$

9

247 ii 18

251 i $34-38$

for gow University what had been granted for his education.

Day, George : after orator insert (1528) after 1537 insert holding the office of vice-cliancellor during the same year

Day, John ( $f$. 1606) : for but there is no record .... left the university. read He was admitted there 24 Oct. 1592, and was expelled for stealing a book from the library, 4 May 1593.

Day, William (1529-1596) : after iii. 135). insert On 29 Aug. 1569 he was presented by the queen to the rectory of Lavenham, Suffolk.

after 39, 50. insert $\mathrm{He}$ also wrote a 'Narratio de Festivitate D. Georgii in reginali Palatio Westmonasteriensi,' etc., extant in Harl. MS. 304, f. 144.

Dayes, Edward : for Abbey read Hall for Bradley read Brayley

Dayrolles, Solomon : after Dayrolles insert or Dayrolle

Deacon, Thomas: for now known read known till 1886

Deane, Sir Anthony: for and comptroller of the victualling .... printed or manuscript. read He was commissioner of the navy from 1672 to 1675 , comptroller of the victualling in November 1675, comptroller of the storekeeper's accounts March-June 1680, and commissioner of the navy for general business 1686-8. According to Le Neve's Pedigrees of Knights (p. 127) he was knighted in Feb. 1660-1.

259 ii 45 Deane, 8 ir Thomas : for Sept. read Oct.

264 ii 35 De Brie, Dick T. : for Dick read DiRk

14 f.e. for Lamb read Lant

265 i 11 De Caux, Salamon: for 1630 read 1626

ii $40 \quad$ for in 1630 read on 6 June 1626 
Page Col. Line

266 i 30 Decker, Sir Matthew : after East India Company insert from 1713 to 1743, being deputy governor 1720-1 and 1729-30, and governor 1725-6 and 1730-3

31 after parliament insert as a tory from 1719 to 1722

ii 48-49 for ' a gentleman named Richardson' read William Richardson

9 f.e. for one writer read Joseph Massie

268 ii 29 De Critz, John : for Sir Francis Meres read Francis Meres [q. v.]

270 ii 21 Dee, Duncan : for was chosen read was a common pleader of the city of London 1682-90, a judge of the Sheriff's court 1690-1700, and was

for in 1700. read from 1700 till death. He was also commissioner of appeals in the excise 1713-4.

280 ii 28 Deering, John P.: after before mentioned. insert He was elected A.R.A. in 1826. 35-36 for After the passing of the Reform Bill he became M.P. read From 1847 till his death he was conservative M.P.

283 i 12 f.e. Defoe, Daniel : for 1602-3 read 1702-3

284 ii 12 for St. Edmund's Bury read Bury St. Edmund's

285 ii $\quad 39 \quad$ for increased read injured

287 i 16 after Secret insert History

293 i 10-9 De Gex, Sir John P.: for Mr. Macnaghten .... appeal in ordinary) read Steuart

f.e. Macnaghten (already co-author of 'Macnaghten and Gordon's Reports ')

294 i 7 Degge, Sir Simon: for 1669 read 1669-70

299 ii 17 f.e. Dekker, Thomas : for (verse) read (prose)

303 ii 22-24 De Lancey, Oliver (1749-1822): for by Susannah, daughter of General Sir William Draper, K.B. read (whose daughter Susannah married General Sir William Draper, K.B.)

304 i $31 \quad$ after 18 Nov. insert 1790

33 for 1792 read 1794

ii 13 f.e. De Lancey, Oliver (1803-1837): for Henry read Howe

305 i 19 f.e. De Lancey, Sir William H. : for 4 Feb. 1813 read 4 April 1815

18 f.e. for John read James

17 f.e. $\quad$ for Douglas read Dunglass

308 ii 15 f.e. Delany, Mary : for 1742 read 1744

9 f.e. for Bucklands read Buckland

309 i 18 for in 1724 read on 8 March 1725

310 i 12 f.e. Delany, Patrick : for 1758 read 1718

ii 14 for 1739 read 1729

313 ii 18 De La Rue, Thomas : for in 1866 read on 7 June 1866

314 i 11 Delaune, Gideon : for London in 1630. read Dowgate Ward 17 Jan. 1625-6, and was discharged as an alien a week later.

ii 8 f.e. Delanne, Paul : after island insert in 1655

315 i 41-43 Delanne, Thomas : for but on finding .... refused to interfere. read Calamy sent no reply to Delaune's appeal, but tried hard to get him off (see Calamy, BenJaMin).

316 i 13 f.e. Delaune, William (1659-1728): for Amherst read Amhurst

ii 22 Delaval, Edward H. : after now extinct. insert On Lord Delaval's death in 1808 he succeeded to his entailed estates at Seaton-Delaval and Doddington.

317 i 16 for his brother's house. read his house, Parliament Place, Westminster, and was buried in the nave of Westminster Abbey. There are several portraits of him at Doddington Hall.

ii 15-14 Delavall, Sir Ralph : for continued a member of the board of read was appointed a f.e. lord of the

14 f.e. $\quad$ for till May 1694 read in 1693, serving till May 1694

8 f.e. $\quad$ after parliament insert as a tory

319 i 20 Delepierre, Joseph 0.:.for 78 read 77

331 i 30 Demainbray, Stephen C. T. : after royal chaplains insert from 1802 till his death, fifty-two years later

334 ii 15 f.e. Dempster, George: for 1762 read 1761

11 f.e. for twenty-eight read twenty-nine

343 i 17 f.e. Denham, Sir James Stewart (1712-1780): for Stewart read Steuart and so through the article.

344 i 20 for Westshield read Westshields 
Page Col. Line

344 i 9 f.e. 7 f.e.

ii $\quad 31$

32

345 i 41

46

347 ii 20

349 ii 24

350 i 33

351 i 4

26

31

352 i 21

33

354 ii 40

355 i 5

360 ii 34

361 i 4-3

f.e.

365 ii 23 f.e.

22 f.e.

366 i 1

ii 16

28-29

35

372 i 34

ii 13

22

14 f.e.

26

27

35-36

40-41

ii $\quad 29$

16 f.e.

386 ii 5 f.e.

392 ii 10

395 ii 16

406 ii 32

408 ii 17

410 i 21

$417 \quad$ ii $\quad 37$

425 ii 15

17

426 i 16

429 i 4 f.e.

431 ii 28

443 ii 21

De nham, Sir James Stewart (1744-1839) : for Stewart read Steuart

for Stewart Debenham read Steuart Denham

for Goodtrees read Westshields

for 1781 read 1784

for 1813 read 1815

for He was never married read He married Alicia, daughter of William Blacker of Carrick, co. Armagh. He had no issue.

Denham, Sir John : after the Bath. insert He was M.P. for Old Sarum from 1661 till his death. for 1678 read 1669

Denis, Sir Peter : for Heydon read Hedon for in 1750 Miss Pappet read on 2 Sept. 1750 Miss Pappet, natural daughter of John James Heidegger [q. v.]

Denison, Albert, 1st Baron Londesborough : for 1826 read 1828 after parliament insert as a whig

Denison, Edward (1801-1854): for Estwicke read Estwick after Salisbury. insert He was prebendary of Southwell (1834-7).

Denison, John E., Viscount Ossington : after D.C.L. insert He was president of the Royal Agricultural Society in 1857.

Denison, William J. : for He sat read As a whig he sat

Denman, Thomas, 1st Lord Denman : for Knowles's read Knowlys's for he found he could not.... Nottingham read he contested Leinster unsuccessfully

Denne, Henry : for was presented to the living read became curate (not vicar) for Pyrton read Pirton

for Conversion read Conversation

for public read several

for not printed till 1796 read (April) 1645 reprinted in 1796, and 1854 (see 'Records of Fenstanton' in Hanserd Knollys Soc., 1850) for Antiquakeristica read Bibliotheca Antiquakeriana

Dennis, John : for Thomasin read Thomson

Dennis, Sir Thomas : for 1560 ?) read 1561)

for While sheriff read He was M.P. for Devonshire in 1529 and 1533. While sheriff of the county

after his death insert on 18 Feb. 1560-1

Denny, Sir William : for ( $f$. 1653), who read (d.1676), author, son of William Denny, recorder of Norwich, who died in 1642 (MS. Addit. 19126, ff. 292, 299 ). $\mathrm{He}$ for 'Peleconicidium read' Pelecanicidium

for 1653 read 1651

omit There was a recorder . . . . in Charles I's reign

for apparently before the Restoration read in June 1676

Denton, John : for 1708) read 1709)

for 1708 read 1708-9

De Quincey, Thomas : for Cotton read Landon

Derham, William: for Stoughton read Stoulton

Dering, Sir Edward : for was chosen read had sat in the House of Commons as M.P. for Hythe in 1625, and was now

Des Granges, David : for Modresfield read Madresfield

Despard, Edward M. : for James read John

Despard, John : after 1805 insert was colonel of the 8th garrison battalion Aug.Dec. 1809

Despenser, Thomas le, Earl of Gloucester: for Duke of Kent read Earl of Kent

Devereux, Robert, 2nd Earl of Essex : for (1567 read (1566

for 10 Nov. 1567 read 19 Nov. 1566 (Sloane MS. 1697, f. 54 b)

for Llanfey read Lamphey (or Llanffydd)

for Ark Royal read Due Repulse

for published read circulated

Devereux, Walter, 1st Earl of Essex : after Essex add and second ViscounT HEREFORD 
Page Col. Line

443 ii 4 f.e. $\mathbf{3 4 6}$ i 34 Devereux, Walter, 1st Earl of Essex : for Llanfey read Lamphey (or Llanffydd)

ii 16 f.e. $\quad$ for said to be read erroneously said to be

14 f.e. for and read was

13 f.e. after antiquary insert and was copied by Cole; Cole's copy

448 ii 14 f.e. Devisme, Louis: for He was afterwards read He was concurrently

13 f.e. $\quad$ after Ratisbon insert (1769-73)

12 f.e. after finally insert in 1773

455 ii 24 D'Eyncourt, Charles T. : for retiring in 1852 read being defeated at the poll in 1852 , and retiring 


\title{
DictionaRY OF NATIONAL BIOGRAPHY
}

\author{
ERRATA IN VOLUME XV
}

\author{
DIAMOND—DRAKE
}

Page Col. Line

2 i 22-24 Dibdin, Charles : for It is most improbable that.... eighteenth child read Charles was probably the twelfth child (of fourteen)

29-31 for won notice at Winchester College.... the concert-rooms read won him the position of chorister at Winchester Cathedral under Fussell, the organist, and soon the Winchester concert-rooms

for 1762 ... next season, 1763 , read 1764 , and twice repeated it next season.

for the former year read 1762

for next season read on 31 Jan. 1765

13-14

16

for 'Love in a Village' read 'The Maid of the Mill'

37

for set the fashion of wearing read his triumph led to the wearing of for altered speedily to read which was given in 1770 the sub-title of for $\mathrm{He}$ had read According to current report he had

40

44-45

14-9

f.e.

for All his children . . . . young. She read with the result that she

for a so-called Mrs. Davenet . . . . was born read Harriet Pitt, a dancer at

Covent Garden, who played small parts Her children by Dibdin included

Charles I. M. Dibdin, born

8 f.e.

7 f.e.

for Thomas read Thomas Dibdin and omit took

for his father's name about 1799. read Dibdin deserted Harriet Pitt about 1774, and she then returned to the stage under the name of Mrs. Davenet.

2 f.e. $\quad$ for Princess Matilda read Princess Louisa Ann

l.l. $\quad$ for In 1768 read On 30 Oct. 1768

19 f.e.

8 f.e.

7-6

f.e.

3 f.e.

for the Haymarket read Drury Lane Theatre

for 1771 read 1772

after two interludes insert 'The Palace of Mirth' and 'The Brickdust man'

for performed in the summer of 1772. read among many other pieces in $\mathbf{1 7 7 2}$.

after knights insert were produced at Drury Lane, the former on 26 Oct. 1772 and the latter 26 Dec. 1771

for Anne Wild or Wyld read Anne Maria Wylde

for the earliest read an early example

for on 3 Jan. 1779 'The Touchstone'. read later in the same year 'The Touchstone,' a speaking pantomime.

28-29 for Dibdin now commenced giving musical entertainments at the Royal Circus read Dibdin established the Royal Circus

80 after Surrey Theatre insert where musical entertainments, many of his own composition, were long given

36-38 for 'The Benevolent Tar'. . . in 1782 read 'The Cestus,' 'Tom Thumb, and 'The Benevolent 'Tar' were brought out respectively in 1783, 1784, and 1785 
Page Col. Line

4 i 40

20-19

f.e.

12-11

f.e.

ii 22

24

26

14 f.e.

5 f.e.

5 i 16 f.e. 14 f.e.

ii 15

22-23

24

6 i 4

14

15

4

7 ii $l . l$.

8 i 9 f.e.

17 ii 19

30 ii

35

36 ii 26

40 ii 1

2

3

9

13

46

52 ii 1

5

$\begin{array}{ccc}56 & \text { i } & 7 \\ 59 & \text { ii } & 10 \text { f.e }\end{array}$

61 ii $\mathbf{3 6}$

65 i 5

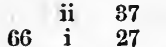

65 ii 7 f.e.

67 ii 1

12

68

i $\quad 9$

$$
20 .
$$

74 i 4 f.e.

75 i 21

76 i 13

Dibdin, Charles: for 1784 read 1785

for by a Dublin misadventure read by failure of a Dublin manager to pay him for musical work done

for before he started in 1787 read on 21 May 1787, after he started

for 1788-9 read 1789-90

for 'The Quizzes' read 'The Quizes'

for 1791 read 1791-2

before and insert 1796 and for Sphynx' read Sphinx'

for 'The Frisk' read 'A Frisk'

for Anne read Anne, born in 1787

after children insert of the union with Anne Maria Wylde

for 1792 read 1796

for in the same year read 1788

for 1795 read 1800

for nearly seventy read far more than seventy

omit was painted by Devis

for It read was painted by Devis, by Thomas Phillips, R.A. (now in the

National Portrait Gallery), by Thomas Kearsley (at Southampton), by

S. Drummond, R.A., by Dighton, and by De Wilde. The earliest portrait of

Dibdin is in a picture of the first scene of 'The Maid of the Mill' by J. I.

Richards, R.A. (1765); Dibdin figures in the part of Ralph Devis's portrait

Dibdin, Henry E. : for 1857 read 1852

Dibdin, Thomas F.: after 1824 insert besides a royal chaplaincy (first to William IV and then to Queen Victoria) from 1831 till death for 'Biographical read'Bibliographical

Dick, Sir Robert H. : after division insert (He was appointed colonel of 73rd foot in 1845)

Dickens, Charles : for Bass read Buss

Dickinson, James: for sixty-five read sixty-three for Rutly's read Rutty's

Dickinson, William : for Muskam read Muskham

Dickson, Sir Alezander : for Macleod's death in 1833 read William Millar's death in 1838

for and combined the offices read in the office

for and read with which he combined that of after K.C.B. insert in 1825 and after.K.C.H. insert in 1817

for aide-de-camp to the queen read royal aide-de-camp (1825-1837)-first to George IV and ultimately to Queen Victoria

Dickson, William G. : for 21 read 19

Digby, Sir Everard: for elder read younger

for younger read elder

Digby, John, 1st Earl of Bristol : for 1654) read 1653)

for 1653-4 read 1652-3

Digby, Sir Kenelm: for galeazzores read galeazzoes

for the only one read the earliest one

for Higham read Highmore

for Hartmann read Hartman

Digby, Robert : for 1815) read 1814)

after 1759 insert $\mathrm{He}$ was M.P. for Wells (1757-61) and colonel of marines (1755-9) for 1815 read 1814

Digges, Sir Dudley : after Company. insert He was M.P. for Tewkesbury in 1610 and 1614.

Digges, Dudley : for 1734 read 1634 for 1674 read 1574

Dighton, Denis : for St. Servant read St. Servan, in Brittany

Dignum, Charles: for 1872) read 1827)

Dilke, Ashton W.: after his seat insert at the beginning of the session of 1888 


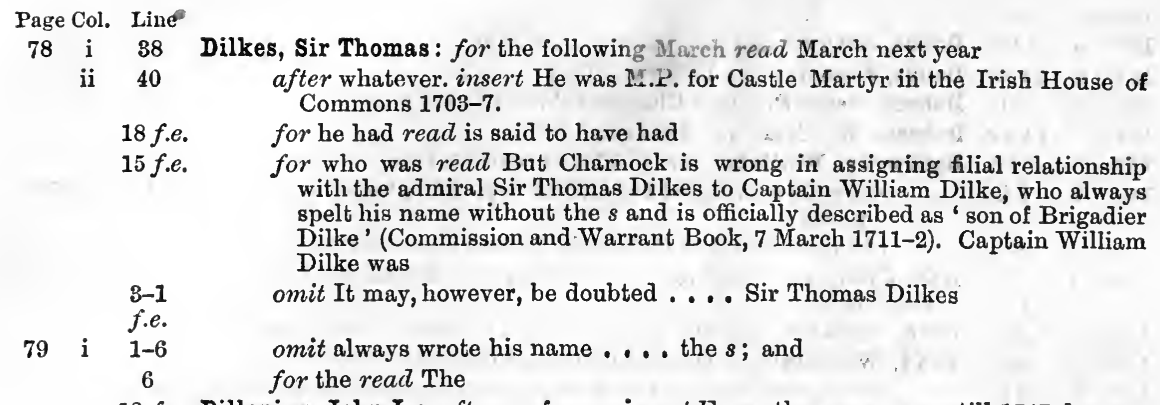

12 f.e. Dillenius, John J.: after professor. insert From the same year till 1747 he was foreign secretary to the Royal Society.
Dillon, Sir James : before He was one insert He was M.P. for co. Westmeath from 1639 till his expulsion in 1642 owing to his share in the rebellion.
Dillon, Sir John T. : for in 1776 read in 1771 as member for Wicklow, and in 1776 for the seat read the latter seat

Dillon, Thomas, 4th Viscount Dillon: for Taffe read Taaffe

Dillon, Sir William H. : for sixty read twenty and for two read one before men insert and sixty

\section{Dimsdale, Thomas : for member read tory member} for Essex read Hertfordshire

Dirom, Alexander : after (Scots Mag. lv. 412). insert He became major-general in 1809 and lieutenant-general in 1813.

100 ii 23 Disney, John : after contested insert as a liberal

101 i 2 f.e. Disney, William: for in 1807 read 28 March 1807

ii 12 Disraeli, Benjamin, Earl of Beaconsfield : for 6 John Street read 6 King's Road (now 22 Theobald's Road)

5 f.e. $\quad$ for in 1834 read in January 1835

108 i $8-10$ for Disraeli did not appear . . . in due time read Disraeli pleaded guilty and after ment insert in the court of Queen's Bench 22 Oct. 1838 before Sir John Campbell insert the attorney-general

for and the future prime minister.... a fine of one shilling. read The attorney-general withdrew his prayer for judgment, and Lord Denman declared that the court, being satisfied with the apology, considered the business to be at an end.

for Wetherall read Wetherell

120 i 12 f.e. Diss, Walter: after for some time insert-before 26 April 1381 (see Cal. Pat. after of a century. insert He had been elected M.P. for Buckinghamshire in 1847.

for November read December

for forty-five read over fifty

for May read July

D'Israeli, Isaac: after architect. insert The newly married couple settled for fifteen years at 6 King's Road, Bedford Row (now 22 Theobald's Road). for 1848 read 1847

122 ii 10 f.e. Dixie, Sir Wolstan: for 1573 read $1573-4$

124 ii 15 f.e. Dixon, James: for in 1871 read 28 Dec. 1871

127 ii 35 Dixon, William H.: for Mapleton read Mappleton

37-38 for was canon of Ripon .... decease read became

39 after ton insert in 1825 and after York insert in 1831, canon of Ripon in 1836 ,

1306 f.e. Dixwell, John : after p. 349). insert He was again M.P. for Dover in the parliament of 1659 .

8 for KeNNET read KeNNetT 
Page Col. Line

130 ii 5 f.e. Dobbs, Arthnr: for 1727-60 read 1727-30

132 ii 15 f.e. Dobbs, Francis : for 1799 read 1797

135 i 10 Dobree, Peter P.: for 'Choephori 'read 'Choephorœ'

138 i 14 f.e. Dobson, William : for 1862 read 1866

139 ii 2 f.e. Dockwray, William: for (d. 1702?) read (d.1716)

140 i l.l.

ii 6

145 i $7-6$

f.e.

151 ii 39

155 ii 32

156 i 11

157 ii 6

165 ii 19

166 ii 21

14 f.e.

17 f.e.

13 f.e.

j.e.

206 i 7 f.e. Don, Sir William H. : for Anderby read Ainderby

207 i 27 $\mathbf{3 1}$

8 f.e.

6 f.e.

211 ii 6 after old
p. 544). add to authorities Delaune's Present State of London, 1681 Bownde [q. v.]

Dodd, William: for Garlick Hill, read Garlickhythe, 1588.

Dodds, James: for in 1885 read 3 Sept. 1885 Carlisle from 1689 to 1693

after 1721, insert resigning the office in 1744, for 1842 read 1742

Dodsley, Robert : for 25 Dec. read 23 Sept. omit and dean .... February 1852 the post of dean of the Arches Court till his death after 1857 insert and created Lord Monk Bretton in 1884

Dodsworth, William : after became insert in 1829

Dodwell, Henry (1641-1711): after the effects of it insert on 7 June

Dodwell, William : after Cathedral insert in 1748 after Berks insert in 1768 for Newport, Cornwall, for 1714 read 1713 for in 1722 read 22 Oct. 1722 for April read October

Domett, Sir William : for in 1828 read 19 May 1828

Dominis, Marco A. de : for (1617) read (May 1618) for an old man read fifty-eight

Domville, silas : for 1664 read 1663

Don, Sir George : for deputy read assistant for 1803 read 1805 for 1823 read 1816 omit and a G.C.M.G. . . . . in April 1831

\}onald IV: for Bindhe read Buidhe for Fearchan II read Fearchar II for Caersden? read Carriden for Strathcaron read Strathcarron

Donaldson, John W. : after father insert Hay Donaldson

Dod, John: for daughcer of Dr. Nicholas Bound read sister of Dr. Nicholas

Dodd, James 8.: for the principal royal storeship read a ship of sixty-six guns for nephew to Lord Chesterfield. read godson and heir to Lord Chesterfield. Doddridge, Sir John: after Discourses). insert He was M.P. for Barnstaple in

Dodington, George B., Lord Melcombe : after Carlisle insert who was M.P. for

Dodson, Sir John : for He held the posts read From Feb. 1852 he held the post

for both these jurisdictions read this jurisdiction and after 1857 insert and

Doherty, John : after Dublin; insert from July to December 1830 he was M.P.

Dolben, Sir Gilbert: for in almost every parliament . . . . 1707. read from 1689 to 1698 and from 1700 to 1710 , usually voting with the tories.

Dolben, John (1625-1686) : for Sir Edward Nicholson read Sir Edward Nicholas

Dolben, Sir John (1684-1756): for Bishopsthorpe read Bishopthorpe

for death on 1 Jan. 1832. read retirement in April 1831, when he was trans. ferred to the governorship of Scarborough Castle: He died 1 Jan. 1832. He was colonel of the 7th West India Regiment 1799-1805. for Janet McColl . . . . that town. read was Betty, daughter of John Cun. dale of Snab Green, Arkholm, Lancashire.

4 f.e. for Letitia read his first wife, Eleanor 
Page Col. Line

212 ii 26

31

214 i 33

ii 34-85

215

220

221

222

228

24 f.e.

16 f.e.

10 f.e.

233 i 25

235 i 34

ii 18 f.e

238 ii $22-23$

Donaldson, John W.: after overwork. insert By his first wife Donaldson had two sons and two daughters, and by his necond wife, Louisa, daughter of John Rawlins, he had three daughters.

for poetry read philosophy

Donaldson, Sir Stuart A. : after success. insert He was a liberal and vainly con. tested Harwich in 1860 .

Donaldson, Thomas $\mathrm{L}$. : for in 1864 read in 1863-4

Donaldson, Walter : for Lamb read L'Amy

Donkin, Sir Rufane 8.: for afterwards read in 1839

Donn, Benjamin : for He was there on 30 Nov. 1773 .... ten guineas a year. read A successor as librarian was appointed 27 March 1773.

Donne, Sir Daniel : after courts. insert In 1601 he became M.P. for Taunton.
Donne, John : for and when the case of the divorce . . . . never will be. read But there is no ground whatever for the statement that Donne took an active part as an advocate for the nullity of the marriage when the case of the divorce of the Countess of Essex from her husband came on; the legal tractate by 'Dr. Donne' in support of the nullity, which still exists in manuscript (Hist. MSS. Comm. 8th Rep. pt. iii. p. $22 b$ ), was by Sir Daniel Donne [q. v.], the dean of Arches, one of the commissioners for the trial of the divorce case.

for Spanish Marriage, i. 277 read Hist. of England, iii. 300

for installed read elected

for Spanish Marriage, ii. 133 read Hist. of England, iv. 847

for Edward read Edwin

for i. 211 read iii. 161

for Foster read Forster

Donne, William B. : for till his death read till 1874. He died

Donovan, Edward : for 1798 read 1768

Dopping, Anthony : for These letters patent contained an unusual clause, read which directed, in accordance with the practice of the diocese,

Banbury in $\mathbf{1 7 8 0}$ on a double return.)

250 i 22 f.e. Dornford, Joseph : for college read university (1830-1)

15 f.e. $\quad$ for 1844 read 1847

14 f.e. $\quad$ for an honorary canon read prebendary

i 17 f.e. Doubleday, Edward: for $\mathrm{He}$ also wrote read It was his brother Henry Double. day [q. v.] who wrote

258 i 17 f.e. Doughtie, John : for in 1672, read on 25 Dec. 1672,

259 i 36 Douglas, Alexander H., 10th Duke of Hamilton : for 1803 read 1802

281 i 19 f.e. Douglas, Archibald ( $f .1568$ ) : after married insert in 1577

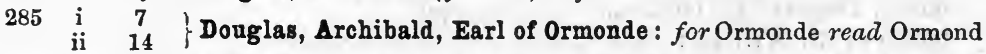

288 ii 21 Donglas, Charles, 3rd Duke of Queensberry: for the second duke read James Douglas, second duke (1662-1711) [q. v.]

300 i 21-22 Douglas, Sir Howard : for In 1823 he was appointed read From 1823 to 1831 he was

$301 \quad$ i $\quad 20$

11

15

322 ii 24

328 ii 22 f.e. Douglas, James, 4 th Duke of Hamilton: for On the conclusion read Before the conclusion

331 ii 35 Douglas, James, 14th Earl of Morton : for Home read Hume

332 i 2-1 f.e. Douglas, Sir James (1703-1787) : for for many years read from 1764 to 1768

334 i 19-18 Douglas, Sir James D.: for was appointed quartermaster-general in Scotland. read $\begin{array}{ll}\text { f.e. } & \text { was deputy quartermaster-general in Scotland from } 1815 \text { to } 1822 \text { and in } \\ \text { Ireland from } 1825 \text { to } 1830 \text {. }\end{array}$ 
Page Col. Line

334 i 16 f.e. Douglas, sir James D.: for 1825 , read 1830 ,

15-14

f.e.

12 f.e.

11 f.e.

10 f.e.

9 f.e.

"for which he held till 1830, when he read In 1837 he

for 1838 , when he read 1842 . $\mathrm{He}$
after lieutenant-general insert in 1838

338 ii 35

for 1846. read 1860. and after colonel insert of 93rd foot in 1840, and for 1836, read 1850 ,

340

i 2 f.e. Douglas, Lady Margaret, Countess of Lennox : for 1557 read 1537

Douglas, Robert, Viscount Belhaven : after Primrose, insert
Donglas, Sylvester, Baron Glenbervie: for and read he had

glas, Sir Neil : omit in which year . . . major-general,
after promoted insert major-general in June 1838,

after promoted insert major-general in June 1838,
Douglas, Robert, Viscount Belhaven : after Primrose, insert the baseless fiction

for but was again read on the formation of 'All the Talents' ministry in the previous February, but was reappointed

18 omit appointed surveyor-general

357 ii 11 Douglas, William, 1st Earl of Douglas : for of Sir William Douglas read to Sir William Douglas

358 i 18-22

23-24

25

17 f.e. onit whose name of the 'Flower of Chivalry' ... . the Hermitage. omit the death of Moray and

for the joint causes read one of the causes

372 ii $8-9$

las, William, 2nd Earl of Angus : for 1436, read 1435,

373 ii 28 Douglas, William, 4th Duke of Queensberry: after. re-elected insert serving

for John read Robert and for 10 Sept. read 30 Sept.

Douglas, William, 1st Marquis of Douglas : after vassals, insert as to their right

Douglas, William, 1st Duke of Queensberry : for the double treasure of Scotland read the treasurership of Scotland until 1790

31 for 1767 March read August 1766 the earl of March

375 i 12 f.e. Douglas, William A. A. A., 11th Duke of Hamilton: for the Duke read the Grand Duke

l.l for 1848 , read 1869 ,

377 ii 10 Dove, Henry : for nonjuror read high churchman

381 i 19 f.e. Dover, Captain Robert : after verses insert (by D'Avenant and printed in modern reprints)

after 1636 ' insert (reprinted by Dr. Thomas Dover, 1700, by Dr. Grosart 1877, and by Mr. Vyvyan 1878)

11 f.e. for Barkfield's read Barksdale's

9 f.e. $\quad$ for no allusion read slight allusion

7 f.e. for about 1644, read under the Commonwealth,

6 f.e. $\quad$ omit a short time only

5 f.e. after Charles II insert and to continue till 1852

382 i 8 f.e. Dover, Thomas : for Guaaquil read Guayaquil

385 i 4 f.e. Dowdeswell, William: for Lyttelton, read George Grenville,

392 i 8-6 Downe, John: for but it is extremely donbtful . . . . be correctly identified. read f.e. but it is certain that in this instance Cole is referring to an incident in the lifo of John Donne, dean of St. Paul's.

393 ii 9 Downes, John : for in 1641-2, read on 20 Dec. 1641,

395 i 29 Downes, William, 1st Baron Downes : after Donegal, insert to which he was elected in 1790,

ii 33 Downham, George : after his time. insert He was made prebendary of Chester 1594, of St. Paul's 1598, and of Wells 1615.

397 ii 32 Downham, William: before he was appointed insert was made archdeacon of Brecknock in 1559;

399 ii l.l. Downing, Sir George (1623 ?-1684) : before Howard, insert He had been elected M.P. for Carlisle in the parliament of 1659 and for Norfolk in the first parliament of Charles II.

400 i 20

401 i $35-36$ for 1565 read 1665

for In February 1682-3 he was removed from his read Despite the rumour to the contrary reported by Luttrell, he seems to have remained until his death in his 
Page Col. Line

401 ii 33

402 i $l . l$.

403 i 4

20-21

39

ii 8

404 i $24-25$

28

31

83-31

409 ii 21

413 i 22

ii $\quad 16$

22

23

14 f.e.

419 i 12 f.e.

440 ii $5-10$

449

Downing, Sir George (1684 ?-1749) : for 1788 read 1688

Downman, Hugh : for Cyrus read Cyres

Downman, John: for (d. 1824), read (1750-1824),

for He was the father of Sir Edwin Downman. read He also left two sons, and was uncle to Sir Thomas Downman [q. v.] for Elizabeth read Charlotte

Downman, Sir Thomas : after lieutenant-general, insert nephew of John Down$\operatorname{man}[\mathrm{q} . \mathrm{v}$.$] ,$

for in which year he was also made a C.B. read being made a C.B. next year

for in 1838, read in Jan. 1837, and lieutenant-general in Nov. 1846,

after 1843, insert was director-general of artillery in 1843-4, omit was promoted .... 1851, and

Doyle, Sir Charles H.: after affair. insert $\mathrm{He}$ was lieutenant-governor of New Brunswick 1866-7.

Doyle, Sir John: after ii. 117). insert He was present at the operations at Quiberon and Isle Dieu in $\mathbf{1 7 9 5}$

after governor. insert He was M.P. for Newport (I. of W.) 1806-7.

for 1812 read 1813

after Charlemont insert in 1818

after 1793 insert He was colonel of the 53rd foot from 1796 till death

D'0yly, George : after 1811. insert He was proctor in 1808.

Drake, Sir Francis: for an anonymous poet .... not sufficient room. read the epitaph suggested by Richard Barnfield (Address prefixed to the Encomion of Lady Pecunia, 1598)-

England his hart, his corps the waters have,

And that which raysd his fame, became his grave.

ii 4 f.e. Drake, Samuel $(d .1673)$ : for prebend read prebendary 


\title{
Dictionary OF NATIONAL BIOGRAPHY
}

\author{
ERRATA IN VOLUME XVI
}

\section{DRANT-EDRIDGE}

Page Col. Line

2 ii 2-1

f.e.

4 ii 3 f.e.

2-1

f.e.

5 ii 6-5

f.e.

10 i 17 f.e.

12 i 19

23 i 33

\section{2 f.e.}

25 i 12-10 f.e.

ii 5

- 8-9

26

$26 \quad$ i 29

30

27

28

31 i 8 f.e.

34 ii 10

$\begin{array}{lll}39 & \text { i } & 7\end{array}$

46 i 8

10-11

$\begin{array}{ccc} & \text { ii } & \mathbf{3 2} \\ \mathbf{5 1} & \text { i } & \mathbf{2 7} \\ & & 28 \\ \mathbf{5 4} & \text { i } & \mathbf{8 1} \\ \mathbf{5 7} & \text { i } & 12 \\ \mathbf{6 3} & \text { ii } & \mathbf{7} \\ \mathbf{7 2} & \text { i } & 16\end{array}$

N.B.-f.e. stands for from end and l.l. for last line

Draper, Edward A. : for the commissioners of inquiry . . . . Colonel Joseph read the fellow commissioners with Picton'for the administration of Trinidad. Colonel William

Draper, Sir William: for 860 read 869

omit under the Rev. Mr. Bryant

for He was appointed lieutenant-governor read In 1761 he had been appointed governor

Drayton, Michael : for unstained read unstayed

for Cathedral read Abbey

Drummond, Annabella : for 1397 read 1367

for Walter, earl of Fife read Robert, earl of Fife

Drummond, George : for His father ..... was educated. read His father, George Drummond, was first master of the Edinburgh Merchants' Hall in 1681.

for 1715 read 1723

for the same year read 1715

after (GrANT, i. 365). insert He was a commissioner of excise for a first time 1725-7.

for the abolition read his surrender

for appointment read reappointment

Drummond, Sir Gordon : for 1824 read 1823

after 1819, insert of the 71st in 1824 and of the 49 th in 1829,

after transferred insert in 1846

for 1837 read 1827

Drummond, James, 1st titular Duke of Perth : for March read May

Drummond, John, 1st Lord Drummond : for 1684 read 1484

Drummond, Robert H. : for earl read viscount

Drummond, William (1585-1649) : for He married about 1614 read About 1614 he fell deeply in bve with

for His wife died within the year. read A marriage was arranged, but before it could take place the lady died, in $\mathbf{1 6 1 5}$.

for he married a second wife, read at length he married. His wife was

Drummond, Sir William: omit two

for ments, those of 1796 and 1801 read ment, 1796-1802

Drury, Sir Dru: for constable read lieutenant

Drury, Joseph : for Charles Kean read Edmund Kean

Drury, William : ( $f$. 1641) for 1621 read 1641

Dryden, John; for Mackay read Marlay 
Page Col. Line

78 i 38

42

84 ii 5

7

Dubois, Edward : for About 1833 read In 1833 for 1846 read 1845

Ducarel, Andrew C.: for Herring read Secker for Terring read Tarring

91 i 18 f.e. Duckett, George : for 1722 read 1722-3

95 ii 37 Duckworth, Sir John T.: after 1810. insert He was colonel of marines 1797 to 1801, and M.P. for Romsey from 1812 till death.

97 ii 20 f.e. Dudley, Ambrose, Earl of Warwick: for fourth son read third son

19 f.e. $\quad$ for 1514 read 1547

99 i 20 f.e. Dudley, Dud : for 1611 read. 1612

ii 13 for In 1619 read On 22 Feb. 1621-2

15 for thirty-one read fourteen

27-28 for an extension of the patent for fourteen years read a special exemption of his patent from the statute of monopolies

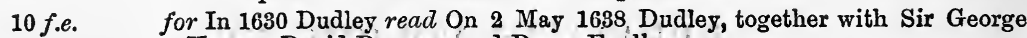
Horsey, David Ramsay; and Roger Foulke

8-4

f.e.

for a new patent 'not only . . . . pit-coal and peat.' read a new patent for twenty-one years ' for the sole making of iron into any sort of cast-works with sea or pit coals, peat, or turf, and with the same to make the said iron into plate works or bars, and likewise to refine all sorts of metals.'

102 i 27 Dudley, Edmund : for Dudley's widow read Edmund Dudley's widow

103 ii 29 Dudley, Sir Henry B. : for 1817 read June 1815

107 i 29

109 ii 32

Dudley, Lady Jane: for 'Zurich Letters' read ' Original Letters.'

Dudley, John, Duke of Northumberland: for Lord Thomas Seymour read Thomas, Lord Seymour

37

111 i 16 f.e.

4 f.e.

3 f.e.

120 i 27

122 i 11

15

after conduct. insert From 1548 to 1550 he was president of Wales. omit Sir

for the fifth son read a younger son

for in $1555 \mathrm{read}$ on 10 Aug. 1557

Dudley, Robert, Earl of Leicester: for tomb read church

Dudley, Sir Robert, styled Duke of Northumberland : for 1573 read 1574 after Effingham. insert He was born at Sheen House, in Surrey, 7 Ang. 1574.

20-21 for in May 1573, two days before his own birth at Sheen, read in the winter of 1573

10-9 omit kept by Owen Robin

f.e.

8 f.e.

2 f.e.

ii $\quad 49$

50

52

123 ii 2

8

l.l.

124 i 13

ii 13

for 1587 read 1588

for in 1589 read on $20 \mathrm{Feb}$. 1589-90

for 1605 read 1603 and after Dudley insert who

omit and

for a month or so later read in July 1605 .

for Carbello Castle read Villa Castello

for Carbello read Villa Castello

after Tyburn insert 17 March 1718

for (1600). read (1600); this was reprinted, with an admirable preface by Mr. G. F. Warner, for the Hakluyt Society, 1899.

after years) ; insert J. Temple-Leader's Life of Sir Robert Dudley, Florence, 1895 ;

3 f.e. Dudley, William : after 1466, insert prebendary of Apthorp (1466) and of Stillington (1470) in York Cathedral,

$l . l$.

after 1473, insert was canon of Windsor 1471,

129 i 41 Duff, James, 2nd Earl of Fife: for Scotch read Irish

ii 4 Duff, Sir James : for He was promoted read He was M.P. for Banffshire 1784-9, was colonel of the 50th foot from 1798 till death, and was promoted

Duffet, Thomas : for Dryden afterwards wrote: read Sir. William Soames in his version of 'Boyleau's Art of Poetry; published in 1683 (reissued as 'revised by Dryden in 1710 '), wrote:

Duffus, Lords : omit this cross reference 
Page Col. Line

134 i 10-12

17

5-4 f.e.

142 ii 20

144 i 18

29

20 f.e.

5 f.e.

ii 7 f.e.

150 i 11

153

167

170

175

176

ii 7

24

28

4 f.e.

178

179

ii 8 f.e.

i 32

ii 12 ,

183

184

185

18 f.e.

14 f.e.

i 16

ii 16

20

$186 \quad i \quad 31$

9 f.e.

ii $\quad 3-4$

8

Dugard, William : for and his peace made with parliament .... upon his death. bed, read In 1694 Dr. Gill and Francis Bernard reported that Henry Hills told them many years before,

after ' Eikonoklastes.' insert (WAGSTAFFE's Vindication of King Charles, 1711 , p. 117). Lauder revived the improbable tale in his 'Charles I Vindi. cated from Plagiarism,' 1754 (pp. 19, 27, 31).

for saved him formerly :... life read previously done him like service

Dugdale, Sir William : after Windsor herald insert Oct. 1676

Duigenan, Patrick : for 1785 read 1790

for 1790 read 1791

after Armagh insert in 1798, and was returned by the same constituency omit the catholic

Duke, Richard : for (1659? read (1658 Dunbar,

f.e. Dunbar, George : for Coddingham read Coldingham

f.e. Duncan, John (1796-1870) : for the Secession read the Anti-burgher Secession

Duncan, Jonathan (1756-1811) : for in 1795 read 12 Nov. 1794

Dunch, Edmund : after 1708 insert He was deprived of the office in 1710

Duncombe, Sir Charles: after before that date. insert He was alderman of Broad Street ward 1683-6.

before Under Charles II insert Duncombe was one of the six clerks in chancery 1682-3. From 1685 to 1687 he was M.P. for Hedon, in Yorkshire. for that constituency read after being M.P. for Yarmouth (I. of W.) 1690-5, Downton

after London insert which he contested unsuccessfully in 1700-1, 1701, and 1702 ,

for five years (1703-8) read less than a year (April 1703 to 29 Feb. 1703-4)

Duncombe, Thomas S. : for 1821 read 1820

for Havre read Ham

Dundas, Charles, Baron Amesbury : for 1774 read 1775

Dundas, Sir David (1735-1820) : for 1797 read 1820

for 1804 read 1803

after York. insert $\mathrm{He}$ was colonel in chief of the rifle brigade, 1809 till death.

Dundas, sir David (1799-1877): for in the following April read on $17 \mathrm{Feb}$. for April read March

Dundas, Francis : for In 1795 read He was A.D.C. to the king from 1793 till he was made major-general in 1795 . In Oct. 1794

191 i 23 f.e. Dundas, Henry, 3rd Viscount Melville: after 1829. insert He was M.P. for for Young read Yonge [q. v.]

for After the 94th . . . . in 1818 read In 1809

for 1787 read 1817

ii 7

Rochester 1826-30 and Winchelsea 1830-1.

after 1860 insert was colonel of the 100th foot 1858-62 and of the 32nd foot 1862-3, and was

16 Dundas, Sir James, 1st Lord Arniston : omit first

192 i 9 f.e. Dundas, Sir James W. D.: after Durham. insert He was clerk of the ordnance 1838-41, and was M.P. for Greenwich 1832-4, for Devizes 1836-8, and for Greenwich again 1841-52.

5 f.e. $\quad$ for in 1846 read from 1846 till 1852

193 ii 8 f.e. Dundas, Robert, 2nd Lord Arniston : omit second

194 i 15 Dundas, Robert, of Arniston (1685-1753): for of ARniston read Lond ARNiston

195 i 1 Dundas, Robert, of Arniston (1713-1787): for of ARNiston read LoRD ARNistoN

ii 24-25 for Sir Ilay Camplell read Alan Wight

27 for 1796 read 1801

$32 \quad$ for 1796 read 1799

4 f.e. Dundas, Robert S., 2nd Viscount Melville: for just of age read twenty-three years old

20 f.e. Dundas, Thomas : after 68th foot insert (appointed May 1794) 
Page Col. Line

197 i 34

17 f.e.

15 f.e.

7 f.e.

200 i 1

2

3

22 f.e.

19 f.e.

Dundas, William : after M.P. for the insert Crail boroughs in 1794; he was

elected for the
for Cullen read Inverary, Elgin, Banff, Cullen, Kintore district of burghs

before On 26 March insert He was a lord of the admiralty from 1812 to 1814 for seven read twenty-six

Dunk, George $\mathbf{Y}$., 2nd Earl of Halifax : for twice resigned (in June read resigned in June omit and again in June 1757), and and both omit occasions and of his resignation was after state insert for the North

for secretaryship continued in read the secretaryship for the South passed into

206 i 13 f.e. Dunlop, James $(d .1832)$ : for 1817 read 1814

10 f.e. $\quad$ for 1813 read 1812

7 f.e. $\quad$ for His grandson, the late Sir James read His son John

208 ii 18-17 Dunlop, John C.: for is announced by Messrs. George Bell \& Sons. read was pubf.e. lished under Mr. H. Wilson's editorship in 1888.

216 ii 11 f.e. Duns, Joannes scotus: for It bears the inscription read An inscription on a wooden tablet is said to have run

221 i 40 Dunstable, John: after music. insert Other musical compositions by him are now in the Imperial Library at Vienna, in the Biblioteca Estense at Modena, in libraries at Rome, Bologna, and Dijon (cf. Times, 21 Feb. 1893).

233 ii 10 Dunthorn, William: for $(d .1489)$ read $(d .1490)$

239 ii 21 Duport, James : after stall and insert resigning after deaconry insert (1641)

240 i 32 for died read was buried omit and was buried

242 i 23

ii 4 f.e.

243 i 2 f.e.

Duppa, Brian : for 1629 read 1628

for 16 March read 26 March

Duppa, Richard : after political character' insert (i.e. Richard Glover, 1712-1785 [q. v.])

246 i 31 Durand, Sir Henry M. : for Polhampton read Polehampton

248 i 8f.e. Duras, Lonis, Earl of Feversham: for In the same year read From 1685 to 1689 he was colonel of the 1st troop of horse guards. In 1686

3 f.e. $\quad$ after (ib. i. 476). insert In 1688-9 he was lord-lieutenant of Kent.

250 i 17 D'Urban, Sir Benjamin: for and in 1821 read in 1820 he was made governor of Antigua and in 1824

18-20 for British Guiana, whence he was transferred . . . . in 1825. read Demerara and Essequibo. These settlements were combined in 1831 with Berbice to form the colony of British Guiana, of which D'Urban was then appointed first governor. for lieutenant-governor read governor omit of the eastern district after 1837 insert when he was succeeded at the Cape by Major-General (Sir) George T. Napier

27

28-81

39-40 omit which he did after some opposition in 1843. omit and in 1842 appointed . . . . Napier, K.C.B.

257

261

ii 11 f.e.

261 ii

f.e.

32

272 i 4

276 i 82

277 ii 29

33-34

35

Durel, John: before On the death of Earle insert for translation into Latin

Durham, Sir Philip C. H. C. : after G.C.B. insert He was elected tory M.P. for Queenborough in 1830 and for Devizes in 1834.

f.e. Durie, John : for Wetteran read Wetterau

for Heilebron read Heilbronn

for council read counsel

for Hildersheim read Hildesheim

Duval, Clande : after 1669-70 insert cf. art. 'Morton, Sir William'

Dwnn, Lewys : for usual read accepted

Dwyer, Michael : after Grattan insert erroneously for according to Ross read Ross is correct in stating that after Sydney insert and being buried in the Devonshire Street cemetery
there 
Page Col. Line

281 ii 17

285 i 42-43

ii 6 f.e.

287 i 35

ii 20

813 i 51-52

316 ii 9

15 f.e.

318 ii 27

320 i 6

ii 7

321

322

323

325

326

329

ii 3 f.e.

i $\quad 35$

ii 39

ii 21

i 12

13

Dyce-Sombre, David 0.: for grandfather read great-grandfather

Dyer, George : omit who had entered . . . . was a Grecian.'

after Watts. insert Another portrait is in the Fitzwilliam Museum at Cam. bridge.

Dyer, Sir James : for king's bench read common pleas

Dyer, John : for Calthorp read Catthorpe

Eagles, Thomas : for For the last few years of his life read From 1809 till death

Eardley, sir Culling E.: for Edward Denison read Edmund Beckett

Earle, Giles : for 1771 read 1774

Earle, Jabez : before Samuel Morton Savage insert John Allan, M.D. (1749-59), for iii. 508, \&c. read ii. 225, iii. 508

Earle, John (1601 ?-1665) : for 1642-3 read 1643-4

after Westminster insert June 1660

Earle, William : for 1887 read 1885

East, Sir Edward H. : for 1823-30 read 1823-31

East, Sir James B. : for liberal read conservative for 1830 read 1831

ii 11 f.e. Easthope, Sir John: for Jan. read June

9 f.e. $\quad$ for 1837 read 1835

7 f.e. for of Lewes, he then sat read of Southampton and afterwards that of Lewes ; he was elected in 1837

5 f.e. after 1847 insert when he contested Bridgnorth unsuccessfully

332 ii 2 f.e. Eastlake, Sir Charles L. : for 14 Dec. read 24 Dec.

344 ii 39 Eborard: for 1230 read 1130

348 ii 10 f.e. Eccles, John : for 1704 read 1700

357 ii 22 Eden, George, Earl of Auckland: after 1809 insert and was under-teller of the exchequer from 1809 till 1812

23 for Elliot read Eden

24 for 19 Jan. read 24 Feb.

$27 \quad$ after 1812 insert when he was defeated at Oxford

32

33

17 f.e. for severed himself from the tory party read supported Addington for The read But the and omit thus

360

i 19 f.e. Eden, Robert : for Perrot read Terrot

ii $\begin{gathered}4 \\ 16\end{gathered}$ for Langley read Longley

361 ii 41 Eden, Robert J., 3rd Baron Auckland : for 'A Letter read 'A Reply to a Letter 44-45 omit with his Lordship's Reply

362 ii 12 f.e. Eden, William, 1st Lord Auckland : for selected as one of the first lords of read appointed in 1776 to fill a vacancy in

11-9 for when that board .... British trade. In that year read $\mathrm{He}$ was re-

f.e.

$2-1$

f.e.

363 i 8

22-24

26-30

33-35 elected for Woodstock on taking office. In the same year omit was re-elected for Woodstock, and in the year

after 1780 insert during which year he was re-elected for Woodstock, for -when Lord Shelburne ..... chancellor of the exchequer- read -when the Duke of Portland became prime minister in the coalition ministry of Fox and Lord North-

for $\mathrm{He}$ attached himself closely ..... of the Shelburne ministry before the coalition read $\mathrm{He}$ went out of office on the dismissal of the coalition ministry

for and with Pitt's return .... He was again made a lord of the read In Dec. 1785 he accepted office under Pitt, and thus began the most important period of his career, though the opposition ridiculed his tergiversation. He was now made a member of the newly established

after plantations insert (in place of the old board)

for 1788 read Aug. 1787 


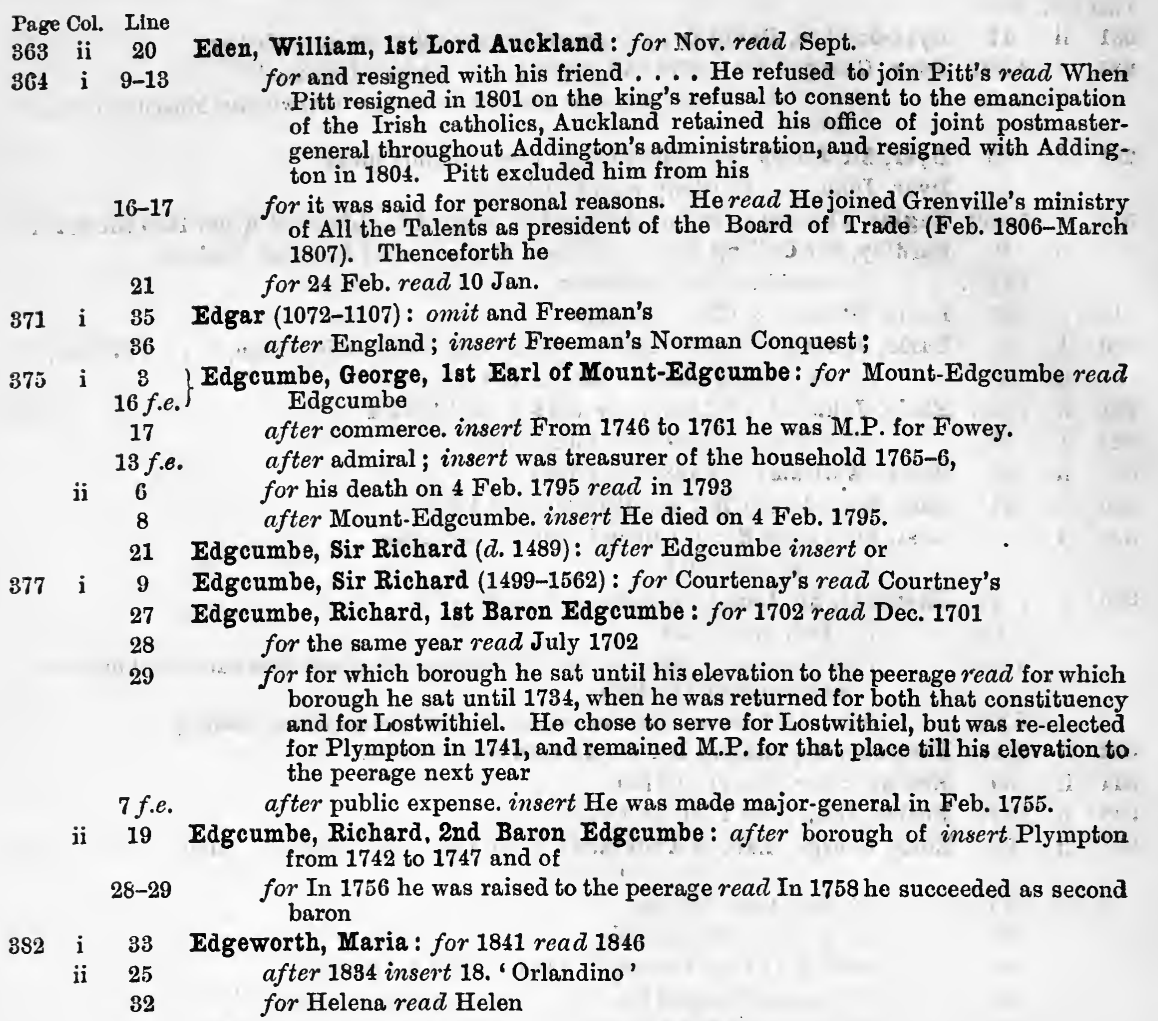

ii 18 f.e. Edgeworth, Richard Lovell : after Irish parliament insert for St. Johnstown, co. Longford (1798-1800)

385 i 16 f.e. $\quad$ for Stirling read Sterling

12 f.e. $\quad$ for Ysidor read Ysidro

386 ii 17 f.e. Edington, William of : for nescitur read nascitur

387 i 14 for at Edington. read in his cathedral south of the choir steps, in a chantry where his effigy can be seen on an altar tomb with a long Latin inscription. His will (in Latin), dated 11. Sept. 1366, is printed in Wiltshire 'Notes and Queries.'

i 13-12 Edlin, Richard: for (d. 1677) astrologer read (1631-1677) astrologer, born 29 Sept.

f.e. 1631 (Sloane MS. 1120, f. 2)

ii 23-24 for in January read 19 Feb.

27 Edmond, $\frac{1}{1606}$ : for Edxond - (16th cent.) read Edmonds, Sir WilliaMr $($ d. 1606)

28-29 omit towards the close of the sixteenth century

30 after baker insert of Edinburgh, according to Peacham's 'Compleat Gentleman' $(1634$, p. 5)

35 for Having won .... returned to Scotland, and read He was in command of a regiment of Scotch foot which was cut to pieces at Leffingen 1 July 1600. He was killed during the defence of Rhineberg, 3 Sept. 1606. While on a visit to Scotland he had

39-41 omit The date of his death .... Earl of Mar

12 f.e. after p. 44 insert Dalton's Sir Edward Cecil, i. 47, 138

392 ii 21 f.e. Edmondes, Sir Thomas : for Henry read John

17 f.e. $\quad$ for His last official work was to visit read He visited

14 f.e. after September insert His last official work was that of special ambassador to France (Jan.-July 1630) 


\section{ERRATA-VOLUME XVI}

Page Col. Line

392 ii 13 f.e. Edmondes, Sir Thomas : for ten read nine 7 f.e. $\quad$ for died at Paris 31 Dec. read was dead on 23 Nov.

$\left.\begin{array}{lll}394 & \text { i } & 29 \\ & & 33\end{array}\right)$ Edmondson, George : for Ackworth read Acworth

399 ii 12 Edmondstone, Neil B.: after Dumbartonshire insert 1761-80 and 1790-6

13 for 1761 to 1796 read 1780 to 1790

408 ii 3 Edmund (Rich), Saint: for Count read Earl

410 i 19 f.e. Edmund of Woodstock, Earl of Kent : for 1329) read 1330)

411 ii 17 for 1329 read $1328-9$

16 f.e. $\quad$ after 13 March insert 1329-30

412 i 22 f.e. for (1309-1349) read (d. 1349)

ii 33 Edmunds, John : for 1817 read 1517

34 after 1519. insert He was prebendary of St. Paul's 1510-17 and chancellor 1517-29. 


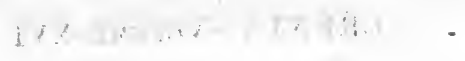

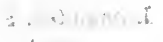

(athina id

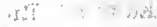

$$
\begin{aligned}
& \therefore 1, \ldots, \pi t s
\end{aligned}
$$




\title{
DiCTIONARY OF NATIONAL BIOGRAPHY
}

\author{
ERRATA IN VOLUME XVII \\ EDWARD - ERSKINE \\ N.B. -f.e. stands for from end and l.l. for last line
}

5 ii 20 Edward the Elder : for Einsiedlen read Einsiedeln

7 i 32 Edward the Confessor: for Wiltshire read Dorset

16 ii 18-27 Edward I: Note.-Edward I's attaek on Gloucester belongs to next year's

$17 \quad$ i $\quad 22$

25 i 17

ii 20

34 i 38

48 i 24-25 campaign-that of 1264 for Lewis XI read Lewis IX for attacked read attacking for Newyn read Nevin for Cottenham read Cottingham

69 ii 38

Edward II : for she was dead in 1357 read she died 14 Aug. 1362

Edward III : for Pedro of Aragon read Alfonso of Castile

Edward IV : for Sir William Conyers read [See RoBIN of REDESDaLE]

Edward VI : for duke of Norfolk read duke of Suffolk for April 1551 read Jan. 1550-1

90 i $\quad 26$

Edward the Black Prince : for Wittlesey read Whittlesey

110 ii $2-3$ 16

Edwardes, Sir Herbert B. : for 1843 read 1848

for knighthood . . . order of the Bath read K.C.B. (1860) after of men.' insert $\mathrm{He}$ was made C.S.I. in 1866.

112

16 f.e.

Edwards, Bryan : for 1794 read 1795

ii 3 before the son of insert (Sir George Henry Rose [q. v.])

113 i 16-15. f.e. for Maria read Martha...

West Indies ' printed anonymously at Kingston in 1792 ; the book is now very rare. A copy corrected by the author is in the library of the Royal Colonial Institute.

117 i 16 Edwards, Edward (1812-1886): after exists. insert In 1883 he completed a calendar of the Carte Historical Papers in the Bodleian Library, which is still in MS.

121

i 20 f.e. Egan, John : omit for some years

19 f.e.

18 f.e.

after borough insert of Ballynakill (1789-90) and

after ford insert (1790-1800)

i 17 f.e. Egerton, Francis, last Duke of Bridgewater : for Edward Egerton read John William Egerton

i 14 Egerton, Francis, Earl of Ellesmere : after was insert first president of the Camden Society in 1838, and after 1854-5. insert $\mathrm{He}$ was lord-lieutenant of Lancashire from 1856 till his death. 
Page Col. Line

156 i 14

7 f.e.

3-1 f.e.

156 ii 8 f.e.

157 ii 20

161 i, 22

162 ii 17 f.e

170 i 9

171 ii 35

175 ii $36-37$

177 ii 19

179 ii 9 f.e.

182 i 28

31-32

ii 16

184 ii 52

$54-55$

185 i 7

ii 25

53-54

186 i 22

25

7 f.e.

ii 3

189

Egerton, John, 1st Earl of Bridgewater : after Flintshire. insert He was M.P.

for Callington in 1597 . Charles I at Theobald's (RyMER, Fœdera, xix. 419-65)

omit where an elaborate series . . . . xix. 449-65)

Egerton, John, 2nd Earl of Bridgwater : for Bridgwater read Bridgewater after suggestion. insert He was made lord-lieutenant of Buckinghamshire in 1660, of Lancashire and Cheshire in 1670, and Hertfordshire in 1681.

Egerton, Sir Thomas, Baron Ellesmere: after 1592. insert $\mathrm{He}$ was M.P. for Cheshire in 1584 and 1586.

after his household. insert $\mathrm{He}$ was lord-lieutenant of Buckinghamshire 1607-16.

Elder, Charles: after portrait painter. insert He was son of Joseph Elder of the ordnance office at the Tower, and went to St..Paul's School in 1834.

Elder, John (1824-1869): after forty-five insert (17 Sept.)

Eleanor, Queen of France and Queen of England : for Montaign read Mortaign for her son read her son Richard

Eleanor of Provence : for Eleanor's sister read her sister

Elford, Sir William: for 1833; M.P. read 1833. In politics he was a tory, he was M.P.

omit He also represented Westbury for some time.

before who insert (M.P. for Westbury for a few months in 1820)

Eliot, Edward, Lord Eliot : for 1775 read 1774, for St. Germans again 1774-5

for In 1771 he was appointed read From 1751 to his death he was

for 1781 read 1780

Eliot, Edward G., 3rd Earl of St. Germans : after 1827 insert and he retained the office under Goderich and Wellington until 1830 for a modest whig read a conservative after the household insert 1857-8 and 1859-66

after family matters. insert He was made C.B. in 1848 and G.C.B. in 1857. for M.P. read liberal M.P.

Eliot, Francis P.: for at the time read from 1806 to the time omit and for many years previously

Eliot, Sir John : after St. Germans insert in the Short parliament of 1640, as well as

i 26 Eliot, John: for Tangiers read Tangier

i 17 Eliott, Sir Daniel : for When read After omit receive the second class, and he and for became read become

ii 4 Eliott, George A., Lord Heathfield : for 1755 read 1756

21 after water. insert $\mathrm{He}$ was promoted major-general in June 1759 and lieutenant-general in 1765 .

23-24 omit and was promoted .... following year

30 for and when he read He

32

196 i 20 f.e. omit he was promoted lieutenant-general

for 25th light dragoons read 29th light drag

208 i 22 f.e. after goons insert 1797-1810 and after guards 1810 till death

ii 14 f.e.

209 i $33-34$

227 i 18 f.e.

Elizabeth, Queen of England : for duke of Suffolk read duke of Somerset for Francis, earl Russell read Francis Russell, earl of Bedford

232 i $20-21$ for At the eleventh hour.... gave way. read The ceremony was, however, performed by Owen Oglethorpe [q. v.], bishop of Carlisle. for Moen read Moens

ill-disposed to the puritan

f.e.

Ellacombe, Henry T. : for in 1790 read 15 May 1790

243 i 5 f.e. Ellerker, Sir Ralph: for Stytnam read Stittenham for Cotingham read Cottingham

244 i 16 Ellerton, Edward : after the same college insert was proctor in 1804,

245 ii 21 f.e. Elley, Sir John : after Waterloo insert (where he was again wounded)

14 f.e. $\quad$ for 1820 read 1826

7 f.e. $\quad$ for April read January 
Page Col. Line

247 i 5

ii 36

248 i 8

11

249 i 3 f.e. 2 f.e.

251 i 20 f.e.

252 i 26

27

28

37

40

16 f.e.

$253 \quad$ ii $\quad 36$

20 f.e.

19 f.e.

18 f.e.

255 i 30

14 f.e.

Ellice, Edward (1781-1863) : after accept insert in April 1833

for Torr-na.Cairidh read Tor-na-Cairidh

Ellice, Edward (1810-1880) : for 1834 read 1835

for in $1836 \mathrm{read}$ at a by-election in 1837

Ellicombe, Sir Charles G. : after general insert (in 1861)

after engineers insert (in 1856)

Elliot, Sir Charles : for 1837 read June 1836

Elliot, Sir George: before He was insert He was naval aide-de-camp to the king $1830-7$, and was M.P. for Roxburghshire from 1832 to 1835 , when he was defeated. for December 1834 read 29 Nov. 1830

for April 1835 read December 1834

for $\mathrm{He}$ had no further service but read $\mathrm{He}$ was commander at the Nore 1848-51 and

after 1853 ; insert he was transferred to the reserve half-pay list in 1855 ;

for Osgodvie read Osgodby

Elliot, Sir Gilbert (1722-1777): for 1754 read 1753

for in 1762 read was a lord of the treasury 1761-2, was

after chambers insert 1762-70

for in 1770 read from 1770 till death

alliot, Sir Gilbert, 1st Earl of Minto: after Morpeth insert and from 1777 to

1784 sat for Roxburghshire
for lost his seat read failed to gain a seat

for Lord Portland read the Duke of Portland

Elliot, Gilbert, 2nd Earl of Minto : for till March 1814, when read till next year He was M.P. for Roxburghshire from 1812 till March 1814, when von Kraut, of Berlin, whom he divorced and by whom he had a daughter, and secondly to Margaret Lewis (1770-1819), by whom he had five sons and three daughters.

262 i 17 f.e. Elliot, John (d. 1808) : before From 1786 insert He was whig M.P. for Cockermouth 1767-8, and colonel of marines 1779-87.

14 f.e. $\quad$ for 21 Feb. read 21 Sept.

264 ii 20 f.e. Elliotson, John: for in 1791 read 29 Oct. 1791

270 i 16 Elliott, Henry V.: for Fowell Buxton read North Buxton

15 f.e. for some of her religious poems are read one of her religious poems is

ii 4 Elliott, John : for ( $f l$. 1690) read (d. 1691)

19-18 for Elliott's name ..... 1693. read Letters of administration were granted

f.e. to his widow Elizabeth 26 Aug. 1691. He was there described as of St. Martin's in the Fields.

271 i 15-16 Elliott, Sir John : for He lived in Great Marlborough Street, London. read (Sir John must be distinguished from John Elliott, M.D. (1747-1787), who lived at one time in Great Marlborough Street, London, and died in Newgate,

16 f.e. before Munk's Coll. of Phys. insert A Narrative of the Life and Death of John Elliot, M.D. 1787

272 i 22 f.e. Elliott, Sir William H.: before On 27 June 1838 insert He was made K.H. in

ii 9 after colonel of the insert 55th foot 1861 and of the

10 for in that year read in 1862

14 for Feb. read March

18 for 3 March read 3 April

273 i 8-10 Ellis, Sir Barrow H. : for from 1855 to $1857 \ldots$... Sir Bartle Frere. read became chief commissioner in succession to General John Jacob [q. v.] in 1857.

279 ii 33 Ellis, Henry : after Georgia insert (1758-61)

33-34 for from which employment he retired about 1770 read (1761-3)

280 i 16 Ellis, Sir Henry (1777-1855) : for Ellis held read Ellis, who was tory M.P. for Boston, was commissioner of customs 1824-5. He held

281 i 8 f.e. Ellis, Sir Henry (1777-1869): for 1833 read 1832

5 f.e. $\quad$ after eminence, read $\mathrm{He}$ was knighted in 1833.

ii 11 f.e. after to the last. insert He was director of the Society of Antiquaries 1853-7. 


\section{Page Col. Line}

284 i 26

21 f.e.

285 i 11-12 Ellis, John (1643 ?-179

i $11-12$

Ellis, John (1606-1681) : for 1662 read 1664

for Wood read Wood's editor

292 i 20 Ellis, Thomas F.: for He was read Ho was from 1839

19 f.e. Ellis, Welbore: after 1681 insert [q. ..]

ii 1

for Sir William read Sir John

294 i 18-16 Ellis, Sir William (1609-1680): for was educated at Caius College ... . M.A. in f.e. $\quad$ in 1636. read

299 ii ' 20 Elliston, Henry T.: for 1683 read 1863

35 Elliston, Robert W. : for Covent Garden read London

302 ii 6 f.e. Ellman, John: for the Earl of Sheffield read Lord Sheffield

304 ii 3 f.e. Ellwood, Thomas : for Pennington read Springett

$305-i \quad 36 \quad$ for 1684 read 1694

306 i 19 Ellys, Anthony: for canon read prebendary

10 f.e. for canonry read prebend

, Sir Richard : for eldest son read younger son

ii 43-44

5 f.e. for Stigmato-logicus' read Stigmologicus'

Elmham, Thomas : after 11 June 1414. insert Elmham was a royal chaplain, and in the spring of 1415 was employed on the king's business at Westminster. (Ducket, Charters and Records of Cluni, ii. 15, 21). As chaplain he served through the campaign of 1415 , being present at Agincourt. Of that campaign he wrote the description carrying events to 1415 , which is known as 'Gesta Henrici Quinti.' This was long described anonymously as 'the chaplain's life' and is a first-rate authority (published by English Hist. Soc. 1850 ; cf. Lenz ' König Sigismund und Heinrich der. Fünfte,' p. 14.)

ii 3-10 for Mr. Hardwick surmises .... about 1440. read The supposition that Elmham may have survived to 1440 rests upon the erroneous ascription to him of the 'Vita Henrici Quinti' edited by Hearne.

20-21 for A prose life of Henry V read 'Gesta Henrici Quinti' ("the chaplain's life'), which is to be distinguished from the 'Vita et Gesta Henrici Quinti,' which was edited by Hearne in 1727, and has been erroneously assigned to Elmham (cf. 'Athenæum,' 23 Aug. 1902; Kingsford's 'Henry V,' p. 6)

26

27

9-8

f.e.

$\mathbf{3 1 0}$ i $\mathbf{3 8}$

316 ii $\quad 37$

321 i $\quad 4$ omit Monachus

for with the additional real with Monachus and the additional

for 'Vita et Gesta Henrici V' by Hearne (1727) read 'Gesta Henrici V' ('the chaplain's life '), ed. Giles 1848 and for English Hist. Soc. (1850)

Elmore, Alfred : for 1877 read 1857

Elphinstone, George K., Viscount Keith : for and after 1790 read from 1780 to 1790 and from 1796 to 1801

322 i 11 f.e. Elphinstone, Sir Howard : after 1837 insert He was made colonel commandant of royal engineers in 1834

3 f.e. Elphinstone, James, 1st Lord Balmerino : after 1553 insert He was a Roman catholic

ii 20-24 for It was believed James intended to appoint . . . speedy disgrace. read As a catholic he used his influence to persecute the presbyterians, and his zeal for his religion led to his disgrace.

33 before James sent insert In Oct. 1608

323 i 18 before Douglas and Wood's Peerage insert Gardiner's History ;

324 ii 17 f.e. Elphinstone, John, 2nd Lord Balmerino : for earl read lord

6 f.e. for 1682 read 1652

325 ii 11 Elphinstone, John, 13th Lord Elphinstone : for 1858 read 1859

14 after Stirlingshire. insert $\mathrm{He}$ was a Scottish representative peer 1832-4, 1847-59.

4 f.e. Elphinstone, Margaret M., Viscountess Keith : after English insert Scottish

332 i 36 Elrington, Thomas : for Pinkethman read Penkethman

834 ii 33 Elstob, Elizabeth: for No. 458 read No. $370-4$ 
Page Col. Line

342 ii 5-6 Elwall, Edward: for Memoir of J. T. read Memoir by J. T.

343 i 12 f.e. Elwes, John: for 1774 read 1772

10 f.e. $\quad$ for 1787 read 1784

346 ii 20 f.e. Ely, William: for Sir Thomas Pope read Sir Thomas White

347 ii $\left.\begin{array}{r}15 \\ 18\end{array}\right\}$ Elyot, Sir Thomas : for St. Mary's Hall read St. Mary Hall

348 ii 15 f.e. for A barrow read à Barrow

12 f.e. $\quad$ for Dwyer read Dyer

351 ii 8 f.e. Imerson, William : for Dr. Morgan read De Morgan

354 ii 33 Emes, Thomas : for 23 Dec. read 22 Dec.

356 ii 6 . Emlyn, Thomas: for eleventh read twelfth

358 ii 14 f.e. for of Gloucester read at Cheltenham

360 i 2 for p. $503 \mathrm{sq}$. read iii. $503 \mathrm{sq}$.

364 i 6-7 Emmet, Thomas A.: for Webbe's Biography of Remarkable Irishmen read Webb's Compendium of Irish Biography

2 f.e. Emmett, Anthony : after until insert in May 1855

367 i 7 Endecott, John : for enactions read enactments

303 ii 17 Enfield, William: for in that city read near that city

374 ii 16 f.e. Englefield, Sir Henry C.: after Arts. insert He was president of the Society of Antiquaries 1811-2. .

376 i $32 \quad$ English, Sir John H. : for 1852 read 1840

384 i 7 Erbury, William : for (Laud) read (Murray)

11 f.e. $\quad$ for 1646 read 1646-7

ii 14 f.e. $\quad$ after of which insert dated 1648

13 f.e. for 1653 read (these were collected in 1653)

11 f.e. omit 1654. 5. and note that the works entitled respectively 'An Olive Leaf' and 'The Reign of Christ' were published in the same volume.

3 f.e. after 1658 insert (this consists of twenty-three tracts collected together with a preface)

l.l. for ii. 100-1, \&c. read iii. 360 for (2nd edit.) read (1793-7)

385 i 4

391 ii 11 f.e. Erle, Thomas : for had been made governor of Plymouth read was governor of Portsmouth from 1694 to 1712

392 i $5-6$ for was made lieutenant read in $\mathbf{1 7 0 5}$ was made lieutenant-general.

43 for lieutenancy read lieutenant-generalship

45-46 omit and governor of Portsmouth

12-10 for and as commander-in-chief .... in 1715, when he was read but held f.e. the post again and was again governor of Portsmouth 1714-18. In 1715 he was

8 f.e. $\quad$ after again insert after 1718

ii 3 for Ellerlee read Ellerton

after Wareham insert as a whig

for in 1698, when read in 1698 and 1700 , when on both occasions

after Parliament). insert $\mathrm{He}$ was M.P. for Cork in the Irish Horse of Commons 1703-13.

393 i 8

$9-10$

Erle, Sir William : for same year. He read same year, after having

for in 1845 read and

11

for knighted, was read knighted. He was

for the following year read 1845

394 i 3-4 Ernest, Angustus, King of Hanover : for both in the English and the Hanoverian armies read in the Hanoverian army

for in 1798 he was promoted read in July 1799 he was made

for general and read general in the English service, his first rank in the English army, the commission being antedated May 1798. In 1799 also he was

18 f.e. $\quad$ for 15 th hussars read 15th light dragoons, afterwards hussars

17 f.e. $\quad$ for 1803 he was promoted general read April 1808 he was gazetted general, the commission being antedated Sept. 1803

396 i 24-28 omit Scandal, too, ... . legitimate daughter.

401 ii 7 f.e. Erskine, David M., 2nd Lord Erskine : for 1825 read 1824

403 i 23 f.e. Erskine, David S., 11th Earl of Buchan: for 1729 read 1792 


\section{ERRATA-Volume XVII}

Page Col. Line

407 ii 6 f.e. Erskine, Edward M.: for Florence read Turin

5 f.e. after Washington insert early in 1858

409 i 10-11 Erskine, Henry (1624-1696): for covenanting minister real presbyterian minister

ii 7 for on read after

$8 \quad$ after indulgence insert (1687)

10 omit first

410 i 1 Erskine, Sir Henry (d. 1765): for 1761 read his death in 1765 after 67 th foot insert (Oct. 1760)

after 25th foot insert (May 1761)

after Royal Scots insert (Dec. 1762)

415 i 20 Erskine, Sir James St. C., 2nd Earl of Rosslyn: for 1781 read 1782

21 for M.P. read whig M.P.

28-29 omit as the representative of his uncle's opinions

39. for 1790 read 1796

422 i 20 f.e. Erskine, John, 1509-1591 : for his will for read for his own will

426 ii 35 Erskine, John, 6th or 11th Earl of Mar: for a regiment of foot read the 9 th foot: (1702-6)

438 i 21 f.e. Erskine, Thomas, Lord Erskine : after 1783 insert becoming K.C. in the sameyear

18-17 omit which had been in abeyance .... Lord Bacon,

f.e.

403 ii 23 f.e. Erskine, Thomas (1788-1864): for He took no part read Although he contestea Lewes as a whig unsuccessfully in 1818 , he took no other part 


\title{
DicTiONARY OF NATIONAL BIOGRAPHY
}

\author{
ERRATA IN VOLUME XVIII
}

\author{
ESDAILE-FINAN
}

N.B.- f.e. stands for from end and l.l. for last line

Page Col. Line

1 i 11 f.e. Esdaile, James: omit his Harveian oration of

3 ii 24-25 Esdaile, William: for picture read drawing

4 i 36 Esmonde, Sir Laurence, Lord Esmonde : before was created insert was M.P. for Wicklow in the Irish House of Commons in 1613 and

$9 \quad$ i 13 f.e. Estcourt, James B. B.: for for many years read in 1803-4

8 f.e. $\quad$ for M.P. read conservative M.P.

11 i 12 f.e. Estcourt, Thomas, H. S. S. : for 1826 read 1827

ii 22 f.e. for On his father's death read In 1855, two years after his father's death

19 i 7-8 Ethelbert (d. 866): for Athelred read Fthelberht

25 i 24 Ethelmær $(d .1137)$ : for 10 July 1865 read 1751

62 ii 21 Evans, George (1630 ?-1702): for 20 March read (according to Le Neve) 2 March

63 i 34 Evans, Sir George de L. : for 1831 read March 1830 for elected read elected on petition after that seat insert at the general election in the following August

$\begin{array}{rrrr} & & 36 & \text { after that seat insert at the general elect } \\ 69 & 17 & \text { Evans, John }(1814-1875): \text { for 1875) read 1876) }\end{array}$

76 i 7 f.e. Evans, William (1811 ?-1858): for 'Troth read' Traeth

78 i 7 Evans, William E. : for 1845 read 1841

81 i 1 Evelyn, John (1620-1706): for 1772 read 1672

33 after Evelyn insert who contested Surrey in 1698

83 ii 1 Evelyn, John (1655-1699): for 1696 read his death in 1699

85 ii 16 f.e. Everard, Mathias : for $\mathrm{He}$ was a K.H., read He was made C.B. in 1826 and $\mathrm{K} . \mathrm{H}$. in 1831,

90 i 20 Evesham, Hugh of: after 'Phœnix.' insert He was prebendary of York in 1279.

96 i 4 f.e. Ewing, Juliana $\mathbf{H}$. : for 1861 read 1866

97 i 19 Exley, Thomas: for (d.1855?) read (1775-1855)

34 for in or about 1855 read $17 \mathrm{Feb}$. 1855, aged 80

98 ii 4

Exton, Sir Thomas: for Previous to 1678 read On 23 Nov. 1675

for appointed read was in July 1686 appointed after 1685. insert $\mathrm{He}$ was chancellor of the diocese of London 1663-85, and dean of the Arches in $\mathbf{1 6 8 6 .}$

99 ii 8 Eyre, Sir Giles : for 31 Nov, read 31 Oct.

104 i 9 f.e. Eyre, sir Vincent: for lieutenant-general read major-general

105 i 38 Eyre, Sir William: for 1852 read 1853

ii 8 for 18 Sept. read 8 Sept.

111 i 19 f.e. Faber, George S. : for 1831 read 1830

113 ii 20 Fabyan, Robert: for 1502 read 1503

117 ii 14 f.e. Fagan, Robert : for Early in the century read In 1809

118 ii 6 f.e. Fagg, Sir John : before in March 1661 insert to the Convention parliament of 1660, and again 
Page Col. Line

128 ii 20 f.e. Fairbairn, sir Peter: for danghter of Mr. R. W. Brindling read daughter of Robert William Brandling of Low Gosforth, Newcastle-on-Tyne, and widow of Captain Charles Bell, R.N.

125 ii 7 Fairborne, Sir Palmes: for Tangiers read Tangier and so throughout the article.

127 i 8 f.e. Fairborne, Sir Stafford : before In June 1707 insert He was M.P. for Rochester 1705-8.

ii 13

before In the petition insert In 1708 he married Rebecca, daughter of Colonel Thomas Paston.

132 i 15 Fairfax, Edward : for 11473 read 11743

25 for Fuiston read Fewston ?

ii 19 Fairfax, Ferdinando: for two read three

140 ii 24 f.e. Fairfax, Thomas, 1st Lord Fairfax : after 1591. insert He was M.P. for Lincoln 1586, for Aldborough 1588, and for Boroughbridge 1601.

141 i 6-7 for unsuccessfully sought a seat read was elected M.P. for

8 after 1625. insert He was unseated on petition, but was returned at \& byelection four months later (in Angust of the same year).

ii 15 f.e. Fairfax, Thomas, 3rd Lord Fairfax: for Heyworth read Heworth

146 ii $20 f$

before For the rest insert He was M.P. for the West Riding of Yorkshire in the parliament of $\mathbf{1 6 5 4}$.

150 ii 2-1 Fairfax, Sir William G.: omit of a family .... the time of Ed-

f.e.

151 i $1-5$

for ward III . ... in the horse guards. read born on 8 March 1738-9, was son of Joseph Fairfax (who after retirement from the horse guards settled at Bagshot, Surrey), and was grandson of Joseph Fairfax of Saxton, Yorkshire.

161 i 14

170 ii 37

174 i 15

33

175 i 13 f.e.

7 f.e.

5 f.e.

23

Falconer, Hugh : for July read January

Falle, Philip : for 1781 read 1681

Fane, Sir Henry : for 1768 to 1796 read 1772 to 1802

for In the previous year he had succeded read In 1802 he succeeded

for 1825 read 1826

for master-general read surveyor-general

after Sandwich. insert $\mathrm{He}$ was M.P. for Hastings 1830-1.

3 f.e. Fane, John, 10th Earl of Westmorland : for paymaster-general read postmasterNorthampton and for 1758 read 1759 general

Fane, John, 11th Earl of Westmorland : after Bourbons. insert He was A.D.C. to George IV both as prince regent and king, 1814-25; became major-general in 1825 and lieutenant-general in 1838.

$178 \quad$ ii $\quad 22$

28

l.l.

179 i 9

182 i 4

8

10

15

189 ii $\quad 37$

190 i 1

3

$38-43$

ii $16-18$

40

206 ii 18

208 i 38

215 ii 6

Fane, Mildmay, 2nd Earl of Westmorland : for $(d .1665)$ read (d. 1666) after 1620-1 insert for Kent in 1625, and again for Peterborongh 1626-8 for 1665 read 1665-6

after fourth earl insert and another son, Horace

Fanning, Edmund : for St. John in the Gulf of St. Lawrence read Prince Edward for In 1799 he was chosen read He remained omit an appointment which he retained for 1793 read 1794

Fanshawe, Thomas (1530 ?-1601): for stucceding read five succeeding after lands. insert $\mathrm{He}$ was returned M.P. for Lancaster on 19 Jan. 1625-6, and again on 10 March 1627-8.

after 1622 add A son, Thomas, was elected M.P. for Lancaster to the Long parliament, but ' was disabled to sit' early in 1646 .

Fanshawe, Sir Thomas, 1st Viscount Fanshawe: for for Lancaster ... for Lancaster) on 26 Oct. 1640, read and again on 26 Oct. 1640. omit was elected M.P. . . . early in $\mathbf{1 6 4 6}$ for 1689 read 1687

Farindon, Anthony : for Branston read Bramston

Farish, William : before. In 1794 insert He was proctor in 1792. Farmer, Richard : for the residentiary prebend read a residentiary canonry and
the prebend 
Page Col. Line

218 i 31 Farnaby, Thomas : for bishop of Durham read bishop of Oxford and afterwards of Durham

221 i 12 f.e. Farquhar, Sir Arthur: after knighted insert and was made K.C.H. in 1832

225. ii 27 Farr, Samuel : for Returning read He was physician to the Bristol infirmary from 1767 to 1780 , practising in Bristol for some years. Afterwards returning

234 i 22 f.e. Farrington, Sir Anthony : for 1812 read the last year.

235 ii 27 Fastolf, Sir John: for 1408 read 1408-9

236 i 39 after England insert He was elected M.P. for Yarmouth the year before.

238 i 14 f.e. for 5 Nov.read on St. Leonard's day, 6 Nov.

12 f.e. $\quad$ for 148 days read 158 days (Sloane MS. 4, f. 38 b)

239 i 3 f.e. for Southwark read Eastcheap

242 i 15-16 Faulkner, Sir Arthur B.: omit Gloucester and :

249 ii 20 Fauquier, Francis: for in April read on 3 March

251 i 13 f.e. Favour, John: for (d. 1623) read (d. 1624).

ii 2 after Yorkshire. insert He was made prebendary of Southwell in 1611 and of Osbaldwick, York, in 1614.

3 for 1616 read 1616-7

14 f.e. $\quad$ for 1623 read 1623-4

252 ii 45-46 Fawcett, Henry : for Henry Edmundson read George Edmundson

254 i 28 for 1862 read 1863

30 for 1863 read 1864

260 i 6 f.e. Fawcett, John (1789-1867) : for H. Huntingdon's read G. Huntingdon's

262 i 3 f.e. Fawcett, Sir William: for 1778 read 1781

ii 7-8 for major-general read lieutenant-general

24 for David Dundas [q. v.] read Sir Harry Calvert [q. v.]

27-28 for never before or since conferred read rarely conferred

263 ii 6 f.e. Fawkener, Sir Everard: for afterwards the first lord read who is to be distinguished from John Crewe, the first lord

264 i 5

268 ii 38-39 Fawkes, Guy : for Bodleian Library read Ashmolean Museum

4 f.e. after Sixteenth Century insert by Robert Davies

269 i 12 Fawkes, Walter R.: for 1802 read 1806

7 f.e. $\quad$ for Keswick read Neswick

275 i 20 Fearne, Charles : for Watts read Watt

276 ii 16 f.e. Featley, Daniel : for (Piercy) read (Percy)

285 ii 24 f.e. Feckenham, John de: for Feckenham read Fickmann

289 i 9 Fielding, Basil, 2nd Earl of Denbigh : for his brother read his nephew, son of his brother

294 i 22 f.e. Fell, John (1625-1686) : for Hearne read Dr. Thomas Smith

ii 6 for 1675 read 1675-6

298 ii 2 f.e. Fell, Samuel : after James I. insert He had become prebendary of St. Paul's in 1613.

299 i $8 \quad$ for 1638 read 1637

300 ii 22 Fellowes, Sir James: for 1809 read 1810

301 i 31 Fellowes, Robert : after suffrage. insert In 1828 he purchased the 'Examiner,' and made Albany Fonblanque [q. v.] editor.

319 i 10 Fenner, Edward : after 1576. insert He was M.P. for Shoreham in 1572.

322 i 15 f.e. Fenton, Elijah: for Lyne read Lyme

323 ii 4 f.e. Fenton, Sir Geoffrey : for 1580 read 1580-1

324 i 22 after Walsingham. insert He was M.P. for co. Carlow in the Irish House of Commons 1585-6.

ii $21 \quad$ for Brodie read Brady

327 i 22 Fenton, Roger : for 1615) read 1616) for 1615 read $1615-6$

330 i 3

331 ii 27

332 ii 5 f.e. Fenwicke, John : for iii. 175 read vii. 175

360 i 31 Fergusson, Sir James: for was appointed read was colonel of the 62 nd foot 9-26 March 1850, and was appointed 
Page Col. Line

364 ii 3-2 f.e.

365 i 11

871 ii 35

374 ii $8-10$

386 i 32

387 ii 30 Ferrers, Robert, Earl of Derby : for brother read own son

392 ii 8 f.e. Festing, sir Francis W.: for major-general read colonel 406 ii $18-16$
f.e.

407 i 20

21 f.e. before Foster's York. Pedigrees insert Yorkshire Archæological Journal, xiv.;

411 i 17

ii 11

416 ii 31

32

425

ii $\quad 27$

\section{Field, Richar}

Fielding, Henry : for general read lieutenant-general

after army insert in 1739 (he died 20 June 1741)

Fielding, Nathan Theodore: for Fielding's four sons read Fielding had five sons, all artists, of whom four

ii 35-36 Fielding, Newton Smith : omit at Huntingdon

430 i .18 f.e. Fiennes, John : before In 1657 insert He was elected M P. for Morpeth in 1645.

432 ii 25 f.e. Fiennes, Thomas, 9th Lord Dacre : for He succeded read Thomas succeeded

434 i 3-4 Fiennes, William, 1st Viscount Saye and Sele : for the island of New Providence in the Caribbean Sea read Providence Island, in north latitude $12^{\circ}$

26 f.e.

19 f.e.

for New Providence read Providence Island 


\title{
Dictionary OF NATIONAL BIOGRAPHY
}

\author{
ERRATA IN VOLUME XIX
}

FINCH-FORMAN

Page Col. Line

1 i 3-2 Finch, Daniel, 2nd Earl of Nottingham : for lord at the admiralty 14 May. read

f.e. lord of the admiralty 22 April

6 i 27 Finch, Edward (1756-1843): for 1824 read 1823

9 f.e. $\quad$ for 1804 read 1802

10 i 14-16 Finch, Heneage, 1st Earl of Nottingham : omit In the same year ..... Somerset. shire.

ii 2 f.e. for daughter read sister

11 ii 36 Finch, Heneage, 2nd Earl of Winchilsea: for but was read and was lord. lieutenant of Somerset from 1675 to 1683 . He was

37-38 for the former post read Kent

12 ii 4-5 Finch, Heneage, 1st Earl of Aylesford : omit In 1711 ... jewel house.

6 for raised to the peerage read advanced in the peerage

16 after nine children. insert His son Heneage, M.P. for Surrey, was made in 1711 master of the jewel house.

26 Finch, Sir Henry : for (d. 1625) read (1558-1625)

38 for degree, and was admitted read degree. Wood is apparently in error. There seems good ground for identifying Finch with a pensioner of the name, of Christ's College, Cambridge, who matriculated in May 1572 and graduated B.A.1575-6 (cf. ANDREW WILLET, Harmony of I. Samuel, pref.) Finch was admitted for the Inns of Court read inns and alehouses

17 before In 1621 insert In 1614 he was elected M.P. for St. Albans.

14 ii 9 f.e. Finch, sir John, Baron Finch : for 1614 read 1620

18 i 26 Finch, Sir John (1626-1682): after Oxford, insert was admitted pensioner of Christ's College, Cambridge, 11 April 1645. Subsequently he

after in 1649 ; insert (he was in 1647 incorporated at Cambridge B.A. from Oxford)

Finch-Hatton, Edward : after in 1718, insert was fellow of Christ's College on the Finch and Baines foundation, 1728-1746,

30 i 31 Finlay, Francis D.: for Mitchell read Mitchel

32 ii 9 Finlay, Kirkman (1773-1842): after advanced type. insert He was M.P. for Malmesbury 1818-20.

10-11 after university insert of Glasgow and contested the city unsuccessfully in 1830 
Page Col. Line

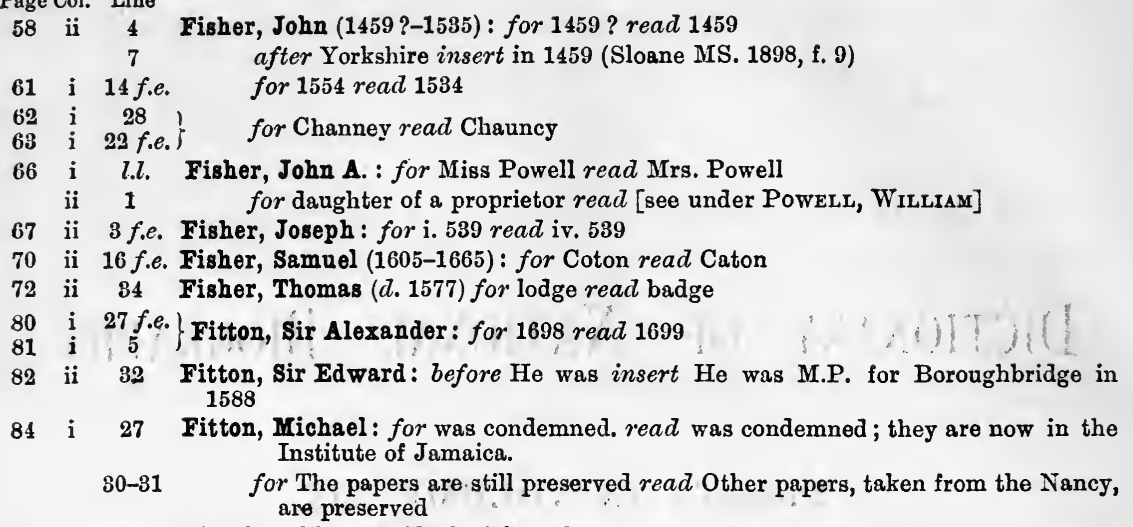

i 17 Fitzcharles, Charles, Earl of Plymouth : after iii. 487). read He was colonel of the 2nd Tangier regiment.

13 f.e. Fitzclarence, Lord Adolphus: after 17 Sept. 1853. insert He was groom of the robes 1830-3 and naval A.D.C. to Queen Victoria 1846-53.

Fitzclarence, George A. F., 1st Earl of Munster : for Eglinton read Egremont for May 1830 read June 1831

30 after the Tower insert (1831-3)

108

113

119

i 14 f.e. Fitzcount, Brian: for five read two

i 29 Fitzgerald Lady Elizabeth: for was executed read died

ii $8 .$. for 1578 read 1597

14 f.e. Fitzgerald, Gerald, 9th Earl of Kildare: for son-in-law read cousin

ii 3-2 Fitzgerald, Gerald, 15th Earl of Desmond : for 'Church of the Name.' read f.e. 'Church of no Name.'

ii 16 f.e. Fitzgerald, James (1742-1835) for 1772 read 1776

14 f.e. for Ennis; in 1776 read Fore, co. Westmeath, and sat for it till 1783 ; in that year

14-13 f.e. for Killibegs read Killybegs

12 f.e. $\quad$ omit in $\mathbf{1 7 8 4}$

11 f.e. for and 1790 read in 1790

10 f.e. $\quad$ for 1798 read 1797 and for county read borough

i 28 Fitzgerald, Sir John Fitzedmund : omit bishop of Kerry

ii 17 f.e. Fitzgerald, Sir John F.: after 1841. insert He was colonel of the 85th foot, 1840-3.

i 22 f.e. Fitzgerald, Maurice $(d .1176)$ : for and Meiler read uncle of Meiler

ii 14-11 Fitzgerald, Maurice (1774-1849): omit $\mathrm{He}$ outlived all his colleagues..... f.e. parliament.'

11. f.e. for four years, 1799-1802, read one and a half years, July 1799 to Jan. 1801,

10 f.e. $\quad$ omit excise

9 f.e. $\quad$ omit and

2 f.e. $\quad$ for $1806 \mathrm{read} 1807$

151 i 21 f.e. Fitzgerald, William R., 2nd Duke of Leinster: for Earl of Offaly read Baron Offaly

152 i 16 Fitzgerald, Sir William R. S. V.: for January 1867 read Nov. 1866

20 omit honorary

23 for third read fifth

153 i 10-11 Fitzgerald, William. V., Lord Fitzgerald and Vesey : for and in the same year he read A year earlier he had

27-29 for When the Duke of Wellington .... he selected read After the retirement of Huskisson and others from the Duke of Wellington's administration in June 1828, the Duke selected

39-40 for In December 1830 .... the Duke of Wellington, read In Feb. 1830 he resigned office, being succeeded by J. C. Herries, 
Pnge Col, Line

167 i 17 Fitzherbert, Alleyne, Baron St. Helens : after year. insert He was M.P. for Carysfort in the Irish House of Commons 1788-90.

34 for (May 1791) read (May 1790, gazetted Nov. 1789)

168 i 20 f.e. Fitzherbert, Sir Anthony : after Gray's Inn, p. 46). insert On 20 March 1508-9 he was appointed recorder of Coventry, and he held the office in 1510 and 1511 (Extraets from Leet Book, ff. 304 b, 309, 311).

170 i 5 f.e. Fitzherbert, Maria A.: for Fulworth read Lulworth

178 i 20 f.e. Fitzjames, James, Duke of Berwick : after England; insert He was made colonel of the 8 th foot in 1686, was lord-lieutenant of Hampshire 1686-8,

9 f.e. $\quad$ after Oxford. insert He was made K.G. 28 Sept. 1688 and on 20 Nov. colonel of the 3rd troop of horse guards.

180 i 14 f.e. Fitzjames, Richard: after 1481. insert He was treasurer of St. Paul's 1483-97, and prebendary 1485-97.

181 i $36 \quad$ for 1522 read 15 Jan. 1521-2

188 i 30-31 Fitzneale, Richard: for Bishop Stubbs has also recently .... evidence read Bishop Stubbs advanced but afterwards withdrew a theory

16 f.e. $\quad$ after ABBas, i. Ivii-lx insert and to Drceto, ii. xxxi

191 ii 15 Fitzpatrick, Richard, Lord Gowran : for Queen's County, and on read He was M.P. for Harristown in the Irish House of Commons 1703-13, and for Queen's County 1713-5. On

192 i 12-13 Fitzpatrick, Richard : for and in 1774 Fitzpatrick read Fitzpatrick was M.P. for Okehampton 1770 to 1774 , and in the latter year

37 after secretary insert He was A.D.C. to the king 1782-93

38 after 1782, insert was M.P. for Maryborough in the Irish House of Commons 1782-3,

ii 3-5 omit and in $1804 \ldots$ the ordnance

8 after war insert and he was concurrently lieutenant-general of the ordnance

201 ii 37 Fitzroy, Charles, 1st Baron Southampton : before In 1760 insert He was M.P. for Orford 1759-61, for Bury St. Edmunds 1761-74, and for Thetford 1774-80.

202 i 19 f.e. Fitzroy, Lord Charles : for 1784 read 1787

12 f.e. after charity. insert He was colonel commandant of a battalion of the 60th foot $1804-5$, and colonel of the 48 th foot from 1805 till death.

203 i 7 Fitzroy, Sir Charles A. : after 1853, insert He was made K.C.B. in June 1854.

11 f.e. Fitzroy, George, Duke of Northumberland: before He commanded insert He was made colonel of the 2 nd troop of horse guards in 1686 .

5 f.e. $\quad$ after 1702-3 insert from which he was transferred to the 2 nd troop of horse guards in Jan. 1711-12

3 f.e. $\quad$ before was sworn insert became lord-lieutenant of Berkshire in 1712,

ii 2 after seats. insert He was deprived of his lord-lieutenancies and his colonelcy after George I's accession.

35-36 Fitzroy, George H., 4th Duke of Grafton: for Euston entered parliament ... conservatives read He was M.P. for Thetford 1782-4. In 1784 the tories

52-53 for For some years read From 1784 to 1807

205 ii 19 Fitzroy, Henry, 1st Duke of Grafton : for 1682 lie became an elder brother read 1682-3 he was master

after House insert was (1681-8 and 1688-9)

206 ii 19 Fitzroy, Henry (1807-1859): for and 1832 read as a conservative

after government. insert He joined the Peelites and ultimately became a liberal.

214 ii 2 Fitzthedmar, Arnold: for Hastings read hustings

224 ii 4 Fitzwilliam, Charles W. W., 3rd Earl Fitzwilliam : for 1807 read 1806 for the county of York read Malton, and in 1807 for Yorkshire for the same constituency. read the latter constituency. In 1830 he was elected for Peterborough.

227 i 11 Fitzwilliam, Fanny E.: for 11 Nov, read 11 Sept.

ii 16 Fitzwilliam, John : for also read in 1688

for in 1699 read 26 March 1699

228 i 37

229 ii 9

Fitzwilliam, Richard, 7th Viscount Fitzwilliam: before On 4 Feb. insert He was M.P. for Wilton from 1790 till death.

230 i 11 f.e. Fitzwilliam, Sir William (1460?-1534): for Bread Street read Broad Street

231 i 15 f.e. Fitzwilliam, William, Earl of Southampton : for he was read he was elected M.P. for Surrey and was 
Page Col. Line 232 ii 37

236 ii 6

241 i 13

253 ii 2

18

10 f.e.

6 f.e.

254 i 2

18 f.e.

255 ii 28

258 ii 4

5

15 f.e.

259 i 12

ii 26

261 i 14-15

Fitzwilliam, Sir William (1526-1599): before In 1560 insert In 1559 he was elected M.P. for co. Carlow in the Irish House of Commons.

Fitzwilliam, William W., 2nd Earl Fitzwilliam : for secretary at war read secretary in the military department

Flambard, Rannulf : for 2031 read 203

Flavel, John (1630?-1691) : for presbytery read classis

for the first indulgence (1671) read the indulgence of 1671

for 1673 read 1671

after 1814 insert 1822

for 1682 read 1681

for 1754 read 1716, 1754, 1770 (Paisley)

Flaxman, John: for Ann Denman, read Ann (1760 ?-1820), daughter of William Denman, a gunstock maker of Mansell Street, Whitechapel, for sister read half-sister after Denman insert (b. 1779)

for 6 Feb. read 7 Feb.

for church read burial ground

after private hands. insert The Flaxman Gallery at University College, London, was founded by Maria Denman.

Fleet, Sir John : for soon afterwards ... been knighted. read of Langbourn ward two days earlier, being knighted soon afterwards.

for 1695 read 1694

after pany insert serving for two years and being re-elected 1698-1700, 1702-4, and 1706-8

266 i 6f.e. Fleetwood, George ( $f$. 1650 ?): for Tangiers read Tangier

l.l. after 246). insert A miniature by S. Cooper dated 1647 belongs to G. Milner Gibson Cullum, Esq., F.S.A. By his wife Katherine, daughter of John Oldfield of London, Fleetwood had two sons, John and Robert, and a daughter, Ann. The descendants of the son Robert were living in London in 1717.

267 i 20 f.e. Fleetwood, James: after shire. insert He was vice-chancellor of Cambridge University in 1663 and 1667.

268 i 9 Fleetwood, Thomas: for Thomas read Peter

ii 7 Fleetwood, William (1535?-1594): after London insert in 1584

271 i 27 Fleetwood, William (1656-1723): after 1705 insert and 1736

276 i 25 Fleming, sir George : for 1700 read 1700-1

281 ii 5 f.e. Fleming, Patrick: for the elector of Saxony read the elector Palatine

287 i 28-31 Fleming, Sir Thomas: for No new writ, however..... Index, i. 1028). read A new writ was issued for Southampton in his place 9 Nov. 1605.

300 i 19 Fletcher, Giles (1549?-1611): after Winchelsea. insert He was remembrancer of the city of London Jan. 1586-7 to 1605 .

303 i 29 Fletcher, sir Henry : after eighteen years insert (1769-87)

before Fletcher insert $\mathrm{He}$ was chairman 1782-3.

after Fletcher insert then chairman of the company

313 i 34 Fletcher, John W. : for Mr. Ireland, who now read Charles Greenwood, who

315 i 37 Fletcher, Joseph (1784-1843): after D.D. insert He was chairman of the Congregational Union in 1837.

316 ii 31 Fletcher, Phineas : for Ezekiel Clarke read Ezekiel Charke

318 i 21-20 Fletcher, Richard (d. 1596): for her father's . . . . which read the see of Bristol, f.e. which her father founded in 1542 and

321 ii 16 Fletcher, Thomas : for (1664-1718) read (1666-1713)

17-19 for Thomas Fletcher.... 1664 read John Fletcher of Winchester was born at Avington, Hampshire, on 21 March 1666

20 for Winchester School and read Winchester School. He matriculated at Balliol College on 9 April 1685, but on 12 Sept. following entered

23-30 for $\mathrm{He}$ was a fellow .... do not establish the fact. read He became fellow of New College, but resigned on his marriage in 1702 . He held the living of Fairfield, Somerset, in 1694, was prebendary of Barton David in the Cathedral of Wells from 1696 till death, and became an under-master of Winchester School in 1701 . He was fellow of Winchester from 12 Sept. 1711 till his resignation next year. 
Page Col. Line

321 ii 23-18 f.e.

330 ii 21

10 f.e.

9-7

f.e.

$337 \quad$ i 2

Fletcher, Thomas : for Fletcher died . Staffordshire. read Fletcher died in
1713 and was buried in Winchester Cathedral. By his wife, a daughter of William Master, a fellow of New College, he had three sons, Thomas, Philip, and William.

Flood, Sir Frederick : for county Wexford read Enniscorthy, and sat for that constituency till 1783. From that year till 1790 he was M.P. for Ardfert and in 1796-7 for Carlow borough

for all the great read many

for 1800 read 1812

omit but was appointed .... Wexford in 1814

Florio, John : after Londra.' insert 'Apologia . . . scritta contro un heretico,' 1557 , is also attributed to him.

Flowerdew, Edward : after Gresham. insert He was M.P. for Castle Rising 157284.

Floyd, Edward : for Charles I read James I

Floyd, Sir John : for 1817 read 1813

Fludyer, Sir Samuel : omit at the election of $\mathbf{1 7 5 9}$

Foldsone, John : for [see MeE, SaraH] read [see MeE, Anne]

Foley, Thomas : for in William III's read in 1694

omit first parliament

omit and afterwards for Worcester

Foliot, Gilbert : for (d. 1187) read (d. 1188)

for $1147 \mathrm{read} 1148$

for 1187 read 1187-8, according to Le Neve

Foliot, Robert : for was a man of considerable learning .... was celebrated read has been confusedly credited by Bale and others with early experiences which really belong to his predecessor in the see of Hereford, Robert of Melun (see Robert of Melun) omit for his achievements . . . . either Melun or Meaux. for William of Maledon read Robert of Melun

Folkes, Martin : for 1753 read 1752 for (about 1714?) read on 18 Oct. 1714 at St. Andrew's, Holborn

Follett, Sir William W.: for four read five for 1435 read 1425

Fonblanque, Albany: for John Samuel Martin de Grenier de Fonblanque [q. v.]. read John de Grenier Fonblanque, 1760-1837 [q. v.].

Fontibus, John de : after Ely insert erroneously called Pherd by Burton,

Foote, Maria, Countess of Harrington : for descendant read kinsman.

Foote, Samuel : omit member for Tiverton and

Forbes, Sir Charles : after one member only. insert $\mathrm{He}$ unsuccessfully contested Middlesex against Joseph Hume at the general election of 1832 . after Hanover insert receiving an English knighthood in March 1844

Forbes, Duncan (1685-1747) : for 1744 read 1704 before In 1722 insert In 1721-2 Forbes was M.P. for Ayr boroughs. for 1747 read 1847

Forbes, Edward: for Spratt and the Rev. Mr. Daniell .... Asia Minor, read Thomas Abel Brimage Spratt [q. v.] and the Rev. Edward Thomas Daniell, M.A., of Balliol College, Oxford (who died on 24 Sept. 1843 at Adalia, in Syria),

after interesting sites. insert Some sketches by Daniell are in the British Museum.

395 ii 35

396 i $\quad 37-9$

16 f.e.
401 i 19

Forbes, George, 6th Earl of Granard : for lieutenant-general read general

for In 1819 he resigned . . . Forbes, M.P., and afterwards read He afterwards

for $\mathrm{He}$ died read He was made full general in July 1830 and

Forbes, James Ochoncar, 17 th Lord Forbes: before He was made insert $\mathrm{He}$ was colonel of 3rd garrison battalion 1807-9.

for was constituted in 1826 read was from 1825 to 1830

Forbes, John (1714-1796) : for 1764 read 1761 
Page Col. Line

407 ii 17 Forbes, John H., Lord Medwyn: for 1847 ;ead 1849

410 ii 15 f.e. Forbes, Walter, 18th Lord Forbes: for Gomme read Gomm

418 i 17 Ford, Emanuel: for Parsimenos read Parismenos

421 ii 27-8 Ford, Richard : omit and for some time an under-secretary of state

429 i 22 Forde, Thomas : for 'Arcadia'read 'Menaphon'

431 ii 13.f.e. Fordyce, Alexander : for Halifax read Hallifax

435 i 18 f.e. Fordyce, Sir William: for in 1787 read 20 Dec. 1782 


\title{
Dictionary OF NATIONAL BiOgRAPHY
}

\author{
ERRATA IN VOLUME XX
}

\author{
FORREST_-GARNER
}

Page Col. Line

N.B.-f.e. stands for from end and l.l. for last line

13 ii 9 Forster, Ejward (1769-1828): for Somerville Aston read Aston Somerville

15 ii 10-12 Forster, Johann G. A. : for for some years teacher . . . . in a school in Warrington read from 1768 tutor of French, German, and natural history in the Warrington academy

17 i 33-34 Forster, John: for In the December of that year Charles Lamb died; read He was soon a close friend of Charles Lamb.

18 ii 5

24 ii $7-5$

f.e.

25 ii 21

50 i 6-4 f.e.

54 i 20 26

86 i 2-1 f.e.

89 i 8 f.e

91 for 2 Feb. read 1 Feb.

Forster, William (1784-1854) : for daughter of Mr. Buxton .... Joseph John Gurney [q. v.] read daughter of Thomas Fowell Buxton of Earl's Colne, Essex, and sister of Sir Thomas Fowell Buxton [q. v.]. for aged 70 read aged 69

Fortrey, Samuel : for and again in Whitworth's .... in 1856, read in Sir Charles Whitworth's 'Scarce Tracts on Trade and Commerce, Serving as a Supplement to Davenant's Works,' 1778, and in 1856 in the Political Economy Club's 'Select Collection of Early English Tracts on Commerce' (ed. McCulloch),

Foster, James : for Joseph Hallet, sen. read Joseph Hallet (d. 1722). for Joseph Hallet, jun. read Joseph Hallet (d. 1722)

Fowler, Edward : for Glanvil's Saducismus read Glanvill's Sadducismus

Fowler, William (fl.1603): after poet, insert son of Thomas Fowler (d. 1590), executor to the Countess of Lennox, Arabella Stuart's grandmother (cf. E. T. Bradley [Mrs. A. Murray Smith], Life of Arabella Stuart, 1889 passim)

\section{0-11 Fowns, Richard : for Stoke Severn read Severn Stoke}

i 5 f.e. Fox, Charles Richard : for 1831 read 1835

ii 34-35 Fox, Edward : for the hospital read the mastership of the hospital

17 f.e. Fox, Henry, 1st Baron Holland : for 26 Nov. read 16 Dec.

i 24 Fox, Henry R. V., 3rd Lord Holland : for 26 Dec. read 16 Dec.

19 f.e. $\quad$ for Lady Godfrey Webster read the wife of Sir Godfrey Webster

16 f.e. $\quad$ for 'Dobledo's read 'Doblado's

i 3 Fox, John ( $f$ l. 1676) : for Calamy's Nonconf. Memorial (Palmer, 1802), read Palmer's Nonconf. Memorial (London, 1802),

25 Fox, Luke : for iv. 331-2 read iv. 305-6

i 25 Fox, Robert W.: for eighty-eighth read eighty-ninth

ii 17 f.e. Foxe, John: for 1629 read 1630

16 f.e. for twelve read eleven

5 f.e. $\quad$ for 1641 read 1642

156 i 2-1 Foxe, Samuel : for A treatise on the Apocalypse dedicated to Archbishop read f.e. The Latin treatise on the Apocalypse dedicated by him to Archbishop

ii 1 for is said to have been written by him. read was written by his father.

ii 2 f.e. Frampton, Robert: omit about 1651

ii 28 for some time in the autumn of 1690. read on 1 Feb. 1690-1. 
Page Ool. Line

162 i 22 f.e. 163 Frampton, Tregonwell: for Anglia Notitia read Chamberlayne's Angliæ Notitia

174 i 27 Francis, Sir Philip: for Chatham read Mansfield

177 ii 18 for a Swiss merchant, read a Swiss officer in the East India Company's service,

6 f.e. $\quad$ for 1779 read 1780

178 ii 28 for in the spring of 1808 , read on 2 Jan. 180:,

180 i 23 f.e. for iii. 258 read ii. 258

9 f.e. for Lang's read Laing's

181 ii 10 f.e. Franck, Richard: for Böhm's read Böhme's

185 ii 12 Frank, Mark : for the following year read the same year

210 ii 40 Fraser, James (1818-1885) : for Perceval read Percival

53-54 for and on 15 June 1880 read Three months before

211 i 22-24 for a rolume of his sermons edited by J. Doyle was published. read two volumes of his sermons appeared, edited by J. W. Diggle, the author of 'The Lancashire Life of Bishop Fraser,' 1889.

213 ii 6 Fraser, James S. . for eighty-third year v'ead eighty-seventh year

216 i 2f.e. Fraser, Robert W.: for 1847 read 1844

223 i 13 Fraser, Simon: for is or was preserved at Farnton House, read is preserved at Farraline House,

229 i 4 Fraunce, Abraham: after Ramus.' insert A manuscript Latin comedy called 'Victoria,' dedicated to Sir Philip Sidney, together with a manuscript copy of the work numbered 1 supra, is at Penshurst (Hist. MSS. Comm. Rep. iii. 230).

233 i 17 f.e. Frederick, Colonel : for 23738 read 23798

ii 33-34 Frederick, Augustus, Duke of York and Albany : for. Frederick abandoned his. episcopal title on being created read Frederick, who retained the bishopric of Osnaburg till 1808, was created

235 i 36-37 for opposition to a speech read opposition to it in a speech

240 ii 23 Freeman, Philip: for 'The Real Science read' The Real Presence

244 ii 20 Freind, Robert: for Freind read his son William

267 ii 26 Frere, John: for Frere also went to Trinity, read Frere went to Caius College, where he was elected scholar,

268 i 37 Frere, John H. : after a fellow of Caius insert (1793-1816)

269 i 3

278 i 3 f.e. for 1812 read 1816

Friswell, James H. : for 1861 read 1858; 3rd ed. 1861 for 1865 read 1864 for 1868 read 1865

Frobisher, Sir Martin : for Isabel, read Isabel, whom he married 30 May 1559 for Thomas Riggat read Thomas Rickard of Snaith

after 1878 ; insert J. J. Cartwright's Life of Frobisher in Chapters in the History of Yorkshire, 1872;

290 ii 9

294 ii 3

5

315

316 ii 11 f.e.

317 ii $\quad 36$

318 ii 23

319 ii 14 f.e.

342 i 25

Frodsham, Bridge : for he never left York, where he died 26 Oct. 1768, read he rarely left York. He died at Hull 21 Oct. 1768,

Froucester, Walter : for the Blessed Virgin read S. Mary de Lode

Fry, Elizabeth : for eldest child read third daughter

for $\mathrm{Her}$ brother was read Her younger brothers included Daniel Gurney [q. v.] and

Fuller, Samuel : for 1682 read 1692

28 Fuller, Thomas (1608-1661): for St. Peter's, Aldwincle read Aldwincle St. Peter

for at Boughton read of Boughton

for 1738 read 1638

for position read petition

for granddaughter read descendant

for Rederivus read Redivivus

Fyneux, Sir John : for 1526 read 1527

for 1505 read 1515

for privileges read privilege

for but read and but 
Page Col. Line

364 ii 29 Gainsborough, Thomas : for has not been recovered since. read was not recovered till 1901.

376 i 33 Gale, Roger : for Gale left read Gale gave

377 i 21 Gale, Theophilus : for prebend read prebendary

379 i 13 f.e. Gale, Thomas (1635 ?-1702): for bequeathed read given in 1738

5 f.e. $\quad$ for $1671-70$ read 1671

380 i 15 for Nicholson's read Nicolson's

381 ii 17 Gall, Saint: for near the bay of Carrickfergus, vead at the mouth of Belfast Lough,

386 ii 28 Galloway, Patrick: for 12 Jan. read 14 Jan.

389 ii 10-11 Galt, John : for the daughter of Dr. Tilloch, real Elizabeth, daughter of Alexander Tilloch [q. v.],

390 i $26 \quad$ for 1817 read 1820

391 ii 15 f.e. after family grave. insert He left two sons, Sir Alexander Tilloch Galt, who became premier of Canada, and Thomas Galt, who became a judge.

394 i 34 Gambier, James, Lord Gambier : for 1799 read 1795

399 i 35 Gammage, Robert G. : for G- (d. 1888) read GEoRge (1815-1888)

37 after Northampton insert born in $\mathbf{1 8 1 5}$

404 i 14

423 ii 16

Garbett, Edward : for Hereford College read Hereford Cathedral School

Gardiner, Stephen : for 1551 read 1550

29 for 18 April 1552 read 15 Feb. 1550-1

432 ii 16 f.e. Gardner, William L. : for (1770 read (1771

433 i 37 for Nepaul read Kamaun

ii $\left.\begin{array}{r}10 \\ 27\end{array}\right\} \quad$ for Parks read Parkes

29

436 i 2 Gargrave, Sir Thomas: omit Thomas

ii 14 Garland, Augustine : for Tangiers read Tangier

437 i 17 f.e. Garland, John : after Henry III. insert The name Garland was familiar in London. One John Garland was prebendary of St. Paul's in 1200 (Le Neve, ii. 417); another was sheriff of London in $\mathbf{1 2 1 2 .}$ 



\section{DicTiONARY OF NATIONAL BIOGRAPHY}

\section{ERRATA IN VOLUME XXI}

\section{GARNETT_-GLOUCESTER}

Page Col. Line

N.B.-f.e. stands for from end and l.l. for last line

5 ii 14 f.e.

6 i 3 f.e.

Garnett, John : for Lynam read Burdy

13 ii 14 f.e. Garraway, Sir Henry: for when Garraway read It is commonly stated in error that then Garraway

9 f.e. after acclamation. insert Garraway's alleged speech was a tract written by Hyde for publication.

7 f.e. $\quad$ for On his way home he read The writer of the published oration fancifully asserted that Garraway on his way home

14 ii 44-45 Garrett, Jeremiah L. : for Christ's College read Christ's Hospital

30 i 3 f.e. Garter, Bernard : for Braystocke read Brigstocke

35 i 15 Gascoigne, Sir Bernard : for 17 Oct. read 24 Sept.

16-17 for thirty-one years at the rent of $20 l$. vead forty-four years at the rent of $20 l$. (Sloane MS. 856, f. 8).

ii 31 for Innsbruck read Austria

Gascoigne, George: for Gaston read Gascoigne (not Gaston, as printed in the Calendar)

28-32 for But the identity of Gaston .... librarians assigned to Gascoigne read There is little doubt that Gascoigne was the author of

23-19 for All the best evidence . . . . in pious exercises. read The 'Spoyle' was ref.e.

Gascoigne, Sir Thomas : for (1596? read (1593? for 1596 read 1593

$46 \quad$ ii $\quad 39$

Gascoigne, Sir William : for Harwood read Harewood

50 ii 16

51 ii 8

Gaskell, Elizabeth C. : for her life read her married life for 1865, \&c.) read in 'Household Words,' 1855, \&c.)

56 ii 27 Gassiot, John P. : for he endowed read he helped to endow

15 f.e. after Gassiot insert who was elected a fellow of the society,

62 i 39 Gataker, Thomas : for Goulson read Goulston

83 i 15 Gawler, George : after rank of colonel. insert In 1833 he contributed to 'The United Service Journal,' part ii., a paper called 'The Crisis and Close of the Action at Waterloo, by an Eye-witness,' which was reissued as a pamphlet (Dublin, 1833) and caused great controversy. Gawler contended that his own regiment (the 52nd), supported by the rest of Adams's brigade, and not the guards, defeated Napoleon's final attack. Gawler defended his contention against Sir Hussey Vivian in 'The United Service Journal' for 1833, and was corroborated by W. Leeke in his 'Lord Seaton's Regiment at Waterloo,' 1866. 


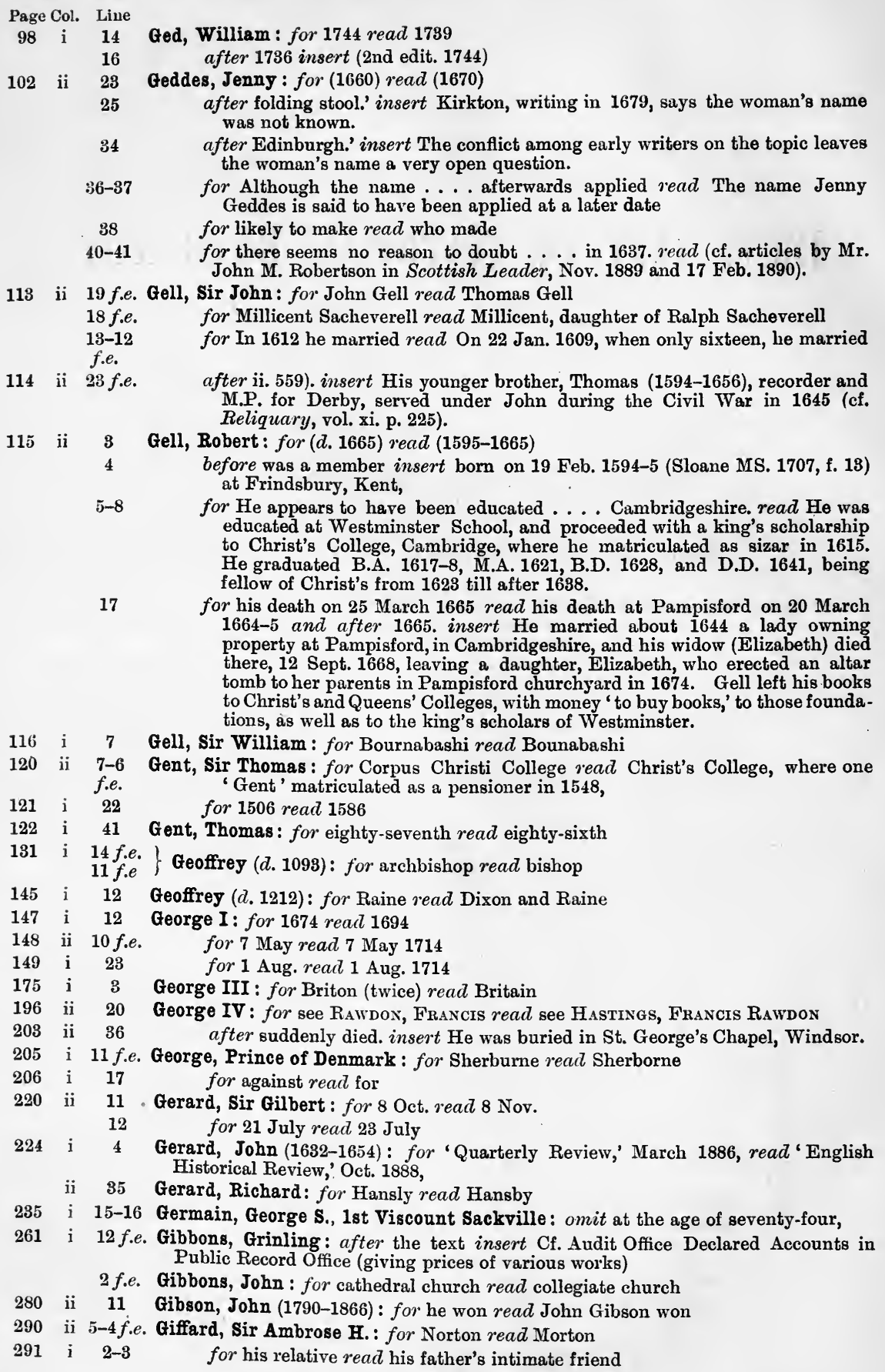


Page Col. Line

294 i 15-14 Giffard, Godfrey : for the Giffards of Weston-under-Edge real the Giffords of f.e. Weston-sub-Edge

295 i 6 f.e. Giffard, John, Lord Giffard of Bromsfield: cifter Prince Edward there insert in March 1264

296 ii 12 Giffard, Stanley L. : omit of cancel

300 ii 33 Gifford, George (d. 1620): after ii. 201). insert He took no degree at Oxford and seems to have graduated B.A. (1569-70) and M.A. (1573) from Christ's College, Cambridge. It is probable that he is the George Gifford who, aged 30, was ordained by the bishop of London both deacon and priest in Dec. 1578.

302 i 12 Gifford, Gilbert: for Achin read Anchine

308 ii 13 f.e. Gifford, William (1756-1826): for Halsworthy read Halsbury

311 i 32 for an elegy beginning read an elegy of which the second line rums

312 ii 20 Gilbart, James W. : for and in Spain at Rio de Janeiro. read at Rio de Janeiro and in Spain.

316 i 9 f.e. Gilbert of Sempringham : after Bollington insert near Wragby

323 ii 31 Gilbert, Davies : for Richard Telford read Thomas Telford

326 i 33 Gilbert, Sir Geoffrey : for Remington read Runnington

ii 3 f.e. Gilbert, George : for $(1559$ ? read $(1555$

327 i 1

for about 1559 and read in 1555 , and was grandson of William Gilbert of Clare, Suffolk (cf. Vincent's Grants of Arms, vol. ii. 380, in library of College of Arms)

330 i 33 Gilbert, John ( $f$. 1680): for had a charge in Peterborough read was vicar of St. John the Baptist in Peterborough

$\begin{array}{cccl} & \text { ii } & 23 & \text { Gilbert, John }(1693-1761): \text { for } 63 \text { read } 68 \\ 337 & \text { i } & 5 & \text { Gilbert, Thomas }(1720-1798): \text { for George Craufurd real Lieutenant-Colonel }\end{array}$ George Craufurd

346 ii 26 Gilderdale, John : for Essex read Yorkshire

355 ii 27 Gill, William J.: for 1881) real 1882)

356 i 29 for Baker read Baber

357 i 8 for 1881 read 1882

365 ii 26 Gillespie, Thomas: for the extended veal the erroneously extended

370 i 14 f.e. Gillies, Robert P.: add to works 16. 'Ranulph de Rohais: a Romance of the Twelfth Century,' 3 vols., 1830, 8vo.

383 i 32 Gilpin, Sawrey: for Gilbert read Gilpin

397 ii 17 f.e. Girtin: for Mr. Henderson read Mr. Henderson's son

408 i 22 Glanvill, Joseph : for 1675 read 1655

411 ii 18 f.e. Glanville, Gilbert de : for Stroud read Strood

422 ii 8 f.e. Glazebrook, James : for Glasebrook read Glazebrook

426 i $17 f . e$. Glemham, Sir Thomas : omit According to Wood

16 f.e. for he read $\mathrm{He}$ and omit gentleman

15 f.e. after Trinity College insert which he entered in 1610

431 ii 16 Glendower, Owen : for 9 Sept. read 9 July

433 i 14 for was real was not omit not

438 i 28 Glisson, Francis : for 14 Oct. reacl 16 Oct. 



\title{
Dictionary OF NATIONAL BiOgRAPHY
}

\author{
ERRATA IN VOLUME XXII
}

GLOVER-GRAVET

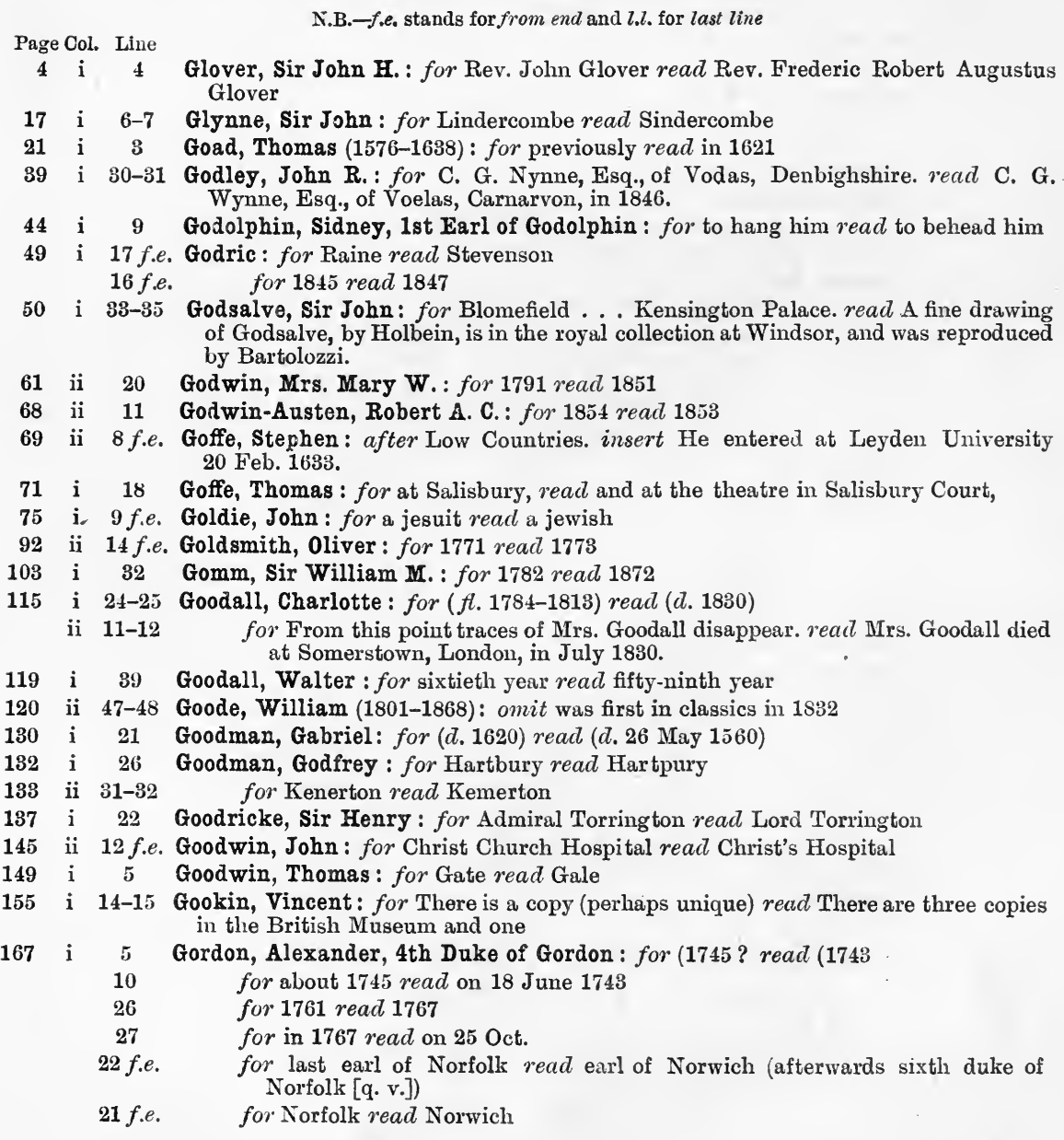


Page Col. Line

161 ii 16

178

203

209 ii

214 ii

219 i
17
220 ii 8
221 i 25
29-30
30
31
14 f.e.
11 f.e.
ii 21

10 f.e.

Gordon, Alexander, 4th Duke of Gordon: before Anderson's Scottish Nation insert Douglas's Peerage of Scotland, ed. Wood;

Gordon, George, 4th Earl of Huntly : for Margaret real Jane

15 f.e. Gordon, Henrietta : for in his house read in the house of James Crichton $(d .1650)$ [q. v.]

Gordon, James B. : omit [q. v.]

Gordon, Sir John, 1st Viscount Kenmure : for in $1721 \mathrm{read}$ about 1627

Gordon, Sir John W. : for (1805 read (1814

for in 1805 read on 4 Nov. 1814

for 1823 read 1833 and for twenty read ten

Gordon, Lucie : for Brandenberg read Brandenburg

Gordon, Osborne: omit double for to the university read in Christ Church for he succeeded read he served as one of the proctors and succeeded omit proctor in the university and for on the board of read one of the for houses read heads of houses for the board of commissioners read the Royal Commission

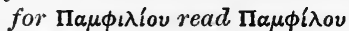

226 ii 13-16 Gordon, Robert (1580-1661) : omit In the edition of $1655 \ldots$ in uncomplimentary terms.

260 ii 4-6 Gosse, Philip Henry: for who helped him to embody them .... in two volumes. read who embodied them in his handsome work (in two volumes) on the subject in 1886 .

262 i 29 Gosset, Isaac (1735 ?-1812): for 16 Dec. read 12 Dec.

263 i 21 f.e. Gosson, Stephen : for (1555 read (1554

20 f.e. for born in 1555, read baptised at St. George's, Canterbury, April 17, 1554, was son of Cornelius Gosson and

269 i 16 f.e. Gouge, Robert : for (1631? read (1630

11 f.e. $\quad$ for 11 March 1646-7 read 8 June 1647

10-3 for Robert Gooch, ..... his early education. read Robert Gouge, born at f.e. Chelmsford, and having been educated there, was admitted at the age of seventeen a sizar of the college. Another entry in the college registers records the admission on 11 March 1646-7 of one Robert Gooch of Great Yarmouth, with whom the independent divine has been wrongly confused.

277 i 1-4 Gough, John ( $f$. 1570) : omit He revised and edited with a preface . . . Wycliffe's translation of the Bible.

282 i 9-10 Gough, Strickland : for ( $f$. 1730-1751) read (d. 1752)

12 omit not earlier than $\mathbf{1 7 1 5}$

13 f.e. $\quad$ after parish. insert He died on 13 Dec. 1752.

289 ii 13-14 Gouldman, Francis: for Prebendary John Boys's read the work by Prebendary John Bois [q. v.] entitled

298 i 19 Gower, Henry : for Monckton read Monkton

300 ii 18-19 Gower, John: omit lost. It is described as

21-22 omit also stated to be

28-29 for The work has disappeared and left no trace. read The 'Speculum Meditantis,' which was long believed to have disappeared, is clearly identical with the 'Mirour de l'Omme,' a French poem of some thirty thousand lines, which was discovered by Mr. G. C. Macaulay in a manuscript in the Cambridge University Library and was printed by him in his edition of Gower's works. A few pages are missing at the beginning of the manuscript.

303 i 18 f.e. for and Cressida read with Cressida

311 ii 25 f.e. Grafton, Richard : after the printer of insert the first book of Homilies in 1547 and

22 f.e. $\}$ Graham, George (1675-1751): for 1675 read 1673 [q. v.] 
Page Col. Line

363 ii 22 Graham, William, 7th Earl of Monteith : after payment. insert But this was never paid.

389 ii 21 f.e. Grant, Sir James (1738-1811): after Seafield. insert He was admitted fellowcommoner of Christ's College, Cambridge, in 1756, and graduated M.A.next year.

390 i 18 for Seafield read Seaforth

417 i 35 Grascome, Samuel: for (ib. read (Hasted's Kent

ii $2 \tilde{5}$

for [Dr. Grove] read [Dr. Robert Grove, q. v.]

after pulled off' insert 1704

after England Man' insert 1702

after Church' insert 1719

after Englishmen' insert 1699 and after Contrivances 'insert 1693

424 ii 19 Grattan, Henry : for Blackford read Blachford

439 i 20 f.e. Graves, Thomas, Lord Graves : for De Grasse read Sir Samuel Hood

441 i 17 Graves, Sir Thomas : after active service. insert The Foudroyant carried his flag in the Bay of Biscay from Oct. 1804 to Feb. 1805 [see Nesham, Christopher].

442 i 32 Gravesend, Richard de : for p. 264). read iii. 264). 12 f.e. for (ib. read (Dunst. 



\title{
Dictionary OF NATIONAL BIOGRAPHY
}

\author{
ERRATA IN VOLUME XXIII
}

\author{
GRAY-HAIGHTON
}

112 i 5 Grenville, Sir Bevil : for 1702) read 1703)

116 ii 9f.e. Grenville, George: for first earl read second earl 
Page Col. Line

121 ii 14 f.e. Grenville, John, Earl of Bath : for Grenville read Granville

123 i 36 Grenville, Sir Richard: for Vercera read Tercera

130 ii $\quad 39$

182 ii 2

151 i 5

156 i 11

159 i 10

11-12

12

160 i 1

162 ii .l.l.

175 i 1

181 i 34

ii 25

183 ii $5-6$

26-27

37

184 i 9 f.e.

5 f.e.

186 i 15 f.e.

188 ii 38

192 ii 13

193 i 17

33

50-52

197

19 f.e. for the ninth baron read third baron

17 f.e. $\quad$ for great-grandson read great-great-grandson

16 f.c. for eighth baron Hastings (d. 1313) read second baron Hastings (12621313) [q.v.]

12 f.e. $\quad$ for son read brother

9 f.e. $\quad$ for gules a manche or read or a maunche gules

200 i 23

29

216 i 18 f.e. Grey, William de, Lord Walsingham : for Wyndham read Windham

16 f.e. for Christ's College read Trinity Hall

234 i 8 Griffith, Matthew : after pt.ii.p. 33). insert Migrating to Cambridge, he graduated M.A. from Christ's College in 1621.

234 ii 12

238 ii $2-4$

$249 \quad$ i $\quad 37$ ii 20 f.e.

9 f.e.

9-6

f.e.

$\mathbf{2 5 0}$ i $\mathbf{3 0}$

f.e. Grimshawe, Thomas S.: for Coldwell Priory read Caldwell Priory

i 9 f.e. Grimston, Sir Harbottle : for 1628 read 1648

ii 11 f.e.

omit near 
Page Col. Line

261 ii 16 Grindal, Edmund : after Christ's College, insert where he was scholar in 1536-7, 19 f.e. for 1541 read 1551

266 ii 28 Grisoni, Giuseppe : after Cibber, insert (now at the Garrick Club)

283 ii 8 Grosvenor, Sir Thomas : for 1705 read 1705-6

307 i 20 f.e. Gruffydd ab Llewelyn : for Llewelyn read Llywelyn

322 ii 7 f.e. Guidott, Thomas: for Addit. MS. read Sloane MS.

328 i 8 Guildford, Sir Richard : for 1458 read 1485

335 i 15 f.e. Gully, James M. : for Two years read Three years

338 i 10 Gumble, Thomas: after biographer insert for some time vicar of Chipping Wycombe, Bucks (cf. Lamb MSS. Aug. 972, p. 79 ; Price, the King's Restauration, p. 35)

340 i 23

341 i $\quad 38-39$

21-19

f.e.

346 i 28

349 i 8

386 ii $39-40$

387 ii 4

394 i 31

32

35

ii 38

413 i 10

416 i 31

32-33

Gundulf: for the archbishop read the monks under the influence of the archbishop

for really belongs to the fifteenth century, read is composed of rough slabs of stone with neither inscription nor moulding to mark its age,

for It is said that a large Bible . . . . and which contained read Gundulf's Bible, formerly at Amsterdam, and more recently in Sir Thomas Phillipps's collection, contains

Gunning, Peter : for Lord Hatton read Lord Hatton's son

Gunning, Sir Robert : for xliv. 400 read 10 Rep. App. p. 400

Guy of Warwick: omit daughter of Siward of Wallingford

for Early in Edward I's reign read In 1268

Guyse, John : for was ordained read began to preach

for $\mathrm{He}$ was chosen assistant to read $\mathrm{He}$ sometimes assisted

for on his death soon afterwards. read in the charge 27 Sept. 1705.

before John Conder's insert Urwick's Nonconformity in Hertfordshire, pp. 542 et seq.;

Haast, Sir John F. G. von : for governor-general read surveyor-general

Hack, Maria : for 1778 ? read 1777

for Chichester, Sussex, about 1778. read at Carlisle on 16 Nov. 1777. Her father was John Barton of that city; her mother's maiden name was Maria Done, and a younger brother was Bernard Barton, a friend of Charles Lamb. On 7 Nov. 1800 she married, at Tottenham, Stephen Hack, merchant of Chichester. Her eldest son, John Barton Hack, was an early settler in Adelaide; a daughter, Margaret, married T. Gates Darton, the publisher, and was author of 'The Earth and its Inhabitants.' On her luusband's death she removed to Southampton, and.with some of her children joined the church of England (Athenaum, 24 Dec. 1892).

428

424

435

i $\quad 7-6$

f.e.

ii 2

4

441 ii $2-3$
4 Hackston, David: for Scottish read Cobbett's

ii 3-4 Haddan, Arthur W.: for William Henry Guillemard [q. v.] read Henry Peter Guillemard

for voted for read supported

Hadley, John: for In early manhood he was already skilled read He must be distinguished from an older John Hadley who was also skilled

after granted him' insert in 1693

for Hadley read the younger Hadley

Haigh, Thomas: for the overture .... flute read 'Lodoiska' for flute (see Clementi's Catalogue) 



\title{
DicTiONARY OF NATIONAL BIOGRAPHY
}

\author{
ERRATA IN VOLUME XXIV
}

\author{
HAILES-HARRIOTT
}

\begin{abstract}
Page Col. Line
N.B. -f.e. stands for from end and l.l. for last line

v ii 8 List of Writers : for W. H. . . W. HAINes read W. H-s . . W. Harnes

5 i 16 f.e. Haines, William : for the Earl of Stanhope read Earl Stanhope

10 i 15 Hakewill, John : omit [q. v.]

17 i 25 Haldimand, Sir Frederick : for 1853 read 1883

18 i 31 Hale, Sir Matthew : for Magdalen College read Magdalen Hall

27 i 13 f.e. Hales, Sir Edward, titular Earl of Tenterden : for lord Weston read lord Wotton

29 ii 29-30 Hales, John (d. 1571) : omit He was clerk . . E Edward VI.

30 i 1-3 for Later in the reign ... Strasburg read On Somerset's fall Hales fled from England and in 1552 was at Strasburg

9 before He returned insert His property was confiscated in 1557.

15-17 omit Hales was restored ... Cal. Dom. i. 125-6).

18 for 1560 read 1564

17 f.e. $\quad$ after Christopher. insert Hales has been confused by Strype and subsequent writers with the John Hales who was clerk of the hanaper under Henry VIII, Edward VI, Mary, and Elizabeth (The Domesday of Inclosures, ed. Leadam, 1897 , p. 5 , note 6 )

33 ii 32 Hales, Stephen: for 195 read 198

44 ii 35 Haliburton, Thomas C.: for 1825 read 1823

40 for 1839 read 1840

17 f.e. $\quad$ for 1843 read 1852

15 f.e. $\quad$ for 1843 read 1853

14 f.e. $\quad$ for 1843 read 1849

12 f.e. $\quad$ for 1843 read 1854

9 f.e. $\quad$ for 1850 read 1851

4 f.e. $\quad$ for Wool read Wood

48 ii 25 Halkett, Lady Anne: for Lady Anne or Anna read Anne or Anna, Lady

56 i $\quad$ l.l. Hall, Arthur : for John Hall read Francis Hall

68 ii 9 Hall, Sir James : after 1776. insert He entered Christ's College, Cambridge, in 1777 , but took no degree.

i 11 f.e. Hall, John (1739-1797): after churchyard. insert He married Mary de Gilles, of Huguenot descent, and was father of George William Hall, master of Pembroke College, Oxford (1770-1843), and of Julia, wife of Rann Kennedy [q. v.].

97 i 37 Hallam, Henry : for Philips read Thomas Phillips

106 ii 1 Halley, Edmund : for Dr. Sykes read Dr. Sike

107 ii 18 f.e. for Professor Rigaud read Stephen Jordan Rigaud, bishop of Antigua

112 ii 4 Halliday, Michael F.: after Wimbledon insert in 1862

117 i 22-21 Halliwell-Phillipps, James 0.: for but the order excluding . . not rescinded. f.e. read On 12 June 1846 the British Museum authorities informed Halliwell that readmission would be granted him if application were made.
\end{abstract}


Page Ool. Line

119 ii 10

120 i 11

12-13

133 i 27

167 ii l.l.

168 i 3 f.e.

ii 6 f.e.

179 i $6-5 f$

179

ii $\quad 22$

185 i 28

24

192

i 15

16

200 ii 27

203 ii 14

209

i $11 f$.e.

214 i 19

223 ii 9

$$
15
$$

237

ii 16 14 f.e.

ii $\quad 19$

23

20 f.e.

19 f.e.

339 i 2-3

Halliwell-Phillips, James 0.: for aged 69 read in his sixty-ninth year forlbut read and although for and it was never conferred. read it was conferred in 1888.

Hamilton, Alexander (d. 1732): for (d. 1732) read (d. 1782?)

Hamilton, James, 2nd Earl of Arran : for second read third for first wife read second wife for 1554 read 1544

Hamilton, James, 1st Duke of Hamilton : for eighteenth year read nineteenth year for 1636 read 1631

Hamilton, James ( $f$. 1640-1680) : for 1666 read 1662 for 1783 read 1736

Hamilton, John (1511?-1571): after together insert in facsimile omit by authority of the Church of Scotland

Hamilton, Sir John (1755-1835) : for eighty-two read eighty

Hamilton, Patrick : for T. B. Johnston of Cairnie read T. P. Johnston of Carnbee

Hamilton, Sir Robert N. C. : for R. T. E. Holmes's read T. R. E. Holmes's

Hamilton, Thomas, 1st Earl of Haddington : for Drumcairne read Drumcairn

Hamilton, Thomas, 9th Earl of Haddington : for Michael Borongh read the borough of Michael or Michell

Hamilton, William (1755-1797) : for 1722 read 1792 for Faust read Fannet

Hamilton, Sir William R. : for Quarternions' read Quaternions'

Hamley, Edward : for 1837 read 1834

for second son read elder son

Hammond, Edmund, Lord Hammond : for 1832, in succession to Palmerston, read 1852, in succession to Lord Granville,

Hammond, Henry : for Bloxam's 'Register of Magdalen College' read Keble's 'Miscellaneous Poems,' 1869, p. 216. for Christian read Christmas

Hammond, John (1551-1617): for (1551-1617) read (d. 1617) omit in 1551

Hampden, John, the younger: for On his deathbed read In 1688 (eight years before his death)

before printed insert two copies in Sloane MS. 3299, ff. 183, 185,

f.e. Hampson, John : for 1748 read 1784

28 Hanbury, William: for 1770 read 1777

38 Hanmer, Sir Thomas : for 1810 read 1710

$6 f$.e. $\quad$ for sixty-eighth read sixty-ninth

Hanna, Samuel : for 1880 read 1808

Hannibal, Thomas : for Sloane MS. read Cotton MS.

-40 Hansell, Edward H.: omit Codex A.B.C.D.Z. et Sinaiticus.

14 f.e. Harcourt, Edward : for burnt down read injured by fire

Harcourt, Robert: for Dollesquebe read Dessequebe [i.e. the Essequibo] for fourth son read third son

$\begin{array}{cl}\text { 39-40 Harcourt, Sir Simon : for earl of Orford read earl of Oxford } \\ 6 & \text { Harcourt, Simon, 1st Viscount Harcourt : for Slebeck read Slebech }\end{array}$

Harcourt, William, 3rd Earl Harcourt: for St. Leonard's Hall read St. Leonard's Hill

Hardham, John : for p. 69 read i. 69

Harding, Mrs. A.: for Mrs. A. (1779-1858), read Mrs. Anne RaIkes (17801858:, for 1779, read 1780, married Thomas Harding, a merchant at Bristol and for at the house read at Boulogne, at the house for Kynaston Groves. read William Kynaston Groves.

15 for Dorchester read Dorset

$$
\text { I } 46
$$


Page Col. Line

343 ii 1

$49-50$

5 f.e.

345 ii 20

350 i 18

362 ii $20-22$

23

25

Hardinge, Sir Henry, 1st Viscount Hardinge : for sketching near the Prussian position read in attendance on Bliicher

for July to December 1834. read December 1834 to April 1835.

for early in 1844 read May 1844

for the present viscount, born 12 Sept. 1822, read second viscount (18221894),

Hardwick, Philip : for survives read died 27 Jan. 1892

Hardyng, John : omit With his master he .... therc. Very soon for afterwards read Afterwards

for and read was present at the battle of Shrewsbury in July 1403, and witnessed Hotspur's death there. Hardyng

365 i 21 f.e. Hare, Francis : after Hoadly. insert Butler wrote a 'Letter of thanks to Dr. Hare for his sermons at Putney,' in which Hoadly was attacked.

for Vatche read Vache

for 1721 read 1731

8

16 f.e.

after his death. insert The younger Francis Hare died without issue in 1775.

15-13 omit and a third, Richard, was father of James Hare [q. v.]

366 ii 6 f.e. Hare, Henry, 2nd Lord Coleraine : for Portman read Potman

369 i 38-39 Hare, James : omit and his grandfather was Bishop Francis Hare [q. v.]

373 ii 28 Hare, Robert: for father read, grandfather

376 i 8 f.e. Harford, John S.: omit eldest

37 for visitor read sub-visitor

381 ii 7 Hargreaves, James: for Epinasse's read Espinasse's

384 ii 20-19 Harington, Henry (1727-1816): for in Bath Abbey. read in the chancel of Kelston f.e. Church.

38.5 ii 11-12 Harington, Sir John : for Christ's College, Cambridge, . . his tutor John Still, read King's College, Cambridge. It is possible that he afterwards migrated to Trinity College. He acknowledged much indebtedness to John Still, master of Trinity (from May 1577) and

392 ii 5-6 Harley, Sir Edward (1624-1700) : for Red Marley read Redmarley

393 ii 13-14 for Essington read Eastington

894 i 19 Harley, Edward (1664-1735): for Essington read Eastington

399 ii 17 f.e. Harley, Robert, 1st Earl of Oxford : for Essington read Eastington

401 i 24 for Dewes read Dawes

405 ii 7-8 for Whitley Court read Witley Court

416 i $\quad 85$ Harness, William: for at Cambridge read in London

14f.e. for learned and tenable read and learned

ii $30 \quad$ omit a

429 i 19 f.e. Harper, Sir William : after St. Aubyn insert (Lord St. Levan)

430 ii 18 f.e. Harpsfield, John : after death ; ' insert (first published in 1547 in 'The First Book of Homilies appointed to be read in Churches')

431 ii 3 f.e. Harpsfield, Nicholas: for 1662 read 1622

437 ii 20-21 Harriot, Thomas : for St. Mary's Hall, read St. Mary Hall,

440 ii 16 Harriott, John : for Piedmontaine read Piedmontese 
i

$$
\text { - }
$$




\title{
Dictionary OF NATIONAL BIOGRAPHY
}

\section{ERRATA IN VOLUME XXV}

\author{
HARRIS-HENRY I
}

Page Col. Line

N.B.-f.e. stands for from end and l.l. for last line

1 ii 20

Harris, Charles A : for Wiltshire read Dorset

22-23 for the same county read Wiltshire

7 ii 37 Harris, James (1709-1780): after death insert his son James Harris serving with him as junior member from 1770 to 1774 and from Sept. 1780 till his death in the following December

Harris, James, 1st Earl of Malmesbury : for Since 1770 he had been M.P. read From 1770 until he was called to the upper house in 1788 he was M.P.

13 i 9 f.e. Harris, John (1667?-1719): for (1667? read (1666?

7-3 for about 1667, .... Graduati, 1787, p 180). read about 1666, was son of

f.e. Edward Harris, and was scholar of Trinity College, Oxford, from 1684 to 1688.

14 ii 6

after ii. 282). insert Goddard presented to Thomas Warton a fragment of Harris's autobiography, which is now in the library of Trinity College, Oxford, and is partially printed in Blakiston's 'Hist. Trin. Coll., Oxford,' pp. 172-6.

23 i 9 Harris, Robert (1581-1658): for Lyson read Lyster

25 i 7-6 Harris, Walter (1647-1732): for twice (1699 and 1707) read four times (1699, f.e. $\quad 1707,1713$, and 1726)

35 i 37-38 Harrison, John (1693-1776) : for mechanician read horologist

41 i 8 Harrison, Thomas $(f l .1658)$ : for $(f l .1658)$ read (1619-1682)

49 ii 28 Harrison, William (1813-1868): after sons insert -William Harrison, rector of Clovelly, N. Devon (d. 1897), who married Mary St. Leger, youngest daughter of Charles Kingsley ('Lucas Malet'), and Clifford Harrison, a professional reciter (d. 1904)

68 ii 23 Hartley, David (1732-1813) : for eighty-fourth read eighty-second

72 ii 6 f.e. Hartlib, Samuel : for their read his

73 i 14 f.e. for [1650]. read [1652]; this is the second edition, prepared for the press by. Hartlib, of a work by Sir Richard Weston, which originally appeared in 1645.

19-20 Hartshorne, Charles H. : for from 1825 to 1828 read until 1828

85 ii 6 Harvey, Gabriel; for the possession of Pembroke College read in the British Museum (Sloane MS. 93)

89 ii 6 Harvey, Sir Henry : for L'Orient read Lorient

97 i 15 f.e. Harvey, William (1578-1657) : for Lenox read Lennox

98 ii 39-40 for Burwash in Sussex, read Burmarsh, Romney Marsh, Kent,

102 i 11 f.e. Harwood, Sir Edward : after colonel insert descendant of a Lincolnshire family,

104 ii 22 Harwood, Isabella: for Heirn read Heir

112 i 14 f.e. Hastings, Sir Edward : for Hastings read Pembroke

121 i 11 f.e. Hastings, Francis Rawdon, 1st Marquis of Hastings : for Machline real Mauchline 
Page Col. Line

123 ii 4 Hastings, Frank A. : for 1861 read ed. Tozer, vols. vi., vii., 1877

ii 9 f.e. Hastings, George, 1st Earl of Huntingdon : for Moore read More

131 ii 1 Hastings, John, 2nd Baron Hastings: for Thomas read William

132 i 33 Hastings, John, 2nd Earl of Pembroke: for who read and and for 1839 read

5 f.e. Hastings, Laurence, 1st Earl of Pembroke: for 13 Feb. read 13 Oct.

133 ii 30 Hastings, Selina, Countess of Huntingdon : for same year she appointed read preceding year (1747) she had appointed

11 f.e. Hastings, Warren: for 6 Dec. read 6 Dec. or 18 Dec. (N. S.)

i 17 f.e. for the widow of a Captain Campbell. read the widow of Captain John Buchanan of Calcutta, being daughter, apparently, of Colonel C. F. Scott, commanding at Fort William (cf. Proc. Asiatic Soc. of Bengal, July 1899, p. 79).

145 i 7 f.e. for council read counsel

148 ii 7 Hastings, William, Lord Hastings : for Niddleham read Middleham

167 ii 13 f.e. Haughton, Sir Graves C. : for 1853 read 1835

172 ii 23 Hauteville, John de : for xiii read $\mathbf{x v}$

179 ii 9 Havelock, Sir Henry : after Lady Havelock, insert who died on 25 Aug. 1882,

181 ii 23 f.e. Havergal, William H. : omit in commendam

187 i 17 Haweis, Thomas: for now read and

18 after Chichester insert (1805-1891)

207 ii 19 Hawkins, Edward (1780-1867) : for 13 read 3

209 ii 2 Hawkins, Edward (1789-1882): for still survives read survived and after him. insert Mrs. Hawkins died 14 Jan. 1892.

230 ii 8-6 Hawkins, William (1673-1746) : for (or possibly . . . . in the books). read and was f.e. $\quad$ called to the bar on 29 June 1707.

245 i 7 f.e. Hawley, Sir Joseph H.: for 100,000l. read about 43,000l.

4-3 for really the property of his friend Stanley. read his friend John Massey

f.e. Stanley, afterwards Sir John Stanley Errington, was joint owner (Job Marson, the Jockey, received 1,000l.).

ii 8

after losses. insert Wells, the winning jockey on Musjid and Bluegown, had already won the same race on Beadsman.

9

10-14

303

ii $30-31$ for he read Hawley omit The entire stakes .... Beadsman.

ii 14 f.e. Hayward, Sir John : for 1600 read 1606

11-10 for mentioned by Lowndes .... now accessible. read is in the chapter f.e. library at Peterborough.

i 17 f.e. Healey, John: for John Healey read an English Mercurye

16 f.e. after Blount insert and W. Barrett

13 f.e. omit with the addition 'by an English Mercury'

11-9

f.e.

340 i 23

$f o r$ is a copy with the title . . . . London, n.d. 8vo. read there are three copies.

Heath, Benjamin : for head-master of Eton. read head-master of Harrow 1771-85;

a younger son, George, became head-master of Eton in 1796.

345

346

1 Heath, Nicholas : for 1579) read 1578)

i 24 f.e.

14 f.e. for Cobham read Chobham

15 f.e. $\quad f o r$ in the beginning of 1579. read at the end of 1578 (Loseley MSS.).

347 i 41

ii 7

37

$356 \quad$ i 12

ii 5 f.e.

Heath, Sir Robert: for Heath himself read Sir John Coke [q. v.]

for 1603-16, ii. 286 read 1603-42, iv.-vii.

for 1531 read 1631

Heber, Reginald : for 1773 read 1772

for An only child died before him. read He left two daughters (1) Emily, married to Algernon Charles, eldest son of the Hon. Hugh Percy, bishop of Carlisle, who took the additional name of Heber, and (2) Harriet, married to John Thornton, Esq.

361 ii 26 f.e. Heddi : for HAEDDA read HeadDA 303 ii $26-25$ Hedges, Sir William : for Mythe, Gloucestershire. read The Mythe, near Tewkes-
f.e. bury.

372 i 35 Helps, Sir Arthur: for eldest son read youngest son

37 for Annie Plucknett read Ann Frisquet 


\section{ERRATA-VOLUME XXV}

Page Col. Line

372 ii 14 Helps, Sir Arthur : for Bissel read Bessy

374 i 25 Helwys, Sir Gervase : for Henry's read Mayerne's

30 for 13 Sept. read 15 Sept.

382 i 6 f.e. Hemans, Felicia D.: for in Duke Street, Liverpool read at 118 Duke Street, Liverpool (where a tablet was unveiled 20 Jan. 1899)

ii 20 f.e. $\quad$ for Captain Hemans read Captain Alfred Hemans

383 ii 22 f.e. for Claude read Claude Lewis (1816-93)

395 i 30 Henderson, Alexander (1583 ?-1646): for Grubb's read Grub's

396 ii 6 f.e. Henderson, Charles C.: for daughter of John By, read eldest daughter of Charles William By,

5 f.e. $\quad$ for six read seven and after Kennett insert Gregg

403 i 22 f.e. Henderson, John (1804-1862): for Enly read Exley

411 ii 12-13 Hengham, Ralph de: for John Tollemache, esq. read John, Lord Tollemache

414 ii 36 Henley, John: for Okeham read Oakham

415 ii $3 \quad$ before printed insert sometimes

439 ii 9 f.e. Henry I : for Dunstaple (Dunstaple read Dunstable (Dunstable

448 ii 10 for Robert read Roger 



\title{
Dictionary OF NATIONAL BIOGRAPHY
}

\section{ERRATA IN VOLUME XXVI}

\section{HENRY II- - HINDLEY}

\author{
Page Ool. Line \\ N.B.-f.e. stands for from end and l.l. for last line \\ 10 i 13 f.e. Henry II : for Bloeth (Hist. read Bloeth, and who became provost of Beverley \\ and was elected bishop of Durham about 1210, but the election was quashed (Le \\ Neve, iii. 283; Hist. \\ 13 i 32 Henry III : for i. 21) read ii. 20) \\ 32 ii 35 Henry IV : for 1392 read 1391 \\ 39 ii 11 \\ 43 ii 16 \\ 44 ii 7 \\ 8-9 \\ 29-31 \\ 32 \\ for brother read second cousin \\ Henry V: for Chester read London \\ for seems to have been absent read was absent \\ for In the council held read He returned in June 1404 and \\ for 235) read 231-2, 235) \\ omit On 22 Sept. the king . . . . the rebels.' \\ before Early in 1406 insert Probably in November 1405 Henry led an expe- \\ dition into Scotland in such force that the Scots yielded without fighting \\ and a truce was made for a year (Monstrelet, liv. i. c. 35) \\ 11-10 for and captured Aberystwith. read for the siege of Aberystwith. On \\ f.e. 22 Sept. the king wrote from York that he had 'left his first-born son in \\ Wales for the chastisement of the rebels.' \\ 10-8 omit Glendower .... the English \\ f.e. \\ 6-2 \\ f.e. \\ 50 i 15 f.e. \\ 53 ii 8

$$
\text { 10-11 }
$$ \\ 55 ii 13 \\ $56 \quad$ ii 19 \\ for In November ..... He attended read Aberystwith held out through \\ the winter and probably did not surrender till the autumn of 1408 . Henry, \\ later in 1407, attended \\ for Harfleur read Honfleur \\ for Bourges read Orleans \\ for withdrew to Senlis, read fell back towards Paris, \\ for Chronicle, read Chronicle; \\ Henry VI : for 1428 read 1426 \\ for Whitsunday read Whitsunday 1426 \\ for March read June \\ for (8 May) read (15 May) \\ 76 i 18 f.e. for 1509 read 1609 \\ 91 i 15-16 Henry VIII : for John Dudley, lord Lisle, afterwards duke of Northumberland \\ [q. v.], read Arthur Plantagenet, viscount Lisle [q. v.], \\ 100 i 15 f.e. Henry of Lancaster, Earl of Lancaster : for 1328 read 1308 \\ 102 ii 27 Henry of Lancaster, 1st Duke of Lancaster : omit about 1 Nov. \\ 28 after Scots insert in Aug. (cf. MuRImuth, p. 158) \\ 110 ii 23 Henry Benedict M. C., Cardinal York : for 5 March read 6 March \\ $39 \quad$ for shows read falsely states
}


Page Col. Line

110 ii 41-42 Henry Benedict M. C., Cardinal York: for Soon returning to Italy he was read The tract is a fabrication and its information untrue. Henry was soon

111 i 12 f.e. for the line read the male line

ii 21 for National Gallery read National Portrait Gallery

120 i 33 Henry of Marlborough: for Heb.' read Hib.'

129 i 8 Henry, William $(d .1768)$ : after 4436, insert (edited by Sir Charles King, bart. It was printed in Dublin in 1893)

$$
\begin{aligned}
& \text { (d. 1757), of Ballycumcan, co. Clare, and his wife Mary (d. 1748). } \\
& \text {. }
\end{aligned}
$$

ii 6 f.e.

Hepburn, Francis : for Brecarton read Rickarton

f.e. Hepburn, Patrick, 1st Earl of Bothwell : for Mary read Margaret

Herbert, Edwar after breast insert but he declined the kindness

after are not known. insert A sixth portrait (a bust), assigned to Larkin, is in the National Portrait Gallery.

for It is all in Latin, read In Sloane MS. A. 3957 is a scrivener's transcript with a dedication to Herbert's brother George-in the author's autograph, dated from Paris in 1622. The book is all in Latin, for 1645 read 1633

for the present Earl of Powis read the third Earl of Powis (1818-1891)

for Burlington read Bridlington

Herbert, George: for 1619 read 1618

after Ecclesia insert (5 July 1626)

for was not ordained . . . . the benefice; but the read was ordained deacon about the same time, and the

after 1630. insert He was ordained priest 19 Sept. following.

after also insert an elaborate anonymous memoir published by S.P.C.K. 1893 ;

15 f.e. Herbert, Sir Henry: for second book read second chapter

ii 27-28 Herbert, Mary, Countess of Pembroke : for (1555 ?-1621), born probably . . . about 1555, read (1561-1621), born at Ticknell, near Bewdley, Worcestershire, 27 Oct. 1561,

39-44 omit Shakespeare .... her prime.

for acceptance read some consideration

i 30-32 Herbert, Philip, Earl of Montgomery and 4th Earl of Pembroke : for a Scottish courtier . . . . Earl of Holderness read 'one Ramsey,' who is more probably identical with William Ramsay, page of the king's bedchamber, than (as has been commonly stated) with Sir John Ramsay, Viscount Haddington, and Earl of Holderness. (Cf. THoms, Anecdotes and Traditions, Camden Soc. p. 72.)

213 ii $\quad$ l.l. Herbert, Sidney, 1st Lord Herbert of Lea : for 1855 read 1856

214 ii 34 Herbert, Thomas (1597-1642 ?): for sixth read seventh

218 ii 14 f.e. Herbert, Sir William, Earl of Pembroke : for Sir Robert read Sir Roger

227 i 24-26 Herbert, William, 3rd Earl of Pembroke: omit In December .... Lord Hertford.

228 i $\quad 6-10$

for Other parts of the dedication ..... Shakespeare's 'Sonnets' read Pembroke and his brother knew Shakespeare in his professional capacity of a king's ' servant,' or member of James I's company of actors, and, like almost all the cultivated nobility, admired Shakespeare's literary genius. In Pembroke, as lord chamberlain, the editors of the greatest dramatic publication of the day naturally sought the patron of their venture. There is no evidence that Pembroke was Shakespeare's special or personal patron or came into any direct personal relations with the poet. No value attaches to the suggestion that the dedication of Shakespeare's 'Sonnets' by Thomas Thorpe [q. v.], owner of the published manuscript,

13-43 for his family name-William Herbert ... 1890, passim, and esp. pp. 44-73) read what is inaccurately represented to have been his youthful nameWilliam Herbert. Being the eldest son of an earl he was known in all relations of life from the hour of his birth until his father's death as Lord Herbert. When the 'Sonnets,' with this dedication, were published in 1609, Pembroke's rank and dignity rendered it practically impossible that he should be deprived of those customary formalities of 
Page Col. Line

Herbert, William, 3rd Earl of Pembroke :

address which played a prominent part in all dedications to him which are extant. Thomas Thorpe, the procurer of the MS. of the 'Sonnets' for purposes of publication, subsequently dedicated two books to Pembroke, and approached him there in the conventional tone of exaggerated subservience. There is no good ground for seeking a clue to the mystery of Shakespeare's 'Sonnets' in the publisher's address to Mr. W. H. All the arguments which would identify Pembroke with the youth for whom Shakespeare in the 'Sonnets' professes affection may safely be neglected. (See Wriothesley, HenRy, 3Rd Earl of Southampton, and the 'Life of Shakespeare' by the writer of this article)

237 i 33 Herd, John : for Addit. MS. 1818, art. 5, read Sloane MS. 1818, f. 132,

243 ii 2 Hericke, Sir William : for (1557 read $(1562$

7-8 for born at Leicester in 1557, read baptised at St. Martin's, Leicester, 9 Dec. 1562.

246 i 16 f.e. Heriot, John : for In 1792 read After 1798

13 f.e. $\quad$ for In the same year read Previously in $\mathbf{1 7 9 2}$

248 i 20 Herle, Charles : after tract insert by Edward Gee (1613-1660 [q. v.])

252 ii 6 Heron, Robert (1764-1807): omit 'Pizarro', a tragedy, 1799.

289 i 14 Hervey, Mary, Lady : omit probably

15-18 for there is, however .....(GAGE, p. 319), but read according to the inscription on her tombstone in Ickworth church (cf. GAGE, p. 319, where the year is misread 1706).

19 f.e. for Edith Bellenden read Mary Bellenden

ii 24-26 for to a large family ... qualities which read It was the marked personality of his brothers and sisters-in-law rather than of her own children that

290 i 18 Hervey, Thomas: for (1698 read (1699

23-24 for a university, no doubt to Cambridge, read Christ Church, Oxford,

26 omit apparently

298 i $35 \quad$ Heslop, Luke: for 87 read 86

316 ii 9 f.e. Heydon, Sir Henry: for Solery read Sollars

319 i 5 f.e. Heylyn, Peter : for grandnephew read second cousin

323 ii 9-6 Heylyn, Rowland : for The names .... born in 1562. read He was son of David f.e. Heylyn of Shrewsbury by his wife, Alice, and was grandson of Robert Heylyn of the same place. The Heylyns of Alderton, Shropshire, were his cousins (see Visitation of Shropshive for 1623). His mother, on his father's death, married Thomas Puller of Shrewbury, by whom she had a son, Abraham Puller. Rowland, born at Shrewsbury in 1562, was admitted to the free school there in 1571.

after Alice insert (daughter of Richard Aldworth, of Reading)

15 f.e. for the grandson read the second cousin

14 f.e. for Heylyn's brother read Heylyn

i 24-25 Heywood, Jasper: for the elector of Bavaria, Duke William, read Duke William of Bavaria,

45-46 Hibbert, Robert: for Ballard Nembhard read John Frederic Nembhard

Hickes, George: for a private chapel of Bishop Turner of Ely at Enfield read the oratory of Bishop White of Peterborough at Southgate bably by Samuel Grascome [q. v.])

Higgins, Godfrey: for Haddam Cost Dumfriesshire

Higham, Thomas : for 1796 read 1795

$39-40$ for line engraver under the Findens, read pupil of Greig,

ii 29-30 Highmore, Nathaniel: for entered at Trinity College, Oxford, in 1632, read was scholar of Trinity College, Oxford, 1632-9,

Highton, Henry: for Mitchell read Michel

11 f.e. for 1586 read Oct. 1583 


\section{ERRATA-VOLUME XXVI}

Page Col. Line

397 i 10-12 Hill, John : for He is stated . . . Book of Dignities), read He died in June 1735, and left his estate to his nephew Samuel Hill, second Baron Masham (see Masham, AbigaIL; cf. Gent. Mag. 1735, p. 33; Wright's Essex, ii. 348).

406 ii 36 Hill, Sir Richard : for St. Mary's Hall read St. Mary Hall

410 ii 6 f.e. Hill, Sir Rowland (1492?-1561): for 1761 read 1561

413 ii 18 f.e. Hill, Rowland, 1st Viscount Hill: after 1812. insert He was himself wounded.

414 i 43-44 for Stapleton, Cotton, read Stapleton Cotton,

421 i 25 Hill, Samuel: for Wood read Bliss 


\title{
Dictionary OF NATIONAL BIOGRAPHY
}

\author{
ERRATA IN VOLUME XXVII
}

HINDMARSH-HOVENDEN

Pagie Col. Line

N.B.-f.e. stands for from end and l.l. for last line

2 ii l.l. Hindmarsh, Robert: Note that 'The Trial of the Spirits' was not by Hindmarsh, but was an attack on his 'Vindication of Swedenborg' by the Rev. William Ettrick of High Barns, near Sunderland.

3 ii 9 Hinds, Samuel: for failing health read domestic circumstances

12 i 7 Hirst, William: for Vellour read Vellore

14 ii 17 Hislop, Sir Thomas: for 79 read 78

19 ii 4 Hoadly, Benjamin: for Poor read le Poer

35 i 19-17 Hobart, Robert, 4th Earl of Buckinghamshire : for He continued to hold office f.e.

$15-13$

f.e.

12 f.e.

10 f.e. for from 14 Jan. . 1805, read on $14 \mathrm{Jan} .1805$, but with Sidmouth re... in which year read In June 1804

for but resigned with Sidmouth in 1805 ... the Melville affair. read He resigned with Addington in May 1804.

for rejoined read joined

signed in the following July, in consequence of Pitt's attitude over the Melville affair.

9 f.e. for and from read From

46 ii 15 f.e. Hobhouse, Sir Benjamin : omit wheat

48 ii 53-54 Hobhouse, John C., Baron Broughton : for Horse Guards read House of Lords

59 ii 35 Hodges, Edward R.: for (1825 read (1840

14 f.e. for the article read an article

13 f.e. $\quad$ omit in the 'Encyclopædia Britannica'

4 f.e. Hodges, Nathaniel : for 13 Sept. read 14 Sept. (Sloane MS. 1810, f. 447)

64 ii 14 Hodgkin, Thomas : for John read James

70 ii 17 Hodgson, John (1757-1846): for the age of ninety read a great age

74 ii 30 Hodgson, Mrs. Margaret: for Sharrow read Sharow

93 ii 11 f.e. Hogarth, William : for Gallomania read Gallophobia

97 i 1 for Wyndham read Windham

101 ii 16 Hogg, James (1806-1888): for a religious though unsectarian read an unsectarian

105 i 7 Hogg, Thomas J.: for married read united himself with Mrs. Williams

124 i 12 f.e. 10 f.e. Holdsworth, Richard: for the Poor read le Poer

130 ii 41-2 Holinshed, Raphael: for but the only Holinshed . . . at a possible date read Of two Holinsheds known there at a possible date one was

44 after B.A. insert Christ's College

12 f.e. after of Ascot insert Another Holinshed matriculated from Christ's College in May 1544 and was in residence there as a scholar in 1544-5; it is probable that he was the chronicler.

142 i 36 Holland, Henry (1583-1650?): omit the line

147 ii 19 f.e. Holland, John, Duke of Exeter: for house read church

14 f.e. for 8 July read in Aug. and for two months read a month

156 ii 32 Holland, Sir Thomas, 1st Earl of Kent : for Oruyk read Creyk

44 omit Plantagenet

48-49 omit In his absence ... married 
Page Col. Lime

156 ii $11-10$

f.e.

Holland, Sir Thomas, 1st Earl of Kent: for but on Holland's return .... dissolved read was, before her marriage with Holland, another suitor for Joan's hand. A contract which she made with Salisbury in Holland's absence was annulled 10 f.e. after (1349) insert [See JoAN, 1328-1385]

167

Holles, Gervase: for an only surviving son read a son

Holles, John, 1st Earl of Clare: for at Cambridge, read at Christ's College, Cambridge (becoming pensioner in April 1579 and fellow-commoner a year later),

174 i 2 f.e. Hollins, William : for eightieth read ninetieth

180 ii 26-27 Holloway, Thomas $(1748-1827)$ : for the son of a respectable tradesman .... 1748. read born in Broad Street, London, in 1748, was eldest son of a merchant in easy circumstances who was an early follower of Wesley. His mother's portrait was painted by John Russell [q. v.].

181 i 22

19 f.e. for in February read near Norwich on 29 Feb.

after magnetism. add $\mathrm{He}$ executed portraits in crayon of himself and of a nephew who was captain in the navy.

207 ii 22 f.e. Holt, Joseph : after career. add R. D. the initials of the writer.

16-15 Holt, Thomas: for the public school there. read the examination schools, now part f.e. of the Bodleian Library,

209 i 38 Holtby, Richard : after bridge insert (spending two years at Christ's College and then migrating to Caius College 19 Aug. 1573 at the age of 20)

211 i 12 f.e. Holtzapffel, Charles : for completed read completed by him ; the work was finished by his son.

212 ii 13 Holwell, John Z.: for (d. 1720) read (d. 1729)

213 i 39

215 i 24

48

ii 23

226 i 35

229 i 26

235 ii 27

18 f.e. for Clive and read almost

Holyman, John : for Hanborough read Handborough

Holyoake, Francis : for 87 read 86

Home, Daniel D. : for Monby read Manby

Home, Francis : for 94 read 93

Home, James (1758-1842): for (1758-1842) read 1760-1844)

for death in 1842. read death on 5 Dec. 1844. He was president of the Royal College of Physicians (Scotland) and physician in ordinary in Scotland to Queen Victoria.

243 i 14 f.e. Hone, Nathaniel : for He left surviving read By his wife, Mary Earl, of York, whom he married on 9 Oct. 1742, he left

249 ii 37-39 Honyman, Sir George E. : omit his brother ..... fifth baronet

20 f.e. after 1881. insert His brother, the Rev. Sir William Macdonald Honyman, succeeded as fifth baronet.

250 i 23 Honywood, Mary: for 286 read 256

32 Honywood, Michael : after grandmother. insert Sir Thomas Honywood [q. v.] seems to have been his half-brother.

251 i $12 \quad$ for 85 read 84

29 Honywood, Sir Robert: after bourn. insert Sir Thomas Honywood [q. v.] was his uncle.

257 ii 10 f.e. Hood, Francis G.: for the Duke of Cambridge read Viscount Hardinge

258 i 8 Hood, John : for Carlow read Donegal

29 after legal writer insert son of Matthew Hood by Margery (Risk)

39

after 248). insert Hood married Ellen Gowen of Philadelphia, by whom he left three sons.

258 ii 36 Hood, Robin : omit Gloucestershire and

261 i 20

for 1264 read 1265

for C. A. Ward read H. L. D. Ward

after passim ; insert Rutland MSS. (Hist. MSS. Comm.) i. 305 ;

271 i 21 Hood, Thomas (1799-1845): for 1824 read 1825 and omit had

279 ii 11 f.e. Hook, William: for matriculated from read became commoner of

10 f.e. $\quad$ for 1620 read 1618

9 f.e. $\quad$ for the same year.... resided read 1620.

8 f.e. for some time in Oxford before matriculating, read He only matriculated in the university just before taking his degree. 
Page Col. Line

279 ii 7 f.e. Hook, William : for and Wood . . . saying read Wood says

290 ii 10 Hooker, Richard: for bishop of London read archbishop of Canterbury

294 ii 17 f.e. for Cambridge read Oxford

300 ii 4 Hoole, John : for tutor' read tailor'

303 i 16 Hooper, George : for Hooker read Hooper

54-55 for at the age of read aged nearly

306 'ii 40-41 Hooper, John : omit Another collected edition .... two volumes.

311 ii 39 Hope, Mrs. Anne : after 1887. insert Mrs. Hope's 'First Divorce of Henry VIII' was edited from her manuscript by F. A. Gasquet.

315 ii 25 Hope, Sir James (1614-1661): after committees insert representing Scotland in the English parliament of $\mathbf{1 6 5 3}$

321 i 6 Hope, Sir John, Lord Craighall : for He was one read His brother, Sir James Hope (1614-61) [q. v.], not himself, was one

322 i 26 Hope, John (1725-1786): for 1871 read 1781

323 ii 16 Hope, John, 4th Earl of Hopetoun : for fifty-seven read fifty-eight

327 ii 41 Hope, Sir Thomas (d. 1646): after Edinburgh. insert Gardiner's History of England, viii. 323, ix. 93.

328 i 1

ii 15

331 ii $18-17$

Hope, Thomas (1770?-1831): omit for after (1808-1862) insert for many years M.P. for the city of Gloucester

f.e.

333 ii 10 f.e.

340

346 ii 4 Hopton, John : for Monks read Friars

existence from its foundation; he also

for 1539 read 1529

for 1532 read 1542

347 i 4 f.e.

3 f.e. $\quad$ for 1601 read 1598

354 i 17 Hornblower, Jonathan: for 1800) read 1780)

358 ii 17 f.e. Horne, Richard H. : for Foggs read Foggo

369 i 8 Horner, Francis : for November read October

372 i 9 f.e. Horner, Leonard: after works insert with memoir

53-55 omit A biography . . . 1848. 6.

383 ii 7 Horsley, Samuel: omit was

394 ii 14-12 Hosier, Francis : for Hosier left a widow ... . Richard Hart. read Hosier died f.e. intestate and without issue, his estate passing to his nephew Richard Hosier.

398 i 26 Hoskins, John (1566-1638): for (GARDINER, Hist. 1603-16, pp. 163-4) read (GARDiner, Hist. of England, ii. 246, 249)

399 ii 6 Hoskins, Sir John (1634-1705): for Hoskyns read Hoskins

405 i 9 Hotham, Charles: for Durand read Durant

ii 21$\}$ Hotham, Sir Charles : for 1800 read 1806

405 ii 8 f.e. Hotham, Durant: for (1619? read (1617?

4 f.e. $\quad$ after vol. ii.) He was admitted to Christ's College, Cambridge, 7 May 1632, aged 15.

Hotham, Sir Henry: for the second .... first lord Hotham read Beaumont Hotham, second baron Hotham omit and a daughter

Hotham, John (d. 1337): for Cottenham read Cottingham

$\begin{array}{llll}414 & \text { i } & 17 & \text { Hotham, Sir John }(d .1645) \text { : for the fleet } r \\ & & \end{array}$

20-21 for and to have moved . . . Florence. read but went to Lucca in 1467.

23 after seems insert also after Spain. insert In 1486 he was invited to England by Henry VII. He died in 1487.

Hoton, Richard of: for Lynche read Lytham

Hough, John : for ninety-third read ninety-second

Housman, Robert: for son read nephew

Hovenden, Robert : for iii. read iv. 



\title{
DiCTIONARY OF NATIONAL BIOGRAPHY
}

\author{
ERRATA IN VOLUME XXVIII
}

\section{HOWARD —INGLETHORP}

Page Col. Line

\author{
N.B. - f.e. stands for from end and l.l. for last line
}

4 ii 22 f.e. Howard, Charles, Lord Howard of Effingham: for 1604-5 read 1605-6

10 i 16 Howard, sir Edward : for Ponynges read Poynings

26 ii 29 Howard, Henry, Earl of Surrey : for Woodford read Woodbridge

28 ii 8 f.e. Howard, Henry, Earl of Northampton: for Thomas Howard read Philip

32 i 18 f.e. for 1056 ; read 1506; Sloane MS. 1432; Stowe MS. 95;

16 f.e. for alone read by itself

ii 14 Howard, Henry, 6th Duke of Norfolk : for second earl read third earl

33 i $31 \quad$ for In 1678 read Before 1678

34 ii 22 f.e. Howard, Henry (1757-1842): for Monticucolli read Montecuculi

36 ii 34 Howard, Henry (1769-1847): after 1847. insert He left three sons, Frank Howard [q. v.], William, advocate-general in Bombay, who was killed while hunting in 1862 , and Edward Irvine, founder of the 'Bombay Quarterly,' who was killed in a. railway accident in 1868 .

62 i 23 Howard, Theophilus, 2nd Earl of Suffolk : for 22 July read 14 July

$37 \quad$ after text insert Gardiner, Hist. of England, vi. 256

64 ii 9 f.e. Howard, Thomas, 3rd Duke of Norfolk: for he joined read he is said to have joined 73 i 36-37 Howard, Thomas, 1st Earl of suffolk: omit after Howard's death . . . . hus-

74 i 19 f.e. Howard, Thomas, 2nd Earl of Arundel: after Stuart, insert third Duko of Lennox,
75 ii 5 for was captured by the Roundheads, but read which had been captured by the Royalists,
6 after Waller insert (6 Jan.)

77 i 18 f.e. Howard, Walter: for (1867) read (1862)

78 ii 16-15 Howard, William, 1st Baron Howard of Effingham : for Château Cambresis read f.e. Câteau-Cambrésis

79 ii 21 Howard, Lord William : for the Earl of Arundel, read Henry Fitzalan, twelfth Earl of Arundel [q. v.],

84 ii 2-1 f.e. Howe, George : for apparently .... Witley, Wor- read daughter of Philip Foley of Prestwood, Staffordshire (marriage licence dated 21 Feb. 1692-3),

85 i 1 omit cester,

103 i 13 f.e. Howe, William, 5th Viscount Howe: for March read May

112 ii : l.l. Howell, James: for to follow read issued and for (1891) read (1892)

113 i 14 f.e. for A few letters read Two letters

13 f.e. after 1623 insert (not included in the 'Epistolø')

11-10 for but these have ..... not been traced. read and were purchased by the f.e. British Museum in 1892.

115 i 17 f.e. Howell, Laurence : after born insert at Deptford 
Page Col. Line

115 i 16 f.e. Howell, Laurence : after education insert at Lewisham Grammar School, where he was a foundation scholar, and

117 ii 9 Howell, Thomas B.: for (1815) read (1814)

119 i 23 Howes, Edward : for Goldanger] read Goldhanger]

125 ii 8 f.e. Howland, Richard : omit migrated to St. John's College, where he

130 ii 7 f.e. Howson, John $\mathbf{8}$.: for (head-master) read (second master)

57-58 for Collegiate Institution, read College,

181 i 8 for Institution read College

183 ii 56-57 Eoyle, Edmond: for (no copy known) read (1747)

134 i 19 f.e. omit lst edit. no title;

136 i 44-45 Hubbard, William: for is believed to have been rescued read was rescued

14-13 for presented by Eliot's son John to the Massachusetts read was subf.e. sequently restored to the governor. It was sold to the British Museum by the latter's great-grandson Peter Orlando Hutchinson in 1884. A copy came into the possession of the Massachusetts

149 i 12 f.e. Hudson, Sir James : for George III read George IV

153 ii 18 Hudson, Robert (1731-1815): after hymn tune insert 'Llandaff'

156 ii 18 Hues, Robert: for Thomas Chapman read George Chapman

158 ii 83 Huggins, William (1696-1761): omit of Ariosto

5-4 for This has an elaborate preface and annotations. read This translation has

f.e. been erroneously attributed to Huggins; it is the work of Temple Henry Croker [q. v.]. Huggins only supplied the annotations.

163 ii 15 f.e. Hugh (d. 1164): for Henry II read Henry I

164 i 26 for prince of Wales, read eldest son of Henry II,

165 i 1 Hugh (d. 1181): for years read days

168 i 4 Hugh (d. 1235): for Lanchester read Launcherley and for west read east

181 ii 6 f.e. Hughes, John (1787-1860): for 1837 read 1832

185 i 11 Hughes, Margaret: for Princess Rupert read Prince Rupert

193 i 37 Huish, Alexander : after election insert to a fellowship

199 i 14 Hullah, John P.: for council of education read education department

201 i 22 Hulls, Jonathan : after sliding scale; insert which he patented in 1753, together with a machine for weighing gold coins;

204 ii 17 Hulse, sir Samnel: for ninety read eighty-nine

207 ii 27 Humby, Mrs.: for Mrs. read Mrs. Anne

210 ii l.l. Hume, Alexander (1560?-1609): after forms. insert A copy, believed to be unique, of Hume's 'Ane treatise of Conscience,' Edinburgh, 1594, 12mo, is in Edinburgh University Library.

211 i 1-2 omit 'Ane treatise ..... 1594, 12mo;

215 i 16 f.e. Hume, Sir David (1643-1707): for 1761 read 1701

225 ii 2 Hume, David (1711-1776): for Brigge read Bigge

230 i 8-6 Hume, Joseph: for and he published ..... the 'Inferno' of Dante. read (He f.e. must be distinguished from another Joseph Hume (1767-1843), a clerk in Somerset House, at whose residence, Montpelier House, Notting Hill, Lamb, Hazlitt, Godwin, and other men of letters met. He published in 1812 a bad translation in blank verse of Dante's 'Inferno', and in 1841 'A Search into the Old Testament.' One of his daughters, Julia, was mother of Mrs. Augusta Webster, the poetess; another daughter married Isaac Todhunter, the mathematician).

235 i 6 Hume, Thomas : omit [q. v.]

242 i 33-40 Humphrey, Duke of Gloucester : for He attended Henry's marriage .... was formally appointed read From Jan. 1420 to Feb. 1421 he replaced Bedford as regent of England (WalsinghaM, Hist. Angl. i. 331). He had been on 30 Sept. 1419 formally appointed

246 i 18 for imprisoned read ordered to be imprisoned

19 for is said read is erroneously said

247 ii 11 f.e.

for six read seven

259 i 13 f.e. Hungerford, Sir Walter, Lord Hungerford (d. 1449): omit after the battle of Verneuil

ii $16 \quad$ for 1461 read 1464

260 ii 8 Hungerford, Walter, Lord Hungerford (1503-1540): for second wife read third

261 ii 13 f.e. Hunnis, William : for the Duke of Devonshire 'read the Earl of Devonshire' 
Page Col. Line

268 i 15 f.e. Hunt, James H. Leigh : for More than once read Thrice

13 f.e. for in each case read in two cases

269 ii 22 f.e. for at the close of June, read on $1 \mathrm{July}$.

277 i l.l. Hunt, Robert (1807-1887): after agent insert [See MERCER, JoHN]

278 i $32 \quad$ for Sport read Spirit

280 ii 1 Hunt, Thomas Frederick (?): omit (?)

286 ii 2 f.e. Hunter, Henry : for Alexander Boswell read Claude rvine Boswell

292 ii l.l. Hunter, John (1728-1793): for 1809 read 1810

299 i 31 Hunter, Sir Martin : for 90 read 89

313 ii 4 f.e. Huquier, James G.: for Louis XVI read Louis XV

316 ii 11 Hurdis, James : for the grammar school read the prebendal school

319 ii 37 Husband, William : after Husband, insert shipbuilder and

38 for 1857 read 1859

42-43 omit he ran away .... to Hayle, where

14 f.e. $\quad$ after founders insert at Hayle

320 i 29 for 1855 read 1885

325 i 3 f.e. Huskisson, William: for the county party read the country party

338 i 25-27 Hutchinson, Francis : omit His brother Samuel . . . . Donoughmore [q. v.]

349 ii 3 Hutt, Sir William : for Appley read Apley

352 i 12 Eutton, Charles : for Surkes read Surtees

13 omit first

ii 9 for Two daughters read He had issue two daughters

10 omit survived him

13 omit and child

14 for all read they

15 after ii. 957). insert Their son was C. B. Vignoles [q. v.].

354 i 24 f.e. Hutton, James: for Cominius read Comenius

357 i 29 Hutton, Matthew (1529-1606): for 1562 read 1561

30 before master insert and next year

358 ii 26 Hutton, Matthew (1693-1758): for Blackbourne read Blackburne

359 ii 9 Hutton, sir Richard : after refused insert to sign (Dec. 1635)

12 for opinion read declaration

31 for friend read friend and relative

:360 i 4-3 Hutton, Robert H.: omit who died 16 July 1887,

f.e.

365 i 14 f.e. Huysmans, Jacob : after Dolben insert [q. v.], then

367 ii 24 Hyde, Anne, Duchess of York: for 13 July read 12 July

385 ii 10 Hyde, Edward, Earl of Clarendon: for contained read contains

400 ii 8 f.e. Hyde, Sir Nicholas: after p. 42 insert Gardiner's History of England, vii. 87, 109

414 i 33 Ilive, Jacob : for Jane read Elizabeth

419 i 17 Impey, Sir Elijah : omit second in the classical tripos,

436 i 12-13 Ingleby, Sir Charles : for His is almost the only .... practice. read, which was not contrary to rule at the time.

438 ii 38 Inglethorp, Thomas : for St. Buryans read St. Buryan 



\title{
DICTIONARY OF NATIONAL BIOGRAPHY
}

\author{
ERRATA IN VOLUME XXIX
}

\author{
INGLIS—JOHN
}

\begin{abstract}
Page Col. Line
N.B. - f.e. stands for from end and l.l. for last line

$\mathrm{v}$ i 2 f.e. List of Writers: insert S. R. G. . . S. R. Gardiner, LL.D.

1 ii 4-2 Inglis, Charles (1734-1816): for apparently in New York .... he conducted f.e. $\quad$ read in 1734 in co. Donegal, where his father; Archibald Inglis, was a beneficed clergyman (d. 1745). Going to America to seek a livelihood, Inglis from 1755 to 1758 conducted

2 i 16 f.e. after phlets. add A monument was placed to his memory in St. Paul's

10 ii 33-35 Ingoldsby, Sir Richard (d.1685) : omit and on 28 Dec. . . . Hist. xxii. 34)

11 i 3 after 1659 , insert received the thanks of parliament for seizing Windsor Castle on its behalf on 28 Dec. 1659 (Commons Journals, vii. 798),

21 i 41-42 Innes, Cosmo: for Kilvarock read Kilravock

30 ii 44-45 Ireland, John (1761-1842): for William IV, and Queen Victoria read and William IV 10 f.e. before A marble bust insert $\mathrm{He}$ was too infirm to be present at the coronation of Queen Victoria, and his place was taken by the sub-dean, Lord John Thynne.

85 ii 27 Ireland, Samuel : after 'Frogmore Fête.' insert Before 1811 he settled at York, where his extravagance led to a temporary imprisonment in the Castle. Andrew Ritchie, who saw much of him at this period, describes him as engaging in manner and very communicative, but vain and unprincipled. He seems to have published at York a weekly print called 'The Comet,' in which he lampooned his neighbours, and contemplated issuing a poem on the 'Pleasures of Temperance' (MS. Letter from Ritchie to Richard Garnett, Nov. 1811).

11-5 for Mr. Ingleby describes his wife . . . married a second time. read Iref.e. land's second wife belonged to the Kentish family of Culpepper and was widow of Captain Paget Bayly, R.N. (brother of the first Earl of Uxbridge), whom she had married 25 Aug. 1791 .
\end{abstract}

45 i 35-36 Irons, William J.: for honorary canon read prebendary

37 for 1840 read 1860

45 for 1871 read 1876

50 i 15 f.e. Irvine, James : for sixty-seventh read fifty-seventh

58 ii 15 f.e. Irwin, Sir John: for 15th foot read 5 th foot

59 i 14 f.e. $\quad$ for 1766 read 1768

84 ii 86 Izacke, Richard: for 1700?) read 1698)

4 f.e. for is stated to have died 'about 1700.' read was buried in the church of Ottery St. Mary, 18 March 1697-8.

90 ii 19-20 Jackson (afterwards Duckett), Sir George : for presided read was present

91 ii 18 f.e. Jackson, Sir George : after survived him insert till 9 Dec. 1891

99 ii 17 Jackson, John (1811-1885): after offered), insert and whose curate he had been at Hornsey, 
Page Col. Line

104 ii $6-5$

107 f.e.

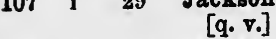

114 i 6 Jacob, Benjamin: for Wesley read the elder Wesley

12 f.e. Jacob, Edward: for Mary Chalker . . . . county. read Jane, daughter of Strangford Violl, vicar of Upminster.
141 i 31 James III of Scotland : for in his ninth year. read when nine years old.
146 i 25 James IV of Scotland: for Larg read Largo.
150 ii 2-3 for Denmark read Dantzic
195 i 2 f.e. James II of England: for p. 488 read iv, 288
197 i 33 for Stuart read Churchill
202 i 9 f.e. James Francis Edward Stuart: for Petro read Retiro
209 ii $\left.\begin{array}{r}33 \\ 34\end{array}\right\}$ James, George P. R. : for 1801 read 1799
210 ii 18 for May read June
22-23 for During the last years .... to write. read His last novel appears to have been 'The Cavalier,' published in America in 1859.

\section{9 f.e. James, Thomas (1573 ?-1629): for Bishop Aungervile's read Richard de Bury's}

ii 18 James, Thomas (1748-1804): for sixty read fifty-two

23 for over three hundred read two hundred and forty-five 17 f.e. $\quad$ for 1810 read 1824

James, William (1542-1617): for only read only other

James, Sir William (1721-1783): after Wiltshire. insert Among his friends was Laurence Sterne, who was a frequent visitor at his town house in Gerrard Street, Soho.

246 ii 4 Janeway, James : for unmarried read leaving a widow, Hannah

250 i 6 Jardine, David : after The son insert who graduated M.A. at Glasgow University in 1813 ,

265 i 9 f.e. Jefferies, Richard: for Surrey read Kent

274 ii 17 f.e. Jeffrey, Francis, Lord Jeffrey : for sessions read session

276 ii 2 f.e. Jeffreys, George (d. 1685): after 30,829 , insert 30,830 ,

289 ii 19 f.e. Jekyll, Joseph : before Most insert His correspondence was edited collectively with a brief memoir by the Hon. Algernon Bourke in 1894.

307 i 8 f.e. Jenkinson, Anthony : after tsar insert Ivan the Terrible,

325 ii 22-23 Jenner, Thomas ( $f$. 1631-1656) : for Probably a posthumous work, London, 1686, 4to. read London, 1656, 4 to.

332 i l.l. Jenye, Thomas : for 1890 read 1891

839 i 20 Jeremie, James A.: after originality. insert He was created D.C.L. at Oxford at Commemoration 1862

341 i 5 Jermy, Isaac: for John read James

342 i 33 Jermyn, Henry, Earl of St. Albans : after knt. insert by Mary Barber

344 i 29 Jermyn, Henry, 1st Baron Dover: before Thomas insert Sir and after Suffolk insert (by Rebecca, who afterwards married Viscount Brouncker)

845 i 18 for Abbeville read Albeville

55-57 omit one of himself .... . who died young

4-3

f.e.

ii 1

for Judith Pooley, probably of Boxted, read Judith, daughter of Sir Edmund Poley of Badley,

after iii. 241). insert She died at Cheveley in 1726 and was buried beside her husband.

3-4 for who had married his niece. read his grand-nephew, son of his niece by her marriage with Sir Robert Davers.

849 ii 2 Jerrold, Douglas W.: for eldest read youngest

350 i 10 f.e. for $70 l$. read $60 l$.

ii 6 for the one-act read his one-act

30 for 13 Sept. read 12 Sept.

33 for 1845 read 1843

35 for 1843 read 1845 
$\mathrm{P}$ age Col. Iine

351 i 1

2

ii 5

12

17

18-19

21

22

24

29

32

33-34

37

60-61

352

i 8

19

22

23-24

353 i 6

366 ii 32

373

Jerrold, Douglas W. : omit part

for six read eighteen

for SYDNEY read SIDNEY

for 'Works' read chief 'Works'

for Witch read Gipsey

for about 1823 read 26 Aug. 1821

for 1825 read 1834

for about 1825 read 15 Sept. 1828

for about 1826 read 11 Jan. 1830

for about 1828 read 21 May 1829

for 1828 read 1829

for in 1828 read 4 April 1831

for three-act read two-act

omit ' Hercules, King of Clubs' . . . . in $\mathbf{1 8 3 6}$

for essays read stories

for 1852. read 1840-1, edited and in part written by Jerrold.

for 1852-4 read 1868 and for two-act read three-act

omit was nominally Jerrold's . . . . John Poole

Jerrold, W. Blanchard : for fifty-seventh read fifty-eighth

$15-18$

21

43-44

11 f.e.

385 i 23 Jewsbury, Geraldine E.:

Jesse, Edward : for Halifax read Driffield
Jeune, Francis : for Colburn read Colborne

for and at the same time .... Gloucester Cathedral. read to which office a canonry in Gloucester Cathedral is attached. Shortly afterwards he was appointed rector of Taynton, Gloucestershire. As master of his college and as sub-dean of Gloucester his services were highly esteemed.

for hebdominal council read hebdomadal board

fortin 1858, and the following year read from 1858 to 1862 ,

395 ii 29

400 i 2

Jobson, Sir Francis : for his half-brother read his wife's half-brother

a student of Gray's Inn in 1709 .

3 for in 1706 read 27 Jan. 1718-19

38 after first insert in $\mathbf{1 7 2 0}$

20 f.e. $\quad$ for Earl Roden read Earl of Roden

8 f.e. for ten read nine

ii 33 Jocelyn, Robert, 1st Earl of Roden : for 9 Sept. read 1 Dec.

403 ii 16 f.e. John, King of England : for Luggarshall read Ludgershall

406 i 32 for twenty-second read thirty-second

427 ii 5 f.e. John of Lancaster, Duke of Bedford : for May read June

433 i 23 for Nantes read Mantes

435 i $31 \quad$ for later years read earlier years

436 i 37 John, Saint (d. 721): for Barton read Burton

449 ii 3 f.e. John (d. 1320), called of Dalderby: Compare this article with that on DaLDERBY, JOHN DE, in volume xiii. pp. 383-4.

451 i 17-21 John (d. 1379), called of Bridlington: for This shows that $1395 \ldots$. . formally canonised, read He was actually canonised by a bull of Boniface IX, dated 24 Sept. 1401.

29 for Holland read Beaufort

452 ii 1 John ( $f$. 1460), called of Bury : for Learning read Blaming 



\title{
DiCTIONARY OF NATIONAL BIOGRAPHY
}

\author{
ERRATA IN VOLUME XXX
}

\section{JOHNES-KENNETH}

\author{
N.B.-f.e. stands for from end and l.l. for last line \\ Page Col. Line \\ 6 i l.l. Johnson, Charles (1679-1748): for Estramaduran read Estremaduran \\ ii 3 f.e. after 1748. insert He was buried at Hendon on 18 March. \\ 9 ii 23 Johnson, Francis (1562-1618): for Oxford read Cambridge \\ 12 i 7 f.e. Johnson, George H. S.: for Earl Selborne read Earl of Selborne \\ ii 9 for Wells read St. Cuthbert's, Wells \\ 16 i 22 Johnson, James (1705-1774) : for Ricard's Castle read Richard's Castle. \\ 22 i 4 Johnson, Joseph : for seventy-first read seventy-second \\ 23 i 14 f.e. Johnson, Maurice: for Vertue read Virtue \\ 25 i 19 f.e. Johnson, Richard (1573-1659 ?) : for 218 read 318 \\ 40 ii 26 Johnson, Samuel (1709-1784): for Streatham Place read Streatham Park \\ 45 ii 12 for mark read mask \\ 46 i 22 for 1724 read 16-24 \\ 56 i 2 Johnston, Archibald, Lord Warriston : for (1610 ? read (1611 \\ for probably about 1610 read in 1611 \\ for of Beirholm in Annandale, read a merchant of Edinburgh, who died 24 \\ April 1617, \\ 6-7 for In early years .... a pupil of read He was baptised at Edinburgh \\ 28 March 1611. He was educated at Glasgow University, under his kins- \\ man \\ after versity insert and graduated M.A. \\ for 1640 read 1646 \\ for $(1643$ ? read $(1655$ \\ 58 ii 2 \\ 61 i 3 \\ Johnston, Francis : omit probably \\ for Richard Johnston, who read William Johnston, architect of Armagh. A \\ brother, Richard Johnston, who died in 1806, \\ 6 for $\mathrm{He}$ read Francis \\ 36 for J. C. Thompson read Martin Creggan \\ 87-38 for has been engraved. read is in the council chamber of the Hibernian \\ Academy. \\ ii 8 f.e. Johnston, George (1814-1889): for nephew read brother \\ 64 i 23 Johnston, James : for (1643? read (1655 \\ 25 after Warriston [q. v.] insert and was baptised 9 Sept. 1655 (Brodie, Diary, \\ 155) \\ 65 i 15-14 for according to ... the age of read at the age of eighty-two. The
f.e. \\ 13 f.e. $\quad$ for but according to read and \\ 12 f.e. for at the age of ninety-three only read as ninety-three
}

67 ii 18 f.e. Johnston, Nathaniel: for Ufflete read Usflete

86 ii 13 Jollie, Thomas : for in September read 14 Sept. 


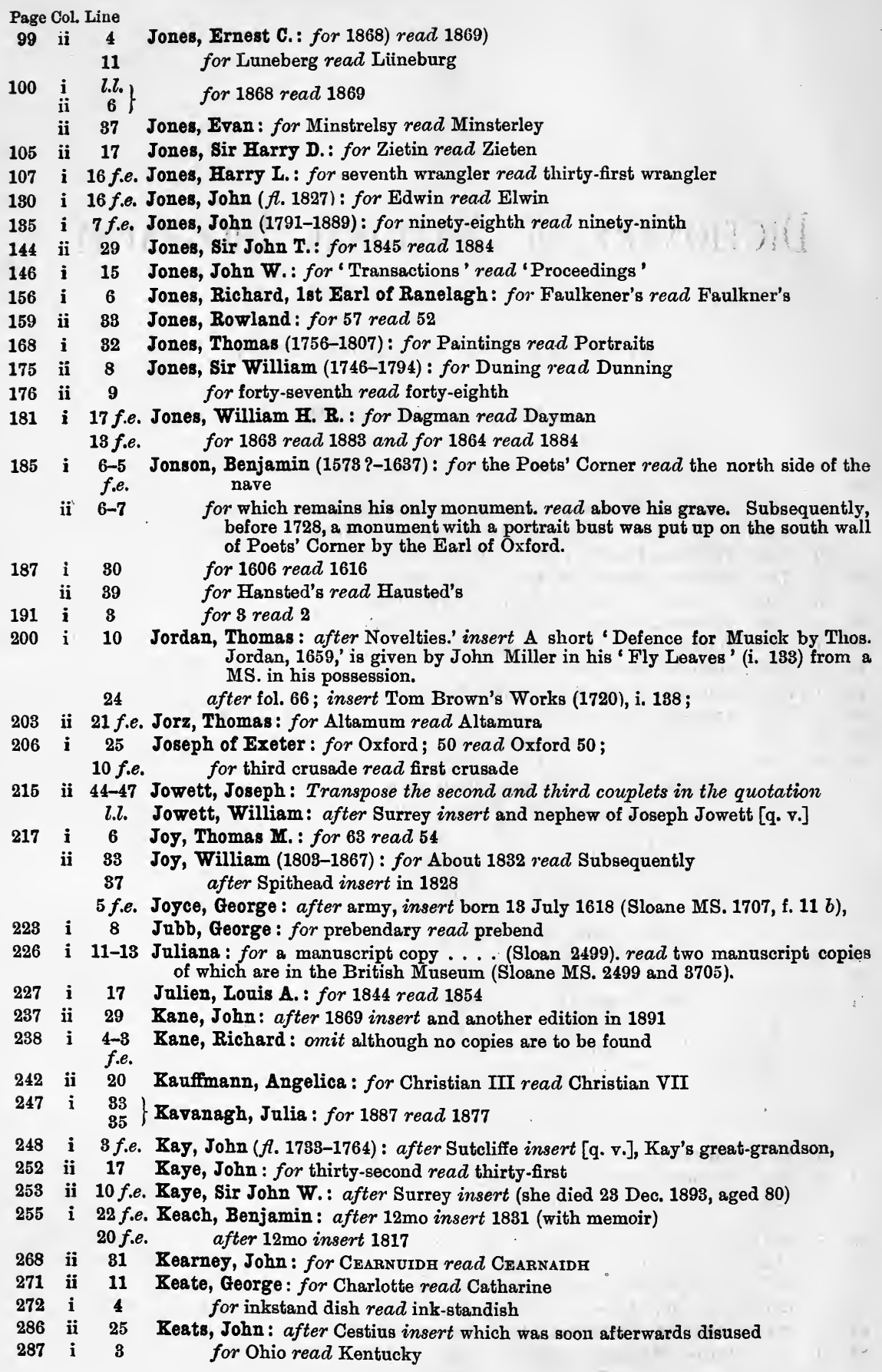


Page Col. Line

295 i $1-4$

Keble, John: for A portion of this volume . . . Church and State,' read In 1869 an article from the 'British Critic' of Oct. 1839 was republished under the title of 'The State in its Relations with the Church,'

296 ii 12 Keble, Thomas : after vol. $x$. insert He also wrote several in vols. i., ii., and iv.

316 ii 37 Keith, George, 5th Earl Marischal : for 9 Oct. read 7 Oct.

323 ii 2 Keith, George S.: for 71 read 70

326 ii 11 f.e. Keith, Sir Robert $(d .1346)$ : for Durham read Neville's Cross

329 i 8 Keith, Robert (d. 1774): omit only

330 i 24-25 Keith, Sir Robert M.: for In 1773 .... and during read During

32 after 1780. insert On 1 Sept. 1777 he was promoted major-general.

342 i 15 Kellett, Edward : after proditionis insert suæ

343 ii 18 f.e. Kelley, Edward : for Appolonius read Apollonius

355 ii 30 Kelly, Michael: for' $O$ haste read' Haste

360 ii 17 Kelty, Mary A. : after Literature; insert Mrs. Douglas's Life of Whewell, pp. 84-85, 101, 110;

367 i 24 Kemble, Charles : for elder read younger

26 for second read elder

371 i 13 Kemble, John M. : for Bombay read Bengal

384 i 26 Kemp, John (1380?-1447: for 1447) read 1454)

390 i 7f.e. Kemp, William ( $f$. 1590): for was educated at read matriculated at Cambridge as a pensioner of Christ's College in June 1578 and afterwards migrated to

391

i 11 f.e. Kemp, William ( $f .1600)$ : after 1598. insert At Christmas 1594 he was summoned with two other leading members of the company, Richard Burbage [q. v.] and William Shakespeare, to act before the queen at Greenwich.

396 i 6 f.e. Kempenfelt, Richard: after 39-41; insert Thicknesse's Autobiography ;

399 i 35 Kemys, Lawrence : for xl, read xlviii.

403 i 18 f.e. Ken, Thomas : omit his

414 ii 7 Kennedy, Benjamin H. : for cxiv. read ch. xiv.

24 f.e. for Bishop Heber read Richard Heber

415 i 14 f.e. for the present read the present chapel at

427 ii 34 Kennedy, John $(d .1760)$ : for John read PATRIck (cf. MS. Egerton 22, ff. 35-37; Nichols's Literary Anecdotes, ix. 409)

437

ii 18 f.e. Kennedy, William D.: for Willemont read Willement 



\title{
DiCTIONARY OF NATIONAL BIOGRAPHY
}

\author{
ERRATA IN VOLUME XXXI
}

\author{
KENNETT-LAMBART
}

N.B. $-f . e$. stands for from end and l.l. for last line

Page Col. Line

4 ii 11 f.e. Kennett, White: after Havers, M.D. insert (she died 9 July 1743)

5 i 1 before wife insert [i.e. his third]

28 i 28 l.l. Kenton, Benjamin : for 1802 read 1800

ii 3 f.e. Kenton, Nicholas : for votorum read votivum.

38 ii 12 f.e. Keppel, Augustus, Viscount Keppel : for second earl read third earl .

51 ii 15 Ker, John, 3rd Duke of Roxburgh: after London, insert (No. 13, now the Windham Club)

58 i 15 f.e. Ker, Sir Thomas : for (Bannatyne Club) read (Abbotsford Club)

63 ii 24 Kerr, Robert, 1st Marquis of Lothian : after June insert 1689

98 i 18-17 Kidgell, John : for Wilkes's 'Essay on Woman' read the 'Essay on Woman' f.e. (printed by Wilkes and probably written by Thomas Potter [q. v.])

99 i 4 Kiffin, William: for (1634) read (1638)

8 for Lathrop read Lothrop or Lathrop

9 for 1638 read 1641-2

11-12 for and seceded .... John Spilsbury. read but remained a member of Jessey's church till 1644 (Gound, Baptists of Norwich, 1860, pp. cxxviii sq.)

1.l. after communion. insert He signed the declaration of 1651.

ii 1 for John Dethick read Christopher Pack

10 after Biddle [q. จ.]. insert Kiffin was M.P. for Middlesex 1656-8.

13 f.e. after came of it. insert In 1669 his meeting-house was in Finsbury Court, Moorfields.

100 i $53-54$ for (Cardinal Ferdinand Dada) read (Count Ferdinand D'Adda)

101 i 30 Kilburn, William : for in his seventy-third year read aged seventy-three

ii 24 Kilburne, Richard: for 74 read 73

18 f.e. Killigrew, Thomas : for buried read hanged

37 Killigrew, sir William : for Lancashire read Lincolnshire

ii 39-40 King, Charles W.: omit About 1866 . . . . (Clergy List, 1866).

i 12-11 King, Edward (1612-1637): for recording the fate of another Lycidas; read in f.e. which Phyllis's death is bemoaned by a shepherd called Lycidas;

143 i 4 King, Oliver: after Secretary insert and sent him to the Tower in June (Excerpta Historica, No. viii. 17)

ii 8 f.e. King, Robert (d. 1557): for Bernardines read Cistercians, now St. John's College

ii 33-34 King, William (1650-1729): for consecrated read enthroned

i 19 f.e. for 7 read King is credited in error in the British Museum Catalogue with

14 f.e. after 8vo. insert This work is by Bishop William Nicolson [q. v.].

sley, Charles : for 1860 read 1864 
Page Ool. Line

184 i 17 f.e. Kingsmill, Thomas: for and was obliged read about 1579, and his duties as professor were discharged by deputies, one of whom was Richard Hooker. He was obliged

8 f.e. $\quad$ after iv. 153 ; insert Walton's Life of Hooker, ed. Keble, i. 18 ;

185 i 9 Kingston, Sir Anthony: for Gloucestershire read Painswick, Gloucestershire

198 ii 5 Kinwelmersh, Francis: for ( fl. 1570) read (d. 1580?)

12-13 omit The poet was probably son of

15 after ii. 424) insert but does not appear to have had a son named Francis (see his will, P.C.C. 18, Pickering)

for $\mathrm{He}$ read The poet

30 for arts read acts

10 f.e. after compiler. insert The poet is probably identical with Francis Kinwelmersh of Charlton, Shropshire, whose will (P.C.C. 79, Leicester) was proved on 21 Oct. 1589. He died apparently before 16 May 1580 (Notes and Queries, 8th Series, xii. 423).

4f.e. after $\mathrm{p}_{\mathrm{i}}$ 285). insert This was Anthony Kynwolmershe of Wing, Buckinghamshire, who died early in 1600 .

194 i 20 Kip, Johannes : for Malphigi read Malpighi

200 i 35 Kirby, William: for James Spence read William Spence

201 ii 3 f.e. Kirk, John (1760-1851): for 90 read 91

203 i 12-11 Kirk, Thomas (1765?-1797): for the African prince Leboo read the Pelew prince f.e. Lee Boo

205 ii 6 Kirkby, John (d. 1290) for St. Berian's read St. Buryan

217 i 20 Kirkham, Walter de: for Ireland read Staffordshire

219 i 19 Kirkland, Thomas : for (1721 read (1722

20-21 for a native of Scotland, was born in 1721. read born at Ashbourne, Derbyshire, on 14 Oct. 1722, was son of Thomas Kirkland, attorney at law (d. 1751), by his wife, Mary, daughter of Colonel Allsop.

28-29 for By $1774 \ldots$. . Edinburgh read Kirkland graduated M.D. at St. Andrews on 27 Dec. 1769

31 after Edinburgh insert (May 1777)

230 ii 35-36 Kitchin, Anthony : for Gloucester (now Worcester) College read Gloucester Hall (now Worcester College)

39-40 for Gloucester College read Gloucester Hall

$\begin{array}{llcr}281 & \text { i } & 8 & \text { for No bishop read No Marian bishop } \\ 242 & \text { i } 5 \text { f.e. } & \text { Kneller, Sir Godfrey: for in } 1729 \text {, read }\end{array}$

242 i 5 f.e. Kneller, Sir Godfrey: for in 1729, read at Bath on 24 Nov. 1729 (Monthly Chronicle, 1729, p. 285),

275 i 28 Knollys, Sir Francis : for the proofs are wanting read this is an error

32-34 omit Lord-mayor Knollys . . . . the soldier.

280 ii 21 f.e. Knollys, Hanserd : for (1699-1702) read (1698-1745)

282 ii 16 Knollys, Sir Robert: for d'Erran read d'Evran

289 i 12 Knollys, William, Earl of Banbury : for Edward read Michael after Leicestershire insert and South Carlton, Lincolnshire omit surviving

340 Knox, Vicesimus : for Sterring read Stenning

Knyvet, Sir Thomas : for Rowland read Roland

350 ii 22-23 Kyd, Thomas : for $1608 \ldots$... Amsterdam read 1621 A. van den Bergh published at Utrecht

25-26 for which was republished in 1683. read while another Dutch rendering appeared at Amsterdam in 1638 and was republished in $1644,1669,1683$, 1698 , and 1729.

351 i 6 for 1593 read 1595

352 i 19 f.e. for iv. read 5 th ser.

367 ii 9 f.e. Labouchere, Henry, Baron Taunton: before Lords insert Messrs. Stanley, Denison, and Stuart Wortley, afterwards respectively

376 i 11 Lacy, Hugh de, 5th Baron Lacy : for de Lusignan's read of Angoulême's

380 i 24 Lacy, John de, 1st Earl of Lincoln : for second earl read justiciar

882 ii 9 f.e. Lacy, John ( $f$. 1737): for Francis Maximilian read Francis Maximilian Misson

383 ii 7 f.e. for art. See Anne read art. Lee, AnNe 
Page Col. Line

383 ii 5-4 Lacy, John William: for LACY, JohN WilliaM or Williay (1780?-1865 ?) read LACY, WilliaM (1788-1871)

4 f.e. $\quad$ for about 1780 read in 1788

384 i $\quad 39 \quad$ for about 1865 read in July 1871

385 ii 34 Lacy, Michael R.: for Schälcher's read Schœlcher's

403 ii 5 f.e. Laing, John (1809-1880): for appointed minister read ordained assistant and successor to John M. Robertson, minister

406 i 19 Laing, Samuel: for both of whom still live read (the latter died 7 Aug. 1897)

407 i $\left.\begin{array}{rl}6 \text { f.e. } \\ 5 \text { f.e. }\end{array}\right\}$ Laird, Macgregor : for Great Western read British Queen

408 i 27 for appears to have been printed read was in 1892 in the possession of Laird's widow

417 i 17 f.e. Lake, John : omit in 1682

424 i 6 Lamb, Charles : for 1772 read 1792

428 ii 21 f.e. after 1826 insert (life-size, exhibited at the Suffolk Street gallery 1827 ; until June 1902 in possession of Miss Talfourd; of two small replicas one is in the National Portrait Gallery, the other belongs to Sir Charles Dilke, Bart., M.P.)

430 ii 5 Lamb, Frederick, 3rd Viscount Melbourne : for 1848 read May 1848

431 i 12 f.e. Lamb, George : for p. 488 read i. 437-8

432 i 17 f.e. Lamb, Sir Matthew : omit [q. v.]

436 i 27-28 Lamb, William, 2nd Viscount Melbourne: for the divorce case Norton .... Melbourne read the case Norton $v$. Melbourne

438 i 3 for no heir. read no child. His brother Frederick James Lamb [q. v.] succeeded to the title.

441 ii 8 Lambart, Sir Oliver : for Sir David Blagrave read Sir John Blagrave 


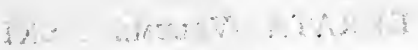

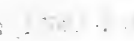

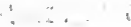

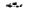

$, \cdots, \ldots$ 


\title{
DICTIONARY OF NATIONAL BIOGRAPHY
}

\section{ERRATA IN VOLUME XXXII}

Page Ool. Line

\section{LAMBE LEIGH}

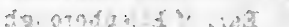 \\ N.B.-f.e. stands for from end and l.l. for last line
}

1 ii 11 f.e. Lambe, John : for 23 June read 13 June

3 i 36-37 Lambe, Sir John : omit married .... the other, 39 after Denbigh [q. v.]. insert Lambe's sister married Dr. Robert Sibthorpe [q. $\mathbf{v}$.$] .$

6 i 16-17 Lambe, William (1765-1847): for one Dr. Landon of Warwick, read Dr. Landor (father of the poet),

Lambert, Sir John (1815-1892) : after ecclesiis insert usui

$40\}$ for Organistrarum read Organistarum

30 ii 19 Lamphire, John : omit Bath and

33 ii 3 f.e. Lancaster, Edmund, Earl of Iancaster: after Acre insert (Sept. 1271-May 1272)

35 i 25

49 ii 11

53 ii 30

54 ii 5

55 ii 14

58 i. 5

77 i 9

92 i 35

94 ii 7

for p. 773 read p. 778

Lander, John: for thirty-three read thirty-two

Landon, Letitia Elizabeth : omit [q. v.]

Landor, Walter Savage : for Henry VII read Henry IV for Bolus Smith read Bobus Smith for 1832 read 1823

Lane, John B.: for 1884 read 1864

Langbaine, Gerard (1609-1658) : for tabarder read taberdar

Langbaine, Gerard (1656-1692): for A son read She married after Langbaine's death William Smith (1650?-1735), the rector of Melsonby, and was buried at Melsonby on 8 May 1724. Langbaine left a son

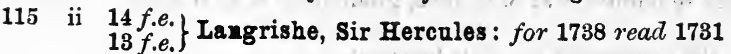

5 f.e. $\quad$ after proprietor insert and was made a freeman 29 Sept. 1752

116 ii 22 after married insert on 31 May 1755

35-36 for all efforts . . . in failure. read Copies of some of Langrishe's politica 1 letters belong to his descendant Mr. R. Langrishe of Dundrum House, co. Dublin.

118 i 14 f.e. Langtoft, Peter of: for Thorpe read Wright

121 i 9-10 Langton, John : for the lollard Henry Crump read Henry Crump [q. v.]

32 Langton, Robert: for president read provost

33 for D.C.L. read LL.D.

12 f.e. $\quad$ for outer hall read ante-chapel

ii 4 for pp. 297, 305 read iv. 297, 303

Langton, Thomas: for Edward V read the Duke of Gloucester

i 18-17 Lankester, Edwin: for Dr. (now Sir Lyon) Playfair read Dr. Lyon (afterwards f.e. Lord) Playfair

139 ii 32 Lanquet, Thomas : for 1552 read 1452 
Page Col. Line

141 ii 5 Lanyon, sir William 0.: for 45 read 41

143 ii 15 f.e. Larcom, Sir Thomas 4 . : for Academy read Military Academy

182 i 22 f.e. La Touche, William G. D. : for (1746 read (1747

19 f.e. $\quad$ for in 1746 read 28 Aug. 1747

7 f.e. $\quad$ for Judith read Martha Judith

187 ii 32 Laud, William : for On 30 Sept. 1626 he sent him read On 20 June 1626 he was nominated bishop of Bath and Wells, and he held the office till his translation to London two years later. On 30 Sept. 1626 the king sent him

196 i 5 f.e Fauder, 8 jo John, Lord Fountainhall: for James V read James II

210 ii 11-13 Lanrie, Sir Peter : for a clerkship in the office ... marriéd, ahd reald employment with David Pollock, founder of the well known legal family, who was saddler to George III and his court

18

11 f.e. for sons read nephews

Jack, bat had no children "

f.e.

l.l.

before $12 \mathrm{mo}$ insert a skit

216 i 2 f.e. Law, Edmund : for fourth read fifth

221 ii 2-1 Law, Edward, Earl of Ellenborough : for J. D. Sumner, read John Bird Sumner f.e. [q. v.],

287 i 21 f.e. Law, William : for Rusbroch read Rusbroek

242 i 14 Lawes, Henry : for Colraine read Coleraine

244 i 20 Lawes, William : for i, 107 read ii. 107

245 i 5 f.e. Lawless, Valentine B., Lord Cloncurry : for bishop of St. Asaph, afterwards master read bishop of Chester and master

251 i 30 Lawrence (d. 1175) : after ii. 186; insert Vita S. Godrici (Surtees Soc., pp. 232-3);

257 i 17 Lawrence, Eenry : for Altena read Altona

16 f.e. $\quad$ for 16 Dec. 1653 read 16 Jan. 1654

13 f.e. $\quad$ for p. 298 read pp. 298, 860

264

279

282

286

289

292

296

297

299

9-7

f.e.

2 f.e. $\quad$ for Cambridge read Oxford

ii 11 f.e. Lawrence, sir Henry M.: for of Harrow-on-the-Hill, read who became in 1892 head master of Sedbergh School.

ii $\quad$ l.l. Lawrence, Sir Thomas : for Daniel de read Daniele da

5 f.e. $\quad$ for 22 April read 20 April

6 Lawrence, Sir William: for in Gloucester read at Elmore, near Gloucester

ii 12 f.e. Lawson, George (1749-1820): for placed him read sent him to the university of Edinburgh. During the vacation he studied classics for Lawson proceeded .... studied read Later he studied

ii 24 Lawson, James A. : after Society. insert He was made D.C.L. of Oxford in 1884.

i 17 Lawson, John (1728-1779): for Prisms read Porisms

i 29-30 Lawson, Thomas (1630-1691): for at Cambridge, and read at Cambridge. One Thomas Lawson, son of Thomas Lawson, born at Lakeland near Settle, Yorkshire, and educated at Giggleswick, was admitted sizar of Christ's College 25 July 1650, and was apparently re-admitted 21 May 1652, graduating B.A. 1655-56. Lawson became

ii 13-14 Lax, William : for the vicarage of read his house at

23 f.e. Laxton, Sir William : for Limehouse read Lime Street

i 3-1 for Laxton died childless and read Laxton's daughter Anne married Sir Thomas Lodge [q. v.]. He

11 f.e. Leake, Stephen M. : for Captain Martin read Stephen Martin

ii 16 f.e. for Lahne read Lahn

13 f.e. for Nieu read Neu

i 4 f.e. I Ie Cène, Charles : for ou read où

ii 2 f.e. Lechmere, Nicholas, Lord Lechmere : for Swift read Steele

i 10 f.e. Lee, Alfred T. : for topographer read miscellaneous writer

ii 28 after 1883 insert leaving a widow and several children

Lee, George H., 3rd Earl of Iichfield : before He was also insert He was the first to offer to the University the Chancellor's Prizes 
Page Col. Line

362 ii 9 f.e. Lee, John (1783-1866) : for their suppression read the exclusive privilege of prac-

365 i 29 Lee, Nathaniel: for'Gloriana read'Glorian

ii 11-12

366 ii 39

368 i 26

\section{Club; it was engraved for}

391 ii 7 f.e. Leedes, Edward : for and M.A., read and M.A. Before 1660 he became head-

407 ii 13 Le Geyt, Philip : for president read master

$\begin{array}{llc}414 & \text { i } & 20 \text { f.e. } \\ 416 & \text { i } & 13\end{array}$ Legge, William : for 1672 read 1670

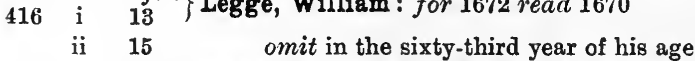

419 i 27 Legge, William, 2nd Earl of Dartmouth : for Pompeio read Pompeo

421 i 15 Legh, Sir Thomas : for abbey read priory

429 ii 21-22 Leigh, Chandos, 1st Lord Leigh : for Leigh Hunt, his father, read Leigh's father

434 i 17 Leigh, Sir Ferdinand : for Rothwell, Haigh read Rothwell Haigh

437 i 34 Leigh, Percival: for he read be 


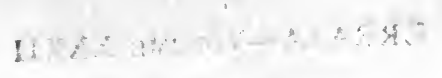

$$
\begin{aligned}
& !+1+\ldots+\infty+\cdots
\end{aligned}
$$

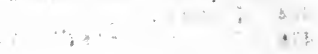

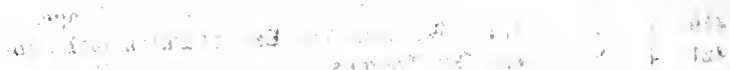

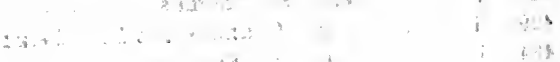

$$
\begin{aligned}
& \text { t }
\end{aligned}
$$




\title{
DiCTIONARY OF NATIONAL BIOGRAPHY
}

\author{
ERRATA IN VOLUME XXXIII
}

\section{LEIGHTON—LLUELYN}

N.B.-f.e. stands for from end and l.l. for last line

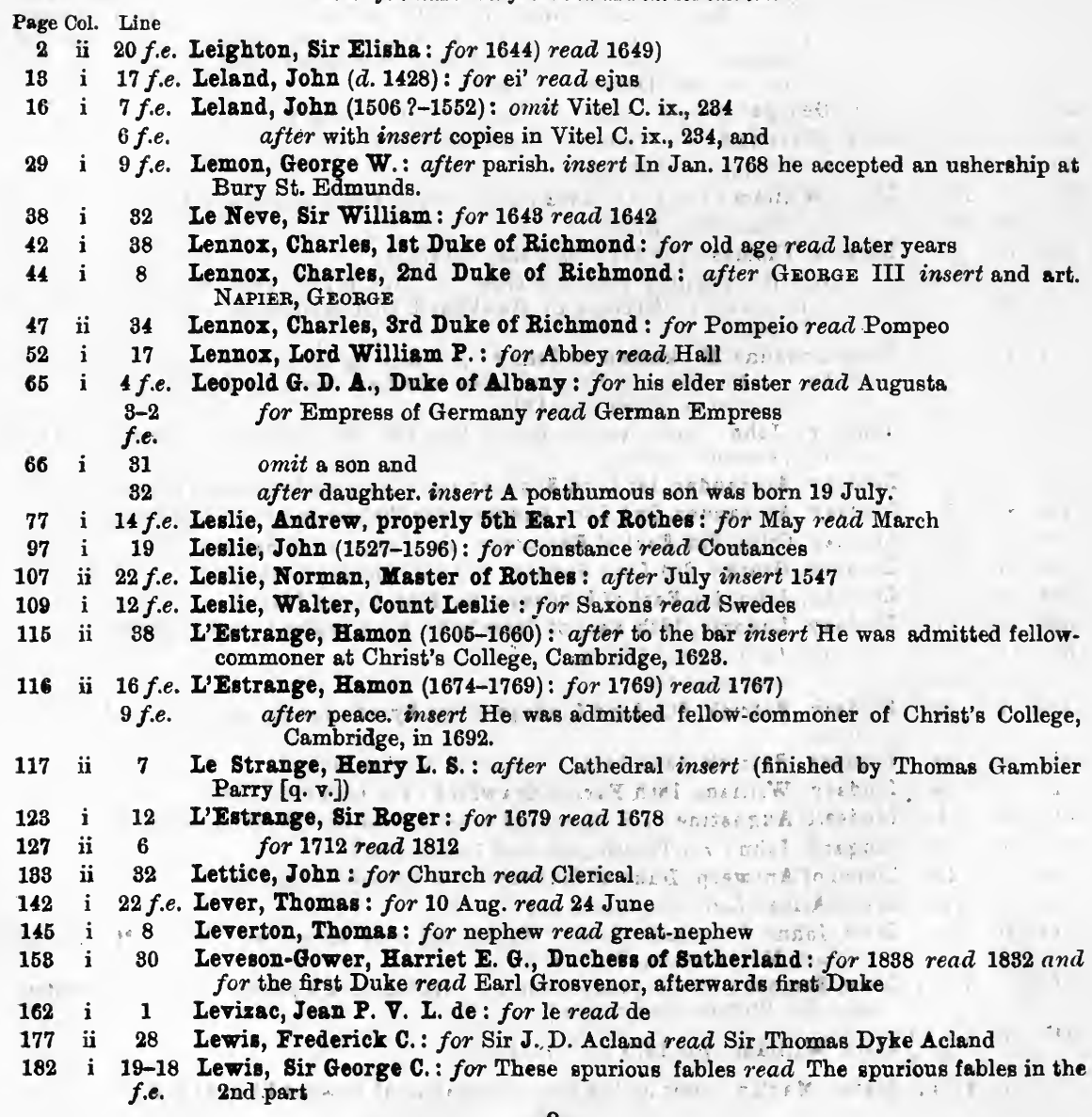


Page Col. Line

187 ii 6

7

Lewis, John : for Rochester' read the Cathedral Church of Rochester' for 1723 read 1717 and after 8vo insert by Richard Rawlinson [q. v.]

198 ii 6 f.e. Lewis, William (1592-1667): for Richard Price read Theodore Price

199 ii 20 f.e. Lewis, William (d. 1855 ?) : for (d. 1855 ?) read (1787-1870)

19 f.e. $\quad$ after chess-player, insert born 6 Oct. 1787,

2-1 f.e. for Lewis is believed .... 1855, i. 442). read Lewis died 22 Aug. 1870

(Illustrated London News, 26 Nov. 1870).

203 i 54-55 Lexinton, John de : for Monastice read Monastici

205 ii 24 Ley, James; 1st Earl of Marlborough : for Witton read, Wilton .

210 ii / 23 \& Ieybourne, Roger de:/for (Whitsana read Witsand

$228 \mathrm{i}^{4}{ }^{34}$ Light, Edward : for (d. 1832 ?) read (1747-1832)

40 omit is said to have

5 f.e. $\}$ for harp-lute read lute-harp

229 ii 34 Light, william: for Light was the author of read To Light have been erroneously attributed two books by Sir Henry Light, viz.

36 for and published read William Light himself published

251 i 18 f.e. Lilburne, Robert : for unitersity read college

ii 51-52 Lillingston, Luke : for Luke Lillingston or Lillingstein read Henry Lillingston

5-4 for Luke the younger read Luke was son of his father's second marriage,

f.e. his mother being Elizabeth, daughter of Marmaduke Dolman of Bottesford, Lincolnshire; the elder Lillingston had purchased a moiety of Bottesford manor after it had been forfeited to the parliament by his father-in-law, Dolman: Luke

253 ii 8 Lillo, George : for princess of Wales read princess royal

255 ii 12 f.e. Lilly, Christian : for Barbadoes read Barbados

256 . 17 for Buston read Beeston

258 i 18 f.e. Lilly, William : for 1 May 1602 read 30 April 1602 (Sloane MS. 1707, f. 12 b).

267 ii 25 Linacre, Thomas : for 1510 read March 1510-11

35-38 for $\mathrm{He}$ possibly received them . . (in 1515?) read It was concerning Linacre's preferment to Hawkhurst that Ammonius wrote to Erasmps in 1511

ii 9-7 f.e. Lind, Johanna $\mathbf{M}$, known as Jenny : for Among the many provincial engage. ments ... the Norwich Festival: read Sho had immense success at a concert which she gave at Norwich in 1849.

278 i 8 f.e. Lindley, John : after works. insert His son Sir Nathaniel, afterwards Lord Lindley, became a juidge.

281 i 6 Lindsay, Alexander, 1st Lord Spynie : for the accused read the accuser

282 ii 5 Lindsay, Alexander, 2nd Lord Spynie ; for Tibbermuir read Tippermuir :

287 ii 5 f.e. Lindsay, Colin, 3rd Earl of Balcarres : for Salton read Saltoun.

299 ii 13 f.e. Lindsay, George, 3rd Lord Spynie: for dormant read extinct

304 ii 6 Lindsay, John, 1st Earl of Lindsay f for 1651-2 read 1641-2

308 ii 17 Lindsay, Ludovic, 16th Earl of Crawford : for Crawfurd read Crawford

309 i 20 for 12 Oct. read.19 Oct.

for 1668 read 1653

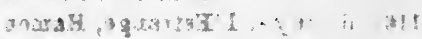

310 i . 26

Lindsay, Patrick, 6th Lord Lindsay of the Byres : for the muraer read Darnley's. murder

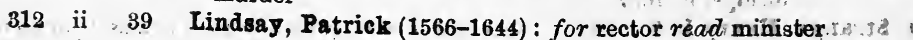

315 i 26 Lindsay, William, 18th Earl of Crawford : for 1695 read 1685

317 ii 9-10 Lindsell, Angustine : for Bumstead-Steeple read Steeple-Búmpstead

323 i 2 Lingard, John : for Huntinford read Huntingford :

337 ii 28 Lionel of Antwerp, Duke of Clarence: for Bernabò's read Galeazzo's

340 i 6 f.e. Lisle, Alice : before in insert and

342 ii 6 Lisle, John: for named Thomas Macdonnell read known as Thomas Macdonnell (see art. MAccartark, WrLlaM)

343 i 37-38 Lisle, Samnel : for his predecessor ... Baker, read a predecessor in the wardenship, Dr. William Baker:[q. v.],

345 i 7 : $\quad$ tisle, William : for 1579 read 1569

350 i 41-42 Iister, Martin: omit on the recommendation of Edward Lhuyd [q. v.] 
Page Col. Line

357 ii 21 Iiston, Robert: for fifty-third read fifty-fourth

364 ii 19-21 Littledale, Richard F.: for 'Unity and the Rescript . . . the A.P.U.C.,' 1864. read 'The North Side of the Altar,' 1864 (3rd edition, 1865).

373

i 10 f.e. 7 f.e. $\}$ Littleton, sir Thomss : for 1402 read 1422

ii 12-13 omit under the . . . Earl of Warwick

384 ii 10 Livingstone, Charles : for 1874 read 1864

392 i 44-45 Livingstone, David : for Barrup read Burrup

14 f.e. for Hugh read Henry

396 ii 13 f.e. Livingstone, George, 3rd Earl of Linlithgow : for the Restoration read the Revolution

403 i 5 f.e. Livingstone, Sir Thomas, Viscount Teviot : for 1796 read 1696

408 ii 3 Iloyd, Sir Charles : for Bronghill read Brochwel

409 ii 11 f.e. Lloyd, Charles (1748-1828): for seven read the first seven 10 f.e. for remained in manuscript read appeared in 1810 (Birmingham, 12mo)

410 ii 10 f.e. Lloyd, Charles (1766-1829): for 63 read 62

5 f.e. $\quad$ for he had no issue. read with Sara Maria Smith he had issue a son, Francis Vaughan Lloyd, born at Palgrave 14 Oct. 1811.

416 ii 9 Lloyd, David (1635-1692): for Abergeley read Abergele

417 i 31 Lloyd, David (d.1714?): for (d. 1714 ?) read (d.1716?)

ii 5-6 for and to have died suddenly read He was alive in 1716 and seems to have died

420 ii 9 Lloyd, George : for Wurall read Wirrall

33 Lloyd, sir Godfrey : for Bronghill read Brochwel

428 ii 23 f.e. Lloyd, Julius : for a wrangler read twenty-second wrangler

429 i 33 Lloyd, Ludovic: before was, according insert was fifth son of Oliver Lloyd, lord of the manor of Marrington, by his wife Gwenllian, daughter of Griffith ap Howel ab Ieuan Blayney of Gregynog. He

431 ii 8-10 Lloyd, Sir Richard (1606-1676): for born in 1606 . . . Shropshire. read was called 'of Esclys' (History of Powys Fadog, iii. 32).

440 i 2-4 Lloyd, William Forster : for was the only son ... born in 1794. read born in 1794, was son of Thomas Lloyd, rector of Aston-sub-Edge, Gloucestershire, and younger brother of Charles Lloyd, bishop of Oxford [q. v.]. 


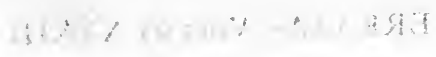




\title{
DiCTIONARY OF NATIONAL BIOGRAPHY
}

\author{
ERRATA IN VOLUME XXXIV
}

\section{LLWYD-MACCARTNEY}

Page Col. Line

N.B.-f.e. stands for from end and l.l. for last line

2 ii 7 f.e. Llwyd, Humphrey : for at the end of his read together with Ortelins'

18 ii 30 Llywelyn ab Iorwerth : for his marriage read this marriage

23 i 17-18 Llywelyn of Llangewydd : for Iolo Morganwg (Edward Williams) read Edward David or Dafydd [q. v.]

19 after Beirdd' insert which was sanctioned at a 'Gorsedd' held in 1681. It was edited by Iolo Morganwg (Edward Williams) and after i. 29, 30 insert Preface to the Heroic Elegies of Llywarch Hên (1792), lxiii

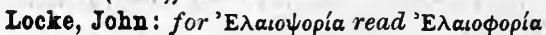

ii 26-27 for 1785-1786 read 1685-1686

35 for Laudabridis read Lindabridis

for Duke read Earl

for 1708 read 1696

6

20 f.e. Locke, William : for leaving read having had

19 f.e. Lockhart, sir George (1630 ?-1689): for presbyters read presbyterians

36 Lockhart, John G.: for Giffard's read Gifford's

Lockman, John : before In the British insert Histories by him, in question and answer, of England, Greece, and Rome, passed through numerous editions.

Lockyer, Nicholas : for Harewood's read Harwood's

Lodge, William : after Leodiensis insert Thoresby's Diary and Correspondence

Loe, William : after 4to, insert London, 1607,

2 after copy insert of the latter

76 ii 15 f.e. Loftrs, Adam (1583 ?-1605): for 1 April read 5 April

85 i 28-29 Iogan, John: for as virtually to settle the question. read as to give Logan's claim genuine substance.

89 ii 12 f.e. Loggan : after vol. v.; insert Oldham's Poems, ed. Bell, p. 280 ;

90 ii 36 Logier, John B.: after later. insert From Westport Logier went to Dublin, where he taught military bands and directed the music at Johnson's theatre.

91 i 7 after ii. 161; insert Gent. Mag. 1846, ii. 484; Biog. Dict. of Musicians, 1824

Lombe, Sir Thomss : for but have long since disappeared. read the few fragments that survive are preserved at South Kensington (Victoria and Albert Museum).

Long, Edward : for son read grandson

Longley, Charles T. : after 1815 insert (with a first class in classics) 
Page Col. Line

126 ii 19

130 i 17

151

152

154

165

168

172

173

i 38

ii 14

175 ii 24-25

180 ii 35

183 ii 13

185 ii 19

20

187 ii 24-25

189

\section{i $\quad 11-10$}

f.e.

9 f.e.

8 f.e.

ii 1-5

191

202

208

216

220

24 f.e.

$11 f . e$.

\section{i. 21 f.e. Loyd, Sam}

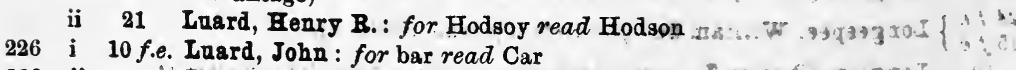

229 ii 25 "Lucas, Sir Charles (d. 1648) : after i. 124). insert He was admitted a fellowcommoner of Christ's College, Cambridge, 7 June 1628, aged 15, his tutor being John Alsop, Laud's chaplain. 


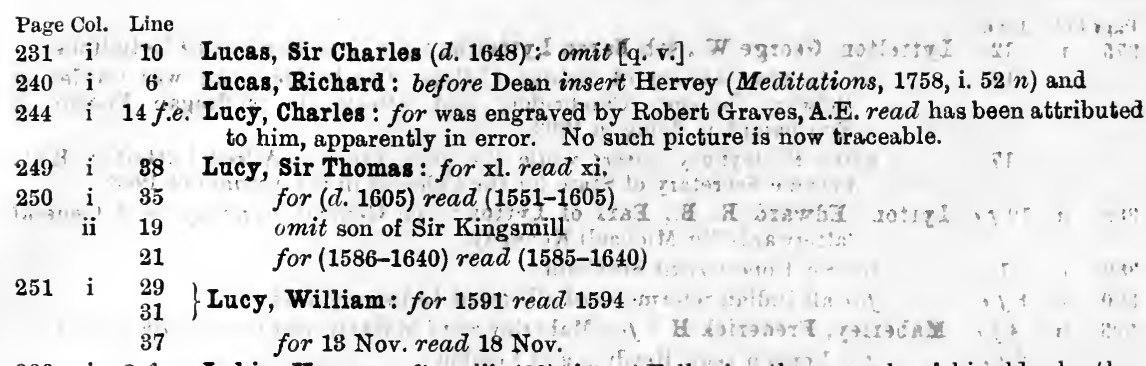

266 i 2 f.e. Lukin, Henry : after xiii. 438). insert Following the example of his elder brother William, who was admitted a pensioner of Christ's College, Cambridge, in 1041, he joined that College 8 July 1645 aged 17

ii 11 Lumley, John, Lord Lumley : for ib. 1855 read Gent Mag. 1855

19 f.e. Lumley, Marmaduke: for 1399 read 1400

i 20 Lumley, Richard, 1st Earl of Scarborough : for Morton read Moretón

283 i 19 f.e. Lunsford, Sir Thomas : for East Hatherley read Down Hatherley

286 ii 9-8f.e. Lupton, Roger: for built by him was really the beginning of the collegiate church read which he added to the collegiate church

7-6 f.e. " omit which encloses . . . north side

288 i 18 f.e. Lupton, Thomas : after 1578. insert A detailed philanthropic scheme by Lupton is in MS. in the Bodleian Library (MS, Jones 17).

296 i 26-31 Lutterell, John: for Lutterell purposed to leave ... in 1329. read An enquiry was held at York, but was not settled much in his favour (RAINE, Letters from Northern Registers). Bishop Grandison recommended him to Pope:John XXId on 22 Feb. 1329. Lutterell was back in England by 12 Oct. 1329, and Grandison then next year recommended him for preferment, without much success (Reg. Grandison, i. 103, 234, 247).

303 i 15 Luxmoore, John: for St. George's, Bloomsbury, read St. George the Martyr, Holborn,

304 i 4-5 Lyall, George: for Margaret, born Conyn, read Jane, born Comyn

ii 2 Iyall, Robert: for in Scotland read at Paisley in 1790

for Mauritius in September read Port Louis, Mauritius, on 23 May

ii 8 f.e. Iyall, William R. : for St. J. Rose read Hugh James Rose [q. v.]

ii 16 f.e. Iydgate, John: for 2256 read 2255

8-7 f.e. for Cambr. 39 read Oxford, 38

314 i 6 for 314 read 306

321 ii 29 Iyell, Sir Charles: for Russell read Russel

323 ii 34 for the high church party read many high churchmen

325 ii 7 Lygon, Frederick, 6th Earl Beauchamp : for liturgy read hymnal

328 ii 27-28 Iyly, John: for Harvey, but Lyly in a further tract read Harvey in a further tract, but Lyly

331 ii 21 for sang, read and $m y$

338 ii 27 Iynch, Thomas T. : for 1856 read 1859

339 i $\begin{array}{lll} & 14 \text { f.e. } & \text { for his 'Memoirs' read the 'Memoir' by William White } \\ & 2 & \text { for to read for }\end{array}$

13 f for 'Memoirs' read 'Memoir'

340 i 19-20 Lyndwood, William: for Hereford read St. Davids

26 for Gonville and Caius College read Gonville Hall

343 i 10 f.e. Iynn, George, the elder: for Roubillac read Roubiliac

356 ii 12 f.e. Iyons, Edmund, Lord Iyons : for She was author read There is no ground for assigning to her three novels which, according to their title pages, were by 'Lady Lyons'

8 f.e. for she died in 1852, read She died at Stockholm, while her husband was still minister there, on 10 March 1852,

372 i 11 Iyttelton, George, 1st Baron Lyttelton: after chaplain. insert Other literary friends were Glover, James Hammond, and Shenstone, who placed an inscription to him at the Leasowes.

f.e. Iyttelton, George W., 4th Baron Iyttelton: after Park. insert There is a fine monument to him in Worcester Cathedral. 
Page Col. Line

375 i 12

15

17

Iyttelton, George W., 4th Baron Iyttelton : for Lyttelton's read Lytteltons for is now warden of Selwyn College, Cambridge, read was warden of Selwyn College, Cambriage, and afterwards suffragan bishop of Southampton, dying in 1908,

after Haileybury insert while the youngest son, Alfred Lyttelton, K.C., became Secretary of State for the Colonies in the autumn of 1903

388 ii 10 f.e. Lytton, Edward R. B., Earl of Lytton: for General Kennedy read General (afterwards Sir Michael) Kennedy

389 i 1 for Sir Robert read Sir Colin

390 i 8 f.e. for all Indian reforms read all recent Indian reforms

393 ii 4 f.e. Yaberley, Frederick H.: for Maberley read Maberly and so through article 2 f.e. $\quad$ for London read Reading and London

394 ii 3 Maberly, William I.: after 1798 insert Frederick Herbert Maberly [q. v.] was his uncle

398 i 2-3 McAll, Robert 8.: for of Paris; read promoter in 1872 of the Independent Protestant Mission at Paris, who died at Auteuil 11 May 1893;

406 i 25 Macartney, George, Earl Macartney : for He did homage to the emperor read He managed to evade the necessity of doing homage to the emperor for and ' Journal read (1773), extracts of which, together with his 'Journal for all of which are published read were published after 'Memoir' insert with a somewhat misleading title page

410 i 19

412 i 30 ii $\cdot 33$ 31

Hacaulay, Kenneth : for south from the Hebrides read to the Hebrides

Macaulay, Thomas B., Lord Macanlay : for 1 March read 2 March for December by 1,804 and 1,792 read December 1832 by 2,012 and 1,984 for 1,353 read 1,596

413 i 16 f.e.

ii 11 f.e.

415 ii 17 f.e. for the last fortnight read the first fortnight

16 f.e. for 1843 read 1834 for 1846 read 1872 for 18 July read 14 July

31 omit and the Armada after Magazine,' insert and 'The Armada,' first published in 'Friendship's Offering ' in 1833,

422 i 16-15 Macbean, Alexander: for Biography read Geography 


\title{
DiCTIONARY OF NATIONAL BIOGRAPHY
}

\author{
ERRATA IN VOLUME XXXV
}

\author{
MACCARWELL-MALTBY \\ N.B.-f.e. stands for from end and l.l. for last line
}

Page Col. Line

141 f.e. McCrie, Thomas (1797-1875) : for secession read original secession and for 1820 read June 1822

20 f.e. $\quad$ for in 1828 read 16 April 1829

19-18 for West Richmond Street meeting-house read Davie Street church

f.e.

6 f.e. for the English presbyterian church read the presbyterian church of England

ii 5

26-27 for As a young minister he read McCrie occasionally

16 i 1

MacCulloch, Horatio : for William Henry read William Home

18 ii 6 MacCulloch, John : for third read fourth

21 i 2 McCulloch, John R.: for his native whisky. read the ancient national beverage claret.

ii 15 for Gilzean read Galbraith

$27 \quad$ i $\quad 39$

Macdonald, Alexander, of Glencoe (d. 1692): for 16 June read $16 \mathrm{Jan}$.

43 ii 20

Macdonald, Sir John A. : for Toronto read Ontario

10 f.e. for Canada West read Upper Canada

ii 17 f.e.

for Toronto read Ontario

30

24 f.e.

22 f.e.

$\left.\begin{array}{ll}51 \text { ii } 36 \\ 37\end{array}\right\}$

Macdonell, James : for 1841 read 1842

for its viceroy read governor-general

for 1882 read 1870

52 i 5

for 1873 read 1875

71 i 1

Macdowell, William : after 262 insert Addit. MS. 15858, ff. 68, 70

Maceroni, Francis : omit of Liondon

Mackay, Andrew : for 153 read 163

119 ii 5

147 ii 10

150 ii 15

151 ii 22 f.e.

153 ii 30

Mackenzie, George, 1st Earl of Cromarty : omit in a letter . . 1670

Mackenzie, Henry: for Henry David Inglis [q. 'v.] read George Inglis of Redhall for 1771 read 1791 .

Mackenzie, James : for Doddrige read Doddridge

Mackenzie, John, Count Cromarty: omit now have for the Duke of Sutherland. read Anne, daughter of John Hay Mackenzie - and wife of George Granville William Leveson Gower, third Duke of Sutherland, whose second surviving son, Francis (d. 1893), inherited the Cromarty estates with the title of second Earl of Cromartie, being succeeded by the elder of his two daughters.

168 i 8 McKerrow, William : for McKelvie read McKerrow 
Page Col. Line

196 ii 26

206 i 4 f.e.

211 ii 3

16-18

228

231

10-7

f.e.

5 f.e.

267 i 26

$275 \quad$ i $\quad 29$

277

27-28

30

f.e.

ii $10-11$

$$
\text { i } 19
$$

ii 17

i 2 f.e.

i $\quad 6-5$

$f . e$.
8

12

Yaclaurin, Colin : omit (1753-1821) [q. v.]

Hacleay, Sir William: omit first

McLennan, John F.: for who survives him read who died in 1896

for has since been continued ... towards completion. read and then by that of William Robertson Smith [q. v.], was completed by McLennan's widow and Mr. Arthur Platt, and published in 1896.

i 28 Uacmahon, Sir Thomas W.: for 1800) read 1860)

18 Macmillan, Daniel: for 1853 read 1835

1 16. f.e. : aften Alexander insert (1818-1896)

ii 25 f.e. Hacmoyer, Florence : for given read sold for $200 l$.

ii 19 f.e. MacNally, Leonard: for 1778 read 1787

11 McNeill, Duncan, Baron Colonsay : omit and the title became extinct

33 Hacpherson, Ewen : for Maitland Club read Spalding Club

27-28 for through the good offices of read after being refused by
i 25-26 Hacpherson, James (1736-1796) : for Macpherson had again hinted at read Blair referred to for he read Macpherson

for 1762 read Dec. 1761

22 f.e. for by Blair read of his own

for Strahan read Johnson

for 14 Oct. read 19 Oct.

for $\mathrm{He}$ induced the government. . . in the Jacobite rising. read The government offered him the lands of his relative Macpherson of Cluny, which had been confiscated in the Jacobite rising, but he refused them in favour of the rightful heir.

for Kensington Gore read Manchester Buildings ;

after controversy insert Cf. T. Bailey Saunders's Life and Letters of Macpherson, 1895

Macqueen, Robert, Lord Braxfield : for St. George's Square read George Square

9 Hacrae, James : after p. 280 ; insert Cockburn's Memoirs, p. 8;

ii 44-45 Madden, sir Frederic: for One of his sons read His eldest son $i$

ii 6 f.e. Madden, sir George A. : after painted insert in 1817

4 f.e. for engraved read copied in oils

ii 21 f.e. Magauran, Edmund : for Russell read Fitzwilliam

i 21 f.e. Magee, William C. : for and in 1859 also read In May 1860 . Y

19-16 for Within a year. ... Enniskillen. read He preached his first sermon there 7 Oct. A month later (28 Nov, 1860) he was instituted to the Trinity College living of Enniskillen. His association with Quebec Chapel finally ended in March 1861. for is in course of preparation read was published in $\mathbf{1 8 9 6}$

20 Magellan, Jean H. de: for hardly possible read quite impossible

Maguire, John F.: for John Forster read William Edward Forster [q. v.]

Maine, Sir Henry J. s.: for Frederick read Edgar

Mainwaring, Sir Philip : for Gowes-worth read Gaws-worth

Maitland, John, 1st Duke of Lauderdale: for $(d$. 1698) read [see MuRRAy, ELIZABETH]

for Talmarsh read. Tollemache Maitland, Sir Peregrine : for Caroline, daughter of George Dewar read Jane,
daughter of General Mathew of Clanville, Hampshire

for a daughter read Lady Jane, third daughter

for Ancaster read Ancaster and Kesteven

for in 1777 read 6 July 1777

after the passage of insert Bidassoa, at the battle of Nivelle and at the passage of

12 f.e.

after (gold medal), insert also at the operations before Bayonne, at the action of Bidart, and the passage of the Adour,

for and governor read He resigned on account of his aversion to the official countenance given to heathen religious festivals. He was governor 
Page Col. Line

367 ii 10-9

f.e.

$\begin{array}{ccc}368 & \text { i } & 4 \\ 387 & \text { i } & 27\end{array}$

387 i 27

$397 \quad$ ii

$\left.\begin{array}{c}9 \\ 10\end{array}\right\}$

420 ii 9 f.e.

433 ii 21

Maitland, Sir Peregrine: for from December .... 1846, read from 18 March 1844 to 27 Jan. 1847,

after secondly insert in 1815

Major, John: for the college of Christ Church read Cardinal College, afterwards Christ Church

Malby, Sir Nicholas : for Limerick read Smerwick

Malet, Sir Thomas : for 18 June 1663 read 3 Dec. 1660 (Sloane MS. 856, f. 25 b).

Malone, Edmund: after 292-3). insert His wife's portrait was painted by Reynolds.

439 i 11 f.e. Malory, Sir Thomas: after his book. insert One 'Thomas Malorie, miles' was excepted, as an adherent of Warwick, from a pardon granted by Edward IV in 1468. He seems to have been son of John Malorie by Alice, daughter of John Revell, to have served under Richard de Beauchamp, captain of Calais, about 1430 , to have been knighted in 1445 , to have been M.P. for Warwickshire, to have died in March 1471, and to have been buried at Grey Friars, Newgate (cf. Athenaum, 11-18 July 1896).

441 i 20 Maltby, Edward : for a prebend at Lincoln, read the prebend of Leighton Buzzard in Lincoln Cathedral in $\mathbf{1 7 9 4}$

22-23 for and Leighton Buzzard, Bedfordshire. read While at Buckden, Maltby received Edward Bouverie Pusey [q. v.] and his brother as private pupils in October 1817, and notwithstanding later differences wrote that he had no recollections of Pusey 'but such as are most agreeable' (LiDDon, Life of Pusey, i. 19-22).

ii 5

after religion. insert On the publication of Tract XC Maltby was one of the bishops who 'charged' against the Oxford Movement. 


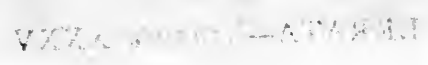

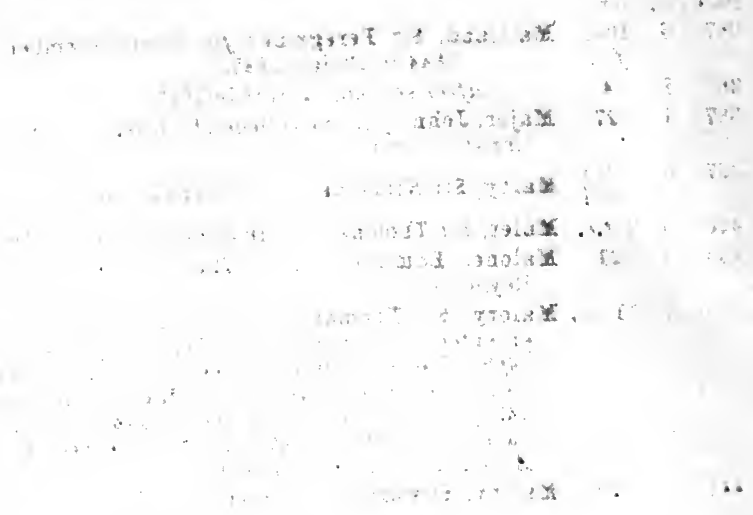




\title{
DicTIONARY OF NATIONAL BIOGRAPHY
}

\author{
ERRATA IN VOLUME XXXVI
}

\author{
MALTHUS-MASON \\ N.B.-f.e. stands for from end and l.l. for last line \\ Page Col. Line \\ 8 i 16 Malverne, John : for (d.1415 ?) read (d. 1414?) \\ 28-29 for $\mathrm{He}$ seems to have died . . . 1415. read He died before November 1414 \\ (44th Rep. Dep. Keeper, p. 556). \\ $\begin{array}{lll} & 32 & \text { for iv. read ix. } \\ \text { ii } \quad 7 & \text { for } \text { MS. } 57, \text { ff. 186-8 read } \text { MS. } 59, \text { ff. 186-9 }\end{array}$ \\ 8 for 'Consilium contra Pestem' read 'Remedium contra Pestilenciam' \\ 18 ii 3 f.e. Manby, Thomas : for (1766? read (1769 \\ 2 f.e. $\quad$ after admiral, insert born 1 Jan. 1769, \\ 20 i 15 f.e. for 18 June read 13 June \\ 14 f.e. $\quad$ for in 1800 Miss Hamond read in 1810 Miss Julia Hamond \\ 5 f.e. $\quad$ after France insert Norfolk Archæology, vol. iii. p. 130 \\ 21 i 18 Mandeville, Bernard : for 1785 read 1685 \\ 35 ii 3 f.e. Manley, Mrs. Mary de la Riviere : for (1672 ? read (1663 \\ l.l. $\quad$ for about 1672 read 7 April 1663 (Sloane MS. 1708, f. 117) \\ 38 ii 20 f.e. Manley, Thomas: for $(f$. 1670) read (1628-1690) \\ 19f.e. after 1628 insert third son of George Manley of Lack, Cheshire, by Eliza- \\ beth, daughter of Richard Lee of Lee Magna, Kent. $\mathrm{He}$ \\ 18-17 for In the preceding year read He became king's counsel 18 Sept. 1672. In \\ f.e. \\ $39 \quad$ i $\quad 6$ \\ 17 f.e. $\quad$ after literature. insert Manley died 22 March 1690, and was buried in St. \\ Margaret's Church, Rochester. His wife, Jane, was daughter of Richard \\ Lee. \\ ii 19-20 Manlove, Edward : for is separately noticed. read was possibly father of Timothy \\ Manlove [q. v.]. \\ 26 Manlove, Timothy : for (1633-1699) read (d. 1699) \\ 28 for son read grandson \\ 29 omit in 1633 \\ 46 ii 5 Manners, Charles, 4th Duke of Rutland : for elder read eldest \\ 49 i 13 f.e. Manners, Francis, 6th Earl of Rutland : after Cambridge. insert With them he \\ was admitted a fellow-commoner of Christ's College in 1594-5. \\ 51 ii 12 Manners, John, 8th Earl of Rutland : for 1545-6 read 1645-6 \\ 53 i 11-14 Manners, John, Marquis of Granby: for $\mathrm{He}$ appears to have been in Germany \\ ... (ib. p. 201). read On the outbreak in July 1758 of the Seven Years' \\ War Granby went to Germany in command of a brigade of cavalry. \\ 16 \\ for at the head of the blues read in command of the second line of \\ cavalry \\ 21-22 omit Granby and Sackville . . . but \\ 23 f.e. after hard drinking insert though the prince was a most abstemious, even \\ ascetic man and the sternest of disciplinarians
}


Page Col. Line

53 i 13 f.e. Manners, John, Marquis of Granby : after the day.' insert He left a sick bed on an inclement night (September 1760) during the cannonade of Brückermühl to take command of his division and relieve General Zastrow, who had held the bridge for eight hours. Ligonier afterwards rallied him on his new cure for fever (ib. ii. 859 ).

ii 7-14 omit He left a sick bed .... (ib. ii. 859).

33 omit Windsor

34 for London read Belvoir

13 f.e. for the horse guards read the commandership-in-chief

54 i 22 .

after creditors insert Granby maintained his independence in the face both of the court and the public. George II respected and loved him; George III respected and feared him. He was the intimate friend of Lord Chatham, of Prince Ferdinand, and of Lord Holland, in all of whom he excited a sense of admiration. To serve political ends he was maligned by Walpole and 'Junius.'

35 for twice painted read twelve times painted

36-37 for and one of those portraits .... National Gallery. read The chief portraits are at Trinity College, Cambridge, Belvoir Castle, Petworth, Stowe, Audley End, Kelham Hall, and St. James's Palace. A crayon study (a bust) by Sir Joshua is in the National Portrait Gallery.

7 f.e. after originals. insert See the Newcastle Papers in the British Museum and Mr. W. E. Manners' Life of Lord Granby, 1899, 8vo.

ii $32 \quad$ Manners, Sir Robert : for 1461) read 1461 ?)

2 f.e. Manners, Lord Robert : for second son read third son

55 ii 6 f.e. Manners, Roger, 5th Earl of Rutland : for uncle read great-uncle

5 f.e. $\quad$ for nephews read great-nephews

56 i 8

for Northamptonshire read Nottinghamshire

ii 34-35 Manners, Thomas, 1st Earl of Rutland: for Nun Burnham read Nunburnholme

73 i 4-3 f.e. Manning, William (1630 ?-1711): for was born, . . . about 1630. read may be well identified with William Manning (son of William Manning) who, born at Cockfield, Suffolk, was educated at Stowmarket and was admitted a sizar of Christ's College, Cambridge, on 25 Oct. 1649, aged 16 (Henry More being his tutor).

79 ii 14 Manny, Sir Walter de: for second son read fifth son (the eldest son of the second marriage)

82 ii 7-9 Mansel, Henry I. : for the readership .... Magdalen College. read the Waynflete professorship in moral and metaphysical philosophy.

90 i 6 f.e. Mansfield, Charles B.: for Berkshire read Hampshire

92 i 27 Mansfield, Sir James: for the university of Cambridge read Trinity Hall, Cambridge

ii 26 Mansfield, Sir William R., 1st Lord Sandhurst : for Hampshire read Hertfordshire

114 i 31 Mapletoft, John : for Duchess read Countess

122 ii 2 f.e. Marcet, Mrs. Jane: for Francis read Anthony Francis

128 i 14 f.e. Marckant, John: for Purforte read Purfoote

132 i 11 f.e. Margaret, St. (d. 1093) : for deserves read derives

158 i $\left.\begin{array}{l}4 \\ \end{array}\right\}$ Margetson, James : for Armagh read Arvagh

ii 12 f.e. omit eldest

6 f.e. after son insert (d. 1729)

161 ii 11-12 Marisco, Geoffrey de: for of the justiciar, Hugh de Lacy [q. v.] read [see LAcY, HUGH DE, Earl of Ulster]

16 after justiciar insert Meiler Fitzhenry 162 i 20-21 for William, the earl-marshal, in 1224, read William Marshal [q. v.],

4 f.e. $\quad$ after Lacy insert [q. v.]

ii 7 for Richard, the earl-marshal read Richard Marshal

for the marshal read Marshal

for the earl-marshal read Richard Marshal

163 i $\quad 13$

for Richard, the earl-marshal read Richard Marshal

175 ii 15-19 Markland, Abraham: Note that the poem numbered 3 was by the son, George Markland (see $l .4$ supra), and not by the father, Abraham. 
Page Col. Line

181 ii 2 Marlowe, Christopher: after Marlowe. insert In October 1588 Marlowe was summoned to the next gaol delivery of Middlesex to take his trial for an unspecified offence (cf. Athencum, 18 Aug. 1894, and art. by Prof. F. S. Boas in Fortnightly Review, Feb. 1899, ' New Light on Marlowe and Kyd.')

190 i 36 for 1800 read 1830

205 ii 12 Marsden, John H. : after 1842 insert reissued in 1878

13 f.e. Marsden, Samuel : for placed . . . . Cambridge read on 7 Dec. 1790 was admitted a scholar of Magdalene College, Cambridge (see the College Register)

206 i 14 f.e. for 1847 read 1836

213 ii 50-51 Marsh, Herbert: omit with the professor's house at Cambridge,

214 i 12 for' a trap read' cobwebs

ii 6 for He had read The bishop had

34-35 for to which his opponents were driven in 1812 by read which was formed in 1812 by men opposed to the party that Marsh represented, but largely owing to

222 i 60-61 Marshal, John, 1st Baron Marshal : for Worcester read Gloucester

230 i 37 Marshal, William, 1st Earl of Pembroke : for Bristol read Gloucester

ii 8-5 for recalcitrant barons .... Robert de Gaugi, read recalcitrants. In the

f.e. $\quad$ autumn Marshal had to fight with Morgan of Caerleon, and early in 1218 he besieged Robert de Gaugi

231 i 31

$$
\text { after sea insert in } 1200
$$

ii 17-19 Marshal, William, 2nd Earl of Pembroke : for It was perhaps he .... In March 1217 read But in February 1217

23-24 for From this time .... fought with him read In the following month he took part with his father in the operations against Louis in Surrey and Hampshire and played a foremost part in the fight

234 ii $34 \quad$ for Wallia, read Wallia

237 i 12 Marshall, Francis A. : for W. S. Wills read W. G. Wills

246 i 23-22 Marshall, Stephen : for John Dutton, of Dutton, Cheshire read Robert Castell, of f.e. East Hatley, Cambridgeshire, by Elizabeth, daughter of Edmund Alleyne.

251 i 27 Marshall, William ( $f$. 1630-1650): for 'Plays ' read 'Poems'

252 i 6 f.e. Marshall, William (1745-1818): after p. 241). insert His 'Yorkshire Words' was reprinted by the English Dialect Society.

254 ii 32 Marsham, Sir John: after treatises. insert His nephew Thomas Stanley [q. v.] dedicated to him his 'History of Philosophy' (1655).

255 i 19 Marshman, John C. : for weekly read magazine

279 i 15 Martin, Henry : after 'Spectator' insert and the 'Guardian'

290 ii 7 Martin, Peter J. : after one son insert Robert Martin (d. 1891)

292 ii 9 f.e. Martin, Richard : for (1808-1858) read (d. 1858)

295 ii 13 f.e. Martin, Sir Samuel : for now Lady Macnaghten. read who became wife of Lord Macnaghten.

311 ii 7 Martineau, Harriet: for Society' read Travel'

323 ii 38 Martyn, William : after 1589, insert was M.P. for Exeter 1597-8,

329 i 12 Marvell, Andrew : after 491-3). insert A bronze tablet on the wall of Waterlow Park marks the site of his house on Highgate Hill.

335 ii 20 f.e.$$
336 \text { i } 1
$$

337 ii 26 f.e.

8 f.e.

7 f.e.

5-4

f.e.

338 i 4 f.e.

345 ii 36

350 i $l . l$.

ii 1-3
Mary I : for Clement VIII read Clement VII
after Newhall insert near Chelmsford

for ten days read twelve days

for made read had already made

for displeased read had displeased

for The rising in the north impelled Cromwell, too, read The somewhat similar insurrection in the west now impelled Cromwell

for Pannell read Paynell

after fact. insert One Epithalamium was by Lodovico Paterno.

omit nego-

for tiated .... he had urged read tried to effect a truce between the emperor and the French king, and his negotiations resulted in 1556 in the peace of Vaucelles. He had also urged

352 i 23

374 ii 23 f.e. Mary Stuart: for 10 Jan. read 11 June 


\section{ERRATA-Volume XXXVI}

Page Col. Line

378 i 3 Mary Stuart: for Huntly read Moray

383 i 16 f.e. for morning read mourning

391 i 32 Mary of Gueldres: for de Coussy read d'Escouchy

392 i 26 Mary of Guise : after child insert who was really born five or six days later,

415 ii 4-3 Maskelyne, Nevil: for a daughter of Henry Turner.... Lady Booth. read f.e. Sophia, daughter and co-heir of John Pate Rose, of Cotterstock, Northamptonshire, and sister of Lætitia, wife of the Rev. Sir George Booth, bart.

420 ii 16-15 Mason, George H.: for William Ralph Cartwright.... 1832 to 1846, read f.e. William Cormwallis Cartwright, afterwards M.P. for Oxfordshire,

425 i 17 f.e. Mason, Sir John : for was read is said to have been

12 f.e. $\quad$ after vi. 114 insert but cf. Visitations of the College of Arms and MS. Harl. 1092, ff. 121-5 


\title{
DiCTIONARY OF NATIONAL BIOGRAPHY
}

\author{
ERRATA IN VOLUME XXXVII
}

\section{MASQUERIER-MILLYNG}

\begin{tabular}{|c|c|c|}
\hline Page & Col. & Line \\
\hline 3 & $\mathbf{i}$ & 38 \\
\hline & ii & $4-5$ \\
\hline & & 7 \\
\hline & & $9-11$ \\
\hline & & 14 \\
\hline 4 & ii & 34-35 \\
\hline 24 & ii & $3 f . e$. \\
\hline 85 & ii & $15-25$ \\
\hline
\end{tabular}

\section{Massey, Sir Edward : for Bruckthorpe read Brookthorpe} omit But his success . . . . failure.

for was retaken read was reoccupied by the royalists but Massey returned on 14 Oct. and

for a musket; Monmouth .... the royalists read a musket, succeeded in dislodging the enemy, killing 30 and capturing 230

for Lydney read Sir John Winter's house, near Lydney

for does not seem to have gone read did not go

Master, William: for Rudler's read Rudder's

Maule, Fox, 2nd Baron Panmure : for and again under Lord Aberdeen ..... the fall of Sebastopol. read When Lord Palmerston formed an administration in Feb. 1855 Panmure took office as secretary for war, and it was thus under his direction that the Crimean war reached its termination. Although he was in no way responsible for the errors for which his predecessor in the department, the duke of Newcastle, was severely blamed by the press, all Panmure's acts were rigorously scrutinised.

Maule, Sir William H.: for 1810 Maule entered read 1806 Maule came into residence

91 i 21 Mauley, Peter de : for It was he read It was probably he 20 f.e. $\quad$ for Peter IV read Peter III

Maurice, Prince : for the Earl of Forth read the Earl of Brentford and Forth

Maurice, Frederick D.: for the October following read November 1831 omit in Great Ormond Street, Queen Square, after pupils insert in Red Lion Square, afterwards removing to Great Ormond Street

31

ii 10 f.e. Mawson, Matthias : for Greene read Green

ii 2 f.e. Maxse, Sir Henry B. F. : for 1813 read 1873

32 Maxwell, James C. : for Jeens's engraving read G. J. Stodart's engraving

18 f.e. Maxwell, William H. : for Appleby read Apperley

36 Mayerne, Sir Theodore T. de : for 1661 read 1653

Maynard, Sir John (1592-1658): for Estaines Parva read Little Easton

\section{Mayow, John : for (1643 read (1640}

for in May 1643 read on 24 May 1640 (Sloane MS. 1708, f. 117)

193 ii 2-1 f.e. Meadows, Sir Philip: for one married Sir Thomas Powis, read Elizabeth married Sir Thomas Powys [q. v.],

200 ii 9-8 Mechi, John J.: for his affairs were put read Mechi was forced to place his f.e. affairs 
Page Col. Line

204 i 6 f.e. Medland, Thomas : for ( fl. 1777-1822) read (d. 1833)

ii 28 after 1822. insert He died at Hertford 30 Oct. 1833 (Gent. Mag. 1833, ii. 476).

205 i 25 Medley, John : for entered the church read was ordained deacon

7 f.e. $\quad$ for 1035 read 1835

225 ii 26 f.e. Melmoth, William (1710-1799): for he read she

229 i 12 f.e. Melton, William de: after preacher insert and was for some time tutor to Fisher (cf. De Veritate Corporis, p. 327)

8 f.e. after Library. insert His wills and inventories are printed in 'Testamenta Eboracensia' (Surtees Soc.), pp. 251-63

20 after p. 696 insert Yorkshire Archæological Journal, viii. 291

265 ii 6 f.e. Mercer, John: for cotton-spinner read weaver

273 i 23 Meres, Francis : for (ib.) read (ib.; Yorkshire Record Series, vol. ii.)

30 after son insert Francis

35 for He seems to have had a son read The son

$36 \quad$ omit who

274 i 13 f.e. after presented insert for the speakership

275 i 28 Meres, John: after 1.28). insert He compiled a useful catalogue of English plays (London, 1713, 4to, with continuation, 1715).

276 ii 15-14 Merewether, Sir William I. : for he commanded . . . Sind horse, read he was f.e. second in command of Sir George Malcolm's detachment of Sind horse,

282 i 16 Merivale, John H. : for the Rev. H. J. T. Drury read the Rev. Joseph Drury for is read was omit the present

Merry, Robert: for Cambridge. read Cambridge, being admitted there 2 April 1771 .

40 for was entered of Lincoln's Inn read studied at Lincoln's Inn, where he had been entered 5 Nov. 1770,

303 ii 29 Metcalf, John: for Boynes's read Boyne's

305 ii 30-31 Metcalfe, Charles T., Baron Metcalfe: for is in the Kingston town-hall, Jamaica. read by a Canadian artist, named Bradish, is in the court house at Falmouth, Jamaica.

327 ii 24 Michel, Sir John : for (now Sir Henry) read (afterwards Sir Harry)

336 i 14 Michell, Richard : after children. insert One daughter, Mary, married the third duke of Sutherland and subsequently Sir Albert Rollit, M.P.

346 i 8 f.e. Middleton, Conyers : for thus read then

347 i $36 \quad$ for 'Letter to Rome' read 'Letter from Rome'

352 ii 10 f.e. Middleton, John, 1st Earl of Middleton : for 1673) read 1674)

354 i $35 \quad$ for 1673 read June 1674 (Sloane MS. 3512, f. 79)

357 i 18-19 Middleton, Richard: for William Middleton, a D.D. of Paris read William of Meliton [q, v.]

364 i 17 Middleton, Thomas F.: for Sharpe read Sharp

366 i 6 f.e. Midgeley, Robert: after Spy, insert has been doubtfully identified with the Robert Midgeley who was

ii 1 for and removing to Christ's College, read The alleged author of the 'Turkish Spy' seems more probably identical with another Robert Midgeley (son of Samuel Midgeley) who, born at Adle, near Leeds, was admitted a sizar of Christ's College, Cambridge, 27 June 1671, aged 16,

369 i 4 Miers, John: for his father, who was a jeweller; read his father, John Miers, a jeweller and miniaturist, who executed a portrait of Robert Burns;

377 ii 8 f.e. Miles, George F. : omit Edward I'Anson

388 ii 7 Mill, James: after 1808. insert Spence replied in 'Agriculture the Source of the Wealth of Britain.'

399 i 32 Mill, John Stuart : for H. R. L. Mansel's read H. L. Mansel's

401 i 20 f.e. Millar, Andrew : for (No. 4053) read (No. 4059)

5 f.e. Millar, James: for (d. 1827) read (1762-1827)

4 f.e. $\quad$ after writer, insert born at Ayr on 4 Feb. 1762,

i.l. after science. insert $\mathrm{He}$ acted for some years as a tutor in Jamaica, and afterwards as chaplain to the University of Glasgow.

ii 6 for in July read on 13 July

403 i 18

Millar, John (1735-1801) for Allan Thomson read Dr. John Thomson, by whom . she was mother of Allan Thomson 
Page Col. Line

Miller, Edward : for 1731 read 1730

34

after Lynn insert His brother Thomas is noticed separately.

410 i 10 f.e. Miller, Hugh: for 2 Dec. read 23 Dec.

411 i 10-1 Miller, James (1706-1744): omit'Mister Taste, . . . Hogarth, 1833, p. 176).

f.e.

ii 3

after 1735 insert (this piece must be distinguished from another also called 'The Man of Taste,' which was published in 1733 , being a reissue with a new title of 'Mister Taste, the Poetical Fop : or, the Modes of the Court,' a comedy [1732]; 'Mister Taste,' for which Hogarth designed a satirical frontispiece, was an insolent attack on Pope)

414 ii 18-19 Miller, John C.: for collected 5,000l read organised simultaneous collections on a given Sunday in the churches of Birmingham, by which means the sum of 5,000l. was raised, and the first foundation laid of Hospital Sunday.

36 after issue. insert The Miller Hospital of Greenwich, grafted upon the Royal Kent Dispensary, was opened in December 1884 as a memorial to Miller.

7f.e. before Christian Cabinet insert John Poland's Records of the Miller Hospital and Royal Kent Dispensary, 1893;

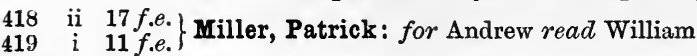

423 ii 8 f.e. Miller, Thomas (1731-1804) : after pavior insert and brother of Edward Miller [q. v.]

424 ii 1-2 Miller, Thomas (1807-1874): for Harrison Ainsworth read W. H. Harrison

427 ii 27 Miller, William (1795-1861) : after (Chicago, 1892); insert Basil Hall's Journal in Chili, part i. ch. iii.;

$\left.\begin{array}{lll}437 & \text { i } & 29 \\ 34\end{array}\right\}$ Millhouse; Robert: for J. B. Briscoe read J. P. Briscoe 



\title{
Dictionary OF NATIONAL BIOGRAPHY
}

\author{
ERRATA IN VOLUME XXXVIII
}

\author{
MILMAN-MORE \\ N.B.-f.e. stands for from end and l.l. for last line
}

Page Col. Line

$\begin{array}{rrr}3 & \mathrm{i} & 13 \\ 4 & \mathrm{i} & 21 \\ 35 & \mathrm{i} & 17 \\ 40 & \mathrm{i} & 9-7 \\ & & \text { f.e. }\end{array}$

Milman, Henry H. : for shifted read sifted

for Lieutenant read Lieutenant-General

Milton, John (1608-1674): for the work read the agreement

for Cambridge were left .... died in 1700. read Cambridge, of which the history is very obscure, may have formed part of a donation made to the college by Sir Henry Newton, afterwards Puckering [q. v.].

43 i 36 Milverton, John : after MSS.; insert Gregory's Chronicle (Camden Soc.);

53 i 8 f.e. Misson, Francis M. : for 1798 read 1698

ii 35 for 22 Jan. read 12 Jan.

67 i 11 f.e. Mitchell, Hugh Henry : for (1764? read (1770

10 f.e. $\quad$ after Colonel, insert born 9 June 1770,

95 ii 23-24 Modyford, Sir Thomas: for Charles, the elder, predeceased his father. read Thomas the elder, survived his father little more than a month.

24 for Thomas read Charles

97 ii 39-40 Moffat, Robert: for Stellen-booch read Stellen-bosch

102 i 11 f.e. Moffett, Thomas : for Barnes Elms read Barn Elms

103 i 3 f.e. for he is there described read he is described at the foot of the dedication

107 i 29-34 Mohun, Charles, 5th Baron Mohun: omit His only would-be apologist ... Own Time, ii. 130).

17 f.e. $\quad$ for and engraved by Cooper. read in 1707 and was engraved by John Faber the younger, in 1732 .

111 i 18 f.e. Mohun, Reginald de: for 1146 read 1246

112 ii 5 Mohun, William de: for Dunstan read Dunster

120 i 10 Molesworth, John E. N.: for 1825 read 1815

122 i 17 Molesworth, Robert, 1st Viscount Molesworth : before were issued insert [see ROGERS, THOMAS, 1660-1694]

123 i 21 f.e. Molesworth, Sir William: for His father .... and he read $\mathrm{He}$

15-3 for and he was sent.... at the university. He read With his mother f.e. and two sisters he removed during 1824 to Edinburgh, and studied at the university till 1827. In that year he entered at St. John's College, Cambridge, but soon migrated to Trinity. He gave promise of mathematical distinction, but a quarrel with his tutor led to his expulsion from Cambridge in April 1828. He sent his tutor a challenge, and both were bound over by the mayor of Cambridge to keep the peace for a year. Molesworth spent the next few months in the family of Dr. Bekker at Offenbach, near Frankfort, studying German and philosophy. At the end of a year he travelled by coach to Munich to fight the postponed duel with his Cambridge tutor. Lord Queensberry acted as his second. Shots were exchanged, but neither was hurt. Molesworth

l.l. $\quad$ for Naples read Rome and at Naples

ii 10 f.e. after generally. insert He purchased the 'Westminster Review' in 1836 and amalgamated the two. 
Page Col. Line

123 ii 9 f.e.

124 i 12

25

125

10

33

127 i $50-51$

136 ii 3-2

f.e.

160

21

161

i $\quad 33-38$

23 f.e.

ii $\mathbf{3 1}$

167 ii 18

168 ii 10

202 ii 30 ii $13-14$

Molesworth, Sir William: for it read the proprietorship

after troubles insert after championing Lord Durham's policy

before He was insert He took part in founding the Reform Club in London in the same year.

after Mrs. Grote, insert and on her death it passed to his sister, Mrs. Ford, who presented it to the parliament house at Ottawa, where it now stands in the library,

before The Philosophical Radicals insert Mrs. Fawcett's Life of Sir William Molesworth appeared in 1903.

Molines, Sir John de : for Mautravers read Maltravers

Molyneux, Samuel: for the death of Molyneux's widow, on 27 May read the marriage of Molyneux's widow to Nathaniel St. André, on 17 May

Monck, George, 1st Duke of Albemarle : for no longer shown to visitors read is in a very decayed condition

after 1866. insert A fourth was painted by Dr. Logan, of which, and of two other pictures of Monck, engravings belong to James Falconer, esq.

omit A portrait of Monck . . . . James Falconer, esq.

after Albemarle, insert born 25 March 1619 (Sloane MS. 1708, f. 117),

for said to be aged 54 read aged nearly 51

Moncreiff, Sir Henry: for (1738-1767) read (d. 1767)

Moncreiff, Sir Henry W. : for fifty read fifty-two

Monson, Sir William (1569-1643): for What appears to be the original manuscript read The original manuscript, corrected for the press by the author and dated 1624, is in Sloane MS. 2496, ff. 113-188. Another manuscript

Montacute, John de, 3rd Earl of Salisbury : omit baron and after Monthermer insert [q. v.]

2-1 Montacute, William de, 1st Earl of Salisbury : for Sir William Grandison read f.e. William de Grandison, first Baron Grandison

Wntagu, Henry, 1st Earl of Manchester: for Sidney, who died in infancy, read Sidney, who, having been admitted fellow-commoner at Christ's College, Cambridge, 20 May 1641, graduated M.A. in that year, entered the Middle Temple 2 Aug. 1642, and died young,

Montagu, John, 4th Earl of Sandwich : after first lord. insert Sandwich, however, interested himself in getting Captain Cook's two vessels fitted out adequately in 1778, and Cook named the Sandwich Islands after him.

i 23 f.e. Montgomerie, Robert (d. 1684): for 1661 read $1651^{\circ}$

\section{ii 33 Montgomery, Henry : for 1800 read 1830}

i 2 Montgomery, Robert (1807-1855): after 1841. insert The most ambitious of his f.e. later works was 'Luther: a Poem' (1842, 8vo, 6th ed. 1851). Of immense length, this volume contains Montgomery's one memorable line, viz. 'the solitary monk that shook the world.'

Chancellor [q. v.]

350 ii 35 Moore, Sir Garret, Viscount Moore: for Sloane MS. read Addit. MS.

443 i 20-21 More, Sir Thomas: omit and personal liberty is at its zenith

444 ii 26 f.e.

445 ii $18 f . e$.

6 f.e.

2-1 f.e.

446 ii 21

22

447 i 8

ii 25 f.e.

21 f.e. for Barus read Barms

before the anonymous insert Christopher St. German [q. v.]

for in an anonymous treatise entitled read by St. German in

omit Dialogi

for festinissimo, read festiuissima

for Mendacjis read Mendacijs

for now belonging read belonging in 1892

after 121-2) insert The MS. figured in the 33rd 'Antiquarischer Katalog ' of Heinrich Schöningh of Münster, 1894 omit the Rev. 


\title{
Dictionary OF NATIONAL BIOGRAPHY
}

\author{
ERRATA IN VOLUME XXXIX
}

\section{MOREHEAD—MYLES}

Page Col. Line

\author{
N.B.-f.e. stands for from end and l.l. for last line
}

5 i 14 f.e. Morell, Thomas : for Hertford read Hereford

8 ii 27-33 Moret, Hubert : for His portrait .... Moret. read His portrait was formerly supposed to have been painted by Holbein, but the alleged portrait of Moret by Holbein (picture and drawing at Dresden) represents Charles de Solier, seigneur. de Morette, a French ambassador who flourished in 1534.

23-22 Moreton, Henry J. R., 2nd Earl of Ducie: for John Reynolds read George. f.e. FrancIS

9 i 10 f.e. for $\mathrm{G}$. V. Briggs read $\mathrm{H}$. P. Briggs

22 ii 18 f.e. Morgan, John M.: for 1851 read 1837

32 i 13 f.e. Morgan, Thomas (1543-1606?): omit the jesuit

51 ii 14 f.e. Morier, James J.: for Troutroud read Toutrond

52 i 2 after Ispahan insert in England

12 for Troutroud, or the Frenchman in London,' read Toutrond, or a Frenchman in London in 1831,'

54 i 3 f.e. Morins, Richard de : for he seems read he studied at Bologna (Gesta Abbat. i. 307). $\mathrm{He}$

70 i 34 Morland, Sir Samuel : for In 1666 read On 13 Jan. 1666-7

73 i 18 f.e. after 1672 8vo. insert (the 'Perpetual Almanack' is reprinted in John Playford's 'Vade Mecum,' 1717)

l.l. for Joseph read Samuel

74 i 2

4-5

$\begin{array}{lll}75 & \text { i } & 27\end{array}$

77 i 36

81 i 36

ii 3

91 i 23-25

106

i $\quad$ 17-18

107

126

152

153

164

165

172

173

Morley, Christopher L. : for Of these a few read Thirty-six of these for Nos. 1259 . . . . 1289 read Nos. 1256-8, 1259-80, 1282-94, 1297-9

Morley, George: for affixed read prefixed after Chelsea insert and his books for the use of the clergy of his diocese

Morley, John (1656-1732) : for Gestringthorpe read Gestingthorpe

Morley, John (d. 1776 ?) : for (1655 read (1656

Morris, Charles : for proceeded B.A. . . . . joined the 17 th foot. read joined the 17 th foot in Ireland on its return from Minorca in 1748 ( $\mathrm{He}$ did not, as has been stated, proceed to Oxford).

1851, and was buried in the churchyard of Beverley Minster.

Morrison, George : for 1829 read 1729

ii 13 Mortimer, George F. W., for still survives read died in 1901

20 f.e. Morton, John (1420 ?-1500): for to have read to leave

14 for 12 Oct. read 15 Sept.

ii 36 Morton, John (1671 ?-1726): for In 1701 read As early as 1694 (Sloane MS. 4062)

Morton, Thomas (1564-1659): Note that the works numbered 1, 2, and 22 which ii 8-19 are here attributed to Thomas Morton, bishop of Durham, were by another. i 20-19 Thomas Morton of Berwick and of Christ's College, Cambridge. The date of f.e. ( publication of No. 22 should be 1599, not 1669 .

i 3 f.e. Morys, Sir John : after Ireland ; insert Book of Howth, pp. 161, 164, 456;

ii 1 Moryson, Fynes: for 1617?) read 1630)

ii 17 f.e. after ccc. 94). insert A large portion of it was printed by Mr. Charles. Hughes under the title of 'Shakespeare's Europe' in 1908. 
Page Col. Line

173 ii l.l. Moryson, Fynes : omit appears to have

174 i 1 for in 1617 read on 12 Feb. 1629-30

175 i 11 f.e. Moseley, Henry : for Lyne read Lyme

191 ii 3 f.e. Mostyn, Sir Roger : after Carnarvonshire. insert Farquhar's 'Constant Couple' was dedicated to him.

192 i $29-30 \quad$ omit was appointed ... in 1768

193 i 38 Motherby, George : for in the summer of read on $19 \mathrm{July}$

221 ii 16 Mowbray, John (V), 2nd Duke of Norfolk: for In April and May read In the early spring

20 for May read March

236 ii 21 f.e. Mowbray, Thomas (II), Earl Marshal: omit Lady

238 ii 2 f.e. Mowse, William : after to him. insert But he withdrew from that office early in 1557, when he was succeeded by Henry Harvey or Hervey (d. 1585) [q. v.]

239 i 6

$7-8$

240 i 5 f.e. omit and of the mastership .... soon

omit [cf. HARveY . . . LL.D.]

Moxon, Edward : after 1843-6, insert also of 'Cleon' and the 'Statue and Bust' (both in 1855)

for impression read copy

for Moxon read Mrs. Moxon

241 i 31

245 ii 21

Moyle, Sir Thomas : for probable that he supported her read that he proclaimed her queen

268 ii 26 Muir, Thomas : for Thomas read James

30 after university, insert where he matriculated in 1777 and graduated M.A. on 24 April 1782,

279 ii 16 Müller, William J.: after 1883. insert Two hundred of Mïller's works were exhibited at the Birmingham Art Gallery in 1896.

297 ii 12 Munday, Henry : for 1615 read 1715

319 ii 11 Murchison, Sir Roderick I. : for quartzoles read quartzites

12 for from their fossils, read from their fossils, of

321 i 15 f.e. Murcot, John : for Ashbury read Astbury

328 ii 15-16 Murdock, William : for in the 1882 .... National read in the Wallace Monument at Stirling. In 1882 the National

332 ii 19 Murimuth, Adam : for 1331 read 1337

387 ii 34-35 Murphy, Edward: omit on the recommendation of James II, 38-39 for in that year read 1724

350 ii 11 f.e. Murray, Lord Charles, 1st Earl of Dunmore : for third earl read second earl

361 i 20 Murray, Lord George (1761-1803): after (WooD). insert Amelia Matilda Murray [q. v.] was the fourth daughter.

873 ii 12 Murray, James (1725 ?-1794): for (1725? read (1719?

14 for 1725 read 1719

376 i $19-20$

392 i 29 Murray, John (1778-1843): for former read latter

30 for latter read former

394 i 15 f.e. Murray, John (1786?-1851): after 1833. insert In 1835 he gave evidence on the safety lamp and ventilation before the House of Commons Select Committee on accidents in mines (Reports, pp. 237-49).

404 i 2 Murray, Sir Terence A. : for A son. read The second son by the second marriage 10 f.e. Murray, Thomas (1564-1623) : after daughters insert one of whom was wife of Sir Henry Newton, afterwards Puckering [q. v.], while the other was Anne, Lady Halkett [q. v.],

408 ii 25 Murray, William, 1st Earl of Dysart : for two daughters read four daughters

409 ii 8-9 Murray, William, Marquis of Tullibardine : for Corri-garrick read Corry-arrick

413 i 14 f.e. Murray, William, 1st Earl of Mansfield : for brother read nephew

421 ii 16 f.e. Musgrave, Sir Philip : after Oxford, insert where he became a commoner in 1624,

425 i 20 f.e. Musgrave, Thomas, Baron Musgrave : for Harca read Harcla (or Hartley)

429 i 16-17 Mush, John: for Anne Clithero read Margaret Clitherow [q. v.]

435 i 23 Musters, George C.: for Coldwick Hall read Colwick Hall

25 for Mary Anne Chaworth. read Mary Ann Chaworth.

436 ii 14 f.e. Myddelton, Sir Hugh: omit near

445 i 2 f.e. Mykelfeld, William: before at Paris insert (the seminary of the Jacobins or Dominican friar preachers) 


\title{
Dictionary OF NATIONAL BIOGRAPHY
}

\author{
ERRATA IN VOLUME XL \\ MYLLAR-NICHOLLS \\ N.B.-f.e. stands for from end and l.l. for last line
}

13 ii 15 Mynn, Alfred : for Nathaniel read Nicholas

22 i 25 Nagle, Sir Richard : after Ireland, insert son of James Nagle of Clogher,

Nairne, John, 3rd Lord Nairne: for Caroline read Carolina

Nalson, John: for Conyng Street read Coney Street

for Peter Williams read Philip Williams

33 i 9 f.e. Napier, Sir Alexander ${ }^{\text {for }}$ 1636-7 read 1436-7

57 i 12 f.e. Napier, George : for 88 read 81

58 i 10 f.e. Napier, Sir Gerard : after brother. insert He was a commoner of Trinity College, Oxford, in 1623-4.

75 i 9 f.e. Napier, Robert C., Lord Napier of Magdala : for (1811 read (1810

100 i 7 Nash, Richard: after 1703 insert (cf. art. VenNer, Tobias)

105 ii 13 f.e. Nash, Thomas : after 4to. insert It gives a rationalistic explanation of dreams and exposes many popular superstitions.

108 ii 17 f.e. after Library. insert Another imperfect copy, called 'The Choosing of Valentines by Thomas Nashe,' is in Inner Temple MS. 538. A few of its opening lines were printed by Dr. Grosart and the whole by Mr. John S. Farmer for private circulation in 1899.

109 i 2 for Tanner MSS. read Tanner and Inner Temple MSS.

3-7 omit An indelicate poem . . . . Dr. Grosart.

111 i 14-15 Nash, Treadway R. : for vicarage read rectory

114 ii 4 f.e. Nasmyth, Alezander: for 1778 read 1787

116 ii $30 \quad$ Nasmyth, James : after foundry. insert In 1836 also he gave evidence on the arts and principles of design before a select committee of the House of Commons (see Report, p. 28).

117 i 18 f.e. for Napier read Nasmyth

120 ii 14 Nassyngton, William : for Three read Ten

15 for viz. read including

128 ii 17 f.e. Naunton, Sir Robert: for 22951 read 22591

141 i 14 f.e. Neale, Erskine: for Whycotte read Whychotte

143 ii 31 Neale, John M. : for 1841 read 1851

34-85 omit he was elected . . . . College, where

36 after tutor insert at Downing College (he was not elected fellow)

145 i 20 for the Jews read the Pews

for in read on

149 i 20 Neale, Walter : for was son read is erroneously said to have been son after 149). read This Walter Neale, who married twice, died between 9 Oct. 1612 , when he made his will, and 29 April 1613, when his will was proved (New England Hist. and Geneal. Reg. April 1898). The explorer's parentage is not known 
Page Col. Line

149 i .37 Neale, Walter: for there read at Portsmouth

150 i 3 f.e. Neale, William J.: after 1842 insert (an adaptation of a 'History of the Mutiny, by George Roberts, $d .1860$ [q. v.])

154 ii 31

35

36

37

155

157

226

243

247

47

252

260

266

402 i 6 f.e. Newton, Thomas (1542?-1607): after Thence insert (according to Warton)

405 i 28 Newton, Thomas (1704-1782): for 1682 read 1782
18 f.e. after West insert The twentieth edition appeared in 1835

413 i 8 f.e. Nichol, John P.: for in 1853 Miss Pease read on 6 July 1853 Elizabeth, daughter of Joseph Pease

7 f.e. $\quad$ after survived him insert (she died, aged 90, on 8 Feb. 1897)

416 ii 12 f.e. Nicholas de Farnham: for bishop read archbishop

417 ii 6 for De Illustratione Anglorum Scriptorum; read De Illustribus Angliæ Scriptoribus;

431 ii 24 f.e. Nicholas, Robert: for (1597-1665?) read (1595-1667)

23-15 for probably the son of Robert Nicholas ....25 July 1614, and on read f.e.

f.e. son of John Nicholas of Devizes and Roundway, in the parish of Bishops Cannings, Wiltshire, and was baptised at St. James's, Southbroom, in that parish, on 21 Sept. 1595. Nicholas on

for Nicholas probably died during the next year. read Nicholas resided in later life at Seend, Wiltshire, where he made his will 6 May 1667 . He was buried on 28 Dec. (in accordance with the provision of his will) in the church of St. James's, Southbroom, where he had been baptised. 


\title{
Dictionary OF NATIONAL BIOGRAPHY
}

\author{
ERRATA IN VOLUME XLI
}

\section{NICHOLS-O'DUGAN}

\author{
N.B. - f.e. stands for from end and l.l. for last line
}

\begin{abstract}
Page Col. Line
1 ii 9 Nichols, James : for (1845) read (1845 and 1848)

19 ii 13 Nicholson, John (1821-1857): for Read read Reed

28 i 35 Nicholson, William (1591-1672): for aged 72 read aged 80

29 i 17 f.e. Nicholson, William (1753-1815) : for many patients read four patients

16 f.e. after his own insert respectively in $1790,1802,1806$, and 1812 (the last not being completed)

88 ii 8-7 Noel, Baptist, 3rd Viscount Campden: for Thomas Watton, lord Watton, read f.e. Thomas Wotton, lord Wotton,

103 i 21 f.e. Nonant, Hugh de: for Hubert of Salisbury read Herbert of Salisbury

107 i 1 Norden, John : omit and

8 omit Additional

110 ii 37 Norgate, Robert : after 1573-4. insert He became master of Corpus Christi College in 1573.

112 ii l.l. Norman, George W.: for Baron Overston read Baron Overstone

118 i 9 Norris, Sir Edward : for Francis read Francis Vere

130 i 14 Norris, Sir John: for was finally recalled read was superseded in command, though he remained at Brest till near the end of the yeur

152 ii 10 North, Sir Dudley : for third son read fourth son

154 ii 24 f.e. North, Edward, 1st Baron North : for Sconington read Sinnington

163 ii 36 North, Frederick, 2nd Earl of Guilford : for Bassett read Basset

200 ii 25-26 Northey, Sir Edward : for Sir Thomas Raymond [q. v.], baron of the exchequer. read Robert Raymond, Lord Raymond [q. v.], lord chief justice.

201 ii 10 f.e. Northmore, Thomas: for Earle read Erle

207 ii $\left.\begin{array}{c}1 \\ 3-4\end{array}\right\}$ Norton, Caroline E. S.: for Lockhart read Henry Nelson Coleridge

220 i 6 f.e. Norton, Samuel : for ff. 31-90 read ff. 17-21, 24-28, and 31-90

221 i 12 f.e. Norton, Thomas ( $f$. 1477): before Addit. MSS. insert Sloane MSS. 1198, 2174, and omit 300 [1]

222 i 12 f.e. Norton, Thomas (1532-1584): omit Middle

245 ii 32 Nowell, Alexander : for Jewell's read Jewel's

247 i 25-26 for name unknown, read whose name seems to have been Blount,

27-31 for who had been married before .... she had issue. read widow of Thomas Bowyer, grocer, of London.

32 after 1612 insert being buried at Mundham, near Chichester (see monumental inscription and parish register at Mundham)

248 i 13-14 for Pankhurst's read Parkhurst's

253 i 15 Nower, Francis : for C. P. Nowers read G. P. Nowers

278 ii 30 Nutter, William: for 21 March read 14 March

279 i 5 f.e. Nye, Nathaniel : after astronomy' insert (Nye also published an almanack for 1642 and two others in 1645)
\end{abstract}


Page Col. Line

283 i 31

$287 \quad$ i $\quad 29$

300 i 13

301 i 35

303 ii 5

Nye, Stephen: after 1729) [q. v.] insert An 'Examination' by John Jackson (1686-1763) [q. v.] appeared in 1715

0akeley, Frederick: for Time read Tones

Oates, Titus : for Buckingham read Oates for Withins read Wythens [q. v.]

after Cartwright; insert Lord Kenyon's MSS. pp. 105-8; Rochester's Familiar Letters, 1714, p. 150 ;

312 i 11 f.e. O'Brien, Donogh C.: for March read de Marisco [q. v.]

816 ii 11 f.e. O'Brien, James T. : for Westmeath read Wexford

317 i 23 after ings insert as well as those of the deists

ii 11-12 for seven sons and six daughters read eight sons and five daughters

17 after year insert (4th edit. 1877 and 5 th edit. 1886)

19 for directed against ritualism, read in great part directed against Tractarianism,

O'Brien, Murtough : for Murtough read Murtogh

ii

omit He attended a synod .... three thousand students.

after 1086. insert His daughter Mòr (d. 1137) married Murchadh O'Maelsechlainn.

40 after vol. ii. ; insert Annals Loch Cé (Rolls Series);

330 i 31 0'Brien, Turlough: for Murtough read Murtogh

372 i 4 0'Connell, Daniel (1775-1847): for brother read uncle

16 f.e. $\quad$ for return read recovery

400 i 24 0'Connor, Cathal (1150-1224): for March read de Marisco [q. v.]

405 i 8 f.e. O'Connor, Luke S.: for February 1868 read January 1867

ii 13 f.e. O'Connor, Roderic (1116-1198): for (1116 read (1116?

428 i 5 f.e. Odo of Canterbury : for Odo read Odo 'de Cancia'

3-2 for These sermons are remarkable for their frequent introduction read They

f.e. have been attributed both to Odo of Canterbury and to Odo of Cheriton, but the frequent introduction

l.l. omit which helps to explain the

ii 1-3 for confusion with Odo.... the latter author read points to the latter's authorship; they are, however, distinct from Odo of Cheriton's sermons

429 ii 13 f.e. Odo of Cheriton: for undoubtedly read probably and for Canterbury read: Cheriton

12 f.e. for Cheriton read Canterbury

434 i 28 0'Donnell, Calvagh: for 1581 read 1561

449 ii 35 O'Donovan, John : for Henthorne read Henthorn 


\title{
DICTIONARY OF NATIONAL BIOGRAPHY
}

\author{
ERRATA IN VOLUME XLII
}

\section{O'DUINN-OWEN}

\section{N.B. - f.e. stands for from end and l.l. for last line}

Page Col. Line

6 ii $\quad 8$ Offor, George: for biography read bibliography

7 i 35 Offord, Andrew : for Newbold read Newbald

10. ii 34 Ogborne, David : for ( $f$. 1740-1764) read (d. 1801)

11 i 20-22

24

$25-26$

28

34

35-36

37

38

10 f.e.

9 f.e.

ii 1

6

7

26

30

31

34-35 [q. v.]

for and Elizabeth [q. v.] . . . his children read was son

Ogborne, Elizabeth : for (1759 read (1763?

omit born at Chelmsford . . 16 May 1759, for elder brother read husband for Miss Ogborne read Mrs. Ogborne

for ninety-fifth read ninetieth

before Gent. Mag. insert Essex Review (July 1899);

Ogborne, John : for ( $f$. 1770-1790) read (1755-1837)

omit possibly

omit the line

for but in read In

for After 1704 Ogborne appears ... his death. read Ogborne died at Chelmsford and was buried in the churchyard there 6 Jan. 1801.

for three sons ... John [q. v.] read three sons and three daughters. John

before Baker's Biogr. insert Essex Review, vol. viii. No. 31 (July 1899);

for David Ogborne [q. v.] read Sir John Eliot, bart., by Jane Jackson. She married about $1790 \mathrm{John}$ Ogborne [q. v.], son of David Ogborne [q. v.]

for wife read sister (baptised at Chelmsford, 31 Aug. 1764)

for This may have ... same name. read $\mathrm{He}$ died a pensioner of the National Benevolent Institution, being buried in Tottenham Court Road Burial Ground 13 Nov: 1837. His wife, Elizabeth Ogborne, is separately noticed.

36 before Redgrave's Dict. insert Essex Review (July 1899);

12 i 13 Ogden, James : for 1889 read 1869

ii 21 f.e. Ogden, Samuel (1626 ?-1697): for.(1626? read (1628?

19 f.e. $\quad$ for about 1626 read about 1628 , the son of John Ogden,

18 f.e. for and Christ's College, Cambridge, read and was admitted to Christ's College, Cambridge, as a sizar 4 May 1648, aged 20.

17 f.e. $\quad$ after B.A. insert (1651-2)

15 i 32 Ogilby, John : for Rathfurm read Rathfarnham

17 ii 17 f.e. Ogilvie, Charles A.: for Jenkinson read Jenkyns

21 ii 16 Ogilvie, John (1797-1867): for Grant read Smart

85 ii 26-27

29-30 Ogle, sir Chaloner : for Trevelyan read Trelawney

41 i 10 Ogle, Sir John: omit the judge

43 i 7 f.e. Ogle, Robert, 1st Baron Ogle: for Tailboys read Talboys 
Page Col. Line

57 i 9

18

63 ii 3

77 ii 24

103 i 8 f.e.

110 ii 9

139

151

ii 4

i 30

0'Halloran, sir Joseph : for in Connaught Terrace read 42 Connaught Square for Bayley read Bayly

0'Hara, James, Lord Kilmaine: for 201 read 121

Okely, Francis : omit [q. v.]

Oldfield, Thomas : for her read his

Oldham, John (1653-1683) : after rate. insert An edition by Robert Bell appeared in $\mathbf{1 8 5 4}$.

Oliphant, Sir William (1551-1628) : after. WILLIAM insert LORD NEwTON

Oliver, Thomas (d. 1624): after Cambridge. insert He is probably the Thomas Oliver who matriculated as pensioner from Christ's College, Cambridge, in Nov. 1569

ii 29-31 Oliver, William (1659-1716): for His rules ,... and a discourse read Oliver's discourse

36 for Sir Hans Sloane read James Petiver [q. v.]

i 18 f.e. O'Neill, Hugh: for 1605 read 1600

i 8 O'Neill, Sir Phelim : for Statement read Settlement

19-20 O'Neill, Shane, 2nd Earl of Tyrone : omit second EArL of Trrone -

i 14 Ord, John W. : for Langburgh read Langbargh

18 for Boyce read Boyne

ii 15 Ordish, Rowland M.: for Great Western read South Western

i 30 O'Reilly, John B.: for its newspaper read their newspaper

22 Ornsby, George : for Book read Books

i 2 O'Rourke, Tiernan: for eight read eighteen

ii 28-34 Osbaldeston, Richard : omit Archdeacon Moss . . . Bishops, ii. 69).

i 25 Osbern, Claudianus : after Canterbury [q. v.] insert The 'Panormia' is identical with a work entitled 'Thesaurus Novus Latinitatis,' which was edited by A. Mai in 'Classici Auct. e Vat. Cod.' Rome 1836, tom. viii. (cf. W. MAYer in Das Rheinische Museum, vol. xxix., and Loswe; Prodromus Corp. Gloss. Lat. 1876, p. 240).

ii 9-8f.e. Osborne, Sir Thomas, 1st Earl of Danby and Duke of Leeds : for to warrant his nomination as member read (It was Henry Osborne and not, as is often stated, Thomas Osborne who was nominated a member

$\begin{array}{ccc} & & 6 f . e . \\ 298 & \text { ii } & 22 \\ 300 & \text { ii } & \mathbf{3 2 - 3 3} \\ \mathbf{3 2 3} & \text { i } & 13 \text { f.e. } \\ \mathbf{3 4 7} & \text { i } & \mathbf{2 9}\end{array}$

21 f.e.

350 i 21 f.e.

352 i 3 f.e.

ii 28-49 0tway, Thomas (1616-1693): for is said to have been born in Wiltshire ... D.D. for 1667. read 1667).

for leaner Dick read leaner, Dick,

for December read October

Oswald, Saint (d.972): for (d.972) read (d.992)

Otway, Thomas (1652-1685): for Introducing himself read During the previous year, 1671, introducing himself

after plays. insert When Mrs. Behn's 'Fore'd Marriage' was published, in 1671 , 'Mr. Westwood' figures in the part of the king in the cast of characters.

after the world.' insert This portrait is at Bretby Castle, Derbyshire. An engraving by Mr. W. J. Alais was published by Dr. Grosart in 1880.

for W. T. Thornton read Thomas Thornton from Trinity College, Dublin. read born at Alderbury, Wiltshire, on 1 Nov. 1616, was son of George Otway, vicar of that place. The father, who was apparently first cousin of Humphrey Otway, father of Thomas Otway, the dramatist, graduated B.A. 1599-1600 and M.A. 1603 from Christ's College, Cambridge. Thomas, the future bishop, was educated at Winchester, and was admitted a sizar of Christ's College, Cambridge, on 13 June 1632, 'aged 15.' He graduated. B.A. 1635-6 and M.A. in 1639, afterwards taking the degree of D.D. at Trinity College, Dublin.

7 f.e. $\quad$ after i. 257). insert He was rector of St. Botolph's, Bishopsgate, June 1663June 1664, and of Etchingham, Sussex, June 1664-1670. 
Page Col. Line

357 ii 15 f.e. Oughtred, William : for Horizonal read Horizontall

359 ii 13 Ouseley, Sir Frederick A. G. : for Lorchill read Lovehill

361 i 25 Ouseley, Gideon : for Liga read Siga

365 i 15-16 Outram, Benjamin : for Jessopp read Jessop

375 ii 5-6 Overall, John: omit and having graduated B.A.

$7 \quad$ after 1578. insert He graduated B.A. in 1579 and M.A. in 1582.

382 i 17 Overbury, Sir Thomas : for (d. 1683) read (d. 1684)

4 f.e. $\quad$ for 1683 read 1683-4

383 i 7 ,

36 Overton, Charles : for Ronaldkirk read Romaldkirk

384 ii $\left.\begin{array}{c}29 \\ 50-51\end{array}\right\}$ Overton, John (1763-1838): for Churchman read Churchmen

386 ii 2 f.e. Overton, Richard: for 54 real 55

398 i 18 Owen of Wales: before In August insert Owen is doubtless the person claiming to be 'heir of Wales' with whom Sir John Menstreworth was intriguing in 1377 (Chron. Anglia, p. 135).

399 ii 19 Owen, Alice: for Pinks's read Pink's

419 i 16 0wen, Jacob : for Belston real Bilston

420 i 10 f.e. Owen, John (1560?-1622): for Plas Dhu read Plas du

3 f.e. $\quad$ for Trelleck read Trelech

435 ii 10-12 Owen, Sir Richard (1801-1892): omit owner of Fulmer Place ... in 1741,

13 after Eskrigge insert owner of Fulmer Place and high sheriff of Bucking. hamshire in 1741

442 ii 33 for and he made read and, as guest of Sir John Fowler, he made 



\title{
DicTiONARY OF NATIONAL BIOGRAPHY
}

\author{
ERRATA IN VOLUME XLIII
}

\author{
OWENS—PASSELEWE
}

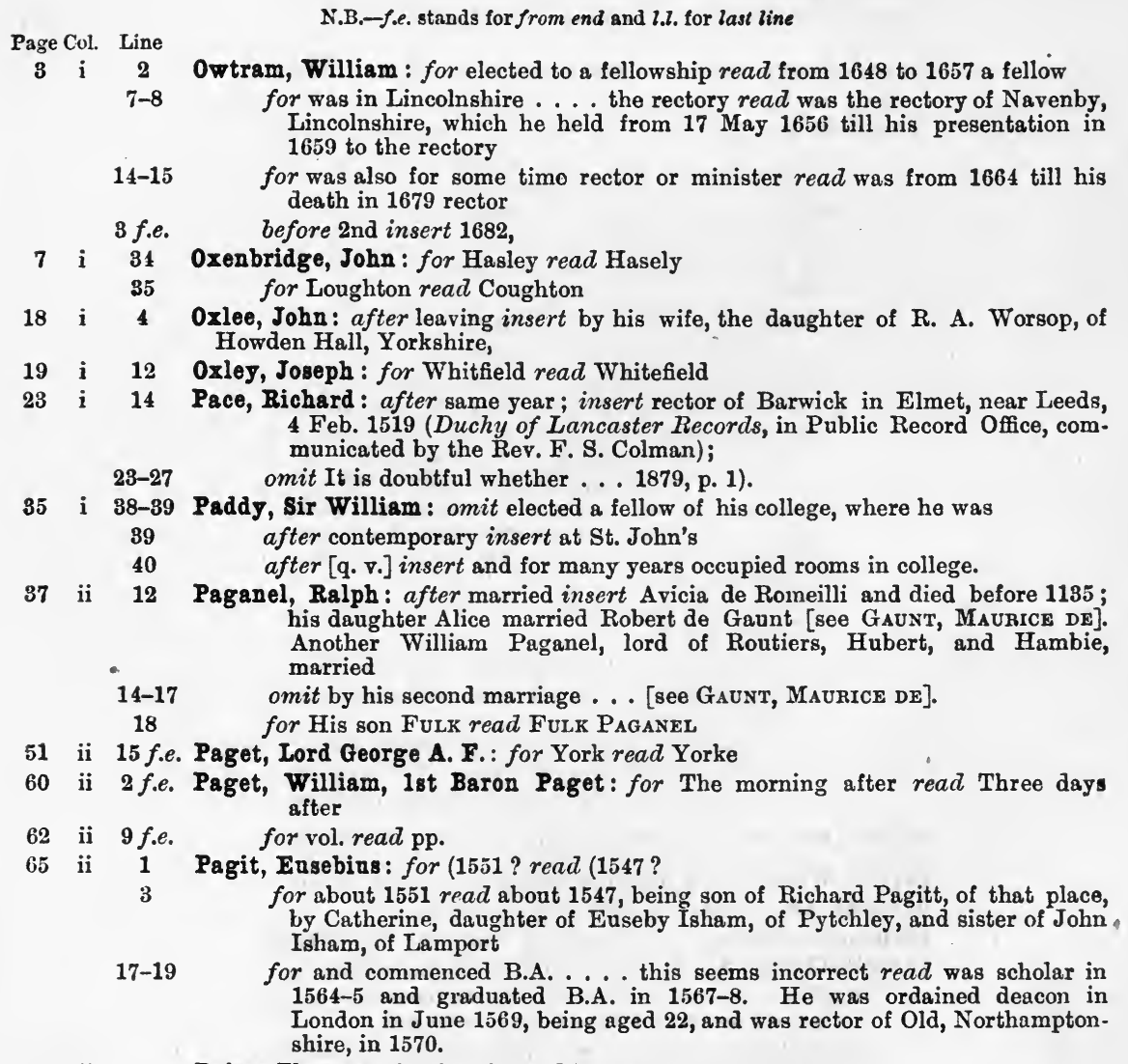

76 ii 31 Paine, Thomas : for Penn's read Paine's

79 ii 22 f.e. Painter, Edward: for Stratford read Stretford

86 ii $\quad 30$ Pakington, Dorothy, Lady : for Warwickshire read Worcestershire

88 i 3 after the 'Duty' insert (cf. Atterbury's Sermons, 1737, iv. 45) 
Page Col. Line

88 ii 10

121 ii $34-85$

126 ii 18

127 i 13

144 ii 11

147 i 36

149 ii 6

153 ii 22

3 f.e.

ii 5

166 i 4

184 i 14

187 i 5

229 i 5

240

245

f.e.

Pakington, Sir John (d. 1560): for Lyttleton read Lyttelton

Palmer, Edward : for Crompton Scorfen read Compton Scorpin

Palmer, Sir Geoffrey: after in 1598 read Matriculating as a pensioner from Christ's College, Cambridge, in Dec. 1612 (in the same year as Miles Corbet, the regicide), he graduated B.A. in 1615-6 and M.A. in 1619. He was admitted to the Middle Temple in June 1616.

for Thomas read Francis

Palmer, formerly Budworth, Joseph : for son read nephew after shire insert and was son of Joseph Budworth, originally of Coventry

Palmer, Richard (d. 1195): for latter read letter

Palmer, Roger, Earl of Castlemaine : for duly read drily

Palmer, Roundell, 1st Earl of Selborne : for effort read effect for 1875 read 1878

Palmer, Sir Thomas (d, 1553) : for 1550 read 1551 for Queen Jane read Queen Mary

Palmer, William (1824-1856) : for William read Walter

Panter, David : after 1558 insert and was succeeded in the bishopric by Henry Sinclair [q. v.]

Pantulf, William: for Henry II read Henry I

Parke, Thomas H. : for Lieutenant Stair read Lieutenant William Grant Stairs [q. v.]

Parker, Henry, 8th Baron Morley : for James read John

Parker, Sir Hyde (1739-1807): omit but the latter . . his father

, John $(f l .1655)$ : for Anthony à Wood states that he read $\mathrm{He}$

i 10 f.e. Parker, Richard (1767?-1797): for (1767? read (1767

9-8f.e. for born about 1767 ... well-to-do baker read baptised in the church of St. Mary Major, Exeter, 24 April 1767, was son of Richard Parker, baker

7 f.e. $\quad$ for Exeter read the parish of St. Mary Major, Exeter

6 f.e. $\quad$ for to have entered read $\mathrm{He}$ entered

4f.e. for and to have read and is stated to have been acting lieutenant at the close of the American war. He is also said to have

ii 20-27 for What appears to be true. . by volunteering for the navy and read About 1791 he married Anne MacHardy (of a Scottish family), who lived at Exeter, and leaving the sea went to Scotland. $\mathrm{He}$ is said to have been employed at one time in making golf balls for players on Bruntsfield Links. While imprisoned for debt, apparently at Edinburgh, he, in 1797 , accepted the bounty of $30 l$. as a volunteer for the navy, and was drafted to a tender off Leith. He

33

269 i 7-12

4 f.e.

3-2 f.e.

l.l.

for Parker was recognised read Parker's officer-like bearing caused him to be recognised

omit Nor has it ever been explained . . . their clief.

for it was said, to take it to Exeter. read she said, to take it either to Exeter or to Scotland.

for It was, however... magistrate read After an attempt to bury the remains in Aldgate churchyard was frustrated by the mob, they were

274

275

284

319

322

324

328

i 11 f.e. 13 f.e. Parker, Samuel (1640-1688): for Transpos'd read Transpros'd

ii 22 f.e. Parker, William, 4th Baron Monteagle : for His mother read Parker's mother

ii 11 f.e. Parkyns, Sir Thomas : for Knype.read Knipe

i 4 f.e. Parmentier, James : for the town of Hull read Holy Trinity Church, Hull

ii 5 Parnell, Charles s.: for Mr. Shaw read William Shaw. [q. v.]

ii $\mathbf{3 1 - 3 3}$

for Upon the announcement . . . the house, read Parnell was not in the house when this decision was announced,

329 ii $\quad 17$

after Land Act insert and pointing to the ravages of crime in Ireland warned Parnell that the resources of civilisation were not exhausted by the government.

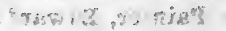

for replied read announced 
Page Col. Line

329 ii 21-24 Parnell, Charles S.: for by pointing to the ravages . . . by the government. Next day Parnell read the intention of the government to put Parnell in prison. On the same day he

347 i 37 Parnell, James : for Abbey Ripon read Abbot's Ripon for or read of for Matins read Meetings

374 i 13 f.e. Parry, Edward (1830-1890): after in title insert Richard Rogers [q. v.]

382 i 8 Parry, Sir Love P. J. : for Carmarthenshire read Carnarvonshire

384 i 25 Parry, Robert ( $f$. 1595): after book ii. insert In 1597 'Robert Parry, gent.' issued a volume of verse entitled 'Sinetes,' of which a unique copy, formerly at Lamport Hall, is now at Britwell. It is dedicated to Sir John Salusbury.

387 i 29 Parry, Thomas G.: for (d. 1849) read (d. 1848)

388 i 28 Parry, William (d. 1585) : omit jesuits like

ii 12 for 1630 ? read 1618

13 f.e. $\quad$ for on Tower Hill read in Westminster Palace Yard

420 ii 47-48 Parsons, Sir William (1570?-1650) : omit attorney-general in Ireland and

421 i $27 \quad$ for Sloane MSS. read Addit. MSS.

435 i 29-30 Pasco, John : for three sons and two daughters; read six sons (two of whom died in infancy) and three daughters; 



\title{
DiCTIONARY OF NATIONAL BIOGRAPHY
}

\author{
ERRATA IN VOLUME XLIV
}

PASTON-PERCY

Page Col. Line

N.B. - f.e. stands for from end and l.l. for last line

514 f.e. Paston, Robert, 1st Earl of Yarmouth : for 1676 read 1675

36 i 13 Paton, Mary A.: for Woods read Woon and so through the article

43 ii 11 Patrick, John : for Shircross read Thriscross

44 i 6 f.e. Patrick, Richard : for the following year was read 1794 became

3 f.e. for in February read on $9 \mathrm{Feb}$.

2f.e. after published insert 'The Adventures of a Hull Eighteenpenny, Token' (anon.), 1811; 'Geographical, Commercial, and Political Essays' (anon.), 1812 ; and

45 i 8 f.e. Patrick, Simon (d. 1613): for i. 496 read ii. 496

47 i 8 Patrick, Simon (1626-1707): omit [see Vaughas]

66 i 12-10 Patton, Philip: for Robert Patton .... was entitled read Robsrt Patron f.e. $\quad(1742-1812)$ who entered the army of the East India Company; became governor of St. Helena, and died at Wallington, Hampshire, in 1812. His daughter married Sir Henry Torrens [q. v.] He published (with Charles Patton's preface)

l.l. after Brit. Mus. Cat.insert Conolly, Fifiana, p. 32 ; Gourlay, Anstruther, p. 112 ; ADAM, Political State of Scotland, p. 124

68 ii 21 Paul (d. 1093): for Settringham read Settrington

69 i $\quad \begin{aligned} & 23 \\ & 25\end{aligned}$ Paul, Earl of Orkney (d. 1099): for at read in

77 ii 20-19 Paul, William (1678-1716): for installed read instituted f.e.

81 i 18-19 Panlet, Sir Amias (d. 1538): for By her he left.... other children. read Sir Hugh Paulet [q. v.] is said to have been his son.

89 i 15 f.e. Paulet, Sir Hugh : for was the eldest read is said to have been the eldest

102 i 35 Paxton, George : for accepted the call of read was ordained to

14 f.e. for the synod read the anti-burgher

13 f.e. for seceders read synods

117 ii 22-21 Payne, Peter: for 6. 'Petri Anglici .... ecclesiæ' read He has been wrongly f.e. credited with the 'Speculum Aureum' of Paul Anglicus [q. v.]

124 i 26 Payne, William (1650-1696): for (1693) read (1693, 2nd ed. 1708)

125 ii 19 Payne, William H. S.: after Drury Lane insert (1833-95)

129 i 30 Paynell, Thomas : for Cayley read Caley

130 ii 12 Peabody, George : for his native state, Maryland. read Maryland, the state where he lived.

131 i 8 f.e. Peach, Charles W.: for Maleson read Mabson :

131 ii 15 f.e. Peacham, Edmond: after traitor, insert seems to have been the Edmond Peacham, born about 1554 at Barton, Northamptonshire, who matriculated as a sizar from Christ's College, Cambridge, in June 1575, was ordained deacon in 1580 (aged 26) and priest in 1581, and became vicar of Ridge, Hertfordshire, on 22 July, 1581. He 


\section{ERRATA-VOLUME XLIV}

Page Col. Line

133 ii 2 f.e.

l.l. for 15 read 13 and for $\mathrm{pp}$ read $\mathrm{ff}$.

143 ii 24 Peacock, Thomas : for Burley read Barley

150 i 9 Pearce, Nathaniel: for in June read on 12 Aug.

152 i 22 Pearce, Zachary : for 1786 read 1768

ii 19 f.e. after his life. insert $\mathrm{He}$ assisted Bishop Thomas Newton in preparing his books for the press.

ii 15 f.e. 12 f.e.

167 i 12

Pearson, Hngh N.: for 1767 read 1776

169

26

omit was and for preferred read exchanged

173

10 f.e. Pearson, John (1613-1686) : after 25 Dec. insert (but cf. Hearne, Collections, iii. 443)

ii 7 for Admonitions read Administrations

ii 17 f.e. Peck, Francis: for 4 to read fol.

ii 34 for Cayley read Caley

ii 16 Peckham, John : for the royal courts read ecclesiastical courts

ii 12 f.e. for as read at

11 Peckitt, William : for Yorkshire read York

35) Peden, Alexander : for Scot read Scott

30 Peel, Sir Robert (1750-1830): for Drayton Park read Drayton Manor

37 Peel, Sir Robert (1822-1895): for Alexander I read Alexander II

15 Peele, George : for 1844 read 1884

ii 9-8 Pelham, Henry Thomas, 3rd Earl of Chichester: omit and Mr. Gladstone f.e. became member in his stead.

i 29 Pelham, John Thomas: for third son read fourth son

ii 19 f.e. Pelham, Thomas, 1st Baron Pelham: for Lyne read Lyme

ii 23 f.e. Pelham, Thomas, 2nd Earl of Chichester: for third son read fourth son

20 f.e. for second son read third son

ii 6 Pelham-Holles, Thomas, Duke of Newcastle : for Lyne read LyME

$7 \quad$ omit only

ii 15 f.e. for Lyne read Lyme

i 3 for Hampton Court read Bayfordbury, Hertfordshire

8 f.e. Pell, John : after notice. insert His daughter, Bathsua Makin, is also separately noticed.

i 15 f.e. for Kennet's read Kennett's
ii 16 f.e. Pellham, Edward : after 1855, 8vo insert as well as in Arber's 'English Garner,' vol. viii.

ii 12 f.e. Pemberton, Charles R. : for Fox read Mr. John Fowler, with memoir by Fox 22 f.e.
19 f.e. Pemberton, Thomas, Lord Kingsdown: for Home's school read Horne's school

i 7 Penda: for East-Angles read East-Saxons

31 Penington, Sir Isaac: for 1661) read 1660)

36 Penn, Granville : for fifth son read second surviving son

ii 2-4 for An illegitimate son..... which he sold, read Pennsylvania Castle passed on the death of the second son, Thomas Gordon Penn, to his first cousin, William Stuart, the heir-at-law, who transferred it to Colonel Stewart Forbes, a near relative. It was purchased

5 for to read by

18 Penn, John (1760-1834): for eldest read eldest surviving

ii 18 Penn, Sir William: for 8th read 12th

9 f.e. Penn, William: before Paget's New Examen insert Academy, 1886, i. 365 (letter by Mr. C. E. Doble);

ii 9 f.e. Pennefather, Sir John L.: for nephew read cousin

10 Pennefather, Richard: omit surviving

ii 17 f.e. Pennington, Sir Isaac : for Foreness Fell read Furness Fell

ii 18 f.e. Pennington, John, 1st Baron Muncaster: for Penington read Pennington

20 for Warter read Wartre 


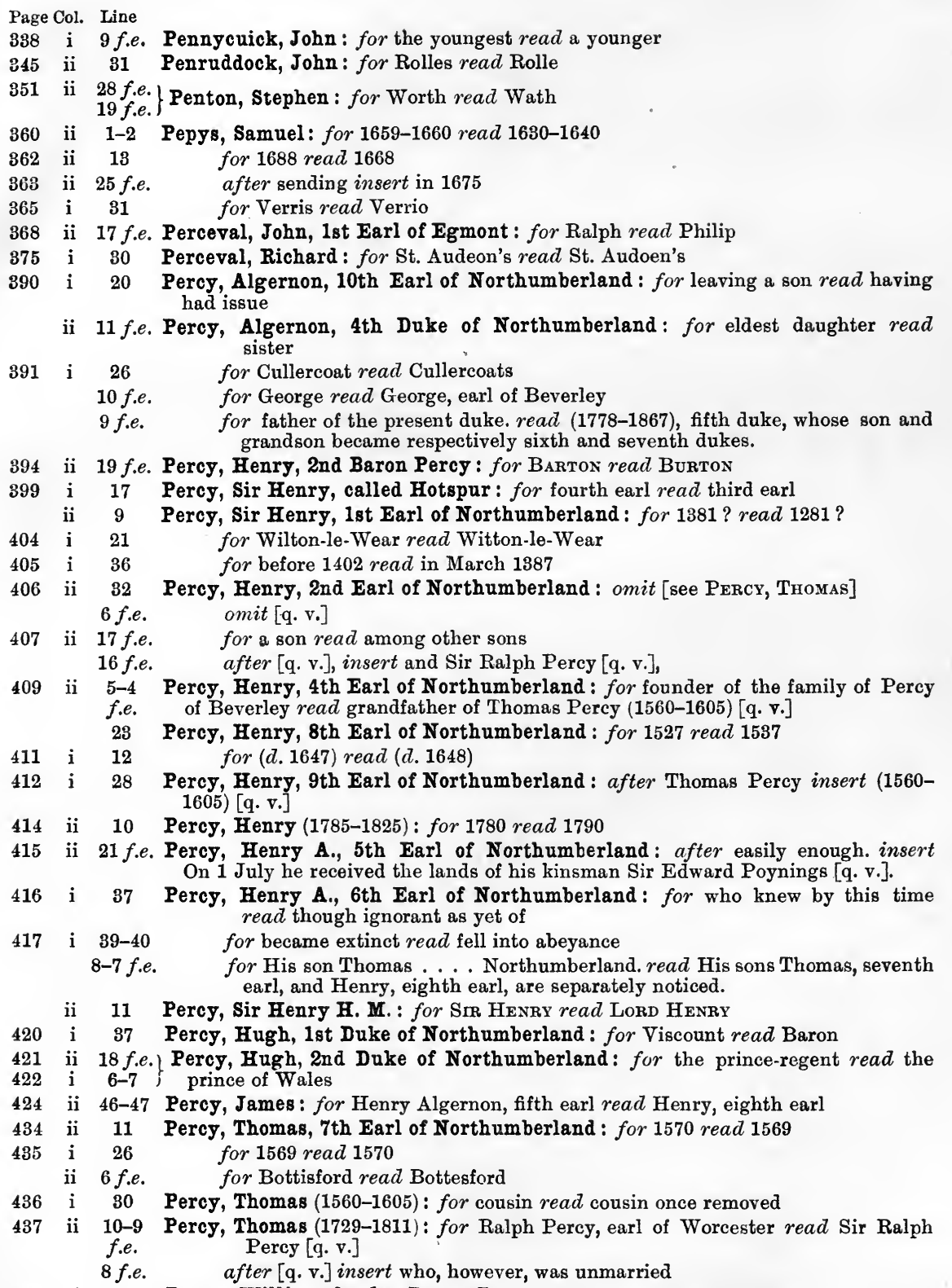

440 ii 13 f.e. Percy, William de, 1st Baron Percy : after et seq. insert Whitby Chartulary (Surtees Soc.)

441 i 12 f.e. Percy, William, 6th Baron Percy : for eldest son read third son 



\title{
DiCTIONARY OF NATIONAL BIOGRAPHY
}

\author{
ERRATA IN VOLUME XLV
}

\section{PEREIRA-POCKRICH}

\begin{tabular}{ccc}
\multicolumn{2}{c}{ Page Col. } & Line \\
3 & ii & 18 \\
& & 27 \\
& & 28 \\
& & \\
& & $30-31$ \\
& & \\
& & \\
& & 32 \\
16 & ii & 33 \\
17 & ii & 20 \\
18 & ii & $36-12$
\end{tabular}

26

36
7-3 f.e.

N.B.-f.e. stands for from end and l.l. for last line

Perkins, Sir Christopher: for (1547? read (1543 ?

for apparently in 1547 read about 1543

for and is probably distinct from the Christopher read and seems to be identical with the Christopher

for and subsequently . . . E Eaton, Berkshire read (cf. Cal. Hatfield MSS. pt. vi. p. 122). The Winchester scholar should doubtless be distinguished from Christopher Perkins, who became rector of Easton, Hampshire, in 1559

for $\mathrm{He}$ was read The diplomatist was

Perronet, Vincent : for 1707 read 1708

for 5 Feb. read 5 Dec.

for There is, however . . . . left no children. read His wife's Christian name was Durial and she died in 1792, her will being proved in December of that year. There was no issue of the marriage.

Perrot, Sir John : for daughter of Sir Lewis Pollard, read widow of Sir Lewis Pollard and daughter of Hugh Pruet, of Thorry, Hartland, Devonshire,

Perry, Sampson : for and was brought up .... and in 1786 read Before and during 1772 he was practising as a surgeon in Aldersgate Street, London. There he seems to have invented the solvent for the stone which was known as Adams' Solvent. Perry described the invention in a 'Disquisition on the Stone and Gravel,' which was first published under the name of William Adams. Second, third, and fourth editions, appearing respectively in 1772,1773 , and 1775 , bore a like designation, but in the appendix to the fourth edition Perry disclosed his authorship, which was acknowledged in the fifth, sixth, and seventh editions, appearing in 1777, 1779, and 1785 respectively. Perry was appointed lieutenant (1 May 1777), surgeon (9 April 1778), and captain (28 March 1780) in the East Middlesex militia. In 1786 he published

for In 1791 he was read In 1791 he was served with five informations and one indictment by the attorney-general for libels on the government. In the course of the year he was

after chancellor. insert He edited his paper from prison.

ofor the king and Pitt read during 1791 Pitt's agent

for and was convicted .... which he alleged, read After writing to show that the House of Commons

for the country. To avoid imprisonment.... January 1793, read the country, he learnt of the government's resolve to ruin him and his paper. In consequence he fled in Nov. 1792

after apprehension. insert $\mathrm{He}$ was tried in absence for his last libel and found guilty. His paper was suppressed, he was outlawed, and his property seized in January 1793.

after club insert in Paris

for August read Sept. 
Page Col. Line

36 ii $28-29$

33

36

43

44

$46 \quad$ i 33

52 i 12

ii 6

54 i 30

56 ii 19 f.e.

58 i 11 f.e.

82 ii 12

85 i 13-14

20

30

33

15

36

ii 4

7

106

ii 7 f.e.

2 f.e.

132

i 17 f.e. Petyt, William: for (1636 read (1641 ?

16 f.e. $\quad$ for in 1636 read about 1641

5 f.e. for William read William, who was educated at Skipton School, and matriculated as a pensioner of Christ's College, Cambridge, 26 April 1660, aged 19,

145 ii 15-16 Phelips, Sir Robert: for is said to have been read and was

17

for (his name does not appear in Haydn), and read from 25 May 1687 till 21 March 1689. $\mathrm{He}$

Phelps, Samuel : for thirty-four of them read thirty-one of them (all except 'Richard II,' the three parts of 'Henry VI,' 'Troilus and Cressida,' and 'Titus Andronicus')

150 i 15 f.e. Pherd, John : Note that a fuller account appears under FonTIBus, JoHN DE

153 ii 31-32 Philip de Thaun : for There is only one manuscript .... E. x. read Manuscripts of Philip's 'Bestiaire' are in Cotton MS. Nero, A. v., in Royal Library at Copenhagen, No. 3466, and in Merton College, Oxford, No. 249. The Latin 'Bestiarium ' in Cotton MS. Vespasian, G. x., is not Philip's work.

157 ii 32 Philip, John (1775-1851): for Earl read Lord

163 ii $\quad$.l. Philipot, Thomas : for Benlowe's read Benlowes's

167 i 23-24 Philippa of Hainault : for a statue of her ..... the principal entrance read there is a wooden effigy of her in the library

173 i 30 Philips, Ambrose : for bishop read archbishop

for county read borough

177 ii 17 Philips, John : after 1720 insert and a third in 1763

189 ii 28-29 Phillip, Arthur: for during November read on 31 Aug. -

29 after Bath insert and was buried in Bathampton Church.

195 ii 11 Phillipps, Sir Thomas : for Huddersford read Huddesford

201 ii 8 f.e. Phillips, Henry $(f .1780-1830)$ : for ( $f$. 1780-1830) read (1775-1838)

7-6 for said to have been a schoolmaster read a native of Sussex, was originally f.e.

202 i 4

205 ii $26-25$ f.e.

24 f.e. a banker at Worthing. He
after p. 135), insert He died at Brighton in 1838.

Phillips, John (1631-1706): for 'Sportive Wit or the Muses Merriment' read 'Sportive Wit: The Muses Merriment. A New Spring of Lusty Drollery, \&c.'

for a unique copy of which is read copies of which are 
Page Col. Line

205 ii 23 f.e. Phillips, John : after Library insert and at Britwell 22 f.e. 16 f.e.

Phillips, Sir Richard : after da the National Portrait Gallery.

218 ii 21 Phillips, Sir Thomas : for Court-y-hella read Court-y-bella

220 ii 26 Phillips, William (1731 ?-1781): for Sir Grey read Sir Guy

225 i 17 Phillpotts, Henry : for palace read residence

243 ii 17 Pickering, Sir James : after p. 286). insert He was sheriff of Yorkshire in 1390 and 1398 (DRake, Eboracum, p. 392).

5 f.e. Pickering, John : for p. 62 read i. 62

245 ii 8 Pickering, William : after publisher, insert born on 2 April 1796,

246 i 38

19 f.e. after 1854 insert and was buried at Kensal Green after subscription. insert He married in 1819 Mary Ann Gubbins (1796-1849), by whom he had five daughters and one son.

262 ii 30 Pierrepont, Evelyn, 1st Duke of Kingston : for Evelyn was'returned read Born at Dean, Wiltshire, Evelyn was educated at Winchester and was admitted a fellow-commoner of Christ's College, Cambridge, 19 May $1683 . \mathrm{He}$ was returned

264 i 11 f.e. Pierrepont, Evelyn, 2nd Duke of Kingston : after Manvers insert [see art. Meadows, Sir Philip]

4 f.e. $\quad$ for Manners read Manvers

280 ii 18

19

27

$\begin{array}{ccc}284 & \text { ii } & 24 \\ 286 & \text { ii } & 3-2 \\ & & f . e . \\ 287 & \text { i } & 6 \\ & & 7-8 \\ & & 8\end{array}$

ii $18-13$ f.e.

289 i 11

292 ii 21 f.e.

19 f.e.

18 f.e.

49-50

3 f.e.

$l . l$.

293 i 1

2

23

ii 22

295 i 26

29-33

Pigot, George, Baron Pigot : for three read several for viz. read among others

after aged 82. insert and (4) Leonora, who received a fortune under her father's will and who married, 17 Oct. 1777, Claud Russell, a member of the Madras Council; to the memory of her and her husband there is a tablet in the north wall of Marylebone Church.

Pigott, Nathaniel: for Hewit read Heworth

Pigott, Robert : for (1766-1839) read (1766-1846)

omit shortly after her death

omit another posthumous work, after She insert died in July 1846, having by will dated 25 Nov. 1845,

Pike, John D. G.: for In 1805 he was charged..... 1806, i. 206). read Subsequently he appears to have taught geography and belles-lettres in the school at Enfield.

Pike, Richard ( $f l .1625)$ : for Foy read Fowey

Pilkington, Sir Andrew : for a daughter read at Hayes on 9 May 1808, Maria Elizabeth, danghter

for a daughter, afterwards read two daughters : Maria Georgina

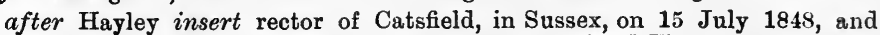
Louisa Elizabeth, married on 1 Sept. 1853 to Richard Thomas Lee.

Pilkington, Francis : for (1570?-1625) read (1564?-1638)

after choir insert in 1578

for In 1623- read In 1612

omit 1624 and for chaunter read he was precentor

after Cathedral insert from 1623 till his death in 1638

after 1650 ?), insert also a chorister of Chester Cathedral, and

Pilkington, Gilbert : after 1717 insert and again in 1718, 8vo

Pilkington, James: after Rivington. insert Many are in St. John's College, Cambridge, and in the University Library.

for The only known portrait ... taken in 1821. read It is a copy taken partly from the remains of the original, which was damaged by fire in 1834, and is now in the possession of Lieutenant-Colonel John Pilkington at Sandown Park, near Liverpool, and partly from a copy made in $\mathbf{1 8 2 1}$.

for youngest read younger

after Easington. insert He was buried at St. Oswald's, Durham, on 31 Oct. 1603.

after 1564. insert Several MSS. formerly belonging to him are at Sidney Sussex College, Cambridge. 


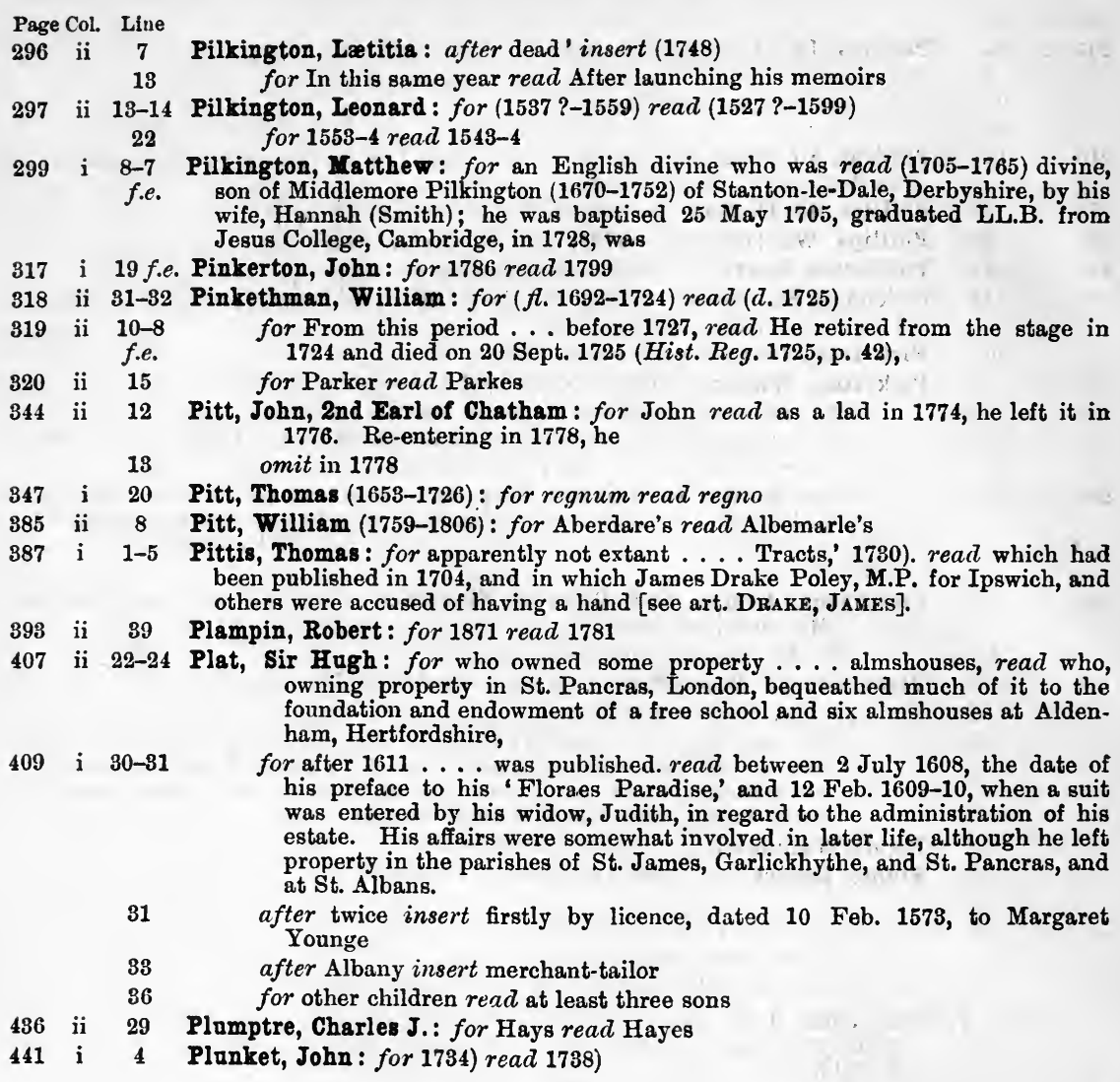




\title{
Dictionary OF NATIONAL BIOGRAPHY
}

\author{
ERRATA IN VOLUME XLVI
}

\author{
POCOCK_-PUCKERING
}

\author{
N.B. - f.e. stands for from end and l.l. for last line
}

Page Col. Line

11 ii 38 Pocock, Edward: for Sloane read Addit.

10 f.e. for (1711) read (1708)

12 ii 34-35 Pococke, Richard : for rector of Colmer . . . afterwards headmaster read (16661710). His grandfather, also Richard Pococke, LL.B., was rector of Colmer, Hampshire, from 1660 till his death in 1719 . His father was headmaster

Pole, John de la, 2nd Duke of Suffolk: for three sons ... separately noticed. read six sons ; of whom John, Edmund, and Richard are separately noticed ; of four daughters, Catherine, the eldest, married William, Lord Stourton, and the youngest, Elizabeth, married Henry Lovel, second and last Lord Morley of the Lovel family $(d .1489)$.

33 i 6 f.e. Pole, Michael de la, Earl of Suffolk : for left three sons read had five sons

5 f.e. for Thomas and Richard read Thomas, prebendary of St. Paul's Cathedral from 1419, William, Richard, and John (d.1415), canon of York (cf. will at Somerset House, 31 March 1415; WeEver, Funeral Monuments, s.v. Wingfield)

4 f.e. for a daughter Anne read three daughters, Margaret, Elizabeth, and Anne

118 f.e. Pole, Michael de la, 2nd Earl of Suffolk: after daughters insert one of whom, Isabel, seems to have married Thomas, fifth Baron Morley (d. 1545)

8-7f.e. for Thomas ... died read Sir Thomas had a daughter, Katharine, married to Sir Miles Stapleton (d. 1466). Miles

ii 12 f.e. Pole, Reginald : after passed insert in 1539

9 f.e. after reached him insert in 1541

49 i 38 Pole, Sir William de la : for Miton in Holderness read Myton in Yorkshire

50 i 8 omit at

14 f.e. $\quad$ for Trinity Chapel read Church of the Holy Trinity

ii 11 f.e. Pole, William de la, 1st Duke of Suffolk: after i. 117). insert In 1423 Suffolk served in the important campaign in Champagne as second in command to Thomas de Montacute, Earl of Salisbury [q. v.].

51 ii $60-61$

53 ii 17

54 ii 8

56 i $10-11$

13 for it is clear ... Orleans read Suffolk seems to have worked with Orleans for the incapable Edward Beaufort read Edmund Beanfort

after Suffolk [q. v.] insert who had married Margaret Beaufort, the infant heiress of John Beaufort, Duke of Somerset, and Suffolk's ward omit Her only child was

William, and a daughter, Anna.

10 f.e. for Villet read Vallet

60 i 16 f.e. Pollard, Lewis : after Nottinghamshire insert was a scholar of Christ's College, Cambridge, in 1542-3,

62 ii 21 f.e. Pollexfen, John : after about 1638. insert He was second son of Andrew Pollexfen, of Stancombe, in the parish of Sherford, Devonshire, and was younger brother of Sir Henry Pollexfen [q. v.]. 
Page Ool. Line

69 i 8 Pollock, Sir Jonathan F.: for Hanwell read Hanworth

76 i 10 f.e. Pond, Edward : for ( $f$. 1623) read (d. 1629)

76 ii $10-11$ for It is probable . . . after 1643. read Pond died at Peterborough, and

was buried in the church of St. John the Baptist there on 10 Sept. 1629.

81 i 26 Ponsonby, Sir Frederic C.: for K.C.M.G. read G.C.M.G. (1828)

91 i 6 Ponsonby, William B., 1st Baron Ponsonby : for York read Cork

94 i 35 Pont, Timothy : for (1560 ?-1630 ?) read (1560?-1614?)

57-58 for between 1625 and 1630 read before 1625 , probably in 1614

ii 11 for Bleau's read Blaeu's

12 for 1668 read 1654 (reissued in 1662, vol. ii.)

17 for Topographised read topographized

18-19 for Continuation ... of Cumnock, read Continuations and Illustrative Notices by the late James Dobie of Crummock,

20-21 for Skelton Robie,' read Shedden Dobie,'

96 ii 20 Poole, George A.: after 1883. insert He married a daughter of Jonathan Wilks, of St. Ann's, Burley.

ii 16 f.e. Poor, Richard: after p. 128). insert Poore is now considered to be responsible for the final form of the 'use of Sarum' (cf. Frere, Use of Sarum).

108 ii 8 f.e. omit better

125 ii 22 Pope, Alexander (1688-1744): for Nos. 268-70 read 1st Ser. vol. x.

126 ii 19 f.e. for John Warton's read Joseph Warton's

18 f.e. for 1752 read 1756

136 i 60-61 Pope, Sir Thomas : for (cf. STRYPE's transcripts) read of Strype's alleged transcripts

ii 11 for 1895 read 1896

21 f.e. $\quad$ for Morwen read Morwent

137 ii $28-29$

31

13 f.e.

150 i 7

154 i 20

21 after Robins insert and another by John Faber from the copy at Oxford for 1895 read 1896

Popple, William : for Sheehan's read Sheahan's

Porson, Richard : for eldest read second after sister insert Elizabeth (1756-1842) omit apparently

for it is not recorded . . . his married life. read During the few months of his married life Porson lived in London at 11 Lancaster Court. after rooms insert at No. 8 Old Jewry

Porter, Jane : for 85 read 185,352

Portman, Sir William : for His descendant read His collateral descendant

Pottinger, sir Henry : for Sir Benjamin read Sir Peregrine

Poulson, George : for Nunkealing read Nunkeeling

Powell, Mrs. : for ( $f$ l. 1787-1829) read (1761 ?-1831)

for the date of which is unknown read in London on 81 Dec. 1831, when she. was 'about seventy' (Annual Biog. and Obit. p. 451)

Powell, Baden : after p. 204 ; insert Darwin's Origin of Species, ed. 1894, p. xx ;

36 Power, Henry : for whole read shott

18 f.e. for Ealand read Elland

i 20 f.e. Pratt, Charles, 1st Earl Camden : for Middle Temple read Inner Temple

299 i 32-33 Prence, Thomas : for who survived him . . . descendants. read and thirdly in 1662 Mary, daughter of Constance Southworth and widow of Samuel Freeman. By his first wife he had six and by his second four children (cf. Landmarks of Plymouth, p. 209).

304. i 32 Prescott, Sir Henry : after p. 448). insert At the desire of the government he remained beyond the usual limit, but resigned at the end of seven years.

306 ii 38 Preston, Gilbert de : after Soc.); insert Annales Monastici, passim ; Flores Hist. ii. 426-7;

312 i 10 f.e. Preston, Richard: for near Exeter read in North Devon

314 ii 21 f.e. Preston, Thomas, Viscount Tara : for 1653 ?) read 1655)

818 i 15-16 for The date of Preston's death is uncertain. read He was buried at Paris 21 Oct. 1655 (Egerton MS. 2535, f. 474).

21 for 1657 read 1659 , at Bruges

328 i 33 Price, Hngh : for foundation read re-foundation 
Page Col. Line

329 i 5 f.e. Price, Sir John : for Ap Price read Ap Rice

335 i 9-11 Price, Richard (1723-1791) : for In 1769 Price received . . . of Glasgow. read In 1767 Price received the degree of D.D. from Marischal College, Aberdeen, and not, as stated by his biographer, Morgan, from Glasgow in 1769.

348 ii 16 Pricket, Robert : after 469 insert 6th Ser. ii. 235

359 i 9 f.e. Priestley, Joseph : omit [q. v.]

380 i 37-38 Primrose, Archibald J., 4th Earl of Rosebery : for earl of Stanhope read Earl Stanhope

$397 \quad$ i $\quad 4$ f.e.

398 ii 26-27 Prior, Matthew : for Shepherd read Sheppard

402 i 35 Prior, Thomas: for 1871.] read 1871; Dialogue between Dean Swift and Thomas Prior, 1753.]

406 ii 24 f.e. Pritchard, Edward W. : after 1853 insert (3rd edit. 1856)

421 ii 19 Proctor, Thomas : for Mr. C. W. Hazlitt read Mr. W. C. Hazlitt

430 ii $\left.\begin{array}{c}8-9 \\ 12 \text { f.e. }\end{array}\right\}$ Pryme, Abraham de la : for Transactions read Publications

443 ii 13-15 Puckering, Sir John : for member for Bedford .... in the other. read member successively for Carmarthen, Bedford, and Gatton in Surrey. after confederates. insert In 1586 he joined the council of the Marches. 



\title{
DictionaRy OF NATIONAL BIOGRAPHY
}

\author{
ERRATA IN VOLUME XLVII
}

\author{
PUCKLE-REIDFURD
}

Page Col. Line

20 ii 36 Pullen, Samuel (1598-1667): after bridge insert (1623)

21 ii 13 Pullen, Tobias : after Joshua Pullen insert dean of Midaleham from 1638 until his death in 1657

22 ii 30-31 Puller, Sir Christopher: for son of Christopher Puller read grandson of Christopher Puller (d. 1789) and son of Richard Puller (1747-1826)

32 after 1786-9, insert afterwards of Painswick Court, Gloucestershire. Christopher

$36 \quad$ for Queen's read Oriel

14 f.e. $\quad$ for Puller married Louisa King read Puller married, on 9 Aug. 1804, Louisa (1772-1857), daughter of Joseph King, of Taplow, and

13 f.e. after Hertfordshire insert to which estate she succeeded

34 ii 15-18 Pulteney, William, Earl of Bath : for having died . . . . and had obtained read having died at Madrid on his way home from Portugal on 12 Feb. 1763, aged 32. He had a promising career. He obtained

21

after 167). insert He was lieutenant-colonel 1759 and M.P. for Old Sarum 1754 and for Westminster 1761-3. He was buried in Westminster Abbey 21 April 1763.

36 ii 25 Pulton, Ferdinando : after afterwards insert (from Lady-day 1556 to Lady-day 1557)

57 ii 16 f.e. Pusey, Edward B.: for Gaumé's 'Manual of Confessors' read Gaume's 'Manual for Confessors'

60 ii $30 \quad$ for 14 Sept. read 16 Sept.

83 i 27 Pym, John : for Brynmore read Brymore

95 ii 8 f.e. Quarles, Francis : after Dibdin), insert and the Chiswick Press edition of 1812,

111 ii 21 f.e. Quin, Walter: after Spencer's book insert [i.e. Edmund Spenser's 'Faerie Queene,' where the king's mother, Mary, Queen of Scots, was denounced under the name of Duessa]

120 i 30 Radcliffe, Ann : for 1822) read 1823)

129 ii 28 Radcliffe, John (1650-1714): for Dulie of Portland read Earl of Portland

135 ii 4 f.e. Radcliffe, Robert, 1st Earl of Sussex : for She died read Radcliffe's second wifo died

136 ii 2 f.e. Radcliffe, Thomas, 3rd Earl of Sussex: for 20 March 1557 read 22 March

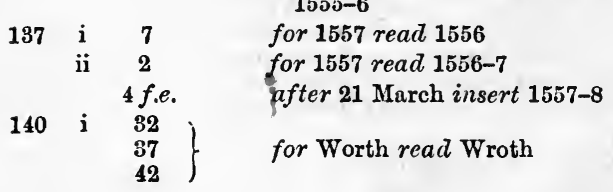


Page Ool. Line

142 ii 23 f.e. Radcliffe, Thomas, 3rd Earl of Sussex : for the Duc d'Anjou read Henry, Duc d'Anjou (afterwards Henry III of France)

17-16 for renewed in 1578 and again read renewed in 1578 with Francis, Duc f.e. d'Alençon and d'Anjou, brother of the earlier suitor. The new French suitor again

16 f.e. for in him read in Sussex

15 f.e. for Anjou's read the French prince's

143 i 1

146 ii 16

$147 \quad \mathrm{i}, 12$

\}adclyffe, William: for 1796 read 1783

for $\mathrm{He}$ left three sons, of whom read Of his three sons ? after 1846 insert in his father's lifetime

$\begin{array}{lll}151 & \text { i } & 27\end{array}$

Rae, James : for Margarie' read Marjorie'

159 ii 8

Raffald, Elizabeth : after 1733 insert (baptised there on $8 \mathrm{July}$ )

160 i 29

Raffles, Thomas: for where he was ordained read being ordained at Kensington Chapel

Raffles, Sir Thomas s.: after terest. insert A second edition appeared in 1830 and a French translation in $\mathbf{1 8 2 4}$.

after memoir of him. insert Another bust is in the Lion House of the Zoological Gardens.

9 f.e. Raikes, Henry C. : for and his father was read His father, Henry Rarkes (18111863); of Llwynegrin, Flint, was a barrister who twice unsuccessfully contested Derby in the conservative interest, was

7 f.e. $\quad$ before of 'A Popular Sketch insert of a translation (1839) of Cardinal Pole's 'The Reform of England,' with an introductory essay, and

168 i $10-11$ for unsuccessfully contested Derby as a conservative. read assisted his father in his candidature at Derby.

ii 15-16 for Denbighshire read Flintshire

Raikes, Robert: after James Raikes' insert (afterwards belonging to General Robert Napier Raikes, of Strangford Villa, Park Road, Watford)

Ralegh, Sir Walter: for has been now identified read is identical for 1650 read about 1650

for 1615 read 1665

for Ninias read Ninus

for 1583 read 1581

Ralph (d. 1174): for (ib. read (Röhricht

Ramsay, Andrew M. : for 1730 read 1728

for 1795 read 1795 and 1816

for National read Natural

after 1747. insert His 'Apology for the Free and Accepted Masons,' published in Dublin in 1738 and London in 1749, was burnt at Rome 1 Feb. 1739.

241 ii 32 Ramsay, Edward B.: for 1846 read 1841

247 ii l.l. Ramsay, James A. B., 1st Marquis of Dalhousie : for as a child, but was sent to Har- read in 1816, when four years old, but in 1822 he was sent to East Sheen and in Sept. 1825 to Harrow. omit row when he was ten years old.

for established himself at Firozpur. read went into camp at Makhu.

for deemed it right to consult . . . . was declared to be read carefully considered the objections to that course, which were powerfully urged by Sir Henry Lawrence, and were shared in a less degree by his brother John. Feeling that hesitation and delay would give ritse to disorder, Dalhousie acted on his own responsibility and on 29 March 1849 declared the Punjab
to be

omit the establishment. . . . British India; 
Page Col. Line

250 i 13-9

f.e.

251 i 20-21

256 i 1

275 ii 19

279 i 26

282

285

287

307

312

$$
15 \text { f.e. }
$$

19

39

ii 34

35-36

41-42

5

20-23

18 f.e.

818

322

324

384

\section{7}

Ramsay, James A. B., 1st Marquis of Dalhousie: for suspending without the authority .... in the Punjáb. read reversing without the authority of the government an order issued by Lord Hardinge in $\mathbf{1 8 4 5}$ for calculating the allowances paid to native troops and compensation for the dearness of provisions.

for was away in Sind, and consequently read was consulted, and with his concurrence

before The Marquess insert A full life by Sir William Lee-Warner appeared in 1904.

Randolph, Sir Thomas, 1st Earl of Moray : for 1305 read 1305-6

Randolph, Thomas (1523-1590) : for the autumn of 1562 read April 1562

Randolph, Thomas (1605-1635): for quiet read quick

Randulf, Earl of Chester (d.1129 ?): for c. 5 read C. 5 for Mericia read Mercia

Randulf, Earl of Chester (d. 1153) : for Maradoc read Maredudd for Counsylth read Consyllt

for Dominatus read Dominabus

Rastrick, John U.: for Shut read Shutt

Rattray, Sylvester : for But the latter read The latter omit whereas the Sylvester . . . . in Glasgow.

after p. 51). insert $\mathrm{He}$ had a son, Sylvester, a student of medicine at Glasgow

Ravenscroft, Thomas : before In 1614 insert In 1613 Ravenscroft issued 'Musalia,' a collection of glees (cf. Musical World, 1840, ii. 139).

ii 17 Rawdon, Marmaduke : for 1868 read 1863

ii 36 Rawlet, John : for' Public read 'Poetic

20 Rawlinson, Sir Thomas (1647-1708) : for A grandson read A second cousin

22-23

18-15

f.e.

13 f.e.

12 f.e.

335

for of the elder Sir Thomas's ..... in 1732). read of the Rev. Robert Rawlinson of Charlwood, Surrey, and his grandfather Daniel Rawlinson was the first Sir Thomas Rawlinson's first cousin.

for He was twice married . . . . mason of Sudbury. read He was buried at Haughley, Suffolk. He married his first cousin Dorothea (1704-43), daughter of the Rev. Richard Ray of Haughley, Suffolk.

for Walter read Sir Walter

after estates, insert married Mary, daughter of Sir Robert Ladbroke, lord mayor of London,

Rawlinson, Thomas (1681-1725) : transfer inverted comma to close of article

Rawlinson, Sir William : for 1696) read 1703)

before entered read was admitted from Hawkshead School pensioner of Christ's College, Cambridge, 13 April 1655, aged 15,

Raymond, Robert, Lord Raymond: after 1673, insert was educated at Eton and was admitted pensioner of Christ's College, Cambridge, in Nov. 1689, aged 15, afterwards becoming a fellow-commoner. $\mathrm{He}$

Raymond, Sir Thomas : after in 1627, insert was admitted from Stortford School pensioner of Christ's College, Cambridge, 5 April 1643, aged 16, being admitted student of Gray's Inn 4 Feb. 1644-5 and graduating B.A. at midsummer 1646. He

i 20 f.e. Raynalde, Thomas : for In 1540 there appeared read In 1545 he edited

18-17 for the writer, whose initials, .... given, read the original writer, who is

f.e.

5 f.e.

ii 30 supposed to have been one Richard Jonas (1540), omit in $\mathbf{1 5 4 5}$

after 8vo. insert He also issued Wyat's 'Certaine Psalmes' and an edition of Matthew's Bible. In all about thirty books bear his imprint.

348 i 12 f.e. Rayner, Lionel B.: for 1832 read 1831

353 i 16 f.e. Read, Thomas : for has then become read was afterwards

ii 3 omit Pink

355 ii 9 Reade, Charles : for 1831 read 1851

359 i 5 Reade, Edward A.: for a connection read a cousin

361 i 3 f.e. $\mathbf{2}$ f.e. Reade, Joseph B.: for Fairish read Farish

ii 7 f.e. Reade, William W. : for 30 Jan. read 26 Dec. 
Page Col. Line

391 i 20 f.e.

392 i $\quad 13$ f.e.

Reed, Isaac : for Staple Inn read Staple's Inn

$$
15 \text { f.e. r. for } 1837 \text { read } 1807
$$

405 i 11 f.e. Reeve, Edmund : after judge, insert son of Christopher Reeve,

10 f.e. after 1585 insert and was admitted to Caius College, Cambridge, 30 Sept. 1605

414 i 13 Reeve, Sir Thomas: for After becoming read After entering Trinity College, Oxford, as a commoner in 1688, and becoming

415 i 18-17, Reeves, John (1752 ?-1829): for In 1778 he became .... proceeded M.A. read f.e. On 11 Nov. 1775 he was elected Michel scholar of Queen's College, and on 8 Oct. 1777 he proceeded M.A.

424 ii 15 f.e. Reid, Alexander (1586?-1641): for younger brother read elder brother

439 i 7 Reid, Thomas (1710-1796): for internal read external 


\title{
DiCTIONARY OF NATIONAL BIOGRAPHY
}

\author{
ERRATA IN VOLUME XLVIII
}

\author{
REILLY-ROBINS
}

Page Col. Line

19 ii 20 f.e. Rennie, John (1761-1821) : after Bridge insert (a copy of Kelso Bridge)

28 i 2

3-4

26 ii 31

28 i 16

19

30 ii 24

36 ii $\quad 8-9$

37

\section{i 8}

0 ii 7 f.e.

43 ii $26-28$

22 f.e.

47 ii $\quad 25$

28

ii $\mathbf{1 7 - 2 4}$

\section{Renouard, George C. : for Sidney Sussex read Trinity}

for where in 1800 he was elected a pensioner. read whence in 1800 he migrated to Sidney Sussex.

Repington, Philip : after pp. 296-7). insert He incepted as Doctor of Divinity in the summer term, 1382.

for Marmorea read Marmoris

for quisque read quique

Reresby, Sir John : for Moysey read Moyser

Reynardson, Sir Abraham: for Sir Nicholas Crisp [q. v.] read Alderman Nicholas Crisp

Reynell, Carew : omit on 27 Feb. 1663

Reynolds, Edward: for Bramston read Braunston

Reynolds, George W. M.: omit in which was published ....'Mysteries of Paris'

after 1879). insert His 'Mysteries of London,' suggested by Eugene Sue's

'Mysteries of Paris,' appeared in a long series of weekly penny numbers.

Reynolds, Sir John : for (d. 1657) read (1625-1657)

after [q. v.] insert and was born 10 March 1625 (Sloane MS. 1707, f. 11)

Reynolds, Sir John R. : for Hall was exposed . . . and he was elected read Hall announced to his patients in a printed circular that Reynolds had succeeded him in practice. Such procedure was contrary to a recognised understanding among physicians, and Hall incurred the censure of the College of Physicians. Reynolds, who was ignorant of Hall's intentions, was in no way responsible for the circular, and was in no way involved in the censure. He was duly elected

73 ii 17 f.e. Reynolds, Samuel W.: after 1855. insert A portrait by his friend, Ary Scheffer, is at Dordrecht.

105 i 21 Rich, Barnabe : for 1620 ?) read 1617)

ii 14 f.e. for A second edition of his read His

10-9. for 24 June $1618 \ldots$... its publication. read 14 May 1617. He died on

f.e. $\quad 10$ Nov. following, from which date his pension was ordered to be paid to one Bourne (Carte MSS. in Bodleian Library, vol. lxii. p. 290).

107 i 21-23 omit It was reissued . . . (British Museum).

145 i 7-8 Richard I: for From Knighton ( $f$. 1395) come read A thirteenth-century romance supplies

165 i 6 f.e. Richard, Earl of Cornwall : for 1215 read 1216

173 ii 10 f.e. for New Burnham read Nunburnholme

201 i 10 f.e. Richard of Wendover : after physician insert although all may not be from the same pen

209 i 29 Richard, Henry : for 1894 read 1893

217 ii 1-2 Richards, Nathaniel: for ( $f$. 1630-1654) read (d. 1652) 
Page Col. Line

217 ii 2

4

11

12-13

Richards, Nathaniel : for son read second son (by Elizabeth, daughter of Thoinas Hancock, of Combmartin)

for the parsonage there about 1612. read Kentisbury about 1612. His father rebuilt the chancel of the parish church (cf. Inscriptions on Stones from Kentisbury Church Tower)

omit appears to have

for where he was 'preaching minister' in 1654. read $\mathrm{He}$ died in 1652 and was buried at Barnstaple.

223 ii 59-60 Richardson, David L.: onit under Macaulay

224 i "5 ' for 'Bengal Monthly Magazine' read 'Calcutta Monthly Journal'

for In 1835 he became principal read In 1836 he became protessor of English literature

8 omit Metropolitan and after Calcutta insert largely on Macaulay's recommendation, and in 1839 he was promoted to the newly created post of principal of the college, while retaining his professorship

233 i 16 f.e. Richardson, John (1787-1865): for JoHn reaid SrR JoHN

240 i 13-14 Richardson, Moses A. : for St. Kilda's Cemetery read the St. Kilda Cemetery

246 ii 13 f.e. Richard, Samuel (1689-1761): for M. Howell read Mary Howitt

247 ii 19 Richardson, Sir Thomas (1569-1635): after 1569. insert He matriculated as a pensioner from Christ's College, Cambridge, in June 1584.

259 i 19-23 Richmond, Legh : omit A library designed . . Uxbridge Road, London.

296 ii 34 Rigaud, John F.: for younger read second

35 after Rigaud insert (1705-1764)

36 for Girardet read Guiraudet

$37 \quad$ after Dutilh insert (1655-1705)

10 f.e. $\quad$ after baptised insert 9 Sept. 1742

$297 \mathrm{i} \cdot 13$ f.e.

12-11 for including Nelson. read His portrait of Nelson was acquired by the f.e. present Earl Nelson for $70 l$.

ii 16 after Mary insert (1740?-1808)

25 Rigand, stephen F. D.: for 1862) read 1861)

l.l. for in 1808 read on 1 Jan. 1808 and for Miss Margaret Davies read Margaret, daughter of John Davies

298 i 4 after death insert on 1 Jan. 1839 for 1862 read 1861

ii 36 Rigaud, Stephen P.: for 1857-8 read 1837-8

304 i 14 f.e. Rigby, Richard : for A contemporary of Rigby's said of him read Sir George 0. Trevelyan in his 'Early Life of C. J. Fox' (chap. iii.) wrote of Rigby

55-56 Riley, Henry T. : omit the residence of his sister

22 f.e. Ripley, George : for 1719 read 1709 and for 1577 read 1557

338 ii 2 Robartes, Foulk: omit being then of Trinity

15 f.e. Robartes, Francis : after about 1650. insert He was admitted fellow-commoner of Christ's College, Cambridge, 2 May 1663, aged 13.

$$
\text { i } 13 \text { f.e. Robert II : for 1370) read 1390) }
$$

346 i 14 for fifteen read nineteen

348 ii 22 Robert III : for duke of Fife, Earl read earl of Fife, duke

350 i 6 f.e. Robert, Duke of Normandy : for autumn read autumn of 1080

351 i $36 \quad$ for invaded read prepared to invade

ii 34 for 27 Sept. read 23 Dec.

1 Robert (d. 1139) : after pp. 251-4 ; insert Newminster Chartulary (Surtees Soc.) ;

\section{2 f.e. Robert de Bethune : for Flanders read Artois}

366 i 2 Robert of 'Salesby' for Roger read Roger of Salisbury and for Robert read Robert of Salesby

867 ii 6 Robert of Melun : for p. cxcix read vol. cxcix.

377 ii 22 Roberts, Francis : for About 1642 or 1643 read In 1643 (Commons Journals, iii. 148)

398 i 13 f.e. Roberts, William P.: for granddaughter to read descendant of

ii 33 Robertson, Abraham: for astronomy read geometry

10 f.e. after security. insert $\mathrm{He}$ was made Savilian professor of astronomy in 1810.

419 ii 10 Robertson, Thomas (d. 1799): for a minister read probationer 
Page Col. Line

425 i 23

ii $\quad 35$

36

129 i 23

$40-41$

430 ii 12 Robertson

12 Robertson, William (1740-1799): for 1799) read 1803)

432 ii 21 Robethon, John : after George I, insert born at Authon in Perche of a respectable Calvinist family (cf. English Hist. Rev., January 1898), 



\title{
Dictionary of NaTiONAL Biography
}

\author{
ERRATA IN VOLUME XLIX
}

\author{
ROBINSON-RUSSELL
}

Page Col. Line

10 i 14-13 f.e.

$17 \quad$ ii 11 13

Robinson, Frederick J., 1st Earl of Ripon : for the Melbourne ministry consequently broke up and read Grey resigned in July and was succeded by Melbourne, on whose sudden dismissal by the king (15 Nov.)

Robinson, Hercules : for Wedman read Widman for F. A. Robinson read G. R. Robinson

Robinson, John (d. 1598) : for 1586 read 1580

Robinson, John (1576?-1625) : for Mr. Alexander Brown read Dr. John Brown

Robinson, John (1650-1723) : for Hawick read Hewick

i 10 f.e. Robinson, John (1774-1840): after Penrith, insert and at Christ's College, Cambridge, where he was admitted a sizar on 1 Jan. 1807,

ii 26-27 Robinson, Mary : for royal mistress read mistress of George, Prince of Wales, afterwards George IV for Wolcott read Wolcot

4 f.e. Robinson, Nicholas : for sub-dean read sub-deacon

39 i 8 f.e. Robinson, Richard, 1st Baron Rokeby : for Elton read Etton

53 ii 22 Robinson, Thomas R.: for Cumberland read Windermere

61 i 1 Robson, George F.: for FenNel read FenNell

2-4 for the eldest son . . . in Lancashire, read one of twenty-three children of John Robson (1739-1824) by his second wife, Charlotte, eldest daughter of George Fennell, R.N.,

63 i 3 Robson, Thomas F.: for Brownbill read Brownhill

65 i 12 f.e. Roby, John : for Last Fiddler read Poor Fiddler

79 ii 22 f.e. Roden, William T. : for $\mathrm{Mr}$. Dew, an engraver. read Mr. Tye, an engraver, who married an elder sister. Subsequently on Tye's recommendation he removed to London to become an apprentice to George Thomas Doo, R.A.

20 f.e. for then took to portrait-painting. read and produced, among much other work, a good engraving of Rubens's portrait of himself. He then abandoned engraving altogether for portrait-painting, and returning to Birmingham rarely left it thenceforth.

4 f.e. for three portraits of Lord Palmerston read two portraits of Lord Palmerston from life

after illness. insert He married twice and left children by both wives.

Roger of Salisbury: after minster insert He witnessed the charter issued at Oxford in April

106 ii 15 f.e. Roger of Ford: for and wrote read and while there wrote 14 f.e. for of Savigny, abbot of Schonau read abbot of Savigny

6 f.e. $\quad$ for clxix read cxlix 
Page Col. Line

107 ii 21 f.e. Roger (d. 1179): for Roger read Robert de Melun

108 i 14 f.e. for [see HeNRY II] read [see HenRY, 1155-1183]

117 i 16 Rogers, Daniel (1538?-1591): after clerk. insert He was M.P. for Newport, Cornwall, 1588-9.

118 ii 13 f.e. Rogers, Sir Edward : after 1565. insert He was M.P. for Tavistock 1547-52 and Somerset 1553, 1558, 1559, and 1563-7.

119 i 17-18 Rogers, Ezekiel : for M.A. from Christ's College, Cambridge, 1604, read B.A. in 1604-5 from Corpus Christi College, Cambridge, whence he migrated to Christ's College, Cambridge;

120 ii 20 - Rogers, Frederic, Lord Blachford : after survived him insert dying at Blachford, 13 July 1900

121 ii 20 Rogers, Henry (1585 ?-1658): for Prosse read Prosser

122 ii 8 Rogers, Henry (1806-1877): for Church read Churchyard

36 for twice read four times

17 f.e. after tribunal. insert $\mathrm{He}$ married thirdly, in 1842, Emma, daughter of John Watson, of Finsbury Square, London. She also died in giving birth to her first child. Rogers married fourthly, in 1857, Jane, eldest daughter of Samuel Fletcher, of Manchester; she died in 1891, having endowed scholarships in her husband's memory at the Lancashire Independent College and the Owens College, Manchester.

Rogers, John (1627-1665 ?) : for prison-born read Prison-born

Rogers, Nehemiah : for Londini read Londinium

23 Rokeby, Ralph : for Belfreys, Yorkshire, read the Belfrey Church, York

ii 15 Rokeby, sir Thomas de (d. 1356): for grandfather read grandfather of

31 for in 1417 read in 1415 and 1417

31-32 for next year read in 1418

\section{i 18 f.e. Rokewode, Ambrose: for (1518? read (1578?}

i 18-19 Rolfe, John: for Edwin of Boston Hall . . of the Rolfes; read the Rev. Whitwell Elwin of Booton Rectory, Norfolk, whose family intermarried with the Rolfes;

i 1-2 Rolle, Henry : for which he represented ... of 1681. read and was elected M.P. for Bridgewater 30 March 1660, for Hampshire 26 April 1675, for Bridgewater again 14 Feb. 1678-9, and for Hampshire again 21 Feb. 1680-1.

ii 9 Rolle, Richard: for 1895 read 1895-6

i 27 f.e. Rolph, John : for son read eldest son

26 f.e.

24-23

f.e.

after Rolph insert medical practitioner, and after Frances insert (Petty)

for and was originally brought.... studying read $\mathrm{He}$ was entered as a student at the Inner Temple on 8 Nov. 1809, and soon afterwards accompanied his parents on a visit to Canada. He was there during the war with the United States in 1812, and served in it as a volunteer. On returning home he spent some time at Cambridge, and then turned his attention to medicine, studying in London

20-17 for But soon abandoning medicine . . . Canada in 1820 read He was called to the bar at the Inner Temple on 1 June 1821. A year before he had migrated finally to Upper Canada, settling at first in Norfolk County (then the Talbot district)

16 f.e. for the bar in 1821 read the bar of Upper Canada in Michaelmas term 1821, soon

15 f.e. for first at Dundas read at Dundas. For a time he was the professional adviser of Colonel Thomas Talbot [q. v.], the colonial pioneer in Upper Canada, but Rolph rapidly developed strongly liberal political views, with which Talbot was out of sympathy

13 f.e. $\quad$ for 1825 read 1824

ii 20

for Russia read Rochester, N.Y. (cf. J. C. DEnT's Story of the Upper Canada Rebellion)

for the Toronto school of medicine read a school of medicine at Toronto after regularly insert and which was incorporated in 1853 as "The Toronto School of Medicine.'

31

after crown lands insert in 1851

17 f.e. $\quad$ after racter insert and subtle, comprehensive intellect

176 i 10 f.e. Romaine, William: after London insert (a predecessor of Romaine in the lectnreship) and omit happened

9 f.e. $\quad$ omit to precede him in the pulpit 


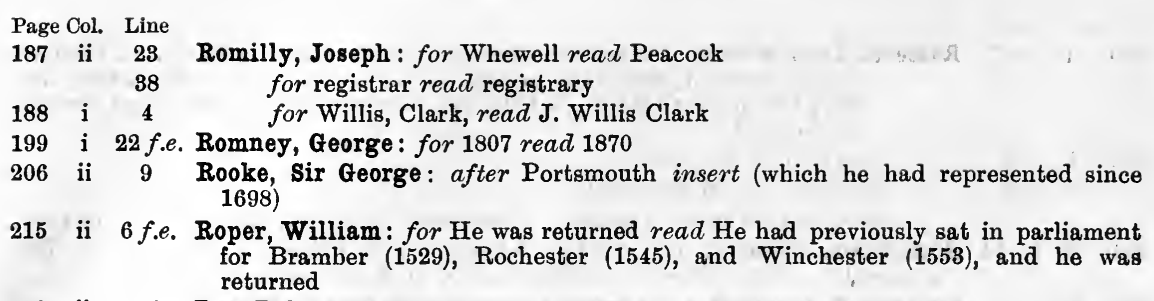

216 ii 16 f.e. Ros, Robert de: for Furfan read Fursan

221 i 3 Roscarrock, Nicholas : for Trevernor read Trevenor

6 f.e. for Haworth read Naworth

225 ii 19 f.e. Roscoe, William C.: for a parish school read a private school (St. Domingo House, near Liverpool).

226 ii 26 Rose, George (1744-1818): omit second son of David Rose, after was insert second son of David Rose,

251 i 41 Ross, Alexander (1590-1654): for (1590 read (1591

42-43 for in 1590 read on 1 Jan. 1590-1 (Sloane MS. 955, f. 192)

252 i 18 for Hobbs and Dr. Hervey read Hobbes and Dr. Harvey for Hervey read Dr. William Harvey

255 ii 16-14 Ross, Alexander (1742-1827): for brother of Andrew Ross ... Sir John Ross f.e. [q. v.]. read the youngest of the five sons of Ross of Auchlossin.

257 i 18 f.e. Ross, Andrew : omit his uncle

266 i l.l. Ross, sir James C.: for His portrait, by Stephen Pearce, for- read Stephen Pearce

ii 1 for merly in the Painted Hall at Greenwich read twice painted his portrait: one picture is in the Franklin Museum at Greenwich, the other

278 ii 3 f.e. Ross, Thomas (d. 1675) : omit a native of Scotland, and

l.l. before received insert may have

279 i 1 for where he graduated B.A. in 1642 read where one Thomas Rosse, son of James Rosse, and a native of Richmond, Surrey, having been educated at the Charterhouse, was admitted in 1639 and graduated B.A. in 1642-8.

281 ii 21 f.e. Ross, Sir William C. : for 1870 read 1800

282 ii 30 Rossetti, Christina G. : for Lavinia read Frances Mary Lavinia

10 f.e. after illness. insert She assisted her mother in teaching a day school at Camden Town, and afterwards at Frome.

283 i 2-3 for As an ardent Italian patriot read As a sympathiser (at least in early years) with the Italian cause

6 f.e. $\quad$ after 1872, insert and 'Speaking Likenesses' (tales for children) in 1874,

ii 2 omit 'Speaking Likenesses,' 1874;

6 f.e. $\quad$ for Upon her brother read In 1873, the year preceding her brother

5 f.e. for she felt at liberty to follow read she followed

284 i 19 f.e. Rossetti, Dante G. : for 1826 read 1826-7 (2 vols.)

2-1 for fourteen read thirteen

f.e.

ii $\quad 9$

15 for two years read three years

18 for July 1842 read Nov. 1841

18 f.e. for Sathanas 'read Sathana'

9 for Madox Brown read the school of the Royal Academy

25-22 for by which the majority .... in the least. read which, though he shared

f.e. in early years to a marked degree, he very soon abandoned.

287 ii $12-13$

for procure his removal read he was removed

288 i 19 for when the clouds read just before the clouds

for wrote read completed a still unpublished poem, which was originally composed at a very early date

for Mario' read Mano'

29-30 omit originally sketched in watercolour in $\mathbf{1 8 5 5}$,

81 after period insert ( $\mathrm{He}$ had treated the same subject in watercolour in 1855)

22 f.e. $\quad$ for 10 April read 9 April 
Page Col. Line

289 ii $9-7$

f.e.

290 i 7

8

13

301 ii $19-14$

f.e.

305 ii 3 f.e.

306 i 10

- 25

313 ii $8-9$

329 ii 11

339 ii 17 Rowe, Mrs. Elizabeth : for It is read It is summarised

347 ii 23 f.e. Rowe, Sir Samuel : for Hawker read Hawsker

362 ii 9-11 Rowley, Samuel: for successively with ... companies of actors. read with the company of actors known successively as the Admiral's, Prince Henry's, and the Palsgrave's men.

38

after extant. insert In 1602 Rowley and William Bird were paid by Henslowe 4l. for making additions to 'Faustus.' Possibly some of the feeble comic scenes in the extant edition of Marlowe's tragedy, which was first published in 1604, are from Rowley's pen [see MarLowe, Christopher]

365 ii 21 f.e. Rowley, Sir William: for of an old Essex family read of an old family of Warfield, Shropshire, being son of William Rowley of Whitehall, a court official under William III and Anne,

371 i 11-12 Roy, William: for 'Rede me not' read 'Rede me and be not wroth'

383 ii 28 Rudge, Edward: for purchased read possessed

390 ii 13 Rufus, Geoffrey : after 1134 insert certainly after 1 Oct. 1133

21 f.e. after Durham insert (Luurentrus Dunelmensis, Dialogi, p. 12)

392 i 2 Rugge, Thomas : after 1836. insert A transcript by J. Meares of the first volume of Rugge's work, dated 1687, somewhat more complete than that in the British Museum, belongs to Mrs. Tucker, 75 Warwick Road, London, S.W.

Rumbold, Sir George B.: after James Berriman, Esq. insert He was on 13 Jan. 1781 admitted a pensioner of Christ's College, Cambridge, afterwards becoming a fellow-commoner.

416 i 2 Rupert, Prince : for June read July

3 for Breda read Buda

417 ii 38 Rush, John B.: for JoHn read JAves

426 ii 11-12 Russel, William : for Anti-Quaker-istica read Anti-Quakeriana

428 ii 33 Russell, Charles William : after Ballystrew. insert His brother Arthur was father of Sir Charles Russell, Lord Russell of Killowen [q. v. suppl.].

430 ii 32 , Russell, Edward, Earl of Orford : for La Hogue read La Hague

431 i 28 after 1699, insert He had represented Launceston (1689), Portsmouth (1690), and Cambridgeshire (1695) in the lower house,

433 i 12 f.e. Russell, Francis, 2nd Earl of Bedford : for issue read male issue

ii 34 Russell, Francis, 4th Earl of Bedford: after 1607, insert was M.P. for the borough of Lyme Regis 1610-1,

435 i $17-21$

Note that Francis, who is here described as the eldest son, was the second son, and that William, who is here described as the second son, was the eldest son.

i 17 f.e. Russell, John (1787-1863): for Mary Augusta, read Mary Augusta Lloyd (a cousin of Charles Lloyd, bishop of Oxford [q. v.]),

15-14 for one daughter, Mary, read two daughters: Augusta, wife of the Rev. G. f.e. Bridges More, and Mary, wife of General Hutchinson.

462 i 16-15

Russell, Iord John, 1st Earl Russell : for who still (1897) survives read who died on 18 Jan. 1898

473 ii 35

479 ii 36

485 ii $4-3$

Russell, Thomas (1767-1803) : for ' the clerk of the parish' read 'parish priest'

Russell, Sir William $(d .1654)$ : after Chippenham insert Cambridgeshire

f.e. eldest son 


\title{
DiCTIONARY OF NATIONAL BIOGRAPHY
}

\author{
ERRATA IN VOLUME L
}

\section{RUSSEN—SCOBELL}

N.B. - f.e. stands for from end and l.l. for last line

2 ii 11 Rust, Thomas C. : for Thomas Cyprian read Cyprian Thomas

42 i 20 Ryder, Sir Dudley : omit by Tabitha Waller

54 ii 20 Rygge, Robert: for 1393 read 1392

87 i 16 f.e. Sackville, Charles, 6th Earl of Dorset: after taste. insert When Prior was employed as a boy in his uncle's tavern (about 1680), Sackville discovered his promise, helped to defray his schooling at Westminster, and aided him with his influence.

120 ii 1 St. Aubyn, Catherine : after CATHerive insert afterwards Mrs. MoLesworth

121 ii 35 St. Aubyn, sir John (1758-1839) : for (d. 1841) read (d. 1844)

124 ii 32 Saint-Evremond, Charles de M. de St. D. de : after written. insert He also wrote the life of Rochester prefixed to his 'Poems' (1707).

i 25-26 St. John, Oliver, Viscount Grandison : for into the same branch of the family. read to the family of his brother, Sir John St. John, great-great-grandfather of Vis. count Bolingbroke, the statesman.

166 ii 17 St. Leger, Sir Anthony : for vol. xxiii. read no. xxiii.

230 ii 32 Sampson, Henry (1841-1891): after the author insert (together with 'Dictionary of Modern Slang,' 2nd ed. 1860)

231 ii 30 Sampson, Richard: for any read a

244 ii 29 Sancroft, William: for fellow and tutor read fellow; he became tutor

$245 \quad$ i 29

249 ii 17

251

20 f.e.

for select preacher read university preacher

for Vandergucht, Elder read Vandergucht the elder

ii 34 Sanders, George : after Saunders insert (1807-1863)

37 for he was living in 1856. read he died at Bristol on 25 Aug. 1863.

272 ii 7 f.e. Sandford, James: for John read James

286 i 23 Sandys, Edwin: for Abindon's read Habington's

304 i 15 f.e. Sargent, John N.: for Shanghai read Hongkong

342 i 14 Savage, Sir John B.: for Princess Charlotte read Princess Sophia

32 for entered the royal read rose to be a colonel in the royal

33 for and afterwards the civil service read and settled in

354 17 f.e. Savery, Thomas: for 1698 reall 1702

356 i 6 Savile, Bourchier W.: for Dictionary read Directory

368 i 10 f.e. Savile, Sir Henry : for Patrerson read Pattison

390 i 22-25 Sayer, Augustine : for was possibly a son . . . . holy orders. read was grandson of Valentine Sayer of Sandwich, who was thrice mayor of that town.

394 ii 6 f.e. Scalby, John de : after shaw. insert Scalby was also author of the lives of several bishops of Lincoln (cf. Giraldus CaMBrensis, vol. vii. pp. 193-216, where they are printed).

Scardeburg, Robert de : for East Riding read North Riding 


\section{ERRATA-VOLUME L}

Page Col. Line

408 i 33

brass ordnance, 16 May 1718.

414 ii 16 Scheemakers, Peter : after Exchange, insert the statue of William III at Hull,

424 i 13 Schomberg, Sir Charles M. : for first lieutenant read lieutenant

486 ii 30 Schomberg, Raphael : for was no doubt obtained from a foreign read was obtained from Aberdeen

40

for Croucher read Crowcher and after London insert and master of the Vintners' Company in 1752

448 i 11 f.e. Sclater, William (1575-1626)

ii 21. Sclater, William (d. 1717?) for St, Peter-le-Poor read St. Peter-le-Poep 


\title{
DiCTIONARY OF NATIONAL BIOGRAPHY
}

\author{
ERRATA IN VOLUME LI \\ SCOFFIN—SHEARES \\ N.B. -f.e. stands for from end and l.l. for last line
}

Page Col. Line

3 i 12 f.e. Scogan, Henry : for 1891 read 1821

5 i 21 Scarburgh, Sir Robert de : for Scorbrough read Scorbolough

28 for Scorby read Scoreby

13 i 38 Scott, Alexander J. : for Jesus,' 1859; read Man' 1860;

15 i 15 Scott, Cuthbert : for (d. 1565) read (d. 1564)

ii 36-37 for some time in 1565. read on the feast of St. Denys (9 Oct. ?) 1564

(Molanus, Hist. Lovaniensis) and was buried in the church of the Friars

Minor.

20 ii 22 Scott, Sir George G. : for Hayley read Haley

22 i 19 f.e. for In 1879 read About 1870

ii 23 for prejudice against the read prejudice in favour of the

40 ii 16-15 Scott, Sir John: for Bleau. Scot .... the survey read Blaeu. Scot interested f.e. himself in the survey

14-12 for purchased his drawings .... getting them revised read Pont's

f.e. drawings, after his death about 1614, were purchased by the crown. Scot, having caused them to be revised

4 f.e. $\quad$ for Bleauaniæ volumen sextum,' read Blaeuaniæ volumen quintum,'

3 f.e. $\quad$ omit as its real author

2 f.e. $\quad$ for Bleau read Blaeu

41 i 9 f.e. Scott, John (1639-1695): after 1752, 8vo insert (the work was ultimately extended to 5 vols.)

46 ii 7-5 Scott, afterwards Scott-Waring, John (1747-1819): omit was Maria, .... The f.e. second,

47 i 1 for $1746 \mathrm{read} 1745$

13 after Faber [q. v.]. insert Waring's second wife was Maria, daughter and heiress of Jacob Hughes of Cashel.

62 ii 20 f.e. Scott, Michael (1789-1835): for Raymond Lodge read Raymond Hall

18-17 for It was probably written .... business. read Probably he there wrote f.e.

$16-15$

f.e. most of the sketches which were worked up into the 'Log.'

for 1836, after Scott's death. read 1834, when it formed vol. liv. of a 'Collection of Ancient and Modern English Authors' in Baudry's 'European Library.'

67 ii 16 f.e. Scott, Thomas (1480 ?-1539): after Thomas insert Lond Pergonuo.

72 i 11 f.e. Scott, Thomas $(d .1660)$ : for The name of the regicide's wife is not known. read The regicide was thrice married, first to Alice Allinson at Chesterford in 1626 ; secondly in 1644 to Grace, eldest daughter of Sir Thomas Mauleverer (she was buried in Westminster Abbey, 26 Feb. 1645-6); and thirdly to Alice (of unknown surname), who petitioned to visit him before his execution (Noble, Regicides, ii. 197; Chester, Westminster Abbey, p. 140).

ii 20-26 omit and his wife Grace . . . Registers, p. 140;

75 i 37 Scott, Thomas (1747-1821): for 18 Oct. read 16 Oct. 


\begin{tabular}{rccc}
\multicolumn{2}{r}{ Page Col. } & Line \\
87 & ii & $\mathbf{2 7}$ \\
91 & i & 15 \\
92 & i & 6 \\
101 & ii & 7 f.e. \\
& & \\
& & \\
& & $3-1$ \\
102 & i & f.e. \\
& & 4 \\
& & \\
& & $5-6$
\end{tabular}

$\begin{array}{ccc}103 & \text { ii } & 21 \\ & & 24 \\ & & 3 f . e . \\ 104 & \text { i } & 3 \\ & & 19 \\ 112 & \text { i } & 28 \\ & \text { ii } & 30-31 \\ 113 & \text { ii } & 12-11 \\ & & f . e . \\ 114 & \text { i } & 34-35 \\ 125 & \text { ii } & 3 f . e . \\ 132 & \text { i } & 47-48 \\ 135 & \text { i } & 33 \\ 139 & \text { i } & 35-36\end{array}$

37

19-17

f.e.

16-15

f.e.

$14-11$

f.e.

ii $\quad$ 17-19

Scott, Sir Walter (1771-1832): for 1809 read 1809-10

for (1816) read (1815)

for 1815 read 1816

for Scott's children were: read Scott was succeeded in the baronetcy by his eldest son, Walter, who was born on 28 Oct. 1801, and died on 8 Feb. 1847, when the title became extinct. His other children were :

omit Walter, born . . . . no issue. (3)

for (4) read (3)

for Scott has now no descendants except read Scott is now lineally repre. sented by the family of his great-granddaughter,

for daughter of Hope-Scott and her children. read now of Abbotsford; she is second daughter of J. R. Hope-Scott [q. v.] and wife of the Hon. Joseph Constable Maxwell (third son of William Maxwell, Lord Herries), who assumed the additional surname of Scott on his marriage.

after printed) insert 1808

after 1813 insert (really 1812)

for 1849 read 1820 and after 1820 insert (really 1819)

for George III's read George IV's

after 1651,' insert 1826

Scott, William, Lord Stowell (1745-1836) : for Colburne's read Colburn's

Scott, William (1797-1848): for Knaveshire read Knavesmire

Scott, William : for Parliament House read a tenement overlooking Parliament House Square

for Perthshire read Ayrshire

Scriven, Edward : for 1318 read 1818

Scrope, Adrian : for thirty-seventh read twenty-seventh

Scrope, Sir Geoffrey : for Ufflete read Ufflete or Usflete

Scrope, Henry le, 3rd Baron Scrope of Masham : for A modem writer says read According to Monstrelet,

for but he gives no authority (Gesta read (ed. Panthéon Littéraire, p. 366 ; cf. Gesta

for wife from the royal family. Even .... and the prince read wife, Joan Holland, from the royal family, the lady's father being half-brother of the late King Richard II. When at the end of 1411 the prince

for Scrope continued at the treasury. read Scrope resigned the treasurership 16 Dec. 1411 (WyLIE's Henry IV, iv. 51).

for His supersession by Henry $\mathrm{V} \ldots$. he was entrusted read After the accession of Henry V he was entrusted

for Possibly he had resented . ... two years before. read Rumour ascribed the conspiracy to bribery with French gold; if so, it is possible that Scrope was the go-between.

Scudamore, William E.: for survives with read died 7 June 1898, aged 82, leaving

14 f.e Scudder, Henry : after Cambridge insert whence he graduated M.A. in 1606

ii 18 f.e. Seager, Charles : for Brecknor read Bicknor

ii 14 f.e Sedgwick, Thomas: for Gainsford read Gainford

ii 7 Sedley, Sir Charles : for earl of Rivers read Earl Rivers

ii 6-5 Sedulius: for must be the commentator read must be differentiated from the

ii 36 segrave, Sir Hugh: for Brustwick read Burstwick

ii 36 Segrave, Sir Hugh: for Brustwick read Burstwick

i 17 Segrave, John de : for Almondbury read Alkmundbury (Alconbury)

ii 8 f.e. Selby, Walford D. : for 1865 read 1867

9

Sellar, William Y.: for his death in Octo

28

Dalry, Galloway, on 12 Oct. 1890

after 1892. insert $\mathrm{He}$ also contributed ' Characteristics of Thucydides' to 'Oxford Essays,' 1857.

Selwyn, George A. (1809-1878): for Major Charles Selwyn read His father's uncle, Major Charles Selwyn

omit His father's uncle,

for the first of a series read an early foundation in the series of colonial sees 
Page Col. Line

232 ii 7

3 f.e.

233 ii 35.

235 ii $10-15$

$\begin{array}{ccc}248 & \text { ii } & 42 \\ 270 & \text { i } & 22 \\ & & 23 \\ 281 & \text { ii } & 19-18 \\ & & f . e . \\ 282 & \text { ii } & 13 \\ 296 & \text { i } & 31 \\ 297 & \text { i } & 5-7\end{array}$

32-38

304 i 25-34 Seymour, Edward, Duke of Somerset: for But he had lost faith . ${ }^{\cdot}$

Selwyn, George A. (1809-1878): omit in the colonies

for an only son, read two sons: William, vicar of Bromfield, and

Selwyn, William (1806-1875) : for (1806-1875) read (1809-1878)

Sempill, Hew, 11th Iord Sempill: Note that the author of 'A Short Address - . of the Author,' London, 1793. was not by the subject of this article, but $\dot{b y}$ his grandson, Hugh Sempill, thirteenth Lord Sempill (1758-1830).

Senlis, Simon de, Earl of Northampton : for $(d .1170)$ read $(d .1159)$

Seton, George, 5th Lord seton : for ducesque alii, read aliique duces, for Dominium read Dominus

-18 Seward, Anna : for Johnson, writing .... declared read Johnson remarked to Boswell, 25 June 1784, that

\section{Seward, Thomas : for may read may be}

Seymour, Catherine, Countess of Hertford: for Catherine reaid Lady Catherine for and she would probably .... for a revival read but all hope of her complete restoration was dispelled by a revival

for As a result .... lieutenant of the Tower. read On Grey's death, 21 Nov. 1564, the countess was transferred to the custody of Sir William Petre [q. v.] at Ingatestone, Essex. Afterwards she was handed over to the charge of Sir John Wentworth, and on his death to that of Sir Owen Hopton at Cockfield Hall.. The fact that Hopton was subsequently lieutenant of the Tower has led to the erroneous assumption that the countess was confined there a second time. collected a large army read At first he avoided all reference to the feudal claim which Henry VIII had revived in 1542, and sought to win over the Scots to the projected union with England by promising free trade between the two kingdoms, autonomy for Scotland, and the substitution of the words Great Britain for England and Scotland. France encouraged the Scots to resist, and during the summer the Protector collected a large army

18 f.e. for Dumbarton read Dunbar

305 ii 19

26

20 f.e.

19 f.e.

17 f.e.

306 ii 32

308 ii $25-26$

309 i $10-5$

f.e. after dington insert (Sept. 1549)

for Ballemberg read Boulogneberg and after Newhaven insert (Ambleteuse)

after enclosures insert (June 1548)

after rejected insert in the following session of parliament

for May read May 1549

for twenty-nine read thirty-one

for She was divorced soon after 1530 read She is erroneously said to have been divorced

for Owing to the misconduct .... by his second wife read By an act of parliament passed in 1540 Somerset's estates were entailed upon his issue by his second wife in preference to his issue by his first, and similar clanses were introduced into the patents for his subsequent dignities and grants of land.

Seymour, Edward, Earl of Hertford (1539 ?-1621): for recommitted to the Tower. read committed to the custody of Sir John Mason [q. v.].

for he was released .... but was kept read but he was kept

after 153 insert cf. Notes and Queries, 8th series, vii. 422-3

Seymour, Francis, 1st Baron Seymour of Trowbridge: for is now an inn read was used as an inn until 1842, when it became Marlborough College

Seymour, Lord Kugh : for at Jamaica read while cruising for his health off Jamaica.

$\begin{array}{lll}333 & \text { i } & 14 \\ 335 & \text { i } & 26 \\ 345 & \text { i } & 9\end{array}$

14

Seymour, William, 2nd Duke of

Seymour, William, 2nd Duke of somerset: for Lanesborough read Londesborough

for m

, Thomas, Baron seymour of Sudeley : for Meanwhile, in the summer states, but Clinton who was sent in command of the fleet against Scotland during the summer and autumn of 1548. Seymour remained at home, busy with his intrigues against his brother's authority. In August he was

Shairp, John C. : for October read November 
Page Col. Line 355 i 21

ii 1

\section{i $19-1$} f.e.

Shakespeare, William : for Charles Howard read Charles, Lord Howard of Effingham ...

for The company, read At first the company performed at the Theatre,

for The quotation read The italicised quotation $\mathrm{K}$, for The quotation read The italicised quotation.

4 f.e. for 26 Feb. read 6 Fob.

25 If after their friends. insert Shakespeare was not present; he was acting the same night before the queen at Greenwich.

for involved him ..... Shakespeare avows read led to the production of his 'Sonnets.' Between 1591 and '1597 no aspirant to poetic fame in England failed to seek a patron's ear by 'a trial of skill as a sonneteer. Shakespeare applied himself to sonneteering when the fashion was at its height. Many critics are convinced that throughout the 'Sonnets'

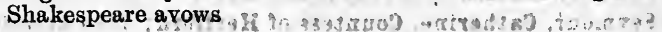

ii 5-6 for Their uncontrolled ardour read But the two concluding sonnets (cliii. and cliv.) are directly based on an apologue illustrating the potency of love which figures in the Greek anthology (Palatine Anthology, ix. 627). Elsewhere many conceits are adapted from contemporary sonnets by English and foreign writers.' Although Shakespeare's poems often seem coloured by personal experience, they were probably undertaken to a large extent as literary exercises. His ever-present dramatic instinct may be held to account for most of the illusion, which they create, of personal confession." Their style

$364 \cdot$ i $24-45$

for But when all allowance.. the twofold influence read No. clear and connected story is deducible from the poems, which divide themselves into two main groups.

16-14 for the young man :... three years old (civ.) read for the most part a young man

f.e.

$9-8$

f.e.

3 f.e.

$2-1$

f.e.

ii 1

2

for with an emphasis ..... will perpetuate read in language originally borrowed from classical literature, but habitual to the sonneteers of the day, that his verse will perpetuate for ever

for his devotion read love

omit he has made ..... in the

omit the line

omit xl.-xlii.

for At one period . . by the young man read In one sequence the writer's equanimity is disturbed by the favour bestowed by a young patron

omit calmness and

for The second group . . ... to her seduotions (cxxxiii.-cxxxvi.) read In the second group, most of which are addressed to a woman (cxxxvi.-clii.), Shakespeare, in accordance with a contemporary convention of sonneteers, narrates more or less connectedly the story of the disdainful rejection of a lover by a dark-complexioned siren. In one group of six sonnets (xl., xli., xlii., cxxxiii., cxxxiv., and exliv.), which seem to stand apart from those that immediately precede or follow them, a more personal note appears to be struck. The six poems relate how the writer's mistress has corrupted his friend and drawn him from his 'side.' Sonnet cxliv., published by Jaggard in 1599, suggests the state of feeling generated by this episode. The poet declares that he is tempted by 'two spirits': 'a man right fair,' 'the better angel,' and a worman 'coloured ill,' 'the worser spirit.' The story of intrigue developed in these six sonnets, which is not readily paralleled, may owe its origin to a genuine experience of the poet.

for actors in the poet's narrative read persons to whom the poet seems to refer

for the young read a young

for would well apply read would (it is commonly 'suggested) apply

for If there is no direct proof ". . . of 'Southampton. read But Chapman was only one among many of the protégés of 'Southampton, and another of them, Barnabe Barnes, has claims to be considered the 'rival poet.'

for mysterious read coniventional

omit There was a contemporary musician called William Hughes

for Pembroke doubtless read Pembroke, who was known from birth until his father's death exclusively as 'Lord Herbert' 
Page Col. Line

366 i 27-81

34

13-12

f.e.

$\begin{array}{ccc}367 & \text { ii } & 28 \\ & & 29 \\ 376 & \text { i } & 10 \text { f.e. } \\ 380 & \text { i } & 33-34 \\ & & 37 \\ 383 & \text { ii } & 3 \text { f.e. } \\ 386 & \text { ii } & 57-58 \\ 388 & \text { i } & 10 \text { f.e. } \\ & & 6 \text { f.e. } \\ 390 & \text { i } & 37 \\ & & 7 f . e . \\ 396 & \text { i } & 8 \text { f.e. }\end{array}$

400 ii 6

7

27

401 i 11

13

438

Shakespeare, William : for But the intrigue .... in full tide. read But no historical justification is needed for the creation of that conventional personage, and one of the sonnets in which she figures was surreptitiously published by Jaggard in 1599, before the intrigue between Pembroke and Mary Fitton is known to have begun.

for William Herbert read Lord Herbert

for The emotional stories . . . . subsided quickly read The story of a lover's supersession by his friend in the favours of a mistress-the burden of those six sonnets that may have a personal significance-may possibly reflect an affair of gallantry in the poet's own life to which obscure reference would seem to be extant elsewhere. The adventure in that case would have caused no lasting wound

for Eastcheap, which read Southwark;

after frequent insert the Boar's Head, Eastcheap

for 26 March read 24 March

for in 'Two Noble Kinsmen,' ed. Littledale, read by

for 1874). read 1874 ; 'Two Noble Kinsmen,' ed. Littledale).

for impression read definite impression

for the Grange read Denby Grange

after (both in 1600), insert 'Titus' (1600 and 1611),

omit 'Titus' (1600),

for Watkins reall Watkiss

after Hudson insert first issued in 1851-6 (11 vols. 16mo), and reissued as

after plots. insert Alexander Schmidt's Shakespeare-Lexicon, 1874, and Abbott's Shakespearean Grammar, 1869 (new edit. 1897), elucidate the text.

Sharp, Abraham : after Bradford insert and baptised in June 1653

for He was apprenticed read After attending Bradford Grammar School he was apprenticed to William Shaw, mercer, of York, and then

for From 1676 read From about 1684

after 1690). insert Early in 1691, however, he removed to Portsmouth to take ' a clerk's place in the king's shipyard.'

for 15 July read 18 July

after cited insert cf. Cudworth's Life and Correspondence of Abraham Sharp, 1889

32 Shaw, John (1559-1625): for 'Bibliorum read' Biblii

36-40 for Shaw also wrote .... but it was translated read The work, which was in Latin, was translated

41-42 for posthumously .... 12mo. read London, $1623,12 \mathrm{mo}$, under the title 'A True Christian's Daily Delight'; this was reprinted in 1688 under the new title of 'The Divine Art of Memory.'

441 i 4 Shaw, John (1776-1832): for Ham Hall read Ilam Hall

450 ii 19-20 Shaw-Lefevre, Charles, Viscount Eversley: for St. Mary's, Winchester, read Winchester College

452 ii 17-19 Shaxton, Nicholas : for He became ultimately president .... sometimes called. read He was president of Physick's Hostel, which was attached to Gonville Hall, 1512-13. 



\title{
DiCTIONARY OF NATIONAL BIOGRAPHY
}

\section{ERRATA IN VOLUME LII}

\section{SHEARMAN-DMIRKE}

\begin{tabular}{rcc}
\multicolumn{2}{r}{ Page Col. } & Lin \\
$\mathbf{v}$ & i & 19 \\
3 & ii & 2 \\
15 & i & 6 \\
19 & ii & 37 \\
21 & i & 39 \\
21 & i & 18 \\
& & 21
\end{tabular}

25 i 12

26 ii 19 f.e.

29 ii 29

32 i 5 f.e.

38 i 34

40 ii 4

41 i $9-10$

44 i 16 f.e.

ii 5 f.e.

51 i 2 )

21)

20

69

5-1

f.e.

ii $1-3$

30

77 i 5-6

80 i 18

84 i 3

\author{
N.B.-f.e. stands for from end and l.l. for last line
}

List of Writers : insert A. M. C-E . . . Miss A. M. CookE

Shebbeare, John : after happily. insert Mrs. Shebbeare died 25 Nov. 1779.

Sheffield, John, 3rd Earl of Mulgrave : for 1763-4 read 1703-4

Sheil, Richard L. : for Penenden read Pennenden

for 1850 read 1849

Sheldon, Gilbert : for Ashbourne read Stanton, in the parish of Ellastone

after shire. insert An inscription by Bishop Hacket is still to be seen in the room where he was born.

for Sneltson read Snelston

after dark moustache. insert Another, the property of the Earl of Home, is at Bothwell Castle, Lanarkshire.

Shelley, Mary W.: for eight years read six years

Shelley, Percy B.: for but not one ... light. read only one of which has come to light; this copy was found, in 1898, in the possession of Mr. V. E. G. Hussey, and has since been reprinted.

after Redding [q. v.]. insert Another edition of his 'Works' in one small volume was published by Charles Daly in 1836.

Shelley, Sir Richard: for (d. 1566) read (d.1559)

for the British Museum read the Government Library at Malta

Shelton, Thomas ( $f$. 1612): for Besley read Beoley

after Cambridge, insert in the library of Wadham College, Oxford,

Shepard, Thomas: for Darly read Darley

for Touteville read Stoutville

Sherborne, Robert : for (1440? read (1450?

for about $1440 \ldots$ and at Oxford, where read probably about 1450 . He entered Winchester College as a scholar in 1465 (KIRBY) and

omit he graduated M.A. . . . St. Paul's Cathedral and

after 722). insert On 17 March 1496-7 he was made prebendary of Mora in

St. Paul's Cathedral (Le Neve erroneously dates this preferment 1468-9).

Sheridan, Mrs. Frances: for Sir Oliver Chamberlaine, bart., read Walter Chamberlaine

Sheridan, Richard B. : for Mathews read Matthews

after required. insert Sheridan died on 7 July 1816.

for 7 July read 16 July

for eight read nine

after Charles insert (d. 1843)

after only son insert by his first wife 
Page Col. Line

86 ii 16 f.e. Sheridan, Thomas (1687-1738): for the birthday of Queen Anne read the day of Queen Anne's death

94 i 26 Sherlock, Thomas : for Interest réad Intent

101 ii 20 Sherwin, Ralph (1799-1830): for Wilton (bis) read Witton

106 i 40 Shilleto: for Ulleshelf read Ulleskelf

118 ii 17 Shippen, William : for Joemund read Jesmund

$\left.\begin{array}{lcc}120 & \text { i } & 9 \\ 48\end{array}\right\}$ Shipton, Mother: for Skipton read Shipton

132 i 24 Shirley, James: for 1651 read 1751

134 if 18 shirley, John (1366 ?-1456): bmit 2251,

29 after 73). insert Harl. MS. 2251, often ascribed to Shirley, was written in Edward IV's reign, parts of it being copied from one of Shirley's MSS.

138 i 11 Shirley, Sir Robert (1629-1666): for father read brother

37 for Harold read Harrold.

139 i 13 Shirley, Sir Thomas : for Coppenthorp read Copmanthorpe

153 i 8 Short, Augustus : after consecrated insert (29 June)

155 ii 12 f.e. Shortland, Edward: after Courtlands insert near Lympston

171 ii 22 Shute, Robert: after (d. 1621), insert matriculated from Christ's College, Cam. bridge, in 1598, graduating B.A. in 1601-2, and

l.l. Shute, Samnel : after Shute insert who matriculated as a fellow-commoner of Christ's College, Cambridge, 12 Dec. 1683,

194 i 18-19 Siddons, Henry: for during the summer of 1801 rad on 22 June 1802

195 ii 1 Siddons, Sarah: for Greathead read Greatheed

197 i 13-14 for The highest honour .". Reynolds's picture read Reynolds paid her a unique compliment when in his pieture

\begin{tabular}{|c|c|c|c|}
\hline & 20 & for he said read Dr. Johnson said af & $\therefore$ \\
\hline 199 & 27 & for Galeotti read Galotti & $\therefore$ \\
\hline & 12 & for minus), read minus, which stood until 1856), & $\because$ \\
\hline & 15 & for now marked read marked until its demolition in 1904 & \\
\hline & 11 f.e. & for Howe read Hone & i \\
\hline & :.l. & for Newnham in Oxford read Nuneham, near Oxford & \\
\hline & 35 & y, Algernon : for 1682) read 1683 ) & \\
\hline & ii & for in June following read on 14 May following (Sloane MS & 19, f. 112 \\
\hline & $\begin{array}{l}\text { i. } 16 \text { f.e. } \\
\text { ii } 15 \text { f.e. }\end{array}$ & $\begin{array}{l}\text { for } 26 \text { June read } 26 \text { June } 1683 \\
\text { for } 1682 \text { read } 1683\end{array}$ & \\
\hline
\end{tabular}

217 ii 29 )

221 ii 24

228 ii 27 )

231 i 22 f.e.

232 ii . 31

236 ii $14-12$

f.e.

6 f.e.

Sidney, Henry, Earl of Romney : for 1675 read 1677

Sidney, Sir Philip : for services read exercises

\section{for Frances read Elizabeth}

for 1542 read 1557 or 1560

for Bacon read (Sir Nicholas) Bacon

Sidney, Robert, 1st Earl of Leicester : for During the political disturbances ... at Flushing; read Sidney spent much time at Flushing during 1598 and the following years;

after iv. 28-9). insert During the political disturbances due to 'Essex's rebellion in the winter of $1600-1$ he was the chief channel of communication between the court and Essex (Sloane. MS. 1856, ff. 10-13 b ; State Papers, Dom. 11 Feb. 1600-1).

244 ii 12 Sigebert $(f .626):$ for was one read who was one

256 i 19 Simeon, Charles: for Law's read the

268 ii 20 f.e. Simpson, David: for Shropshire read Yorkshire

310 i 11-10 Sinclair, Sir William, 3rd Earl of Orkney: for Elizabeth Douglas read Margaret, f.e.

8 f.e. eldest daughter of Archibald, fourth earl of Douglas,

after he had insert a daughter Catharine, who married Alexander Stewart, Duke of Albany [q. v.], and

314 i 8 f.e. Singer, Samuel Weller: after Alfred insert (1816-1898)

316 i 14 f.e. Sion or John, Llywelyn : for a further account of the subject of this article see

317 i 1 Sirr, Henry Charles : for (1756 read (1764 
Page Col. Line

317 i 2 Sirr, Henry Charles : for Dublin in 1756 read Dublin Castle on 25 Nov. 1764!

3

11

12

14-15

24

$57-58$

l.l.

ii $\quad 7$

22

37

318 i 14

342 i 40

343 i 5

\section{6 fe. Skinner,}

6 f.e. Skinner, James (1818-1881) : for Gloucestershire read Worcestershire

\section{2 ii $55-56$}

57-58

358 ii 32

379 ii $21-22$

403 i

for the e

for 1768 read 6 June 1778

for a regiment read the 68 th regiment

for About 1790 read In 1791

after town-major insert with a residence in Dublin Castle

omit and was given a suite ... till his death

after full pay insert and in consideration of his public services was allowed to retain his official residence in Dublin Castle

for by himself read by Joseph D'Arcy Sirr, D.D., and by Mr. George Norman D'Ärcy

after humane insert (23 May and 26 June 1823 ; cf. HANSARD, n.s. ix. 468, 1309)

for Thomas D'Arcy read James D'Arcy

for a copy is read copies are in the British Museum, the library of Trinity College, Dublin, and

Skinner, James (1778-1841) : for Bussagong read Burragong for and another is read another, believed to be by W. Melville, is in the vestry

Skip, John : omit though his will points to Norwich

for in the graveyard at Hereford read at St. Mary Mounthaw, London

Skirlaw, Walter : for University College read Trinity College

Sloane, Sir Hans : for on the accession of the house of Hanover read in August

1722, on the death of Sir Thomas Gibson (Sloane MS. 4046, f. 273)

\footnotetext{
8 Smelt, Leonard : for Horsham read Howsham
} 



\title{
DicTIONARY OF NATIONAL BIOGRAPHY
}

\author{
ERRATA IN VOLUME LIII
}

SMITH—-STANGER

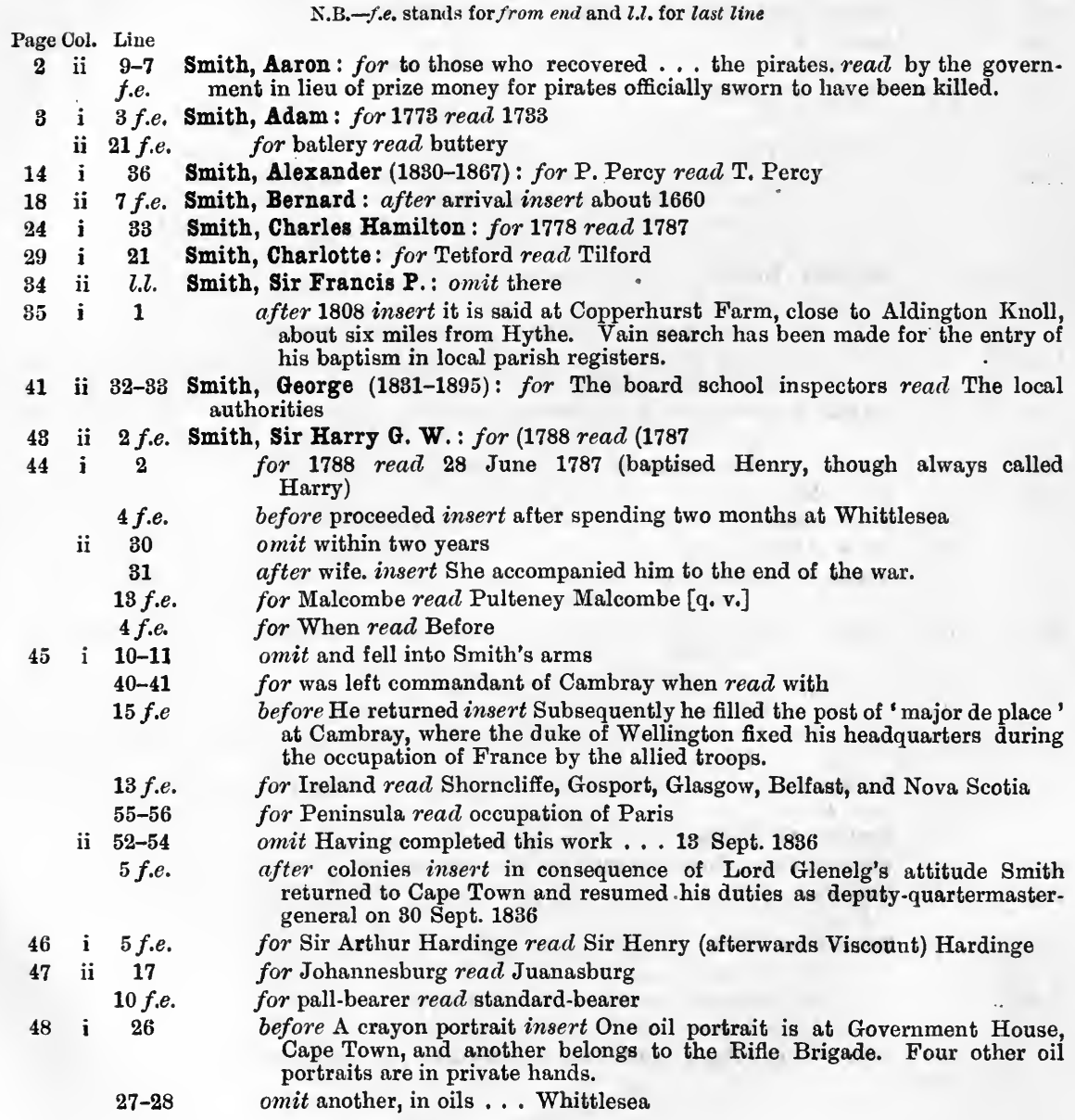


Page Col. Line

48 i 34

54 Autobiography, 1901;
i 24-26 Smith, Horatio or Horace

Smith, Sir Harry G. W. : before War Office Records insert Sir Harry Smith's

read but Smith's name appeared on it in 1869, when it was issued as No. 8 in Bradbury and Evans's 'Handy Volume Series'

70 i 5 Smith, John $(d .1612)$ : for Brooks's read Brook's

75 ii 22 f.e. Smith, John ( $f$. 1673-1680): for another read other

21 f.e. $\quad$ for edition 1723, read editions 1706 and 1723

76 i 13 f.e. Smith, John (1659-1715): for Witten read Witton

88 ii 7 f.e. Smith, John Sidney : for John Sidney read John Spry

91 ii 4 f.e. Smith, John Thomas (1805-1882): omit in 1886

94 ii 12 Smith, Joshua T. : for grandmother read great-grandmother

95 ii 16 for two daughters read three daughters

104 ii 2 Smith, Richard (1590-1675): for MS. 338 read MS. 388

121 i 8 Smith, Sydney : for Hesslington read Heslington omit near Foston

126 ii $\quad 8-9$

Smith, Sir Thomas (1513-1577): for 'Smythus Valdinatus . . . sive read - Gabrielis Harveii Valdinatis Smithus vel

for 75 read 73

127 ii 3

130 i 24 Smith, Thomas (1615-1702): for Hulton read Hutton

140 i 4 Smith, William (1460?-1514): for Chalgrave read Chalgrove

142 i 17-18 Smith, William ( $f$. 1596): for but its present whereabouts is unknown. read it is now in the British Museum (MS. Addit. 35186).

149 i 42-46 Smith, William (1756-1835): omit He was probably . . Portraits, p. 413).

ii 36 for a dissenter read a unitarian dissenter

171 i 11 f.e. Smithson, James : for brother read uncle

172 ii $30 \quad$ after at Genor. insert The cemetery with Smithson's tomb was demolished by the municipal authorities of Genoa during 1903 in making a city improvement. Smithson's remains were thereupon surrendered to the United States government, and were reinterred in Washington early in 1904.

176 ii 38

180 ii 27

38

182 ii 26

189 i $\quad 45$

50-51

190 ii 35

$\begin{array}{llc}205 & \text { ii } & 32 \\ 206 & \text { ii } & 55-56\end{array}$

208 i 32

210 i 4

218 ii 11

16

17

22

14 f.e. Somer, John : after 1380. insert He was alive on 10 Oct. 1409 (cf. WYLIE, Henry IV, iv. 47, 218).

220 i 8 f.e. Somers, Sir George : for Somerset read Somers

223 ii 4 Somers, John, Lord Somers : for Ryegate read Reigate

245 ii 7 f.e. Somerset, John: for his 'Life of Henry V' read his metrical account of

252 ii 12 f.e. Somerville, John: for guilty, and, with read guilty;

11 f.e. for was read were

253 i 5 for Margaret, read Margaret or Alice,

6 for had issue read Elizabeth had issue

16-15 Somerville, John S., 15th Lord Somerville: for unmarried read without issue f.e. 
Page Col. Line

257 ii 38

269. ii 6f.e.

271 i 32

288 ii 1

289 i $l . l$.

297. ii 20

321 i 6

324. i 24

328 ii 32

337 i. $\quad 25$

348 ii 21-24

Somerville, William : after 1801 insert and a 'diamond ' edition in 1825-6

Sothern, Edward A. : for White,' read Mauve,' for Jefferson in read Jefferson;

Southey, Robert : for chap. 127 read chap. 129

for 5 Dec. read 22 Dec.

Southwell, Robert : for but it is not now traceable. read it is now in the library of Mr. Robert Hoe at New York.

Speght, Thomas : for He matriculated read Thomas Speght matriculated

Speke, John H. : for Ilchester read Ilminster

Spelman, Sir Henry :' for He was admitted read In Sloane MS. $(1466$, f. 16) he describes himself as of Oxford University, but he was certainly admitted

Spence, Joseph : for Lyne read Lyme

pencer, Charles, 3rd Earl of Sunderland : for When removed to Blenheim . $\therefore$ second duke read The library was divided in 1749 , one portion going to Blenheim and the other remaining at Althorp in possession of the younger branch of the family [see Spencer, George John, second Earl Spencer]. The library at Blenheim was increased by Charles, third duke

355 i 4 Spencer, George, 4th Duke of Marlborough : for Valderfen's read Valdarfer's

358 ii 34 Spencer, John (1601-1671): after bridge. insert He was probably the John Spencer who matriculated from Christ's College in 1618.

359 ii 36 Spencer, John (1630-1693): for Thummin 'read Thummim'

368 ii 18 Spencer, Robert, 2nd Earl of Sunderland: for in the autumn of 1640 read on 4 Ang. 1640 (Sloane MS. 1782, ff. 16-22 b).

369 ii 6 f.e.

391 ii 17 for 1685 read 1675

Spenser, Edmund : for 'a piece sharp and satirical' read'some satire keen and critical'

36 for powers read howers

412 i 24 Spottiswood, John (1565-1637) for 1637) read 1639)

424 i 19 f.e. Spratt, James: for stern-posts read stern-ports

443 i 20 Stackhouse, Thomas (1677-1752): for two read three

448 i 8 Stafford, Sir Edward: for p. 185). read p. 135); his chaplain was Richard Hakluyt [q. v.].

for treasurership of first-fruits read remembrancership of first-fruits Nov. 1591

for no issue read two sons, who probably died young

453 ii $\begin{gathered}16-15 \\ \text { f.e. }\end{gathered}$

11-9

f.e. Dorset, and Southwick, Hampshire

for John Stafford [q. v.] ... great-uncle read Sir Humphrey Stafford (d. 1413), of Hook and Southwick, great-grandfather of the subject of this article, was father of a second Sir Humphrey Stafford (1379-1442), called 'of the silver hand.' Another son of the elder Sir Humphrey was John Stafford [q. v.], archbishop of Canterbury. The latter's legitimacy is questioned, although he is usually described as the earl of Devon's great-uncle Stafford, John $(d .1452)$ : after Stafford insert of Southwick Court, North Bradley,
Wiltshire, as well as of Hook, Dorset, who was twice married, and had by his first wife, Alice Greynville or Greville, or (according to some authorities) Beville, a son, Sir Humphrey Stafford (1379-1442)

26-35 for and a kinsman of his contemporary . . . earl of Devon [q. v.] read and calls the archbishop his brother in his will. The elder Sir Humphrey's second wife was Elizabeth (d. 1413), daughter of Sir William Aumâle and widow of Sir John Maltravers (d. 1386), of Hook, who in her will, dated 14 Oct. 1413, refers to Master John Stafford. There are difficulties in accepting the statement that the archbishop was a legitimate son of the elder Sir Humphrey's first marriage.

37-38 for an allegation for which ... no foundation. read and although Gascoigne is an hostile witness uncertainty exists as to the name and status of his mother. A handsome monument to 'Emma', mother of Archbishop Stafford, stands in North Bradley Church. It is said to have been erected by the archbishop. The mother, 'Emma,' is described as having died, a sister of the priory of the Holy Trinity at Canterbury, on 5 Sept. 1446 . It is probable that the archbishop was her illegitimate child by the elder Sir Humphrey. In that case a papal dispensation propter defectum natus would be required before he could be ordained priest. At present search in the Vatican records has only revealed at the requisite period a papal 
Page Col. Line

454 ii 37-38 stafford, John (d. 1452)-continued.

dispensation dated 17 March 1403, which entitled John Stafford, clerk of the diocese of Lincoln, who was then in or about his fourteenth year, to hold a benefice (Lateran Register, cviii. f. 79 b). Whether the John Stafford mentioned in this dispensation was the future archbishop is uncertain. If so he was born about 1389 . In 1408 his father, Sir Humphrey, presented him to the living of Farnborough, Somerset, a fact which might suggest an earlier date of birth.

469 i 27 Stalham, John : after Oxford. insert It seems more likely that he was the John Stalham who was matriculated as a sizar of Christ's College, Cambridge, in April 1617, graduating B.A. in 1620-1, M.A. 1624, and whose son John, admitted to the same college in 1667-8, was born at Terling, where the puritan divine was beneficed.

470 i 2f.e. Stanbridge, John : after Stanbridge, insert who was B.A. 1511 and M.A. ii 8 omit one 9-10 omit who was B.A. 1511 and M.A. 1518 


\title{
Dictionary OF NATIONAL BIOGRAPHY
}

\author{
ERRATA IN VOLUME LIV
}

\author{
STANHOPE—STOVIN
}

Page Col. Line

N.B.-f.e. stands for from end and l.l. for last line

$\begin{array}{rcc}7 & \text { ii } & 6 \\ 20 & \text { i } & 6 \\ 36 & \text { ii } & 12\end{array}$

13

38 ii 7

54 i 24

25

28

61 ii 40

65 i 19 f.e.

Stanhope, Sir Edward : for Wharffe read Wharfe

Stanhope, John, 1st Baron Stanhope : for Nottingham read Northampton

Stanhope, Philip D., 4th Earl of Chesterfield : for Life,' by read Life' (1750), at one time attributed to

after [q. v.], insert but in large part written by Chesterfield,

Stanhope, Philip H., 5th Earl Stanhope: for After Talfourd's death read After Talfourd lost his seat in 1841

Stanley, Edward G. G. S., 14th Earl of Derby : for 1820 read 1822

omit a tory,

after peer insert Earl Grosvenor

Stanley, Edward H., 15th Earl of Derby : for 1835 read 1853

Stanley, Edward J., 2nd Baron Stanley of Alderley: omit for the colonies 1833-4, and

70 i 16 f.e. Stanley, Henry, 4th Earl of Derby : for Brandon read Suffolk

79 i 15 Stanley, Thomas (1625-1678): for was incorporated in the same degree at read is said to have joined the university of

$80 \quad$ ii 15

88 i $9-10$

10 for Enyon read Engan

Stanyan, Abraham: omit (the original edition after 8vo, insert (' a large paper copy' for rare; it read rare). The original edition

Stapleton, Miles de (d. 1314) : for Brustwick read Burstwick

Stapley, Anthony : after Anthony insert who about 1640 gave $10 l$. to the new building at Christ's College, Cambridge, and was probably educated there,

Stark, Adam : after Gent. Mag. insert 1816, ii. 542, 1823, ii. 613,

Stark, William : for of Irish parentage . . . . Scotland. read eldest son of Thomas Stark, a merchant of Manchester.

after University insert where he graduated M.A. in 1758 (Adprson's Graduates of Glasgow University, 1898)

ii 3 f.e. Starkey, George: after. STARKEY insert or STIRK and for (d. 1666) read (d. 1665)

2-1 for may be identical .... Leicester-read born in the Bermudas, was son f.e. of George Stirk (d. 1636-7), a minister of Scottish nationality in those islands, and author of 'Musæ Somorenses' (London, 1635, 8vo), of which there is a copy in the Bodleian Library (cf. Lefrox, Memorials of the Bermudas, 1877, vol. i.) In early life the son occasionally designated himself Storkey, but in his printed works his name appears as either Starkey or Starkeius. He graduated M.A. at Harvard College, and, while practising as a doctor in America,

omit shire by his wife . . . settlements. There he

for In 1646 Starkey returned read Between 1646 and 1650 Starkey proceeded 
Page Col. Line

27

$\begin{array}{ccc}112 & \mathrm{i} & 4 \\ & & 12 \\ & & 16\end{array}$

123 ii $\quad 17$

19

20

138 ii 22

4

ii 7 f.e.

6-4

f.e.

3 f.e.

144 i 5

$\begin{array}{ccc} & & 6 \\ 145 & \text { ii } & 13 \\ 146 & \text { i } & 26-27 \\ & \text { ii } & 11 \text { f.e. } \\ & & 7 \text { f.e. } \\ 148 & \text { i } & 30 \\ & & 32 \\ & & 38 \\ & \text { ii } & 22\end{array}$

108 i 25

143 i 3

Starkey, George : for In 1666 read Before 14 Sept. 1665

after zeal insert (ALLIN's 'Notices of the Last Great Plague, 1665-6,' in Archcoologia, 1857, vol. xxxvii. p. 10 ; but see, for another version of his fate, SiblEy, Biog. Sketches of Graduates of Harvard Univ., 1873, vol. i. p. 184)

Statham, Nicholas : for ( $f$. 1467) read (d. 1472)

after no mention insert in records of judicial appointments

after the office. insert He was member for Old Sarum in the parliament of

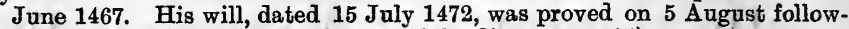
ing (cf. Skotrowe, Short History of Parliament, p. 14).

Stebbing, Henry (1687-1763): for Malton read Walton

for $(d .1821)$ read $(d .1721)$

Steele, William: for was admitted to read joined Caius College, Cambridge, in 1627, and was scholar there 1629-31. He entered

Steevens, Charles : for (d. 1761) read (1705-1761)

after rear-admiral, insert born at West Hanningfield, Essex, on 7 Feb. 1705, was fifth son of John Steevens, a captain in the army, and brother of George Steevens, father of the Shakespearean commentator. $\mathrm{He}$

for A brother George read The George Stevens

for was probably the Mr. Stevens .... p. 242) read who is

after his pay insert was probably the admiral's nephew, the Shakespearean commentator

Steevens, George: for son read child

after Mary insert (Perryman)

after Oliver Goldsmith. insert Johnson left him his watch by will.

for Beauclerk Topham read Topham Beauclerk

for Mirror' read Review' (1763, i. 61-6)

for Birkenhout's read Berkenhout's

for housekeeper read cousin and housekeeper

for his sister read his 'dearest cousin,' Mrs. Collinson's sister

for Her brother's books read Steevens's books

after vol. vii. insert A miniature belongs to Mrs. Inglis, Mrs. Collinson's great-granddaughter.

188 i 1

Stephenson, James : for Morton read Martin

201 i 20 f.e. Sterne, Laurence : for Ritson read Riston

202 i 12 f.e. for MSS. read Charters

205 ii $27 \quad$ for Totteston read Tollerton

222 i 18 f.e. Sterne, Richard: for Bishopsthorpe read Bishopthorpe

ii 5 after Place. insert There is a portrait of the archbishop in the hall of Jesus College, Cambridge.

Stevenson, Joseph : after Durham, insert He entered the university there, became a licentiate in theology in 1841 ,

Stevenson, Robert L. : for James Balfour read Lewis Balfour for 4 Dec. read 3 Dec.

Stewart, Alexander, Earl of Mar: for duke of Burgundy, read count of Holland and Hainault,

Stewart, Alezander, 4th Earl of Moray : for fourth EARL read fifth EARL for third read fourth

Stewart, James (d. 1309) : for Melton read Malton

Stewart, Lord James, Earl of Mar and Moray : for 1556 read 1556-7 for June read Jan.

Stewart, James, Earl of Moray (d. 1592) : for EARL of Moray of a new line read second EARL OF Moray

Stewart, Matthew, 4th or 12th Earl of Lennox: after Lennox; insert Yorks. Arch. Journ. x. 63-82, 407, 422;

tewart, Matthew (1717-1785) : before On 21 June insert In 1756 Stewart was created D.D. of Glasgow University.

29 Stewart, Murdac, 2nd Duke of Albany : for Fife read Fife and Menteith 
Page Col. Line

370 ii 31-32 Still, John : for After 1561 he was elected a fellow read From 1562 to 1572 he was a fellow.

38 for the former was a fellow real the former was an undergraduate of Christ's College, whence he matriculated in 1566

372 i $8 f . e$.

ii $24-52$ after the first edition. insert There seems no doubt that the author of the play was William Stevenson, born at Hunwick, in Durham, who matriculated as a sizar at Christ's College, Cambridge, in Nov. 1546 (B.A. 1549-50, M.A. 1553, and B.D. 1560); was fellow of the college 1551-4 and 1559-61; was ordained deacon in London in 1552; became prebendary of Durham 1560-1, and died in the course of 1575. In 1559-60, according to the books of Christ's College, five shillings was 'spent at Mr. Stevenson's plaie,' which may be safely identified with 'Gammer Gurton's Needle' (see art. by Mr. Henry Bradley in GayLEx's Representative English Comedies, i. 197 sq.)

388 i 17-16 Stisted, Sir Henry W.: for daughter of Lieutenant-colonel Burton. vead sister of f.e. $\quad$ Sir Richard Francis Burton.

415 ii 10 Stone, Samuel: for Aspen read Ashen

427 i 19 Story, George W.: for Warter read WALTER 



\title{
DicTiONARY OF NATIONAL BIOGRAPHY
}

\author{
ERRATA IN VOLUME LV \\ STOW-TAYLOR.
}

Page Col. Line

4 i 15 f.e. Stow, John: for 506 read 516

ii 2 f.e. for $1876 \mathrm{read} 1842$

8 ii 28 Strachan, Archibald : for (d. 1651 ?) read (d. 1652)

9 ii 16 after ii. 86). insert He died in November 1652.

10 i 21 f.e. Strachan, John (1778-1867) : for Govenor read Governor

22 ii 2 Strange, Sir John: for 'Causidecade read ' Causidicade

23 i 10 f.e. Strange, John (1732-1799): for Spalatro read Spalato

34 i 13 Stratford, Nicholas : for Raine's read Raines's

50 ii 29-30 Strickland, Hugh E. : for Eustasius read Eustatius

56 i 22 Strickland, William : for He was undoubtedly read He may have been

62 ii 18 f.e. Strother, Edward: for born in Northumberland, read born in 1675 at Alnwick, in Northumberland

17 f.e. $\quad$ omit perhaps

14 j.e. before On 8 May insert $\mathrm{He}$ was admitted a pensioner of Christ's College, Cambridge, 24 Aug. 1695, aged 20 , but did not graduate.

04 i 22 f.e. Strutt, Edward, 1st Baron Belper : for 26 Aug. read 29 Aug.

65 ii 6 f.e. Strutt, Joseph: for Robert Younge of Halstead, read John Ingold, miller, of Woodham Walter, near Maldon, Essex, for Newcastle read Northumberland

Stuart, Lord Bernard, titular Earl of Lichfield : for 1646) rear 1645)

Stuart, Charles, 6th Duke of Lennox : for (1640 read (1639 and jor 7 March read 6 March for 1639-40 read 1638-9 (Sloane MS. 1708, f. 121)

Stuart, Sir Charles (1753-1801): after American war. insert In 1780 he was returned to parliament for Bossiney, Cornwall.

Stuart, Frances T., Duchess of Richmond and Lennox : for (1648 read (1647

23 - for in 1648 read on 8 July 1647 (Sloane MS. 1708, f. 121) after in wax insert modelled by Antoine Benoist

Stuart, Henry W. V. : for 1849 read 1850

Stuart, James (d. 1793): for 1868 read 1869

38 Stuart, Sir James : omit Lower

21 j.e. Stuart, Sir John (1759-1815) : for Philipstadt read Philipsthal

118 i i.l. Stubbs, John: for Britanniæ read Britannicæ

16 f.e. for is said to have been read was

15 f.e. for in Birmingham read at Howard's Place, Birmingham

15-15 for the anniversary ...23 April 1824 read on 5 July 1821

f.e.

8-7

f.e.

for Young Meadows read Eustace 
Page Col. Line

159 ii 8 f.e. Sullivan, Barry : for Charles James Lever [q. v.] read Charles Sever, a journaljst. 166 i 8 Sumner, Charles R.: for Dawson read John Dawson

170 i 15 Sumner, John B.: for the university of Durham; read University College, Durham;

180 i 32 Sutton, Sir Charles : for Thornton read Thoroton

182 ii 32 Sutton, Sir Richard $(d .1524)$ : for His portrait read The portrait

185 i l.l. Sutton, Thomas (1532-1611): for St. Swithin read St. Swithun ii 4 for Snaith read Knaith

189 i 11 f.e. Swain, Charles : for Tavaré read Tavarez

229 i 7 f.e. Swinburne, Henry (1560?-1623): after 1500-1714; insert Yorkshire Archæolog. Journal, i. 202, vii. 54 ;

247 i 10 Sydenham, Thomas : for 3 March 1626, read 26 Feb. 1626-7,

264 i 18 f.e. Sylvester, Josuah : for Frascatorius read Fracastorius

271 ii 21 f.e. Symonds, John : for 1728-9 read 1729-30

277 i 15 f.e. Symonds, Richard (1607-1692): for Ellington read Ettington

300 ii 7 Tait, William : for 1846 read 1864

342 i 19 Talboys, Sir William : for Guy read Grey

349 i 12 Tallis, Thomas : for Willersley read Willersey

353 i 12 Tancred, Christopher: for Hargreave's read Hargrove's

370 i 11 Tarlton, Richard: after improvisation insert Roger Williams, in the address to the reader prefixed to his 'Discourse of War' (1590), wrote of Tarlton that he 'would counterfeite many artes, but he was no bodie out of his mirth.'

372 i 16 Tarver, John C.: for in 1818 read about 1822

374 ii 8 f.e. Tassie, James: for 1777 read 1772

385 ii 20 Tatham, John : after requests insert to Queen Henrietta Maria

390 ii 9 f.e. Taunton, John : for Gloucestershire read Worcestershire

407 ii 34 Taylor, Edward : omit as an ironmonger

412 i 9 f.e. Taylor, Sir Henry : for 1876 read 1870

424 i 9 Taylor, Jeremy : for Seyes Court read Sayes Court

426 i 21 for repeated read repealed

439 ii 5 f.e. Taylor, John (1694-1761): for Manchester New College read Manchester College

442 i 38 Taylor, John (1703-1772): after Extraordinary insert History

447 i 8 Taylor, John (1781-1864): for Parker read Parkes

465 ii 14-15 Taylor, Simon : omit The date of his death is uncertain.

23-25 Taylor, Thomas (1576-1633) : for Cambridge, ..... B.D. 1628, read Cambridge, where he matriculated from Christ's College, graduating B.A. in 1594-5 and M.A. in 1598. He was fellow of his college (1599-1604) and Wentworth Hebrew lecturer (1601-4), proceeded D.D. 1628,

473 ii 12 Taylor, Tom : after Clothing' insert (10 Feb. 1857)

480 i 33 Taylor, Wittewronge : for said read improbably said 


\title{
Dictionary OF NATIONAL BIOGRAPHY
}

\author{
ERRATA IN VOLUME LVI
}

TEACH—TOLLET

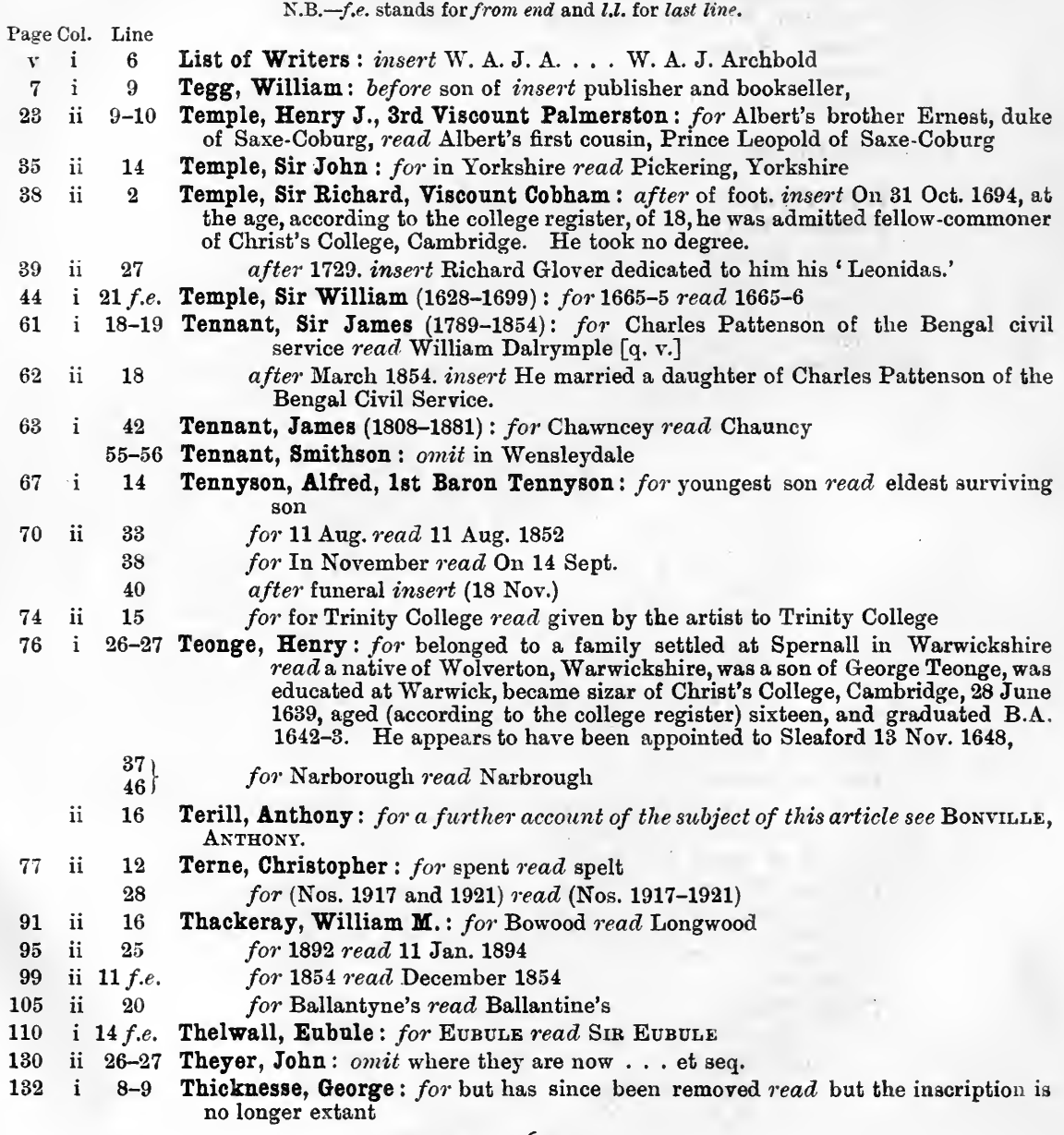


Page Col. Line

141 ii 11

12

142 i 5 f.e.

180 i $52-53$

184 ii 36

37

18 f.e.

193

208

223

i 8 f.e.

ii 26 .

i 16 f.e. Thompson, Sir Thomas B.: for son of Cap-read son of Mr. Boulden by his wife, Sarah, sister of Cap-

15-14 for R.N., by Sarah Boulden read [q. v.]

f.e.

224

i 24 f.e.

21 f.e. Thompson, Thomas P.: for Brooks read Briggs

ii 16 f.e.

11 f.e.

226

ii 1

2

228

245

249

263

279

280

284

285

290

299

300

\section{$35-56$}

ii 5

301

ii 11

for Rasal read Râs al

for at Soor read near Soor

for J. P. Thompson read T. P. Thompson

for Colonel read his son, General

Thompson, William (1811-1889): for 1889) read 1880)

Thomson, Henry W.: for Ghita read Gita

Thomson, James (1700-1748) : for 1781,' read 1751,'

Thomson, Joseph : for 1883 read 1882

Thomson, William (1819-1890) : for Bishopsthorpe read Bishopthorpe

Thoresby, John : for Hovington read Honington
Thoresby, Ralph: for Johnson read Johnston

-51 Thorius, Raphael : for Frascatorius read Fracastorius

Thorn, Sir Nathaniel : for Bishop's Hall read Bishop's-Hull

Thorndike, Herbert: for KenNeT read KenNetT

ton, Sir Edward : for 1818 read 1813

Thornton, Edward P. : omit In 1833 he published . . . . (London, 8vo).

omit and in $1840 \ldots$. . Wollaston, appearing in 1886.

after two daughters. insert Several works, commonly attributed to Thornton, are by others of the same name. A Captain Thornton, R.N., was author of 'A Summary of the History of the East India Company' (London, 1833, 8vo). EDWARD ThorNTon (1799-1875), probably a cousin of Edward Parry Thornton, who was in the East India House from 1814 to 1857 , and was head of the maritime department from 1847, wrote: 1 . 'India: its State and Prospects,' London, 1835, 8vo; 2. 'Chapters of the Modern History of British India', London, 1840, 8vo; 3. 'History of the British Empire in India,' London, 1841-5, 6 vols. 8vo (second edition, 1 vol., 1858); 4. 'Gazetteer of the Countries adjacent to India on the NorthWest,' London, 1844, 2 vols. 8vo; 5 . 'Gazetteer of the Territories under the Government of the East India Company; London, 1854, 4 vols. 8vo (other editions followed, the last, revised by Sir Roper Lethbridge and Mr. Arthur Naylor Wollaston, appearing in 1886).

Thornton, Henry : omit as his second wife

ton, Robert J.: for little woodeuts. read little woodcuts; reissued in 1824 with additional woodcuts by Blake of fine quality.

for second wife read wife

12 f.e. Thoroton, Robert : for Thoroton combined read Thoroton was born and educated. On 30 June 1639 , when aged 16 , he was admitted sizar of Christ's College, Cambridge, where he graduated B.A. 1642-3 and M.A. 1646. In the last year he received from the university a licence to practise medicine. - Thoroton combined

$314 \quad$ ii 39 Thorpe, Charles: for THORPE read THORP

18 f.e. for at Peterhouse read at Durham School and at Peterhouse

17 f.e. $\quad$ after 1758 insert as senior wrangler

315 i 44 after popularity. insert A portrait by J. R. Swinton was engraved by G. R. Ward in $\mathbf{1 8 4 6 .}$ 
Page Col. Line

315 i 53-54

327 ii 17

\section{7}

337 i 33

359 i 40

i 4 f.e.

ii $\quad 39$

362

367

368 ii

369 i 20 f.e

383 ii 19 f.e.

391 ii 39

40

41

392 ii 21

22

101 ii 12

414 ii 2

415 i 30

31-32
Thorpe, Charles : for Mr. R. J. N. Davison read Mr. R. J. W. Davison

Throckmorton, Francis : after Sir John Throckmorton insert (d. 1580) omit [q. v.]

Thrupp, Joseph F.: for Daniel read David

Thurtell, John : for James Phillips read Charles Phillips after Abernethy insert and his skull is preserved at the Royal College of Surgeons

after xliii. 306). insert A published play, "The Hertfordshire Tragedy, or the Victims of Gaming,' by H. M. Milner, was produced at the Royal Coburg Theatre, 12 Jan. 1824.

Thweng, Robert de: for the North Riding read East and North Ridings

Thynne, Thomas : for Balanquil read Balcanquhall

for Kennet's read Kennett's

Thynne, Sir Thomas, 1st Viscount Weymouth : for Deverill Longbridge read Longbridge Deverill

Tidey, Henry : for Bedford read Bedford Square

Tilloch, Alexander : for Tilloch read Tulloch for tobacconist read tobacco merchant after 1759 insert (Soon after 1787 he changed his name to Tilloch) after wife insert Elizabeth Simpson after daughter insert Elizabeth

Timberlake, Henry : for 1601 read 1601-2

Tiptoft, Robert de : for Robert read John

Tisdal, Philip : for (1707 read (1703

for born at Finglas, near Dublin, in 1707. read baptised at St. Mary's Church, Dublin, 1 March 1702-3. 



\title{
Dictionary OF NATIONAL BiOgRaPhY
}

\author{
ERRATA IN VOLUME LVII \\ TOM-TYTLER
}

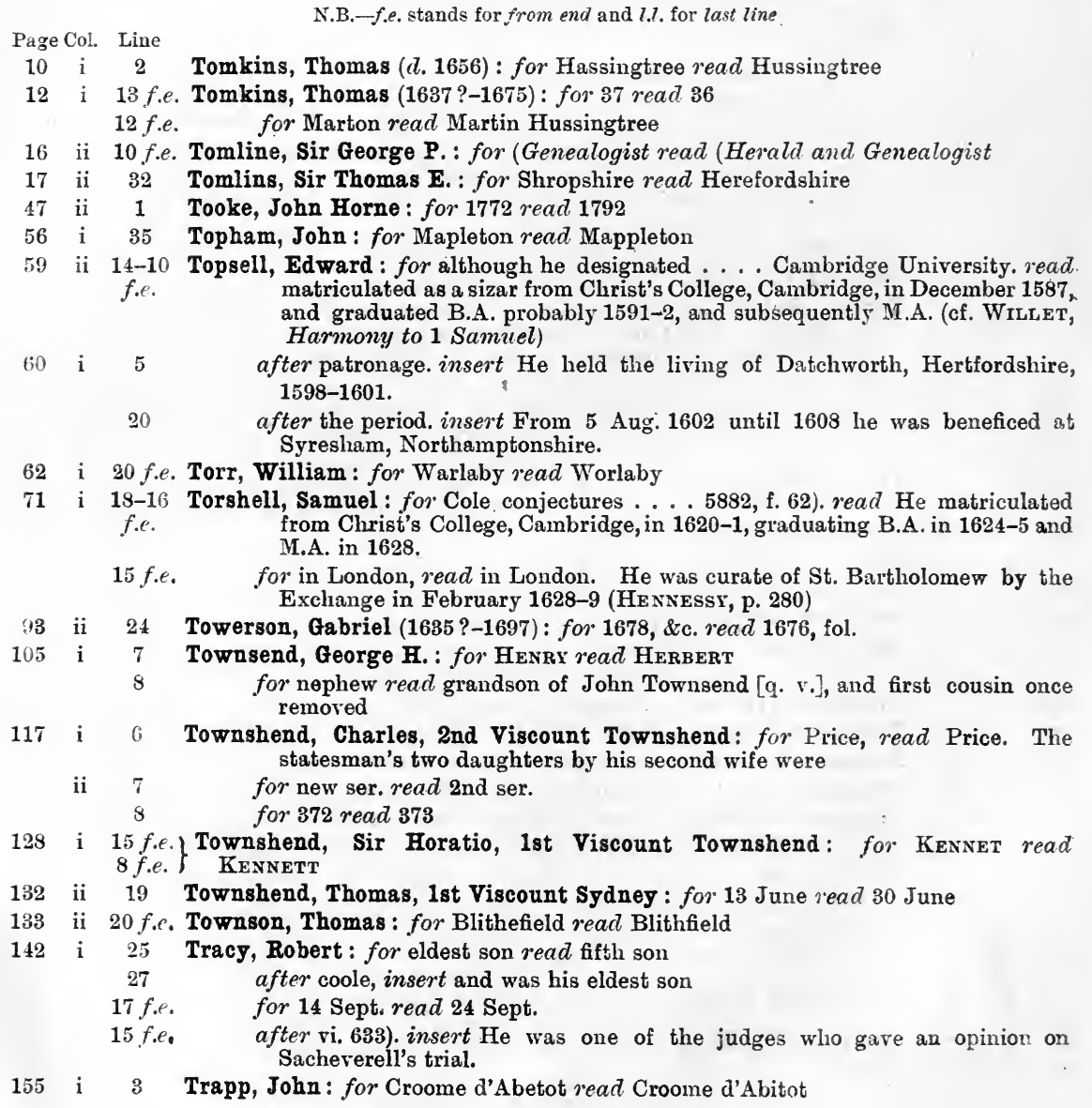

N.B. - f.e. stands for from end and 1.1. for last line 
Page Col. Line

163 i 18

174 i 25

180 ii 20

187 ii 12

191 i 9

194 i 32-33

195 ii 10

207

ii 6 f.e.

210 ii 14

226 i 19

233 i 7

238

245 i

249

$\begin{array}{ll} & \text { ii } \\ 250 & \text { i } \\ & \\ 303 & \text { ii } \\ 311 & \text { ii } \\ 353 & \text { i }\end{array}$

30

40 )

ii $\mathbf{1 1}$ f.e.

10 f.e.

9 f.e.

ii 18

Travers, Walter : for lay, however, with Whitgift, who read lay with the crown. Archbishop Whitgift

Trelawny, Charles : after November insert 1688

Trelawny, Sir Jonathan : omit with the rest

Tremellius, John I. : for Caius College read Corpus Christi College

Trench, Power le P.: for French read Trench

Trench, Richard C. : for He committed suicide read He died

Trench, Richard le P., 2nd Earl of Clancarty : for English peerage read peerage of the United Kingdom

Tresilian, sir Robert : for Call. read Cal.

after month, insert a famous pirate merchant (d. 1408),

Trevelyan, Sir Walter C. : for Loft read Lofft

Trevor, Richard : for Bishop's Auckland read Bishop Auckland

Trimnell, Charles: for (1630? read (1630

14 f.e. Trollope, Anthony: after elder brother. insert He was elected a scholar of Winchester in 1826.

12 f.e. for placed his son at Harrow school read removed his son next year to Harrow school

20 Trollope, Frances : for 1855 read 1843

25 for her house read her son's house

Trollope, Thomas A.: after Anthony insert in the year 1826

for Alban Hall read St. Alban Hall

for 1886, when he paid read 1886. While at home on one occasion he paid for his wife read 'George Eliot'

for Some four years later read In 1890

i 32-33 for the heroine of Webster's famous play read the widow of the Imperialist general Pescara

13 Tuke, William : for Yorkshire read York

l.l. Tunstall, Cuthbert: for Tyndall's read Tyndale's

20-19 Turner, Robert (d. 1599): for He received his education . . . but left the

f.e. university read $\mathrm{He}$ spent some time both at Exeter College, Oxford, and at Christ's College, Cambridge, whence he matriculated in 1567, but he left each university

7-8 Turner, Robert ( $f l$. 1654-1665): for and educated at Cambridge University. read near Saffron Walden, and matriculated from Christ's College, Cambridge, in 1636, graduating B.A. in 1639-40.

7-6f.e. Turner, Samuel (d. 1647?): for According to Wood . . . . foreign university. read He graduated M.D. at the university of Padua in 1611 (Sloane MS. 1729).

366 i 29 Turner, William (1653-1701): for 1600 read 1680

19 Tnrner, William (1714-1794): for Lyne read Lyme

ii 7 Turnour, George: for Candragupta read Chandragupta

ii 25 Tweddell, Ralph $\mathrm{H}$.: for Hawthorne read Hawthorn

ii 18 Twiss, Horace : omit editor of the 'Times,'

19-20 for who succeeded Bacon read editor of the 'Times'

i 21 Twiss, Sir Travers: omit 1.

i 18 f.e. Twisse, William : omit (ib.)

i 35 Twysden, Sir Roger : for in 1823 read about 1815

ii 25 Tyerman, Daniel : for Asmotherly read Osmotherly

i 13 f.e. Tyndale, William: for On 13 April read So latè as 13 April

3 f.e. $\quad$ for September read September 1535

for burial read trial

13 for 6 Aug. read 6 Oct.

5 f.e. for Europe read England

i 29 Tyrrell, Sir John : omit or Alice

Tyrrell, Sir Thomas : for Hanslape read Hanslope

6 f.e. Tyrwhitt, Sir Robert : for 15 Oct. read 25 Oct.

Tysilio : omit brut 


\title{
DiCTIONARY OF NATIONAL BIOGRAPHY
}

\author{
ERRATA IN VOLUME LVIII
}

\author{
UBALDINI—WAKEFIELD
}

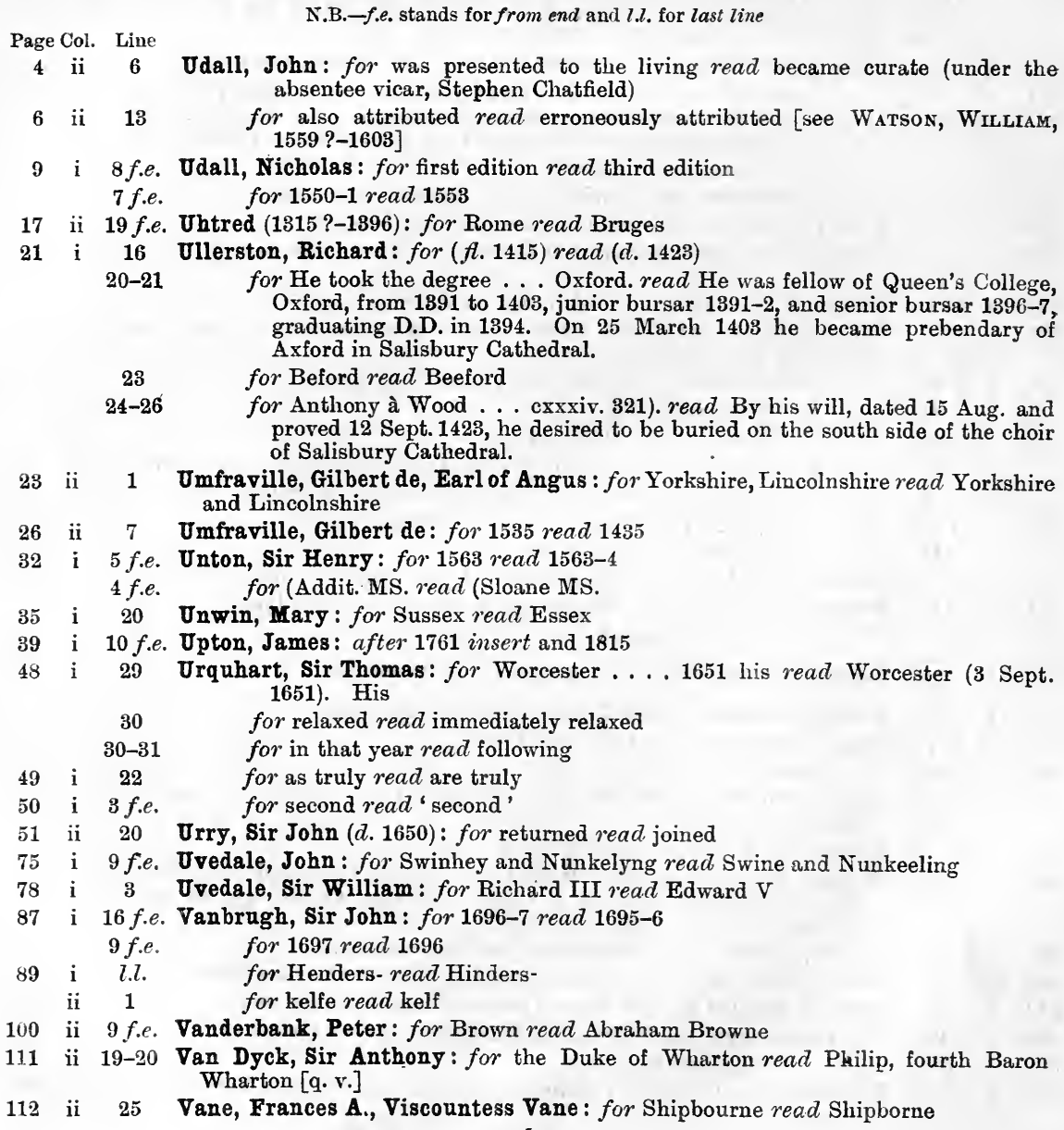


Page Col. Line

126 ii 21 f.e. Vane, Sir Henry, the younger : for 1669) read 1660)

10 f.e. for 1661 read 1660

130 ii 14 f.e. Vane, William H., 1st Duke of Cleveland: for whose widow read who married

12 f.e. for married secondly read widow of

11 f.e. omit was

10 f.e. after Rosebery. insert She died on 18 May 1901.

Vannes, Peter: for (d.1562) read (d.1563)

f.e.

6 f.e.

$\begin{array}{ccc}138 & \text { i } & 5 \\ & & \\ 139 & \text { i } & 40 \\ & \text { ii } & 33 \\ & & 38\end{array}$

140 i 16 f.e.

omit and a replica ... of the college

Vansittart, Henry (1732-1770): for His you Club.' read He was an unruly youth. for Mír Jafar read Mír Kásim

for Amelia read Emilia

for Ann read Emilia

Mildert, William : omit with it

after writer. insert In the winter of 1746-7 he took part in the defence of the place, when the French made an abortive attack on it.

after riotous living insert With his elder brothers, Arthur and Robert, he joined the graceless Society of the Franciscans of Medmenham.

after 367 insert See also Gent. Mag. 1767, pp. 79, 80,84; P. Auber's Rise and Progress of the British Power in India, 1837, and J. Talboys Wheeler's Early Records of British India, chap. ix.

ii 5 f.e. Vansittart, Nicholas, 1st Baron Bexley : for Amelia read Emilia

141 i 12

after 1812. insert Vansittart had joined as cornet in 1797 the City of London and Westminster. Light Horse Volunteers, a fashionable regiment in which he was promoted lieutenant in 1798 and captain in 1799.

8 f.e. for Lorentin read Zornlin

20 f.e. Van Straubenzee, Sir Charles T. : for Busby read Buskby

l.l. Varley, John : for Nottinghamshire read Lincolnshire

3 Vaughan, Richard, 2nd Earl of Carbery : for both honours were read the honour was

13 f.e. Vaughan, Thomas : for (Addit. MS. read (Sloane MS.

i 5 Vaux, Thomas, 2nd Baron Vanx: after apparently insert in the neighbourhood of his seat, Harrowden

i for Gatehouse at Westminster read Fleet prison

ii 4 for 1662) read 1661)

6-7 for Elizabeth read Eleanor

34 for a daughter of William read a daughter of George, son of William

40 for another daughter read another daughter of George, son

7 f.e. Venn, Henry (1796-1873): for 1827 read 1826

ii 1 for till 1848 read twelve years

27-28 Venn, Richard : omit usually known as the Bangorian controversy,

1 Vennor, Henry G.: for and afterwards studied read studying

2 for took read taking

17) Vernon, Theobald de : for Theodore read Theobald

16 Vere, Sir Horace, Baron Vere : for 1624) read 1625)

ii 19 f.e. Vergil, Polydore : for 1498 read 1503

ii 33 after 3rd ser. insert i. 55,

24-25 Vermuyden, Sir Cornelius : for Stonhouse's Hist. of Asholme read Stonehouse's Hist. of Axholme

\section{6 f.e. Verney, Sir Francis : omit Richard}

35 Verney, Ralph, 2nd Earl Verney: for Ralph succeeded read Ralph, who was admitted fellow-commoner of Christ's College, Cambridge, 20 April 1733, and graduated M.A. in 1735, succeeded

4-5 Vernon, James : for Staffordshire read Worcestershire

14 Vesey, John : after inscription insert adapted from Horace (Odes, ii. 14)

37 Villiers, Charles P.: for did not read the committee did not

40 Villiers, George, 1st Duke of Buckingham : for 1617 read 1619

30 for daughter read sister

i 2 f.e. Vincent, John P. : after Donnington. insert Richard Budd Vincent [q. v.] was his brother. 


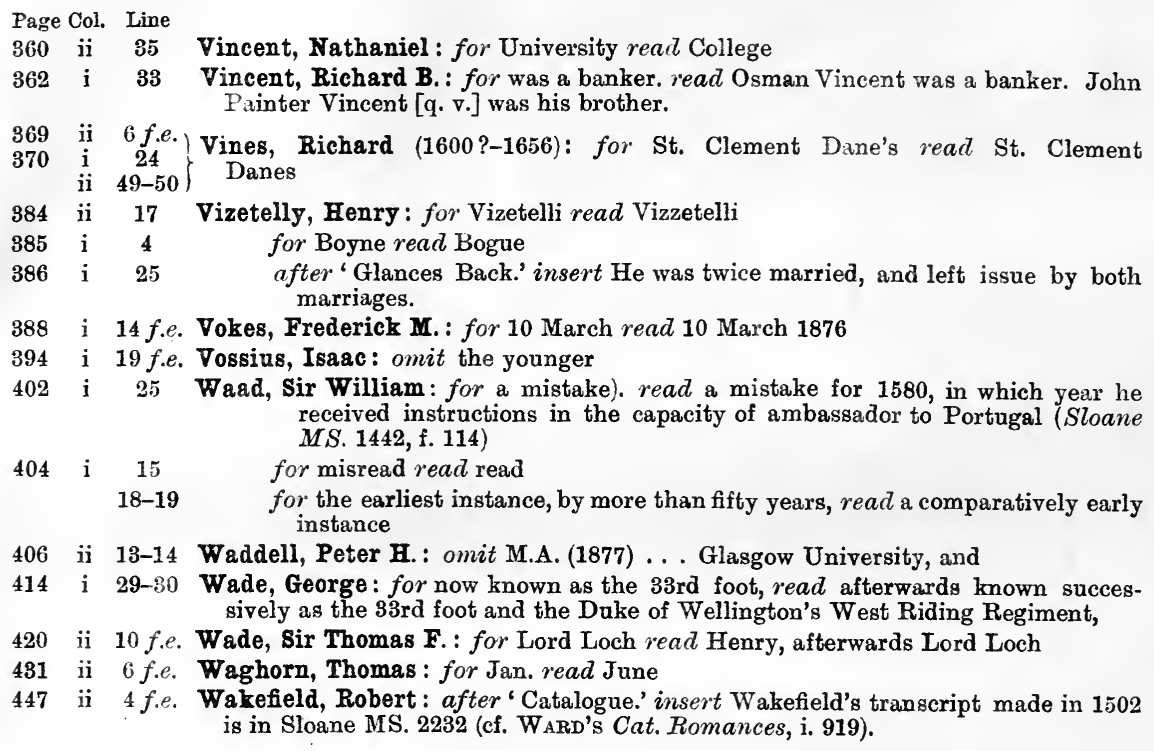





\title{
Dictionary OF NATIONAL BIOGRAPHY
}

\author{
ERRATA IN VOLUME LIX
}

\author{
WAKEMAN—WATKINS
}

\begin{abstract}
N.B.-f.e. stands for from end and l.l. for last line
\end{abstract}
Page Col. Line

1 i 14 Wakeman, Sir George: for was educated abroad read studied at St. Omer 1647 and Pavia, and

2 i 24

19 i 19 f.e. Waldegrave, James, 2nd Earl Waldegrave : for Brampton read Brompton

20 ii 4 Waldegrave, Robert : for Blacklay read Blockley

21 ii 23 for Revelations read Revelation

50 i 25

Walker, Sir Edward : for Walker died read Walker purchased on 18 May 1675 New Place, Shakespeare's house at Stratford-on-Avon, after the death of Lady Barnard, Shakespeare's granddaughter and last surviving descendant. He died there after p. 159). insert A portrait of Sir Edward by Robert Walker [q. v.] remains at Clopton House.

61 i 38 Walker, George A. : for 1853 read 1837

68 ii 29 Walker, James (1770?-1841): for deacon read priest

33 for 1729 read 1829

74 i 17-18 Walker, John (1731-1803): for Glencross read Glencorse

78 i 17 f.e. Walker, Joseph C. : for (1762 ?- read (1761-

15 f.e. $\quad$ for in or about 1762 read in 1761

95 ii 7 f.e. Wall, Martin : for M.D. on 9 June 1773, read M.B. 1773, and M.D. 1777,

96 i 34-35 Wall, Richard: for and belonged ... that family read at Coolnamuck, co. Waterford, where a branch of that family was settled

99 ii 11-15 Wallace, James (d. 1688): omit He was 'deprived by the council' . . . the revolution of 1688-9.

116 ii 20 f.e. Wallace, William V.: for (1814 read (1813

123 ii 10 Waller, Edmund: for first read second
15 f.e. $\quad$ for Carey read Cary

127 i 16 f.e.

130 i 15 f.e. Waller, John F. : for Bishop's Stortford read Bishop Stortford

138 i 15 f.e. Wallingford, William: for our read one

l.l. for abbey read town

142 i 12 f.e. Wallis, John (1616-1703): for 1653 read 1654

145 ii 21-22 Wallis, John (1714-1793): for Simondburn read Simonburn

150 ii 8-9 Wallop, Sir Henry : for in October read on 30 Sept. 1579

151 i 5 for 21 June read 20 June

18 for 10 March read 16 March

33 for 1585 read 1586

ii 19 for 2 July reäd 22 Aug.

33 for Enniscelly read Enniscorthy

152 i 6-5 for George Carew ... Totnes) [ [q. v.] read George Carey, kt. (lord justice f.e. until 26 Feb. 1600) 
Page Col. Line

154 i 19

159 i 14-15

160 i $\begin{gathered}16 \\ 17-18\end{gathered}$

18

20

36

161 ii $\quad 27$
Wallop, sir John : for 1540-1 read 1539-40

Walmesley, Sir Thomas : for Showley-in-Clayton and Cunliffe-in-Rishton, read Showley, in the township of Clayton, and Cunliffe, in the township of Rishton, for the manor of Dunkenhalgh read at Dunkenhalgh omit first for and secondly with . . . baron Stourton read her first husband omit doubly for day. read day ; by her second husband, Charles, fifteenth baron Stourton, she had no issue.

after xxviii ; insert Whitaker's History of Whalley; Abram's History of Blackburn;

. Walmisley, Thomas A. : for 'Portfolio' read 'Cambridge Portfolio'

for edited read adapted

Walpole, Edward : for embraced read showed sympathy for for Jessop's read Jessopp's

Walpole, Ralph de : for coronation read consecration

Walpole, Sir Robert, 1st Earl of Orford : for Strafford read Stafford for (Mary) read (Catherine)

Walsh, Antoine V.: for 1759 ?) read 1763) and for born at St. Malo in 1703, read baptised at St. Malo on 22 Jan. 1702-3,

for shipowner read wealthy Waterford merchant for Mary O'Shiel read Mary, daughter of Luke O'Shiel for 1755 read 1753

for and he died ... about 1759. read Subsequently he went to San Domingo, where he died at Cap Français on 2 March 1763; his will, dated 11 Nov. 1758, was proved at Châtelet, Paris, on 13 Sept. 1763.

for Paulin, who died ... issue, read (1745-1798), who was in 1772 appointed chamberlain to Maria Theresa,

Walsh, John (1725?-1795) : omit Walsh was returned . . . until 1780.

Walsh, John E.: for following read same

Walsh, Peter: for Dean read Dease

for In March read On 24 Feb.

for Caron read Coppinger

Walsh, Robert: omit but though his title pages . . . cannot be traced

for he accepted read during which, year he received the diploma of M.D. from the Royal College, Aberdeen, as well as the degree of LL.D. from Trinity College, Dublin, Walsh accepted

Walsh, William (1512?-1577): for no doubt read perhaps

for convent read abbey

Walsingham, Sir Edmund : for Somerby read Somerley

Walsingham, Edward : for (fl. 1643-1659) read (d. 1663).

for The last reference to Walsingham .... died abroad. read Walsingham was already acting as secretary to Walter Montagu, then abbot of St. Martin's, near Pontoise, and filled that post until his death. He interested himself in the settlement at Pontoise of the English Benedictine Dames in July 1659, and next year being ordained priest and named curé of Aronville, near Pontoise, became spiritual director of the nunnery, for which he wrote a manuscript manual of prayer called 'The Evangelique Pearle' (now preserved at the convent at Newhall, Essex). Accompanying his chief, Abbot Walter Montagu, to England in the autumn of 1663 , he died there suddenly on 9 Oct. of that year (cf. FouEY's Records of Society of Jesus, vol. ii. ser. iii. pt. ii. 383).

240 ii 2-3 Walsingham, Sir Francis (1530?-1590): omit in other manuscript collections than those named

241 ii 9-13 Walsingham, Francis (1577-1647): for He left in manuscript ... . nunnery at Pontoise read A manuscript manual of prayer, 'The Evangelique Pearle' (now preserved at the convent at Newhall, Essex), which was written for the use of the English nunnery (the Benedictine Dames) of Pontoise, has been erroneously assigned to Francis Walsingham, whose death preceded by eleven years the conventual settlement at Pontoise; the manuscript is from the pen of Edward Walsingham [q. v.].

248 . i 14 f.e. Walter, Sir John : for Woolvercott read Wolvercote 
Page Col. Line

262 i 16 f.e. Walters, Edward: for From 1848 to 1860 read Until 1860

275 i 38 Walton, Izaak: for Winchester Cathedral read Salisbury Cathedral

12 f.e. $\quad$ after 1888. insert A memorial to Walton has been placed outside the church of St. Dunstan's in the West, Fleet Street.

277 ii $\quad \begin{gathered}8 \\ 10\end{gathered}$ Walton, James : for Somerby read Sowerby

284 i 6

291 i 41

Walwyn, William: for born about 1600 read baptised on 17 Aug. 1600

Wanostrocht, Nicholas: after 1876. insert His widow died in 1901.

after esp. ii. 61 ; insert Caffyn's Seventy-one Not Out;

292 ii 40 Warbeck, Perkin : for Flanders read England

300 i 32 Warburton, Peter : for Kimbleton read Himbleton

302 i 52-53 Warburton, William: for Lincolnshire read Leicestershire

335 i 7-9 Ward, Samuel (d. 1643): for He was originally a scholar... In 1595 he was elected read He matriculated as a pensioner of Christ's College, Cambridge, in 1588-9, and graduated B.A. 1592-3 and M.A. 1596. In the last year he was elected

339 ii 4 f.e. Ward, Seth: for Wood read Thomas Wood

344 i 22 Ward, William (1787-1849): for a London merchant, read of Northwood Park, Cowes, a London merchant and large landowner in the Isle of Wight and Hampshire,

4 f.e. $\quad$ after currency. insert Ward was a famous cricketer and patron of the game. John Nyren dedicated his 'Cricketer's Guide' to him in 1833, and congratulated him on ' having gained the longest hands on record,' referring to his at that time unequalled score of 278, made on Lord's Ground on 24 July 1820 for the M.C.C. against Norfolk. In 1825 Ward bought the lease of Lord's Ground, to save it from sale for building purposes (Cricket, in Badminton Series, and Pycrofr's Cricket Field). He continued to play occasionally down to 1845 .

349 i 19-18 Warde, James Prescott: for On becoming a player read Intended for the army, f.e. he became a cadet at the Royal Military Academy, Woolwich, on 15 Sept. 1807, and was appointed second lieutentant in the Royal Artillery in December 1809. He took part in theatricals at the Academy, playing in 1808 the title part in 'Douglas.' Subsequently his absorbing passion for the stage led to his supersession in the army for 'absence without leave' (1 April 1815). On becoming a professional player

357 ii 12 Ware, Hugh: for Rathcoffrey read Rathcoffey

361 ii 6 Warelwast, William de : for 1197 read 1097

390 i 15 Warmestry, Thomas: for Noakes's read Noake's

403 i 24 Warner, Sir Thomas : for Meanwhile Warner had been read Warner was

404 i 15 f.e.

415 i 16

416 i 22

428 ii 1-2

for a negro woman read a Carib woman

Warren, John B. L., 3rd Baron de Tabley : for Salis-Saglio read Salis-Soglio for Mr. W. H. Miles read Mr. A. H. Miles

436 ii 19 f.e. Warton, Thomas (1728-1790): for Royle Lee read Boyle Lee

439 ii 50-51 Wase, Christopher: omit Dr. Johnson ... commonplace

440 ii 39 Washbourne, Thomas : for Gloucestershire read Worcestershire

444 i 1 Waterhouse, Sir Edward : for Armagh read Cashel

450 i 5 Waterton, Charles : for the remainder of his life read most of his remaining life

452 i 31 Wath, Michael: omit or Sir Michaex

17 f.e. for Sir Michael read 'Sir' [i.e. Dominus] Michael 



\title{
DiCTIONARY OF NATIONAL BIOGRAPHY
}

\author{
ERRATA IN VOLUME LX
}

\author{
WATSON—WHEWELL
}

Page Col. Line

vi ii 8

13

9 ii $41-42$

14 i 15-16

17

18

19-20

23

30 ii 10-11

34 i

35 ii 20-21

$\begin{array}{lll}37 & \mathrm{i} & 7\end{array}$

62
i 4-2 f.e.

i 6 f.e.

ii 28

List of Writers : for Sylvanus read Silvanus omit A. W. W. . . A. W. WARD, LitT.D.

Watson, James (d. 1722): for Painting ' read Printing'

Watson, John (1520-1584): for p. 315), and on 17 Sept. following was collated read p. 315). He was vice-chancellor of Cambridge 1518-20 and 1530-1. On ceasing to be master of Christ's in 1531 he seems to have become rector of White Notley, Essex, where he died in 1537. Another John Watson, who died before May 1530, was collated on 17 Sept. 1523

for He was also read The master of Christ's was

after Erasmus insert who bears witness to his high character and appreciated his humanism

for learned in scholastic divinity read one of Latimer's early opponents omit $\mathrm{He}$ died before 12 May 1530

Watson, Robert (1746-1838) : for is at least questionable, read underestimates the fact, for he received in $1817600 l$, a further $500 l$. in June 1822, and a final sum of $2,500 l$. on 21 Dec. of the same year.

Watson, Thomas (1513-1584): for Addit. MS. read Sloane MS.

-21 Watson, Thomas (1557?-1592): for a translation read a very distant paraphrase for five 'epistolæ' read eighteen 'epistolæ.' Five of these were rendered into English verse by 'I. T. Gent' in 'An Ould facioned loue or a loue of the ould facion' 1594 .

31 Watt, James : for Jeffreys read Jeffrey

20 Watts, Alaric A. : after 1825 insert died 22 Jan. 1901

ii 33-34 Watts, Richard : for proctors [i.e. itinerant priests] read proctors [of bedridden persons in hospitals, i.e. licensed beggars]

Weale, John: omit He was the father of . . . Henry James Weale.

19 f.e. Webbe, Joseph : for 1626) read 1633)

ii 18 after 1620. insert His letters and papers on languages, dating from 1623 to 1633 , are in Sloane MS. 1456.
Webster, John (1580 ?-1625) : after No. 19; insert Painter's 'Palace of Pleasure,' ii. 23.

Wedderburn, Alexander, 1st Earl of Rosslyn : for burgh read borough

i 24 Wedgwood, Hensleigh : after sixty years. insert He was fellow of Christ's 1829-30.

Weld, Sir Frederick A. : for Marsh read March for Garenden read Garendon

Weld, Thomas (1590?-1662): for America read Americana

Wellesley, Arthur, 1st Duke of Wellington : for C. W. Glass read J. W. Glass

Wellesley, Richard C., Marquis Wellesley : for Lahore read Indore for 1858 read 1855 
Page Col. Line

218 i 7

18 f.e.

13 f.e.

222 ii 5

223 i 3

38

242 i 36-39

40

260

261

\section{6 f.e.}

\section{4}

ii 3 f.e.

i 7 f.e.

i 22 f.e.

i 15 f.e.

10 f.e.

53-54 9 f.e.

ii 20 f.e. i 18-19 12

(1)

ii 12 f.e. i 32

Wellesley, Richard C., Marquis Wellesley : for allowances read alliances for discovered read discerned for a citadel of Calcutta read at Calcutta for Musgrave read Mulgrave for an external name read an esteemed name for aristocratic read autocratic

Welsted, Robert : omit He also translated . . . London, 1712, 8vo; and with for Richard West edited Pindar read Welsted joined Richard West in editing the works of Pindar

Wentworth, Paul : after Burnham Abbey insert Buckinghamshire after 1593. insert He was buried in Burnham Church.

Wentworth, Peter : for Lillingstone Darell read Lillingstone Lovell

Wentworth, Thomas, 1st Earl of Strafford: for Atkins read Atkinson

Wentworth, Sir Thomas, Baron Wentworth : after expense. insert He died in his father's lifetime.

for succeeded him read succeeded his father

Wentworth, sir Thomas, 4th Baron Wentworth: for baroness Wentworth, who died in 1860. read Lady Byron never assumed the title of baroness Wentworth, although she became entitled to it in $\mathbf{1 8 5 6}$.

Werferth : omit now lost for -a translation which Pits ... in Cambridge. read Manuscripts of this translation are extant at Cambridge, Oxford, and London.

Wesley, Samuel (1662-1735): omit under Richard Busby [q. v.],

Wesley, Samuel S.: after painted in oils insert by W. K. Briggs, which is now in possession of his eldest son, F.,G. Wesley, vicar of Hamsteels, Durham for 1855 read 1885 omit A portrait of Wesley .. . Julian Marshall, esq.

West, Sir Thomas, 9th Baron De La Warr: for Halfnaked read Halfnaker for 1547-8 read 1549-50

Weston, Richard (1620-1681): for Bushby read Buskby

Weston, Stephen : for Cleave Hill read Cleeve Hill

Weymouth, George : for Kennebee read Kennebec

Wharton, Sir George : after prefixed insert to his 'Works.'

Wharton, Philip, 4th Baron Wharton : after p. 7). insert The former collection, containing the finest work of Van Dyck's latest years, is now at the Hermitage, St. Petersburg

after p. 35). insert A fine portrait of Wharton as a young man is at the Hermitage, St. Petersburg.

Wharton, Philip, Duke of Wharton: for Northumberland read Westmoreland

Wharton, Thomas, 1st Baron Wharton : for Heydon read Hedon

Wheare, Degory : for in 1624 his opening address ... and death. This record read a record of Camden's life and death

omit were included

omit his 'Dedicatio . . . (1626), and

Wheatley, Benjamin R. : for Kersell read Kersal

Wheeler, Sir Hugh M. : for Browne Thompson's read Mowbray Thomson's

Wheler, Sir George: after Nottinghamshire. insert He was admitted at Christ's College, Cambridge, 10 May 1717, aged 16, from Durham School, graduated B.A. 1720-1, M.A. 1724, and was fellow of his college from 25 Jan. 1721-2 till 18 Jan. $1723-4$, when he succeeded to his father's estates.

Whetstone, George: after p. 387). insert An account of the death of Sir Philip Sidney, related on the authority of George Whetstone, an eye-wituess, is to be found in Thomas Churchyard's 'True Discours Historical of the Succeeding Governors in the Netherlands and the Civill Warres there,' London, 1602, 4to. 


\title{
DiCTIONARY OF NATIONAL BIOGRAPHY
}

\author{
ERRATA IN VOLUME LXI
}

\author{
WHICHCORD—WILLIAMS
}

N.B. - f.e. stands for from end and l.l. for last line

List of Writers : for B.D. read D.D.

Whiddon, Jacob: for ( $f$. 1585-1595) read (d. 1595)

for It is probable that he was read He was

for the expedition against Cadiz .... is not mentioned. read but he died on the return journey, and was buried by Ralegh, who styles him 'a man most honest and valiant,' in the island of Trinidad (Discoverie of Guiana, in RALEGH's Works, viii. p. 398)

Whinyates, Sir Edward C.: for first captain read post-captain

Whiston, William : for Grabes's read Grabe's

Whitaker, Tobias : for ( $f$. 1634-1661) read $(d, 1666)$

Whitaker, William : for seventeenth read sixteenth for Bromley read Burnley

White, Charles : for (1695- read (1696-

for Royal College of Surgeons read Corporation of Surgeons (now the Royal College of Surgeons) for 13 Feb. read 20 Feb.

for 1759 read 1757

for 1733 read 1773 and for 1785 read 1784

for 1773 read 1793

White, John (1576-1618) : for Hinlip read Hindlip

White, Richard (d.1584). There seems reason to believe that the Richard Gwyn of St. John's College, Cambridge, whose career is described in the lines indicated is to be distinguished from the martyred Richard White who, according to the college register, matriculated as a pensioner from Christ's College, Cambridge, in May 1571, graduating B.A. and M.A. (1578).

13

ii 9 f.e.

ii $18-19$

ii 18 f.e.

13-12

f.e.

7 f.e.

ii $\quad 39$

i 21 f.e. Whittington, Robert

Whittington, Robert: for 1528 read 1521, 1525

ii 26-7 Widdrington, Ralph : for before 30 Aug. 1688, when read on 10 June 1688: on 30 Aug. following

ii 5 f.e. Widdrington, Sir Thomas : omit perhaps

4 f.e. after who insert matriculated as a pensioner in April 1617, and

17 f.e. Wiglaf : for Hambury read Hanbury 
Page Col. Line

203 i 23

ii 2 f.e.

207 i 6-5

f.e.

221 ii 38

256 i 16

265

ii 13

14-15

267 ii 40

271 i 25

272 i 29

287 i 2 f.e.

306 i 25-26

314 i 50-51

331 i 15

367 ii 33

369 ii 21 f.e.

379

396

396 ii 8

34

36

18 f.e.

409 i 32

$410 \quad$ i $\quad 27$

Wilberforce, Robert I. : for Brown read Browne

Wilberforce, Samuel : for denied the bishop's right to refuse institution to read reversed the sentence of a year's suspension passed by the Court of Arches on some of

Wild, George: after old age. insert Several plays that he
College, Oxford, are extant in Brit. Mus. Addit. MS. 14047.

Wilkie, Sir David : for seized for the rent of the room. read unfairly seized for rent owing by a previous tenant of the room.

Wilkins, John: for probably read became in $\mathbf{1 6 6 3}$

for though some authorities . . . . this appointment; read (cf. Sloane MS. 1326, f. 40 b)

Wilkins, William : for Oxberton read Osberton

Wilkinson, Henry : for Kennet's read Kennett's

Wilkinson, James J. G. : for A bust read A bust by F. Leifchild

Willes, Sir John : for Bishop's Ickington read Bishop's Itchington

William II: for and the duchy of Normandy were read was

William III: for KENNET read KENNETT and so through article

William IV : for of Victoria read Victoria

William de Fors, Earl of Albemarle: for King Stephen read Count Stephen for Beforth read Beeford

Williams, Sir Charles H. : after (1664-1734) insert [q. v.]

6 f.e. Williams, Edward E.: for ELLIKER read ELLERKER

4-2 for His father, a merchant .... attained his majority. read His father, Captain John Williams, a captain in the East India Company's army, died on his voyage home from India in June 1809.

for the lady read Jane, sister of General John Wheeler Cleveland, of the Madras army

for Bysshe]. Williams left a son, read Bysshe]. Mrs. Williams subsequently formed an union with Thomas Jefferson Hogg [q. v.] Williams's children included, besides a daughter (Mrs. Lonsdale), a son, Edward Medwin, .

for a daughter, married to read a daughter, Rosalind, married to Henry Sylvan Leigh,

after cemetery add in 1884. Williams kept a diary from 21 Oct. 1821 till 4 July 1822 , four days before his death. The original MS. was presented, with other relics of Williams, to the British Museum by his grandson, Mr. J. W. Williams. The diary was edited in 1902 by Dr. Richard Garnett. Williams, Isaac: for The college historian read James Pycroft, in 'College
Memories,

after (d. 1871). insert A portrait painted about 1850 by W. H. Cubley, of Newark, was lately presented to Trinity College to be hung in the Hall. 


\title{
DictionaRY OF NATIONAL BIOGRAPHY
}

\author{
ERRATA IN VOLUME LXII
}

\section{WILLIAMSON-WORDEN}

Page Col. Line

13 ii 11 f.e.

6 f.e.

3 f.e.

18 i 34-35

20 ii 22

44 ii 34

58 i 34

61 i l.l.

ii 1

$69 \quad$ ii $\quad 33$

70 ii 8 f.e.

81 ii 7

23

8 f.e.

82 i 17

85 ii $\quad 36$

\section{Willibrord, Saint : omit or 696} for St. Cecilia's day (22 Nov.) read the feast of St. Clement (21 Nov.) for (BEDE read (but cf. BEDE

Willis, Francis : for became physician-in-ordinary . . . attended read attended the king

Willis, Richard : for MACLURE read McCluRE

Wills, Sir Charles : for Friend's read Freind's

Willyams, Cooper : for 1891 read 1819

Wilmot, Sir Edward : for physician read physician extraordinary

after 1737 insert and physician-in-ordinary in 1732

Wilmot, John E. (1750-1815): for liberal read conservative

Wilmot, Lemuel A. : for Sir Charles Grant read Charles Grant

Wilson, Arthur : for 1619 read 1614 for 1630 read 1631

for November 1654 read November 1634

after ii. 278). insert The MS. of the 'Switzer' was acquired by the British Museum in Feb. 1903, and was edited by M. Albert Feuillerat, of Rennes (Paris, 1904).

Wilson, Bernard : omit and Wilts

23-24 Wilson, Harriette : for ( $f$. 1810-1825) read (1789-1846)

23-24 for Nothing further is known of Harriette's career. read This 'modern Aspasia,' as Sheil calls ber (Irish Bar, 1854, i. 348), is believed to have returned to England a pious widow, and to have died in $\mathbf{1 8 4 6 .}$

ii 26 Wilson, Henry B.: omit unmarried

3 f.e. Wilson, James (1805-1860): for fourth son read third son

28 Wilson, Sir John (1780-1856): for 11 Nov. 1851 read 20 June 1854

11-12

13

15

19

119 i $18-19$

120 i 12

130 ii $32-33$

Wilson, Sir John M. : for 17 June on a strong fort read 19 June on a strong position

for Lake Ontario read the Niagara river near Erie

for 12 July read 11 July

for 29 Dec. read 30 Dec.

for Chippewa read Chippewa or Lundy's Lane

Wilson, Nicholas: omit in Holderness

for Bolton read Bilton

Wilson, Sir Robert T. : for Wilson regarded it read Wilson voted for the second reading, but spoke without voting in favour of Gascoyne's amendment opposing the reduction of the number of members for England and Wales, which was carried against the government. He did not seek re-election after the consequent dissolution (April 1831). He regarded the measure in its final shape 
Page Col. Line

130 ii 34-37

132 ii $19-20$

135 ii 19

138 ii $19-20$

Wilson, Sir Robert T. : for in consequence, . . . . his seat, losing read he lost

Wilson, Thomas (1525?-1581): for it contains read the third edition contains for Lidney read Lydney

Wilson, Sir Thomas (1560?-1629) : for Wilson died .... letters read Wilson was buried at St. Martin's in the Fields on $17 \mathrm{July} 1629$, and on the 31st letters

Wilson, William (1690-1741): for Williams read Wilson

Wilson, Sir Wiltshire : for 1838 read 1836

Wilson-Patten, John, Baron Winmarleigh: for Lord Stanley, afterwards read Edward G. G. S. Stanley, afterwards Lord Stanley, and

for his friend Lord Stanley, read his friend's father, Lord Stanley, afterwards thirteenth earl of Derby, for again of his friend read of his friend Edward Stanley, afterwards Lord Stanley

for In the year following read In September of the year following

for a post he held .... three months later. read under Disraeli, and held the post till Disraeli's resignation in Dec. 1868. for 12 July read 11 July

Windham, Sir Charles A. : for 4 Feb, read 2 Feb.

Windham, William : for Ash Windham read William Windham

after Sudbury insert 1722-7

for between 1721 and 1727 read until his death in 1730 ,

\section{omit and Helston in 1766}

for secretary for war read secretary at war

for He took refuge ....8 8 May 1807, read Throughout these proceeding 3 he retained his seat for New Romney, and held it till the dissolution on 29 April 1807. At the general election in May he was returned for Higham Ferrers,

ii 12 Windsor, Thomas, 1st Earl of Plymouth : omit (Sir)

i 2 Windsor, Sir William de, Baron Windsor : for G. T. read G. F.

ii 11 Wingfield, Sir Anthony : for thirteenth earl read fourteenth earl

ii 7 Wingfield, Anthony (1550?-1615 ?): for Oxford read Orford

i 4 f.e. Wingfield, Sir Humphrey: for Partiger read Pargiter

ii 37 Winniffe, Thomas : for receiving at the same time read he also held

i 11 Winnington, Thomas : for Whitley read Witley

i 16-17 Winslow, Edward: for Richard Holdrip and Edward Blagge read Daniel Searle and Gregory Butler

i 9 f.e. Winstanley, Henry : for (d. 1703) read (1644-1703)

8-7 for was probably a native ... of William read baptised at Saffron

f.e. Walden on 31 March 1644, and was eldest son of Henry Winstanley (d. 1680) of that place. He was nephew of William

09 ii 23-24 Winstanley, William : for (1628?-1690?) read (1628?-1698)

24-27 for was related to .... Henry Winstanley [q. v.], read was second son of William Winstanley, of Quendon, Essex (d. 1687), by his wife Elizabeth. Henry Winstanley [q. v.] was his nephew. William was sworn a freeman of Saffron Walden on 21 April 1649.

8 f.e. for died about 1690 .... married, and read was buried at Quendon on 22 Dec. 1698. He was twice married;

7 f.e. $\quad$ for wife read first wife

5 f.e. after p. 35). insert His second wife, Anne, was buried at Quendon on 29 sept. 1691.

for birth of one Robert . . . (brother of Henry read baptism on 14 March 1646-7 of Robert Winstanley (a nephew of William and a younger brother of Henry

28 for sixteen reac fifteen

213 ii 40 Winter, Sir Edward : for 20 Sept. read 20 Dec.

215 ii l.l. Winter, Sir John: for Metcalf's read Metcalfe's

216 ii 15 f.e. Winter, Samuel : for 24 Oct. read 24 Dec.

223 ii 23 Winterbottom, Thomas M. : after 1800. insert He left more than 5,000 philological books to Durham University.

253 i 33 Wishart, Sir James : for (d. 1729) read (d. 1723) 
Page Col. Line

253 ii 36

18-17

f.e.

$13 f$.e

Wishart, Sir James : before On the accession insert He was M.P. for Portsmouth 1711-15.

for and there he died in 1729. read $\mathrm{He}$ died on 31 May 1723 (Boyer, Political State of Great Britain, May 1723, p. 571)

Wishart, Sir John : after JoHn insert LoRd PitTaRRow

Witchell, Edwin: for Nymphsfield read Nympsfield

9 f.e. Witham, George : for Burton Constable read Constable Burton

32 Wither, George : for Anne Serle read Mary Hunt, apparently, of Theddon, Hampshire (cf. The Poetry of George Wither, ed. F. Sidgwick, 1902, i. xvi. sq.) for four editions read at least five editions

for in 1617 for private circulation read in 1615 for private circulation. A copy of the private issue is in the Bodleian Library. for Hambledon, Surrey read Hambledon, Hampshire after Fidding insert (Theddon)

Wodelarke, Robert: for' 'Acero read' Cicero for ' Etymologire' read 'Etymologiarum'

Wolfe, Arthur, 1st Viscount Kilwarden : for Six years read Five years for the chief justice read formerly the chief justice

Wolfe, James : for right bank read left bank for commanding read cannonading

Wolfe, Reyner : for History of read History or

Wolley, Sir John : for 1572 read 1571. after Elizabeth. insert According to Browne Willis, he was elected M.P. for East Looe in 1571

i 20 f.e. Wolseley, William (1640?-1697): for C. D. read C. D-N.

Wolsey, Thomas: for 16 Nov. read 15 Nov. omit and though he was never consecrated

Womock, Laurence : for with the promise of a prebend in Ely Cathedral read On 22 Sept. in the same year, according to Le Neve, he had been installed in the sixth prebendal stall at Ely. omit On 22 Sept. ... . at Ely after Bibl. Brit.; insert Cat. Tanner MSS. (Bodleian);

Wood, Alexander (1725-1807): for His father was the youngest son of Wood read He was the son of Thomas Wood and grandson of Jasper Wood after Edinburgh insert He married Veronica Chalmers

i 33-34 Wood, Sir Charles, 1st Viscount Halifax : for lost his seat at Grimsby in 1831, but read in 1831

ii 28 Wood, Sir David E.: after 1877. insert He was an unsuccessful candidate for Durham in the conservative interest in 1847.

ii 25-26 Wood, James (1672-1759): omit Another son, Robert . . . Everett Wood [q. v.]. ii 26-27 Wood, Mary A. E. : for James Wood (1672-1759) [q. v.] was her grandfather. read Her grandfather James Wood, a friend of Wesley and twice president of the Wesleyan Conference, must be distinguished from James Wood (1672-1759) [q. v.].

2 f.e. Wood, Robert (1717?-1771): after i. 289). insert From 1764 to his death he was groom-porter in the royal household.

\section{0 f.e. Wood, William (1745-1808) : for 1807 read 1809}

ii 13-12 Wood, William P., Baron Hatherley: for Robert Monsey Rolfe, first baron

f.e. Cranworth [q. v.]. read Sir George James Turner [q. v.], who was made lord justice in succession to the newly appointed lord chancellor, Robert Monsey Rolfe, first baron Cranworth [q. v.].

ii 23 Woodard, Nathaniel: for 1844 read 1894

ii 2 f.e. $\}$ Wooddeson, Richard : for 1823 read 1822

i 36-37 Woodford, Sir John G.: for Sir William Colville read Sir Charles Colville

ii 14 f.e. after the service insert in Oct. 1841 . He had been made C.B. in 1815 and K.C.B. in 1838

ii 26 Woodley, George : for Maclure's read McClure's

ii 19-20 Woodville, Anthony, 2nd Earl Rivers: for he is said to have fought at Morat (22 June) for the read he visited (7-8 June) the camp at Morat of the for (RAmsay, ii. 418) read (KIRK's Charles the Bold, iii. 370-1) 



\title{
Dictionary OF NATIONAL BIOGRAPHY
}

\author{
ERRATA IN VOLUME LXIII
}

\author{
WORDSWORTH_-ZUYLESTEIN
}

\begin{abstract}
N.B.-f.e. stands for from end and l.l. for last line
Page Col. Line

25 i 23-24 Wordsworth, William : for Nelson read Milton

34 ii 10 f.e. Worsley, Sir Henry : for 1821 read 1831

36 ii 37 Worsley, Sir Richard: for 1802 read 1801

45 i 4 Wortley, Sir Francis : for 1625 and 1626 read and 1625

57 i 13-15 Wotton, Sir Henry: for is said to have been printed printed in 1614 with the fifth edition of Overbury's 'Wife.'

Wotton, Nicholas : for fourth son read fourth child

Wotton, William : for 1726) read 1727)

for 1726 read $1726-7$

19 f.e. Woty, William: omit in chancery

64 ii 2

Woulfe, Peter : for a religious prophet named Brothers read the prophet Richard Brothers [q. v.])

$65 \quad$ i 19 Woulfe, Stephen: for 1834 read 1835

4 f.e. Wrangham, Francis : for Raisthorpe read Raysthorpe

ii 1-3 for Stephen Thirlwell ... ultimately vicar read Thomas Thirlwall (grandfather of Connop Thirlwall [q. v.]), afterwards vicar

Wraxall, Sir Nathaniel W.: for a short while read in 1728, eight years

$$
\text { for ninth read twelfth }
$$

Wren, Sir Christopher : for partition read parhelion for Allenbury read Atterbury after 1897 insert Birch's London Churches, London, fol. 1896

Wright, Sir James (1716-1785) : for he received the commission read he received from England the commission (dated April 1761)

Wright, Robert (1560-1643) : for (September 1643) read (August 1643)

Wright, Thomas (fl.1740-1760) : for (fl.1740-1760) ... (Brit. Mus. Cat.). read (1711-1786), natural philosopher, was born at Byer's Greell, near Durham, and brought up as a pliilosophical instrument maker. Subsequently he taught private pupils in mathematics, and became so well known that he was offered, but declined, the professorship of mathematics at the Imperial Academy of St. Petersburg. In his 'Original Theory . . . of the Universe'(London, 1750,4 to) he anticipated the modern physico-philosophical theory of the material of the universe. He 'gave the theory of the Milky Way, which is now considered established,' and predicted the 'ultimate resolution of the rings of Saturn into congeries of small satellites' (DE Morgan in London, Edinburgh, and Dublin, Phil. Mag. vol. xxxii.) He died at Byer's Green in 1786.

after Lit. insert Gent. Mag. 1793, i. 9, 126, 213; Kant's Kosmogony, ed. 1900, pp. 193-205

\section{Wriothesley, Henry, 3rd Earl of Southampton: for times read tennis}


Page Col. Line

153 ii $27-28$

29

Wroth Sir Robert: for Francis Stonather,

167 i 4 f.e. Wrottesley, Sir John, and Baron Wrottesley: for was defeated read retired before the poll

3 f.e. $\quad$ for 1825 read 1823

ii 1-3

: for Barrow in Atwood read Barrow-on-Humber

180 ii 21 f.e. Wyatt, John : after Boulton \& Watt insert which was established in 1762

20 f.e. $\quad$ omit about 1744

189 ii 9-7 Wyatt, Thomas Henry : for Anne, sister of Sir Thomas ... ii. 445). read Anne f.e. danghter of George Hillier of Devizes.

191 ii 21 f.e.

225 ii 10

228 i 2

7

10 f.e.

ii $17-19$

234

240 ii 37

247 ii 14

260 ii 22

$308 \quad$ i 19

316 i 36

324 ii 30

332 i $8-11$

$l . l$.

339 Wyatville, Sir Jeffry : $b$
1822 and R.A. in 1824.

Wyke, Sir Charles L. : for 1859 read 1860

Wykeham, William of : after death insert in June 1376 after 11 Oct. insert 1376

after 7 Jan. insert 1377

for and Wykeham bought... for Winchester College. read Three years later, in 1380, Wykeham acquired the manor of Meonstoke Perrers from Alice's husband, William de Windsor, who had obtained a grant of her lands after her pardon in Dec. 1379. But it would be hazardous to connect this purchase with the events of 1377 .

Wyld, James : after 1868 insert (except for a few months in 1859)

Wyndham, Sir Charles, 2nd Earl of Egremont: for 1734 read 1735

Wyndham, Robert H. : for in April read on 8 April

Wynn, Sir Watkin W.: for 1660 read 1678-9

Yeamans, Robert : for alderman read councillor

Yelverton, Sir Henry : after the university. insert $\mathrm{He}$ and his brother Thomas were admitted fellow-commoners of Christ's College, Cambridge, on 1 July 1581. Like his father he was afterwards counsel for the college.

Yonge, Sir George : after continuously insert (excepting from 1761 to 1763) for 1794 read 1796

Yonge, Sir William : for to replace his father ... to meet on 10 May 1722, read to represent Honiton on 4 Feb. 1714-5,

for Byng, Torrington, Norris, and Wager, read Byng (Viscount Torrington), Norris, Wager, and others,

Yorke, Charles (1722-1770): omit Meanwhile he angled . . . the attorney-general (30 Nov.)

for His conduct in this crisis betrayed read Pitt saw in his conduct during this crisis

after general warrants. insert At the end of the year he angled for his reinstatement in the attorney-generalship, which his successor, Fletcher Norton [q. v.], was wrongly thought to be about to vacate, in order to succeed to the mastership of the rolls, vacant by the death of Sir Thomas Clark. Yorke also professed himself willing to accept the vacant mastership of the rolls with a salary of $4,000 \mathrm{l}$. and a peerage. These ridiculous advances were repulsed by Lord-chancellor Northington, and Yorke ended by . accepting a patent of precedence next after the attorney-general (30 Nov.).

ii 27-28 Yorke, Charles P.: for secretary for war read secretary at war

ii 21 Yorke, Joseph, Baron Dover: for 1761-4 read 1761-74

ii 12-13 Yorke, Sir Joseph S.: for nearly continuously since 1790. read from 1790 to 1806 and from 1818 to 1831, having in the interval represented St. Germans, West Looe, and Sandwich.

13 f.e. Yorke, Philip, 1st Earl of Hardwicke : for brother read uncle

i 30 Yorke, Philip (1743-1804): for the dissolution of March 1784 read his retirement in 1781

ii 12 Young, Bartholomew : for Tw'enty-four read Twenty-five 
Page Col. Line

370 i $20-19$ f.e.

Young, Edward : for daughter of George Henry Lee, second earl of Lichfield read younger daughter of Edward Henry Lee, first earl of Lichfield

376 i 22 Young, Sir Henry E. F. : for was created K.B. read was knighted

ii 33-35 Young, James $(d .1789)$ : for In July $1778 \ldots$ admiral of the white. read On 29 Jan. 1778 he was promoted to be admiral of the white and in July he returned to England.

400 ii 15 Young, Sir William (1749-1815): omit in the whig interest

16 after Cornwall. insert He was a follower of Pitt until 1801, when he joined the ranks of his patron Grenville.

408 ii 8-12 Zerffi, George G. : omit He was also for some time . . . a biographical memoir.

422 ii 15 Zouche, William la : for (Histories read (Historians

424 ii 37 Zucchi, Antonio P.: after at Reculver' insert (from KEATE's Sketches from Nature)

430 i 34 Zuylestein, William H., 4th Earl of Rochford : for In December of this year Pochford showed read In December 1770 Rochford, though still nominally under Weymouth's direction, showed

ii $41 \quad$ for a master read master 



\section{DiCTIONARY OF NATIONAL BIOGRAPHY}

\section{ERRATA IN SUPPLEMENT-VOLUME I}

\section{ABBOTT-CHILDERS}

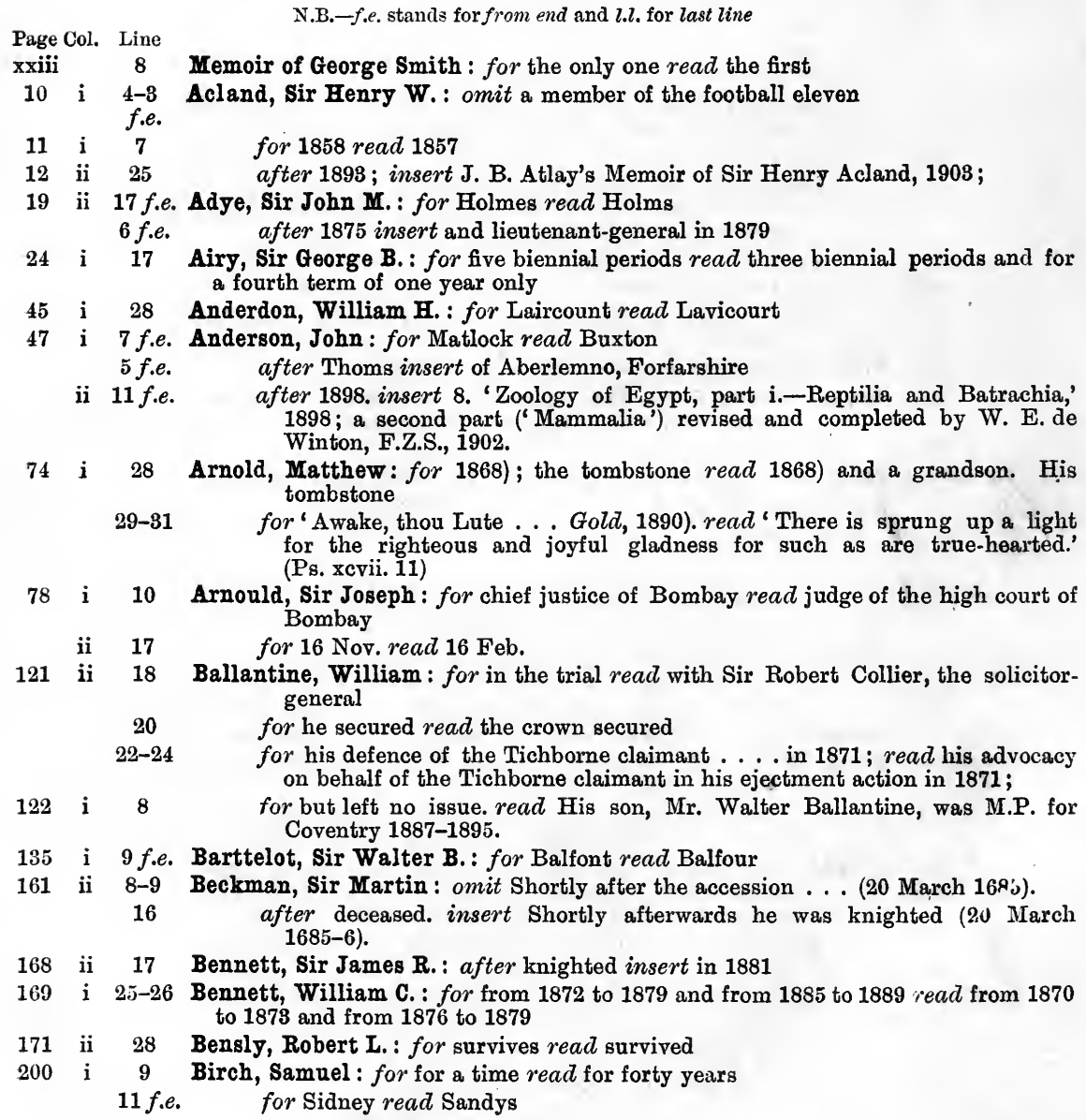


Page Col, Line 204 i 14

207

\section{i 13}

34-35

39-41

18 f.e.

16 f.e.

11-10

f.e.

5 f.e.

4-2

f.e.

ii $11-14$

27-30

33-34

40-42

17 f.e.

6 f.e.

208 i $9-10$

$209 \quad 10$

34

87

210 i 9

233 ii 20

238 i 21

$239 \quad$ i 24

245 ii $43-4$

257

13-11

f.e.

259 ii 2

8-13

262 i 23

265 i 15

16-19

271 i $7-6$

f.e.

ii 4

14-13

f.e.
10 f.e.

272 i 11

34-36

Blackburn, Colin, Baron Blackburn: for Mr. John Edward Eyre read Mr. Edward John Eyre

Blackmore, Richard D. : for vicar read curate in charge

for His father took pupils ... and three read Three

for his mother ... all the servants died. read his mother died of the disease which she contracted while visiting the parish, and others of the household also succumbed.

for a living read a curacy

for settled in that of Ashford read settled in 1847 as curate in charge ai Ashford

for until a boy of eleven, ..... who presently sent him read for several years, and was then sent to a preparatory school at Bruton, in Somerset. Thence he went

for now read afterwards

for who had formerly been a private pupil .... at Longworth. read who had formerly taken, whilst living at Culmstock, lessons from Blackmore's father.

omit $\mathrm{He}$ was also famous .... academic honours.

omit and, after quitting the university ... Bromley, Kent

for Miss Lucy .... of Portuguese extraction read Miss Lucy Maguire omit At this time he was engaged . . . . the Middle Temple.

for she died read she died on 31 Jan. 1888

after 'Christowell.' insert He was a pupil of John Warner of the Inner Temple and the chancery bar.

for and fell back on his old work as a teacher.read by taking up educational work which he never liked and for which he was ill adapted.

for 1853 read 1855

after father. insert Another parson, John Rosedew, in 'Cradock Nowell,' is his uncle, the Rev. H. Hey Knight. Perlycross is the home of Blackmore's boyhood, Culmstock.

for sixty read seventy

for 1885 read 1895

after game of chess insert and whom he introduced into 'Tommy Upmore'

Bond, Sir Edward A. : for (1858) read (1868)

Bowen, Charles S. C., Baron Bowen : for rector of Southwark, read perpetual curate of St. Mary Magdalene, Southwark,

for 1888 read 1882

Boyd, Andrew K. H. : for Mr. F. N. Boyd read Mr. F. M. Boyd

Brand, Sir Henry B. W., 1st Viscount Hampden: after peerage. insert He was a lord of the treasury under Palmerston 17 April 1855 to 1 March 1858.

for succeeded Sir William .... the treasury. read became parliamentary secretary to the treasury, a post held in the previous liberal administration

by Sir William Goodenough Hayter [q. v.].
Brand, Sir Johannes H. : after opinion. insert In 1882 he accepted the honour of G.C.M.G. in spite of the demurs of the council.

omit The queen offered him the dignity . . . . they gave way.

Brassey, Anna or Annie, Baroness Brassey : for at Brisbane read at sea

Brett, William B., Viscount Esher: for in April 1859 read on the death of Cobden in $\mathbf{1 8 6 5}$

for against Cobden ... . Potter [q. v. Suppl.]. read against Cobden's friend Thomas Bayley Potter [q. v. Supp.], but he was defeated.

Bright, Sir Charles T.: for a druggist of Bishopsgate Street, London, read a manufacturing chemist of London (of an old Yorkshire stock to which belonged Colonel Sir John Bright, 1619-88 [q. v.]),

for Magnetic Company read Magnetic Telegraph Company

for Atlantic Cable Company read Atlantic Telegraph Company

for R. Newall \& Co. read R. S. Newall \& Co.

omit Bright was ... the Agamemnon. 
Page Col. Line

272 ii 22-23 Bright, Sir Charles T.: for was himself not directly concerned read was associated as consulting engineer

2 f.e. $\quad$ for Institute read Institution

273 i 21 for E. B. Bright read E. B. Bright and his son, Mr. Charles Bright

292 ii 37 Brind, Sir James : for daughter read niece

295 i 23 Broadhead, William: for Forth's read Firth's

296 i 21 f.e. Broome, Sir Frederick N.: after services. insert He had been made C.M.G. in 1877 and K.C.M.G. in 1884.

18 f.e. $\quad$ after afterwards insert in 1891

302 i 8 f.e. Brown, Robert : omit at Copenhagen

7 f.e. $\quad$ for the degree of $\mathrm{Ph} . \mathrm{D}$. read the honorary degree of $\mathrm{Ph} . \mathrm{D}$. in 1870.

l.l. after expedition insert in 1863

ii 12-18 for the high school read the School of Arts

13 after college. insert He was also an extra-mural lecturer of the university and interim lecturer on botany there in 1873 , and for part of that year in geology also. for In 1875-6 read In 1873

25-80 for and in 1876 was writing . . to the preparation of read as well as for the 'Academy' and the 'Scotsman.' In 1876 he accepted a post on the staff of the 'Echo,' and removed to London. In 1879 he became a leader writer for the 'Standard,' and retained that post for the rest of his life. Meanwhile he prepared many

4 f.e. $\quad$ for Rink's insert 'Danish Greenland,' 1877, and his

2f.e. $\quad$ for is valuable read their valuable

303 i 21

after Zemlya insert as well as by two flowering plants, two lichens, and a fossil plant called after him by English and Swiss botanists

306 i 6 f.e. Browning, Robert: for Woodgates inn read Woodyates inn

5 f.e. for Partridge read Pentridge

308 i 18 f.e. for his horse read his uncle's horse

313 ii 17 f.e. $\quad$ for Mr. Smith read Mrs. George M. Smith

319 ii 12 Brown-Séquard, Charles E. : for physiologist read physiologist and physician

14-16 for Edward Brown . . . belonging to Philadelphia. read Edward Brown (a native of Philadelphia), captain in the merchant service.

820 ii 9

after Geneva. insert $\mathrm{His}$ second wife had died in 1874, and in 1877 he married a third wife, who was an Englishwoman.

for his old master read his friend and rival

28 for second wife read third wife

15-14

f.e.

321 i $6-9$

for the localisation of the tracts in the spinal cord. read the properties and functions of the nervous system.

for but he was not a philosophical thinker . . . . interpret his facts correctly. read although the interpretation of the facts he had discovered did not always meet with general acceptance.

12 after Normale insert de l'Homme

18 after Animaux, insert the 'Bulletins de la Société de Biologie'

339 i 30 Burke, Ulick R. : for Colne read Calne

848 ii 13 Burton, Sir Frederic W.: before On his retirement read Burton was knighted in 1884.

14-15 for Burton was knighted. Despiteread despite

354 i 18-19 Burton, Sir Richard F.: for ' Proverba read ' Proverbia

370 i 23 Cairns, John : for Bishop Laughton read Bishop Claughton

381 ii 2 f.e. Campbell, Sir Alexander : for Heydon read Hedon

889 ii 11 Campbell, George D., 8th Duke of Argyll : for 1883 read 1884

396 ii 11-12 Cass, Sir John : for in that year read in 1710-11

397 i 18 f.e. Caulfield, Riınard: for Burke read Butler

ii 27 omit unmarried,

30

after co. Cork. insert His wife, Dora Dowden, survived him.

410 i 24

425 i 25

Chambers, Sir Thomas : for 1846 read 1836

Childers, Hugh C. E.: for 1871 read 1870 



\title{
DiCTIONARY OF NATIONAL BIOGRAPHY
}

\section{ERRATA IN SUPPLEMENT-VOLUME II}

\section{CHIPPENDALE- - HOSTE}

\author{
Page Col. Line \\ 9 ii 7 Church, Richard W.: for 'Paschal read' Pascal \\ 38 Churchill, Randolph H. s. (called Lord Randolph Churchill): for Mr. Frewen \\ read Mr. Frewer
}

37 ii 11 f.e. Cochrane-Baillie, Alexander D. R. W., 1st Baron Lamington : for In 1857 read At a by-election in Jan. 1857

10 f.e. for and from read and was rejected at the general election in April. From

43 i 18 Colebrooke, Sir William M. G.: omit on the retired list

22 after 1859 insert and general 26 Dec. 1865

58 i 16 Cooke, Sir George : for 1757 read 1750

71 i 2 f.e. Coventry, Andrew : for Stitchell read the Relief Church at Stitchell

72 i 3 f.e. Cowen, Joseph : for (1829 read (1831

73 i 12 f.e. for 1885 read 1886

74 ii 19 Cowper (afterwards Cowper-Temple), William F., Baron Mount-Temple: for 1863 read 1868

28-29 for from February $1857 \ldots$. . this office read in February 1857 he was transferred to

31 after education insert and on 24 Sept. 1857 resumed the presidency of the board of health, holding both offices together till March 1858

80 i 11 Craven, Mrs. Pauline M. A. A. : for Dublin read Dublin County

81 ii 37 Crealock, Henry H.: for gazetted read promoted

90 ii 10 f.e. Cromwell, Ralph, 4th Baron Cromwell : for 1418 read 1417

91 i 1 for 6 March read 6 March 1418

93 i 4 f.e. ii 20 f.e. Crowther, Samuel A.: for 1892 read 1891

98 ii 25 Cureton, Charles R. : after 1891, insert of the 7th dragoon guards 23 Sept. 1891

106 i 2 f.e. Dale, Thomas P. : for bookseller read publisher, stockbroker, and East India agent

ii 2 omit (where his tutor was Colenso)

3 after 1841 insert and was privately coached by Colenso

107 i 22 for By his wife (married in 1846) read $\mathrm{He}$ married, in 1846, Mary, elder daughter of William Francis of Reigate,

114 i 47-48 Dashwood, Francis, Baron le Despencer: for in the same year read in $\mathbf{1 7 6 3}$

13 f.e. for being succeeded read having been succeeded the year before

12 f.e. for the militia read the Bucks militia

5-3 for and during Lord North's . . . . postmaster-general. read Lord Chatham

f.e. made him joint postmaster-general in 1766, and he continued in that office till 1781, through Lord North's long administration.

115 i 4 Davidson, Samuel : for 1899) read 1898)

117 ii 31-53 Davies, David C.: Note that Davies's namesake David Christopher Davies is separately noticed in the Dictionary (see vol. xiv. p. 183)

118 ii 31 Davis, Sir John F. : for July 1819 read 16 June 1819 
Page Col. Line

120 ii 18 f.e. Dawson, Sir John W.: for 1882 read 1881

127 ii 16 f.e. Denison, George A. : omit ninth

132 i 6-7 Dickson, Sir James R.: for New South Wales read Melbourne

ii 17 f.e. omit cultured

16-15 for yet he was hardly popular, though read and though he was not cultured

f.e. was popular, and

11-10 for one son and four daughters read six sons and seven daughters

f.e.

139 i $\quad 29$ Dixon, Richard W.: for Dr. Giffard read Dr. Gifford

149 ii 26 Douglas, Sir William F.: for 1822 read 1882

180 i 8 f.e. Ellice, Sir Charles H. : for Berkshire regiment read 49th (Berkshire) regiment

183 i 31 Elphinstone, Sir Howard C. : for 1858 read 1855

184 ii 38 Elton, Charles I. : after generation. insert It was largely due to his acumen and research that the chapter of Christ Church, Oxford, was induced in Feb. 1865 to carry out a moral obligation imposed upon them by a conveyance from King Henry VIII, and to endow the chair of the regius professor of Greek (АввотT and CAMPBell's Life of Jowett, i. 819; Times, 16 Jan. 1865).

185 i $37 \quad$ omit his cousin,

186 i $31 \quad$ Elvey, Sir George J.: for 1893) read 1894)

ii 34

200 ii 5 f.e. for 9 Sept. 1893 read 9 Dec. 1894

4 f.e. $\quad$ for 1882-5 read 1881-5, at Brussels March-Dec. 1885,

2 f.e. $\quad$ for 1893 read 1893 to 1898 and at Copenhagen from 1898

202 i $50-51$

Farrer, Sir Thomas H., 1st Baron Farrer : for several years read nearly two years

Findlay, Sir George: for on 21 May 1892 read in 1892

225 i 28 Ford, sir Francis C.: after made insert K.C.M.G. in 1885

234 ii 34 Fowler, Sir John : for 1879 read 1880

237 i 1-2 Fox, Sir William: for and after doing which Fox was knighted. read Fox had been made K.C.M.G. 24 May 1879.

241 ii 2f.e. Franks, Sir Augustus W.: for Baron Pichou read Baron Pichon

250 i 2 Freeman, Edward A. : for 7 May read 7 March

251 ii l.l. Fremantle, Thomas F., 1st Baron Cottesloe : for 1826 read 1830

280 ii 20 Gladstone, William E. : for third son read fourth son for Napp read Knapp for Lord Stanley (afterwards read Mr. Stanley (afterwards Lord Stanley and for James Round read Charles Grey Round for Samuel Chichester read Chichester Samuel

for The suzerainty of the queen ... was afterwards disputed. read As regards the power and position of the queen in relation to the South African Republic, the word 'suzerainty' was deliberately not employed, though the precise effect of the disuse of the term was afterwards disputed.

317 ii 9 f.e. for $5,000,000 l$. read $50,000,000 l$.

329 i l.l Goodwin, Harvey : for 1839 read 1840

847 i 14 f.e. Gray, Sir James: for until his death read until 1770

354 ii 32 Gregory, William : for for many years till 1783 read for three months in 1782

358 ii 13 f.e. Grey, Sir George : after local powers. insert He was made K.C.B. in 1848.

361 i 12 f.e. for 1899 read 1898

11 f.e. $\quad$ for 1896 read 1897

ii 12 Grey, Sir Henry G., 3rd Earl Grey : for 1807 read 1806

364 i 19 f.e. for Mr. G. A. Grey read his nephew Mr. Albert H. G. Grey

ii 2 after Earl Grey. insert He was made K.G. in 1863 and G.C.M.G. in 1869.

367 i 36 Grosvenor, Hugh L., 1st Duke of Westminster : for elected read created

377 ii 15 Halford, Sir Henry St. J.: after issue insert His brother John succeeded him

16 for his death read his brother's death 5 f.e. Hall, Sir Charles: for At the general election of July 1892 read At a by-election
in Aug. 1892

878 ii 10 f.e. Hall, William E.: for 1886 read 1866

381 i 29 Hamerton, Philip G.: after establishment insert in 1869 
Page Col. Line

387 ii 22 Harbord, William: for in 1672, when he read in 1661, when he was returned to the House of Commons for Clifton, Dartmouth, and Hardness borough. In 1672 he

389 ii $\quad 30 \quad$ Hardinge, Sir Arthur E.: after colonel-commandant. insert He was made colonel of the Coldstream Guards on 25 Feb. 1890.

395 i 12 f.e. Harris, George: for deputy court judge read deputy county court judge

400 i 29 Haughton, Samuel: for M.D. Cantab. 1880 read Cambridge 1881

404 ii 18 f.e. Hawksley, Thomas : after civil engineer, insert son of John Hawksley by his wife, Mary Whittle

417 i 17 Heurtley, Charles A.: after 1872 insert and with a canonry of Christ Church, Oxford, till his death

434 i 28 Holden, Hubert A. : for College read School

ii 28-34 Note that it was not the subject of this article but Dr. Benjamin Hall Kennedy [q. v.] who projected the 'Sabrinæ Corolla.' At Dr. Kennedy's invitation Dr. Henry Holden, cousin of the subject of this article, assisted in the preparation of the third and fourth editions, issued in 1867 and 1890 respectively.

438 i 14 f.e. Holloway, Sir Charles : for and settled read and retiring from the army in 1824, settled

444 i 4 Hort, Fenton J. A. : for placed fifth read bracketed third

447 ii 8 f.e. Hoste, Sir George C.: for the battles of Quatre Bras on the 16th, and Waterloo read the battle of Waterloo 



\title{
Dictionary OF NATIONAL BIOGRAPHY
}

\author{
ERRATA IN SUPPLEMENT-VOLUME III
}

\author{
HOW-WOODWARD
}

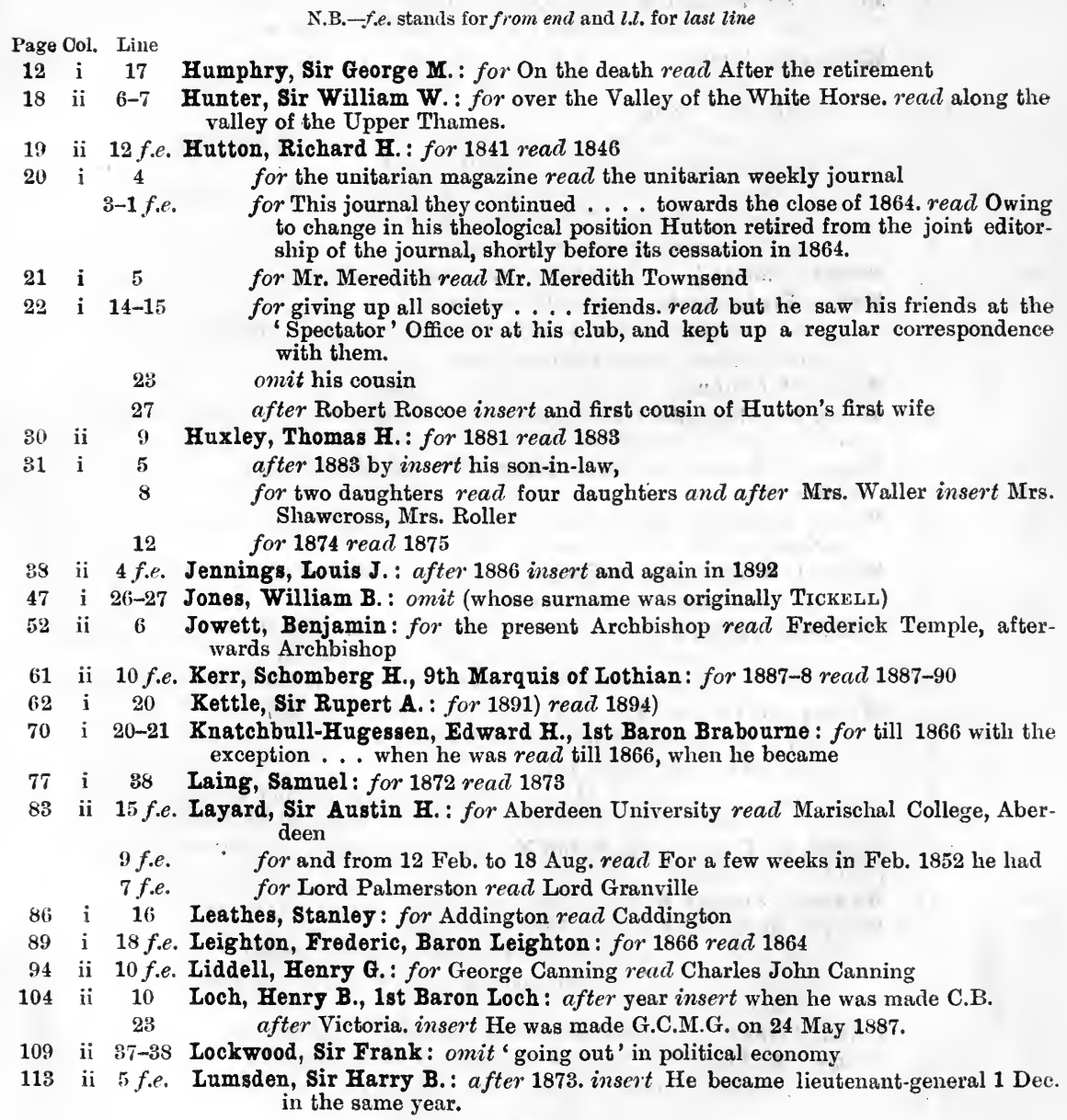


Page Col. Line

113 ii 2-1 f.e. Lumsden, Sir Harry B.: for with the honorary rank of lieutenant-general. read He was promoted general 1 Jan. 1880.

126 i 25 Mackenzie, Colin : omit He was also created a C.B.

ii 14 f.e. after Mackenzie insert who was made C.B. in 1867,

128 ii 2 f.e. McLachlan, Thomas H.: omit banker

i.l. omit at Carbury Hall

129 i 1

for Darlington on 16 March 1845. read on 16 March 1845 at Darlington, where his father was manager of the branch of the National Provincial Bank.

131 ii 13 f.e. McMurdo, sir William M. 8.: after the retired list insert being squbsequently in 1893 made G.C.B.

186 ii 37 Mangles, Ross D.: for $1866 \mathrm{read} 1874$

159 ii 22 Manuche, Cosmo : for which are written read which, according to Percy, were written

42

after Ashby insert according to Percy's account

43

after Manuche. insert But of all these pieces only the comedy called 'The Feast' is still known to be in the library at Castle Ashby, together with an unsigned poem in another hand, which is ascribed to Manuche in the catalogue.

145 ii 14

Martin, Sir William F. : for 1859 read 1858

37

148 i $30-33$ after done. insert On 28 June 1861 Martin became K.C.B.

14 f.e.

Martineau, James : for (cf. his five articles .... p. 185 sq.) read (cf. his article on Bentham's ' Deontology' Monthly Repository, September 1834)

13 f.e.

8 f.e.

ii 5

for he read Martineau, who was much consulted by the latter

for March 1851) read No. xxvi. May 1851)

for For five years after the removal (1853) read For three and a half years after the removal ( 7 Feb. 1854-Oct. 1857)

8 for every week read once a fortnight

151 ii 6

Massie, Thomas I. : after 1866, insert being placed on the retired list in that year,

Maxse, Frederick A. : omit with the rank for of admiral in 1867 read in 1867, becoming rear-admiral in 1875

for Middlesex read Tower Hamlets

Millais, Sir John E. : for (2 parts, read (4 parts,

168 ii 4

177 i 18

Milne, Sir Alexander : after both orders. insert He was promoted vice-admiral 13 April 1865, and admiral 1 April 1870.

195 ii 14-15 Moncreiff, James, 1st Baron Moncreiff: for James Patten [q. v.] read George Patton [q. v.]

187 i 6-7 Monier-Williams, Sir Monier: for He was created a K.C.I.E. read He was knighted in 1886 and became K.C.I.E.

ii l.l. Monsell, William, Baron Emly : omit from 1866 to 1868 he acted as

188 i 2

206 ii 15 for February read December

Muirhead, James P.: for Patrick Muirhead, minister of Dysart, was read Patrick Muirhead was minister of Dysart. His father was

after youth insert and was the subject of one of Raeburn's finest portraits

214 i $l . l$.

Murray, Sir Charles A. : for In 1838 read On 7 July 1837

for a few months later read on 2 June 1838

for 1844 read 31 Dec. 1844

after Naples. insert He was extra groom-in-waiting to the queen from his retirement from the mastership of the household till his death.

218 ii 2 f.e. Napier, Sir Francis, 9th Baron Napier : for Constantinople read St. Petersburg and Constantinople

221 ii 20 f.e. Newman, Francis W.: for 1829 read 1830

224 ii 17 f.e. Newton, Sir Charles T. : for 1853 read 1852

16 f.e. for 1854 he was consul read 1853 he was acting consul

225 i 2-3 for In 1860 he was named consul read From 10 June 1859 to 16 Jan. 1861 he was consul

236 i 10 f.e. Orton, Arthur: for Queensland read New South Wales

244 i 17 f.e. Palmer, Arthur: for The head master read The principal

16 f.e. for Arthur Dobson read William Dobson 
Page Col. Line

259 i 34

ii 11

268 i $l . l$.

ii 1

269 i 11

274 ii 3

279 i 4 f.e.

ii 7

280 i 10

281 ii 34

282 i 13

\section{Pender, Sir John : for 1865-6 read 1862-6} for John read (Sir) John

Pitman, Sir Isaac : for first read first in 1835, and secondly, for and left read by whom he left

Pitt-Rivers, Augustus H. I. F. : for till his death read till 1896

Plume, Thomas : for Plumean read Plumeian

Pole, William : for until his death read until August 1899

omit was

for a setting read an arrangement for four hands

Potter, Thomas B. : for Burle read Buile

for now known as 'Potter \& Norris.' read successively known as 'Potter \& Norris' and 'Potter \& Taylor.'

Price, Bartholomew : after Pembroke insert taking holy orders

for 1891 read 1892

after the college. insert With the mastership went a canonry of Gloucester.

Ryder, Dudley F. S., 3rd Earl of Harrowby: for Defeated at the general election of A.pril 1859, read Defeated at Stafford at a by-election in Aug. 1860,

Ryle, John C. : for until his death read until his resiguation on 1 March 1900. He died

8 f.e. Salvin, 0sbert: for Trinity College read Trinity Hall

2 Stansfeld, Sir James : for Moorlands read Akeds Road

9 for James Ralph read John Ralph

10 for independent read unitarian

Stephens or Stevens, Thomas : for is described read was doubtless son of Thomas Stevens of Bushton, in the parish of Clyffe Pipard, Wiltshire. $\mathrm{He}$ has been described

30-32 for he may therefore be identified .... Dorset, read this place has been erroneously identified with Bourton, Dorset. Stevens

384 i 37 Torrens, Henry W.: for 11 Aug. read 16 Aug.

388 ii 15 f.e. Victor, F. F., Prince Gleichen : for 1867 read Jan. 1866

l.l. Victoria, Queen : for 14 Jan. read 29 Jan.

ii 4

396 i $39-40$

41-42

44

35

8 f.e.

21

for $\mathrm{Six}$ days later read Nine days earlier

for Shadborough read Shugborough

for the old tory statesman Lord Liverpool read the third earl of Liverpool, half-brother of the tory statesman, and himself a politician of ability for Newell Grange read Hewell Grange for six read eight before Marchioness of Normanby insert Countess of Mulgrave, afterwards for leader read speaker for His father read His half-brother (Alexander I) jor 1843 read 1844 for 1838 read 1837 for Lord Derby read Lord Stanley, afterwards Lord Derby for Liverpool read [the third earl of] Liverpool for in impotent rage read angrily for foreign politics read political questions for $200 l$. read $250 l$. for (LoNGMan read (LaughtoN

for the duke read the inauguration of the Commonwealth at Sydney on 1 Jan. 1901 omit in the Australian parliament house

for she exchanged in later years for patience; real she abandoned in later years altogether;

after Donizetti, insert Handel and Bach bored her; omit Handel and for Principal Tulloch read the Rev. Dr. Tulloch for Strafford House read Stafford House chope, Andrew G.: after colonel, insert being made C.B. in 1889, for He left no issue read $\mathrm{He}$ left a son by his first marriage 


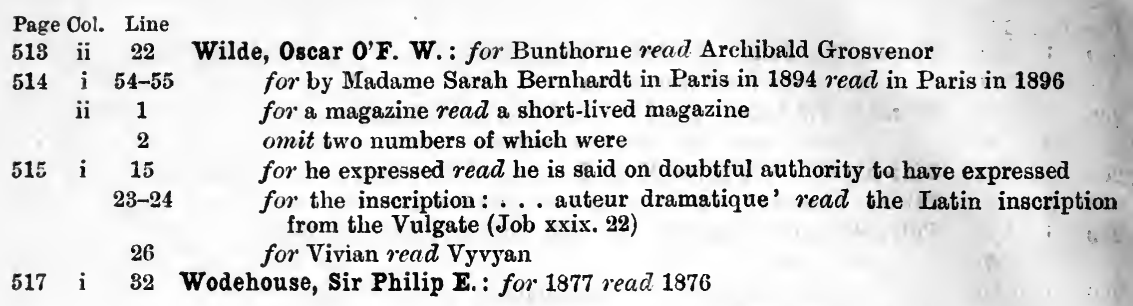





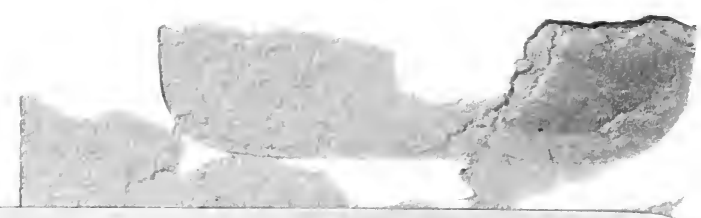

DA Dictionary of national biography 28

D4

1885

Errata

PLEASE DO NOT REMOVE

CARDS OR SLIPS FROM THIS POCKET

\section{UNIVERSITY OF TORONTO LIBRARY}




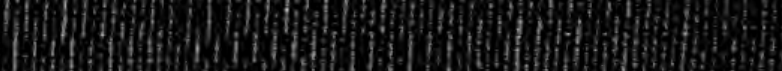

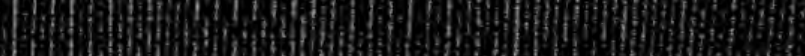
Ahing

Q6 6)

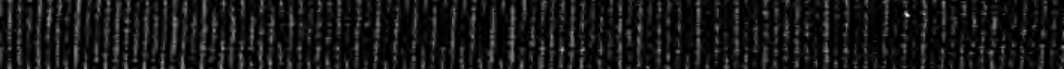

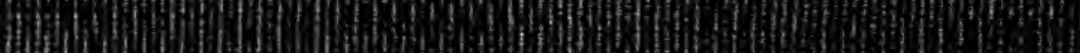

Ef(1)

H. E)

In

(1)

H.

fing

19.

If)

It)

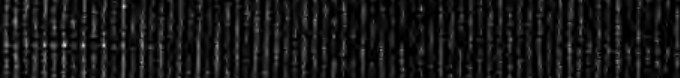

Hef

(1) (I)

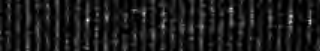

6)

H(1)

fon

If:

f.

If

(1) (1)

(y)

H.

(1)

fif

If

If

(1)

Af

Af

(6)

(I)

If

If

I)

If

(f) 10(1) Hens: 